INSTITUTO DE PESQUISAS ENERGÉTICAS E NUCLEARES

Autarquia Associada à Universidade de São Paulo

\title{
DESENVOLVIMENTO DE UM SISTEMA DE IDENTIFICAÇÃO E CLASSIFICAÇÃO DE TRANSIENTES PARA UM REATOR NUCLEAR A ÁGUA PRESSURIZADA INTEGRAL
}

IVAN DIONYSIO ARONNE

Tese apresentada como parte dos requisitos para obtenção do grau de Doutor em Ciências na Área de Tecnologia Nuclear - Reatores

Orientador:

Prof. Dr. Benedito Dias Baptista Filho

SÃO PAULO 
Dedico esta tese:

À Celeste, Sérgio, Cristiane e Alexandre, com quem eu aprendo continuamente a viver e a ser feliz!

Aos meus pais, Dionysio e Trindade, que me ensinaram a lutar pelos meus sonhos $e$ valores! 


\section{AGRADECIMENTOS}

Para realizar este trabalho contei com a inestimável ajuda de várias pessoas, sem as quais não seria possível vencer este desafio. Menciono alguns nomes pela contribuição direta.

Ao Prof. Dr. Benedito Dias Baptista Filho pela orientação sempre segura e pelo suporte e incentivo nos momentos necessários.

À direção do Centro de Desenvolvimento da Tecnologia Nuclear, pelo importante suporte administrativo e pela viabilização do uso dos laboratórios e infra-estrutura de TI.

À chefia do Serviço de Engenharia de Reatores do CDTN - EC3, na época da elaboração deste trabalho, Dr. João Roberto Loureiro Mattos, pelo estímulo recebido.

A toda a equipe da EC3, pelo apoio incondicional recebido, em particular à equipe do Laboratório de Termo-hidráulica, pelo inestimável suporte durante a fase de experimentos.

Ao colega Dr. Moysés Alberto Navarro, pelas discussões construtivas e sugestões proveitosas, na fase de experimentos, que me ajudaram a concluir esta pesquisa.

Ao Dr. Antônio Carlos Lopes da Costa, pela grande ajuda em conseguir o suporte necessário para conduzir este estudo.

Aos colegas Élcio Tadeu Palmieri e Carlos Vicente de Azevedo, da EC3, pela inestimável ajuda nas simulações e avaliações com o RELAP5, além das preciosas discussões e sugestões.

Ao Prof. Dr. Antônio Carlos Barroso, pela confiança demonstrada ao longo dos anos e pelo incentivo recebido e motivação pelo tema.

À minha esposa, Dra. Maria Celeste R. L. Vasconcelos, pelo inestimável apoio, paciência e ajuda na elaboração e revisão desta tese. 


\section{DESENVOLVIMENTO DE UM SISTEMA DE IDENTIFICAÇÃO E CLASSIFICAÇÃO DE TRANSIENTES PARA UM REATOR NUCLEAR A ÁGUA \\ PRESSURIZADA INTEGRAL}

Ivan Dionysio Aronne

\section{RESUMO}

A demanda por energia no mundo moderno é crescente, em particular nos países em desenvolvimento. Dentre as fontes de energia atualmente disponíveis a opção nuclear tem merecido destaque pelas suas qualidades de não afetar o meio ambiente por meio de emissões de gases de efeito estufa e nem demandar grandes áreas. Porém, a sociedade tem requerido melhoria da segurança dos novos reatores e as empresas de energia necessitam maior disponibilidade das centrais. O projeto do IRIS, um reator nuclear integral a água pressurizada, vem atender a esses requisitos. Um sistema de identificação e classificação de transientes ajudaria a melhorar a segurança e a aumentar a disponibilidade do IRIS, melhorando sua competitividade. Como contribuição para o desenvolvimento de um sistema como esse foi desenvolvido e estudado o Sistema de Identificação e Classificação de Transientes - SICT com capacidade de monitorar a operação da central e disponibilizar informações sobre seu estado operacional. O SICT foi desenvolvido usando a técnica de redes neuronais, mais especificamente os Mapas Auto-Organizáveis (Self-Organizing Maps-SOM). Para o treinamento do SICT foram usados resultados de simulação do IRIS com o código RELAP5. Para comprovar a metodologia de usar resultados de simulações, cujos valores têm características diferentes daqueles medidos, foi feito uma aplicação do SICT para uma instalação experimental, o Circuito Térmico $\mathrm{N}^{O} 1$ - CT1. A partir de experimentos termo-hidráulicos no CT1 e de simulações deste com o RELAP5, pôde-se verificar a validade dessa metodologia. Tem-se disponível para estudos futuros uma nodalização do CT1 validada, uma nodalização do IRIS testada para vários transientes, normais e anormais, e um banco de dados de resultados de simulação do IRIS. Está também disponível, em um CD em anexo a esta tese, os arquivos fontes do aplicativo desenvolvido, SICT, e de alguns programas auxiliares, os dados dos experimentos realizados no CT1 e dados de entrada e resultados de simulações do CT1 com o RELAP5. 


\title{
DEVELOPMENT OF A TRANSIENT IDENTIFICATION AND CLASSIFICATION SYSTEM TO AN INTEGRAL PRESSURIZED WATER REACTOR
}

\author{
Ivan Dionysio Aronne
}

\begin{abstract}
The demand for energy in the modern world is growing, particularly in the developing countries. The nuclear option has been deserving prominence for their qualities of not impacting the environment through emissions of greenhouse gases and nor to demand great areas. However society requests improvement in the safety of new reactors and the utilities request larger availability of the power plants. The IRIS project of an integral nuclear pressurized water reactor proposes to fulfill those requirements. A system for identification and classification of transients would help to improve the safety and to increase the availability of the IRIS increasing its competitiveness. In order to contribute to the development of such a system it was developed in this work a System for Identification and Classification of Transients - SICT - capable of monitoring the operation of the reactor and of providing information on its operational state. SICT was developed using the technique of neural networks, more specifically the Self-Organizing Maps. Results of IRIS simulations with RELAP5 code were used to train the neural network of SICT. To demonstrate the correctness of the methodology of using simulation results, whose values have characteristics different from the measured ones, it was made a version of SICT for an experimental installation, the Thermal Circuit \#1 - CT1. Experiments were run in this test facility and simulations of its operation were done with RELAP5. This CT1 version of SICT was then checked against the simulation and experimental data validating the methodology. As a result of the activities to develop SICT, it is now available for futures studies: the developed application, SICT, a database of experiments in CT1, a validated nodalização of CT1, a database of results of CT1 simulations, a nodalização of the IRIS tested for several normal and abnormal transients and a database with the results of IRIS simulations. Attached to this thesis is a CD with the source files of the application and of some auxiliary programs, the data from the experiments carried out in CT1 and the input data and simulation results of CT1 with RELAP5.
\end{abstract}




\section{SUMÁRIO}

Página

\section{INTRODUÇÃO 1}

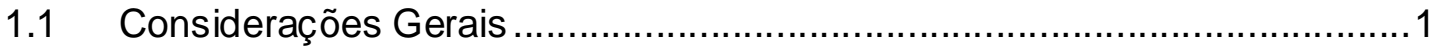

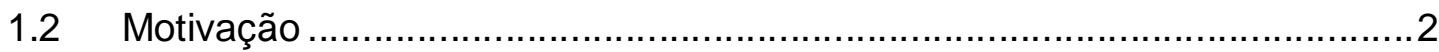

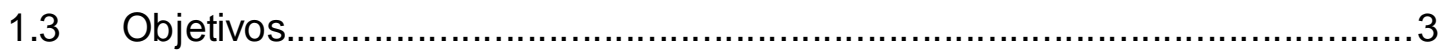

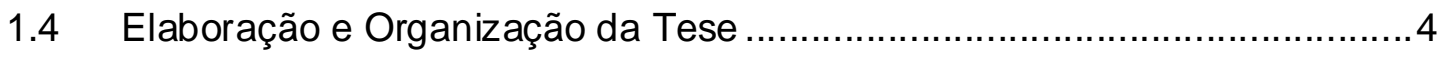

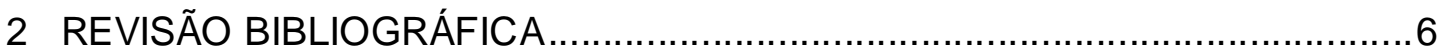

$2.1 \quad$ O Reator IRIS

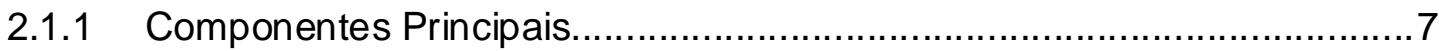

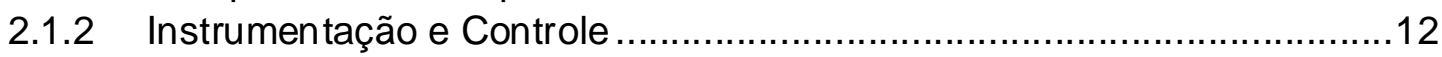

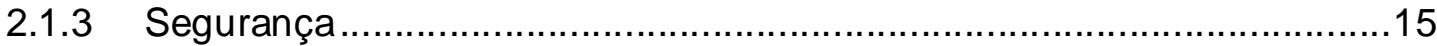

2.1.4 Transientes e Acidentes Usados neste Desenvolvimento .......................18

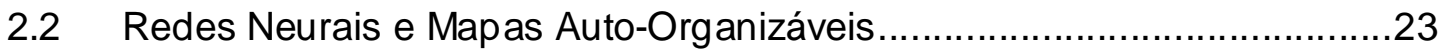

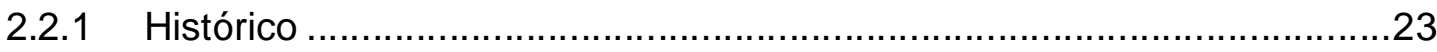

2.2.2 Características Básicas das Redes Neurais Artificiais ............................24

2.2.3 O Aprendizado das Redes Neurais Artificiais .......................................27

2.2.4 Mapas Auto-Organizáveis (Self-Organizing Maps - SOM) .....................29

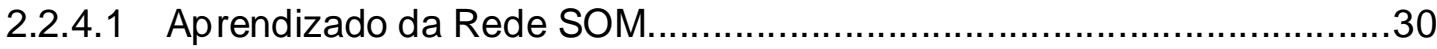

2.3 Identificação e Classificação de Transientes com Redes Neurais ..............32

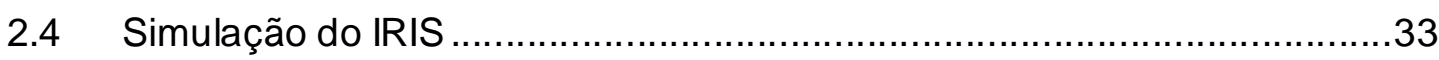

2.4.1 Simulação do IRIS com Modelo Simples (EES) ......................................34

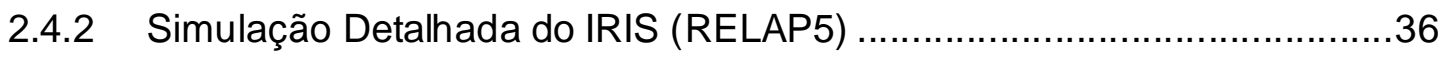

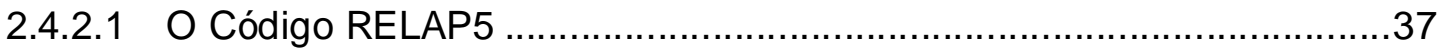

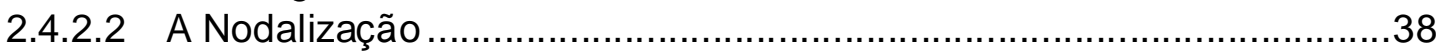

2.4.2.3 Simulação dos Sistemas de Controle e Proteção do IRIS .......................41

2.4.2.4 Principais condições de Contorno ....................................................54

2.4.3 Simulação do Sistema de Controle (MODELICA) ……............................54

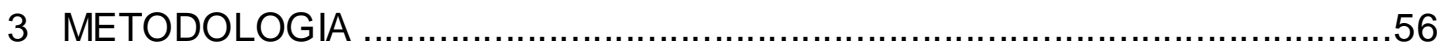

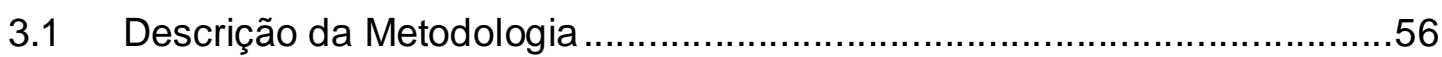

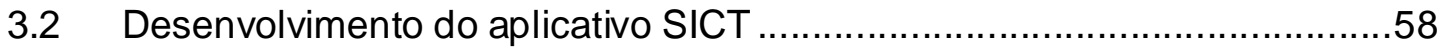

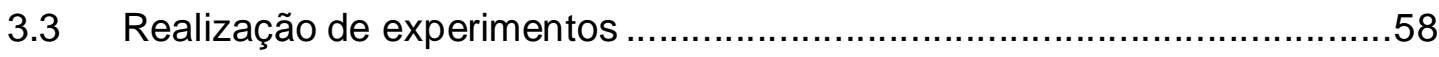

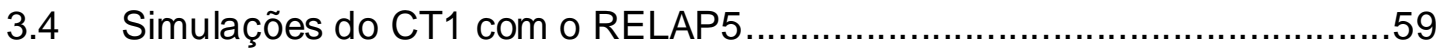

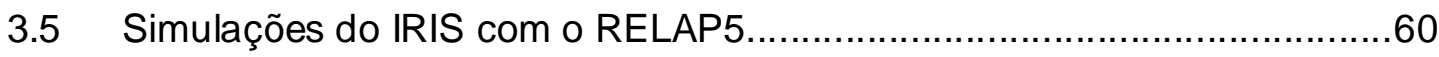

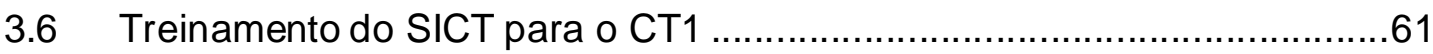




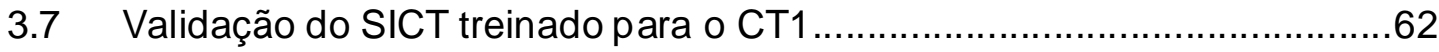

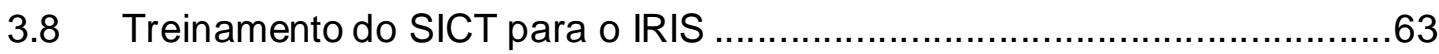

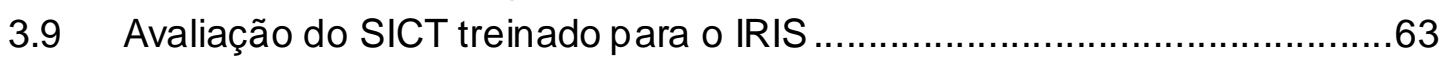

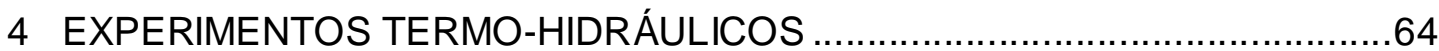

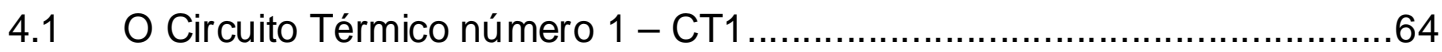

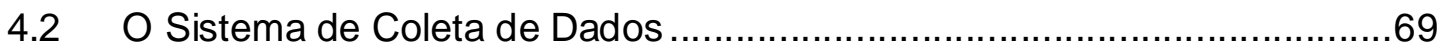

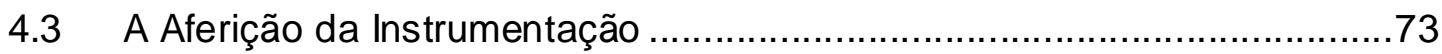

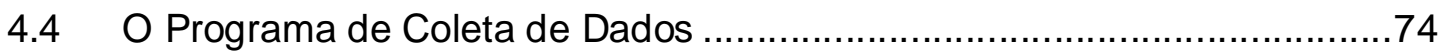

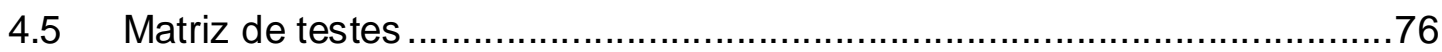

4.6 Caracterização dos Resultados Experimentais .........................................79

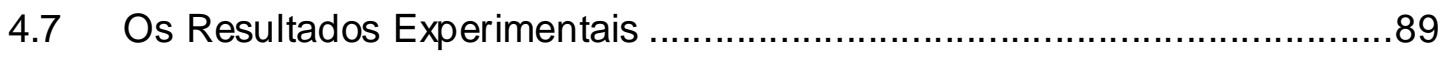

4.7.1 Experimentos para teste e validação da instalação ………………….....90

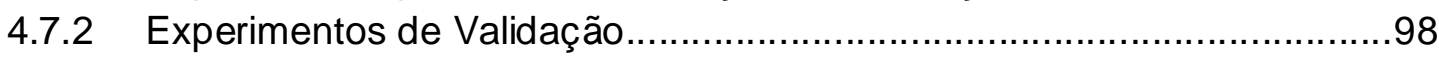

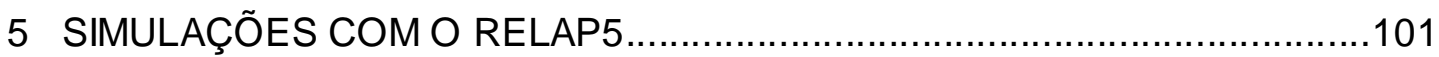

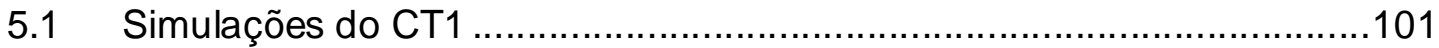

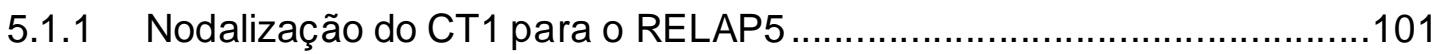

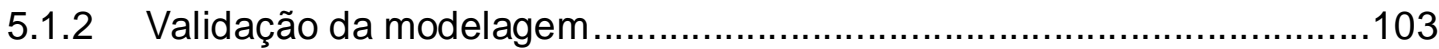

5.1.3 Resultados da Simulação do CT1 com o RELAP5 .................................105

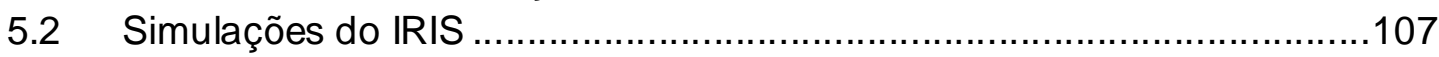

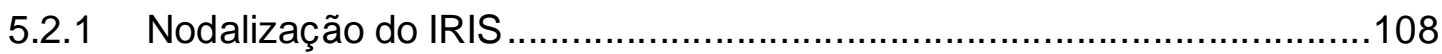

5.2.2 Matriz de Simulações .....................................................................110

5.2.3 Validação da nodalização do IRIS para o RELAP5 .................................111

5.2.4 Resultados da Simulação do IRIS com o RELAP5 …............................120

6 O SISTEMA DE IDENTIFICAÇÃO E CLASSIFICAÇÃO DE TRANSIENTES -

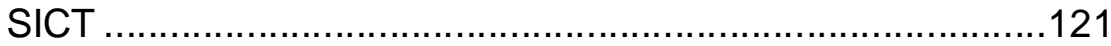

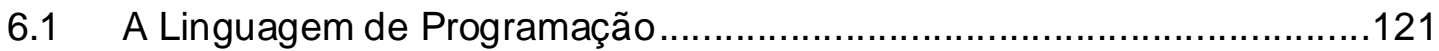

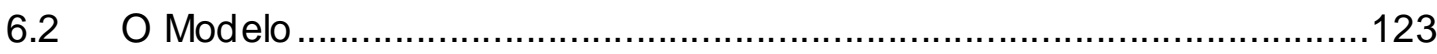

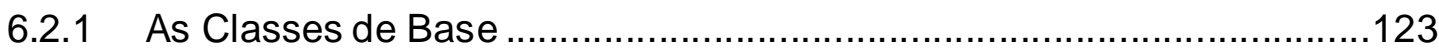

6.2.2 As Principais Classes e seus Inter-relacionamentos.............................124

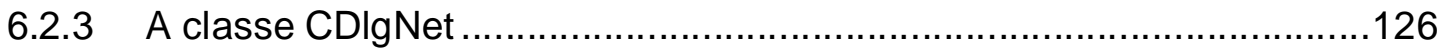

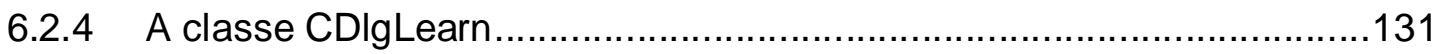

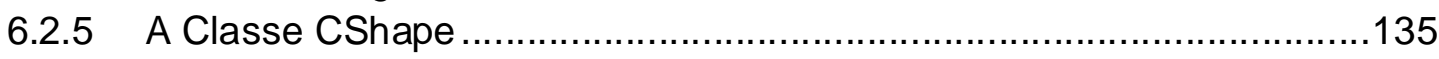

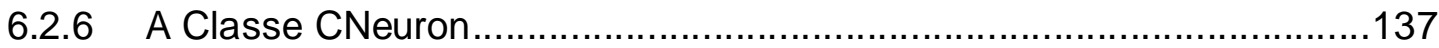

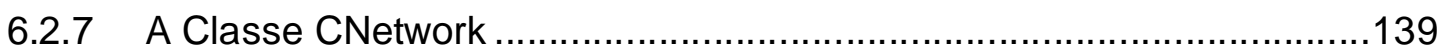

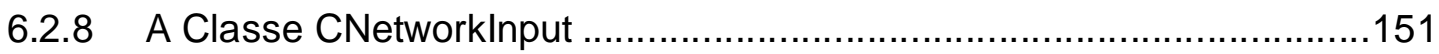

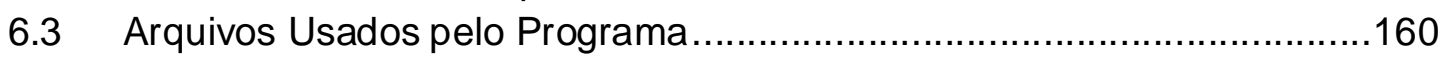

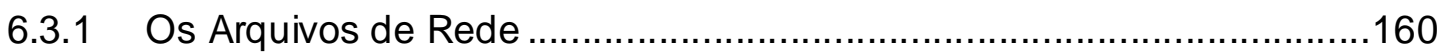

6.3.2 Arquivos de Entrada, com Dados Externos.........................................162

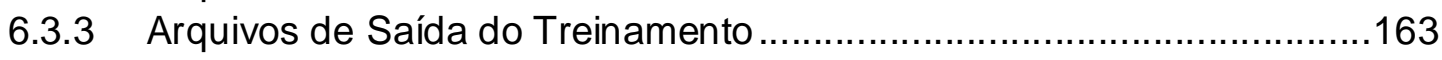


6.3.4 Arquivos de Saída do Monitoramento ………......................................169

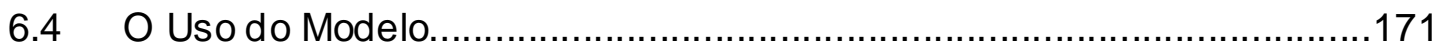

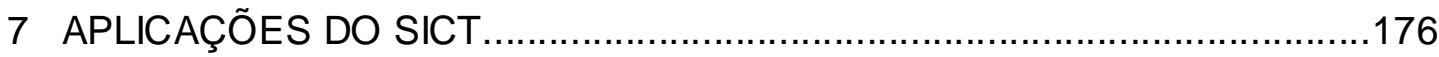

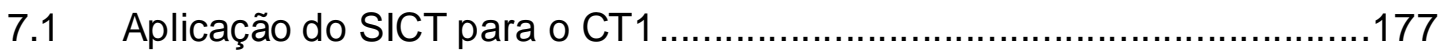

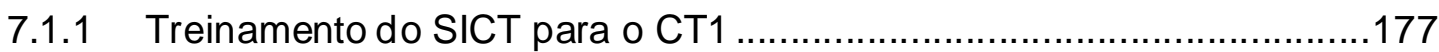

7.1.1.1 Parâmetros Termo-hidráulicos do CT1 para treinamento do SICT ......178

7.1.1.2 Os Buffers para treinamento para o CT1 ........................................179

7.1.2 Uso do SICT com as simulações do CT1 com o RELAP5 ….................197

7.1.2.1 Rede 5D2V com conjunto de buffers DR ( CT1 - 5D2V - DR ) ..........199

7.1.2.2 Rede 5D3V com conjunto de buffers DR ( CT1 - 5D3V - DR ) ..........206

7.1.2.3 Rede 7 com conjunto de buffers DR (CT1 - 710 - DR) ......................213

7.1.2.4 Rede 7D1V com conjunto de buffers DR (CT1 - 7D1V - DR) .............219

7.1.2.5 Rede 810 com conjunto de buffers DR (CT1 - 810 - DR) ...................224

7.1.2.6 Rede 8D3V com conjunto de buffers DR (CT1 - 8D3V - DR) .............231

7.1.2.7 Conclusões sobre as Redes usando o buffer DR para o CT1 .............236

7.1.2.8 Redes Triangular, Quadrada, Hexagonal e Cúbica com conjunto de buffers ALL (CT1 - D2V - ALL) ……………………………….....237

7.1.2.9 Conclusões sobre as redes Triangular, Quadrada, Hexagonal e Cúbica com conjunto de buffers ALL........................................................247

7.1.3 Uso do SICT com resultados experimentais ......................................247

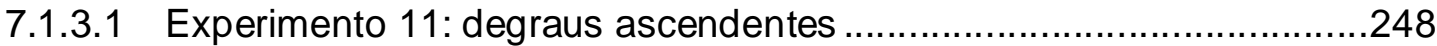

7.1.3.2 Experimento 12: degraus descendentes .......................................252

7.1.3.3 Experimento 18: rampas de $240 \mathrm{~s}$ ascendentes ................................255

7.1.3.4 Experimento 21: rampas de 240 s descendentes ..............................257

7.1.3.5 Experimento 23: desligamento Bomba do Secundário..........................260

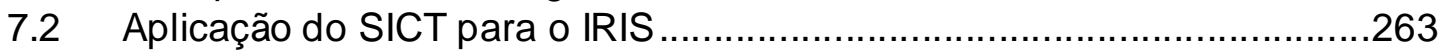

7.2.1 Dados para treinamento e avaliação do SICT para o IRIS .....................263

7.2.2 Uso do SICT com as simulações do IRIS com o RELAP5 …..................266

7.2.2.1 REDE 810 para o IRIS com o conjunto de buffers ALL (IRIS-810-ALL).....

7.2 .2 REDE 8D3V para o IRIS com o coniunto de buffers ALL (IRIS-810-ALL) 266
.. 271

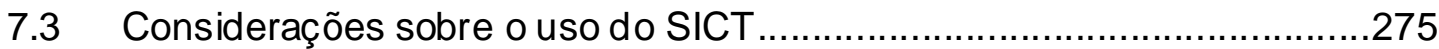

7.3.1 Considerações do uso do SICT com simulações do RELAP5 …...........276

7.3.2 Considerações do uso do SICT com os resultados experimentais ........276

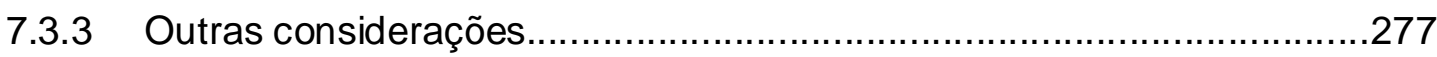

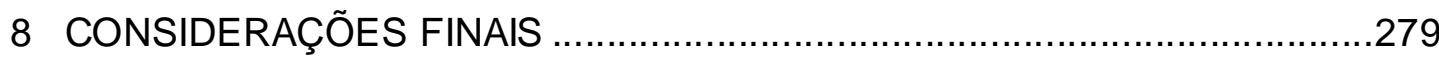

REFERÊNCIAS 283

APÊNDICE A. CONVERSÕES DOS SINAIS MEDIDOS …...........................289

APÊNDICE B PROCEDIMENTOS PARA OPERAÇÃO DO CT1 .................293

APÊNDICE C ARQUIVOS DE ENTRADA E SAÍDA DO SICT .....................297 
APÊNDICE D RESULTADOS EXPERIMENTAIS .......................................309

APÊNDICE E COMPARAÇÃO DOS RESULTADOS DOS EXPERIMENTOS NO CT1 E DE SUAS SIMULAÇÕES ………………............335

APÊNDICE $F$ SIMULAÇÕES DO CT1 E AMOSTRAGENS PARA FORMAÇÃO DOS CONJUNTOS DE BUFFERS DE

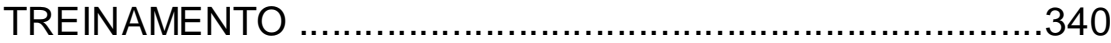

APÊNDICE G RESULTADOS DE SIMULAÇÕES DO IRIS...........................366 


\section{LISTA DE TABELAS}

Página

TABELA 1 - Tempos de Residência do Fluido no IRIS e em ANGRA 2...........114

TABELA 2 - Relação entre as faixas dos parâmetros nos conjuntos de buffers ALLOLD e ALLM .......................................................................... 187

TABELA 3 - Faixa dos parâmetros nos conjuntos de buffers do CT1 ...............196

TABELA 4 - Redes Hexagonais treinadas para o CT1 ..................................198

TABELA 5 - Redes com diferentes geometrias treinadas para o CT1 ..............198

TABELA 6 - Sequência dos neurônios ativados durante o início dos degraus descendentes e durante os estados estacionários na rede CT1 - 5D2V DR

TABELA 7 - Neurônios ativados durante o início dos degraus descendentes (DD) e durante os estados estacionários na rede CT1 - 5D2V - DR.

TABELA 8 - Sequência dos neurônios ativados durante o início dos degraus ascendentes e durante os estados estacionários na rede CT1 - 5D2V - DR

TABELA 9 - Neurônios ativados durante o início dos degraus ascendentes e durante os estados estacionários na rede CT1 - 5D2V - DR.

TABELA 10 - Sequência dos neurônios ativados durante o início dos degraus descendentes e durante os estados estacionários na rede 5D3V - DR..208

TABELA 11 - Sequência dos neurônios ativados durante o início dos degraus ascendentes e durante os estados estacionários na rede 5D3V - DR....209

TABELA 12 - Neurônios ativados durante o início dos degraus descendentes (DD) e durante os estados estacionários na rede 5D3V - DR.

TABELA 13 - Neurônios ativados durante o início dos degraus ascendentes e durante os estados estacionários na rede 5D3V - DR.

TABELA 14 - Neurônios associados aos estados estacionários a diversas potências na rede 5D3V - DR

TABELA 15 - Neurônios ativados durante o início dos degraus descendentes (DD), durante os estados estacionários e no interlavo entre eles na rede 710 - DR 215

TABELA 16 - Neurônios ativados durante o início dos degraus ascendentes (DU), durante os estados estacionários e no interlavo entre eles na rede 710 - DR 215

TABELA 17 - Neurônios ativados na CT1 - 7D1V - DR durante o início dos degraus descendentes, durante os estados estacionários e durante esses estados

TABELA 18 - Neurônios ativados na CT1 - 7D1V - DR durante o início dos degraus ascendentes, durante os estados estacionários e durante esses estados.

TABELA 19 - Neurônios ativados durante o monitoramento da simulação PRESSURIZA70k na rede CT1 - 7D1V - DR 
TABELA 20 - Neurônios ativados na CT1-810-DR durante o início dos degraus descendentes, durante os estados estacionários e entre esses

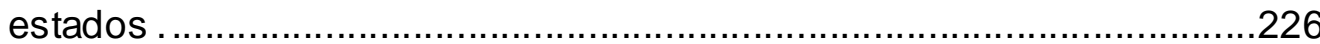

TABELA 21- Neurônios ativados na CT1-810-DR durante o início dos degraus ascendentes, durante os estados estacionários e entre esses estados. 226

TABELA 22 - Neurônios ativados durante o monitoramento da simulação

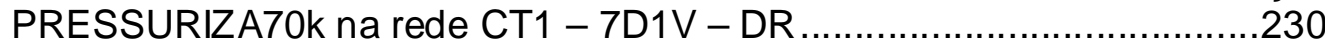

TABELA 23- Neurônios ativados durante os $48 \mathrm{~s}$ iniciais dos degraus ascendentes e descendentes, e durante os estados estacionários..........232

TABELA 24 - Sequencia de neurônios ativados na rede CT1 - 8D3V - DR .....235

TABELA 25 - Distribuições das distâncias buffer-neurônio para rede triangular, quadrada, hexagonal e cúbica...........................................................239 


\section{LISTA DE QUADROS}

Página

QUADRO 1 - Implicações de Segurança do IRIS ….......................................17

QUADRO 2 - Resposta do IRIS a Falhas Limitantes ......................................18

QUADRO 3 - Matriz de experimentos realizados .............................................77

QUADRO 4 - Simulações do CT1 com o RELAP5 usadas para treinamento do

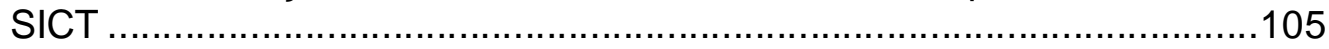

QUADRO 5 - Lista de transientes simulados para o IRIS ................................110

QUADRO 6 - Formas de rede e suas formas de neurônios possíveis ..............129

QUADRO 7 - Parâmetros termo-hidráulicos do CT1 para treinamento do SICT 178

QUADRO 8 - Derivadas dos parâmetros termo-hidráulicos do CT1 para treinamento do SICT

QUADRO 9 - Simulações do CT1 com o RELAP5 usadas para formar o conjunto

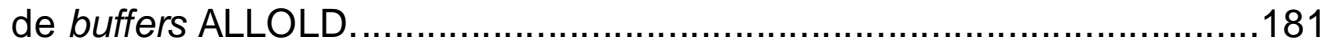

QUADRO 10 - Simulações do CT1 com o RELAP5 usadas para formar o conjunto de buffers AC...................................................................188

QUADRO 11- Simulações do CT1 com o RELAP5 usadas para formar o conjunto de buffers DR................................................................191

QUADRO 12 - Simulações do CT1 com o RELAP5 usadas para formar o conjunto de buffers ALL...................................................................195

QUADRO 13 - Conjuntos de buffers para treinamento do SICT para o CT1 ....196

QUADRO 14 - Sumário das avaliações da rede 5D2V- DR para o CT1 ...........205

QUADRO 15 - Sumário das avaliações da rede CT1 - 5D2V - DR ...................213

QUADRO 16 - Sumário das avaliações da rede 5D2V- DR para o CT1 ...........218

QUADRO 17 - Resumo da avaliação das redes do CT1 treinadas com o conjunto de buffers DR

QUADRO 18 - Neurônios ativados pela rede cúbica para a simulação

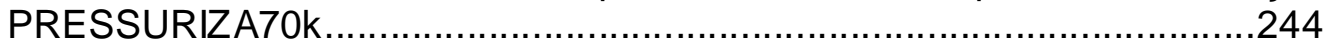

QUADRO 19 - Neurônios ativados na rede hexagonal durante monitoração da simulação ISOLATC 246

QUADRO 20 - Telas do SICT para Transientes do IRIS monitorados e apresentados na FIG. 57. 


\section{LISTA DE FIGURAS}

Página

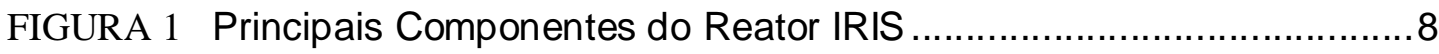

FIGURA 2 Bomba do refrigerante primário, tipo carretel ......................................

FIGURA 3 Parte superior do gerador de vapor de tubos helicoidais ...................10

FIGURA 4 Pressurizador no tampo do vaso de pressão .....................................11

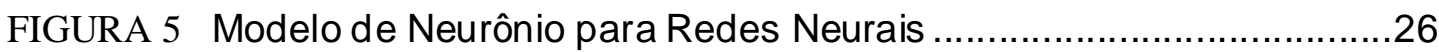

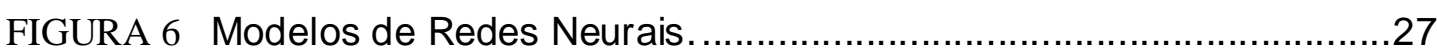

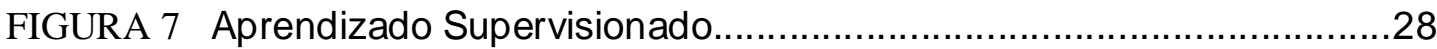

FIGURA 8 Modelo Simplificado do Reator IRIS..............................................35

FIGURA 9 Nodalização do IRIS (só são mostrados 1 dos 8 circuitos de Bomba e Gerador de Vapor e 1 dos 4 Sistemas de Remoção de Calor Residual)....39

FIGURA 10 Nodalização com volumes paralelos de mesma altura no Vaso do IRIS

FIGURA 11 Arranjo dos quatro grupos de Geradores de Vapor..........................41

FIGURA 12 Diagrama do sistema de controle da pressão do primário..................44

FIGURA 13 Diagrama do Sistema de Controle da Pressão do Vapor ...................47

FIGURA 14 Lógica dos controles da pressão de vapor .......................................48

FIGURA 15 Diagrama do sistema de barras de controle até o erro final de

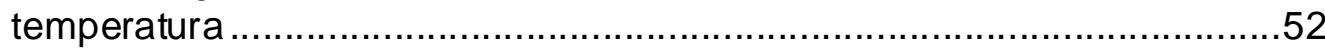

FIGURA 16 Diagrama do sistema das barras de controle até a inserção da

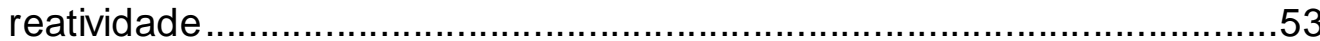

FIGURA 17 Vista do CT1 com seus principais componentes............................65

FIGURA 18 Circuito Térmico Número 1.........................................................66

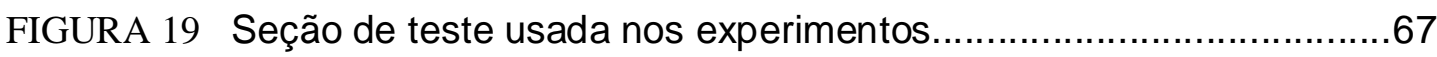

FIGURA 20 Fluxograma do CT1 ...............................................................

FIGURA 21 Conexões da instrumentação na placa 789 e interligação das placas

.

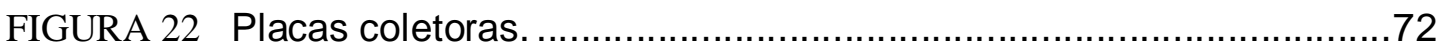

FIGURA 23 Tela de monitoramento da operação do CT1 neste projeto...............75

FIGURA 24 Nodalização do CT1 para o RELAP5 …......................................102

FIGURA 25 Nodalização do vaso do IRIS com seus componentes....................109

FIGURA 26 Relação entre as Classes Cshape, CNeuron e CNetwork...............125

FIGURA 27 Relação entre as classes CNetwork, CNetwork Input e o Exterior..125

FIGURA 28 Classes utilizadas para o desenvolvimento do SICT ......................126

FIGURA 29 Métodos e atributos da classe CDlg Net.......................................127

FIGURA 30 Parâmetros pedidos ao usuário para criação da rede ....................127

FIGURA 31 Redes a) Triangular/Triangular, b) Quadrada/Triangular,

c) Quadrada/Quadrada, d) Hexagonal/Triangular , e) Hexagonal/Hexagonal

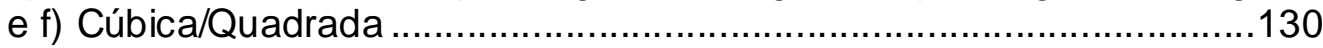




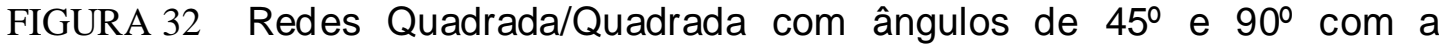
horizontal

FIGURA 33 Métodos e atributos da classe CDIsLearn ....................................132

FIGURA 34 Parâmetros pedidos ao usuário para o treinamento da rede ...........133

FIGURA 35 Métodos e atributos da classe CShape .....................................137

FIGURA 36 Atributos da classe CNetwork.................................................141

FIGURA 37 Métodos da classe CNetwork.................................................141

FIGURA 38 Exemplo de buffer de entrada para treinamento da rede ................152

FIGURA 39 Exemplo de dados de entrada para monitoramento, com os tempos de 0,6 e 12 segundos................................................................ 153

FIGURA 40 Métodos da classe CNetworkInput..............................................154

FIGURA 41 Telas do SICT após o seu início e após abrir uma rede treinada...161

FIGURA 42 Comandos do menu FILE.....................................................172

FIGURA 43 Comandos do menu SICT ................................................... 173

FIGURA 44 Detalhe da Tela do SICT após atualização na época 10 da fase de organização do treinamento ...........................................................174

FIGURA 45 Detalhe da Tela do SICT após atualização na época 12 da fase de convergência do treinamento .......................................................174

FIGURA 46 Neurônios da rede CT1-5D2V-DR ativados em simulações de transientes de potência a)crescente e b)decrescente ............................200

FIGURA 47 Neurônios da rede 5D3V - DR ativados em transientes de potência a) crescente e b) decrescente. 207

FIGURA 48 Arranjos dos buffers nas redes triangular, quadrada, hexagonal e cúbica após o treinamento e o código de cores empregado ....................238

FIGURA 49 Neurônios ativados durante: a) o experimento 11 e b) a simulação de degraus ascendentes com a rede CT1 - 8D3V - DR ...........................248

FIGURA 50 Neurônios ativados: a) durante o experimento 11 e b) durante simulações de degraus ascendentes com rede cúbica CT1 - CUB - ALL250

FIGURA 51 Neurônios ativados: a) durante o experimento 12 e b) durante simulações de degraus descendentes com rede CT1 - 8D3V - DR.........252

FIGURA 52 Neurônios ativados: a) durante o experimento 11 e b) durante simulações de degraus ascendentes com rede cúbica CT1 - CUB - ALL254

FIGURA 53 Neurônios ativados: a) durante o experimento 18 e b) durante simulações de rampas ascendentes de 240 s com a rede CT1 - 8D3V - DR

256

FIGURA 54 Neurônios ativados: a) durante o experimento 21 e b) durante simulações de rampas descendentes de $240 \mathrm{~s}$ com a rede CT1 -

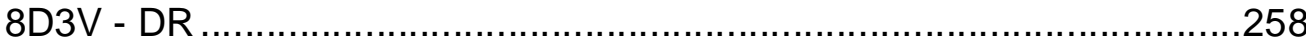

FIGURA 55 Neurônios ativados: a) durante o experimento 23 e b) durante simulação de desligamento da bomba, DESLBS40_2 com rede cúbica CT1 - CUB - ALL .....................................................................262

FIGURA 56 Arranjo dos buffers na rede hexagonal IRIS-810-ALL após o treinamento. 267

FIGURA 57 Telas do SICT para a rede IRIS-810-ALL após monitoramento dos transientes do QUADRO 20. 
FIGURA 58 Arranjo dos buffers na rede hexagonal IRIS-8D3V-ALL após o

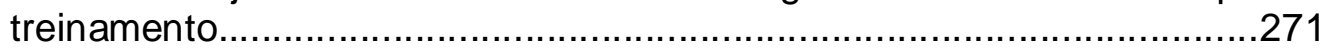

FIGURA 59 Telas do SICT para a rede IRIS-810-ALL após monitoramento dos tran sientes do QUADRO 20........................................................273 


\section{LISTA DE GRÁFICOS}

Página

GRÁFICO 1 Pressão e nível no pressurizador do IRIS usando o Modelo

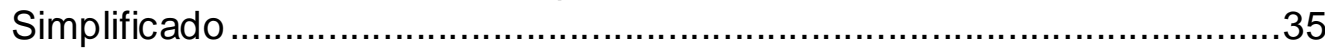

GRÁFICO 2 Temperatura medida na saída da seção de testes (T2) - Exp24 ...80

GRÁFICO 3 Temperatura medida na entrada do primário do trocador de calor (T4) - Exp24 81

GRÁFICO 4 Temperatura medida na entrada do secundário do trocador de calor (T9) - Exp24

GRÁFICO 5 Temperatura medida na saída do secundário do trocador de calor

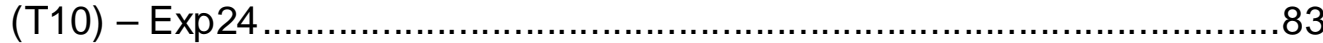

GRÁFICO 6 Potência medida na seção de testes - Exp24 .................................84

GRÁFICO 7 Diferença de pressão medida na placa de orifício do secundário Exp24 85

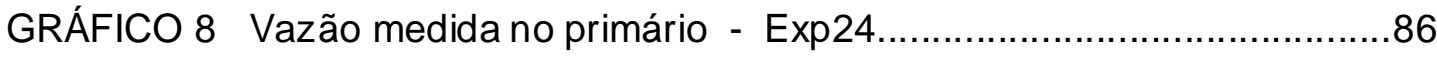

GRÁFICO 9 Vazão medida no secundário - Exp24 …...................................87

GRÁFICO 10 Pressão medida no recalque da bomba principal - Exp24 ...........88

GRÁFICO 11 Pressão medida no pressurizador - Exp24 ……........................89

GRÁFICO 12 Potências elétrica e térmica na seção de testes - Exp01 .............91

GRÁFICO 13 Vazão no secundário - Exp01 ..................................................91

GRÁFICO 14 Temperaturas do refrigerante na entrada e na saída da seção de

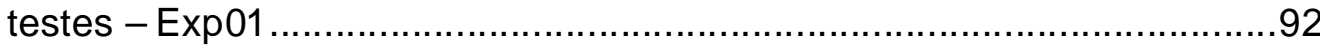

GRÁFICO 15 Perda de potência na seção de testes - Exp01 .............................93

GRÁFICO 16 Vazão do primário e do secundário - Exp02 ……….....................94

GRÁFICO 17 Potência elétrica na seção de testes - Exp02 ……………….......94

GRÁFICO 18 Temperatura na entrada e na saída da ST - Exp02 ......................95

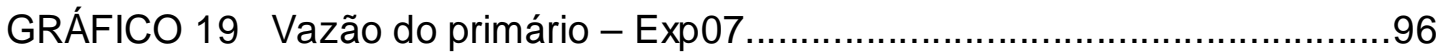

GRÁFICO 20 Potência elétrica na seção de testes - Exp07 …............................96

GRÁFICO 21 Temperatura na saída da ST - Exp07 …….............................97

GRÁFICO 22 Variação da pressão calculada no primário do IRIS após uma

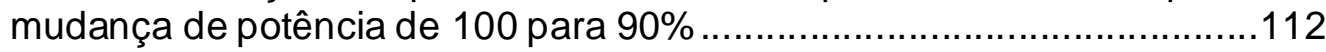

GRÁFICO 23 Variação da pressão calculada no secundário do IRIS após uma mudança de potência de 100 para $90 \% \ldots \ldots \ldots \ldots \ldots \ldots \ldots \ldots \ldots \ldots \ldots \ldots \ldots \ldots \ldots \ldots \ldots . . . . .113$

GRÁFICO 24 Velocidade das barras de controle em função do erro de

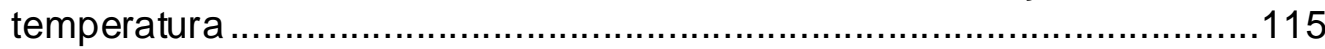

GRÁFICO 25 Detalhe da velocidade das barras de controle em função do erro de temperatura ..............................................................................115

GRÁFICO 26 Pressão no primário do IRIS após uma mudança de potência de 100 para $90 \%$ calculada após alterações na nodalização.........................116

GRÁFICO 27 Pressão no secundário do IRIS após uma mudança de potência de 100 para $90 \%$ calculada após alterações na nodalização. 
GRÁFICO 28 Pressão no secundário a 20\% de potência.................................117

GRÁFICO 29 Potência entregue à turbina a 20\% de potência.........................117

GRÁFICO 30 Influência da Abertura da Válvula na Variação da Vazão com a

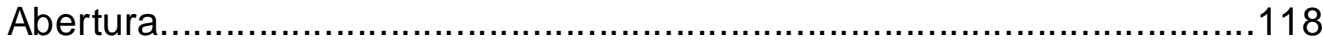

GRÁFICO 31 Pressão no secundário a $20 \%$ de potência depois de alterada a nodalização.

GRÁFICO 32 Potência no secundário a $20 \%$ depois de alterada a nodalização.

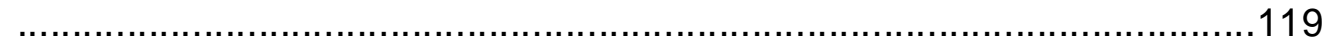

GRÁFICO 33 Evolução de ETA durante a fase de ordenamento .....................145

GRÁFICO 34 Evolução de ETA durante a fase de convergência ......................146

GRÁFICO 35 Distância máxima até o neurônio vencedor para atualização dos pesos durante a fase de ordenamento .............................................148

GRÁFICO 36 Distribuição da distância entre os buffers de entrada em dez faixas

GRÁFICO 37 Evolução da distância máxima entre buffer e neurônio vencedor na fase de ordenamento.......................................................................164

GRÁFICO 38 Evolução da distância máxima entre buffer e neurônio vencedor na

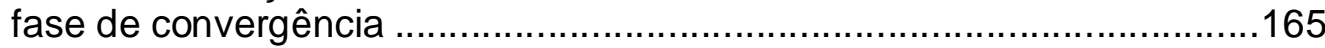

GRÁFICO 39 Evolução dos mínimos e máximos fatores de vizinhança na fase

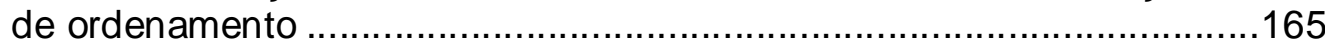

GRÁFICO 40 Evolução dos mínimos e máximos fatores de vizinhança na fase de convergência .............................................................................166

GRÁFICO 41 Distribuições das distâncias geométricas entre os neurônios nas redes Triangular/Triangular, Quadrada/Quadrada, Hexagonal/Hexagonal e Cúbica/Quadrada

GRÁFICO 42 Distribuição das distâncias entre os pesos dos neurônios vizinhos 169

GRÁFICO 43 Distância buffer de monitoramento - neurônio com o tempo.......171 GRÁFICO 44 Potência na seção de testes - Exp06 …….............................176

GRÁFICO 45 Derivada da potência na seção de testes - Exp06 ......................177

GRÁFICO 46 Potência e sua derivada no conjunto de buffers ALLOLD ...........182

GRÁFICO 47 Pressão e sua derivada no conjunto de buffers ALLOLD ............182

GRÁFICO 48 Temperatura de saída da Seção de Testes e sua derivada no conjunto de buffers ALLOLD .............................................................182

GRÁFICO 49 Temperatura de saída da Seção de testes e sua derivada normalizadas no conjunto de buffers ALLOLD ......................................183

GRÁFICO 50 Temperatura de saída do primário do Trocador de Calor e sua derivada no conjunto de buffers ALLOLD..............................................183

GRÁFICO 51 Temperatura de saída do secundário do Trocador de Calor e sua derivada no conjunto de buffers ALLOLD..............................................183

GRÁFICO 52 Vazões do Primário e do Secundário, respectivamente, no conjunto de buffers ALLOLD ...........................................................184

GRÁFICO 53 Potência e sua derivada no conjunto de buffers ALLM................185

GRÁFICO 54 Pressão e sua derivada no conjunto de buffers ALLM.................185 
GRÁFICO 55 Temperatura de saída da Seção de Testes e sua derivada no conjunto de buffers ALLM..................................................................185

GRÁFICO 56 Temperatura de saída do primário do Trocador de Calor e sua derivada no conjunto de buffers ALLM ..............................................186

GRÁFICO 57 Temperatura de saída do secundário do Trocador de Calor e sua derivada no conjunto de buffers ALLM .................................................186

GRÁFICO 58 Vazões do Primário e do Secundário, respectivamente, no conjunto de buffers ALLM................................................................186

GRÁFICO 59 Potência e sua derivada no conjunto de buffers AC ...................189

GRÁFICO 60 Pressão e sua derivada no conjunto de buffers AC ....................189

GRÁFICO 61 Temperatura de saída da Seção de Testes e sua derivada no conjunto de buffers AC

GRÁFICO 62 Temperatura de saída do primário do Trocador de Calor e sua derivada no conjunto de buffers AC .................................................190

GRÁFICO 63 Temperatura de saída do secundário do Trocador de Calor e sua derivada no conjunto de buffers AC ....................................................190

GRÁFICO 64 Vazões do Primário e do Secundário, respectivamente, no conjunto de buffers AC ...................................................................190

GRÁFICO 65 Potência e sua derivada no conjunto de buffers AC ....................192

GRÁFICO 66 Pressão e sua derivada no conjunto de buffers AC .....................192

GRÁFICO 67 Temperatura de saída da Seção de Testes e sua derivada no conjunto de buffers AC ...................................................................192

GRÁFICO 68 Temperatura de saída do primário do Trocador de Calor e sua derivada no conjunto de buffers AC ....................................................193

GRÁFICO 69 Temperatura de saída do secundário do Trocador de Calor e sua derivada no conjunto de buffers AC ...................................................193

GRÁFICO 70 Vazões do Primário e do Secundário, respectivamente, no conjunto de buffers AC .....................................................................193

GRÁFICO 71 Distância entre os buffers de treinamento e os pesos dos neurônios para a rede CT1 - 5D2V - DR 199

GRÁFICO 72 Distância entre os buffers e os pesos dos neurônios vencedores para degraus descendentes da rede CT1 - 5D2V - DR para o CT1 .......204

GRÁFICO 73 Distância entre os buffers de treinamento e os pesos dos neurônios para a rede CT1 - 5D3V - DR ..............................................206

GRÁFICO 74 Distância entre os buffers e os pesos dos neurônios vencedores para degraus descendentes da rede CT1 - 5D3V - DR para o CT1 .......212

GRÁFICO 75 Distância entre os buffers de treinamento e os pesos dos neurônios para a rede CT1 - 710 - DR .................................................214

GRÁFICO 76 Distância entre os buffers e os pesos dos neurônios vencedores para degraus descendentes da rede CT1 - 710 - DR

GRÁFICO 77 Distância entre os buffers e os pesos dos neurônios vencedores para degraus ascendentes da rede CT1 - 710 - DR .............................218

GRÁFICO 78 Distância entre os buffers de treinamento e os pesos dos neurônios para a rede CT1 - 7D1V - DR 219 
GRÁFICO 79 Distância entre os buffers e os pesos dos neurônios vencedores para degraus ascendentes da rede CT1 - 7D1V - DR 222

GRÁFICO 80 Distância entre os buffers e os pesos dos neurônios vencedores para a simulação DELSBS60 da rede CT1 - 7D1V - DR 222

GRÁFICO 81 Distância entre os buffers e os pesos dos neurônios vencedores para a simulação ISOLABS da rede CT1 - 7D1 V - DR 223

GRÁFICO 82 Distância entre os buffers e os pesos dos neurônios vencedores para a simulação PRESSURIZA70k da rede CT1 - 7D1V - DR ..............223

GRÁFICO 83 Distância entre os buffers de treinamento e os pesos dos neurônios para a rede CT1 - 810 - DR 225

GRÁFICO 84 Distância entre os buffers e os pesos dos neurônios vencedores para degraus descendentes da rede CT1 - 810 - DR 228

GRÁFICO 85 Distância entre os buffers e os pesos dos neurônios vencedores para degraus ascendentes da rede CT1 - 810 - DR 228

GRÁFICO 86 Distância entre os buffers e os pesos dos neurônios vencedores para a simulação DELSBS60 da rede CT1 - 810 - DR 229

GRÁFICO 87 Distância entre os buffers e os pesos dos neurônios vencedores para a simulação ISOLABS da rede CT1 - 7D1 V - DR 229

GRÁFICO 88 Distância entre os buffers e os pesos dos neurônios vencedores para a simulação PRESSURIZA70k da rede CT1 - 810 - DR.................230

GRÁFICO 89 Distância entre os buffers de treinamento e os pesos dos neurônios para a rede CT1 - 8D3V - DR 231

GRÁFICO 90 Distância entre os buffers e os pesos dos neurônios vencedores para degraus descendentes da rede CT1 - 8D3V - DR 233

GRÁFICO 91 Distância entre os buffers e os pesos dos neurônios vencedores para degraus ascendentes da rede CT1 - 8D3V - DR 233

GRÁFICO 92 Distância entre os buffers e os pesos dos neurônios vencedores para a simulação ISOLABS da rede CT1 - 8D3V - DR 234

GRÁFICO 93 Distância entre os buffers e os pesos dos neurônios vencedores para a simulação DESLBS60 da rede CT1 - 8D3V - DR 234

GRÁFICO 94 Distância entre os buffers e os pesos dos neurônios vencedores para a simulação da PRESSURIZA70k da rede CT1 - 8D3V - DR .........235

GRÁFICO 95 Distâncias dos buffers aos neurônios nas redes triangular, quadrada, hexagonal e cúbica após o treinamento com o conjunto de

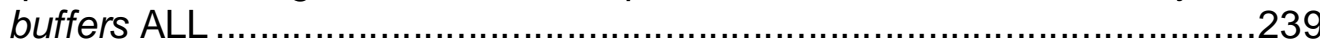

GRÁFICO 96 Distâncias durante o monitoramento da simulação de degraus descendentes para rede a) Triangular b) Quadrada c) Hexagonal d) Cúbica 241

GRÁFICO 97 Neurônios ativados pela rede cúbica para a simulação dos degraus descendentes .....................................................................242

GRÁFICO 98 Distâncias buffer-neurônio para a rede cúbica durante o monitoramento da simulação PRESSURIZA70k ...................................243

GRÁFICO 99 Neurônios ativados pela rede cúbica para a simulação PRESSURIZA70k .....................................................................244

GRÁFICO 100 Distâncias buffer-neurônio para a rede cúbica durante o monitoramento da simulação ISOLATC 
GRÁFICO 101 Neurônios ativados na rede hexagonal durante monitoração da simulação ISOLATC 246

GRÁFICO 102 Distâncias entre os buffers e os neurônios durante monitoração do experimento 11 com rede CT1 - 8D3V - DR

GRÁFICO 103 Distâncias entre os buffers e os neurônios durante monitoração do experimento 11 com rede cúbica CT1 - CUB - ALL 251

GRÁFICO 104 Distâncias entre os buffers e os neurônios durante monitoração do experimento $12 \mathrm{com}$ a rede CT1 - 8D3V - DR. 253

GRÁFICO 105 Distâncias entre os buffers e os neurônios durante monitoração do experimento 12 com rede cúbica CT1 - CUB - ALL..........................254

GRÁFICO 106 Neurônios ativados pela rede cúbica para a simulação dos degraus descendentes 255

GRÁFICO 107 Distâncias entre os buffers e os neurônios durante monitoração do experimento $18 \mathrm{com}$ a rede CT1 - 8D3V - DR.

GRÁFICO 108 Distâncias entre os buffers e os neurônios durante monitoração do experimento $21 \mathrm{com}$ a rede CT1 - 8D3V - DR.

GRÁFICO 109 Distâncias entre os buffers e os neurônios durante monitoração do experimento $23 \mathrm{com}$ a rede CT1 - 8D3V - DR.

GRÁFICO 110 Distâncias entre os buffers e os neurônios durante monitoração do experimento $23 \mathrm{com}$ a rede cúbica CT1 - CUB - ALL. 262

GRÁFICO 111 Distâncias entre os buffers e os neurônios durante monitoração da simulação DESLBS40_2 com a rede cúbica CT1 - CUB - ALL ..........263

GRÁFICO 112 Distância entre os buffers e os pesos dos neurônios para a rede IRIS - 810 - ALL após o treinamento. 267

GRÁFICO 113 Distâncias buffer-neurônio na rede IRIS-810-ALL para os casos a) 2PT-60, b) STP-60->70 e c) SGTR-60 270

GRÁFICO 114 Distância entre os buffers e os pesos dos neurônios para a rede IRIS - 8D3V - ALL após o treinamento. 272

GRÁFICO 115 Distâncias buffer-neurônio na rede IRIS-8D3V-ALL para os casos a) 2PT-60, b) STP-60->70 e c) SGTR-60 .........................................274

GRÁFICO 116 Potência na seção de testes - Exp11 ...................................310

GRÁFICO 117 Temperaturas no CT1 - Exp11 .........................................310

GRÁFICO 118 Pressão no pressurizador e no recalque da bomba - Exp11 ...311

GRÁFICO 119 Vazão no primário e no secundário - Exp11 ..........................311

GRÁFICO 120 Potência na seção de testes - Exp12 ....................................312

GRÁFICO 121 Temperaturas no CT1 - Exp12 ...............................................312

GRÁFICO 122 Potência na seção de testes - Exp13 ......................................313

GRÁFICO 123 Temperaturas no CT1 - Exp13...........................................313

GRÁFICO 124 Potência na seção de testes - Exp14 .......................................314

GRÁFICO 125 Temperaturas no CT1 - Exp14 ..............................................314

GRÁFICO 126 Potência na seção de testes - Exp15..................................315

GRÁFICO 127 Temperaturas no CT1 - Exp15...........................................315

GRÁFICO 128 Potência na seção de testes - Exp16 .....................................316

GRÁFICO 129 Temperaturas no CT1 - Exp16 ............................................316 
GRÁFICO 130 Potência na seção de testes - Exp17 ......................................317

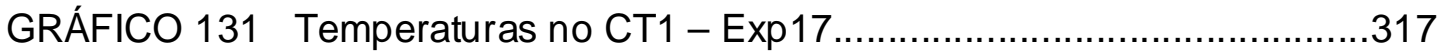

GRÁFICO 132 Pressão no pressurizador e no recalque da bomba - Exp17 ...318

GRÁFICO 133 Vazão no primário e no secundário - Exp17 ……………….....318

GRÁFICO 134 Potência na seção de testes - Exp18 ......................................319

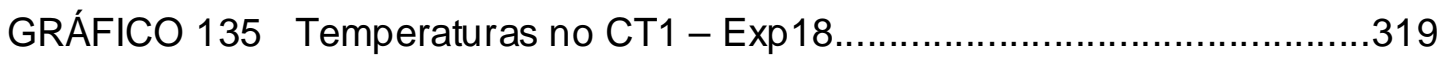

GRÁFICO 136 Potência na seção de testes - Exp19....................................320

GRÁFICO 137 Temperaturas no CT1 - Exp19..........................................320

GRÁFICO 138 Potência na seção de testes - Exp20 .....................................321

GRÁFICO 139 Temperaturas no CT1 - Exp20 .............................................321

GRÁFICO 140 Potência na seção de testes - Exp21 ......................................322

GRÁFICO 141 Temperaturas, até 10000 s, no CT1 - Exp21 ….......................322

GRÁFICO 142 Potência na seção de testes - Exp22 .....................................323

GRÁFICO 143 Temperaturas no CT1 - Exp22 ..........................................323

GRÁFICO 144 Pressão no pressurizador e no recalque da bomba - Exp22 ...324

GRÁFICO 145 Vazão no primário e no secundário - Exp22 ………….............324

GRÁFICO 146 Potência na seção de testes - Exp23........................................325

GRÁFICO 147 Temperaturas no CT1 - Exp23............................................325

GRÁFICO 148 Pressão no pressurizador e no recalque da bomba - Exp23 ...326

GRÁFICO 149 Vazão no primário e no secundário - Exp23 ……………….....326

GRÁFICO 150 Potência na seção de testes - Exp24 .....................................327

GRÁFICO 151 Temperaturas no CT1 - Exp24 ...........................................327

GRÁFICO 152 Pressão no pressurizador e no recalque da bomba - Exp24 ...328

GRÁFICO 153 Vazão no primário e no secundário - Exp24 …………............328

GRÁFICO 154 Potência na seção de testes - Exp25 .......................................329

GRÁFICO 155 Temperaturas no CT1 - Exp25 .............................................329

GRÁFICO 156 Pressão no pressurizador e no recalque da bomba - Exp25 ...330

GRÁFICO 157 Vazão no primário e no secundário - Exp25 ….........................330

GRÁFICO 158 Potência na seção de testes - Exp26.....................................331

GRÁFICO 159 Temperaturas no CT1 - Exp26...........................................331

GRÁFICO 160 Pressão no pressurizador e no recalque da bomba - Exp26 ...332

GRÁFICO 161 Vazão no primário e no secundário - Exp26 ………….............332

GRÁFICO 162 Potência na seção de testes - Exp27 ......................................333

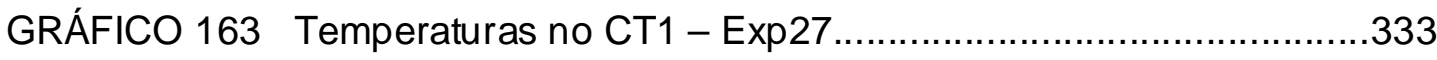

GRÁFICO 164 Pressão no pressurizador e no recalque da bomba - Exp27 ...334

GRÁFICO 165 Vazão no primário e no secundário - Exp27 …………............334

GRÁFICO 166 Temperaturas do fluido na ST, medidas e calculadas - Exp01 336

GRÁFICO 167 Temperaturas do fluido na ST, medidas e calculadas - Exp02 336

GRÁFICO 168 Temperaturas do fluido na ST, medidas e calculadas - Exp11 337

GRÁFICO 169 Temperaturas do fluido na ST, medidas e calculadas - Exp12 337

GRÁFICO 170 Temperaturas do fluido na ST, medidas e calculadas - Exp15338 
GRÁFICO 171 Temperaturas do fluido na ST, medidas e calculadas - Exp19 338

GRÁFICO 172 Temperaturas do fluido na ST, medidas e calculadas - Exp20 339

GRÁFICO 173 Potência na seção de testes para degraus decrescentes.

GRÁFICO 174 Amostragem da potência para todos os conjuntos de buffers de treinamento da simulação de degraus decrescentes 341

GRÁFICO 175 Amostragem da derivada da potência para todos os conjuntos de buffers de treinamento da simulação de degraus decrescentes................342

GRÁFICO 176 Amostragem de temperaturas para todos os conjuntos de buffers de treinamento da simulação de degraus decrescentes .........................342

GRÁFICO 177 Amostragem de derivadas de temperaturas para todos os conjuntos de buffers de treinamento da simulação de degraus decrescentes

GRÁFICO 178 Potência na seção de testes para degraus crescentes..............344

GRÁFICO 179 Amostragem de derivadas de temperaturas para todos os conjuntos de buffers de treinamento da simulação de degraus crescentes

GRÁFICO 180 Potência na seção de testes para rampas de $240 \mathrm{~s}$ crescentes 345

GRÁFICO 181 Amostragem de derivadas de temperaturas para todos os conjuntos de buffers de treinamento da simulação de rampas de $240 \mathrm{~s}$ crescentes...... 345

GRÁFICO 182 Amostragem da potência, para os conjuntos de buffers de treinamento, ALLOLD acima e todos os demais abaixo, da simulação do desligamento da bomba do secundário (DESLBS60) 346

GRÁFICO 183 Amostragem da vazão, para os conjuntos de buffers de treinamento, ALLOLD acima e todos os demais abaixo, da simulação do desligamento da bomba do secundário (DESLBS, DESLBS_2 e DESLBS_3 - 60)

GRÁFICO 184 Amostragem de derivadas de temperaturas, para os conjuntos de buffers de treinamento, ALLOLD acima e todos os demais abaixo, da simulação de o desligamento da bomba do secundário (DESLBS60) .....348

GRÁFICO 185 Amostragem da potência, para os conjuntos de buffers de treinamento, ALLOLD acima e todos os demais abaixo, da simulação do desligamento da bomba do secundário (DESLBS_2 60) ..........................349

GRÁFICO 186 Amostragem de temperaturas, para os conjuntos de buffers de treinamento, ALLOLD acima e todos os demais abaixo, da simulação do desligamento da bomba do secundário (DESLBS_2 60) 350

GRÁFICO 187 Amostragem de derivadas de temperaturas, para os conjuntos de buffers de treinamento, ALLOLD acima e todos os demais abaixo, da simulação do desligamento da bomba do secundário (DESLBS_2 60) ...351

GRÁFICO 188 Amostragem da potência, para os conjuntos de buffers de treinamento, ALLOLD acima e todos os demais abaixo, da simulação do desligamento da bomba do secundário (DESLBS_3 60) ..........................352

GRÁFICO 189 Amostragem da potência, para os conjuntos de buffers de treinamento, ALLOLD acima e todos os demais abaixo, da simulação do isolamento da bomba do secundário (ISOLABS) 353 
GRÁFICO 190 Amostragem da vazão, para todos os conjuntos de buffers de treinamento, exceto para o ALLOLD, da simulação do isolamento da bomba do secundário (ISOLABS) 354

GRÁFICO 191 Amostragem de temperaturas, para todos os conjuntos de buffers de treinamento, exceto para o ALLOLD, da simulação do isolamento da bomba do secundário (ISOLABS) 354

GRÁFICO 192 Amostragem da potência, para os conjuntos de buffers de treinamento, ALLOLD acima e todos os demais abaixo, da simulação do isolamento da bomba do secundário (ISOLABS_25) 355

GRÁFICO 193 Amostragem da vazão, para todos os conjuntos de buffers de treinamento, exceto para o ALLOLD, da simulação do isolamento da bomba do secundário (ISOLABS_25) 356

GRÁFICO 194 Amostragem de temperaturas, para todos os conjuntos de buffers de treinamento, exceto para o ALLOLD, da simulação do isolamento da bomba do secundário (ISOLABS_25) 356

GRÁFICO 195 Amostragem da potência, para os conjuntos de buffers de treinamento, ALLOLD acima e todos os demais abaixo, da simulação do isolamento da bomba do secundário (ISOLABS_75) 357

GRÁFICO 196 Amostragem da vazão, para todos os conjuntos de buffers de treinamento, exceto para o ALLOLD, da simulação do isolamento da bomba do secundário (ISOLABS_75) 358

GRÁFICO 197 Amostragem de temperaturas, para todos os conjuntos de buffers de treinamento, exceto para o ALLOLD, da simulação do isolamento da bomba do secundário (ISOLABS_75) 358

GRÁFICO 198 Amostragem da potência, para o conjunto de buffers de treinamento ALLOLD, da simulação do isolamento do trocador de calor (ISOLATC) 359

GRÁFICO 199 Amostragem da vazão, para o conjunto de buffers de treinamento ALLOLD, da simulação do isolamento do trocador de calor (ISOLATC) ..359

GRÁFICO 200 Amostragem das Temperaturas de entrada e saída, da ST e do Trocador de Calor, para os conjuntos de buffers de treinamento, ALLOLD acima e todos os demais abaixo, da simulação do isolamento do trocador de calor (ISOLATC) 360

GRÁFICO 201 Amostragem da potência, para todos os conjuntos de buffers de treinamento, da simulação do isolamento do trocador de calor (ISOLATC_25). 361

GRÁFICO 202 Amostragem das vazões, para todos os conjuntos de buffers de treinamento, da simulação do isolamento do trocador de calor (ISOLATC_25) 361

GRÁFICO 203 Amostragem de temperaturas, para todos os conjuntos de buffers de treinamento da simulação "isolamento do trocador de calor" (ISOLATC_25)... 362

GRÁFICO 204 Amostragem de derivadas de temperaturas, para todos os conjuntos de buffers de treinamento da simulação do isolamento do trocador de calor (ISOLATC_25) 
GRÁFICO 205 Amostragem da pressão, para os conjuntos de buffers de treinamento, ALLOLD acima e todos os demais abaixo, da simulação de pressurização e despressurização (PRESSURIZA70k) 363

GRÁFICO 206 Amostragem da derivada da pressão, para os conjuntos de buffers de treinamento, ALLOLD acima e todos os demais abaixo, da simulação de pressurização e despressurização (PRESSURIZA70k) ....364

GRÁFICO 207 Amostragem da temperatura, para todos os conjuntos de buffers de treinamento, exceto o ALLOLD, da simulação de pressurização e despressurização (PRESSURIZA70k) 365

GRÁFICO 208 Amostragem das vazões, para todos os conjuntos de buffers de treinamento, exceto o ALLOLD, da simulação de pressurização e despressurização - (PRESSURIZA70k) 365

GRÁFICO 209 Potências nuclear e na turbina - degrau 60->70\%...................367

GRÁFICO 210 Nível no pressurizador - degrau 60->70\%...............................367

GRÁFICO 211 Pressão no pressurizador - degrau 60->70\%...........................368

GRÁFICO 212 Temperaturas nas pernas fria e quente e media - degrau

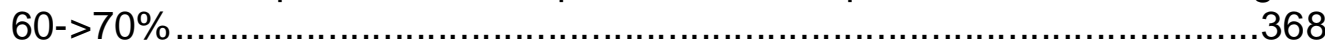

GRÁFICO 213 Potências nuclear e na turbina - SGTR2-60. ...........................369

GRÁFICO 214 Pressão no pressurizador e na turbina - SGTR2-60.................369

GRÁFICO 215 Nível no pressurizador - SGTR2-60 ….................................370

GRÁFICO 216 Temperaturas nas pernas fria e quente e media - SGTR2 .....370

GRÁFICO 217 Potência nuclear - degrau-50->60 com indicação dos buffers usados para o treinamento das redes SOM 371 


\section{NOMENCLATURA}

Vetores são representados em negrito.

e Vetor de entrada

$e_{n} \quad$ Módulo do componente da dimensão $n$ do vetor $\boldsymbol{e}$

w Vetor peso das ligações sinápticas do neurônio

$\mathrm{w}_{\mathrm{n}} \quad$ Módulo do componente da dimensão $\mathrm{n}$ do vetor $\boldsymbol{w}$

I Subscrito indicando inicial

F Subscrito indicando final

o Subscrito indicando fase de ordenamento durante o aprendizado

C Subscrito indicando fase de convergência durante o aprendizado

? Símbolo que representa, em uma palavra, um caractere, letra, algarismo ou símbolo, que pode ter vários valores diferentes. 


\section{INTRODUÇÃO}

\subsection{Considerações Gerais}

A construção de novas usinas nucleares como forma de geração de eletricidade enfrenta sérios desafios neste século XXI devido aos níveis de conscientização e de exigências da sociedade, especialmente no que se refere ao meio ambiente e à segurança. No caso da tecnologia nuclear os requisitos para o meio ambiente e a segurança englobam também as questões relativas aos rejeitos e à resistência à proliferação. É necessário, portanto, desenvolver novos projetos que estejam em consonância com as demandas da sociedade. Outro desafio atual que se apresenta para a implantação de novas usinas é a questão da competitividade, não só econômica, mas também financeira, dos novos projetos num contexto de liberalização e desregulamentação dos mercados de eletricidade onde os investimentos são feitos preferencialmente pelo setor privado, que requer um tempo de retorno do investimento bem mais curto que os antigamente praticados (ROGNER e LANGLOIS, 2000; ARONNE e JACOMINO, 2001).

Várias iniciativas têm sido feitas para estudar a viabilidade de novos reatores que satisfaçam os requisitos exigidos pelos tempos atuais. O Brasil participou de duas dessas iniciativas, uma liderada pela Agência Internacional de Energia Atômica-AIEA conhecida como INPRO-International Project on Innovative Nuclear Reactors and Fuel Cycles (IAEA, 2003) que após definir um conjunto de indicadores está aplicando-o a alguns projetos de reatores inovativos e a segunda iniciativa, liderada pelo Departamento de Energia (DOE) dos Estados Unidos e conhecida como Generation IV. A iniciativa Generation IV foi consolidada na forma de um fórum que contou com a participação de nove outros países: Argentina, Brasil, Canadá, França, Japão, Coreia do Sul, África do Sul, Suíça e Inglaterra e ficou conhecido pela sigla GIF - Generation IV International Forum (US-DOE, 2002; 2003) 
Os projetos inovativos em proposição no INPRO e no GIF devem estar disponíveis somente após 2030. Considerando os fatores apresentados observam-se várias iniciativas direcionadas à definição dos critérios básicos necessários para novos projetos e também ações para identificar aqueles projetos que têm potencial de viabilização no médio, 15 anos, e no longo prazo. Dentro desse grupo, conhecido como NTD-Near Term Deployment, encontra-se o conceito do reator IRIS - International Reactor Innovative \& Secure, que está sendo desenvolvido por um consórcio de 19 instituições de nove países liderado pela Westinghouse (UNIVERSIDADE POLITÉCNICA DE MILÃO, 2003). O Brasil participa desse projeto através da Comissão Nacional de Energia Nuclear e da NUCLEP e esta tese está ligada ao desenvolvimento desse projeto de reator nuclear - IRIS.

\subsection{Motivação}

Desde a intensa e extensa análise do acidente de Three Mile Island sabe-se que os fatores humanos são de fundamental importância para a segurança dos reatores da mesma forma que a disponibilidade de informações claras e confiáveis para a equipe de operação (IAEA, 2000). O trabalho aqui proposto, desenvolvimento de um aplicativo que possa evoluir para um sistema de suporte à equipe de operação do IRIS com uso de Redes Neurais Artificiais - RNA, com o fim de tornar a operação mais segura, é então relevante por contribuir para uma melhoria significativa desses dois fatores diminuindo 0 risco de acidentes e aumentando a disponibilidade e a competitividade da usina.

As técnicas e teorias desenvolvidas para as RNA, em particular para os Mapas Auto-Organizáveis - SOM (Self-Organizing Maps), têm demonstrado sua grande capacidade de resolver os problemas de identificação e classificação de padrões em situações reais sem necessidade de um aprendizado supervisionado.

O avanço das tecnologias de informática tanto em hardware como em software viabilizam a construção de sistemas que possam operar em tempo real. 
Para esse desenvolvimento serão utilizados hardware Pentium 4 e softwares de computadores usando a Programação Orientada a Objeto (POO) como o Visual $C_{++}$.net da Microsoft ou DELPHI 7.0, que foi utilizado na fase inicial desse projeto.

Assim a importância do aumento da segurança e disponibilidade da central, os desenvolvimentos em RNA, em particular o SOM, e o avanço da tecnologia de informática foram razões determinantes para estimular o desenvolvimento deste projeto.

\subsection{Objetivos}

O objetivo da tese é contribuir para o desenvolvimento de um sistema de suporte à equipe de operação do IRIS, com o fim de tornar a sua operação mais segura e aumentar o fator disponibilidade do reator devido à redução de paradas forçadas.

O Sistema de Identificação e Classificação de Transientes - SICT proposto tem a capacidade de atuar durante a operação do reator IRIS e mostrar um histórico recente da evolução dos transitórios do reator com sua identificação e classificação. Este SICT é baseado no monitoramento de alguns poucos parâmetros principais, cerca de uma dezena, identificados como mais relevantes e que são adequados às condições do projeto e da operação do reator.

O desenvolvimento do SICT foi feito usando a linguagem $\mathrm{C}_{++}$que suporta o uso de Programação Orientada a Objeto.

\section{Originalidade e Relevância}

A maior parte dos trabalhos sobre o uso de RNA na área nuclear não trata especifica e diretamente da detecção, identificação e classificação dos 
transientes e acidentes possíveis em reatores nucleares, mas sim de diagnósticos (BARTAL, LIN e UHRIG, 1995 e SANTOS et al., 2003) validação de sinais e instrumentação (FANTONI e MAZZOLA, 1996 e UPADHYAYA e ERYUREK, 1992) e avaliação de desempenho (GUO e UHRIG, 1992) entre outros.

O pré-processamento dos sinais de entrada selecionados e de suas sequências temporais tem recentemente se constituído, per si, em uma nova área de pesquisa que tem gerado vários trabalhos em desenvolvimento para redes de aprendizado supervisionado (MOZER, 1994 e YAMASAKI, 2004) e mesmo para redes de aprendizado não supervisionado, particularmente o SOM (CHO, 2000; MCQUEEN, 2003 e BARRETO, 2003) o que aumenta a motivação e o potencial de contribuição deste trabalho para a área.

Barreto (2003), em seu trabalho sobre redes neurais nãosupervisionadas temporais, fez uma extensa revisão bibliográfica e diz que o campo de identificação e controle de sistemas dinâmicos é totalmente dominado por RNA de aprendizagem supervisionada. Ele afirma ainda que existem poucos trabalhos na literatura sobre o uso de redes não supervisionadas o que dificulta os projetos de pesquisa nesta área e nas conclusões do trabalho apresenta uma série de temas relevantes para pesquisa neste tema.

A relevância e a conjunção das técnicas de RNA, acima citadas, com um reator com características e comportamento inéditos, levando à possibilidade de se fazer um sistema de identificação e classificação de transientes, reúnem vários fatores que compõem a originalidade desta pesquisa.

\subsection{Elaboração e Organização da Tese}

A tese foi elaborada com base em lgami e Zarpelon (2002) e está organizada em oito capítulos, sendo o primeiro esta Introdução, que contém os objetivos da pesquisa e a motivação para a realização da mesma. 
O segundo capítulo apresenta a revisão bibliográfica, descrevendo o reator IRIS, os principais conceitos sobre Redes Neurais Artificiais e Mapas Auto-Organizáveis, a identificação e classificação de transientes, assim como aspectos relativos à simulação de centrais nucleares, em particular do IRIS.

O terceiro capítulo descreve a metodologia utilizada para atingir os objetivos da pesquisa. São apresentados os procedimentos para as simulações do Circuito Térmico № 1 - CT1 e do IRIS com o RELAP5 e do pós-processamento dos resultados dessas simulações.

O quarto capítulo apresenta os experimentos termo-hidráulicos, descreve o CT1, seu sistema de coleta de dados e faz a caracterização dos resultados experimentais.

O quinto capítulo descreve as simulações com o RELAP5 relativas ao CT1 e IRIS.

O sexto capítulo descreve o Sistema de Identificação e Classificação de Transientes - SICT.

O sétimo capítulo apresenta as aplicações do SICT para o CT1 e IRIS e faz a avaliação final do uso do SICT.

O capítulo oitavo apresenta as considerações finais.

Um CD com o aplicativo desenvolvido, os dados experimentais, os dados de entrada para simulação do CT1 com o RELAP5 e os resultados dessas simulações foi anexado no fim deste volume. 


\section{REVISÃO BIBLIOGRÁFICA}

\section{$2.1 \quad$ O Reator IRIS}

O reator IRIS, descrito por Carelli et al., (2003), procura atender aos desafios apresentados pela sociedade para os novos reatores introduzindo melhorias nas questões referentes à: segurança, proliferação, rejeitos, economia e finanças. O conceito básico proposto para alcançar essas melhorias é o de um reator integral a água pressurizada de cerca de $1000 \mathrm{MW}$ térmicos. Essa configuração visa atender o mercado para usinas de médio porte, aproveitar a extensa experiência acumulada na operação dos reatores a água pressurizada (PWR-Pressurized Water Reactor) existentes no mundo e aumentar a segurança, eliminando ou minimizando a possibilidade de ocorrência de uma série de acidentes, entre eles o acidente de perda de refrigerante cuja ocorrência é minimizada pela diminuição das penetrações de tubulações no vaso de pressão.

Com o objetivo de aumentar o fator disponibilidade da usina, e também a sua segurança, o projeto do IRIS tem como meta a troca de combustível a cada oito anos, sendo que para os primeiros núcleos um período de quatro anos é aceitável. A manutenção programada também está sendo projetada para que possa ser realizada a cada quatro anos.

O projeto do reator IRIS tem, então, todos os componentes do circuito primário, geradores de vapor, bombas, pressurizador e blindagem do núcleo, dentro do vaso de pressão. Uma consequência dessa opção é o aumento da massa de água no circuito primário com o consequente aumento da inércia termohidráulica. Essa mudança na inércia e também a previsível mudança nos tempos de resposta da central em relação àqueles de um PWR convencional, mostra que o IRIS terá um comportamento bastante diferente de um PWR normal, fazendo com que sua simulação apresente desafios diferentes e, em decorrência, fazendo com que o desenvolvimento do SICT seja muito particular para esse reator. 


\subsubsection{Componentes Principais}

Conforme descrito por Azevedo et al. (2006) e em documento publicado pela IAEA (2004), o sistema primário do reator IRIS consiste de oito bombas de refrigeração do reator, oito geradores de vapor de tubos helicoidais e um pressurizador, localizado na parte superior do vaso de pressão, como mostra a FIG. 1. Ele engloba ainda o mecanismo de acionamento das barras de controle e uma blindagem do núcleo composta por um refletor de aço que melhora a economia de nêutrons e reduz a fluência dos mesmos no vaso de pressão do reator. Este arranjo integral elimina os componentes individuais e as conexões entre eles por meio de tubulações, resultando em uma configuração compacta e mais econômica.

O núcleo e os elementos combustíveis de $\mathrm{UO}_{2}$ do IRIS, embora similares aos do projeto convencional da Westinghouse, apresentam uma configuração que resulta em baixa densidade de potência, com repercussão favorável sobre a margem térmica. Isso possibilita um aumento da flexibilidade operacional, permite ciclos do combustível de maior duração e maiores fatores globais de capacidade da central. O controle de reatividade é realizado através de absorvedores queimáveis sólidos, barras de controle e do uso de uma quantidade limitada de boro solúvel no refrigerante do reator. A redução na quantidade de boro faz com que o coeficiente de reatividade fique mais negativo, aumentado assim a segurança intrínseca.

O trajeto do refrigerante dentro do vaso é também mostrado na FIG. 1. A água escoa no sentido ascendente no núcleo do reator até atingir uma câmara superior, onde ocorre a sucção das bombas. Cada bomba força o escoamento do refrigerante no sentido descendente através do seu gerador de vapor associado e o refrigerante retorna até a câmara inferior passando pela região anular externa ao núcleo do reator. 


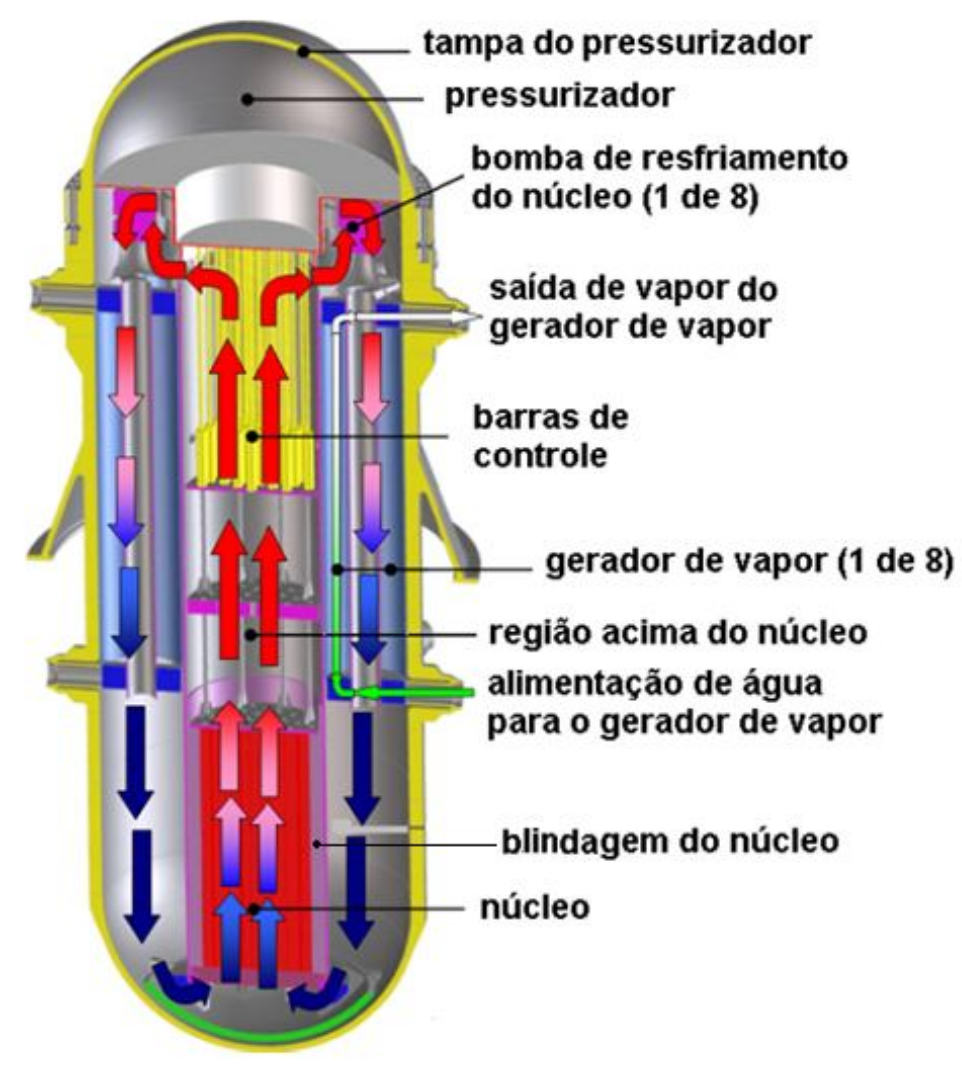

FIGURA 1 Principais Componentes do Reator IRIS Fonte: AZEVEDO et al., 2006

As bombas de refrigeração adotadas no IRIS são do tipo carretel, como mostrado na FIG. 2 e apresentado por Nevo (NEVO 2002). Esse tipo de bomba proporciona altas vazões com baixa altura manométrica. O motor e a bomba consistem de dois cilindros concêntricos, sendo o anel exterior o estator e o anel interno o rotor com os propulsores da bomba com alta velocidade específica. Essas bombas ficam localizadas totalmente dentro do vaso do reator, exigindo pequenas penetrações para os cabos de alimentação elétrica e, se necessário, para seu sistema de resfriamento. Sua configuração geométrica tem alta inércia, o que, em caso de desligamento, proporciona vazão ainda por algum tempo, o que contribui para minimizar as consequências de um hipotético acidente de perda de refrigerante, ocorrendo, por exemplo, pela abertura incorreta da válvula de segurança do pressurizador. 


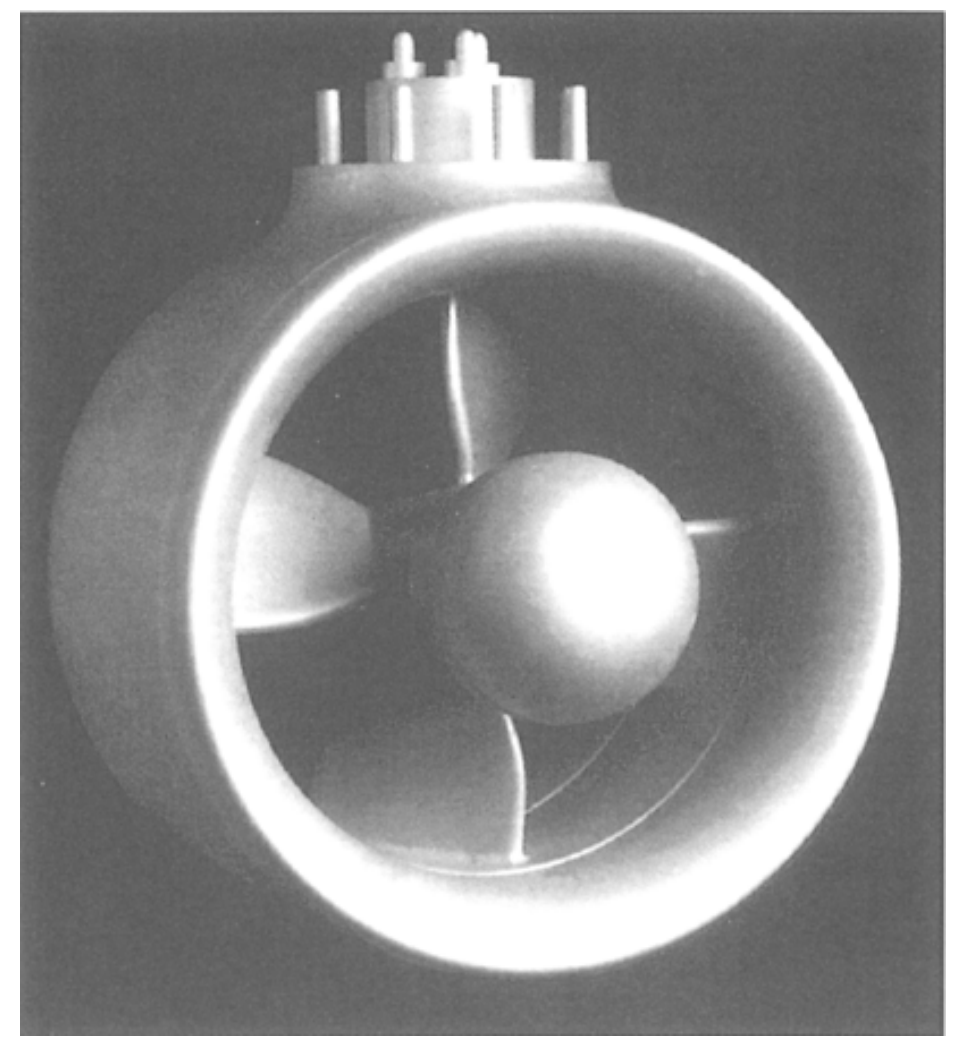

FIGURA 2 Bomba do refrigerante primário, tipo carretel Fonte: KUJAWSKI et al., 2002

Os geradores de vapor são do tipo feixe de tubos, de forma helicoidal, com o refrigerante primário circulando externamente aos tubos. Cada módulo é composto dos tubos, de uma câmara inferior para a entrada da água de alimentação, uma câmara superior para a saída de vapor, uma coluna de sustentação e de uma carcaça externa. Uma ilustração, mostrando a disposição dos tubos e a câmara de saída de vapor é apresentada na FIG. 3. Conforme descrito por Cioncolini et al. (2003) a água de alimentação entra no gerador de vapor pela câmara inferior, através de um bocal na parede do vaso do reator. Em sua subida dentro dos tubos do gerador de vapor até a câmara superior, ela é aquecida à temperatura de saturação, entra em ebulição e fica superaquecida. $O$ vapor, então, sai através de um bocal na parede do vaso de pressão. 


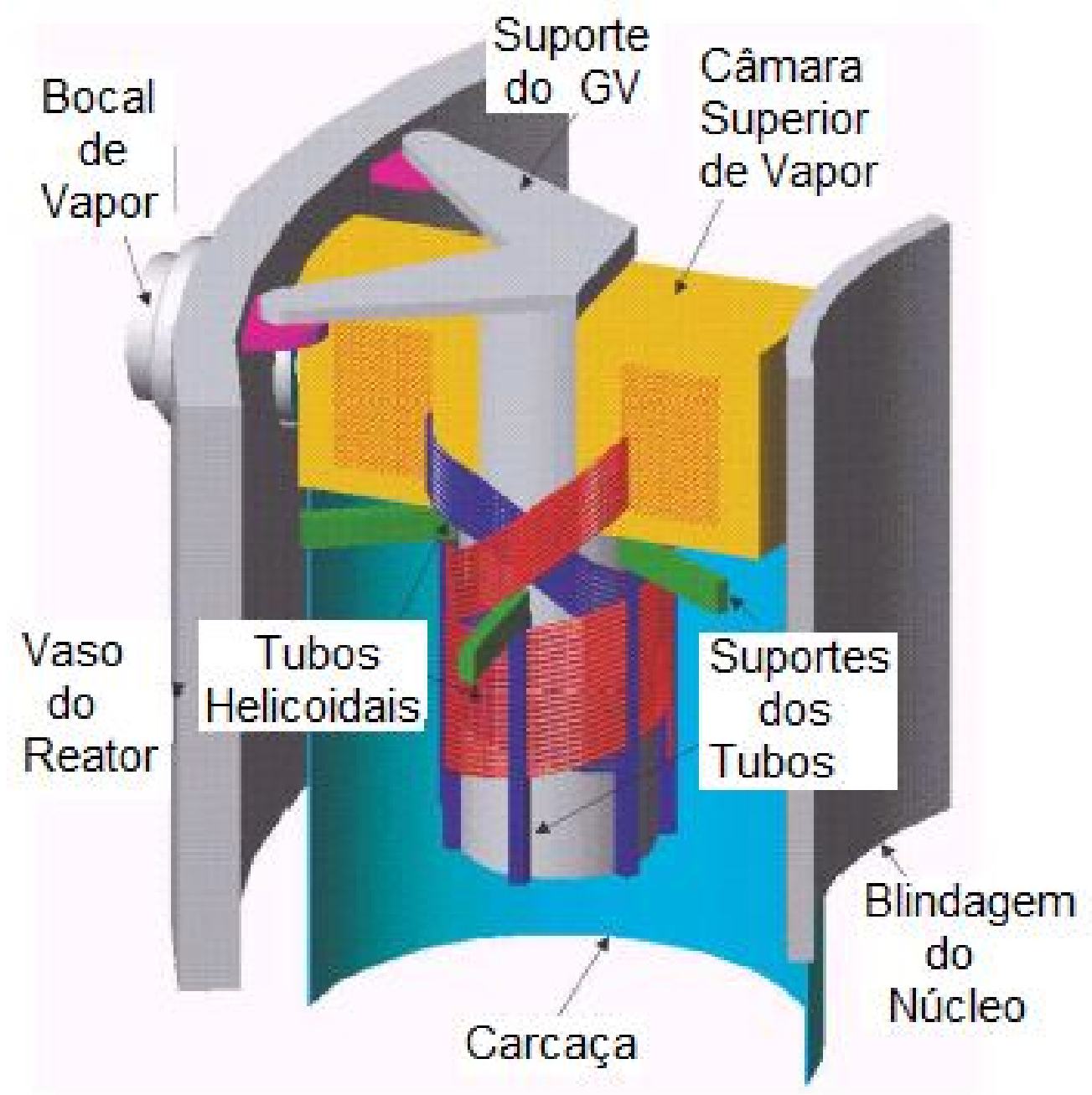

FIGURA 3 Parte superior do gerador de vapor de tubos helicoidais Fonte: AZEVEDO et al., 2006

O pressurizador do IRIS, mostrado na FIG. 4, é integrado ao tampo superior do vaso de pressão. A região do pressurizador é definida por uma estrutura isolada na forma de um chapéu invertido que separa a água saturada do pressurizador da água de circulação normal do refrigerante do reator, normalmente sub-resfriada. Essa estrutura contém uma isolação térmica tipo colmeia para minimizar a transferência de calor entre o fluido mais quente do pressurizador e a água sub-resfriada que está circulando no circuito primário. A estrutura em forma de chapéu invertido possui elementos aquecedores para compensar as perdas de calor e eventualmente aumentar a pressão. Na parte inferior desta estrutura estão localizados furos que permitem a passagem de surtos de refrigerante para esta região, no caso de 
um aumento de pressão no primário, ou dela, no caso contrário. Esses furos estão localizados abaixo dos aquecedores de modo que o surto ascendente passe por eles. Pela utilização da região superior do vaso de pressão, o pressurizador do IRIS proporciona volumes de água e de vapor muito grandes quando comparados com os pressurizadores tradicionais, com um vaso separado. Este fato torna desnecessário o uso da função aspersão para reduzir a pressão do sistema de modo a evitar a atuação da válvula de segurança, em qualquer dos casos postulados de aquecimento excessivo. A Comissão Nacional de Energia Nuclear (CNEN) e a Nuclebrás Equipamentos Pesados (NUCLEP) foram responsáveis pelo projeto e análise do pressurizador apresentado.

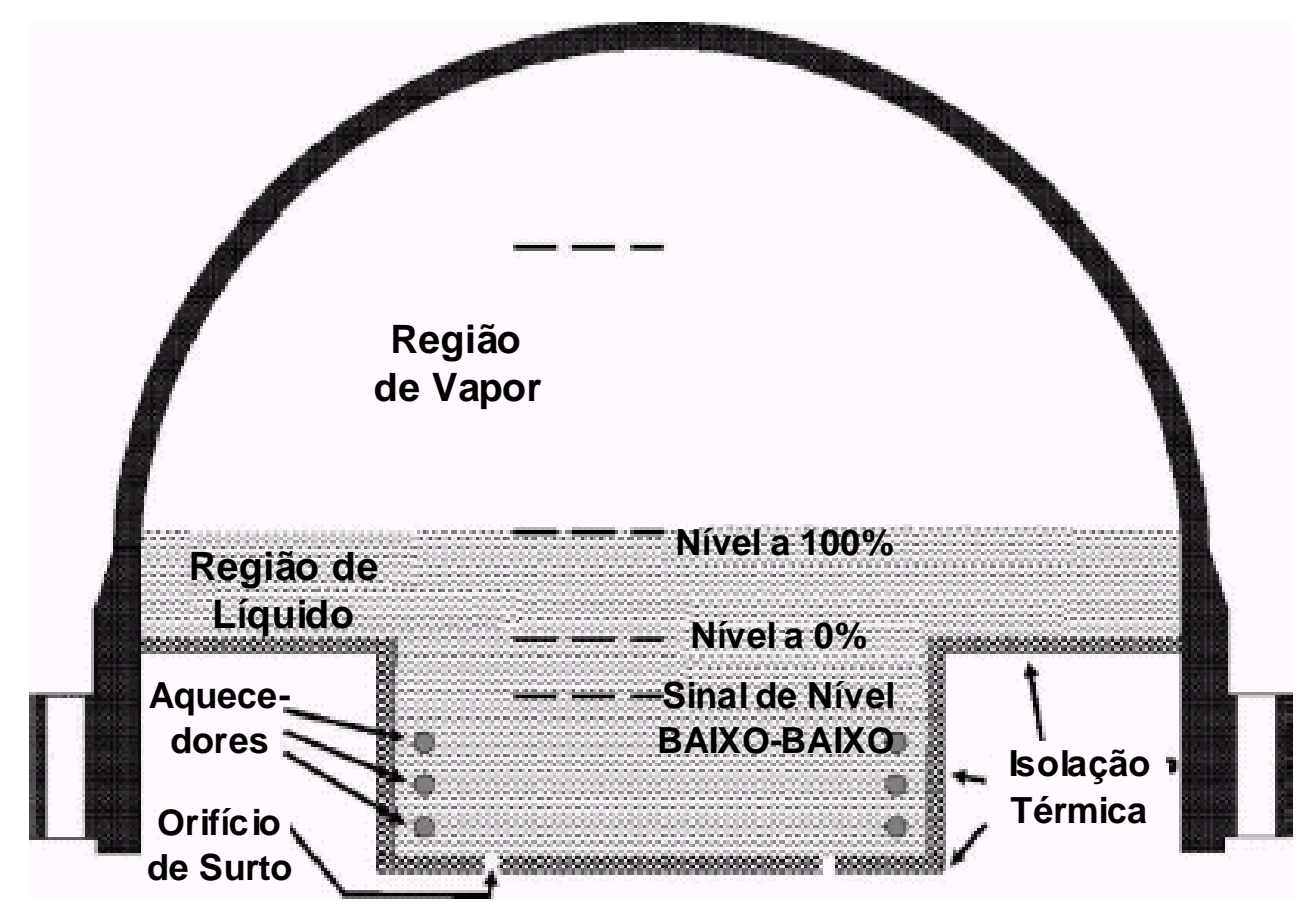

FIGURA 4 Pressurizador no tampo do vaso de pressão Fonte: CARELLI et al., 2004

Devido ao fato que a configuração integral elimina as tubulações dos circuitos e os geradores de vapor e bombas montados externamente, o vaso de pressão do reator pode ser colocado em uma estrutura de contenção de menor diâmetro. Essa redução de tamanho da contenção aliada à sua geometria esférica resulta em uma capacidade de pressão de projeto cerca de três vezes mais alta que uma contenção cilíndrica típica, considerando 
ambas as contenções com paredes de mesma espessura e com o mesmo nível de tensão. O vaso de contenção é construído em aço e faz uso de um reservatório de supressão de pressão que limita o pico de pressão bem abaixo do valor de projeto. Esse reservatório é posicionado em um nível cuja elevação proporciona uma descarga por gravidade em casos de eventos de perda de refrigerante causados por pequena ou media rupturas, uma vez que se considera impossível a ocorrência uma grande ruptura. Na parte inferior, existe também uma cavidade, que assegura que a região inferior do vaso de pressão do reator esteja sempre submersa em água no caso de qualquer evento de perda de refrigerante.

\subsubsection{Instrumentação e Controle}

O controle da central é baseado na estratégia na qual a potência do reator segue a demanda. No caso de queda da frequência da rede, esta é automaticamente compensada pela válvula de controle da turbina e um aumento da pressão na turbina resultará em um acréscimo na potência do reator. O reator IRIS é projetado para, no intervalo de potência entre $15 \%$ e plena carga, suportar as seguintes ocorrências operacionais sem que ocorra o desarme do reator ou a atuação dos sistemas passivos de segurança:

- $\quad$ variação de carga em rampa de $\pm 5 \% /$ minuto,

- $\quad$ variação de carga em degrau de $\pm 10 \%$,

- rejeição total de carga,

- $\quad$ seguimento de carga diária nos níveis de potência de 100-50-100\% (em 90\% do ciclo de vida do combustível),

- $\quad$ variações de frequência da rede equivalentes a uma variação de potência de $10 \%$ (pico a pico) a uma taxa de $2 \% /$ minuto e

- $\quad$ perda de uma única bomba de água de alimentação. 
Para atingir esse desempenho descrito, foi desenvolvido um sistema de controle baseado em parte na experiência dos reatores PWR e em parte no sistema desenvolvido para o AP1000. Conforme descrito por Oriani et al. (2004), os principais sistemas de controle individuais que compõem o sistema do IRIS são:

- $\quad$ sistema das barras de controle,

- $\quad$ sistema de controle da pressão do primário,

- $\quad$ sistema de controle da pressão do vapor,

- $\quad$ sistema de controle do nível do pressurizador,

- $\quad$ sistema de desvio de vapor,

- $\quad$ sistema de controle da água de alimentação e

- $\quad$ sistema de controle da água de alimentação de partida

Desses sistemas de controle, três apresentaram particular interesse durante a simulação do IRIS com o RELAP5:

\section{Sistema de Controle da Pressão do Primário}

O sistema de controle do pressurizador opera para manter a pressão do pressurizador constante e próxima da nominal durante operação normal e durante transientes. A queda de pressão é controlada pelo aumento de potência dos aquecedores e o aumento de pressão é controlado devido ao grande volume de vapor no pressurizador que pode absorver a excursão de pressão e pela perda de calor por convecção para o ambiente da contenção, além da diminuição da potência dos aquecedores. 


\section{Sistema de Controle da Pressão do Vapor}

O sistema de controle da pressão do vapor é feito através do controle da válvula de admissão de vapor na turbina que indiretamente controla também a potência entregue à turbina.

O sistema de controle da pressão do vapor proporciona controle automático da pressão na câmara de entrada da turbina (steam header) durante a operação de potência do reator. O sistema é capaz de manter a pressão do vapor no valor programado em função da potência real da turbina, seguindo variações da potência.

O sistema atua na Válvula Reguladora de pressão da Turbina (TTV) e mantêm a pressão de vapor no valor programado fechando ou abrindo a válvula. No caso do valor de Desligamento da Turbina (Turbine Trip) ser alcançado, a TTV fecha rapidamente e o sistema é desligado.

\section{Sistema de Controle das Barras de Controle ou de Potência Nuclear}

O controle da potência nuclear no IRIS é feito através do sistema das Barras de Controle, que proporcionam controle automático dos bancos de barras de controle durante operação do reator em potência. O sistema é capaz de restabelecer a temperatura média, e por consequência as temperaturas das pernas fria e quente, do reator para dentro do faixa morta de temperatura programada após mudanças na potência. No sistema de controle adotado a temperatura média é definida em função da potência. Ele consiste em dois canais, um que controla a temperatura média do refrigerante e outro que leva em conta $o$ desequilíbrio entre a potência nuclear e a carga da turbina.

No caso de um sinal de desligamento do reator, a queda das barras de controle ocorre por gravidade. 


\subsubsection{Segurança}

Conforme a norma ANSI 18.2 (ANSI, 1973 apud ORIANI, 2002), as condições do reator são classificadas em quatro categorias dependendo da frequência de ocorrência e das consequências radiológicas. O princípio básico incorporado nesta classificação considera que as ocorrências mais prováveis devem resultar em um risco radiológico reduzido e as situações extremas que tenham um risco maior devem ter menor probabilidade de ocorrência. Essas categorias são:

- Condição l: operação normal e transientes operacionais - são os eventos com previsão de ocorrência regular ou frequente durante a operação normal. Nessa condição se incluem a operação em estado estacionário e a de desligamento, operação com desvios permitidos e transientes operacionais.

- Condição II: falhas de frequência moderada - inclui todas as falhas de ocorrência não esperada durante a operação normal do reator, mas que podem ser razoavelmente esperadas durante a vida do reator. Estas falhas, no pior caso, resultarão no desarme do reator com a interrupção da operação da usina. Por definição, esses eventos ou falhas não evoluem para uma condição mais séria e nem se espera que tenham como consequência a perda de função das barreiras de proteção contra o escape de produtos radioativos. O núcleo do reator deve manter a capacidade de controlar a reatividade e de remover 0 calor gerado e, além disso, o número de falhas do revestimento do combustível não deve levar a uma situação que exceda à capacidade do sistema de purificação da central.

- $\quad$ Condição III: Falhas Infrequentes - esses eventos podem ocorrer com baixa frequência durante a vida da central. Eles podem resultar na falha de apenas uma pequena fração das varetas combustíveis. Por definição, esses acidentes não evoluem para um evento da condição IV e nem resultam em perda de função do sistema de refrigeração do 
reator ou das barreiras de contenção. A liberação de radioatividade não é suficiente para interromper ou restringir o uso público de áreas além da zona de exclusão. E

- $\quad$ Condição IV: Falhas Limitantes - são falhas que não se espera que ocorram, mas são postuladas porque suas consequências incluem a liberação de quantidades significativas de material radioativo. São contra essas falhas que a central deve ser projetada e elas representam casos limitantes de projeto. Eventos desta condição não podem levar a uma liberação de produtos de fissão acima de valores estabelecidos em norma e um evento isolado não pode causar uma perda de funções dos sistemas necessários para debelar o acidente.

A primeira linha de defesa na filosofia de defesa em profundidade do IRIS consiste na eliminação de condições iniciadoras que poderiam levar a danos no núcleo. Como é impossível a eliminação de todos os acidentes, o projeto possui características que possibilitam inerentemente tanto a redução da probabilidade de ocorrência como a redução de suas consequências. $O$ emprego da configuração integral é intrinsecamente favorável à eliminação de acidentes, especialmente quanto a acidentes de perda de refrigerante por grandes rupturas. As principais características do IRIS que repercutem na eliminação de eventos iniciadores são mostradas no QUADRO. 1. A resposta do IRIS, frente a eventos classificados como falhas limitantes (condição IV), é mostrada no QUADRO. 2. 
QUADRO 1 - Implicações de Segurança do IRIS

\begin{tabular}{|c|c|c|}
\hline $\begin{array}{l}\text { Característica de } \\
\text { Projeto do IRIS }\end{array}$ & Implicação de Segurança & Acidentes Afetados \\
\hline Configuração Integral & $\begin{array}{l}\text { Inexistência de grandes tubulações } \\
\text { no primário }\end{array}$ & -Acidentes de perda de refrigerante \\
\hline \multirow{3}{*}{$\begin{array}{l}\text { Maior Tamanho e } \\
\text { Altura do Vaso do } \\
\text { Reator }\end{array}$} & Maior inventário de água & $\begin{array}{l}\text {-Acidentes de perda de refrigerante } \\
\text {-Redução na remoção de calor }\end{array}$ \\
\hline & Elevada circulação natural & -Diversos eventos \\
\hline & $\begin{array}{l}\text { Possível acomodação interna do } \\
\text { mecanismo de acionamento de } \\
\text { barras }\end{array}$ & $\begin{array}{l}\text {-Ejeção de barras de controle } \\
\text {-Eliminação de penetrações }\end{array}$ \\
\hline \multirow[t]{2}{*}{$\begin{array}{l}\text { Remoção de Calor do } \\
\text { Interior do Vaso }\end{array}$} & $\begin{array}{l}\text { Despressurização do sistema } \\
\text { primánio por condensação sem } \\
\text { perda de massa }\end{array}$ & -Acidentes de perda de refrigerante \\
\hline & $\begin{array}{l}\text { Efetiva remoção de calor pelos } \\
\text { geradores de vapore peb sistema } \\
\text { de remoção de calor de emergência }\end{array}$ & $\begin{array}{l}\text {-Acidentes de perda de refrigerante } \\
\text {-Todos os eventos que requerem } \\
\text { resfriamento efetivo } \\
\text {-Transientes decorrentes de falta } \\
\text { do desarme do reator }\end{array}$ \\
\hline $\begin{array}{l}\text { Contenção de } \\
\text { Tamanho Reduzido e } \\
\text { MaiorPressão de } \\
\text { Projeto }\end{array}$ & $\begin{array}{l}\text { Redução da força de expulsão } \\
\text { através da ruptura do primánio }\end{array}$ & - Acidentes de perda de refrigerante \\
\hline $\begin{array}{l}\text { Múltiplas Bombas de } \\
\text { Refrigerante }\end{array}$ & $\begin{array}{l}\text { Redução da importância da falha de } \\
\text { uma única bomba }\end{array}$ & $\begin{array}{l}\text { - Travamento do rotor, quebra } \\
\text { de eixo }\end{array}$ \\
\hline \multirow{3}{*}{$\begin{array}{l}\text { Sistema Gerador de } \\
\text { Vapor com Alta } \\
\text { Pressão de Projeto }\end{array}$} & $\begin{array}{l}\text { Inexistência de válvula de } \\
\text { segurança no Gerador de Vapor }\end{array}$ & \\
\hline & $\begin{array}{l}\text { O sistema primário é incapaz de } \\
\text { sobrepressurizar o sistema } \\
\text { secundário }\end{array}$ & $\begin{array}{l}\text { - Ruptura do tubo do gerador de } \\
\text { vapor }\end{array}$ \\
\hline & $\begin{array}{l}\text { O sistema água de } \\
\text { alimentação/vapor projetado para a } \\
\text { pressão do primário reduz a } \\
\text { probabilidade de falhas de } \\
\text { tubulação }\end{array}$ & $\begin{array}{l}\text { - Ruptura da linha de vapor } \\
\text { - Ruptura da linha de água de } \\
\text { alimentação }\end{array}$ \\
\hline $\begin{array}{l}\text { Gerador de Vapor de } \\
\text { Passagem Direta } \\
\text { (Once Through) }\end{array}$ & Limitado inventário de água & $\begin{array}{l}\text { - Ruptura da linha de vapor } \\
\text { - \{Ruptura da linha de } \\
\text { alimentação\} }\end{array}$ \\
\hline
\end{tabular}




\begin{tabular}{ll|l}
\hline $\begin{array}{l}\text { Característica de Implicação de Segurança } \\
\text { Projeto do IRIS }\end{array}$ & Acidentes Afetados \\
\hline Pressunizador Integral & $\begin{array}{l}\text { Alta relação entre volume } \\
\text { pressurizador e potência do reator }\end{array}$ & $\begin{array}{l}\text { - Eventos de sobreaquecimento, } \\
\text { inclusive ruptura da linha de } \\
\text { alimentação. } \\
\text { - Transientes decorrentes de falta } \\
\text { do desarme do reator }\end{array}$ \\
\hline
\end{tabular}

Fonte: CARELLI et al., 2004.

QUADRO 2 - Resposta do IRIS a Falhas Limitantes

\begin{tabular}{l|l}
\hline Eventos Limitantes - Base de Projeto & Efeito do Projeto do Reator \\
\hline Perda de refrigerante por grande ruptura & $\begin{array}{l}\text { Eliminada por projeto (inexistência de } \\
\text { grandes tubulações) }\end{array}$ \\
\hline Ruptura de tubo do gerador de vapor & Consequência reduzida \\
\hline Falha de tubulação do sistema de vapor & $\begin{array}{l}\text { Probabilidade reduzida, consequências } \\
\text { reduzidas ou eliminadas }\end{array}$ \\
\hline $\begin{array}{l}\text { Ruptura de tubulação de água de } \\
\text { alimentação }\end{array}$ & $\begin{array}{l}\text { Probabilidade reduzida, consequências } \\
\text { reduzidas (sem liberação de alta pressão } \\
\text { a partir do primário) }\end{array}$ \\
\hline $\begin{array}{l}\text { Ruptura / dano de eixo da bo mba do } \\
\text { refrigerante do reator }\end{array}$ & Consequências reduzidas \\
\hline Acidentes de ejeção de barras de controle & Potencialmente eliminados por projeto \\
\hline Acidentes de Manuseio do Combustível & Sem impacto \\
\hline
\end{tabular}

Fonte: CARELLI et al., 2004.

\subsubsection{Transientes e Acidentes Usados neste Desenvolvimento}

Foi feita uma análise preliminar de segurança do IRIS (NEVO et al., 2002), abrangendo as suas principais sequências de transientes e acidentes, com o fim de serem usados em simulações com o RELAP5. A seguir será apresentada uma breve descrição dos acidentes simulados neste trabalho. 


\section{Abertura da Válvula de Segurança do Pressurizador (PSV) / Acidente de Perda de Refrigerante por Pequena ruptura}

A abertura acidental da válvula de segurança do reator causa uma forte queda na pressão do reator, que resulta em um decréscimo da reatividade, em virtude do coeficiente de reatividade do moderador. A queda da temperatura média do refrigerante é lenta e o nível do pressurizador também cai. O desarme do reator ocorre tipicamente pelo sinal de baixa pressão no pressurizador. Com pequeno atraso, ocorrem o desarme da turbina e o isolamento das linhas de vapor. A sequência do acidente resulta na atuação de um sinal de segurança, proveniente da baixa pressão do pressurizador combinada com alta pressão da contenção. Neste caso, é atuado o sistema de remoção de calor residual de emergência.

\section{0\% Desligamento abrupto (Turbine Trip - TT)}

Este evento é causado pelo rápido fechamento das válvulas de bloqueio da turbina no caso de um sinal de desarme da turbina, que pode ser originado pelo desarme do reator, pelo desarme do gerador elétrico, por falha da própria turbina, por baixo vácuo do condensador ou manualmente. A vazão de vapor para a turbina é interrompida e desviada para o sistema de desvio de vapor, que tem capacidade para a vazão total. Dependendo das hipóteses consideradas, como a perda simultânea do fornecimento externo de energia elétrica ou falha do primeiro sinal de desarme, a sequência do acidente pode variar. No caso analisado, a ativação do sinal de desarme do reator devido ao desarme da turbina foi atuado desligando a potência do reator.

\section{0\% Desligamento abrupto (Trip do Reator - RT)}

Dependendo das hipóteses consideradas, pode haver uma redução da capacidade do sistema secundário de remover o calor residual gerado pelo 
sistema primário, com a perda da água de alimentação aliada a uma perda do suprimento externo de energia. Mesmo neste caso considerado de queda de energia, ocorre o desligamento do reator devido à falta de alimentação no mecanismo de acionamento das barras de controle e neste caso, o calor residual é removido pelo sistema de remoção de calor residual normal da central, alimentado pelo suprimento de energia local de emergência, e, em caso de falha deste, pelo sistema de remoção de calor residual de emergência, dimensionado para remover todo o calor residual gerado através de circulação natural. No caso analisado, o desarme do reator é atuado manualmente e com pequeno atraso, é gerado o sinal de desarme da turbina.

\section{Desligamento de 2 bombas do primário (2PT)}

Uma perda da vazão do refrigerante primário pode ser resultante de uma falha mecânica ou elétrica, ou da interrupção ou queda de frequência da rede elétrica de alimentação em uma ou mais bombas do refrigerante. Conforme a potência de operação, a perda de vazão pode potencialmente levar a uma situação de afastamento da ebulição nucleada (Departure of Nucleate Boiling - DNB) no núcleo do reator. No acidente considerado neste estudo ocorre a perda de duas bombas do refrigerante devido a perda de alimentação elétrica, resultando em uma redução da vazão até atingir o valor de referência de baixa vazão (ou de baixa rotação), que resulta no desarme do reator. A inércia das bombas e o pequeno tempo de atraso até a ocorrência do desarme são suficientes para evitar o DNB, sem a necessidade da atuação dos sistemas passivos de segurança.

\section{Degrau $100 \% \rightarrow 50 \%$}

Este evento é similar ao isolamento de duas das bombas de água de alimentação. A sequência do evento é, portanto, similar à descrita no caso de perda total da água de alimentação, também resultando no desarme do reator. 
Este caso terá a mesma sequência do evento de perda total da água de alimentação, diferindo apenas nos instantes de tempo, e dependendo, também da ocorrência do sinal de baixa temperatura de entrada no reator. Caso não seja atingido esse sinal, a evolução deste evento será similar à do caso de perda parcial da água de alimentação, descrito acima.

\section{Perda total da água de alimentação dos Geradores de Vapor (TLFW)}

Este acidente consiste em uma redução na capacidade do sistema secundário em remover o calor gerado pelo sistema primário. As principais causas são falha de bomba ou de válvulas associadas ou a perda do suprimento de energia elétrica. Neste caso, ao atingir o sinal de baixa vazão da água de alimentação, a água de alimentação de partida é ativada, a válvula de isolamento da água de alimentação principal é fechada e ocorre o desligamento do reator. $\mathrm{O}$ sinal de baixa vazão da água de alimentação e desligamento do reator são condições que ativam o sistema de remoção de calor residual de emergência. Ocorrendo um sinal de baixa temperatura de entrada no núcleo, ocorre o desarme das bombas do refrigerante e, neste caso, haverá a atuação do sistema de boração extra.

\section{Perda parcial da água de alimentação dos Geradores de Vapor (PLFW)}

Este evento consiste no isolamento de apenas uma das bombas de água de alimentação. A sequência do evento é similar à descrita no caso de perda total da água de alimentação, também resultando no desligamento do reator. A diferença entre os dois acidentes é que, neste caso, não ocorre o desligamento das bombas do refrigerante, pois a atuação do sistema de refrigeração de emergência só ocorre no circuito afetado e, assim, a temperatura de entrada do núcleo não atinge o sinal de baixa temperatura que levaria ao desarme das bombas do refrigerante. 


\section{Ruptura de tubos de Geradores de Vapor (SGTR)}

O IRIS tem geradores de vapor compactos, completamente inseridos no vaso de pressão. Em caso de pequenas rupturas em um ou mais tubos do gerador de vapor, o sistema de monitoração da radiação no secundário detectará alta atividade, provocando o bloqueio das válvulas de isolamento do secundário, isolando assim apenas os circuitos afetados. Geralmente, na análise e simulação desse acidente, não é levada em consideração a imediata detecção da atividade do sistema secundário. Devido à ruptura de tubo do gerador de vapor, o nível do pressurizador começa a cair, exigindo a atuação do sistema de controle de nível, que tenta repor a perda de massa do primário. Ainda do lado do primário, ocorre uma queda da pressão do sistema, exigindo a atuação dos aquecedores, que atuam de modo a evitar a queda de pressão. A consideração da atuação desses sistemas de controle se justifica, pois isso resulta em um atraso para o reconhecimento do acidente. Do lado do secundário, ocorre o desequilíbrio entre a vazão da água de alimentação e a vazão do vapor. Este desequilíbrio é detectado pelo sistema de proteção e resulta em um sinal de desarme do reator, que geralmente não é considerado nas análises. Mesmo considerando as hipóteses mais conservativas, a contínua redução do inventário do primário resultará no desarme do reator, seja devido ao baixo nível do pressurizador, por baixa pressão, por sobretemperatura, ou ainda devido ao baixo superaquecimento do vapor enviado à turbina. Em qualquer caso, o bloqueio das válvulas do vapor $\mathrm{e}$ da água de alimentação evita qualquer liberação de produtos de fissão, sendo desnecessária qualquer ação adicional para trazer o sistema a uma condução segura, pois após o isolamento, o gerador de vapor com o tubo rompido fica repleto com a água do primário. Neste evento, pode ainda ocorrer a atuação do sistema de remoção de calor residual de emergência e do sistema de boração extra, se a perda do refrigerante primário for suficiente para resultar na atuação do baixo nível do pressurizador ou baixa temperatura da perna fria. 


\section{Ruptura total da linha de vapor (SLDER)}

Um aumento excessivo na vazão de vapor do lado secundário resulta em um desequilíbrio entre a potência do reator e a potência demandada pela turbina. Quaisquer desequilíbrios que superem os previstos pelo projeto podem resultar no desarme do reator. O comportamento dos geradores de vapor, de passagem direta, empregados no IRIS difere daquele dos geradores de vapor com tubos em $U$, de modo que, um aumento na vazão de vapor obriga necessariamente a um aumento da vazão da água de alimentação, de modo que é esta quem controla a potência. Portanto, o evento de ruptura da linha de vapor, de maneira similar ao evento de quebra da linha de água de alimentação, resultará em uma redução na remoção de calor. Entretanto, neste caso há uma maior pressurização da contenção devido à liberação de energia para ela. Neste acidente, o desarme do reator ocorre por baixa pressão do vapor, que resulta no isolamento da contenção e na atuação do sistema de remoção de calor residual de emergência. O dimensionamento da área da ruptura é dado pela área da tubulação de vapor, pois não há a previsão do emprego de restrição para a linha de vapor. Devido à interação entre a ruptura e o sistema de controle, a vazão da água de alimentação é interrompida para todos os oito geradores de vapor. O desarme do reator ocorre por baixa pressão do vapor e o fechamento das válvulas de bloqueio de vapor limita a pressurização da contenção.

\subsection{Redes Neurais e Mapas Auto-Organizáveis}

\subsubsection{Histórico}

Conforme descrito por Haykin (1999), o campo de redes neurais artificiais começou a ser desenvolvido na década de 1940, motivado pelo reconhecimento da capacidade do cérebro humano em desempenhar as mais diferentes tarefas. As redes neurais processam informações de maneira inteiramente diferente de um computador digital. $\mathrm{O}$ cérebro pode ser visto como 
um computador paralelo, altamente complexo e não-linear, que tem a capacidade de se organizar para realizar determinadas tarefas, tais como reconhecimento de padrões e controle, de uma forma extremamente rápida e mais eficiente que o melhor dos computadores existentes hoje em dia.

Durante as décadas de 50 e 60 os trabalhos inovadores nessa área foram criando novas técnicas e descobrindo novas características do cérebro humano que estimularam a criação de novos modelos de organização das redes neurais. Os desenvolvimentos de modelos e teorias ficaram, no entanto, aquém das suas aplicações e durante a década de 70 havia certo desânimo na área. Essa situação foi revertida na década de $80 \mathrm{com}$ a introdução do algoritmo de retro-propagação e com a difusão do uso de microcomputadores, que permitiram implementar e testar os complexos modelos desenvolvidos. Portanto a utilização e o desenvolvimento de redes neurais, assim como a compreensão do cérebro, têm evoluído intensamente nos últimos vinte anos.

Os Mapas Auto-Organizáveis foram desenvolvidos por Teuvo Kohonen na década de 80, conforme relatado por Braga et al. (2000) e, desde então, o uso dessa técnica tem se expandido por diversas áreas conforme se pode depreender da lista de 2093 artigos referenciados por Oja et al. (2002) que foram publicados entre 1998 e 2001 e dos 5384 trabalhos relacionados com o SOM citados nessa mesma referência. O desenvolvimento da técnica SOM foi motivado por uma característica particular do cérebro humano: ele é em muitos lugares organizado de uma maneira que diferentes entradas sensoriais são representadas por mapas computacionais topologicamente ordenados, decorrendo daí uma das principais características dessa RNA, a sua capacidade de agrupamento por características semelhantes.

\subsubsection{Características Básicas das Redes Neurais Artificiais}

O desenvolvimento e os conceitos usados nas redes neurais artificiais foram em grande parte inspirados pela organização e funcionamento do sistema 
nervoso dos animais. Uma rede neural artificial é formada de elementos que simulam a unidade básica do cérebro, o neurônio, e também suas interligações (sinapses) e especializações. As RNA se assemelham então ao cérebro em dois aspectos:

1 - o conhecimento é adquirido pela rede através de um processo de aprendizado, que leva à capacidade de generalização, e

2 - as intensidades das ligações entre os neurônios, conhecidas por pesos sinápticos, são usadas para guardar o conhecimento adquirido.

Trabalhar num modelo análogo ao cérebro faz com que as RNA tenham características intrínsecas distintas dos computadores digitais de von Neumann:

- não linear,

- mapeamento entrada - saída,

- adaptabilidade,

- respostas evidentes, não apenas qual, mas também com que confiança,

- tolerância ao erro - se um neurônio falhar, o sistema como um todo não falha - e

- $\quad$ informação contextual - a atividade de um neurônio afeta os demais entre outras.

A FIG. 5 apresenta um modelo de neurônio, k, como usado em RNA. 


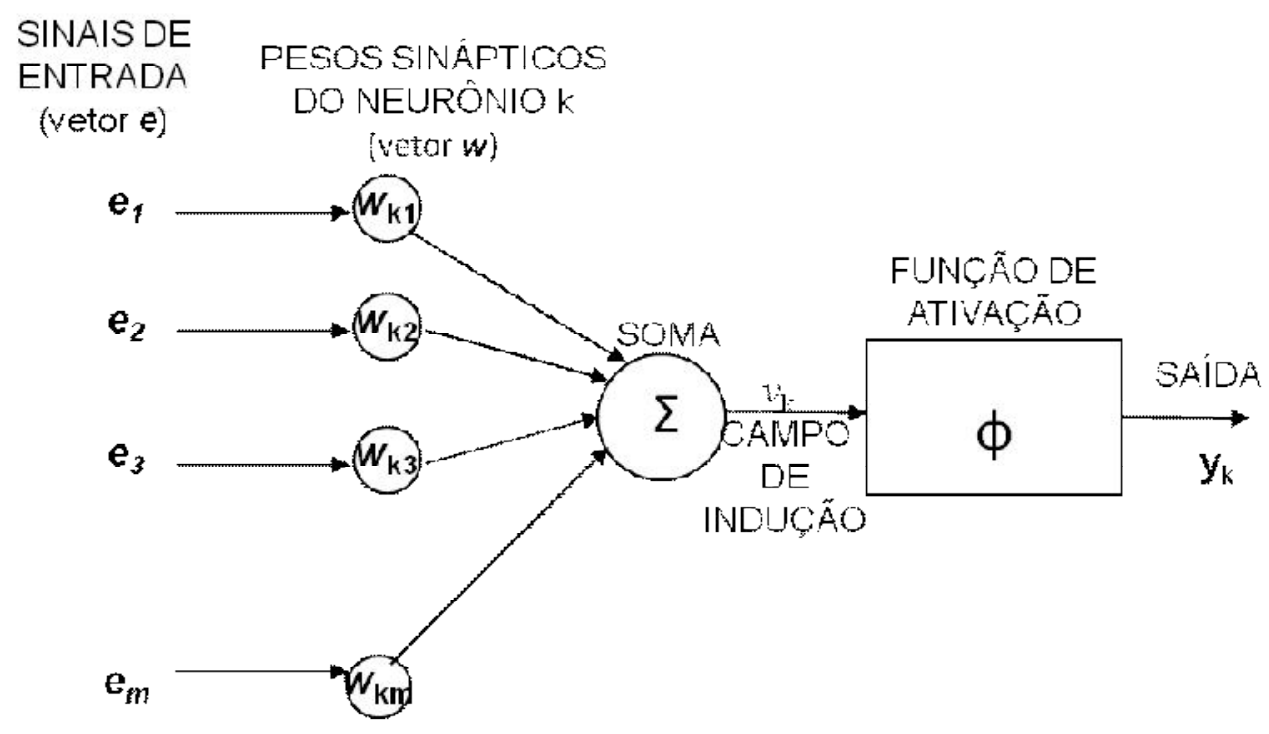

FIGURA 5 Modelo de Neurônio para Redes Neurais

Fonte: adaptado de Haykin (1999)

O vetor erepresenta os dados de entrada fornecidos à rede ou vindos de outros neurônios da mesma. As informações são guardadas na RNA ajustando-se os pesos $\boldsymbol{w}_{\mathbf{k}}$ das ligações sinápticas de acordo com uma estratégia definida, sendo que é através deste processo que se dá aprendizado da RNA. O sinal resultante $\boldsymbol{v}_{\mathbf{k}}$ passa então por uma função de ativação que definirá 0 resultado $\mathbf{y}_{\mathbf{k}}$ apresentado por esse neurônio quando submetido ao vetor de entrada, $\boldsymbol{e}$.

As redes neurais são formadas por camadas de neurônios interligados onde a saída de uma camada é usada como entrada da próxima camada até que a última camada apresente o vetor de saída da RNA. Na parte esquerda da FIG. 6 pode-se ver uma rede neural formada por uma camada de quatro neurônios e, à direita, uma RNA de três camadas de neurônios, sendo duas ocultas e uma de saída.

No caso da rede neural apresentada à direita na FIG. 6, a saída de cada neurônio alimenta a camada seguinte. No entanto, nas arquiteturas recorrentes das RNA a saída de um neurônio pode participar de um processo de retro-alimentação influenciando assim a alimentação de camadas anteriores. A RNA mostrada à esquerda da FIG. 6 representa um diagrama esquemático típico 
das redes SOM. Cada neurônio está conectado com todos os nós de entrada, é uma estrutura alimentada adiante com uma única camada computacional que pode ser arranjada em uma linha ou em um arranjo bidimensional.
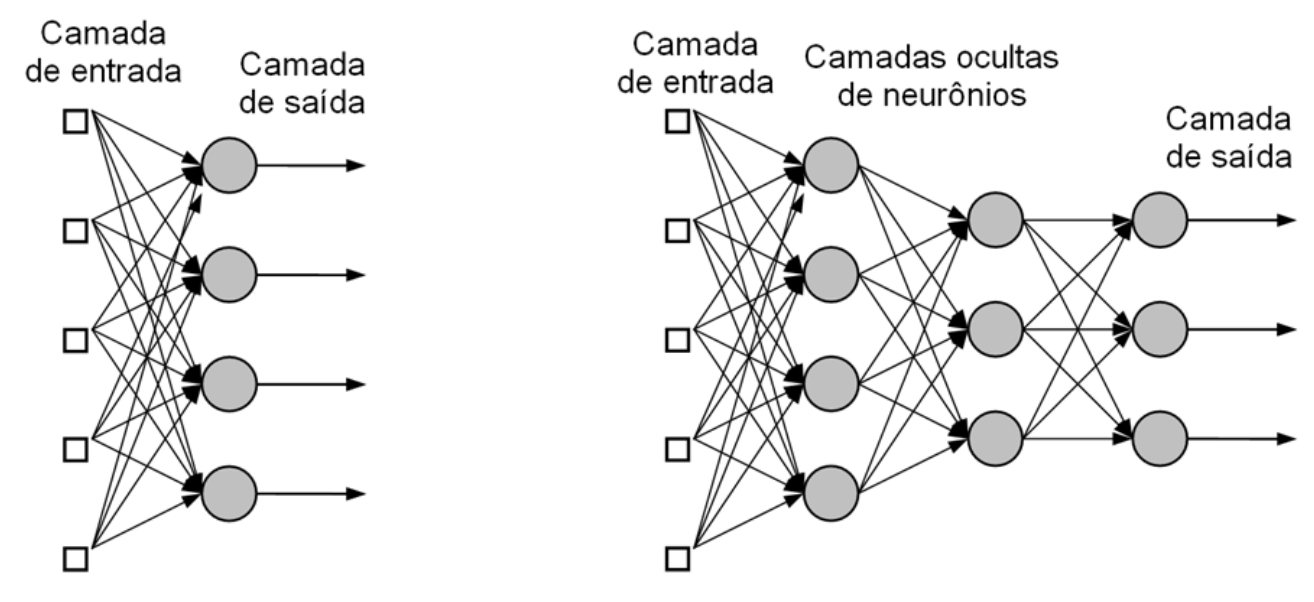

FIGURA 6 Modelos de Redes Neurais.

Fonte: adaptado de Haykin (1999)

\subsubsection{O Aprendizado das Redes Neurais Artificiais}

No contexto de RNA pode-se definir aprendizado como sendo um processo pelo qual os parâmetros livres, pesos sinápticos, da RNA são adaptados através de um processo estimulado pelo ambiente no qual a RNA está imersa. Assim as RNA:

- são estimuladas pelo ambiente,

- $\quad$ sofrem mudança nos seus parâmetros livres devido aos estímulos e

- respondem de uma maneira nova aos estímulos devido às mudanças.

Através do processo de aprendizado a RNA passa a desempenhar melhor a função para a qual foi projetada. Assim a tarefa do aprendizado é capacitar a rede a: associar padrões, reconhecer padrões, controlar processos, filtrar informações ou aproximar funções. 
O tipo de aprendizado é determinado pela maneira que as mudanças nos parâmetros são feitas. Existem várias maneiras de se alterar os parâmetros sendo que os processos mais comuns de aprendizado incluem:

- $\quad$ aprendizado por correção de erros,

- $\quad$ aprendizado baseado na memória,

- $\quad$ aprendizado Hebbiano,

- $\quad$ aprendizado competitivo, utilizado no SOM, e

- $\quad$ aprendizado estocástico ou de Boltzmann.

O processo de aprendizado pode ser classificado também quanto à dependência de um professor. No aprendizado supervisionado, ou com professor, há uma fase de treinamento onde os valores de saída da RNA são comparados com aqueles fornecidos pelo professor e o erro é usado para ajustar os parâmetros, conforme mostrado no esquema da FIG. 7.

No aprendizado sem professor distinguem-se dois processos distintos o aprendizado com reforço também denominado com programação neurodinâmica e o aprendizado sem supervisão ou auto-organizado, que é o processo usado pela rede SOM.

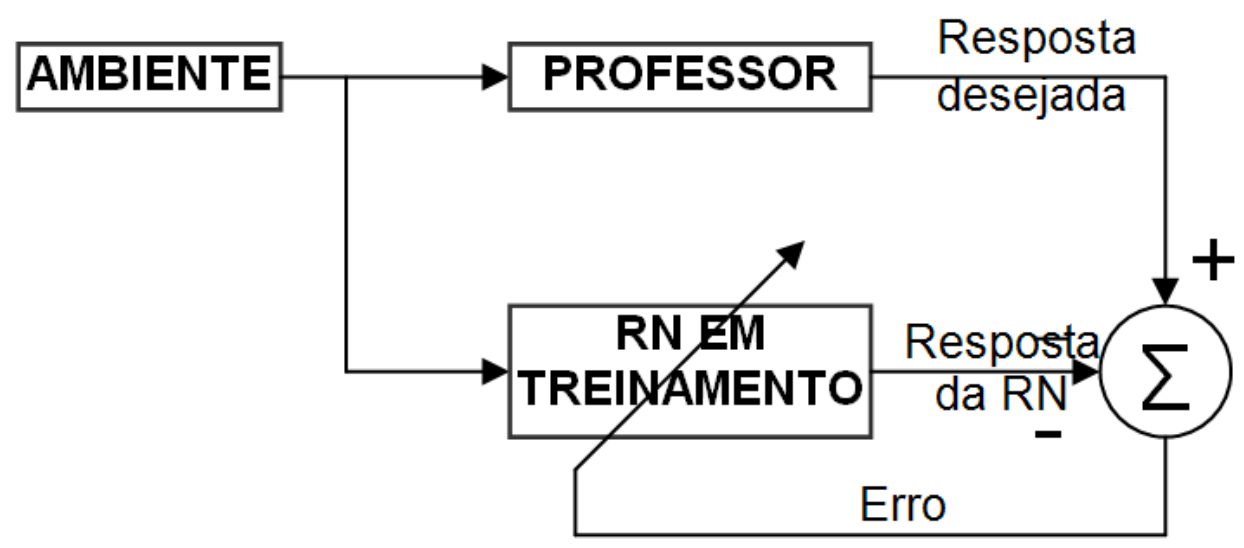

FIGURA 7 Aprendizado Supervisionado

Fonte: adaptado de Haykin (1999) 


\subsubsection{Mapas Auto-Organizáveis (Self-Organizing Maps - SOM)}

Quatro princípios básicos da auto-organização dão suporte ao desenvolvimento das aplicações dos SOMs. Esses princípios são:

1. Modificações nos pesos sinápticos tendem a se amplificar.

2. Limitações de recursos levam à competição entre as sinapses e, portanto a seleção das sinapses favorece que elas cresçam mais vigorosamente à custa das demais.

3. Modificações nos pesos sinápticos tendem a cooperar localmente.

4. Ordem e estrutura nos padrões de ativação representam informação redundante que é adquirida pela RNA na forma de conhecimento, o que é um pré-requisito para o aprendizado auto organizado.

Os Mapas Auto-Organizáveis são baseados no aprendizado competitivo, onde somente um neurônio por grupo está excitado a cada instante vencedor leva tudo (winner takes all). Esses neurônios são colocados nos nós de malhas, usualmente unidimensionais ou bidimensionais e, durante o processo de aprendizado, eles se tornam seletivamente sintonizados com os vários padrões de entrada ou classes de padrões de entrada. As localizações dos neurônios sintonizados se tornam ordenadas com respeito aos demais de maneira que um sistema de coordenadas significante para diferentes características dos estímulos é criado sobre a malha.

Um SOM é caracterizado pela formação de um mapa topográfico dos padrões de entrada, nos quais, as coordenadas dos neurônios na malha são indicativas das características estatísticas intrínsecas contidas nos padrões de entrada.

O objetivo dos Mapas Auto-Organizáveis é então transformar um padrão de entrada de $n$ dimensões em um mapa uni- ou bi-dimensional discreto, 
fazendo a transformação adaptativamente de uma forma topologicamente ordenada.

Para ating ir esse objetivo todos os neurônios devem ser expostos a um número suficiente de excitações da entrada seguindo o algoritmo básico de quatro passos:

1. Inicialização: dos pesos sinápticos com valores aleatórios pequenos, por exemplo.

2. Competição: somente o neurônio com maior valor é ativado.

3. Cooperação: o ganhador determina uma vizinhança espacial de neurônios excitados

4. Adaptação sináptica.

\subsubsection{Aprendizado da Rede SOM}

$\mathrm{Na}$ rede SOM, como mostrada na parte esquerda da FIG. 6, todos os componentes do vetor de entrada, e, são apresentados para todos os neurônios, que atualizam então seus pesos cada vez que um novo vetor e é fornecido à rede. A fórmula básica de atualização dos pesos de cada neurônio e utilizada neste desenvolvimento é descrita pela equação:

$$
w_{n}^{i+1}=w_{n}^{i}+n(i, d)^{*}\left(e^{i}-w_{n}^{i}\right)
$$

O vetor peso de um neurônio $n$ - $\boldsymbol{w}_{\boldsymbol{n}}$ - se aproxima do vetor de entrada - $\boldsymbol{e}$ - usando um fator de vizinhança- $n(i, d)$ - que leva em conta o tempo de evolução, mais conhecido como época - $i$ - e a distância geométrica - $d$ - entre o neurônio e o neurônio vencedor.

A distância geométrica, $d$, entre os neurônios 1 e 2 localizados respectivamente nas coordenadas $\left(x_{1}, y_{1}\right)$ e $\left(x_{2}, y_{2}\right)$ é dada, como usual, por: 


$$
d_{12}=\left(\left(x_{1}-x_{2}\right)^{2}+\left(y_{1}-y_{2}\right)^{2}\right)^{1 / 2}
$$

Ressalta-se que o termo $\left(\boldsymbol{e}^{i}-\boldsymbol{w}_{\boldsymbol{n}}{ }^{i}\right)$ representa a diferença entre dois vetores, no caso o vetor de entrada, $\boldsymbol{e}$, o vetor peso, $\boldsymbol{w}$. Apesar de haver várias proposições diferentes para cálculo da distância entre esses vetores, neste trabalho, a distância entre esses vetores será calculada como a distância geométrica entre eles, ou seja, a distância entre eles é dada por:

$$
d_{e w}=\left(\left(e_{1}-w_{1}\right)^{2}+\left(e_{2}-w_{2}\right)^{2}+\ldots+\left(e_{m}-w_{m}\right)^{2}\right)^{1 / 2}
$$

No capítulo 3.5 de seu livro, Kohonen (2001) divide o processo de aprendizagem em duas partes uma primeira fase de ordenamento e uma segunda fase de convergência. Na primeira fase os pesos dos neurônios vão ficando mais próximos entre si estabelecendo um arranjo entre eles que minimiza a distância entre os pesos dos neurônios, assim os buffers de treinamento vão mudando frequentemente o neurônio que é ativado por eles. Na segunda fase os valores dos pesos dos neurônios variam menos e em geral a ativação de um neurônio diferente por um mesmo buffer, na evolução do treinamento, se restringe a uma vizinhança muito próxima do neurônio que foi inicialmente ativado. Quanto ao número de épocas para treinamento, Kohonen sugere, como uma regra grosseira, que o número de épocas para treinamento seja em torno de 500 vezes o número de neurônios na rede, mas ressalta que em alguns estudos em que foram usadas 100000 épocas 10000 ou menos seriam suficientes.

O fator de vizinhança da equação (1) pode ser expresso na forma de duas outras funções uma dependente do tempo, usualmente conhecida como fator de aprendizagem e aqui denominada ETA, $\eta(i)$, e outra da distância do neurônio ao neurônio vencedor e do tempo, aqui denominada função de vizinhança, $\omega(d, i)$. Assim, pode-se definir:

$$
n(i, d)=\eta(i) * \omega(d, i)
$$


Durante a fase de ordenamento, em geral, em torno das primeiras 1000 épocas a função de vizinhança $\omega(d, i)$ deve iniciar com um valor máximo grande, maior que a metade do diâmetro da rede e decrescer monotonicamente para a menor distância entre dois neurônios na rede. Sobre o fator de aprendizagem, ETA, $\eta(i)$, Kohonen diz que na fase inicial, primeiras 1000 épocas, o valor deve ser alto, próximo de 1 e na fase final deve ser pequeno, da ordem de 0,02 por longos períodos de tempo.

\subsection{Identificação e Classificação de Transientes com Redes Neurais}

$\mathrm{Na}$ literatura encontram-se também trabalhos que tratam da identificação e classificação de transientes em reatores nucleares (ROVERSO, 2000; OHGA, 1993, 1996; CHEON e CHANG, 1993; MOL, 2003) usando redes neurais de treinamento supervisionado e vários deles consideram com relevância o seguinte paradigma: "Se a rede não pode ser treinada em todos os eventos possíveis é importante que ela não classifique os eventos para os quais ela não foi treinada; senão o sistema classificará erradamente o evento que ela não conhece". Roverso (2000) reconhece que isso não é sempre verdadeiro, ou tão sério, para todos os tipos de redes neurais. A rede proposta nesse trabalho, SOM, se enquadra no tipo que tem um grau maior de generalização tendo, portanto uma menor dificuldade com essa questão, além de ser possível também a implementação de não reconhecimento nesta rede se isso for de interesse.

Dos trabalhos encontrados na literatura pública, somente o trabalho de Roverso (2000) cita o uso de SOM nesse tema específico e ainda assim para fins de comparação com o software ALADDIN desenvolvido e apresentado naquele trabalho, o qual não fornece maiores informações sobre o tipo específico de rede SOM criado e nem sobre o seu uso.

A rede SOM não foi concebida para identificação de padrões de condições variáveis no tempo ou sequenciais. Algumas variações de SOM, que abrangem essa área, foram desenvolvidas posteriormente. Entre elas estão os 
Temporal Kohonen Map (TKM), Recurrent SOM (RSOM), Recursive SOM (RecSOM) e o SOM for Structured Data (SOMSD). ‘

Neste desenvolvimento o SOM utilizado segue a sua formulação original usando-se para avaliar as variações temporais a técnica de janela de eventos, onde os parâmetros fornecidos à rede são apresentados além do valor atual um número fixo de valores históricos passados. Mais detalhes dessa técnica de janela de eventos podem ser encontrados em Baptista e Barroso (2003).

\subsection{Simulação do IRIS}

O comportamento esperado do reator IRIS tem que ser usado para treinar a RNA/SOM apresentando a esta a evolução de variáveis selecionadas como entrada para a rede. Muitos conjuntos, milhares, de dados de entrada devem ser usados, representando diferentes tipos de comportamento esperados: em situações como estados estacionários, transientes operacionais, transientes anormais e acidentes.

A simulação de centrais nucleares serve a vários propósitos e usa diferentes metodologias, em função dos objetivos desejados. Alguns propósitos básicos da simulação de centrais nucleares são:

- $\quad$ avaliações simplificadas, usualmente em situações de operação que não envolvem muitos fenômenos variando frequentemente e cujos resultados não precisam ser confiáveis mas dar uma aproximação grosseira do comportamento esperado,

- avaliações de segurança da central nuclear, que precisam ser confiáveis e às vezes conservativas, demandam conjuntos de programas altamente sofisticados e especializados em determinados processos, efeitos ou fases da operação. As avaliações de segurança se dividem em dois tipos básicos: os de melhor estimativa que procuram fornecer os resultados o mais próximo possível dos reais e 
os conservativos que usam métodos e hipóteses para propiciar altas margens de segurança.

- dar suporte ao projeto da central e

- $\quad$ servir como demonstração e treinamento das equipes envolvidas na operação da central.

Para atender a essas diferentes demandas foram desenvolvidos diversas ferramentas ou programas computacionais, muitos deles altamente sofisticados por serem baseados em teorias e experimentos de centenas de fenômenos.

\subsubsection{Simulação do IRIS com Modelo Simples (EES)}

Durante uma fase de prospecção da viabilidade de se usar poucas variáveis termo-hidráulicas do IRIS com uma rede de Mapas Auto-Organizáveis para o desenvolvimento de um sistema de identificação e classificação de transientes, a geração de dados de entrada representativos da operação do IRIS foi inicialmente feita usando-se usando um modelo simplificado desenvolvido no IPEN com a ferramenta de programação "Engineering Equation Solver" (KLEIN e ALVARADO, 2001), mostrado na FIG. 8. A descrição detalhada desse modelo, com suas as equações, foi apresentado por Barroso et al. (2003). 


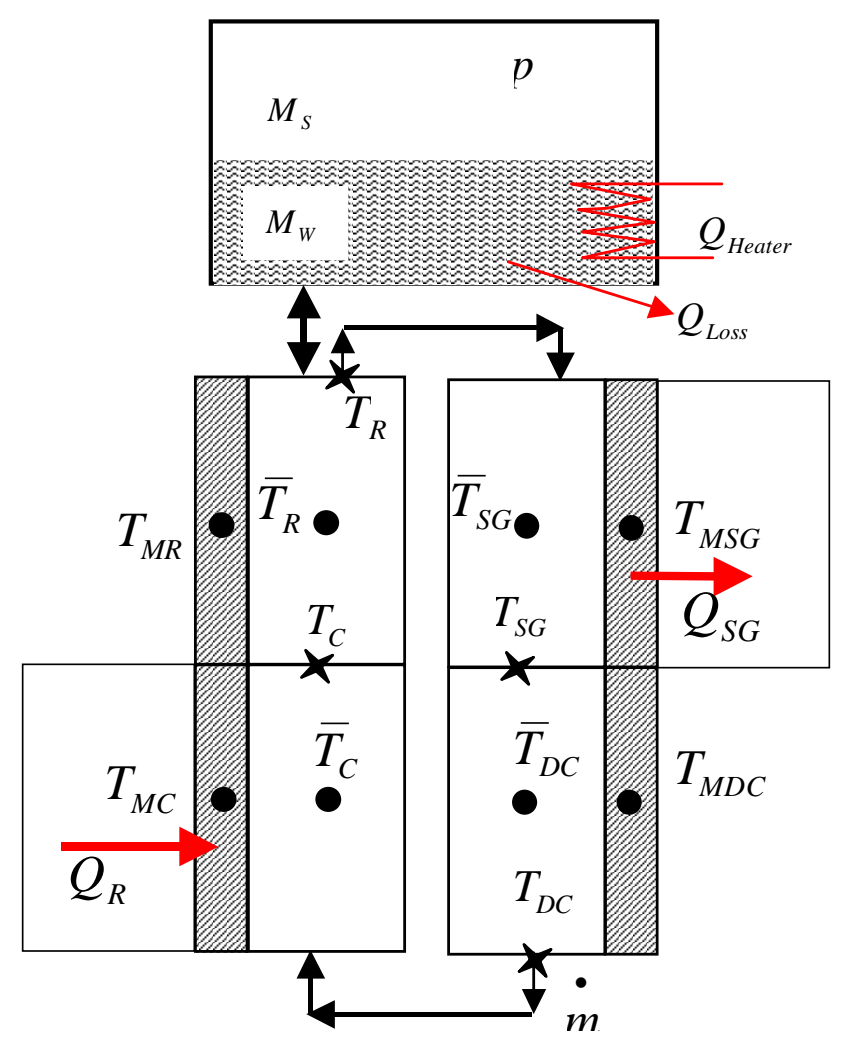

FIGURA 8 Modelo Simplificado do Reator IRIS

Fonte: BARROSO et al., 2003

No GRAF. 1 pode ser observado um exemplo de resultado obtido com esse modelo. As curvas ali mostradas representam a evolução da pressão, à esquerda, e do nível no pressurizador, à direita, como resultado da simulação de um degrau decrescente de potência de $10 \%$, de $100 \%$ a $90 \%$.
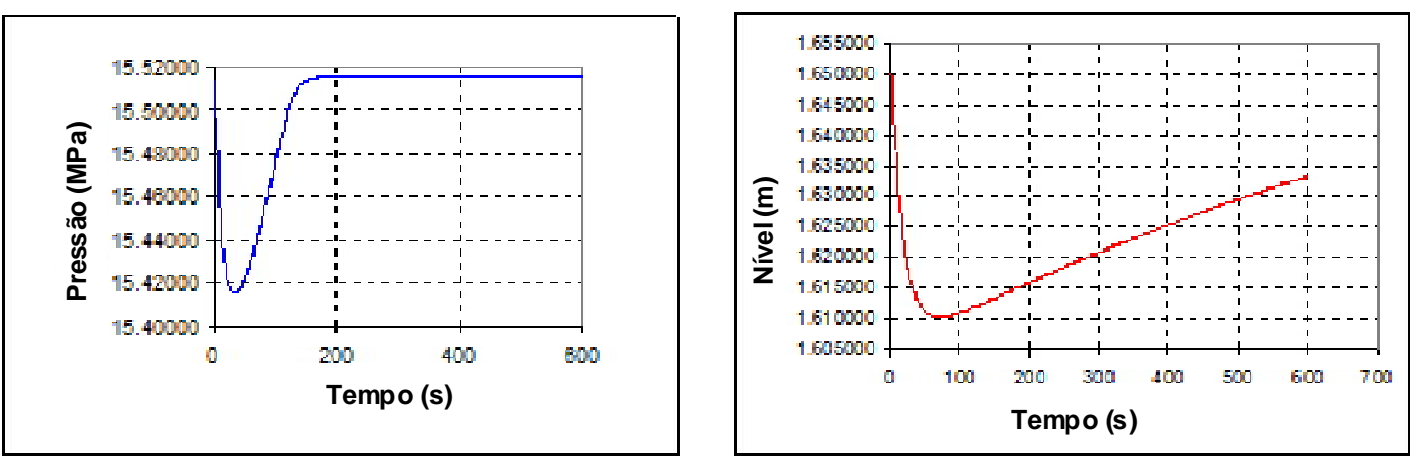

GRÁFICO 1 Pressão e nível no pressurizador do IRIS usando o Modelo Simplificado

Fonte: resultados da pesquisa 
Resultados da simulação com esse modelo foram usados por Baptista e Barroso (2003) para treinamento de redes SOM, demonstrando a viabilidade do uso dessas redes para identificação de transientes.

\subsubsection{Simulação Detalhada do IRIS (RELAP5)}

As avaliações de segurança exigem a simulação das centrais nucleares com conjuntos de códigos computacionais para avaliarem os aspectos relevantes do projeto e da operação das mesmas. Esses códigos de simulação computacional para fins de segurança são baseados em desenvolvimentos teóricos e experimentais e passam por extensivos programas de validação. As avaliações de segurança quando usadas para fins de licenciamento usam metodologias conservadoras e grandes margens de segurança. Já as avaliações de segurança para outros fins, como apoio ao projeto, usam uma filosofia denominada melhor estimativa, best estimate, onde o objetivo é obter da simulação os resultados mais próximos do esperado, sem margens de segurança. Nas últimas duas décadas tem havido um movimento para aproximar essas duas abordagens, usando diversas técnicas e metodologias, entre elas a quantificação de incertezas.

O RELAP é um exemplo de família de códigos em desenvolvimento nas últimas 4 décadas para fins de análise de segurança. Ao longo da evolução desse código, diferentes versões foram desenvolvidas, algumas com métodos conservativos voltadas para o licenciamento, outras que usam a metodologia de melhor estimativa. Esses códigos foram inicialmente desenvolvidos para simulações de acidentes básicos de projeto (design basis accidents) nas centrais nucleares, tal como o Acidente de Perda de Refrigerante. No entanto com o aumento do poder de cálculo dos computadores o RELAP teve sua capacidade estendida para simular quase todos os transientes termo-hidráulicos que podem ocorrer nas centrais nucleares. 
O código RELAP5 foi o usado para simular o reator IRIS com o objetivo de gerar um banco de dados representando vários estados operacionais, transientes e acidentes, que possa ser usado para treinamento do SICT.

\subsubsection{O Código RELAP5}

O RELAP na sua versão 5 (RELAP5) é um código desenvolvido com modelos para fornecer resultados do tipo melhor estimativa, ou seja, tão realistas quanto possível. Ele incorpora características que permitem seu uso para modelagem de centrais nucleares e de seus sistemas de controle e proteção que possibilitam simular o comportamento dessas centrais em condições desde regimes permanentes a acidentes graves passando por toda a gama de transientes. O RELAP5 é um código de simulação termo-hidráulica que considera componentes e fenômenos unidimensionais e escoamento de refrigerante em duas fases, líquido e vapor. Apesar de ser unidimensional ele disponibiliza modelos para escoamento transversal entre os volumes que compõe a simulação e para divisão de escoamento em junções tipo T. Além das fases líquida e de vapor do refrigerante ele ainda considera a presença e o transporte de gases e de boro dissolvido. $O$ modelo hidrodinâmico conta então com seis equações de conservação, 3 para a fase de vapor e 3 para a fase líquida. As equações de conservação são duas de massa, duas de momentum e duas de energia. Essas equações interagem com muitos modelos para diferentes fenômenos, em particular, aqueles que consideram a troca de calor com estruturas sólidas que representam o material da instalação simulada. O RELAP5 tem sido extensivamente usado e seus manuais mostram os modelos e equações usados, exemplos de uso do código, um guia do usuário com recomendações para o seu uso de maneira correta e um manual com descrição de como preparar os dados de entrada (NUREG, 1995).

O RELAP5 usa um arquivo de dados de entrada que descreve as condições geométricas, termo-hidráulicas e de controle do sistema a ser simulado. Como resultado do processamento da simulação com os dados de 
entrada fornecidos, ele gera um arquivo de texto contendo informações sobre o estado calculado em intervalo de tempos chamados major edits. Em geral esse arquivo não é apropriado para ser usado como fonte de dados para pósprocessamento por conter demasiada informação, milhares de dados sobre o sistema termo-hidráulico, em intervalos de tempo muito espaçados. Outro arquivo de saída gerado pelo RELAP5 é o arquivo denominado RSTPLT, que é um arquivo binário com informações para fazer gráficos e para reiniciar uma simulação a partir de um ponto especificado, restart. $O$ arquivo RSTPLT foi projetado para fornecer valores das variáveis termo-hidráulicas e outras ao longo do tempo de uma forma mais compacta possibilitando o seu pós-processamento para obtenção de dados, seja para fazer gráficos, seja para outros fins.

\subsubsection{A Nodalização}

Os resultados das simulações do IRIS com o RELAP5 formam a base de dados para treinamento do SICT. Quanto mais próxima a simulação da realidade melhor a capacidade da rede de desempenhar sua função de identificar e classificar transientes e acidentes. A simulação do IRIS com o RELAP5 reflete o estado de conhecimento do sistema de proteção e controle do mesmo, assim os resultados obtidos apesar de não serem finais proporcionam simular comportamentos que têm características semelhantes ao comportamento final esperado. Isso quer dizer que o SICT desenvolvido com os resultados obtidos neste trabalho não deve ser a versão final, mas uma versão que mostra a viabilidade e capacidade de tal sistema e que poderá então ser facilmente retreinado quando houver resultados de simulação mais realistas.

Grgic et al. (2002), dentro das atividades do consórcio do projeto IRIS, criaram e descreveram detalhadamente uma nodalização do IRIS para simulações com o RELAP5. O desenvolvimento dessa nodalização teve como objetivos fazer análises de segurança e determinar valores limites, setpoints, para os sistemas de controle e de proteção do IRIS. Essa nodalização foi qualificada posteriormente para obtenção do estado estacionário e devido ao seu 
desenvolvimento foram identificadas e feitas modificações no RELAP5 para adequá-lo ao processamento de simulações do IRIS (ORIANI et al., 2004). A FIG. 9 mostra um esquema da nodalização onde são representados o reator e as regiões do vaso, um dos oito circuitos de bomba de refrigerante do primário e gerador de vapor e um dos quatro circuitos de remoção de calor residual.

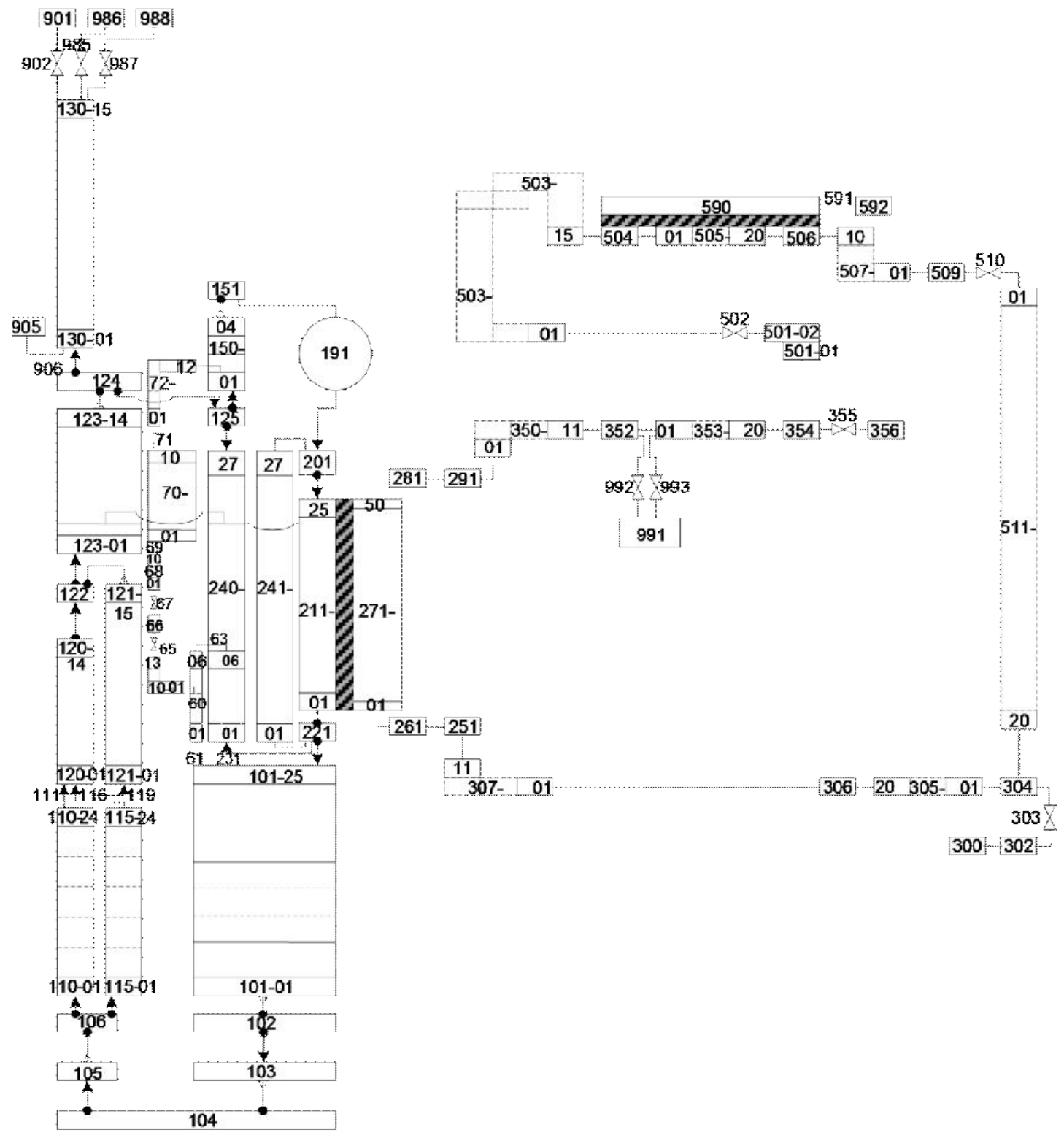

FIGURA 9 Nodalização do IRIS (só são mostrados 1 dos 8 circuitos de Bomba e Gerador de Vapor e 1 dos 4 Sistemas de Remoção de Calor Residual)

Fonte: GRGIC et al., 2002 
O IRIS é um reator com várias características intrinsecamente seguras, entre elas está o seu grande volume de água e a capacidade de refrigeração por circulação natural em situações de emergência. Para simular essa característica é importante uma modelagem geométrica adequada, o que significa entre outros fatores, usar uma nodalização com volumes de mesma altura para regiões de escoamento vertical paralelo do refrigerante, ou seja, volumes com mesma cota têm a mesma elevação vertical. Essa característica foi adotada por Grgic et al. (2002) e está evidenciada na FIG.10.

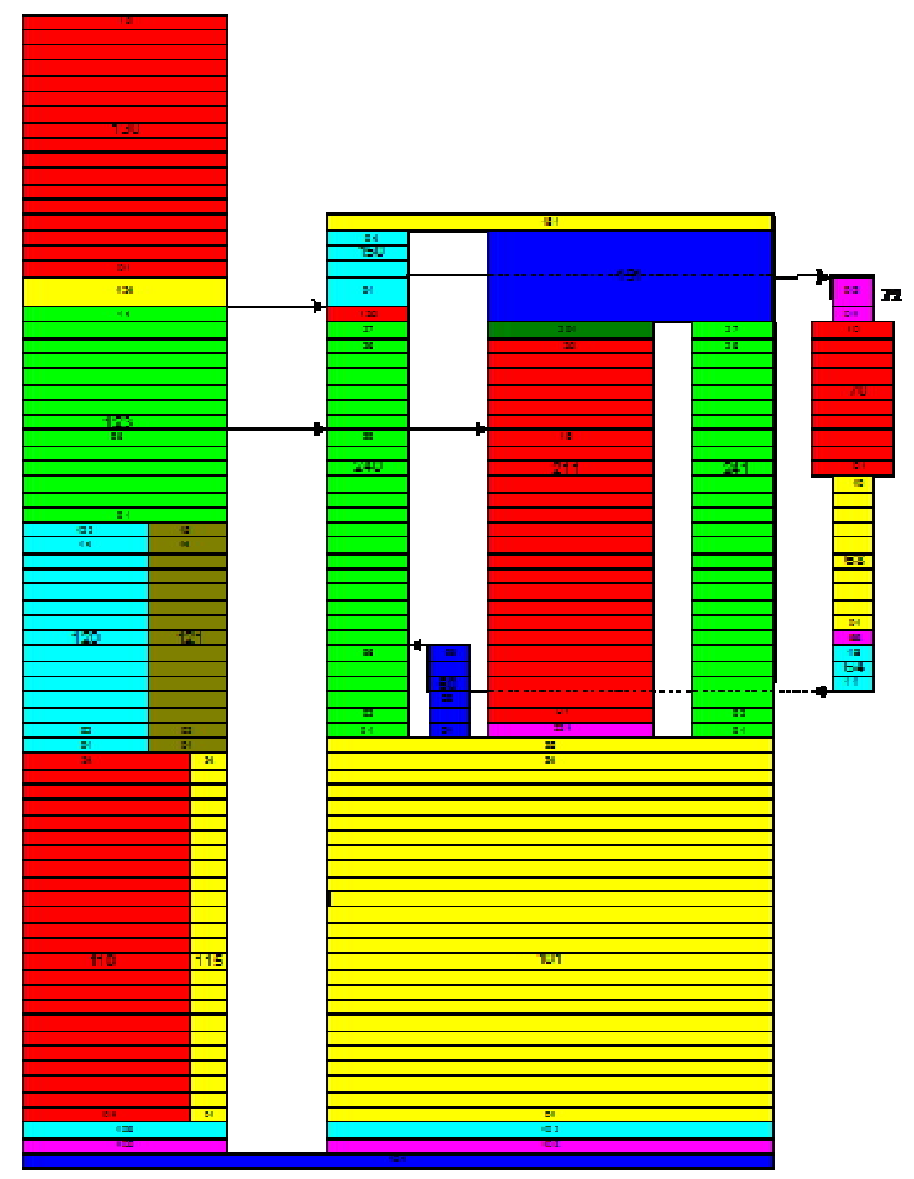

FIGURA 10 Nodalização com volumes paralelos de mesma altura no Vaso do IRIS

Fonte: GRGIC et al., 2002

A FIG. 9 permite observar somente um dos geradores de vapor, no entanto todos os oito são simulados e a FIG. 11 mostra o arranjo desses geradores de vapor que são agrupados dois a dois para a alimentação de água nos tubos do secundário e para a coleta do vapor gerado. 


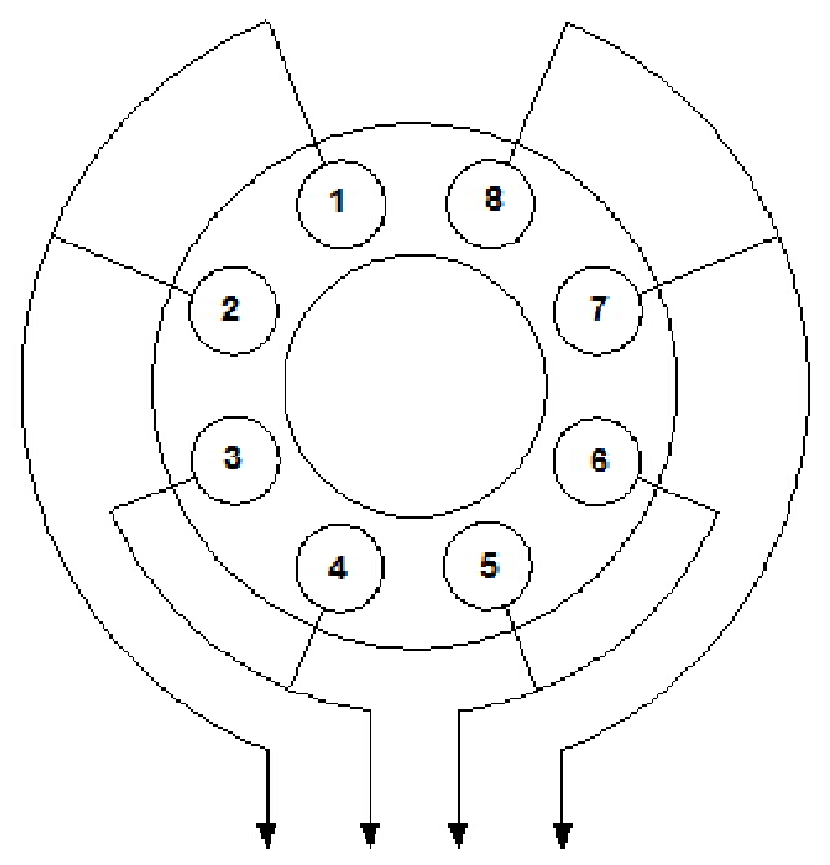

FIGURA 11 Arranjo dos quatro grupos de Geradores de Vapor Fonte: GRGIC et al., 2002

As bases para o desenvolvimento de partes dessa nodalização, tais como a bomba de circulação do primário (NEVO, 2002) e o gerador de vapor helicoidal (CIONCOLINI, 2003), foram determinadas em trabalhos desenvolvidos dentro do projeto IRIS.

\subsubsection{Simulação dos Sistemas de Controle e Proteção do IRIS}

Uma das partes que mais influencia o comportamento simulado pelo RELAP para uma central nuclear é a definição do sistema de controle e proteção que será usado e a forma que foi implementado. O sistema de controle na nodalização descrita no item 2.4.2 não representa a versão final a ser implantado no reator, mas um ponto inicial, baseado na experiência operacional de reatores a água pressurizada e na experiência do desenvolvimento do reator AP1000 projetado pela Westinghouse. A descrição detalhada dos sistemas de controle e proteção como implementada foi apresentada por Oriani et al. (2004). A 
modelagem desses sistemas é feita usando-se dois recursos do RELAP5 que são os TRIPs e variáveis de controle, CNTRLVARs.

Como mencionado no item 2.1.2 três sistemas apresentaram particular interesse na simulação do IRIS com o RELAP5, pois levavam a comportamentos que se desviavam da evolução esperada.

\section{Sistema de Controle da Pressão do Primário}

O sistema de controle do pressurizador opera para manter a pressão do pressurizador perto da nominal durante operação normal e transiente. Reatores PWR convencionais utilizam aquecedores para aumentar a pressão e aspersores (sprays) e válvulas de alívio comandadas (PORVs) para reduzi-la. O IRIS tem somente aquecedores para aumentar a pressão. $O$ aumento de pressão é controlado por ter se projetado um grande espaço de vapor no pressurizador, que pode absorver a excursão de pressão. Além disso, a pressão pode ser diminuída usando a inserção de barras de controle e o sistema controle de água de alimentação. Esse procedimento, presente em reatores da Babcock \& Wilcox - B\&W, deve ser usado no IRIS, mas ainda não está ativo na versão utilizada dos sistemas de controle.

A parte principal do sistema de controle é representada por um controlador proporcional-integral-derivativo (PID) que processa o erro entre a pressão programada e a real gerando o sinal de Pressão Compensada que é usado para comandar os aquecedores.

Os aquecedores do pressurizador são modelados como dois bancos separados com capacidades e controle independentes. O primeiro banco é chamado de aquecedores "proporcionais" porque a sua potência é proporcional ao desvio de pressão, sobre um ponto de operação (setpoint) determinado. O segundo banco é o de aquecedores "On/Off" ou de "Backup" cujo comportamento é controlado por chaves (trips) que os ligam ou desligam completamente. Ambos os bancos são atuados pelo sinal de Pressão Compensado. 
Existem ainda uma chave (trip) baseada no sinal Nível Baixo do Pressurizador que desliga todos os aquecedores e um sinal para ativar ou desativar manualmente o Sistema de Controle de Pressão do Pressurizador.

A definição desse sistema na modelagem segue os passos descritos a seguir e que estão representados na FIG. 12

O sinal de pressão programada (CNTRLVAR 1120) é subtraído da pressão real do pressurizador ( $\mathrm{p}$ 130-15) para criar o desvio de pressão (CNTRLVAR 1123); o erro é computado somente depois do estado estacionário para não saturar o termo integral do controlador PID.

O erro de pressão (CNTRLVAR 1125) é então processado pelo controlador PDI: o primeiro elemento (CNTRLVAR 1126) integra o erro de pressão enquanto a porção derivada é modelada usando uma taxa de atraso (lag). A parte derivativa é, então, simplesmente a diferença entre o sinal e o sinal atrasado (CNTRLVAR 1128 - 1127).

Finalmente, o termo integral e o diferencial são somados para proporcionar o sinal de desvio de pressão compensado. A CNTRLVAR 1130 usa o sinal de desvio de pressão compensado para obter a potência dos aquecedores proporcionais da Tabela Geral 140 (General Table do RELAP5).

A CNTRLVAR 1133 provê a potência dos aquecedores de Backup multiplicando uma potência de aquecimento constante por um valor 0 ou 1 (trip 1131) baseado no valor do sinal de desvio de pressão compensado.

As duas condições são combinadas para determinar a potência total dos aquecedores (CNTRLVAR 1134). No caso de nível baixo de água no pressurizador, os aquecedores são impedidos de fornecer potência pela CNTRLVAR 1135. A CNTRLVAR 1137 representa a constante de tempo de retardo para atuação dos aquecedores.

Finalizando o sistema de controle da pressão do primário pode ser desabilitado pela CNTRLVAR 1138. A potência final dos aquecedores 
(CNTRLVAR 1139) é entregue às estruturas de calor 1360, (Heat Structure 1360) dos aquecedores.

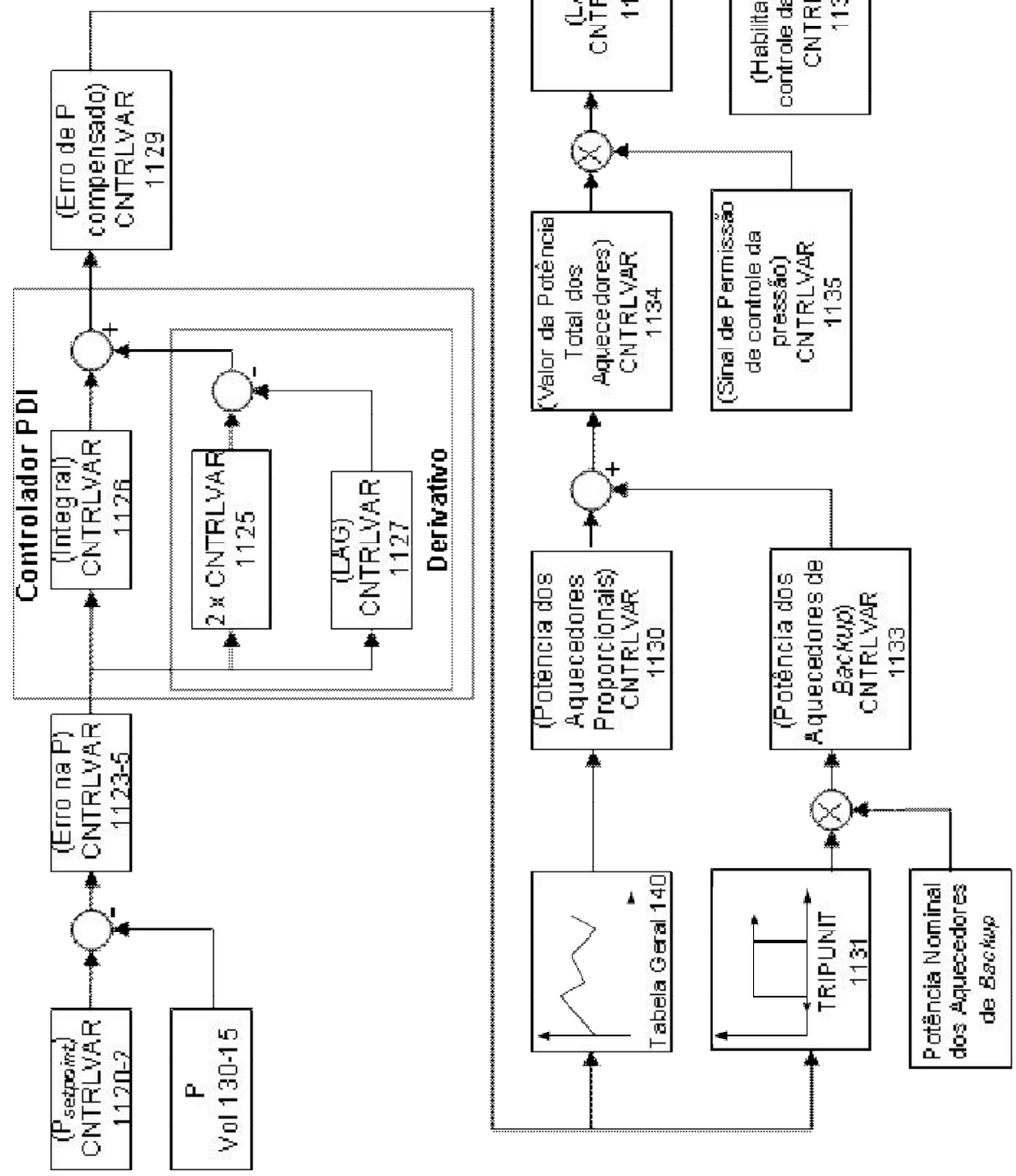

FIGURA 12 Diagrama do sistema de controle da pressão do primário Fonte: adaptado de Oriani et al. (2004) 


\section{Sistema de Controle da Pressão do Vapor}

O Sistema de Controle da Pressão do Vapor proporciona controle automático da pressão no coletor de vapor (steam header), logo antes da entrada da turbina, durante a operação de potência do reator. O sistema é capaz de manter a pressão do vapor programada baseado na potência real da turbina seguindo mudanças de potência.

O sistema atua na Válvula Reguladora de Pressão da Turbina (TTV) e mantém a pressão do vapor programada fechando ou abrindo a válvula. No caso do sinal de Desligamento (trip) da Turbina ser alcançado, a TTV fecha rapidamente e o sistema é desligado. O sistema inteiro pode ser também desabilitado pelo usuário.

A FIG. 13 permite observar o diagrama de funcionamento desse sistema, conforme descrito a seguir.

Baseado na Potência da Turbina (CNTRLVAR 1151), a Pressão Programada do Vapor é obtida da Tabela Geral 160 (CNTRLVAR 1200) e subtraída (CNTRLVAR 1201) da Pressão de Vapor medida no coletor de vapor (steam header, Volume 750-01).

A CNTRLVAR 1202 desabilita o sistema de controle da pressão.

O erro de pressão no coletor de vapor (CNTRLVAR 1203) é usado para determinar se a Válvula Reguladora da Turbina tem de abrir ou fechar (CNTRLVAR 1204/1205). A CNTRLVAR 1206 subtrai o valor do sinal (trip) de fechamento do sinal (trip) de abertura para determinar a direção do movimento da válvula $(+1=$ abre, $0=$ sem movimento, $-1=$ fecha) .

A velocidade da Válvula é obtida da Tabela Geral 161 dependendo do valor do erro da pressão do header (CNTRLVAR 1207) e multiplicando-se esta velocidade pelo sinal de direção obtém-se a taxa de movimento da válvula (CNTRLVAR 1208). 
Integrando-se a taxa de movimento da válvula no tempo obtém-se o deslocamento líquido da posição da válvula (CNTRLVAR 1209) o qual é então subtraída do valor inicial da válvula para se ter a posição corrente da válvula (CNTRLVAR 1211).

No caso de Desligamento da Turbina (CNTRLVAR 1212) a área é feita imediatamente igual a zero (CNTRLVAR 1213). A posição final da válvula (CNTRLVAR 1213) é usada para controlar a área de Válvula Reguladora da Turbina (Componente 752-00, servo valve).

O sinal (trip) 1711 provê a lógica de atuação de fechamento da TTV. Ele se é um elemento bi-estável com uma faixa morta. A atuação (valor 1) ocorre quando o sinal de erro de pressão do coletor (CNTRLVAR 1203) é menor que o valor limite (setpoint) predefinido, -1500, e o desligamento quando fica maior que o valor limite de reinício, -1000 .

O sinal (trip) 1713 provê a lógica de atuação para a abertura da TTV e, como o sinal de fechamento, é um elemento biestável com uma faixa morta. A atuação ocorre quando o sinal de erro da pressão no coletor fica maior que o valor limite pré-definido, 1500, e o desligamento quando o erro cai para um valor inferior ao limite de reinício, 1000.

A FIG. 14 apresenta um diagrama lógico desses sinais de abertura e de fechamento. 


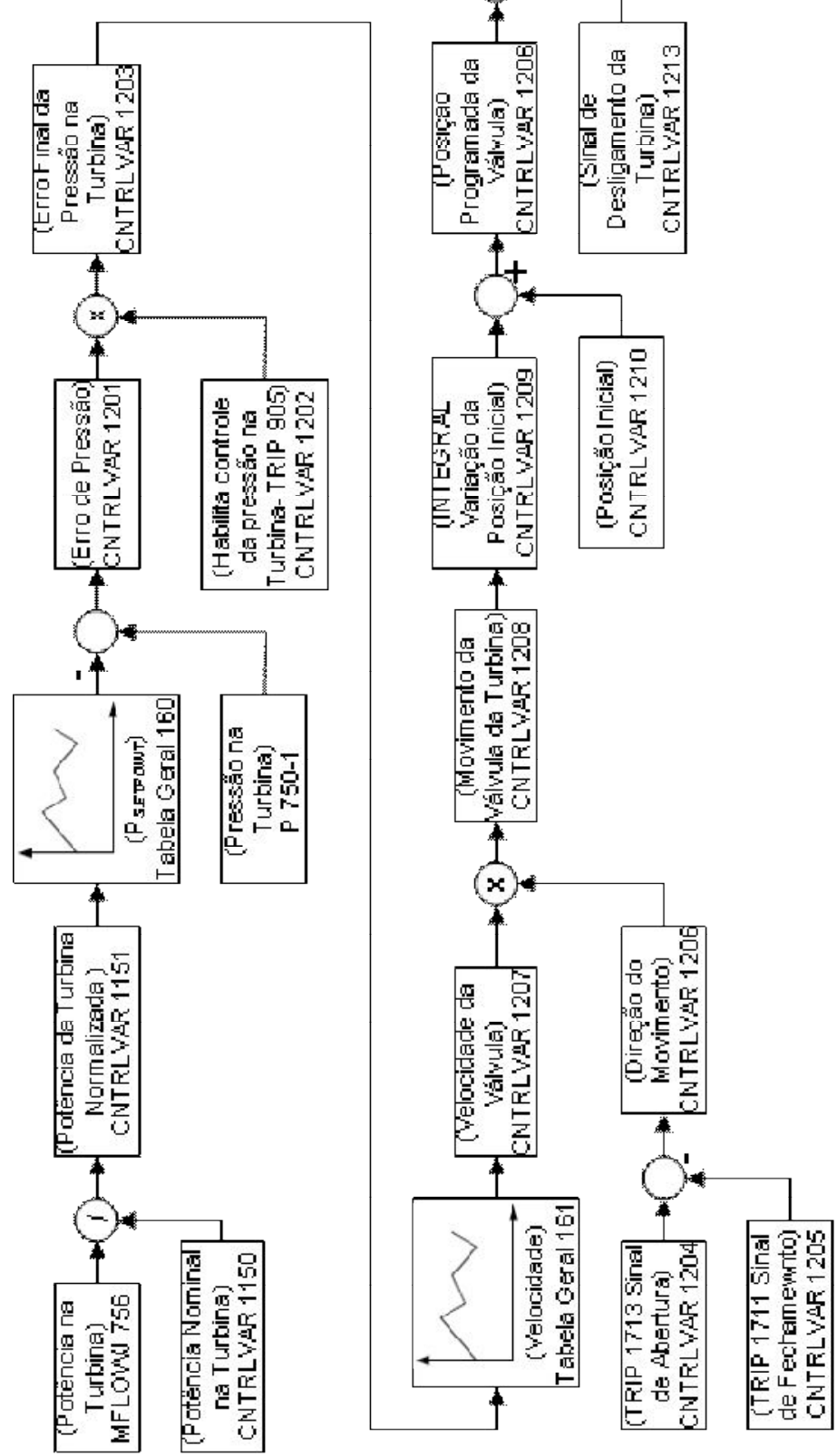

FIGURA 13 Diagrama do Sistema de Controle da Pressão do Vapor Fonte: elaborado pelo autor a partir de dados apresentados por Grgic et al. (2002). 

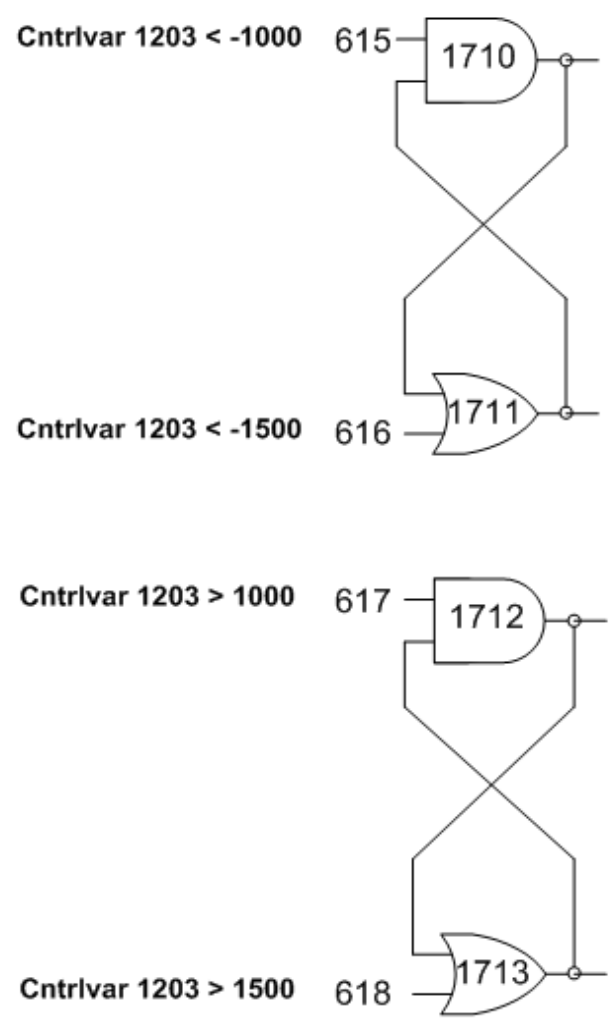

FIGURA 14 Lógica dos controles da pressão de vapor

Fonte: elaborado pelo autor a partir de dados apresentados por Grgic et al. (2002)

\section{Sistema de Controle das Barras de Controle ou de Potência Nuclear}

O sistema das Barras de Controle proporciona controle automático dos feixes de barras de controle durante a operação do reator em potência. O sistema é capaz de restabelecer a temperatura média do reator para dentro da faixa morta de temperatura programada após mudanças na potência. No sistema de controle adotado a temperatura média cresce linearmente com a potência, cerca de $10 \mathrm{~K}$ para a faixa inteira.

O sistema básico das barras de controle do reator consiste em dois canais que dão o desvio na Temperatura (Tavg - Tref = temperatura média temperatura de referência) e desvio da Potência (carga de turbina - potência nuclear). O sistema de controle do IRIS terá um termo de alimentação positivo 
(feed forward) (demanda de potência térmica do núcleo) para substituir a carga de turbina, e um termo de compensação adicional, por exemplo, uma inserção de barras de controle para casos de aumento de pressão de aproximadamente 7 bars acima da pressão nominal.

O sinal de erro total enviado ao sistema de movimento das barras é a soma dos desvios de temperatura e de potência. A posição inicial das barras é fixada pelo usuário, junto com a retirada máxima e inserção mínima permitidas. Quando acontecer um desligamento (trip) do reator, o sinal de erro total é fixado em zero o que desabilita qualquer controle subsequente do movimento das barras assim como qualquer de função de acompanhamento do movimento. O sistema inteiro pode ser também desabilitado pelo usuário.

A potência da turbina é processada (CNTRLVAR 1150/1152) para ser usada por ambos os canais.

A FIG. 15 apresenta um diagrama do sistema das barras de controle até a avaliação do Erro Final da Temperatura.

No canal de temperatura a Temperatura Programada-Tprog (CNTRLVAR 1154) é obtida baseada na carga atual da turbina e então passada por uma função de atraso - LAG - (CNTRLVAR 1155) para produzir o sinal de Temperatura Programada de Atuação - Tprog*.

A Temperatura Média - Tavg (CNTRLVAR 1153) passa por um LAG (CNTRLVAR 1156) seguido de um LEAD/LAG (CNTRLVAR 1157) para gerar a Temperatura Média de Atuação (Tavg de atuação).

No fim Tprog* é subtraido de Tavg de atuação para gerar o erro do canal de Temperatura (CNTRLVAR 1158).

No canal de Potência a carga da Turbina (em fração da carga nominal - CNTRLVAR 1152) é subtraída da potência Nuclear (em fração da potência nominal-CNTRLVAR 1159) para se obter o desvio da potência (CNTRLVAR 1160). 
O desvio da potência é então passado através de um LAG e subtraído de si mesmo (CNTRLVAR 1161/1162). Esse sinal é então convertido em um erro de temperatura equivalente (CNTRLVAR 1163).

Um fator de escala (CNTRLVAR 1164) baseado na carga real da turbina é aplicado no erro da temperatura equivalente para se ter o erro do canal de Potência (CNTRLVAR 1165).

Os erros dos dois canais são somados para obter o Erro Total de Temperatura (CNTRLVAR 1166).

No caso de Trip do Reator, as funções do Sistema das Barras de Controle são desabilitadas (CNTRLVAR 1167/1170); existindo também a possibilidade de o usuário desabilitar o sistema manualmente (CNTRLVAR 1171).

A CNTRLVAR 1172 representa o Erro Final da Temperatura.

A FIG. 16 apresenta um diagrama do sistema das barras de controle a partir da avaliação do Erro Final da Temperatura até a inserção final de reatividade.

O Erro Final de Temperatura é usado para determinar se as barras têm que ser inseridas ou retiradas (CNTRLVAR 1173/1174). A CNTRLVAR 1175 subtrai o valor do TRIP de "Inserção" do valor do TRIP de "Retirada" para determinar a direção do movimento das barras de controle $(+1=$ retirada, $0=$ nenhum movimento, -1 = inserção).

A velocidade das barras é obtida da Tabela Geral 153 dependendo do valor do Erro da Temperatura (CNTRLVAR 1176). Multiplicando-se a velocidade das barras pelo sinal de Direção do movimento das barras se obtém a taxa de movimento das barras (CNTRLVAR 1177).

Para avaliar a mudança líquida de posição de inicial (CNTRLVAR 1178), o movimento das barras é integrado e então subtraído da posição inicial das barras (CNTRLVAR 1179), para obter a posição de atual 
(CNTRLVAR 1180 e CNTRLVAR 1181 em fração do valor nominal). Observe que neste modelo é assumido que a posição inicial das barras está a 161 passos. A extração até passo 171 (barras completamente extraídas) é permitida para simular certa flexibilidade (barras parcialmente inseridas).

Usando a posição das barras, obtém-se, através da Tabela Geral 155, o valor das barras (em pcm/passo, CNTRLVAR 1183); isto é multiplicado pela a taxa de movimento das barras (em passo/s, CNTRLVAR 1184) para ter a taxa de adição de Reatividade (em pcm/s, CNTRLVAR 1185).

A reatividade total adicionada pelo sistema de barras de controle é a integral da taxa de adição de reatividade (CNTRLVAR 1186).

Foi implementada também a opção de se definir a adição de reatividade baseada na posição atual das barras (CNTRLVAR 1182). 


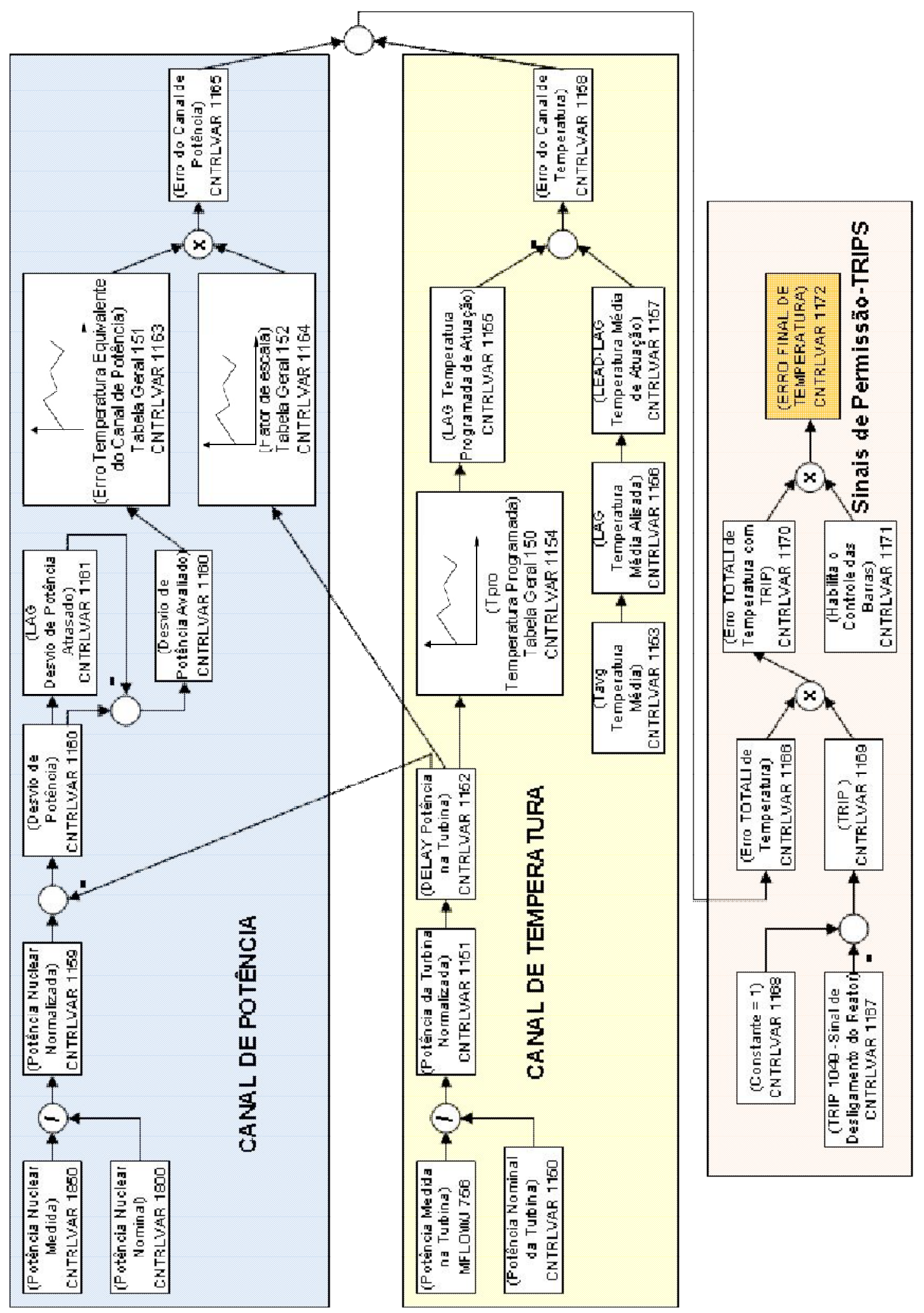

FIGURA 15 Diagrama do sistema de barras de controle até o erro final de temperatura

Fonte: elaborado pelo autor a partir de dados apresentados por Grgic et al. (2002). 


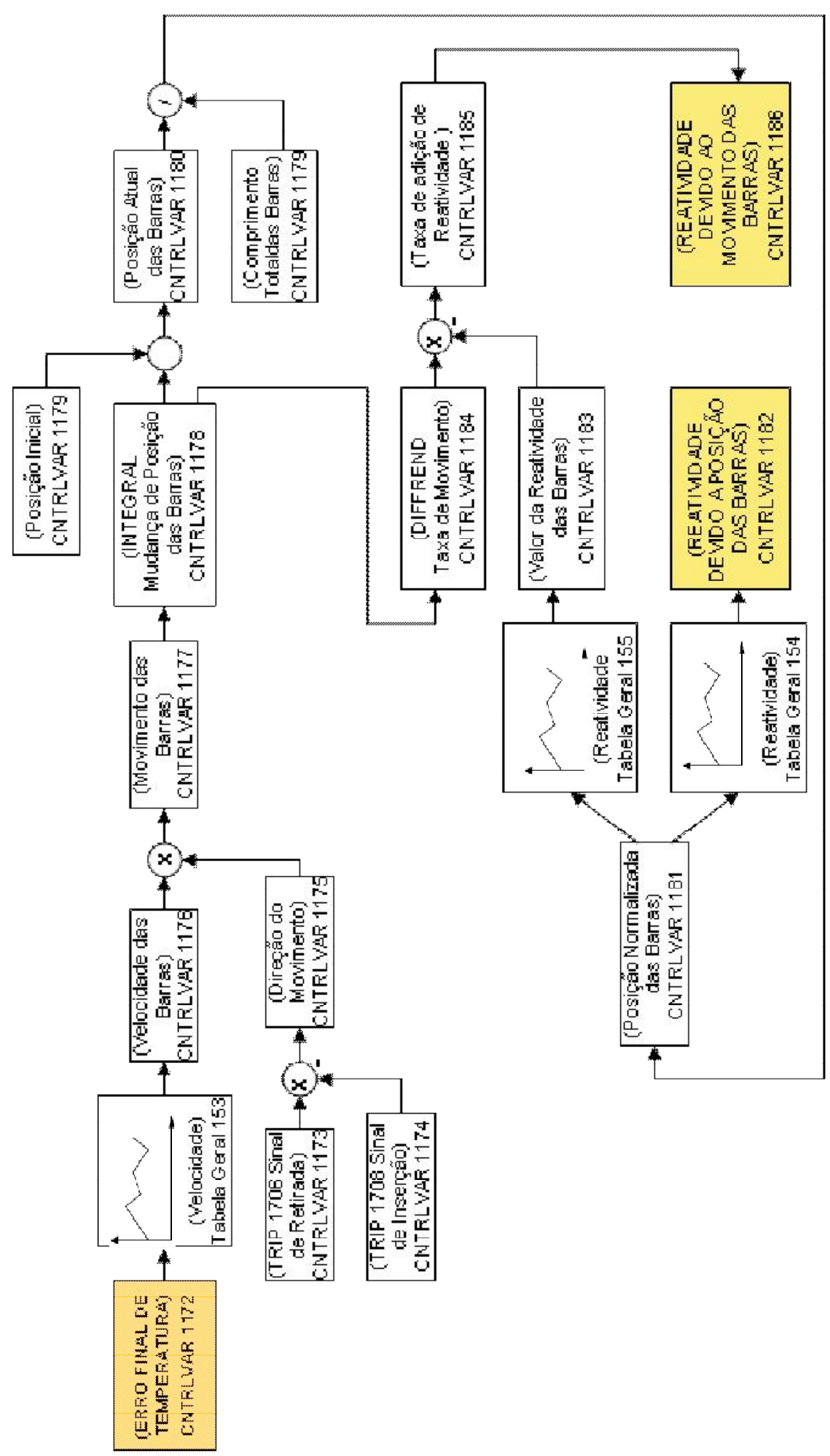

FIGURA 16 Diagrama do sistema das barras de controle até a inserção da reatividade

Fonte: elaborado pelo autor a partir de dados apresentados por Grgic et al. (2002). 


\subsubsection{Principais condições de Contorno}

As principais condições de contorno que definem o balanço termohidráulico da usina foram definidas na modelagem do IRIS através do sistema de controle no sistema de controle (setpoints) e são:

- Pressão do secundário: mantida constante em 56,7 bar,

- Pressão do primário: constante em 155,13 bar

- Temperatura média do primário: varia linearmente de $300{ }^{\circ} \mathrm{C}$ a $310^{\circ} \mathrm{C}$ para potências térmicas entre 0 e $1000 \mathrm{MW}$, respectivamente,

- Nível do pressurizador: varia linearmente entre 1,3 e 2,0 m para temperatura média do primário variando entre $300^{\circ} \mathrm{C}$ e $310^{\circ} \mathrm{C}$. Fora desses limites de temperatura o nível deve ser mantido no valor mínimo ou máximo, conforme a temperatura.

Deve-se ressaltar ainda que o sistema de controle dos aquecedores inclui, de maneira artificial, a perda de calor do pressurizador, até o valor máximo de $240 \mathrm{~kW}$.

\subsubsection{Simulação do Sistema de Controle (MODELICA)}

Dentro do escopo do projeto IRIS, além do uso do RELAP5 para simular o comportamento da central em situações de transientes e acidentes foi aberta outra linha de simulações com o objetivo de detalhar e avaliar os sistemas de proteção e controle. Essas simulações descrevem e permitem avaliar o sistema de controle e proteção com um nível de detalhamento muito maior que o que é possível com o RELAP5, que, no entanto é perfeitamente adequado para a análise de acidentes e avaliações de segurança do projeto (CAMMI et al., 2005) 
Nesse contexto a modelagem do IRIS, e em particular de seu sistema de controle, é feita usando-se um aplicativo/linguagem que usa os conceitos de programação orientada a objeto. Esse aplicativo é o MODELICA.

Avaliações iniciais do IRIS com o MODELICA (CAMMI et al., 2005) explicitam que o conceito inovador do IRIS não representa uma grande dificuldade para a engenharia de controle quando comparado com os reatores de água pesada convencionais.

A disponibilidade do modelo do IRIS com o MODELICA permite estudos de conceitos de controle mais avançados para tratar de situações particulares, por exemplo: controle de carga e frequência em pequenos sistemas elétricos, melhor gerenciamento de transientes em situações de perda de suprimento de energia elétrica (blackout). Outra característica explorada nesse estudo foi a de gerenciamento de variações de simuladores do IRIS ao longo de toda a evolução do projeto.

Os resultados finais dessa modelagem dos sistemas de proteção e controle do IRIS levarão à adoção de sistemas melhorados e até mesmo conceitualmente diferentes dos utilizados nas simulações com o RELAP5 neste trabalho. Quando disponíveis esses novos sistemas deverão então ser transpostos para o modelo do IRIS no RELAP5 e todos os cálculos que compõe o banco de dados utilizado para treinamento e avaliação do SICT devem ser refeitos.

O próximo capítulo descreve a metodologia utilizada na elaboração deste trabalho. 


\subsection{Descrição da Metodologia}

O desenvolvimento de um Sistema de Identificação e Classificação de Transientes - SICT para o IRIS baseado em uma rede neural específica, os Mapas Auto-Organizáveis (SOM), e utilizando poucos parâmetros termohidráulicos, que serão medidos no reator, passa por uma série de etapas.

Primeiro é necessário ter um aplicativo do SICT que possibilite criar e treinar redes tipo SOM que posteriormente serão avaliadas simulando a sua utilização no IRIS.

Entretanto, considerando que o IRIS é ainda um projeto e que, portanto, não existem parâmetros termo-hidráulicos medidos que descrevam seu comportamento, reconhece-se a necessidade de utilizar resultados de simulações do mesmo para se obter estimativas desses parâmetros, que devem ser usados tanto para o treinamento da rede quanto para sua posterior avaliação. Mesmo que o IRIS já estivesse em operação, seriam necessários, para o treinamento da rede, parâmetros termo-hidráulicos representando várias situações anormais de operação que não teriam nunca ocorrido. Assim, novamente, mesmo que o IRIS já tivesse sido construído seriam necessários resultados de simulação para a obtenção de dados para o treinamento do SICT.

A utilização de resultados de simulação para o treinamento e avaliação do SICT levanta questionamentos sobre a validade desse processo e de seu resultado. Um dos questionamentos trata da utilização de dados estimados no lugar de dados reais medidos no reator. Os dados estimados normalmente não possuem ruídos típicos da instalação real e mesmo a técnica de se agregar ruídos, de diversos tipos, nos dados estimados não garante uma completa similaridade dos valores estimados e medidos. Uma segunda questão é sobre o procedimento utilizado, isto é, usar um sistema treinado com dados de simulação 
para avaliar situações reais de uma instalação. Para responder essas questões foi feito um programa de testes experimentais em um circuito termo-hidráulico, o CT1, do Laboratório de Termo-hidráulica do CDTN/CNEN. Os resultados desses experimentos puderam ser então utilizados para avaliar se uma rede treinada com resultados de simulação pode ser usada com sucesso para monitorar uma instalação real.

Assim o desenvolvimento do SICT para o IRIS consistiu nos seguintes passos:

- desenvolvimento do aplicativo SICT usando a linguagem $\mathrm{C}_{++}$,

- realização de experimentos em circuito termo-hidráulico - CT1, gerando um banco de dados de resultados experimentais para uso no SICT,

- $\quad$ simulações do CT1, com o RELAP5, gerando um banco de dados para treinamento e para o desenvolvimento do SICT. Ressalta-se a validação da simulação do CT1 através do uso de resultado experimentais.

- simulações com o RELAP5 do reator nuclear integral IRIS,

- treinamento do SICT para o CT1 usando os dados de simulação do mesmo para treinamento,

- validação do SICT treinado para o CT1, e de todo o procedimento de anteriormente descrito, usando tanto os dados de simulação do CT1 quanto os experimentais,

- $\quad$ treinamento do SICT usando os dados de simulação do IRIS e

- $\quad$ avaliação do SICT treinado para o IRIS usando dados de simulação do IRIS.

Esses passos serão tratados nos capítulos a seguir. 


\subsection{Desenvolvimento do aplicativo SICT}

O aplicativo SICT consta de um programa computacional que permite a criação de redes neurais tipo Mapas Auto-Organizáveis, seu treinamento e uso, fornecendo informações sobre esses processos. A metodologia de seu desenvolvimento seguiu recomendações de engenharia de software e de Programação Orientada a Objeto. A versão final do mesmo foi sendo corrigida e melhorada ao longo da evolução do projeto, fornecendo uma versão bastante estável e testada. O capítulo 6 descreve extensivamente o aplicativo SICT e sua utilização.

\subsection{Realização de experimentos}

Os experimentos para validação da metodologia utilizada, isto é, uso de resultados de simulação para treinar o SICT, que será utilizado com valores medidos na instalação, foram planejados para serem executados no Circuito Térmico $\mathrm{N}^{\mathrm{O}} 1$ do CDTN.

A primeira etapa para a utilização do CT1 para os fins apresentados foi a determinação de quais experimentos seriam possíveis de realizar e que fornecessem resultados utilizáveis. Desse planejamento surgiu a necessidade de adaptar o circuito para que os parâmetros termo-hidráulicos obtidos do CT1 viabilizassem o uso pretendido dos mesmos. Essa adaptação exigiu, entre outras, a troca da bomba principal de refrigerante do CT1.

Com o circuito adaptado foi feito o seu comissionamento. Nessa fase foram feitas a calibração da instrumentação e do sistema de aquisição de dados, desenvolvido o programa de coleta de dados e de controle de potência do retificador e preparado o procedimento de operação para os testes. 
A etapa final foi, então a realização dos experimentos, com arquivamento dos dados experimentais coletados de uma forma temporal sequencial. O procedimento de operação e o programa de coleta de dados e de controle do retificador foram atualizados ao longo da campanha de testes para evitar a repetição de acidentes operacionais.

O capítulo 4 descreve a parte experimental deste trabalho.

\subsection{Simulações do CT1 com o RELAP5}

O passo inicial da simulação do CT1 com o RELAP5 foi o uso dos dados geométricos e termo-hidráulicos disponíveis na literatura para a elaboração de uma nodalização do CT1. Muitos dos dados da literatura tiveram que ser conferidos e atualizados através de medições.

Com a nodalização disponível foram feitas simulações de estado estacionário para verificar se os resultados estavam próximos dos disponíveis na documentação do CT1.

O modelo criado foi então usado para simular alguns experimentos realizados no CT1 no contexto do SICT. Com o resultado das simulações a nodalização era modificada para que os resultados ficassem próximos dos resultados experimentais. Esse procedimento, simulação-atualização da nodalização - simulação, foi executado iterativamente até que os resultados das simulações reproduzissem de maneira satisfatória os resultados dos experimentos simulados.

Com a modelagem do CT1, foram então simuladas várias condições de transientes, cujos resultados foram utilizados para o treinamento do SICT para o CT1 posteriormente para a avaliação do resultado desse treinamento. Ressalta-se que as simulações realizadas nessa etapa não foram simulações de experimentos 
realizados, mas sim de transientes genéricos, representativos de vários estados operacionais e transientes possíveis de ocorrer no CT1.

O banco de dados com os resultados das simulações foi arquivado para processamento posterior.

Essa etapa do projeto está detalhada no item 5.1

\subsection{Simulações do IRIS com o RELAP5}

A simulação do IRIS com o RELAP5 iniciou com base na extensiva e detalhada modelagem apresentada por Oriani et al. (2004), e que foi validada para o estado estacionário do IRIS.

O passo inicial dessa etapa foi processar a nodalização existente e então fazer uma reinicialização do processamento, a partir das condições finais anteriormente calculadas. Essa reinicialização foi feita retirando-se todos os controles artificiais que foram usados para forçar a obtenção mais rápida do estado estacionário.

Tendo-se obtido uma simulação de estado estacionário do IRIS a 100\% de potência e sem controles artificiais, isto é, usando somente o sistema de controle e proteção como projetados, iniciou-se o processamento dos casos planejados para formarem a base de dados de resultados de simulação do IRIS. $O$ procedimento usado nessa fase foi o de processar sequencialmente os casos e avaliar, grosseiramente, se os resultados estão dentro de uma faixa considerada aceitável. Se os resultados da simulação fossem considerados satisfatórios iniciava-se o próximo caso e se não fossem considerados adequados procuravase a causa da não conformidade e uma possível solução para a mesma. Uma vez solucionado o problema encontrado em um caso através de alteração na nodalização, reinicia-se o processamento sequencial de todos os casos a partir do 
primeiro. Esse procedimento foi repetido até se obter uma nodalização que processasse todos os casos planejados de maneira satisfatória.

Essa etapa do projeto está detalhada no item 5.2.

\subsection{Treinamento do SICT para o CT1}

Para o treinamento do SICT para o CT1 é necessário o fornecimento de dados de treinamento no formato apropriado, conforme descrito no capítulo 6 . Os dados de simulação inicialmente disponíveis estão no banco de dados de simulações do CT1 na forma de arquivos RSTPLT. Como muitos desses arquivos RSTPLT, principalmente no caso de simulações do IRIS, ultrapassam o tamanho de $2 \mathrm{~GB}$, os programas de extração de dados disponíveis, incluindo o próprio RELAP5, não processam esses arquivos. Foi então feito um programa, chamado GETRLPDATA, que extrai dados selecionados do arquivo binário RSTPLT e os coloca em uma sequência temporal em um arquivo de texto.

O passo seguinte na preparação dos dados de treinamento é fazer com que a sequência temporal de dados obtida seja interpolada ou extrapolada para formar uma sequência temporal de dados com intervalos de definidos pelo usuário. Foi então criado o programa SICTINPUTSUM, que usando o arquivo de dados gerado no passo anterior pelo programa GETRLPDATA cria dois arquivos com dados espaçados de um intervalo de tempo determinado. $O$ primeiro arquivo com terminação "...var.txt" tem o tempo na coluna 1 e demais colunas com os parâmetros selecionados em um formato igual ao do arquivo SICTRUNDATA.INP descrito no capítulo 6 e mostrado no APÊNDICE C. O segundo arquivo, com terminação "...mix.txt", tem o mesmo formato que o primeiro porém acrescenta colunas com "derivadas aproximadas" de parâmetros selecionados. Esses dois arquivos podem ser usados diretamente pelo SICT no procedimento de monitoração, descrito no capitulo 6 . 
O passo final para obtenção dos dados para o treinamento é a formação de um arquivo com buffers de tamanho fixo, definido pelo usuário, e de dados a partir de instantes selecionado. $O$ formato desse arquivo de buffers é descrito no capítulo 6. Para a obtenção desse arquivo de buffers a partir dos arquivos gerados no passo anterior, foi feito o programa GETSICTTRAININP.

Tendo os arquivos de treinamento disponíveis é iniciado o treinamento da rede usando o aplicativo SICT e condições de treinamento, como o número de épocas e fatores de vizinhança definidos pelo usuário. Após o treinamento é feita uma verificação preliminar de alguns resultados e caso seja necessário mudamse as condições de treinamento anteriormente definidas ou até mesmo o conjunto de dados de treinamento. Esta etapa é repetida até a que a avaliação preliminar mostre que o treinamento não tem problemas sérios facilmente identificáveis.

\subsection{Validação do SICT treinado para o CT1}

A validação do SICT treinado para o CT1 é feita em duas etapas a primeira usando dados de simulação do CT1 com o RELAP5 e a segunda usando dados experimentais.

Na primeira etapa são usados os arquivos gerados pelo programa SICTINPUTSUM a partir dos resultados de simulação, como descrito no item anterior. Esses arquivos são processados pelo SICT no procedimento de monitoração, descrito no capítulo 6, e seus resultados são então avaliados. Caso a avaliação mostre que a rede treinada é inadequada ela é descartada e uma nova rede terá que ser treinada e avaliada.

A rede que passou pela avaliação da etapa anterior deve agora ser validada usando-se os dados provenientes dos experimentos. Os arquivos de dados experimentais armazenados têm o mesmo formato que os dados de simulação gerados pelo programa GETRLPDATA. Assim o procedimento descrito no item 3.6 é repetido, isto é, os dados de entrada são processados pelo 
programa SICTINPUTSUM e geram um arquivo próprio para processamento pelo SICT no modo de monitoração, de maneira similar ao procedimento descrito no parágrafo anterior para os dados de simulação. Caso a rede seja aprovada nessa avaliação tem-se uma rede que comprova a viabilidade da metodologia utilizada.

\subsection{Treinamento do SICT para o IRIS}

Essa etapa segue o mesmo procedimento descrito no item 3.6, usando os dados de simulação do IRIS no lugar dos dados de simulação do CT1.

\subsection{Avaliação do SICT treinado para o IRIS}

O procedimento utilizado nessa etapa é similar ao descrito no item 3.7 , usando os dados de simulação do IRIS no lugar dos dados de simulação do CT1. Ressalta-se que diferentemente do procedimento descrito em 3.7, a avaliação do SICT para o IRIS só tem a primeira fase, que é o uso de dados de simulação, já que não existem dados experimentais do mesmo.

Os próximos capítulos apresentam a aplicação da metodologia aqui descrita. 


\section{EXPERIMENTOS TERMO-HIDRÁULICOS}

O objetivo dos experimentos neste trabalho é disponibilizar um banco de dados de medidas de parâmetros termo-hidráulicos que descrevam o comportamento da instalação e que possam ser usados para demonstrar a correção da metodologia proposta para o desenvolvimento, em particular, para o treinamento do SICT.

\subsection{O Circu ito Térmico número 1 - CT1}

Construído nas dependências do Centro de Desenvolvimento da Tecnologia Nuclear (CDTN), especificamente, no Laboratório de Termo-hidráulica, - Circuito Térmico Número 1 (CT1) é uma instalação experimental muito simplificada dos circuitos primário e secundário de uma central nuclear a água pressurizada.

Foi no Circuito Térmico 1 - CT1 que foram realizados os experimentos que geraram dados para o desenvolvimento do SICT. Os resultados dos experimentos serviram para validar a metodologia usada para o desenvolvimento do SICT, que é o uso de resultados de simulações para o seu treinamento.

O CT1 é um circuito termo-hidráulico, fechado, com geração e extração de calor, utilizando água como fluido, a qual pode ser pressurizada até 1,5 MPa. Basicamente, o CT1 é constituído pelo circuito principal, pelo circuito de remoção de calor e por sistemas de instrumentação e controle. Neste circuito podem ser realizados experimentos para a determinação de parâmetros termo-hidráulicos tais como: coeficientes de transferência de calor, fluxos de calor críticos e coeficientes de perda de carga. Esses experimentos podem ser realizados em regimes mono ou bifásicos e em geometrias tubulares, anulares ou em forma de feixe. Uma descrição detalhada do projeto original do CT1 foi documentada em Souza e Colares (1975). Para a realização dos experimentos de suporte ao SICT, dois de seus componentes principais tiveram que ser adaptados: 
- $\quad$ seção de testes: foi modificada para dissipar o máximo da potência disponibilizada pelo retificador e é composta de um tubo de aço de 12,8 m em forma de U horizontal com circulação interna de água e comprimento aquecido de 10,9 m. A potência máxima dissipada pelo conjunto retificador da seção de teste é de cerca de $120 \mathrm{~kW}$. E

- bomba do Primário: a bomba original fornecia uma vazão muito alta que com a potência de aquecimento disponível não possibilitaria uma variação de temperatura significativa, para os fins pretendidos, na seção de testes. Foi instalada então uma nova bomba que satisfizesse os requisitos dos experimentos planejados.

O sistema de coleta de dados teve também que ser adaptado para fornecer resultados que fossem apropriados para o seu uso no desenvolvimento do SICT.

Na FIG.17 é apresentada uma visão dos principais componentes do CT1 e na FIG. 18 um esquema simplificado do mesmo, na configuração usada para os experimentos deste trabalho e com a indicação dos pontos de medida de temperaturas, pressões e vazões.

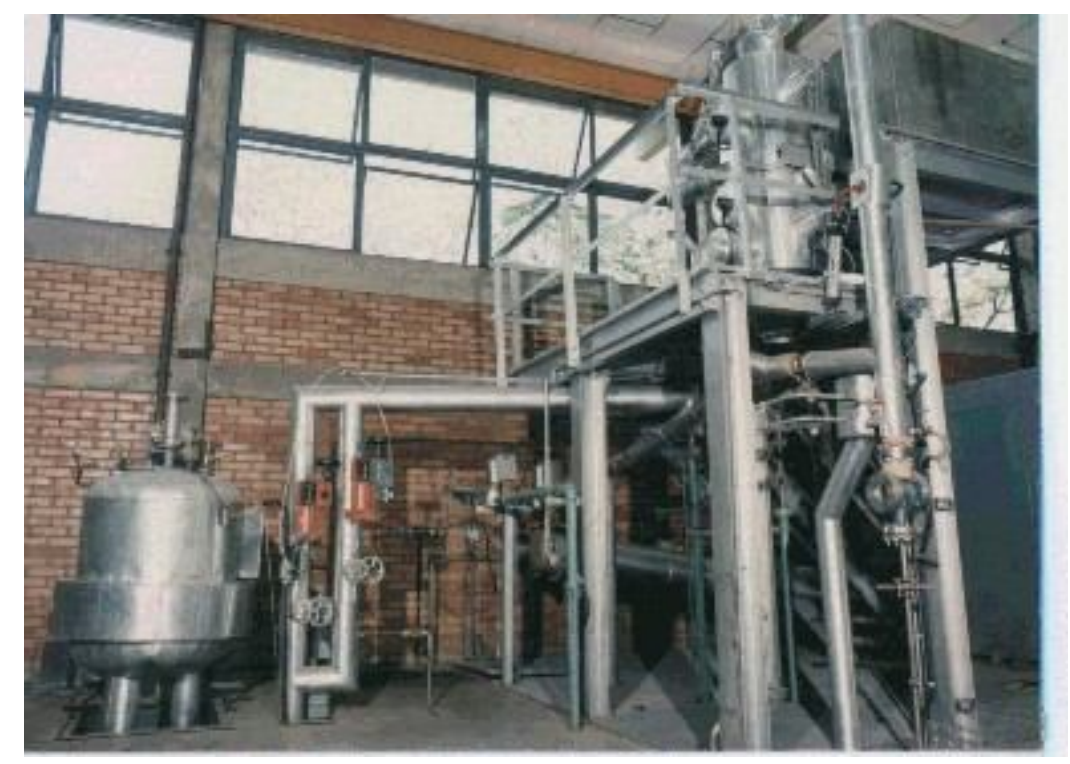

FIGURA 17 Vista do CT1 com seus principais componentes Fonte: foto tirada pelo autor 


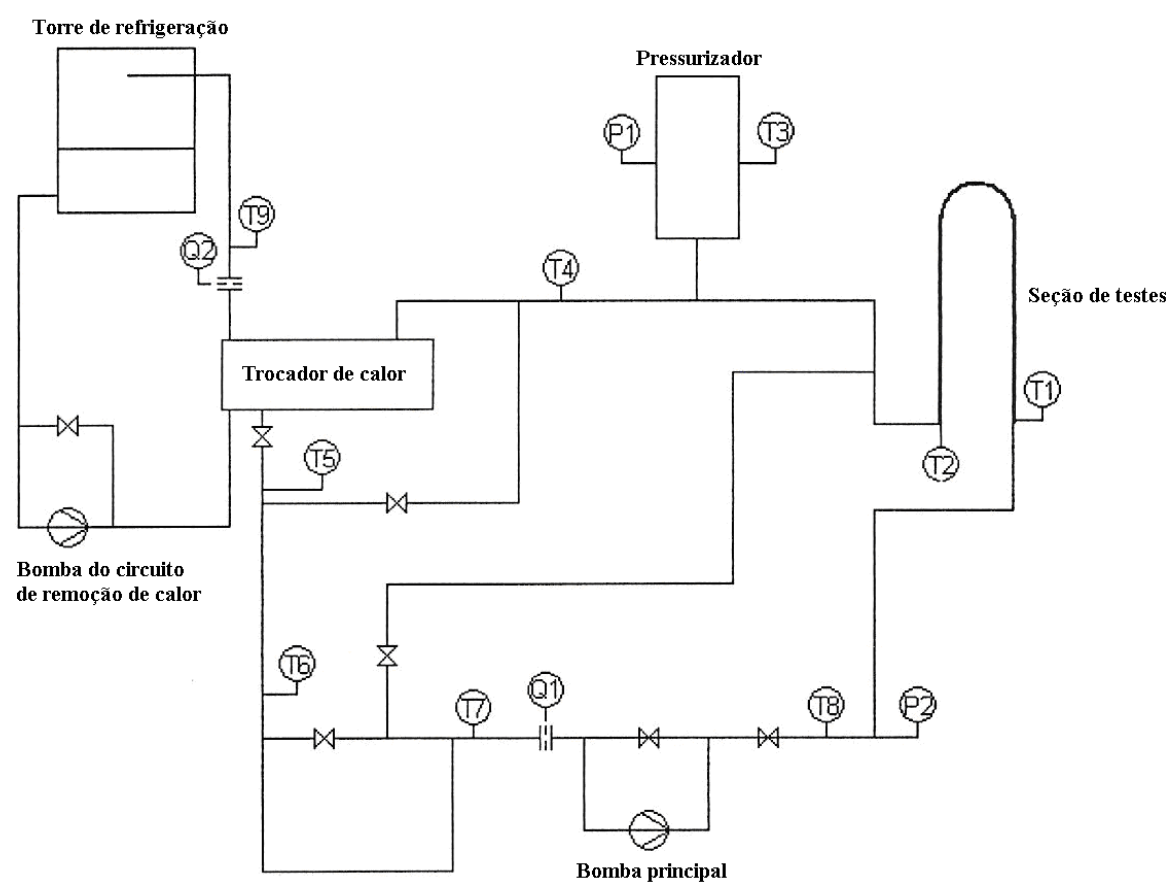

FIGURA 18 Circuito Térmico Número 1

Fonte: adaptado de SOUZA e COLARES, 1975

O circuito principal é fechado e a pressão nominal de operação é de até $15 \mathrm{kgf} / \mathrm{cm}^{2}(1,47 \mathrm{MPa})$. A tubulação que o constitui é de aço inoxidável e a água de circulação é deionizada e desgaseificada. O circuito principal, incluindo todos os seus componentes, é revestido por um isolamento térmico, destinado a impedir que ocorram perdas térmicas, acarretando menor consumo de energia e possibilitando manter a temperatura na área próxima em valores seguros. O revestimento é constituído essencialmente, por fibras isolantes recobertas por chapas de alumínio liso.

Seguindo o fluxograma do circuito principal, FIG. 18, no sentido do escoamento, seus componentes principais são: a bomba principal, a seção de testes, o pressurizador e o trocador de calor.

A bomba principal é do tipo centrífuga, construída em aço inoxidável e mantém a água em circulação no circuito principal. Ela tem uma vazão máxima de $1,3 \mathrm{l} / \mathrm{s}$ a uma diferença de pressão de $0,235 \mathrm{MPa}$ e um recalque máximo de 0,323 MPa. A pressão máxima de operação dessa bomba é de 0,8 MPa e os 
limites, inferior e superior, da temperatura do fluido são $10^{\circ} \mathrm{C}$ e $85^{\circ} \mathrm{C}$ respectivamente.

Na seção de testes (ST) do CT1, são simulados os efeitos termohidráulicos que se deseja investigar e ela pode apresentar geometria tubular, anular ou de feixe de varetas. A seção de testes é composta de um tubo de aço inoxidável, em forma de $\mathrm{U}$, com circulação interna de água e aquecimento por efeito Joule, diretamente na sua parede, através de um retificador elétrico com potência máxima de $120 \mathrm{~kW}$. A FIG. 19 apresenta a seção de teste na configuração usada, podendo-se observar as cordoalhas de ligação com o retificador, dois tubos brancos de isolação mecânica dos termopares na entrada e saída da ST e os fios de medição de potência que se ligam a uma caixa de plástico à direita da foto.

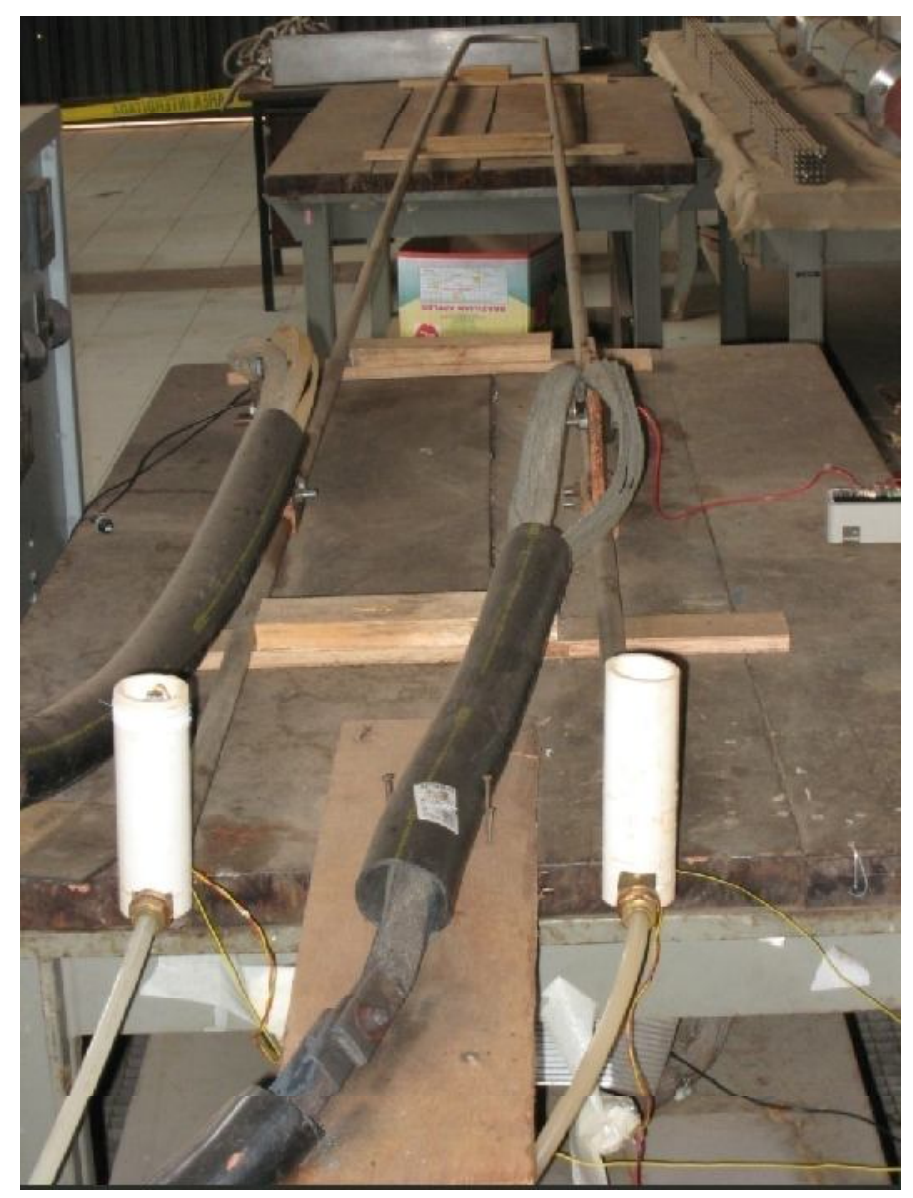

FIGURA 19 Seção de teste usada nos experimentos Fonte: foto tirada pelo autor 
Na saída da seção de testes, o escoamento do fluido é ascendente e um visor, localizado logo após a sua extremidade superior, permite a observação da configuração do escoamento. Imediatamente a jusante do visor, encontra-se o condensador de mistura, uma tubulação cuja finalidade é de levar água, com temperatura aproximadamente igual à da saída da bomba original, à saída da seção de testes, ocasionando, neste ponto, uma redução da temperatura média do fluido. Na configuração do circuito para esses experimentos, como a bomba foi trocada e sua posição alterada, esse condensador de mistura ficou inoperante, já que está ligado á sucção da nova bomba e não ao recalque da mesma, assim ele funciona agora como um desvio (bypass) do trocador de calor.

O pressurizador é do tipo céu de vapor, possui características autoestabilizantes e pressão máxima de trabalho igual a 1,5 MPa. Também auxilia na desgaseificação da água do circuito. O pressurizador é executado em aço inoxidável, dispondo de boias para indicação de níveis máximo e mínimo. Uma resistência elétrica, cuja finalidade é compensar as perdas de calor através das paredes do recipiente, fornece o calor necessário para gerar uma quantidade de vapor igual àquela condensada na sua superfície interna podendo ainda pressurizar lentamente o circuito. A potência dissipada nesta resistência pode ser variada até $2 \mathrm{~kW}$. Possui ainda um indicador de nível externo para observação visual do nível da água.

O trocador transfere calor do circuito principal para o circuito de remoção de calor de maneira similar a que o gerador de vapor de uma central nuclear remove energia térmica do circuito primário para o secundário. Possui uma capacidade máxima de troca de $300 \mathrm{~kW}$. A temperatura da água no circuito principal tem que ser reduzida a um valor que evite a ocorrência de cavitação na bomba principal e no caso da configuração usada que evite atingir o limite de temperatura de operação da bomba.

O trocador de calor é conectado a uma torre de refrigeração, onde o calor é dissipado para a atmosfera. Esta torre é provida de ventiladores e tem capacidade de dissipar $360000 \mathrm{kcal} / \mathrm{h}$ (418 kW) à vazão de $18000 \mathrm{l} / \mathrm{h}(5 \mathrm{~kg} / \mathrm{s})$. 
Para que a condutividade elétrica da água seja inferior a $1 \mu \mathrm{mho} / \mathrm{cm}$, de modo a reduzir a um mínimo a corrosão das superfícies metálicas, as fugas de corrente e a eletrólise da água, dispõe-se de um sistema central de deionização. Este sistema fornece, ao circuito principal, água deionizada com condutividade inferior a $0,2 \mu \mathrm{mho} / \mathrm{cm}$ a uma vazão máxima de $150 \mathrm{l} / \mathrm{h}$, para o enchimento do CT1 antes de uma campanha de testes. Para que não haja contaminação da água, suas tubulações, conexões e válvulas são de PVC.

Para a operação do CT1 são usadas bancadas com chaves para ligar e desligar as bombas, a mudança da posição das válvulas é feita manualmente e o controle da potência é feito através de uma interface do computador com o sistema de coleta de dados e o retificador.

\subsection{O Sistema de Coleta de Dados}

Para acompanhar a operação do CT1, foram instalados 10 termopares tipo $\mathrm{J}$ para medidas de temperatura, 2 transmissores de pressão para medidas de pressão e 2 placas de orifício para medidas de vazão. Todos foram estrategicamente localizados ao longo do circuito principal e do de remoção de calor. Na FIG. 20 são apresentados o fluxograma do CT1 e os pontos de medidas dos parâmetros termo-hidráulicos, temperaturas, pressões e vazões.

Os sistemas de coleta de dados e de controle do retificador são formados por um conjunto de placas da Advantech (PC-LABCARDS, 1994) interligados entre si e com um computador. Esse conjunto é formado basicamente pela placa multiplexadora PCLD789 e pela placa de aquisição e conversão de dados Analógico-Digital-Analógico.

A FIG. 21 é uma foto da montagem das placas do sistema de coleta de dados e as conexões da instrumentação na placa 789. A FIG. 22 apresenta o esquema de entrada e saída dos sinais nas placas 789, 818 e na CPU do computador e as interfaces com a instrumentação e o retificador. 


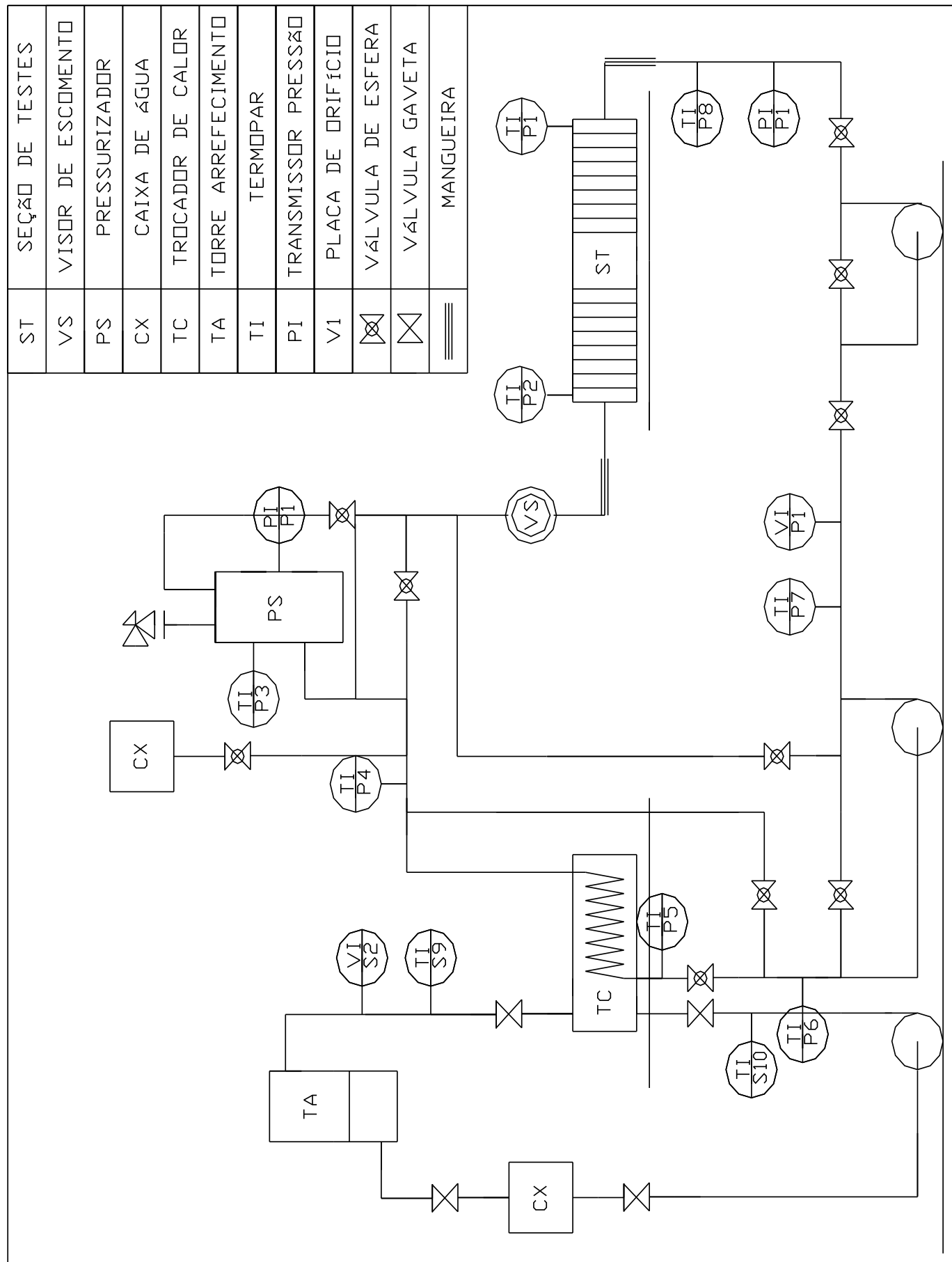

FIGURA 20 Fluxograma do CT1.

Fonte: ARTEAGA (2007) 
A instrumentação é ligada à placa 789 que recebendo uma instrução disponibiliza um dos canais de medida para a placa 818 . A placa 818 converte, no conversor A/D, o sinal analógico disponibilizado pela placa 789 em um valor digital e o transmite para o computador, que pode tratar o dado e o armazenar. A placa 818 pode ainda receber um valor digital do computador e gerar um sinal analógico no conversor D/A. No arranjo usado para os experimentos deste trabalho, o sinal analógico gerado na placa 818 é usado para controlar a potência de saída do retificador que alimenta a seção de testes.

A placa 818 converte sinais de tensão analógica em digital, assim para a leitura das temperaturas e pressões, é necessário converter os sinais de corrente emitido pelos transmissores, em sinais de tensão, por intermédio de resistências na entrada da placa coletora. Para a leitura da tensão na seção de testes, é necessário apenas reduzir o sinal, através de um conjunto de resistências formando um divisor de tensão.

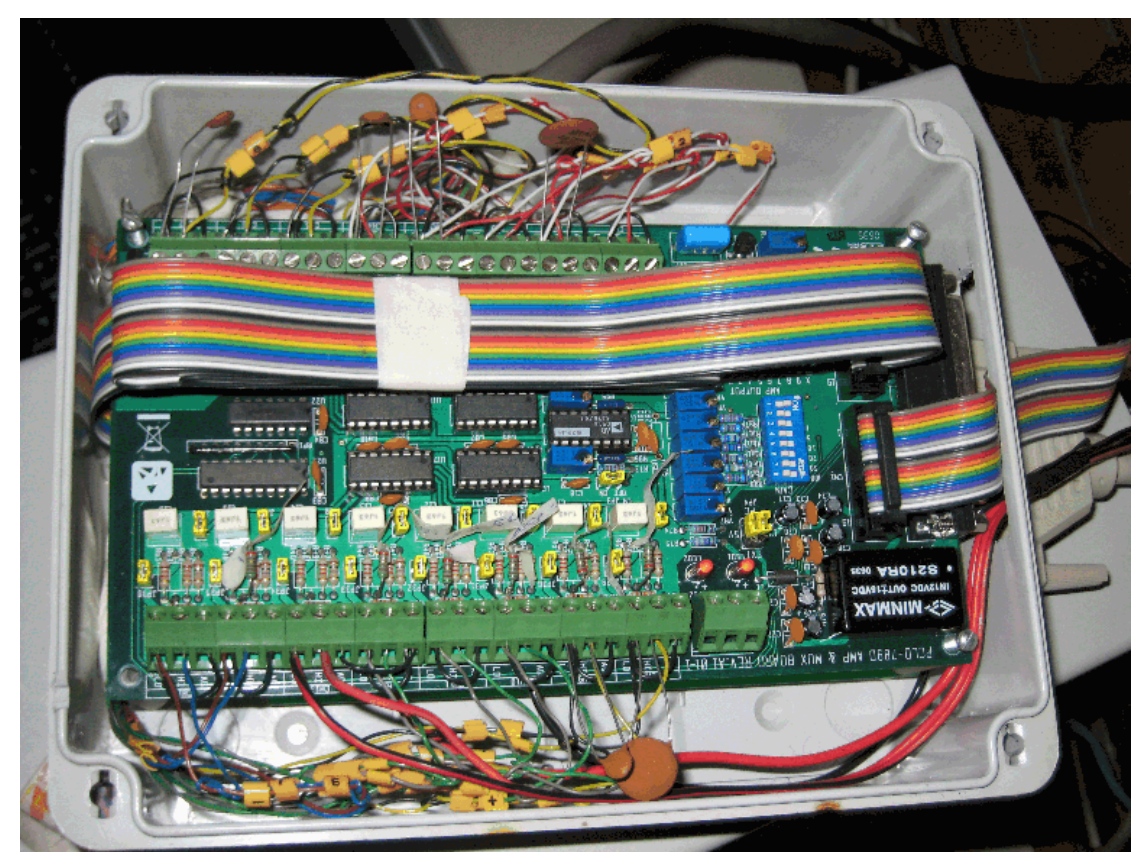

FIGURA 21 Conexões da instrumentação na placa 789 e interligação das placas Fonte: foto tirada pelo autor 


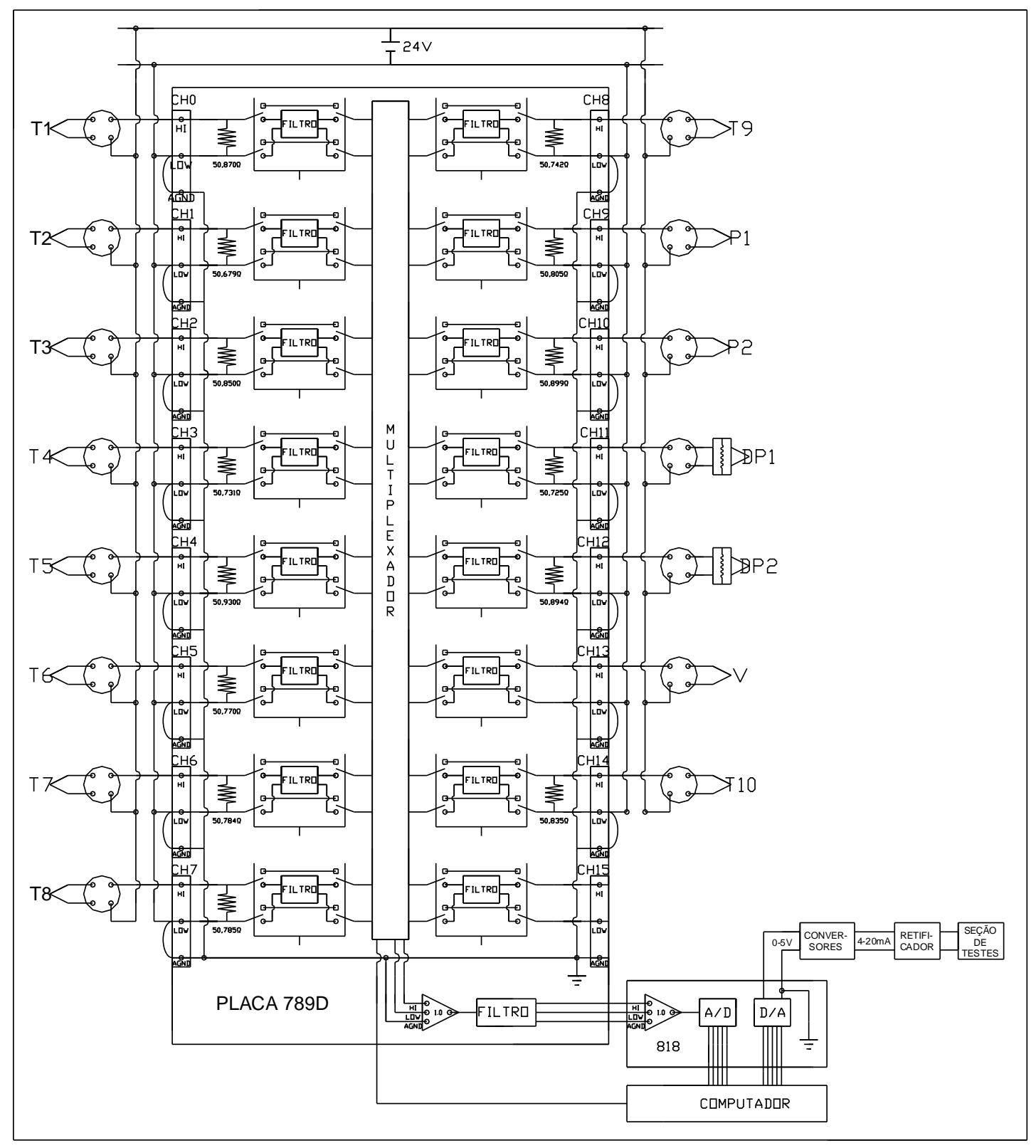

FIGURA 22 Placas coletoras.

Fonte: ARTEAGA (2007)

A placa coletora 789 filtra e amplifica os sinais antes de multiplexá-los e disponibilizá-los para a conversão na placa 818. Para se converter o sinal lido (V) em medidas de engenharia ( ${ }^{\circ} \mathrm{C}$ ou bar), é utilizado um programa de coleta e tratamento de dados desenvolvido em Quick Basic. 


\subsection{A Aferição da Instrumentação}

Toda a instrumentação instalada no CT1 para esses experimentos foi aferida antes de se fazer o programa de coleta de dados e de se iniciar os experimentos.

Os termopares foram aferidos usando-se um forno de calibração, com temperaturas estabilizadas depois de serem aumentadas e depois de serem diminuídas. Esse processo de medição de temperaturas em degraus crescentes e decrescentes foi repetido duas vezes entre $20^{\circ} \mathrm{C}$ e $120^{\circ} \mathrm{C}$ com intervalos de $20 \stackrel{\circ}{ } \mathrm{C}$.

Os transmissores de pressão foram aferidos contra padrões do Laboratório de Termo-hidráulica.

As medidas de vazão são feitas através da medida de pressão diferencial provocada pelo escoamento através de placas de orifícios. Assim, para essas medidas, foram aferidos os transmissores de pressão que estão ligados antes e depois da placa de orifícios.

A potência na seção de testes foi aferida usando-se um conjunto de voltímetro e amperímetro de precisão que mediam a corrente contínua, a alternada e a efetiva ( $r m s$ - root mean square), para fins de validação das medidas.

Os valores obtidos dessas calibrações foram transformados em fatores de conversão que estão apresentados no APÊNDICE A e que foram implementados no programa de coleta de dados, que é apresentado por Arteaga (2007). 


\subsection{O Programa de Coleta de Dados}

Para desempenhar as funções descritas no item 4.2 o sistema de coleta de dados é controlado por um programa computacional. Esse programa atua:

- na interação com o operador, para controle da potência e para definição de como será feita a coleta e o armazenamento de dados,

- no controle de como será feita a coleta, em que intervalo de tempo cada canal será lido,

- na conversão dos sinais de tensão lidos em unidades de engenharia,

- no armazenamento dos dados lidos e convertidos,

- na apresentação dos resultados na tela do computador para monitoramento em tempo real da operação,

- no controle da potência do retificador e

- nas medidas de segurança para evitar acidentes

As equações de conversão do sinal lido em medidas de engenharia, as equações derivadas dessas medidas, mais os parâmetros de calibração são apresentados no APÊNDICE A enquanto o programa de coleta e tratamento de dados é apresentado por Arteaga (2007). A segurança de operação do circuito para evitar acidentes foi implementada através do programa de coleta de dados e através de um procedimento de operação, apresentado no APÊNDICE B, feito para a realização dos experimentos.

A FIG. 23 mostra a tela de apresentação de monitoramento da operação pelo programa de coleta de dados. À esquerda da tela estão dois painéis com gráficos mostrando a evolução dos parâmetros medidos, acima temperatura e abaixo pressões, vazões e potência. À direita, a tela é dividida em 
5 regiões verticais, a superior mostra a data, o número de leituras que forma um ponto de medição e o tempo gasto para ler todos os parâmetros e iniciar um novo ciclo de leitura. Nos experimentos realizados, foi considerado como a melhor opção fazer pontos de leitura com somente uma medida de cada parâmetro, forçando um tempo de espera entre cada leitura de forma que em geral o tempo de ler um conjunto de parâmetros era menor que meio segundo, na FIG. 23, 0,47 s. Logo abaixo são apresentados os valores de todos os parâmetros, exceto os de vazão do secundário e de tensão, que são mostrados no bloco abaixo. Os parâmetros são apresentados no valor bruto medido, convertidos para unidades de engenharia e é apresentada ainda uma estimativa de erro da medida. O quarto bloco de cima para baixo mostra à esquerda que tipo de gravação de dados está sendo feita e logo à direita valores para alterar a potência do retificador, especificando a tensão inicial, a tensão final e quanto tempo levará para ir da potência inicial para a final. Finalmente o bloco mais abaixo é um display mostrando as opções de comandos disponíveis para interagir com o programa.

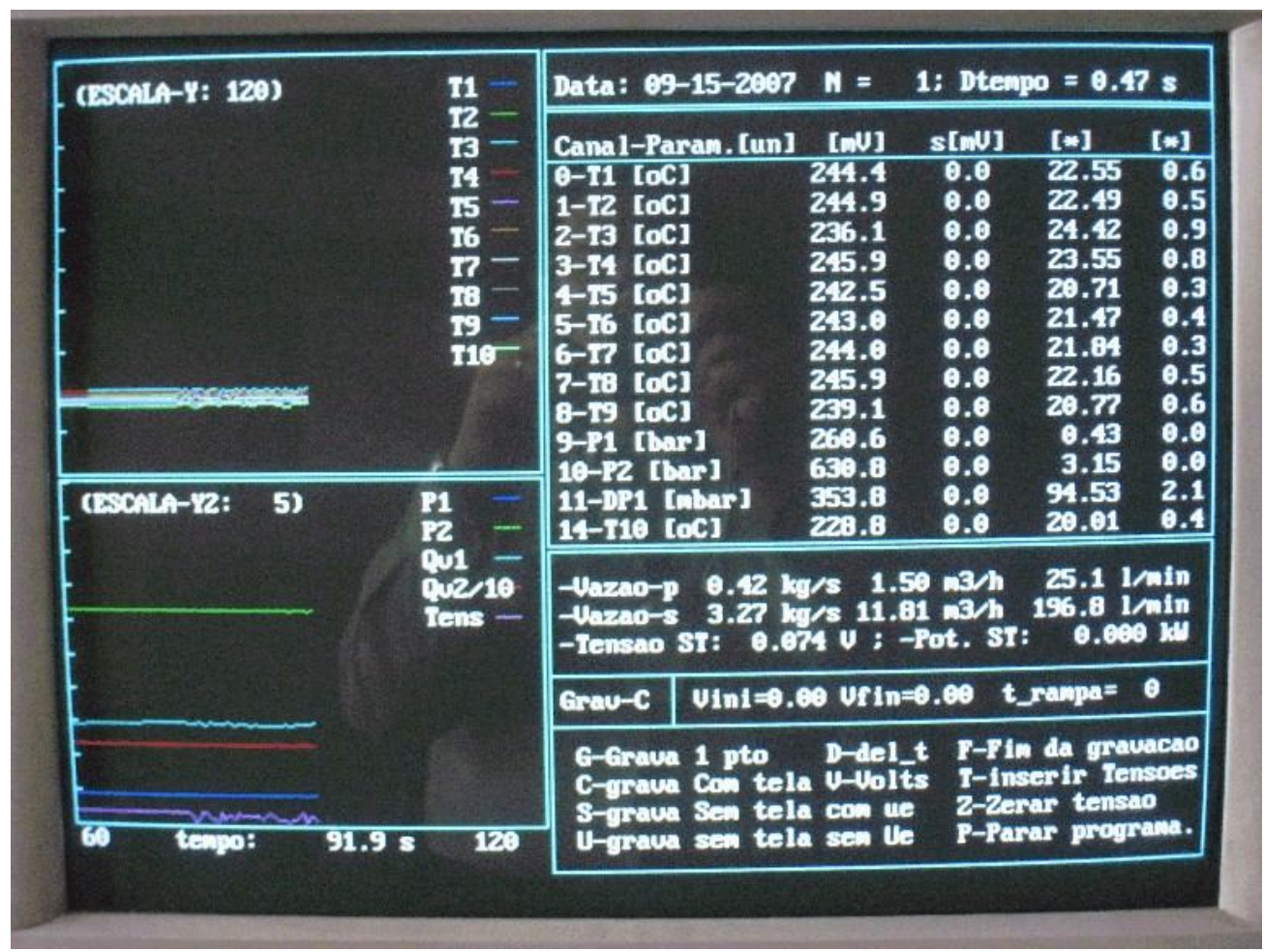

FIGURA 23 Tela de monitoramento da operação do CT1 neste projeto Fonte: foto tirada pelo autor 


\subsection{Matriz de testes}

Para dar suporte ao desenvolvimento de SICT foi montada uma matriz de testes que fosse viável de se executar no CT1.

Sabe-se que, para se evitar que a central nuclear seja posta em perigo, a operação é supervisionada pelas grandezas características de segurança. No CT1, os circuitos são providos de sensores, utilizados para as medidas de potência, vazão, temperatura e pressão.

Quando surgem falhas, ocorrem desvios dos valores estabelecidos pelo projeto. Neste caso, ao invés de estados estacionários e transientes operacionais, efetuam-se transientes anormais e, até mesmo, acidentais.

Para recriar as falhas e os transientes de potência similares aos de uma central, foi elaborada uma sequência de experimentos no CT1, sendo que os valores de potência e as taxas das rampas foram multiplicados por um fator de escala condizente com a capacidade do retificador e da bancada de testes.

Numa central nuclear, os transientes de potência referem-se às variações de energia entregue pelo núcleo do reator. Já no CT1, os transientes referem-se às variações de energia entregue a seção de testes pelo retificador.

Para recriar o comportamento análogo ao do reator, foram realizados experimentos de estado estacionário e transientes lentos de potência crescentes e decrescentes e para as falhas de reatividade com aumento instantâneo de potência, transientes rápidos de potência - degraus crescentes.

Para os "blackouts", sem reposição da energia para o consumo próprio, as bombas param e ocorrem falhas de resfriamento do núcleo. Por apresentar grande risco, a parada das bombas a altas potências não foi planejada. No entanto, ocorreu um acidente de operação onde o retificador fornecia alta potência e não havia vazão suficiente de refrigerante na seção de testes, criando 
assim as condições para a ebulição de filme e atingindo o afastamento da ebulição nucleada (DNB).

Para as falhas de remoção de calor do circuito primário da central, isolou-se o trocador de calor do CT1. Para recriar os efeitos gerados pela ruptura do circuito primário, vazamento do fluido e queda de pressão do sistema, despressurizou-se o CT1.

O QUADRO 3 apresenta a lista dos experimentos realizados neste projeto juntamente com uma descrição muito sucinta dos mesmos. Esses experimentos se prestaram tanto para teste e validação do circuito, de sua instrumentação e do sistema de coleta de dados como para prover resultados para uso na validação da metodologia utilizada para desenvolver o SICT.

QUADRO 3 - Matriz de experimentos realizados

\begin{tabular}{|c|c|c|}
\hline \multicolumn{2}{|c|}{ Identificação } & Descrição \\
\hline \multicolumn{2}{|l|}{ Exp01_22Jun } & Primeiro Experimento para comissionamento \\
\hline \multicolumn{2}{|l|}{ Exp02_09Jul } & Acidente de operação: degrau 15 em vez de 1.5 \\
\hline \multirow{4}{*}{ Exp03_16Ago } & $\mathrm{C} 01$ & 3 leituras sem loop de atraso; ch13 não aterrado \\
\hline & C02 & 1 leitura com 10000 loops de atraso \\
\hline & $\mathrm{CO3}$ & 1 leitura com 25000 loops de atraso \\
\hline & $\mathrm{C04}$ & 1 leitura com 50000 loops de atraso \\
\hline \multirow{9}{*}{$\begin{array}{l}\text { (Rodadas } \\
\text { para achar o } \\
\text { tempo de } \\
\text { retardo } \\
\text { necessário e } \\
\text { a influência } \\
\text { de medidas } \\
\text { entre canais } \\
(0 \text { a } 100 \mathrm{~V}))\end{array}$} & $\mathrm{C05}$ & 1 leitura com 5000 bops de atraso \\
\hline & $\mathrm{C06}$ & 1 leitura sem loop de atraso \\
\hline & $\mathrm{C} 07$ & 3 leituras sem loop de atraso; ch13 aterrado \\
\hline & $\mathrm{C08}$ & 1 leitura com 10000 loops de atraso, ch13 aterrado \\
\hline & C09 & 3 leituras com sem loop de atraso, ch13 x ch15 \\
\hline & C10 & 1 leitura com 10000 loops de atraso, ch13 x ch15, ch13 aterrado \\
\hline & C11 & 3 leituras com 10000 loops de atraso, ch13 x ch15, ch13 aterrado \\
\hline & $\mathrm{C} 12$ & 3 leituras com 25000 loops de atraso, ch13 x ch15, ch13 aterrado \\
\hline & $\mathrm{C} 13$ & 4 leituras com 10000 loops de atraso, ch13 $x$ ch15, ch13 aterrado \\
\hline \multirow{2}{*}{ Exp04_17Ago } & $\mathrm{C} 01$ & T1, T2 teste de calibração, termopares aterrados, 20 a $120^{\circ} \mathrm{C}$ \\
\hline & $\mathrm{C02}$ & T1, T2 teste de calibração, termopares aterrados, 120 a $20^{\circ} \mathrm{C}$ \\
\hline \multicolumn{2}{|l|}{ Exp05_22Ago } & $\begin{array}{l}\text { Termopares aterrados para verificar influência das bombas e da } \\
\text { potência nas medidas }\end{array}$ \\
\hline Exp06_03Set & $\mathrm{C} 01$ & Degraus de Potência, 0-1, 1-2, 2-0 \\
\hline
\end{tabular}




\begin{tabular}{|c|c|c|}
\hline & $\mathrm{C} 02$ & $\begin{array}{l}\text { Potência: } 0-1 / 240 \mathrm{~s}, 1-3 / 240 \mathrm{~s} \text {, degrau } 3-4,4-5 / 120 \mathrm{~s} \text {, } 5- \\
2.5 / 180 \mathrm{~s}, 2.5-0 \\
\text { Válvula do bypass do trocador aberta e Válvula do Trocador } \\
\text { fechada }\end{array}$ \\
\hline \multicolumn{2}{|l|}{ Exp07_05Set } & $\begin{array}{l}\text { Potência } 0-5 ; 0-5 / 120 ; 5-2.5 ; 2.5-0 \text {. Acidente devido válvula } \\
\text { fechada }\end{array}$ \\
\hline \multicolumn{2}{|l|}{ Exp08_10 set } & Calibração do T10 \\
\hline \multicolumn{2}{|l|}{ Exp09_11Set } & Calibração do T10, Implantada segurança \\
\hline \multicolumn{2}{|l|}{ Exp10_14Set } & $\begin{array}{l}\text { Potência 0-5, 5-4, 4-1.5, } 1.5 \text { - 0, Erro no T10 devido água no } \\
\text { conversor. }\end{array}$ \\
\hline \multicolumn{2}{|l|}{ Exp11_01Out } & Degrau crescente de $10 \%$ \\
\hline \multicolumn{2}{|l|}{ Exp12_02Out } & Degrau decrescente de $10 \%$ \\
\hline \multicolumn{2}{|l|}{ Exp13_03Out } & Rampa crescente $10 \% 30 \mathrm{~s}$ \\
\hline \multicolumn{2}{|l|}{ Exp14_04Out } & Rampa decrescente $10 \% 30 \mathrm{~s}$ \\
\hline \multicolumn{2}{|l|}{ Exp15_05Out } & $\begin{array}{l}\text { Estacionário } 4,5 \mathrm{~V} \text { e } 2,5 \mathrm{~V} \text { verificar falta de bolha de ar e } \\
\text { temperaturas }\end{array}$ \\
\hline \multicolumn{2}{|l|}{ Exp16_090ut } & Rampas de diferentes $\mathrm{dV}$ e dt \\
\hline \multicolumn{2}{|l|}{ Exp17_100ut } & Despressurização \\
\hline \multicolumn{2}{|l|}{ Exp18_230ut } & Rampa crescente $10 \% \mathrm{dt}=240 \mathrm{~s}$ (parcial) \\
\hline $\begin{array}{l}\text { Exp19_250ut } \\
\text { Exp20_260ut }\end{array}$ & Exp19_250ut & $\begin{array}{l}\text { Rampa crescente } 10 \% \mathrm{dt}=120 \mathrm{~s} \\
\text { Rampa decrescente } 10 \% \mathrm{dt}=120 \mathrm{~s}\end{array}$ \\
\hline \multicolumn{2}{|l|}{ Exp21_03Nov } & Rampa decrescente $10 \% \mathrm{dt}=240 \mathrm{~s}$ \\
\hline \multirow{2}{*}{$\begin{array}{l}\text { Exp22_15Dez } \\
\text { Troca da } \\
\text { mangueira }\end{array}$} & C01 & 2400 s Estado Estacionário, pressurização \\
\hline & $\mathrm{CO3}$ & $\begin{array}{l}\text { Pressunizador ligado; Desl. Bomba Sec.; Despressurização; } \\
\text { Ebulição; Rampa decrescente } 10 \% \text { dt=240 s }\end{array}$ \\
\hline \multicolumn{2}{|l|}{ Exp23_22Dez } & $\begin{array}{l}\text { Pressunizador ligado; Desl. Bomba Sec.; Despressurização; } \\
\text { Fecha parcialmente a válvula na saída da ST; Rampas e Degraus } \\
\text { Crescentes e Decrescentes }\end{array}$ \\
\hline \multicolumn{2}{|l|}{ Exp24_24Dez } & Degraus Crescentes \\
\hline \multicolumn{2}{|l|}{ Exp25_26Dez } & Abre e Fecha Válvula do Pressurizador \\
\hline \multicolumn{2}{|l|}{ Exp26_28Dez } & Pressunizador ligado; Liga e Desliga Bombas Prim. e Sec. \\
\hline \multicolumn{2}{|l|}{ Exp27_29Dez } & $\begin{array}{l}\text { Bypass Trocador Aberto; Fecha Válvula de Isolamento do } \\
\text { Pressunizador }\end{array}$ \\
\hline
\end{tabular}

Fonte: elaborado pelo autor 


\subsection{Caracterização dos Resultados Experimentais}

$\mathrm{Na}$ avaliação de incertezas usadas para fazer a conversão dos valores de tensão medidos pelo sistema de coleta de dados para unidades de engenharia é usada a avaliação padrão onde um ponto de medida de um parâmetro é a média de $\mathrm{N}$ valores medidos e calcula-se também o desvio padrão dessas medições. Como durante os experimentos foi usada a abordagem de cada ponto de medida ser o valor único medido, não é avaliado o desvio padrão nessa abordagem.

Os gráficos que se seguem neste item apresentam valores de temperaturas, pressões, vazões e potência para que se possa ter ideia de como variam esses sinais e como é o erro da leitura dos sinais analógicos e de sua conversão para digital. Cada conjunto de gráficos apresenta uma visão geral do parâmetro medido, no intervalo de tempo de 0 a 2000 s e uma visão de um intervalo de $50 \mathrm{~s}$ que permite observar cada valor medido naquele intervalo, que usualmente é uma medida de um parâmetro que não varia significativamente nesse intervalo.

O GRAF. 2 mostra a temperatura medida pelo termopar de isolação mineral ligado diretamente na estrutura metálica da seção de teste, como mostrado na FIG. 19. As medidas apresentadas na parte inferior do GRAF.2 permitem observar que o erro de conversão analógica/digital é de 1 passo para cima ou para baixo, o que nesse caso representa uma incerteza devido à medição de $\pm 0,2 \stackrel{\circ}{ } \mathrm{C}$. Pode-se observar também que apesar da potência nesse período estar em torno de $60 \mathrm{~kW}$, conforme GRAF. 6, não se observa ruído devido à alimentação elétrica da seção de testes.

Os GRAF. 3, 4 e 5 apresentam outras medidas de temperatura, respectivamente na entrada do primário do trocador de calor e na entrada e saída do secundário do trocador de calor. O comportamento observado para essas medidas é o mesmo do descrito para a temperatura na entrada da seção de 
testes, com incertezas devido ao processo de coleta de aproximadamente $\pm 0,2 \stackrel{\circ}{\circ}$.
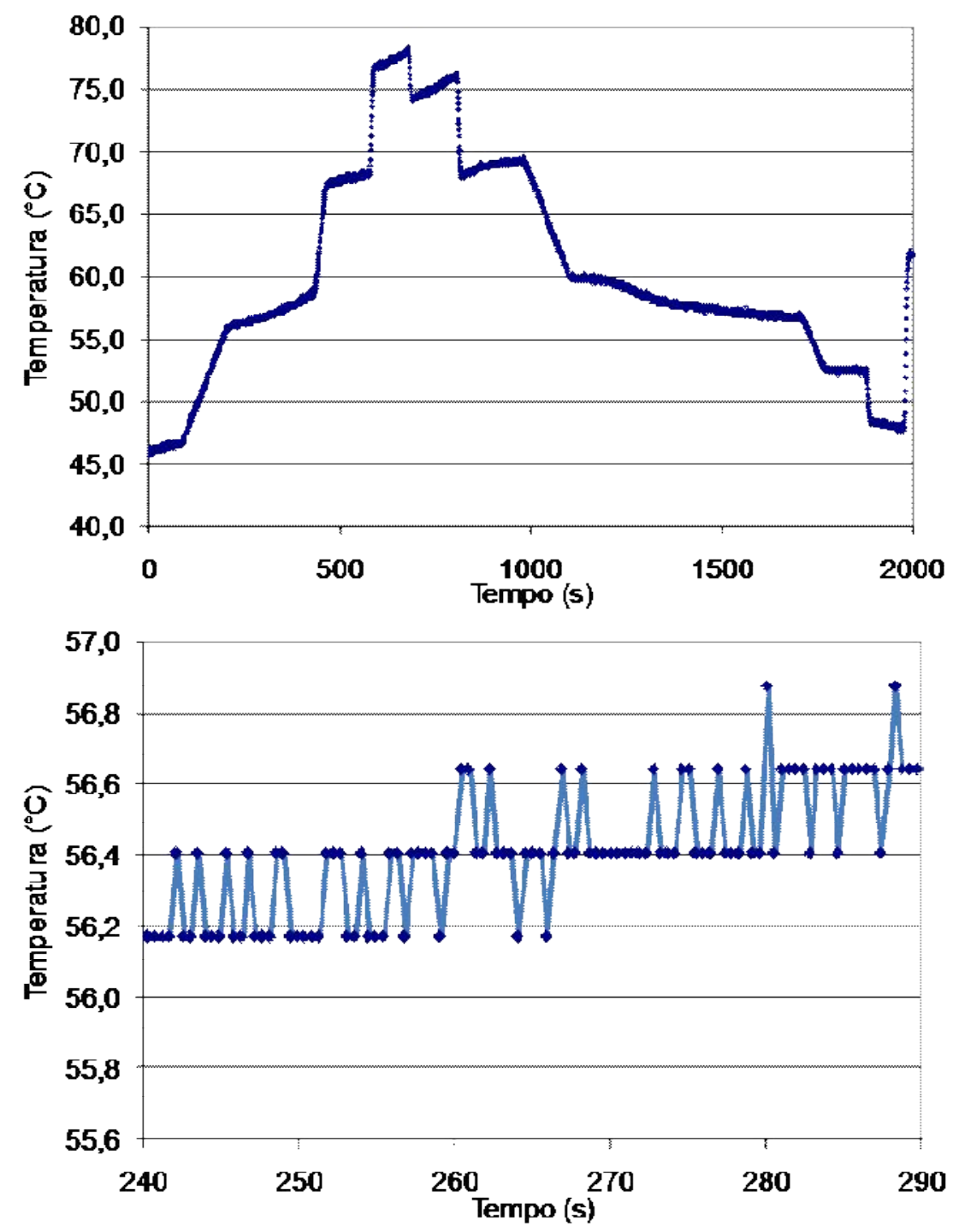

GRÁFICO 2 Temperatura medida na saída da seção de testes (T2) - Exp24

Fonte: resultados experimentais da pesquisa 

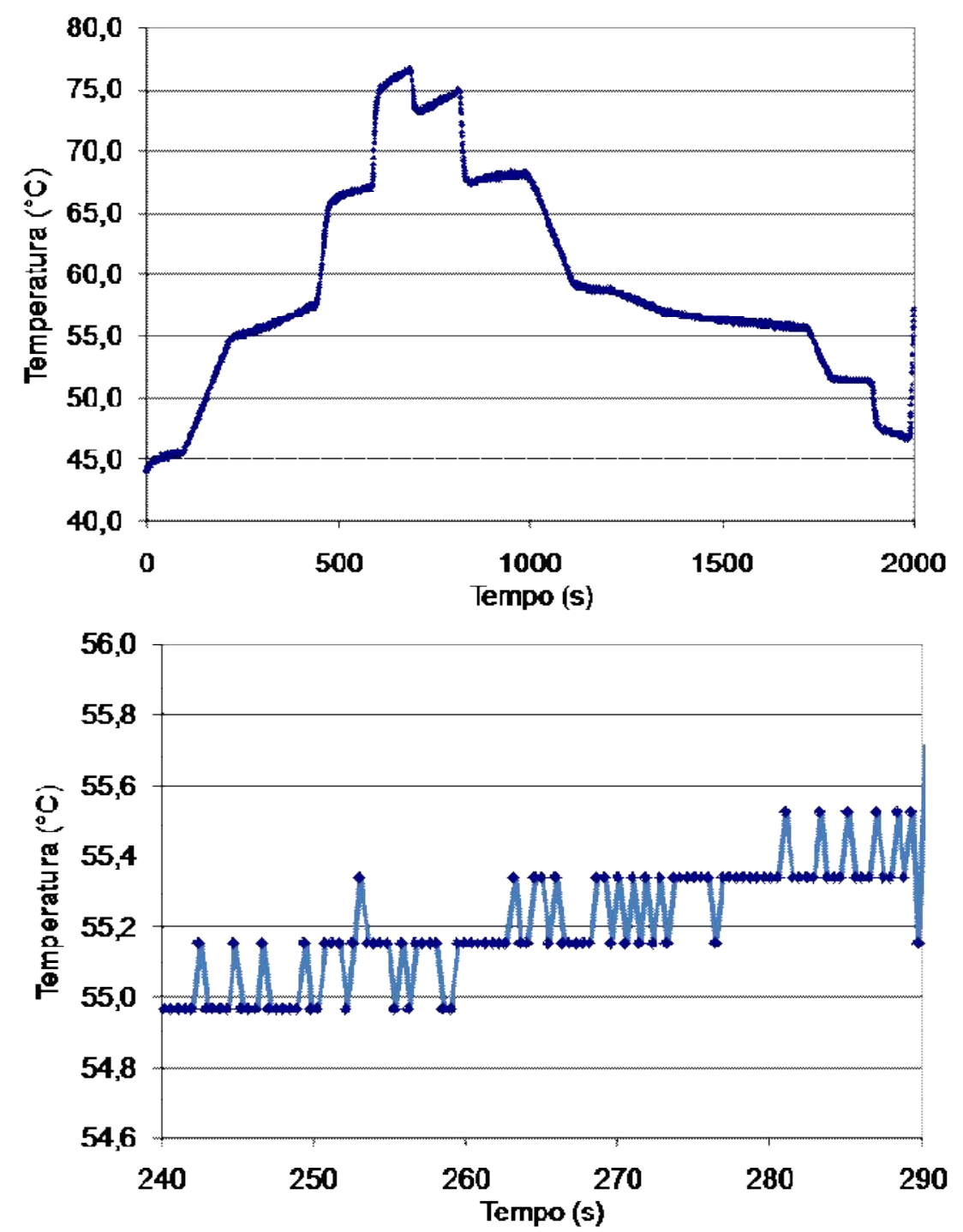

GRÁFICO 3 Temperatura medida na entrada do primário do trocador de calor (T4) - Exp24

Fonte: dados da pesquisa 

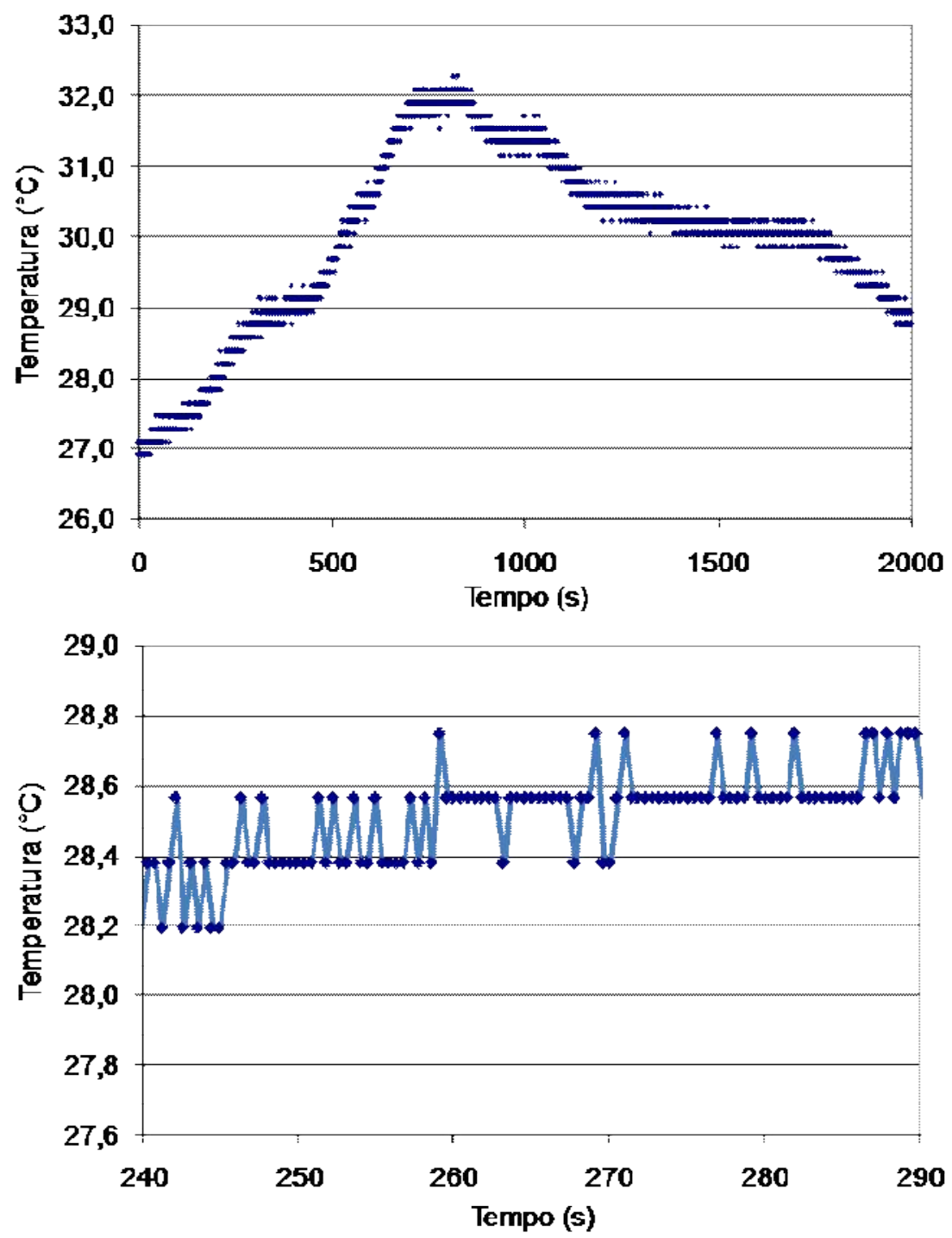

GRÁFICO 4 Temperatura medida na entrada do secundário do trocador de calor (T9) - Exp24

Fonte: dados da pesquisa 

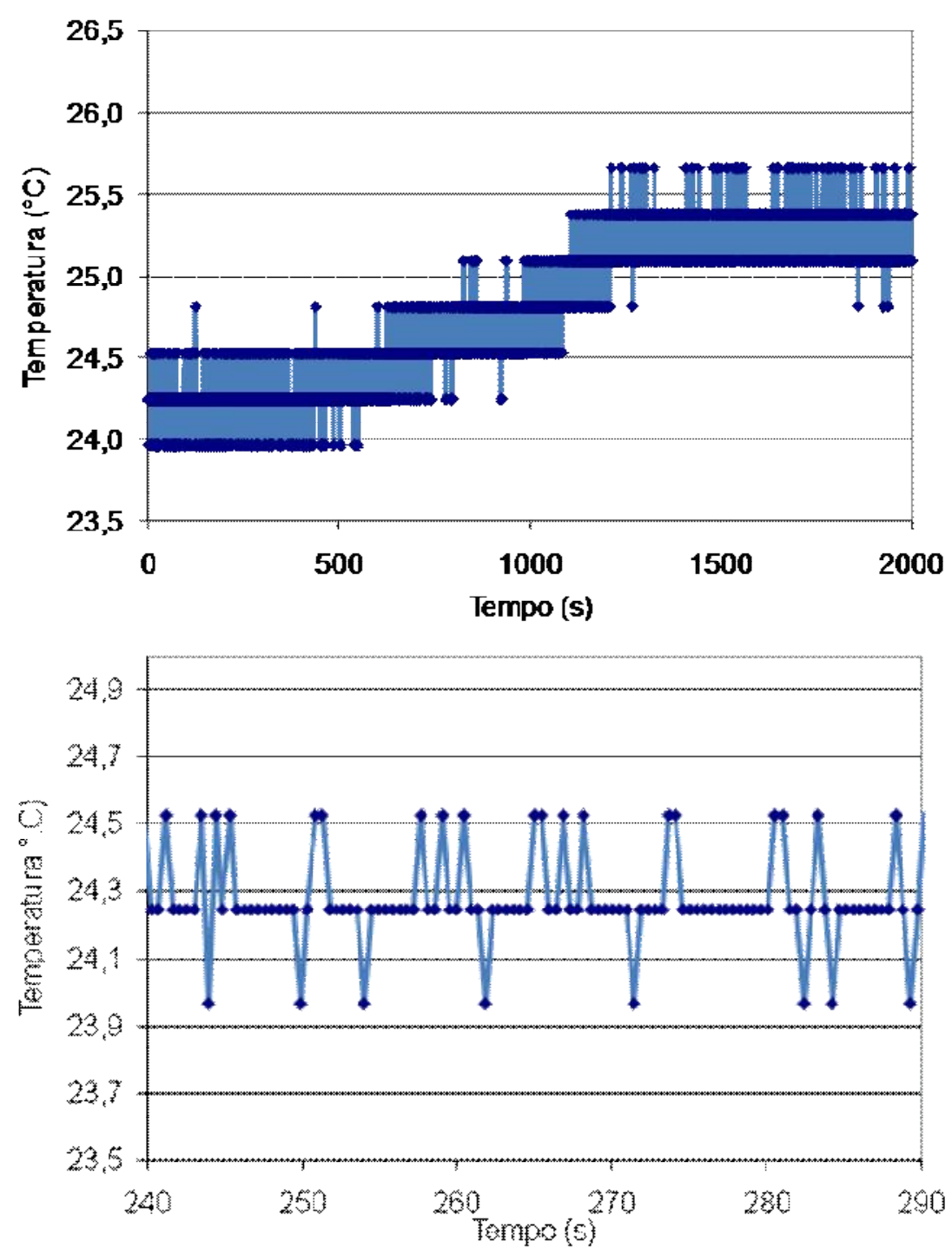

GRÁFICO 5 Temperatura medida na saída do secundário do trocador de calor (T10) - Exp24

Fonte: dados da pesquisa

O GRAF. 6 apresenta o valor de potência medido. Observa-se na parte inferior que 1 passo representa cerca de $0,1 \mathrm{~V}$, e na parte central observa-se que a potência varia entre 62,5 e 63,5 ou seja em uma faixa de $1 \mathrm{~V}$. Assim, diferentemente das medidas de temperatura que têm uma incerteza de cerca de \pm 1 passo a medida de potência tem um erro de cerca de \pm 5 passos, ou $\pm 0,5 \mathrm{~kW}$. 

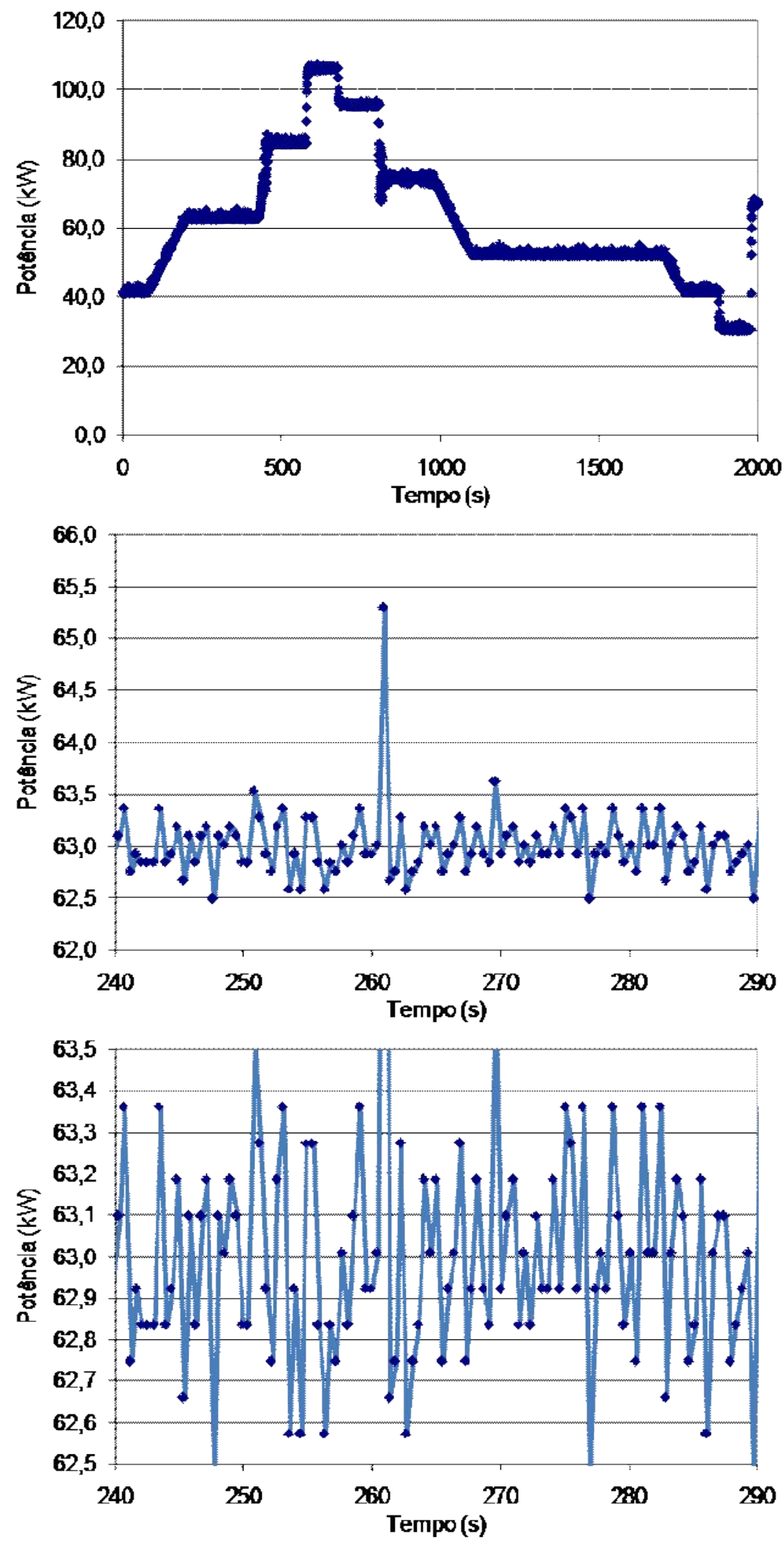

GRÁFICO 6 Potência medida na seção de testes - Exp24

Fonte: resultados experimentais da pesquisa 
O GRAF. 7 apresenta duas vistas da diferença de pressão medida pelo transmissor que está ligado à placa de orifício de medição de vazão do secundário. Pode-se observar na parte inferior que 1 passo representa aproximadamente 0,33 unidades de engenharia. Na parte superior fica fácil de observar que a variação de medida é de 15 unidades, portanto a incerteza nessa medida é de cerca de $\pm 7,5$ unidades ou \pm 22 passos. Considerando as incertezas das medidas dos parâmetros anteriormente apresentados fica evidente que essa incerteza não se deve ao processo de coleta de dados, mas da linha de medida como um todo, onde a principal parcela é devida ao sinal enviado pelo transmissor de pressão.

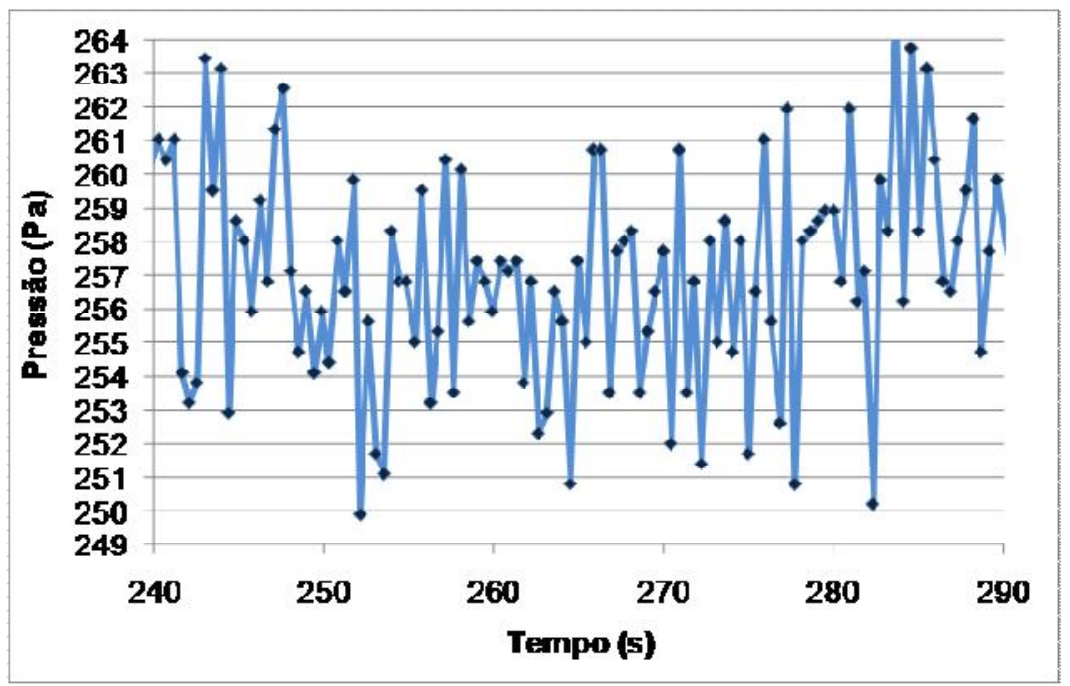

GRÁFICO 7 Diferença de pressão medida na placa de orifício do secundário Exp24

Fonte: resultados experimentais da pesquisa

Os GRAF. 8 e 9 apresentam as medidas de vazão após a conversão do sinal de tensão medido em unidade de engenharia, (GRAF. 7) conforme descrito no APÊNDICE A. Como nessa conversão são envolvidos muitos outros fatores além da mera conversão analógica digital não é possível calcular a incerteza em passos. Observa-se, porém, na parte superior do GRAF. 8 que a incerteza na medida da vazão do primário é de aproximadamente $\pm 0,035 \mathrm{~kg} / \mathrm{s}$ e para vazão do secundário é de $\pm 0,075 \mathrm{~kg} / \mathrm{s}$. Esses valores são relativos às vazões máximas possíveis nos dois circuitos. 

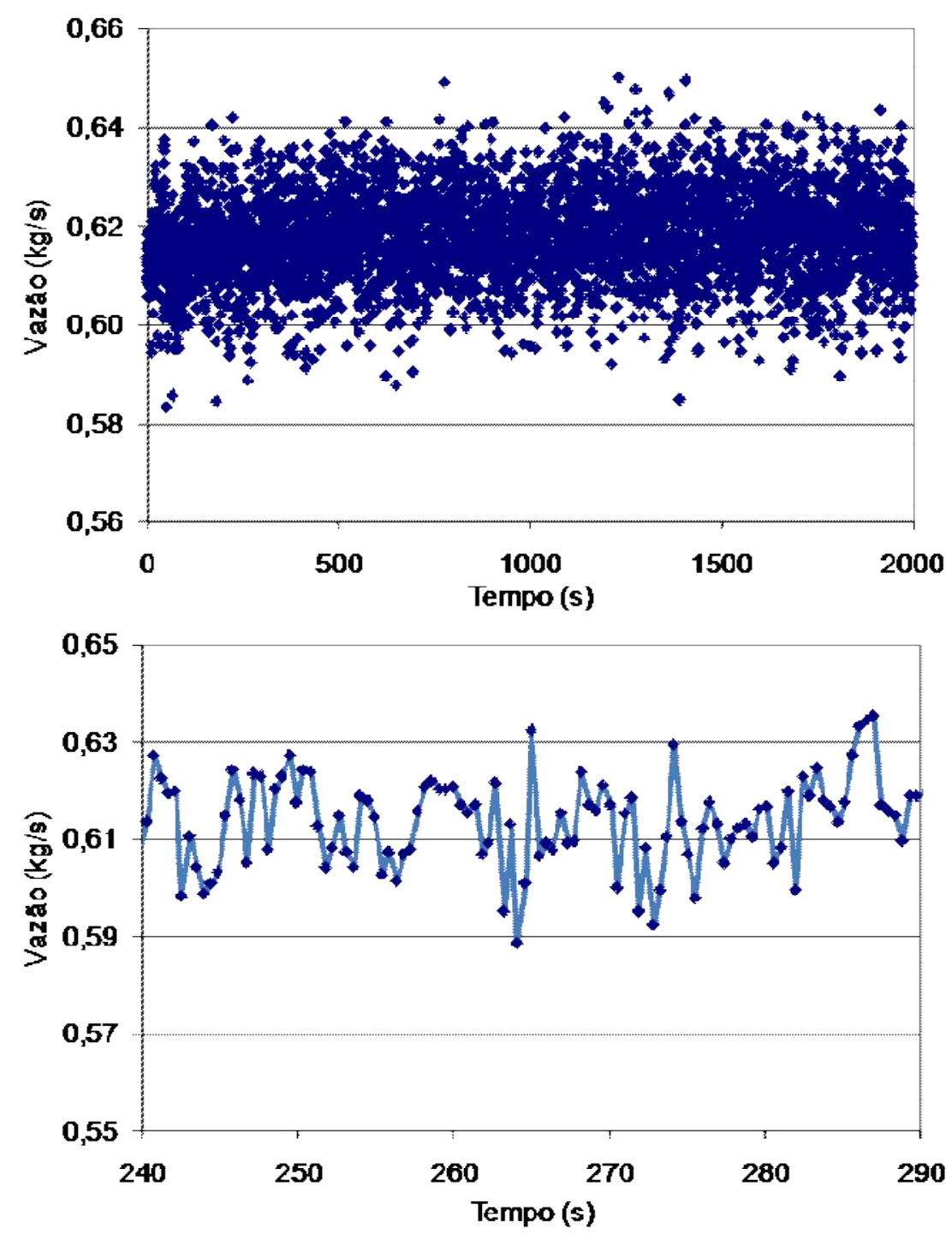

GRÁFICO 8 Vazão medida no primário - Exp24

Fonte: resultados experimentais da pesquisa 

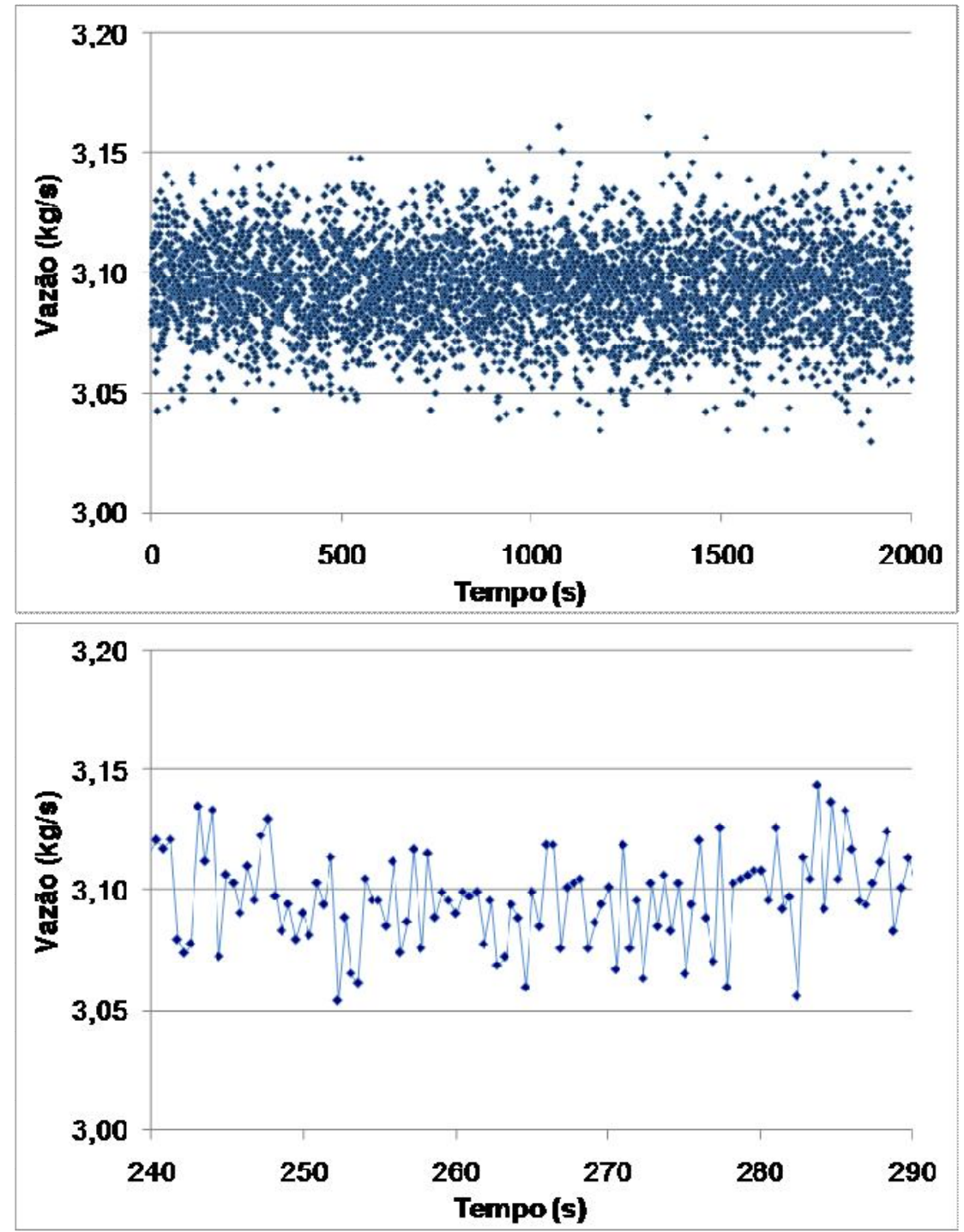

GRÁFICO 9 Vazão medida no secundário - Exp24

Fonte: dados da pesquisa

Os GRAF. 10 e 11 apresentam respectivamente a pressão no recalque da bomba do primário e no pressurizador. Observa-se na parte inferior do GRAF. 11 que a incerteza na medida da pressão é de \pm 1 passo o que corresponde a aproximadamente $\pm 0,0002 \mathrm{MPa}$. Já a pressão medida no recalque da bomba sofre influência da variação da vazão e tem uma incerteza \pm 2 passos, como pode ser observado na parte inferior do GRAF. 10, o que corresponde a aproximadamente $\pm 0,004 \mathrm{MPa}$. 

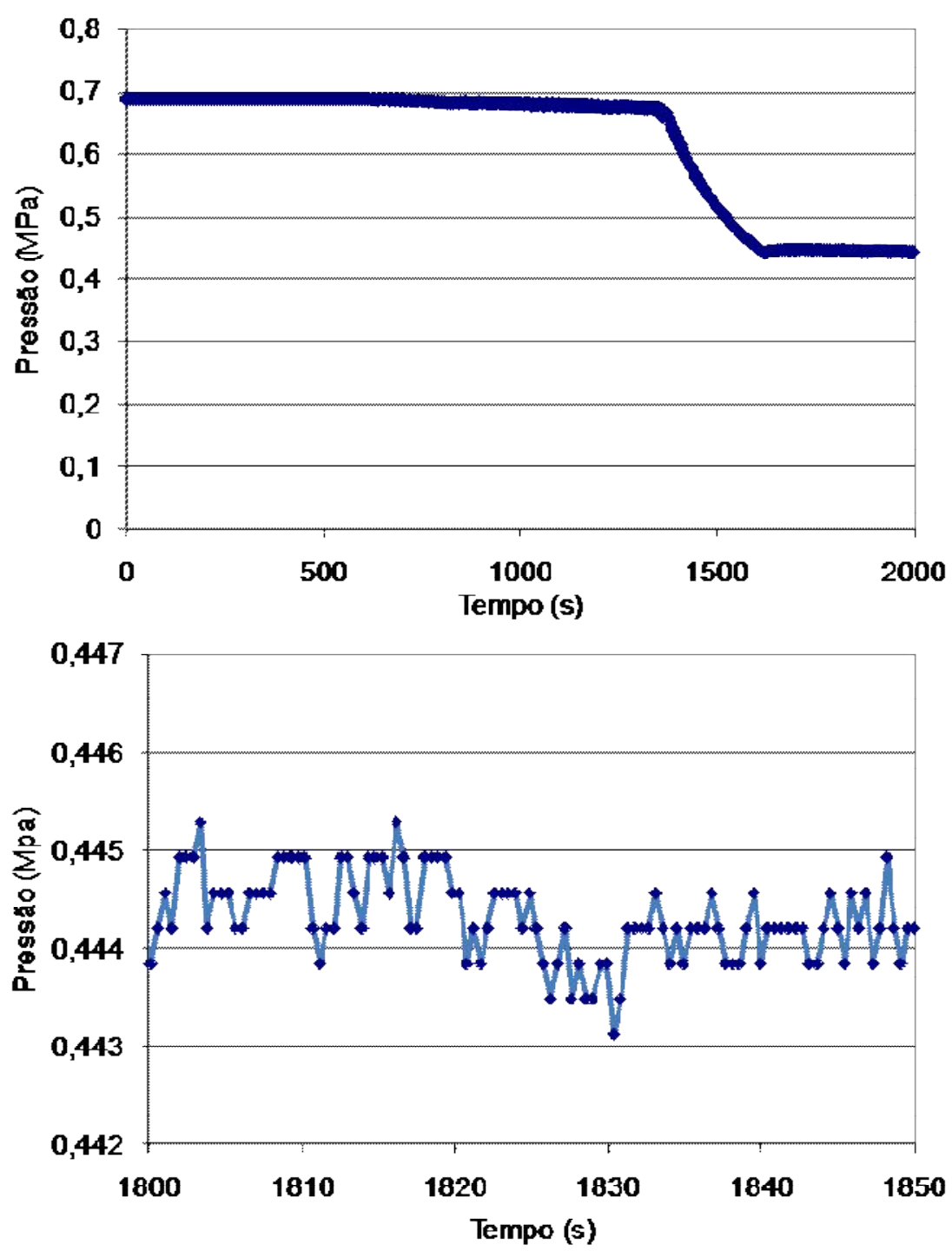

GRÁFICO 10 Pressão medida no recalque da bomba principal - Exp24

Fonte: resultados experimentais da pesquisa 

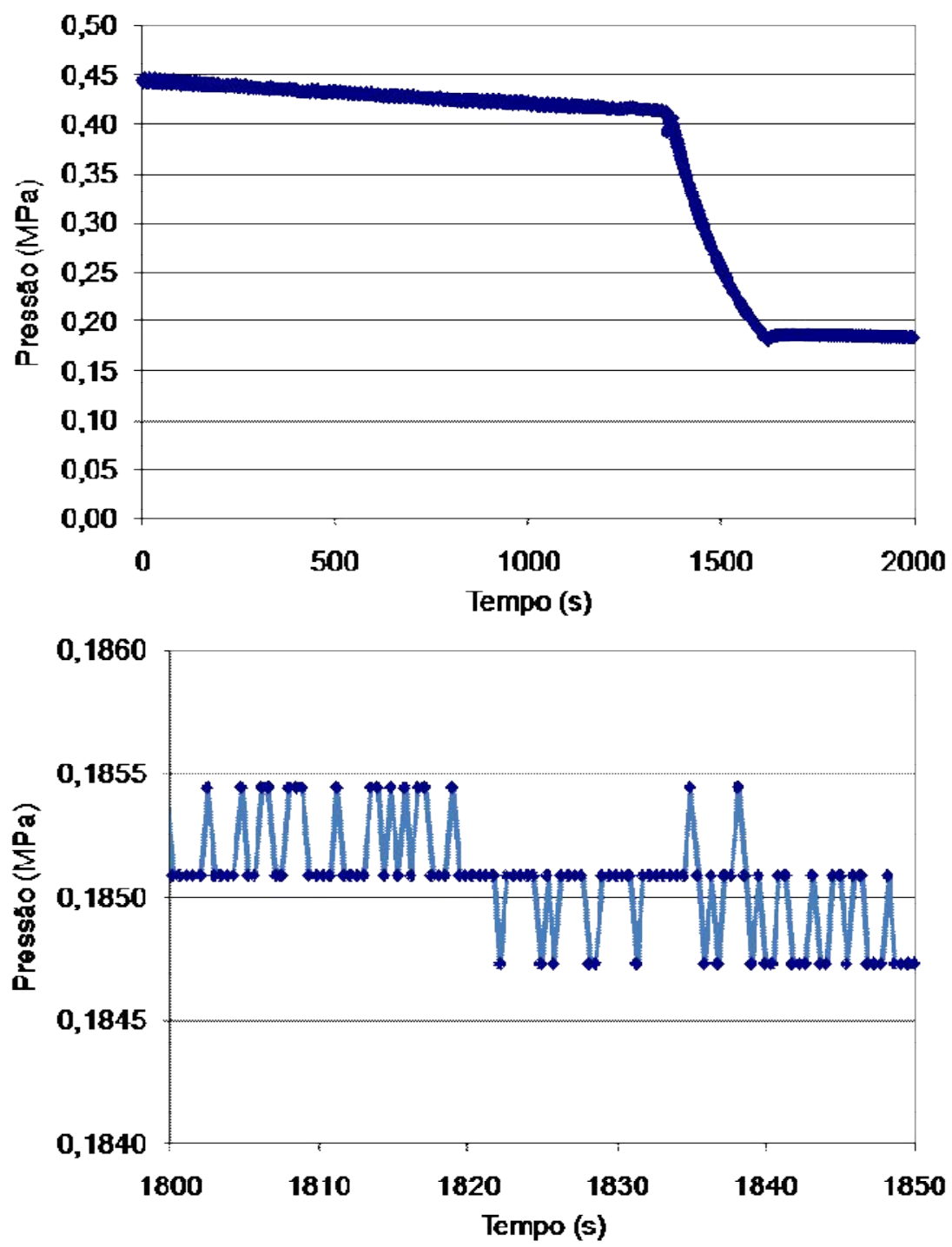

GRÁFICO 11 Pressão medida no pressurizador - Exp24

Fonte: resultados experimentais da pesquisa

\subsection{Os Resultados Experimentais}

Após ter se completado as etapas descritas nos itens anteriores desse capítulo, isto é, adaptação do circuito com instalação de uma nova bomba, instalação de mais instrumentação e instalação da seção de testes, montagem do sistema de coleta de dados e sua interconexão com a instrumentação e com o retificador, calibração da instrumentação, desenvolvimento do programa de coleta 
de dados e controle do retificador e teste de funcionamento de todo o conjunto, pode-se iniciar a operação do circuito para realizar os experimentos que formarão a base de dados para ser usada na avaliação da metodologia de desenvolvimento do SICT.

\subsubsection{Experimentos para teste e validação da instalação}

Os primeiros experimentos realizados foram de estados estacionários e serviram para verificação de todo o conjunto montado, em particular o sistema de medidas, envolvendo a instrumentação e a coleta de dados. Esse sistema de medidas foi verificado e validado fazendo-se os balanços de massa e de energia no CT1 a diferentes níveis de potência, para diferentes trechos. Assim o balanço térmico no primário e no secundário do trocador de calor validou as medidas de vazão e as de temperatura nessa região. O balanço de energia na seção de teste permitiu determinar a perda de energia na mesma a diferentes potências.

Os resultados do Exp01, descrito no QUADRO 3, foram usados para fazer os balanços de energia e de massa. Esse experimento realizado ainda na fase de comissionamento da instalação consistiu de uma série de 5 aumentos de potência seguida de 3 diminuições, GRAF. 12. Além disso, o trocador de calor foi desligado zerando-se a vazão no secundário, entre aproximadamente $2300 \mathrm{~s}$ e $4000 \mathrm{~s}$ (GRAF. 13). O GRAF. 14 permite observar as evoluções de temperatura do fluido refrigerante na entrada e na saída da seção de testes, como resultado das condições de potência e vazão apresentadas anteriormente.

O GRAF. 12 apresenta, além da medida de potência elétrica fornecida à seção de testes, a potência térmica transferida ao líquido, calculada através dos valores medidos de vazão e de temperaturas do fluido na entrada e saída da seção de testes $\left(E_{T}=(m / s){ }^{*} C P .{ }^{*} \Delta T\right)$. A curva da potência térmica, em vermelho e abaixo da preta, apresenta uma dispersão (espessura) maior que a da potência elétrica, uma vez que, como mostrado no item 4.6, a potência elétrica tem uma incerteza de medição pequena e a potência térmica tem como um de seus fatores 
a vazão mássica, que tem uma incerteza de medição muito maior que os demais parâmetros.

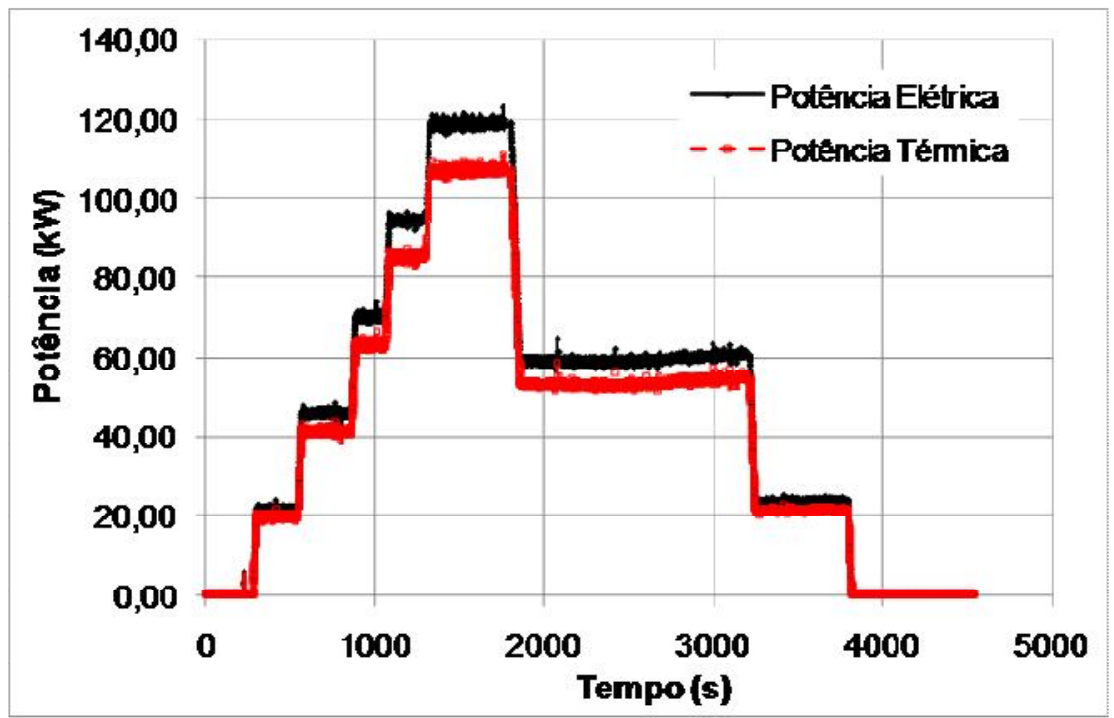

GRÁFICO 12 Potências elétrica e térmica na seção de testes - Exp01

Fonte: resultados experimentais da pesquisa

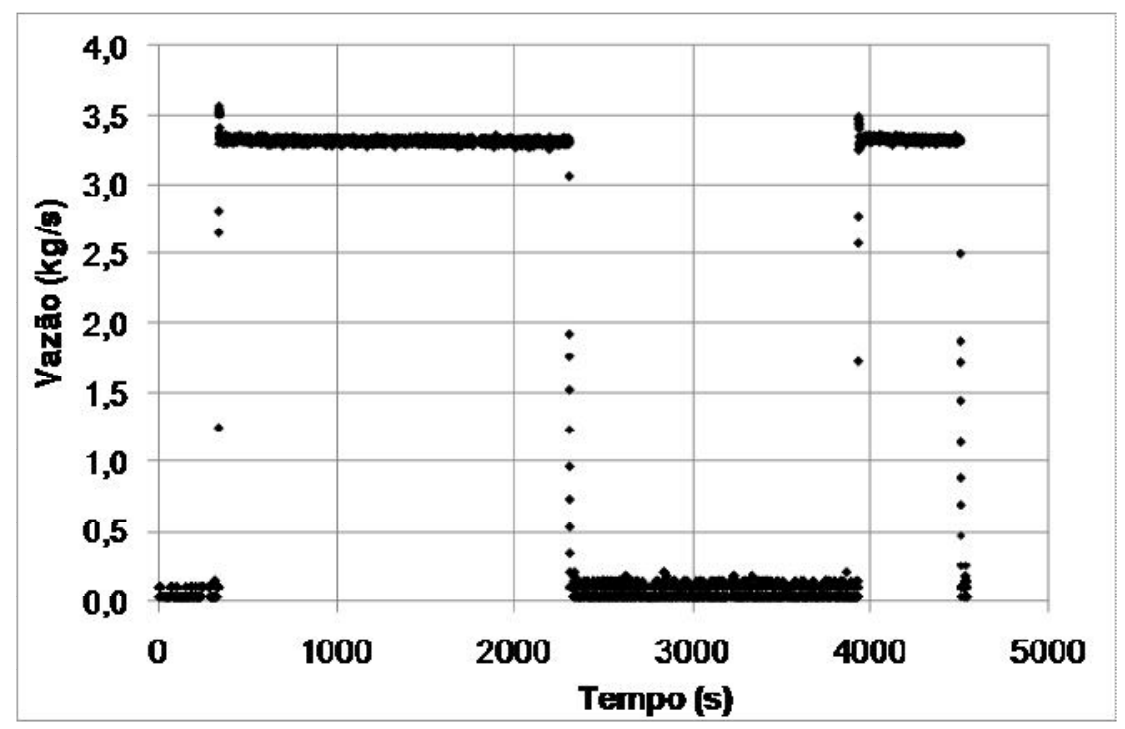

GRÁFICO 13 Vazão no secundário - Exp01

Fonte: resultados experimentais da pesquisa 


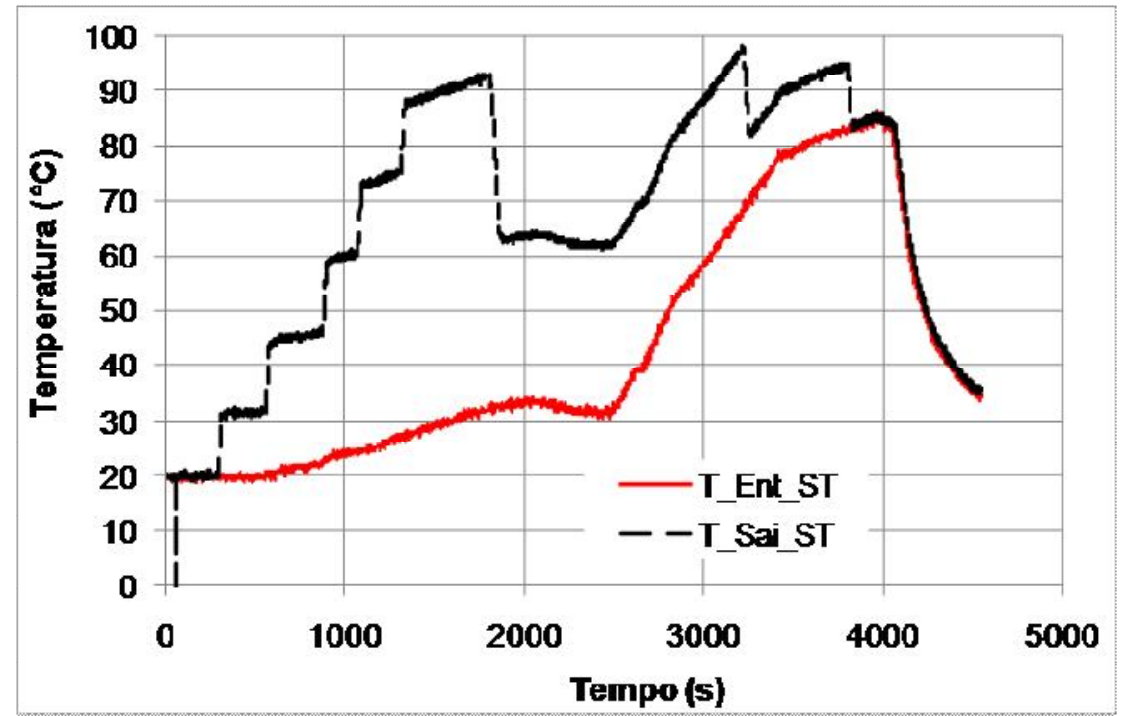

GRÁFICO 14 Temperaturas do refrigerante na entrada e na saída da seção de testes - Exp01

Fonte: dados experimentais da pesquisa

A perda de potência por convecção natural para o ambiente é função da temperatura externa da parede da seção de testes que, como mostrado na FIG. 19, não é isolada termicamente do ambiente. A temperatura externa da seção de testes por sua vez depende da temperatura do fluído, do escoamento e da potência elétrica fornecida à parede da seção de testes. O GRAF. 15 apresenta, para várias potências e temperaturas de fluido, a perda de potência para o ambiente em porcentagem da potência elétrica fornecida. Observa-se que um valor de $10 \%$ é uma boa estimativa para as perdas de calor para toda a faixa apresentada. 


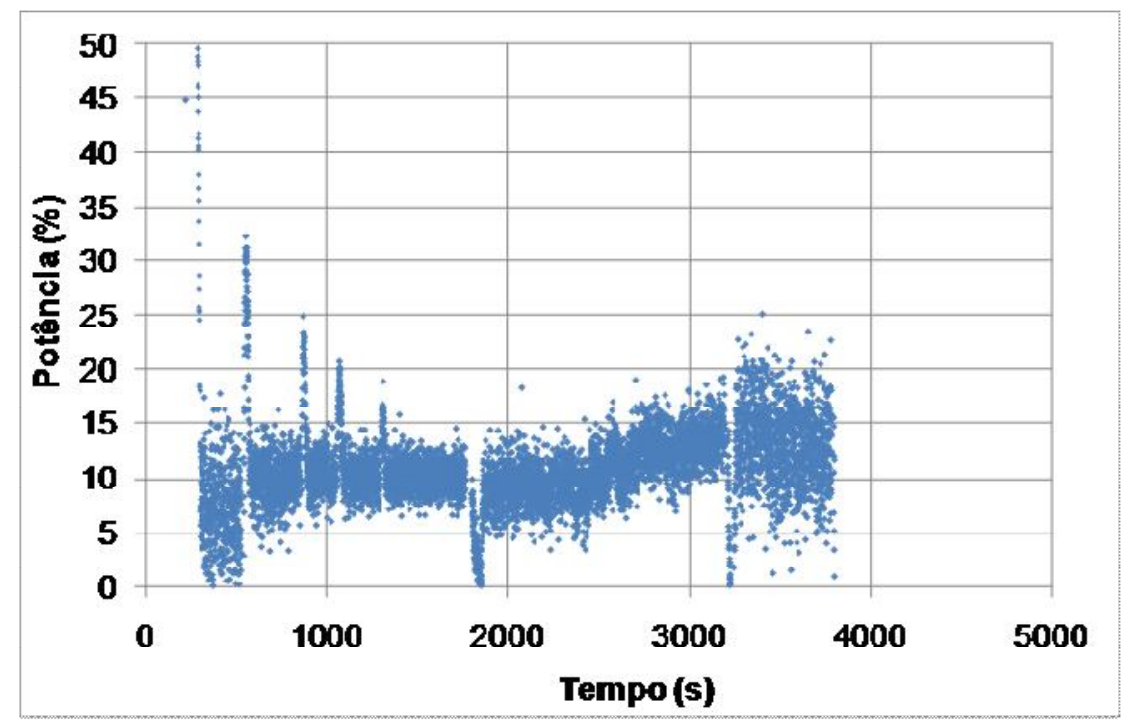

GRÁFICO 15 Perda de potência na seção de testes - Exp01

Fonte: resultados experimentais da pesquisa

O Exp02 foi um experimento realizado para fazer outra verificação da operação e instrumentação do CT1, e repetir as análises de balanço de energia e de massa. Os resultados e as análises confirmaram a adequação de todo o sistema para a execução dos experimentos planejados. $O$ único ponto que precisou ser modificado foi o programa de coleta de dados e controle do retificador que permitiu um aumento acidental de potência, fez-se um degrau de 15 em vez de um degrau de 1,5. Essa operação causou o primeiro acidente operacional com ocorrência de uma explosão de vapor e afastamento das condições de ebulição nucleadas (DNB). O sistema elétrico foi desligado manualmente, num procedimento para emergência. $O$ programa de coleta de dados e controle do retificador foi alterado para não permitir esse tipo de erro de operação e para detectar e bloquear as situações de perigo: temperatura alta na entrada na ST e potência alta.

O GRAF. 16 permite observar que a bomba de refrigerante do secundário estava desligada, assim o CT1 estava operando em uma situação similar à falha de remoção de calor nos reatores. Foi nessa situação que foi feita a operação de aumento de potência abrupta, aproximadamente aos $5340 \mathrm{~s}$ decorridos do in ício do experimento, conforme pode ser visto no GRAF. 17. 


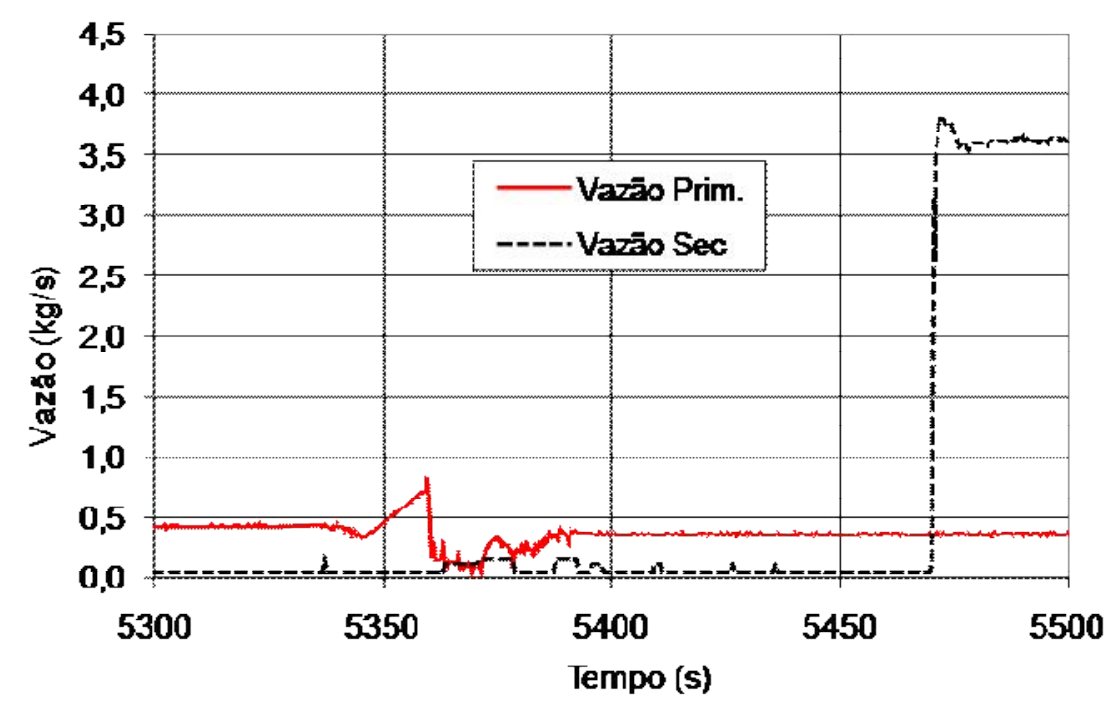

GRÁFICO 16 Vazão do primário e do secundário - Exp02

Fonte: resultados experimentais da pesquisa

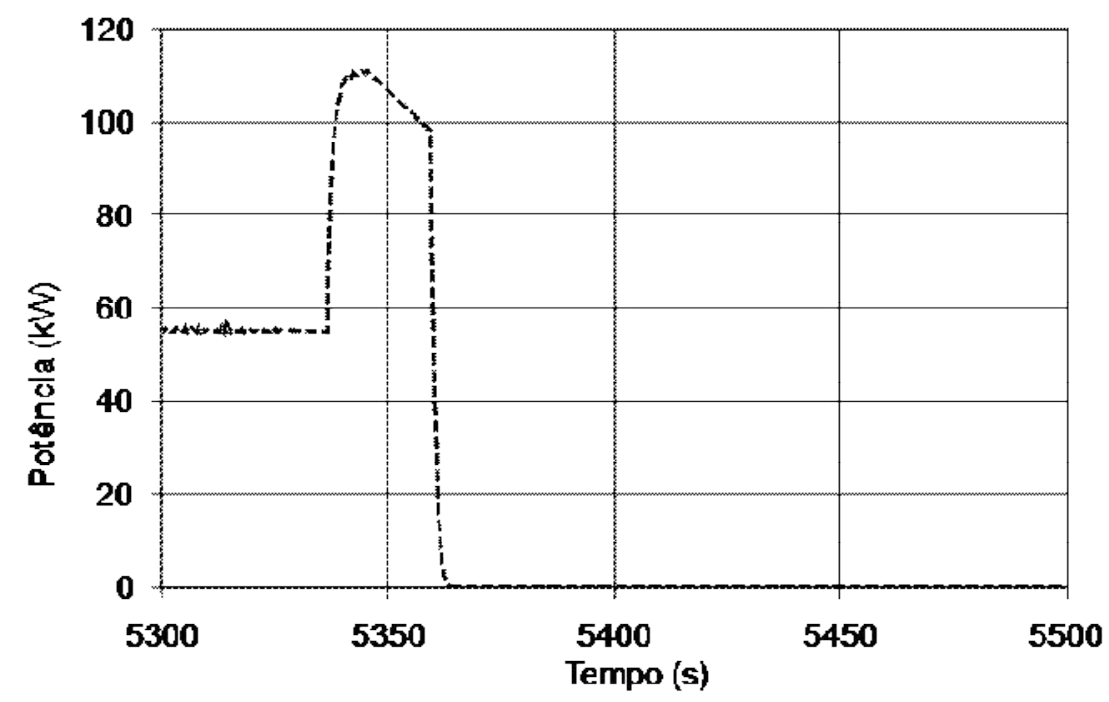

GRÁFICO 17 Potência elétrica na seção de testes - Exp02

Fonte: resultados experimentais da pesquisa

A consequência foi um aumento da temperatura do fluido na saída da seção de testes que provocou uma rápida formação de vapor afetando a vazão no primário (GRAF. 18), o que piorou a refrigeração. A temperatura do fluido atingiu $180{ }^{\circ} \mathrm{C}$ na saída da ST. Ao se perceber a situação, a potência foi desligada em aproximadamente $5360 \mathrm{~s}$. 


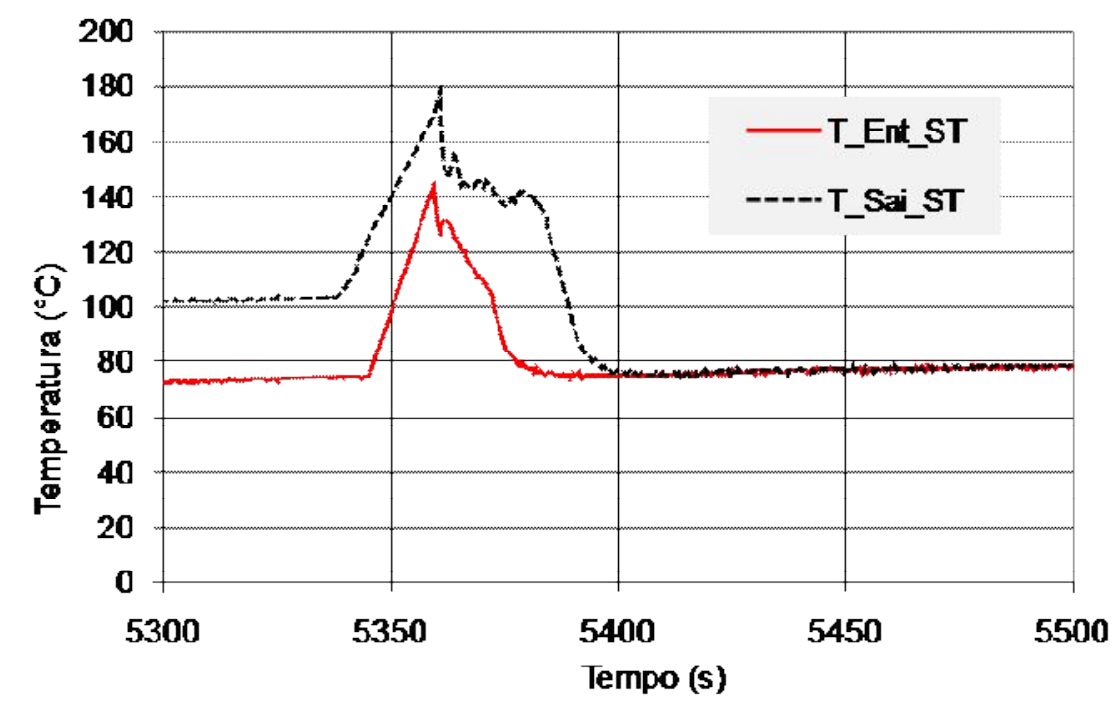

GRÁFICO 18 Temperatura na entrada e na saída da ST - Exp02

Fonte: resultados experimentais da pesquisa

Os Exp03, Exp04 e Exp05 foram realizados com o objetivo de definir a estratégia de coleta de dados, isto é, quantas leituras para formar um ponto de medida e o tempo de espera entre essas medidas. Outro fator avaliado nesses experimentos foi a influência de um canal de medidas no outro e definir o modelo de aterramento a ser utilizado. Como resultado desses experimentos, foi definido que cada ponto de medida seria formado por um ponto de leitura e, através do comando "FOR $\mathrm{K}=0$ TO 50000: NEXT K" no bloco "COLETA DE DADOS" mostrado na listagem do programa apresentado por Arteaga (2007), foi definido também o tempo de espera para fazer uma medida. Essa implementação é dependente do computador e caso o programa venha a ser utilizado em outro equipamento, o valor 50000 tem que ser ajustado. Foi definido também a lig ação do aterramento de todos os canais em um terra comum, o que praticamente eliminou a influência do sinal chegando em um canal sobre os demais.

Nos Exp06 e Exp07 foram retomadas as avaliações do comportamento do sistema como um todo após as modificações no programa de coleta de dados. No Exp07 houve um novo acidente de operação em uma situação diferente das anteriores. Uma válvula de desvio da seção de testes estava fora da posição de operação normal e assim a vazão na seção de testes estava reduzida, apesar da vazão no primário estar normal (GRAF. 19). Assim em uma operação planejada 
de aumento de potência de 0 a 100\%, GRAF. 20, a temperatura do fluido na seção de testes aumentou gradativamente, entrou em ebulição e passou dos limites aceitáveis ocorrendo um afastamento da ebulição nucleada (DNB), (GRAF. 21).

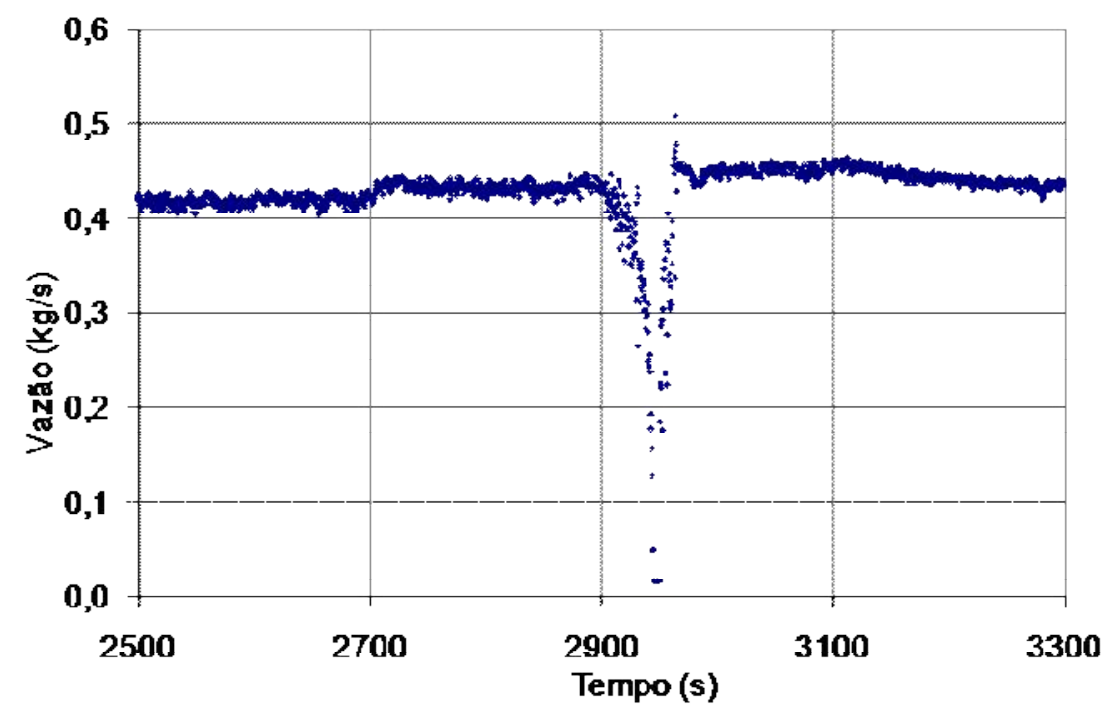

GRÁFICO 19 Vazão do primário - Exp07

Fonte: resultados experimentais da pesquisa

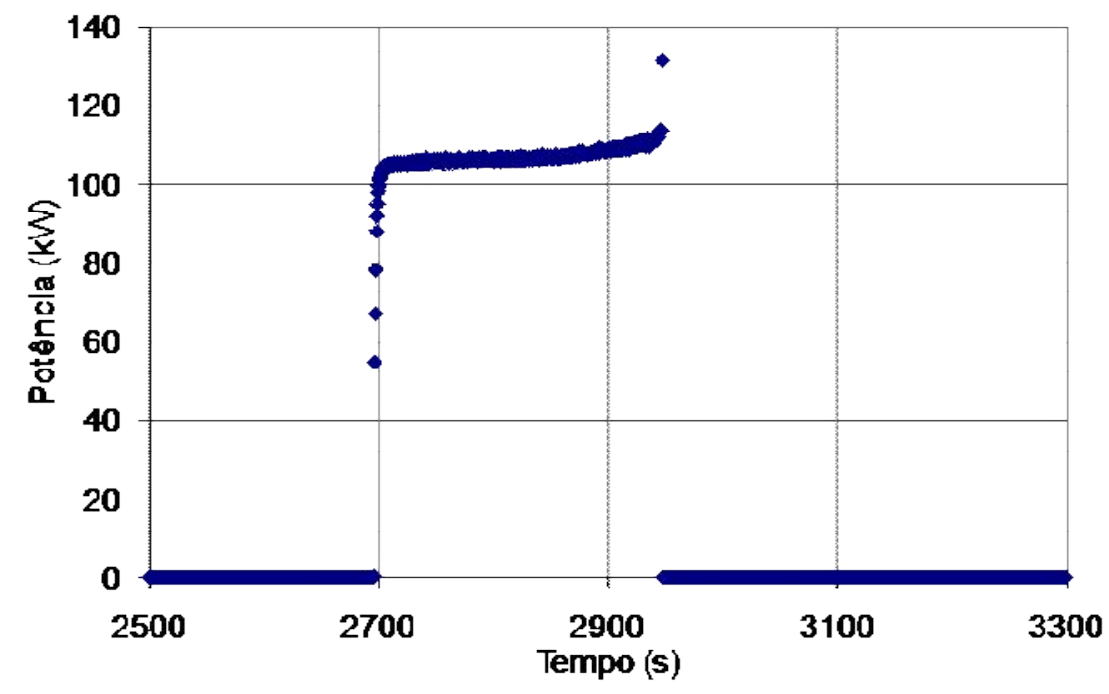

GRÁFICO 20 Potência elétrica na seção de testes - Exp07

Fonte: resultados experimentais da pesquisa 


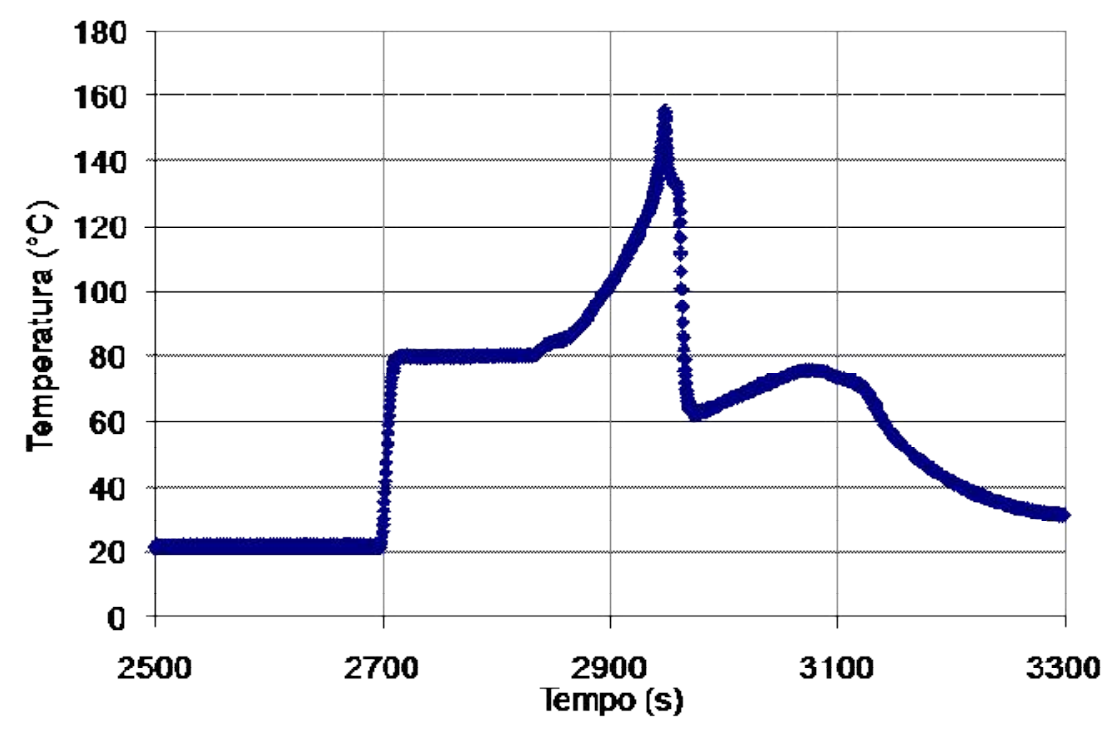

GRÁFICO 21 Temperatura na saída da ST - Exp07

Fonte: resultados experimentais da pesquisa

Após esse acidente uma nova limitação de operação foi adicionada ao programa de coleta de dados. Essa modificação desliga a potência se a temperatura atingir $110^{\circ} \mathrm{C}$. Como foi necessário interromper os experimentos para mudar as conexões, da seção de testes com o circuito, que foram danificadas durante esse acidente, foi colocado um termopar adicional para medir a temperatura na entrada do secundário do trocador de calor. A medida da temperatura de entrada no secundário do trocador de calor permitiu melhorar a simulação que estava em andamento do CT1 com o RELAP5, ao proporcionar informação sobre a retroalimentação da potência/temperatura do primário através da temperatura do secundário.

Os Exp08 e Exp09 foram realizados para verificar a aferição do novo termopar instalado e refazer os balanços de massa e energia usando essa nova medida. O Exp10 teve erros de medição por haver entrado água no transmissor do sinal e suas medidas foram invalidadas.

Os resultados dos experimentos 01, 02, 06, 07 e 10 (desconsiderando a temperatura de entrada no secundário do trocador de calor) estão armazenados e podem ser usados para validações com o SICT. 


\subsubsection{Experimentos de Validação}

Os experimentos de 11 a 27 foram realizados depois de a instalação, a instrumentação e o programa de coleta de dados e controle do pressurizador terem sidos testados e validados pelos balanços de energia e massa. Além disso, o programa estava com as limitações de operação que davam mais segurança para a realização dos experimentos.

Resultados dos experimentos 11 a 27 estão apresentados no APÊNDICE D na forma de gráficos de:

- temperaturas:

- de entrada e saída na seção de testes,

- de saída do primário do trocador de calor e

- de entrada e saída do secundário do trocador de calor,

- pressões:

- no pressurizador e

- no recalque da bomba,

- vazões:

- no primário e

o no secundário e

- $\quad$ potência elétrica aplicada na seção de testes.

Os experimentos 11 e 12 são de mudança de potência em degraus de aproximadamente $10 \%$ da potência máxima. O primeiro gráfico do APÊNDICE D (GRAF. 116) mostra uma grande oscilação da potência entre 6000 s e 7000 s, 
que se deve a uma instabilidade do retificador que ocorre quando a potência fica em torno de $70 \mathrm{~kW}$.

Os experimentos 13 e 14 são similares aos 11 e 12 só que a potência era alterada de $10 \%$ em uma rampa de 30 s. Nos experimentos 19 e 20 a rampa de mudança de $10 \%$ da potência máxima demorava 120 s. Nos experimentos 18 e 21 a rampa foi de 240 s. Observa-se, no GRAF. 134, que o experimento 18 foi interrompido na potência de $60 \mathrm{~kW}$, isso ocorreu devido à falta de energia elétrica no CDTN, no período de execução do mesmo.

O experimento 15 foi realizado para eliminar uma suspeita de falha nas medições, já que foram observadas bolhas a temperaturas abaixo da de saturação. Determinou-se que as bolhas visíveis no visor após a seção de teste eram de gás dissolvido na água que se separavam da fase líquida com o aquecimento. Esse fenômeno não é usual quando se opera o CT1 em experimentos de transferência de calor onde se executa um procedimento de purga do gás dissolvido e após esse procedimento se opera com a válvula do pressurizador fechada, ao contrário do que se fez nos experimentos a pressão atmosférica.

Nos experimentos 16 e 17 foram feitas várias mudanças de potência diferentes das 4 padronizadas, (10\% em degrau e em rampas de 30, 120 e 240 s). O objetivo desses experimentos foi obter dados de situações diferentes das usuais. O experimento 17 foi o primeiro em que se pressurizou e despressurizou o circuito. A pressurização alcançou somente cerca de 0,5 bar por preocupação com a mangueira de ligação da seção de testes com o circuito. Essa mangueira foi trocada possibilitando que outros experimentos fossem realizados com pressões mais altas.

Os experimentos 22 a 27 caracterizam-se pela pressurização e despressurização do circuito.

O experimento 22 iniciou com a pressurização do circuito até cerca de 6 bar no recalque da bomba. Com o circuito pressurizado foram feitas mudanças 
de potência. Após $7100 \mathrm{~s}$ foi provocada uma despressurização e foram feitas várias manobras com desvio do escoamento somente pelo pressurizador e pelo pressurizador e pelo seu desvio.

O experimento 23 foi realizado a dois níveis de potência, além da nula, e foram feitas pressurizações, até 2 bar, e despressurizações. Foram feitas ao mesmo tempo operações de desligamento da bomba do secundário para se ter uma situação de perda de refrigeração.

No experimento 24 foram feitas diversas operações de mudança de potência, padrão e diferenciadas, enquanto o circuito era pressurizado.

Os experimentos 25 e 26 foram realizados sem potência na seção de testes. Após a fase de pressurização foi feita a despressurização através da válvula de descarga do pressurizador ou pela válvula de alívio do mesmo.

O experimento 27 foi realizado com o desvio do trocador de calor aberto e foram feitas duas despressurizações uma em $1200 \mathrm{~s}$ e outra em $2400 \mathrm{~s}$. Ressalta-se o comportamento da temperatura de entrada do refrigerante na seção de testes muito diferente da temperatura de saída do primário do trocador de calor.

A realização desses experimentos disponibilizou uma base de dados experimentais de operação do CT1 que foi usada neste projeto para validação da metodologia e que está disponível para outros estudos que venham a ser feitos seguindo essa linha. 


\section{SIMULAÇÕES COM O RELAP5}

O RELAP na sua versão 5 (RELAP5) incorpora características que permitem seu uso para modelagem de centrais nucleares incluindo seus sistemas de controle e de proteção com um nível de detalhes que não era possível nas versões anteriores. Com isso ficou viável a simulação do comportamento dessas centrais em condições que vão desde regimes permanentes a acidentes graves passando por uma ampla gama de transientes. Considerando ainda que ele opera no modo que proporciona resultados mais realistas (best estimate), as simulações com o RELAP5 formam a base de dados para treinamento do SICT. Quanto mais próxima a simulação da realidade melhor a capacidade da rede de desempenhar sua função de identificar e classificar transientes e acidentes. A simulação do IRIS com o RELAP5 reflete o estado de conhecimento do sistema de proteção e controle do mesmo, assim os resultados obtidos apesar de não serem finais possibilitam simular comportamentos que têm características semelhantes ao comportamento final esperado. Isso quer dizer que o SICT desenvolvido com os resultados obtidos neste trabalho não deve ser a versão final, mas uma versão que mostra a viabilidade e capacidade de tal sistema e que poderá então ser facilmente retreinado quando houver resultados de simulação mais realistas.

\subsection{Simulações do CT1}

Como exposto no capítulo 3, a validação de toda a metodologia passa por se ter uma base de dados de resultados de simulação do CT1, que possa ser usada para treinar uma versão do SICT.

\subsubsection{Nodalização do CT1 para o RELAP5}

A nodalização usada para simular o CT1 pode ser vista na FIG. 24, com a identificação dos pontos de medição de temperatura, pressão e vazão. 


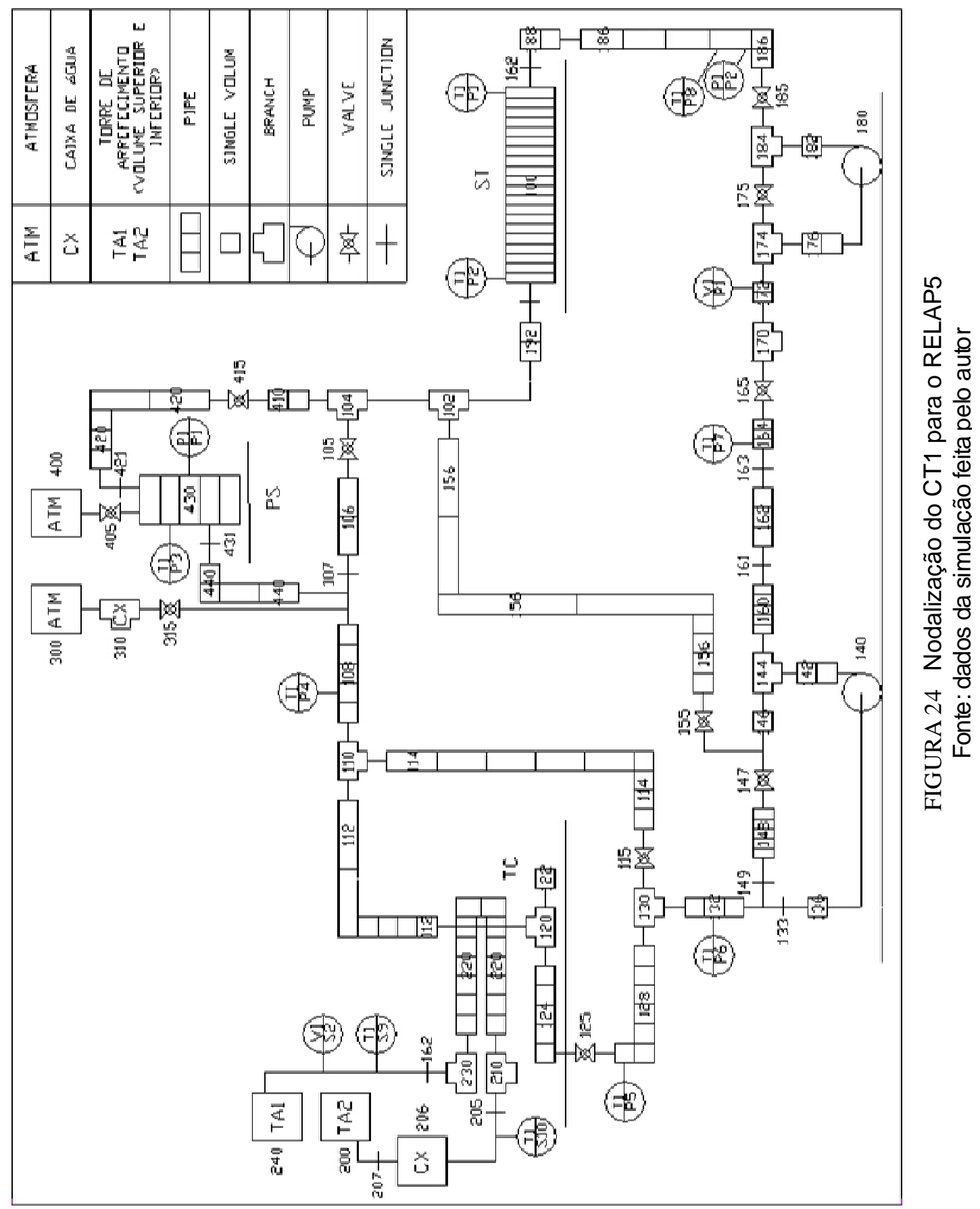


$\mathrm{Na}$ nodalização, os principais componentes com os seus identificadores numéricos mostrados na FIG. 24 são:

- $\quad$ seção de teste -100 ,

- trocador de calor - 120, 122 e 124 representam o primário, que é a região externa aos tubos e o secundário é representado pelos volumes 210, 230 e 220, que representa o interior dos tubos,

- bomba principal-180,

- pressurizador e suas conexões - 400 a 440 ,

- mangueiras de conexão da seção de testes com o circuito (Diâmetro externo=12,7 mm espessura $=1,57 \mathrm{~mm}$ ) $-188 \mathrm{e} 192 \mathrm{e}$

- $\quad$ reservatório da torre de refrigeração e sua tubulação - 206 .

O circuito primário foi considerado isolado termicamente, com exceção da seção de testes onde foi usado o coeficiente de transferência de calor para convecção natural para o ar de $25 \mathrm{~W} / \mathrm{m}^{2} \mathrm{~K}$. Posteriormente, com os resultados dos experimentos, optou-se por considerar a seção de testes também isolada e fornecer uma potência $10 \%$ menor que a potência elétrica aplicada à seção de testes.

As válvulas foram todas simuladas como válvulas abertas ou fechadas dependendo de um sinal (trip). Somente para a válvula 185 foi usado o modelo de válvula motorizada, que admite uma abertura entre 0 e $100 \%$ de sua área.

\subsubsection{Validação da modelagem}

A primeira fase, de teste e validação, dessa nodalização foi acertar os valores de perda de carga ao longo do circuito ajustando os valores das perdas diretas nas junções e da rugosidade nas mangueiras que conectavam a seção de 
testes ao circuito. A validação foi feita comparando-se os resultados da simulação com os valores medidos no CT1 e assim, através de um processo iterativo e interativo, obteve-se a vazão correta fornecida pela bomba e as perdas de carga.

A segunda etapa consistiu em verificar se a transferência de calor em condições de estado estacionário estava correta. Para isso, foram verificados se as temperaturas da simulação e do experimento 01 estavam compatíveis e feitos ajustes iterativamente até se atingir os valores desejados. A modelagem da transferência de calor foi então validada por esse processo.

A etapa final da validação consistiu em se simular os experimentos:

- 1 (ARONNE et al., 2007b) e 2, que além das mudanças de potência tinham também o isolamento do trocador de calor que causa uma perda de refrigeração do primário,

- 15 , que são dois estados estacionários,

- $\quad 11$ e 12 , que são de mudança de potência em degrau e os

- 19 e 20, que são experimentos de mudança de potência em rampa de $120 \mathrm{~s}$.

As temperaturas de entrada e saída da seção de testes são os parâmetros mais representativos do comportamento do circuito, por serem influenciadas pelos vários processos de transferência de calor ao longo do circuito. Os gráficos das temperaturas de entrada e saída da seção de testes, medidos nos experimentos acima citados, estão apresentados no APÊNDICE E juntamente com os resultados das simulações com o RELAP5.

Os resultados obtidos mostraram que a modelagem do CT1 com o RELAP5 fornece resultados de simulação que têm o comportamento similar aos experimentais e os valores obtidos para os parâmetros avaliados são, em geral, da ordem de erro da medida experimental. 
Desta forma as simulações do CT1 feitas com esta nodalização estão validadas para o seu uso no treinamento do SICT.

\subsubsection{Resultados da Simulação do CT1 com o RELAP5}

Para compor um banco de dados de treinamento do SICT para o CT1 não foram usadas nenhuma das simulações de casos experimentais anteriormente apresentados. Foi feito um conjunto de simulações próprias para esse fim. O QUADRO 4 apresenta as simulações realizadas para compor esse banco de dados.

QUADRO 4 - Simulações do CT1 com o RELAP5 usadas para treinamento do SICT

\begin{tabular}{|c|c|c|}
\hline Nome da simulação & Descrição & Potência \\
\hline DD & $\begin{array}{l}\text { Mudanças de potência em degrau } \\
\text { descendente de } 10 \mathrm{~kW}\end{array}$ & $\begin{array}{l}\text { Potência inicia em } 110 \mathrm{~kW} \mathrm{e} \\
\text { muda a cada } 3000 \mathrm{~s}\end{array}$ \\
\hline DU & $\begin{array}{l}\text { Mudanças de potência de } 10 \mathrm{~kW} \mathrm{em} \\
\text { degrau descendente }\end{array}$ & $\begin{array}{l}\text { Potência inicia em } 0 \mathrm{~kW} \mathrm{e} \\
\text { muda a cada } 3000 \mathrm{~s}\end{array}$ \\
\hline $\begin{array}{l}\text { R30D } \\
\text { R120D } \\
\text { R240D }\end{array}$ & $\begin{array}{l}\text { Mudanças de potência de } 10 \mathrm{~kW} \text { em } \\
\text { rampas descendentes de } 30 \mathrm{~s}, 120 \mathrm{~s} \\
\text { e } 240 \mathrm{~s} \text { respectivamente }\end{array}$ & $\begin{array}{l}\text { Potência inicia em } 110 \text { kW e } \\
\text { muda a cada } 3000 \mathrm{~s}\end{array}$ \\
\hline $\begin{array}{l}\text { R30U } \\
\text { R120U } \\
\text { R240U }\end{array}$ & $\begin{array}{l}\text { Mudanças de potência de } 10 \mathrm{~kW} \text { em } \\
\text { rampas ascendentes de } 30 \mathrm{~s}, 120 \mathrm{~s} \text { e } \\
240 \mathrm{~s} \text { respectivamente }\end{array}$ & $\begin{array}{l}\text { Potência inicia em } 0 \mathrm{~kW} \mathrm{e} \\
\text { muda a cada } 3000 \mathrm{~s}\end{array}$ \\
\hline $\begin{array}{l}\text { DESLBS20 } \\
\text { DESLBS40 } \\
\text { DESLBS60 } \\
\text { DESLBS80 } \\
\text { DESLBS100 }\end{array}$ & $\begin{array}{l}\text { Desligamento da bomba do } \\
\text { secundário com perda de } \\
\text { refrigeração. } \\
\text { Desliga a bomba do secundário entre } \\
1000 \text { e } 2500 \text { s. }\end{array}$ & $\begin{array}{l}\text { Potência na seção de testes: } \\
\text { ???kW até } 900 \mathrm{~s} \\
50 \mathrm{~kW} \text { até } 1500 \mathrm{~s} \\
20 \mathrm{~kW} \text { até } 2000 \mathrm{~s} \\
0 \mathrm{~kW} \text { até } 6000 \mathrm{~s}\end{array}$ \\
\hline $\begin{array}{l}\text { DESLBS20_2 } \\
\text { DESLBS40_2 } \\
\text { DESLBS60_2 } \\
\text { DESLBS80_2 } \\
\text { DESLBS100_2 }\end{array}$ & $\begin{array}{l}\text { Desligamento da bomba do } \\
\text { secundário com perda de } \\
\text { refrigeração. } \\
\text { Desliga a bomba do secundário entre } \\
1000 \text { e } 2500 \text { s. }\end{array}$ & $\begin{array}{l}\text { Potência na seção de testes: } \\
\text { ???kW até } 900 \mathrm{~s} \\
70 \mathrm{~kW} \text { até } 1500 \mathrm{~s} \\
80 \mathrm{~kW} \text { até } 2000 \mathrm{~s} \\
0 \mathrm{~kW} \text { até } 6000 \mathrm{~s}\end{array}$ \\
\hline
\end{tabular}

Fonte: elaborado pelo autor. 
QUADRO 4 - Simulações do CT1 com o RELAP5 usadas para treinamento do SICT - Continuação

\begin{tabular}{|c|c|c|}
\hline Nome da simulação & Descrição & Potência \\
\hline $\begin{array}{l}\text { DESLBS20_3 } \\
\text { DESLBS40_3 } \\
\text { DESLBS60_3 } \\
\text { DESLBS80_3 } \\
\text { DESLBS100_3 }\end{array}$ & $\begin{array}{l}\text { Desligamento da bomba do } \\
\text { secundário com perda de } \\
\text { refrigeração. } \\
\text { Desliga a bomba do secundário } \\
\text { entre } 1000 \text { e } 2500 \mathrm{~s} \text {. }\end{array}$ & $\begin{array}{l}\text { Potência na seção de } \\
\text { testes: } \\
\text { ???kW até } 900 \mathrm{~s} \\
35 \mathrm{~kW} \text { até } 2300 \mathrm{~s} \\
0 \mathrm{~kW} \text { até } 6000 \mathrm{~s}\end{array}$ \\
\hline ISOLABS & $\begin{array}{l}\text { Desligamento da bomba do } \\
\text { secundário com perda de } \\
\text { refrigeração. } \\
\text { Desliga a bomba do secundário } \\
\text { entre } 2000 \text { e } 4000 \mathrm{~s} \text {. }\end{array}$ & $\begin{array}{l}\text { Potência na seção de } \\
\text { testes: } \\
53 \mathrm{~kW} \text { até } 4000 \mathrm{~s} \\
0 \mathrm{~kW} \text { até } 6000 \mathrm{~s}\end{array}$ \\
\hline ISOLABS25 & $\begin{array}{l}\text { Desligamento da bomba do } \\
\text { secundário com perda de } \\
\text { refrigeração. } \\
\text { Desliga a bomba do secundário } \\
\text { entre } 2000 \text { e } 4000 \mathrm{~s} \text {. }\end{array}$ & $\begin{array}{l}\text { Potência na seção de } \\
\text { testes: } \\
25 \mathrm{~kW} \text { até } 4000 \mathrm{~s} \\
0 \mathrm{~kW} \text { até } 6000 \mathrm{~s}\end{array}$ \\
\hline ISOLABS75 & $\begin{array}{l}\text { Desligamento da bomba do } \\
\text { secundário com perda de } \\
\text { refrigeração. } \\
\text { Desliga a bomba do secundário } \\
\text { entre } 2000 \text { e } 2500 \mathrm{~s} \text {. }\end{array}$ & $\begin{array}{l}\text { Potência na seção de } \\
\text { testes: } \\
75 \mathrm{~kW} \text { até } 2500 \mathrm{~s} \\
0 \mathrm{~kW} \text { até } 6000 \mathrm{~s}\end{array}$ \\
\hline ISOLATC & $\begin{array}{l}\text { lgual a ISOLABS, mas isola o } \\
\text { primário do trocador de calor. }\end{array}$ & $\begin{array}{l}\text { Simulado até } 3000 \mathrm{~s} \text {, igual } \\
\text { a ISOLABS mas abre a } \\
\text { válvula } 115 \text { e fecha a } \\
\text { válvula } 125 \text { entre } 2000 \mathrm{~s} \text { e } \\
3000 \mathrm{~s}\end{array}$ \\
\hline ISOLATC25 & $\begin{array}{l}\text { lgual a ISOLABS25, mas isola o } \\
\text { primário do trocador de calor. }\end{array}$ & $\begin{array}{l}\text { Simulado até } 4000 \mathrm{~s} \text {, igual } \\
\text { a ISOLABS25 mas abre a } \\
\text { válvula } 115 \text { e fecha a } \\
\text { válvula } 125 \text { entre } 2000 \mathrm{~s} \mathrm{e} \\
4000 \mathrm{~s} .\end{array}$ \\
\hline $\begin{array}{l}\text { PRESSURIZA0k } \\
\text { PRESSURIZA30k } \\
\text { PRESSURIZA70k } \\
\text { PRESSURIZA110k }\end{array}$ & $\begin{array}{l}\text { Pressurização do CT1 até } 7 \text { bar } \\
\text { seguido de despresssurização. }\end{array}$ & $\begin{array}{l}\text { Potência na seção de } \\
\text { testes: } \\
0 \mathrm{~kW} \text {, } \\
30 \mathrm{~kW}, \\
70 \mathrm{~kW} \text { e } \\
110 \mathrm{~kW} \text {, respectivamente. }\end{array}$ \\
\hline
\end{tabular}

Fonte: elaborado pelo autor. 
Os resultados dessa simulação, em particular, a potência e as vazões, que definem os casos, e as temperaturas da entrada e saída da seção de testes são mostrados, para grande parte das simulações realizadas, no APÊNDICE F. Não são apresentados os resultados que são similares aos já apresentados, como as rampas que seguem a mesma estrutura que os degraus e os casos de mudança de potência durante os experimentos de desligamento da bomba do secundário que só foram apresentados para a potência inicial de 60 kW.

As primeiras 28 simulações, isto é todas menos as quatro de pressurização, foram realizadas para a pressão de 1 bar e replicadas para as pressões de 3 e 5 bars totalizando 54 simulações. No fim considerando as quatro simulações de pressurização foram geradas 58 simulações que compõem o banco de dados disponíveis para uso com o SICT.

\subsection{Simulações do IRIS}

O comportamento esperado do reator IRIS tem que ser usado para treinar a RNA/SOM apresentando a esta a evolução de variáveis selecionadas como entrada para a rede. Muitos conjuntos, milhares, de dados de entrada, devem ser usados, representando todos os tipos de comportamento esperados: estado estacionário, transientes operacionais, transientes anormais e acidentes. No início deste desenvolvimento, a geração desses dados de entrada representativos foi feita usando-se um modelo simplificado desenvolvido no IPEN (BARROSO et al., 2003). Até 2005 as simulações do IRIS com o RELAP5 ainda não estavam adequadas para o uso nas aplicações pretendidas com o SICT (ARONNE et al., 2005). Posteriormente os dados para treinamento do SICT foram obtidos de simulações do IRIS com o RELAP5 (ARONNE et al., 2007a) pelas razões apresentadas no início deste capítulo. 


\subsubsection{Nodalização do IRIS}

As simulações com o RELAP5 foram feitas a partir da nodalização, desenvolvida pela Universidade de Zagreb e mantida pela Westinghouse, para avaliação preliminar de segurança do IRIS. Essa nodalização havia sido validada para as condições nominais a 100\% de potência (ORIANI et al., 2004). Na FIG. 25 pode-se ver a nodalização básica utilizada para os internos do vaso de pressão do IRIS, onde estão localizados o núcleo do reator nuclear, as bombas de circulação do refrigerante principal, os trocadores de calor e o pressurizador. Essa nodalização é composta de 1647 volumes conectados por 1700 junções, 625 estruturas de calor e foram usados para o controle 311 Trips, 16 Tabelas Gerais e 257 Variáveis de Controle.

As principais características dessa nodalização foram apresentadas e discutidas no capítulo 2 . 


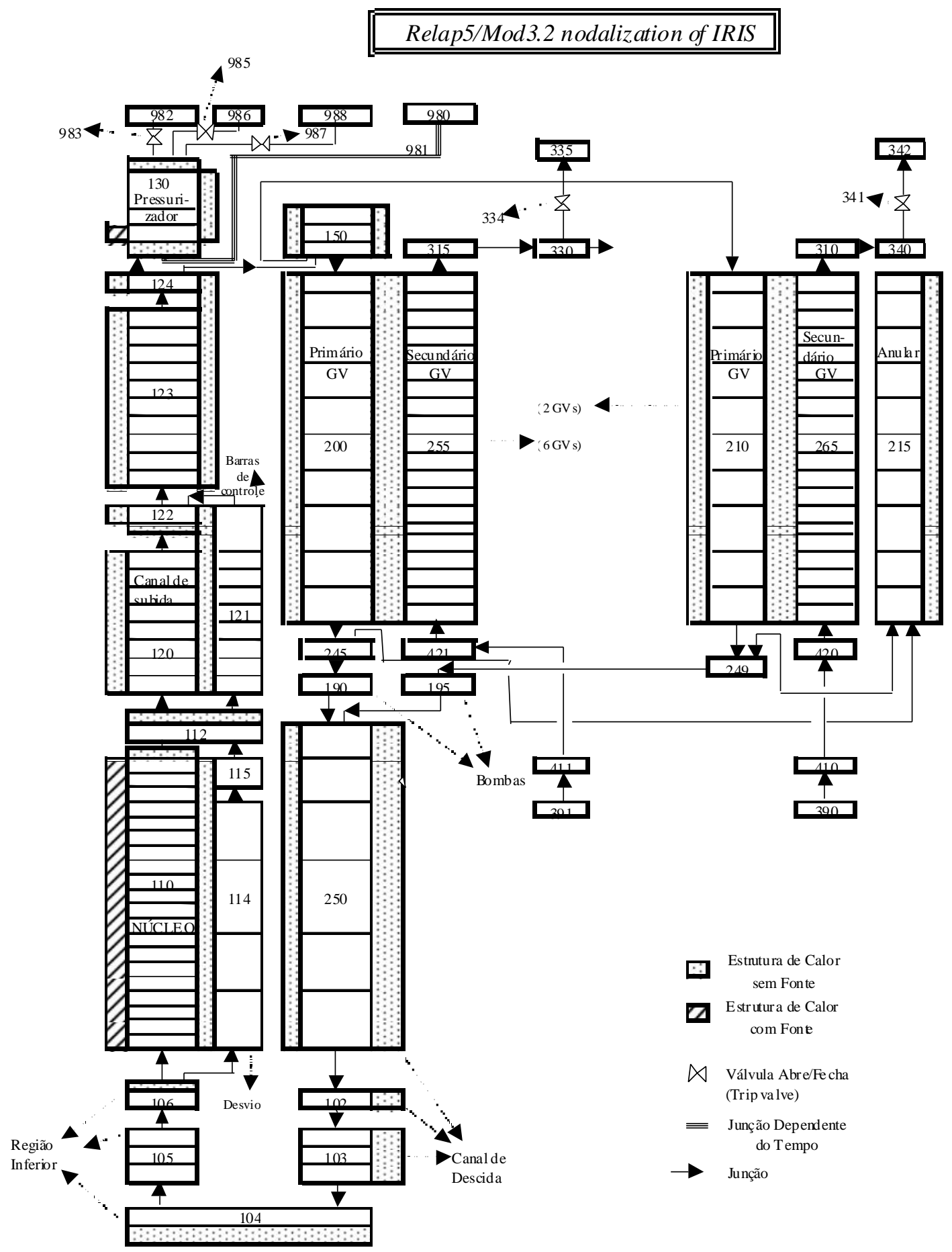

FIGURA 25 Nodalização do vaso do IRIS com seus componentes

Fonte: adaptado de Grgic et al. (2002) 


\subsubsection{Matriz de Simulações}

Foi estabelecida uma matriz de simulações que serão utilizadas como base de dados para fornecimento das informações para a RNA. O QUADRO 5 mostra as simulações realizadas para serem usadas no treinamento e avaliação do SICT. Os estados estacionários não foram simulados separadamente, mas sim como resultado das mudanças de potência em degraus e rampas, que após o tempo do transiente atingem o estado estacionário nas novas condições.

QUADRO 5 - Lista de transientes simulados para o IRIS

\begin{tabular}{|c|c|c|c|c|c|}
\hline \multicolumn{2}{|c|}{$\begin{array}{c}\text { Degraus } 10 \% \text { Aba ixo } \\
\text { (Pot. Inicial } \rightarrow \text { Pot. Final) }\end{array}$} & \multicolumn{2}{|c|}{$\begin{array}{l}\text { Rampa } 10 \% \text { Abaixo em } \\
2 \text { min } \\
\text { (Pot. Inicial } \rightarrow \text { Variação) }\end{array}$} & \multicolumn{2}{|c|}{$\begin{array}{c}\text { Rampa } 10 \% \text { Abaixo em } \\
4 \text { min } \\
\text { (Pot. Inicial } \rightarrow \text { Variação) }\end{array}$} \\
\hline 1 & $100 \% \rightarrow 90 \%$ & 9 & $100 \% \rightarrow 90 \%$ & 17 & $100 \% \rightarrow 90 \%$ \\
\hline 2 & $90 \% \rightarrow 80 \%$ & 10 & $90 \% \rightarrow 80 \%$ & 18 & $90 \% \rightarrow 80 \%$ \\
\hline 3 & $80 \% \rightarrow 70 \%$ & 11 & $80 \% \rightarrow 70 \%$ & 19 & $80 \% \rightarrow 70 \%$ \\
\hline 4 & $70 \% \rightarrow 60 \%$ & 12 & $70 \% \rightarrow 60 \%$ & 20 & $70 \% \rightarrow 60 \%$ \\
\hline 5 & $60 \% \rightarrow 50 \%$ & 13 & $60 \% \rightarrow 50 \%$ & 21 & $60 \% \rightarrow 50 \%$ \\
\hline 6 & $50 \% \rightarrow 40 \%$ & 14 & $50 \% \rightarrow 40 \%$ & 22 & $50 \% \rightarrow 40 \%$ \\
\hline 7 & $40 \% \rightarrow 30 \%$ & 15 & $40 \% \rightarrow 30 \%$ & 23 & $40 \% \rightarrow 30 \%$ \\
\hline 8 & $30 \% \rightarrow 20 \%$ & 16 & $30 \% \rightarrow 20 \%$ & 24 & $30 \% \rightarrow 20 \%$ \\
\hline \multicolumn{2}{|c|}{$\begin{array}{c}\text { Degraus } 10 \% \text { Acima } \\
\text { (Pot. Inicial } \rightarrow \text { Pot. Final) }\end{array}$} & \multicolumn{2}{|c|}{$\begin{array}{c}\text { Rampas } 10 \% \text { Acima em } \\
2 \text { min } \\
\text { (Pot. Inicial } \rightarrow \text { Variação) }\end{array}$} & \multicolumn{2}{|c|}{$\begin{array}{l}\text { Rampas } 10 \% \text { Acima em } \\
4 \mathrm{~min} \\
\text { (Pot. Inicial } \rightarrow \text { Variação) }\end{array}$} \\
\hline 25 & $100 \% \rightarrow 105 \%$ & 34 & $100 \% \rightarrow 105 \%$ & 43 & $100 \% \rightarrow 105 \%$ \\
\hline 26 & $90 \% \rightarrow 100 \%$ & 35 & $90 \% \rightarrow 100 \%$ & 44 & $90 \% \rightarrow 100 \%$ \\
\hline 27 & $80 \% \rightarrow 90 \%$ & 36 & $80 \% \rightarrow 90 \%$ & 45 & $80 \% \rightarrow 90 \%$ \\
\hline 28 & $70 \% \rightarrow 80 \%$ & 37 & $70 \% \rightarrow 80 \%$ & 46 & $70 \% \rightarrow 80 \%$ \\
\hline 29 & $60 \% \rightarrow 70 \%$ & 38 & $60 \% \rightarrow 70 \%$ & 47 & $60 \% \rightarrow 70 \%$ \\
\hline 30 & $50 \% \rightarrow 60 \%$ & 39 & $50 \% \rightarrow 60 \%$ & 48 & $50 \% \rightarrow 60 \%$ \\
\hline 31 & $40 \% \rightarrow 50 \%$ & 40 & $40 \% \rightarrow 50 \%$ & 49 & $40 \% \rightarrow 50 \%$ \\
\hline 32 & $30 \% \rightarrow 40 \%$ & 41 & $30 \% \rightarrow 40 \%$ & 50 & $30 \% \rightarrow 40 \%$ \\
\hline 33 & $20 \% \rightarrow 30 \%$ & 42 & $20 \% \rightarrow 30 \%$ & 51 & $20 \% \rightarrow 30 \%$ \\
\hline
\end{tabular}

Fonte: elaborado pelo autor 
QUADRO 5 - Lista de transientes simulados para o IRIS - Continuação

\begin{tabular}{|c|c|c|}
\hline \multicolumn{3}{|c|}{$\begin{array}{c}\text { Condições Anormais / } \\
\text { Acidentes }\end{array}$} \\
\hline $\begin{array}{l}52 \quad \text { Abertura da } \\
\text { Válvula de Segurança do } \\
\text { Pressurizador (PSV)/ } \\
\text { Acidente de perda de } \\
\text { Refrigerante Pequena } \\
\text { ruptura }\end{array}$ & $\begin{array}{l}55 \text { Desligamento de } 2 \\
\text { bo mbas do primário (2PT) }\end{array}$ & $\begin{array}{lr}58 & \text { Ruptura de tubos de } \\
\text { Geradores de Vapor (SGTR) }\end{array}$ \\
\hline $\begin{array}{l}53 \quad 100 \% \\
\text { Desligamento abrupto } \\
\text { (Trip Turbina - TT) }\end{array}$ & $\begin{array}{c}56 \text { Perda parcial da } \\
\text { água de alimentação dos } \\
\text { Geradores de Vapor } \\
\text { (PLFW) }\end{array}$ & $\begin{array}{l}59 \quad \text { Ruptura total da linha } \\
\text { de vapor (SLDER) }\end{array}$ \\
\hline $\begin{array}{l}54 \quad 100 \% \\
\text { Desligamento abrupto } \\
\text { (Trip do Reator - RT) }\end{array}$ & $\begin{array}{cc}57 & \text { Perda total da } \\
\text { água de alimentação dos } \\
\text { Geradores de Vapor } \\
(\text { TLFW })\end{array}$ & \\
\hline
\end{tabular}

Fonte: elaborado pelo autor

Os casos 52 a 59, Condições Anormais e Acidentes, foram simulados para cinco níveis de potência: 20, 40, 60, 80 e 100\%. Assim os oito casos representaram 40 simulações totalizando 91 diferentes situações de operação simuladas.

\subsubsection{Validação da nodalização do IRIS para o RELAP5}

A nodalização já havia sido validada para o estado estacionário a 100\% de potência (GRGIC et al., 2002 e ORIANE et al., 2004). Para a validação da nodalização foi definida a seguinte estratégia descrita a seguir. Inicia-se o processamento em forma sequencial das simulações listadas no QUADRO 5. Caso os resultados de uma simulação sejam aceitos continua-se para a próxima simulação, caso contrário procura-se uma solução para o problema e após a correção na nodalização reinicia-se o processo pela primeira simulação. Esse procedimento foi seguido até que se terminou o processamento do último caso listado. 
Apesar de ter sido validada para o estado estacionário logo nas primeiras simulações surgiram problemas com a nodalização. Como exemplo da estratégia de validação, resultados obtidos para a simulação da variação de potência do IRIS de 100\% para 90\% em degrau e em rampa foram apresentados no XIV ENFIR e são mostrados nos GRAF. 22 e 23, em marrom tracejado e preto pontilhado respectivamente. Pode-se observar nessa figura que o caso de rampa terminou em erro, abruptamente, pouco depois de $2000 \mathrm{~s}$ além de ambos apresentarem uma oscilação de pressão crescente com o tempo.

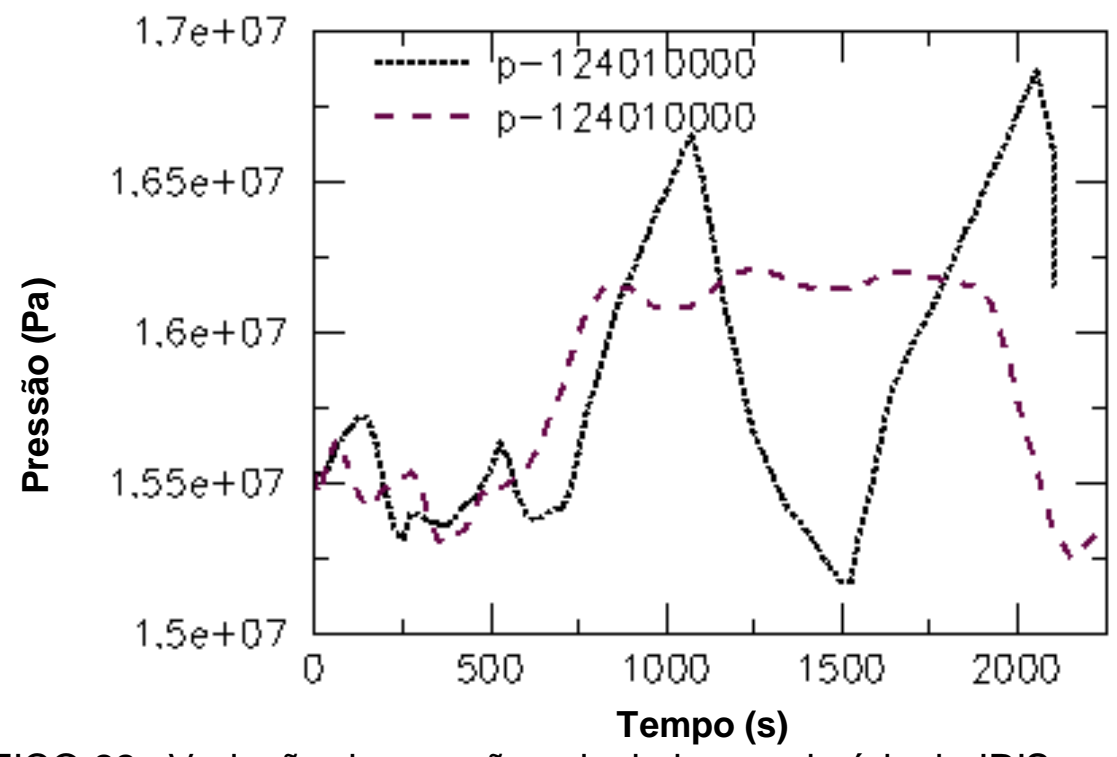

GRÁFICO 22 Variação da pressão calculada no primário do IRIS após uma mudança de potência de 100 para $90 \%$

Fonte: resultados de simulação da pesquisa 


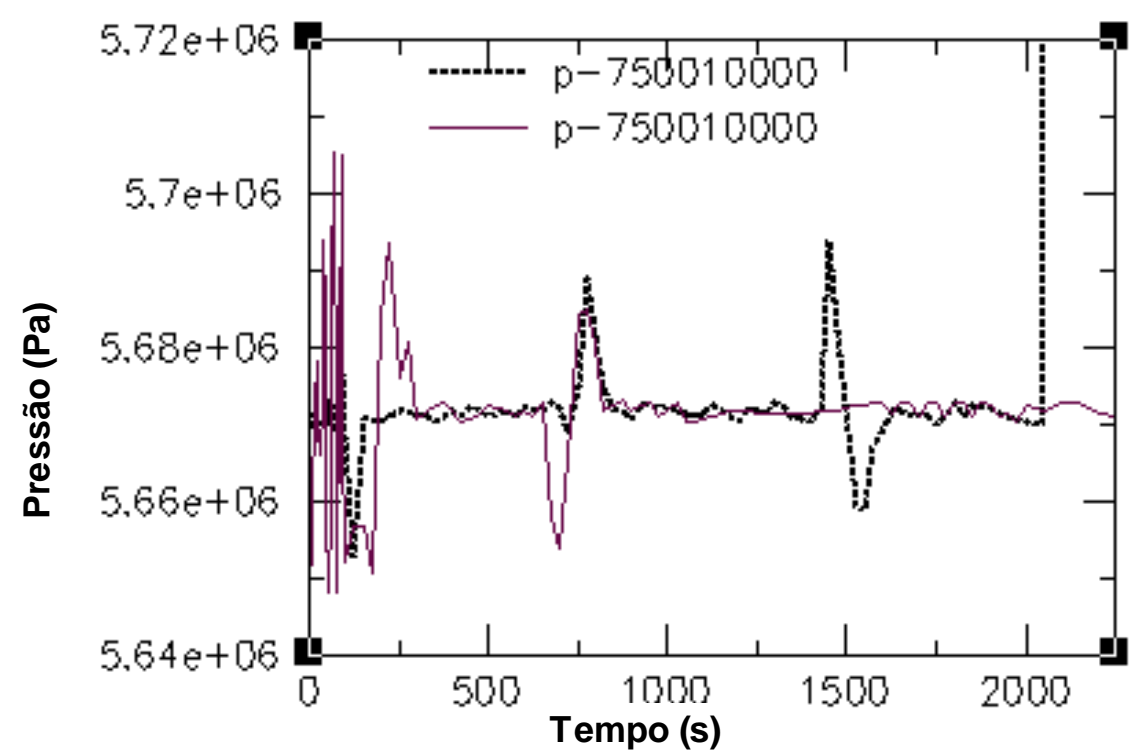

GRÁFICO 23 Variação da pressão calculada no secundário do IRIS após uma mudança de potência de 100 para $90 \%$

Fonte: resultados de simulação da pesquisa

Considerando esse comportamento anormal simulado, foi, então, realizado um estudo, com o RELAP5, para avaliar os tempos de trânsito do fluido no reator IRIS e em um reator tipo PWR como ANGRA 2. Na TAB. 1 pode-se observar que o tempo total para o refrigerante do primário completar um ciclo no IRIS é quase quatro vezes o tempo em ANGRA 2. Observa-se ainda que enquanto os tempos de residência nos componentes termicamente ativos, núcleo e geradores de vapor, no IRIS é cerca de duas vezes maior que aqueles em ANGRA 2, o tempo de residência na região entre o gerador de vapor e o núcleo no IRIS é cerca de 5 vezes maior que em ANGRA 2 e na região entre o núcleo e os geradores de vapor é de cerca de 9 vezes maior. 
TABELA 1 - Tempos de Residência do Fluido no IRIS e em ANGRA 2

\begin{tabular}{c|c|c}
\hline Região & $\begin{array}{c}\text { IRIS } \\
(\mathbf{s})\end{array}$ & $\begin{array}{c}\text { ANGRA 2 } \\
\text { (s) }\end{array}$ \\
\hline Núcleo & 4 & 1,9 \\
\hline $\begin{array}{c}\text { Núcleo - Gerador de } \\
\text { Vapor }\end{array}$ & 7 & 0,8 \\
\hline $\begin{array}{c}\text { Gerador de Vapor } \\
\begin{array}{c}\text { Gerador de Vapor- } \\
\text { Núcleo } \\
\text { TOTAL }\end{array}\end{array}$ & 7,5 & 3,3 \\
\hline
\end{tabular}

Fonte: resultados de simulações feitas pelo autor

Após procurar avaliar algumas constantes de tempo envolvidas no processo, identificou-se que o problema era causado por um movimento demasiado intenso das barras de controle para pequenos desvios de temperatura (potência). Como descrito no item 2.4.2.3 e mostrado, na parte inferior esquerda, na FIG. 16 esse movimento é definido pela Tabela Geral 153 do sistema de controle do IRIS no RELAP5 e mostrado graficamente no GRAF. 24. Foram determinados, então, novos valores de movimento, para valores de desvio de temperatura menores que $3 \mathrm{~K}$, que estão mostrados no GRAF. 25. Para desvios de temperatura maiores que $3 \mathrm{~K}$ não foi feita nenhuma alteração do movimento das barras como mostrado no GRAF. 26. 


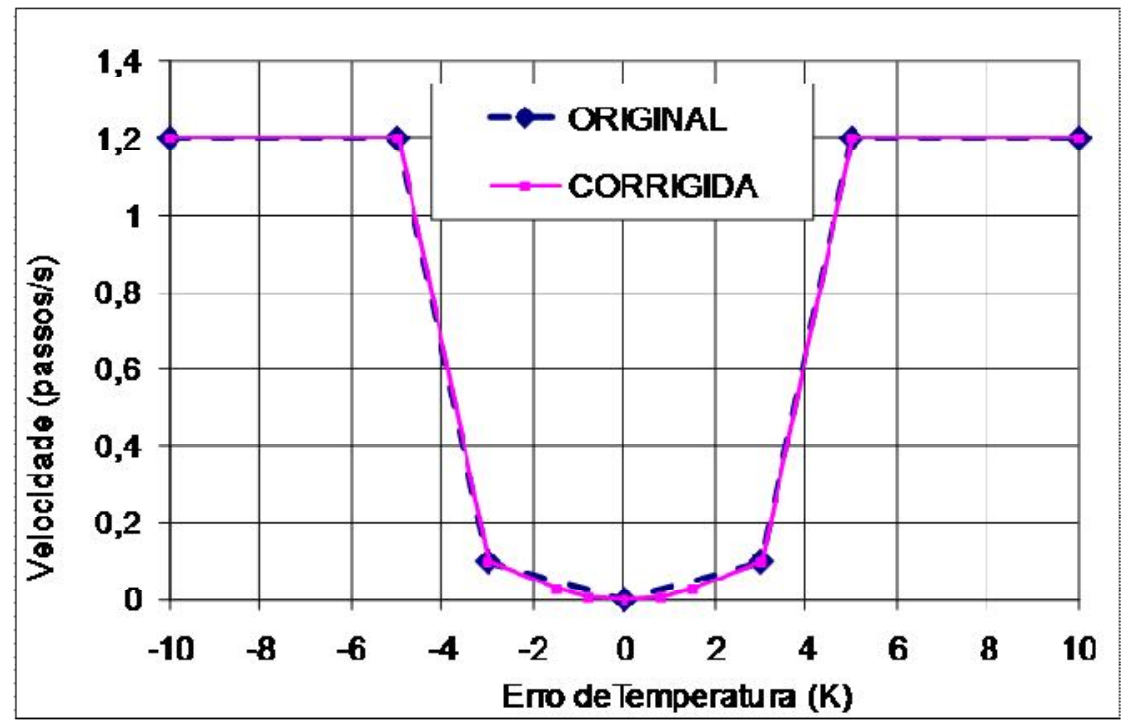

GRÁFICO 24 Velocidade das barras de controle em função do erro de temperatura

Fonte: elaborado pelo autor

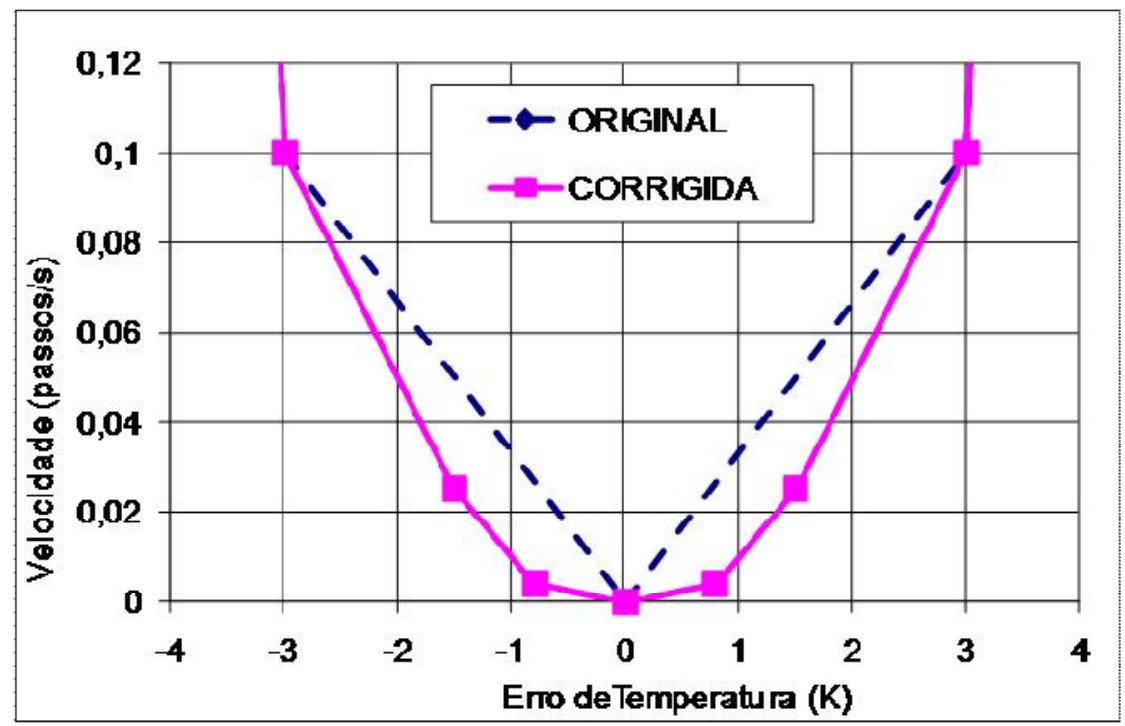

GRÁFICO 25 Detalhe da velocidade das barras de controle em função do erro de temperatura

Fonte: elaborado pelo autor

Ao refazer a sequência de cálculos com as modificações comentadas foram obtidos resultados mostrando que o problema para as simulações com potência alta havia sido resolvido, como pode se observar nos GRAF. 26 e GRAF. 27 que apresentam as mesmas informações dos GRAF. 22 e GRAF.23, porém obtidas de simulações com as modificações implementadas. 


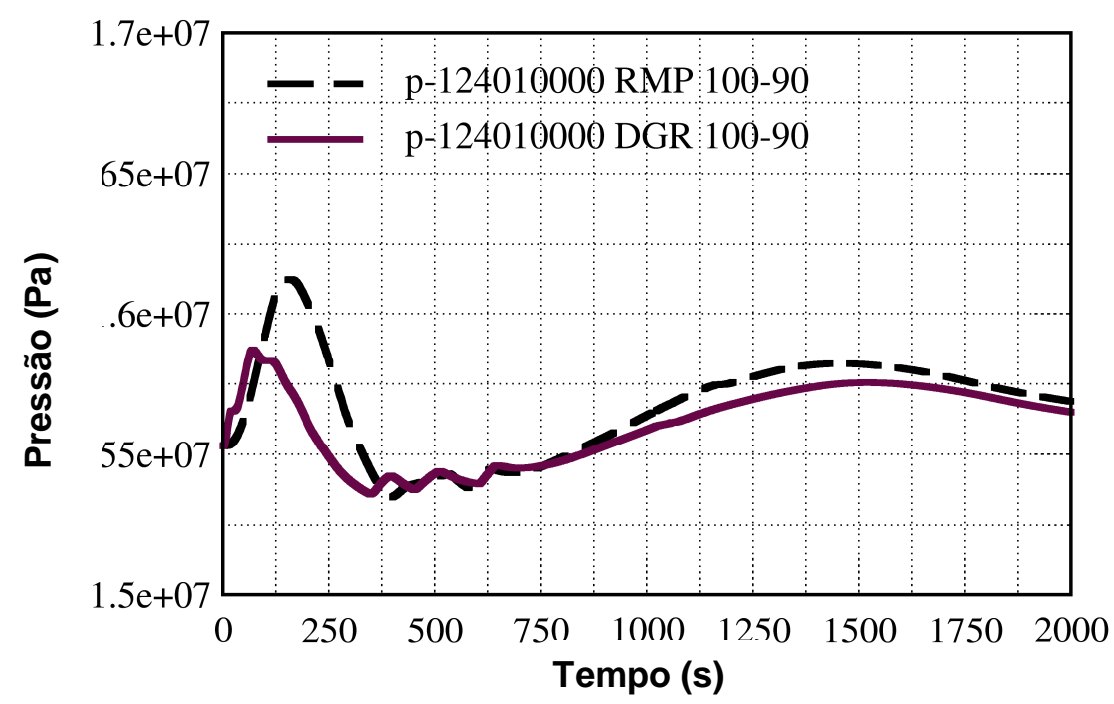

GRÁFICO 26 Pressão no primário do IRIS após uma mudança de potência de 100 para $90 \%$ calculada após alterações na nodalização

Fonte: resultados de simulação da pesquisa

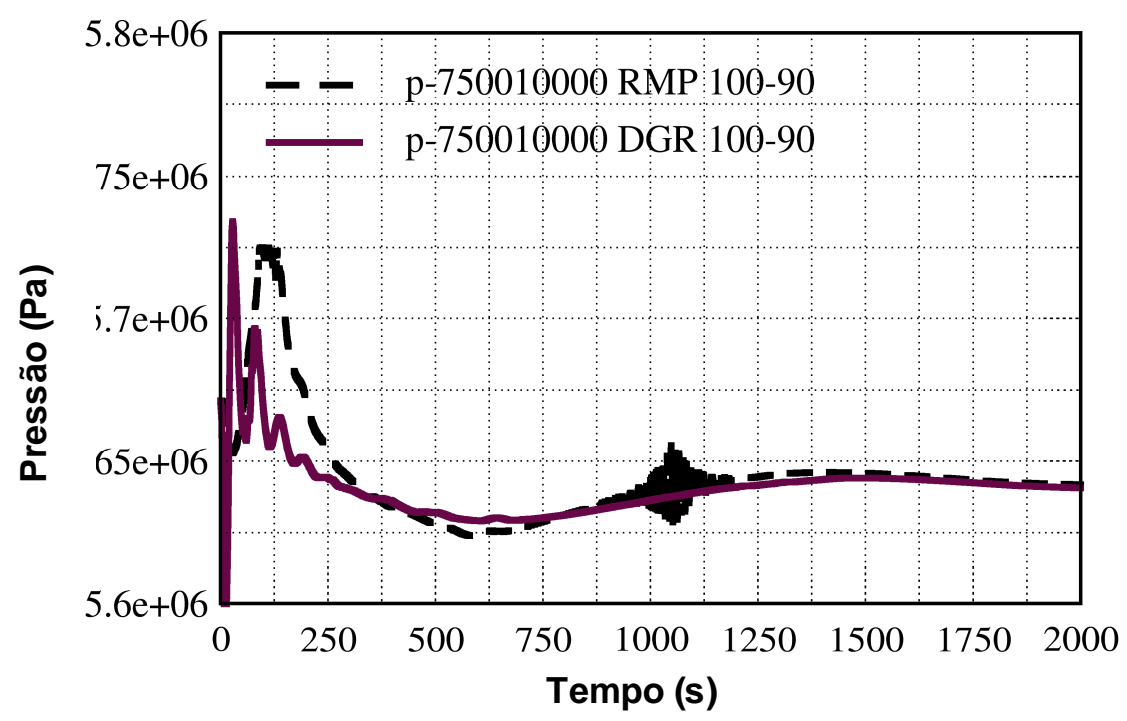

GRÁFICO 27 Pressão no secundário do IRIS após uma mudança de potência de 100 para 90\% calculada após alterações na nodalização

Fonte: resultados de simulação da pesquisa

Com as modificações introduzidas novas não conformidades apareceram nas simulações de mudança de potência a baixas potências onde a pressão do secundário oscilava muito. No GRAF. 28 pode-se observar a oscilação na pressão do secundário em uma simulação de $20 \%$ de potência e no GRAF. 29 observa-se que apesar de a potência média na turbina ser de $20 \%$ a oscilação é de mais de $10 \%$. 


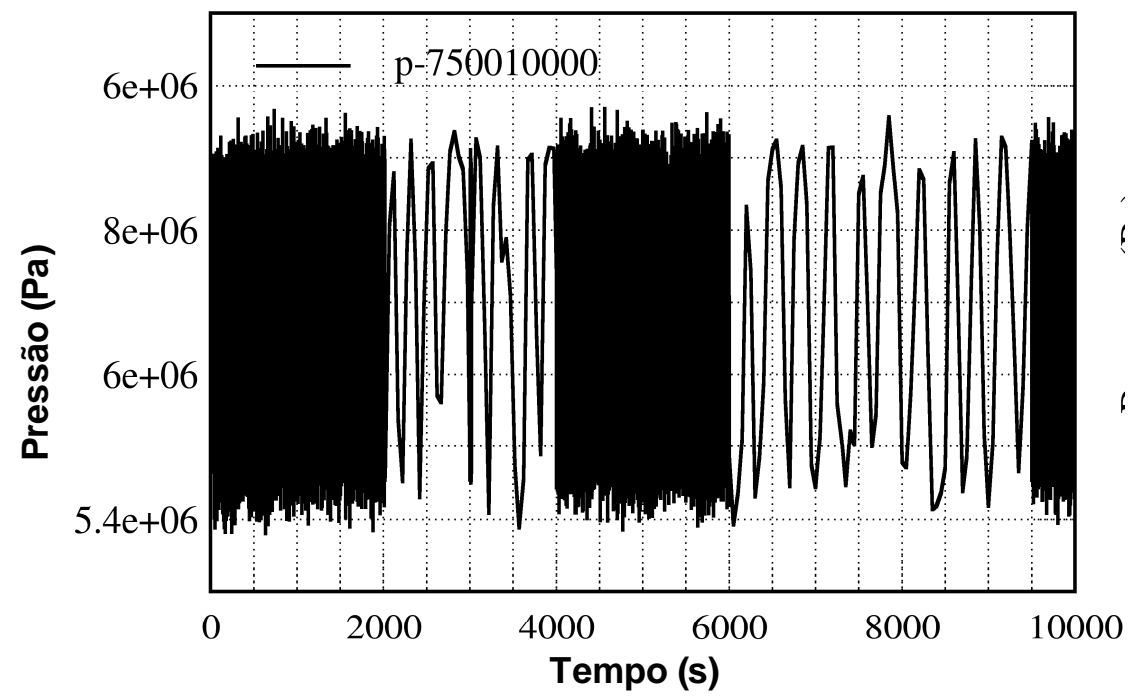

GRÁFICO 28 Pressão no secundário a $20 \%$ de potência.

Fonte: resultados de simulação da pesquisa

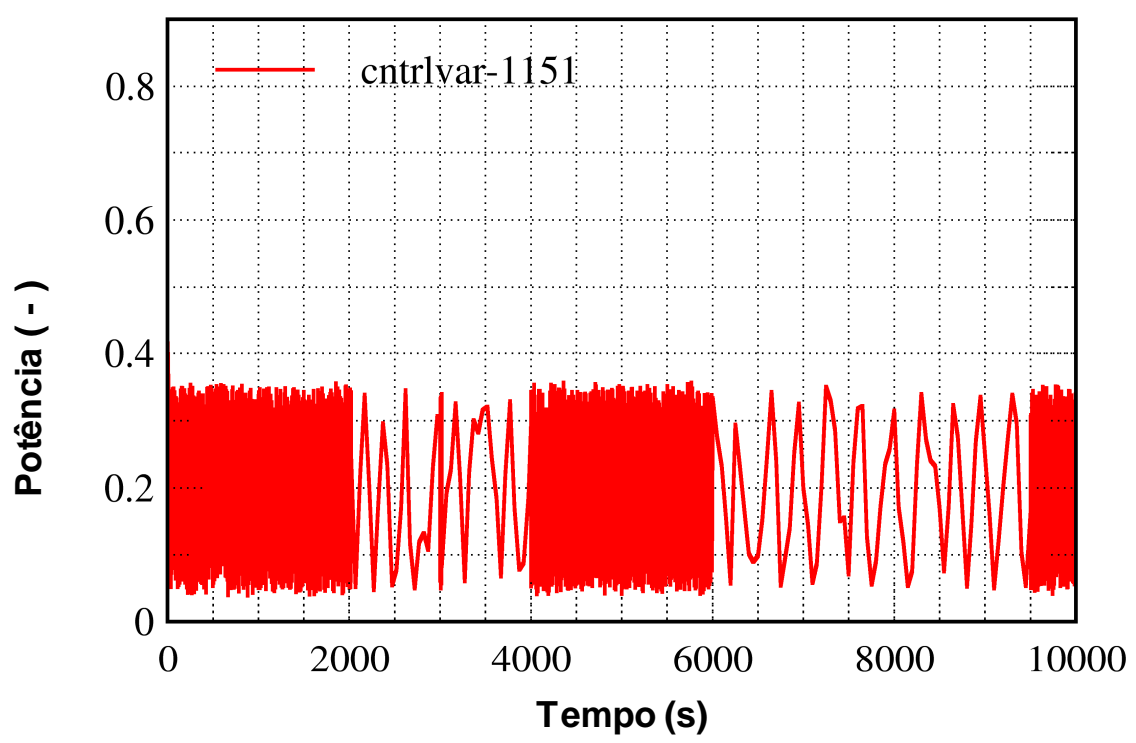

GRÁFICO 29 Potência entregue à turbina a $20 \%$ de potência.

Fonte: resultados de simulação da pesquisa

A solução para esse problema foi conseguida alterando-se o sistema de controle da pressão do secundário. Observou-se que uma variação da abertura da válvula de admissão de vapor na turbina tinha uma influência na vazão muito grande quando a abertura era pequena e pequena quando a abertura era grande, conforme mostrado no GRAF. 30. 


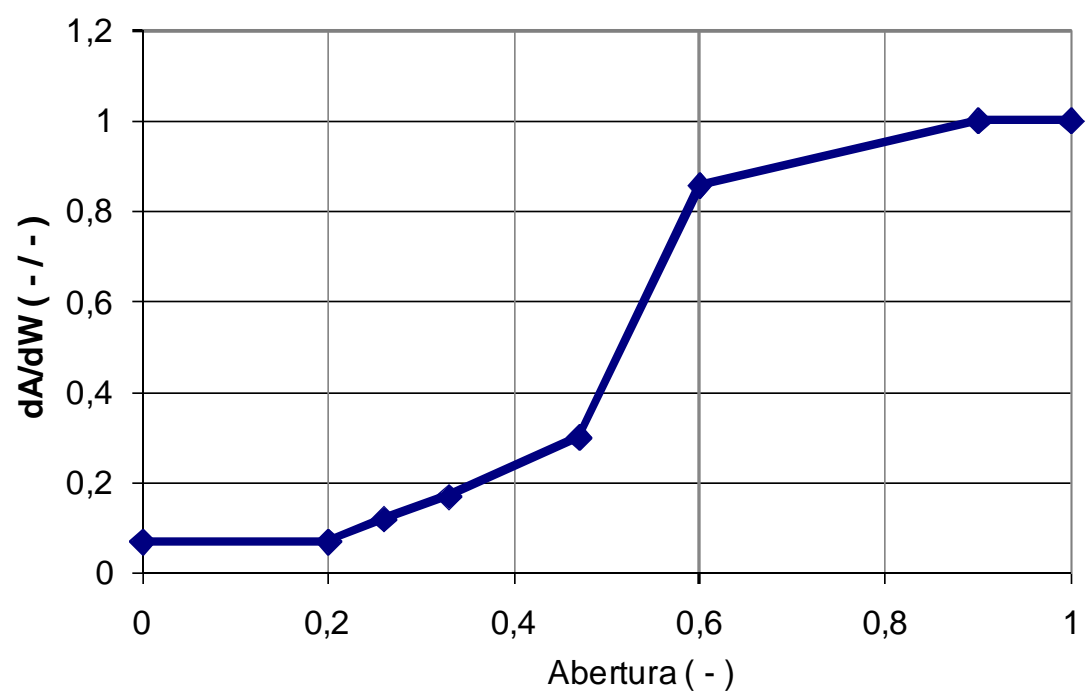

GRÁFICO 30 Influência da Abertura da Válvula na Variação da Vazão com a Abertura

Fonte: elaborado pelo autor

Assim a principal mudança feita nesse sistema foi a introdução de um fator para a velocidade de abertura da válvula em função de sua posição. Com essa nova modificação do sistema de controle do IRIS foi possível executar todos os casos obtendo-se resultados sem grandes não-conformidades. Os GRAF. 31 e GRAF. 32 apresentam resultados da simulação com o RELAP5, com essas modificações implementadas, que correspondem aos mesmos parâmetros mostrados nos GRAF. 28 e. 29. 


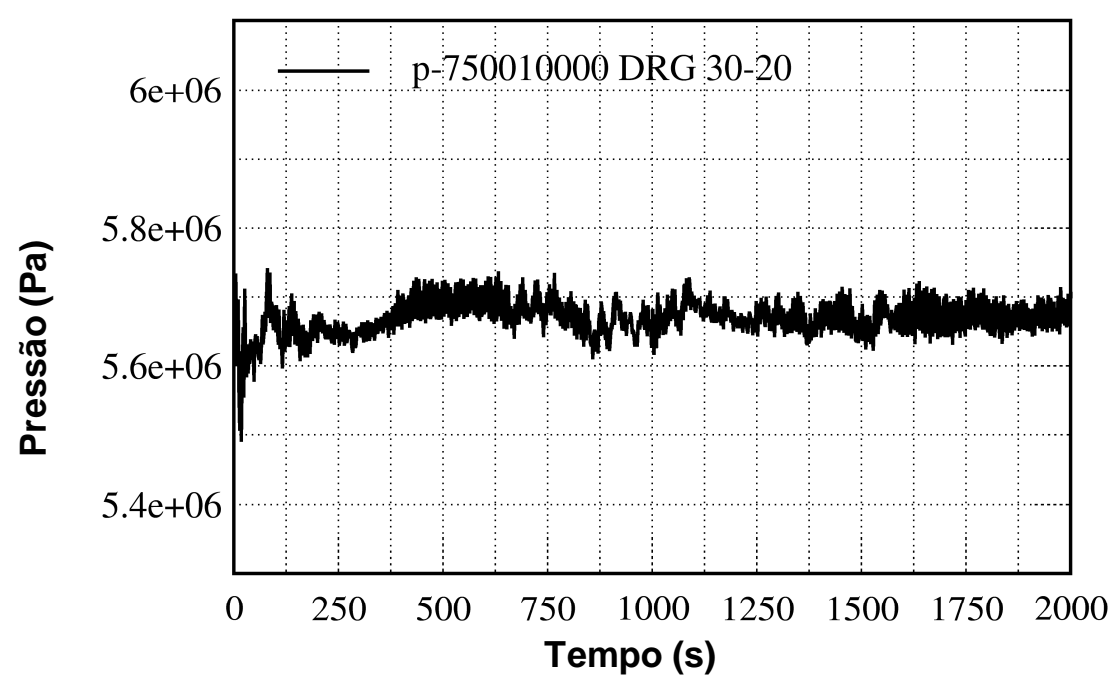

GRÁFICO 31 Pressão no secundário a 20\% de potência depois de alterada a nodalização.

Fonte: resultados de simulação da pesquisa

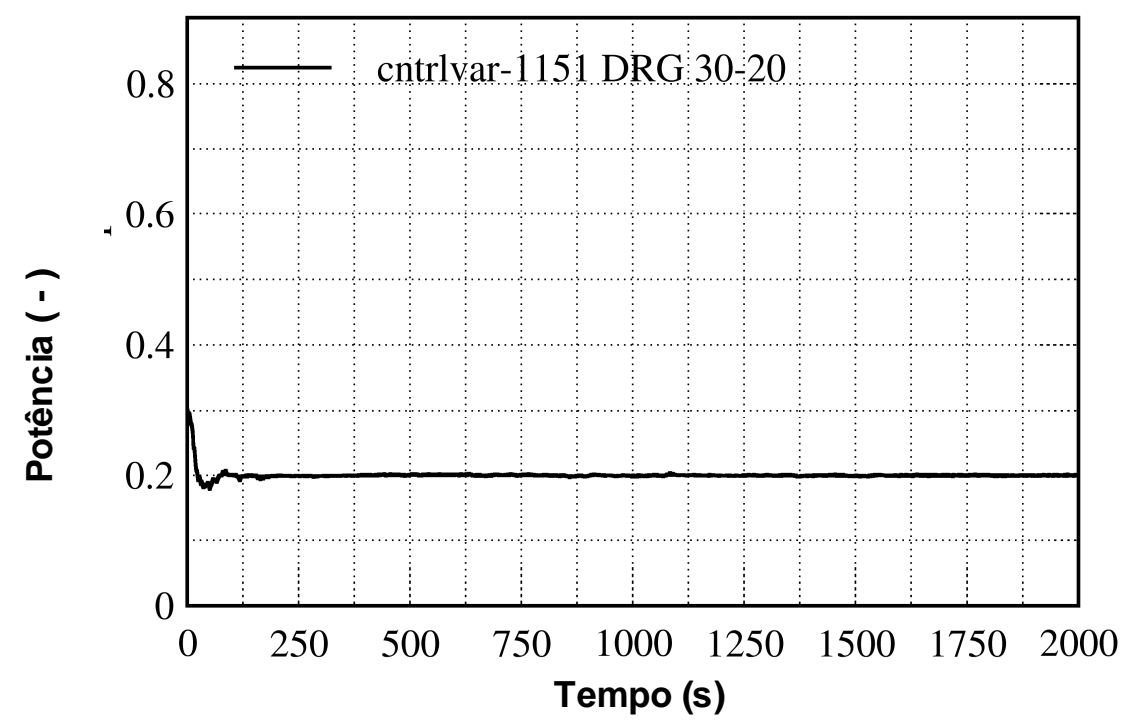

GRÁFICO 32 Potência no secundário a 20\% depois de alterada a nodalização.

Fonte: resultados de simulação da pesquisa

A maior parte das não conformidades foi resolvida durante as simulações de degraus de rampas de potência. Nas simulações das condições anormais e acidentes não houve modificações na parte do sistema de controle e proteção, mas somente mudanças de nodalização de volumes próximos a 
válvulas de linhas de injeção para que quando essas fechassem não interrompesse o fluxo de uma time dependent junction.

\subsubsection{Resultados da Simulação do IRIS com o RELAP5}

Com as modificações introduzidas na nodalização, pôde-se concluir todas as simulações listadas no QUADRO 5, completando assim o banco de dados de simulações do IRIS.

As simulações foram feitas até um tempo de $6000 \mathrm{~s}$ para a maior parte dos casos, porém as primeiras simulações foram feitas até 10000 s para verificar se não apareceria alguma instabilidade ainda não detectada. Os transientes e condições anormais ou acidentes começavam 100 segundos após o reinício, no tempo final, de uma simulação anterior de mudança de potência de degrau ou rampa. Nessas condições toda simulação começava a partir de um estado estacionário de potência definida.

O APÊNDICE G mostra alguns resultados, pressões, temperaturas, potências e nível do pressurizador, de duas simulações. A primeira simulação é de uma mudança de potência em degrau de $60 \%$ para $70 \%$ e a segunda é de uma ruptura de tubos do gerador de vapor, que inicialmente se comporta como um aumento de potência, mas depois acaba desligando o reator por abaixar muito o nível do pressurizador. 
6 O SISTEMA DE IDENTIFICAÇÃO E CLASSIFICAÇÃO DE TRANSIENTES -

SICT

O objetivo desta etapa foi disponibilizar um programa computacional, um aplicativo, que possa ser usado para dar suporte ao desenvolvimento de um Sistema de Identificação e Classificação de Transientes - SICT durante a sua fase de treinamento e avaliação e que, além disso, fosse ele próprio o Sistema de Identificação e Classificação de Transientes a ser utilizado na monitoração da instalação, seja esta o IRIS ou uma instalação experimental.

O capítulo inicia com uma breve descrição das razões para a escolha da linguagem de programação (item 6.1). No item 6.2, o modelo, é apresentado, juntamente com a descrição dos diversos módulos que compõem o programa, como os fundamentos, apresentados na revisão bibliográfica e outros modelos próprios que foram incorporados ao SICT. Ao longo do item 6.3, "Arquivos Usados pelo Programa", são apresentados os dados requeridos pelo SICT e as informações para análise disponibilizadas por ele com alguns exemplos de tratamento dessas informações para facilitar as análises. No conjunto este capítulo apresenta o SICT nos seus aspectos computacionais e de arquitetura de rede SOM assim como de sua capacidade e funcionalidade.

\subsection{A Linguagem de Programação}

O Sistema de Identificação e Classificação de Transientes em desenvolvimento foi programado em $\mathrm{C}++$ usando, portanto, o conceito de Programação Orientada a Objeto (POO). Os principais elementos conceituais utilizados na POO (LIBERTY, 1999) são:

- Classe: representa um conjunto de objetos com características afins. Uma classe define o comportamento dos objetos, através de seus métodos e atributos. 
- Objeto: é uma instância de uma classe. Um objeto é capaz de armazenar diferentes estados através de seus atributos.

- Métodos: são as funções que definem as capacidades dos objetos, alterando seus atributos e se comunicando com outros objetos.

- Atributos: representam as características dos objetos, são as variáveis do objeto.

- $\quad$ Mensagem: é o pedido enviado a um objeto para que um de seus métodos seja executado, desempenhando assim as funções descritas pela sua classe.

Além desses elementos básicos dois outros conceitos importantes levaram á escolha dessa linguagem como base para o projeto, uma vez que possibilitam segurança e facilidade de utilização, modificação, ampliação e melhoria por outros desenvolvedores. Esses dois outros conceitos são:

- Encapsulamento: é basicamente a separação dos métodos e atributos de uma classe em internos e externos. Isso é utilizado amplamente para impedir o acesso direto aos atributos de um objeto, possibilitando o seu acesso externamente apenas por métodos do próprio objeto que podem copiá-los ou alterá-los.

- Herança: é o mecanismo pelo qual uma classe pode herdar de outra classe seus comportamentos (métodos) e variáveis (atributos), que passam então a fazer parte intrínseca dela.

A versão final do modelo, por incorporar as características da POO acima descritas, é facilmente utilizável em outros softwares que podem usá-lo como parte de outros desenvolvimentos. Na programação foram utilizadas técnicas e recomendações usuais em livros de $\mathrm{C}++$ e cujos fundamentos foram descritos por Chapman (CHAPMAN 2002). 


\subsection{O Modelo}

Neste item é feita uma descrição tanto da parte de estrutura do programa como dos fundamentos e opções usados para definir o seu comportamento . O objetivo dessa descrição é facilitar o seu entendimento para utilizá-lo no desenvolvimento de um sistema de identificação e classificação de transientes ou para utilizá-lo como parte de outra aplicação. A base dessa descrição são as classes e seus atributos e métodos criados neste projeto.

\subsubsection{As Classes de Base}

A aplicação SICT foi desenvolvida, então, usando o Microsoft Visual C++.net na configuração de projetos que usa a interface MFC (Microsoft Foundation Classes) na forma de multi-documentos. A inicialização do projeto começa com a criação das quatro classes básicas para o programa existir nesse ambiente Windows:

- $\quad$ CSICTApp: a aplicação, contém o controle básico das janelas utilizadas pelo programa incluindo a barra de menus que permite a iteração com os usuários,

- CSICTDoc: que guarda o documento, isto é, o conteúdo da rede, e as informações de como processá-lo,

- CSICTView: que processa o documento disponibilizando a sua visualização do na tela e

- CAboutDlg: que contém informações sobre a versão do programa. 


\subsubsection{As Principais Classes e seus Inter-relacionamentos}

Após a criação das quatro classes de base iniciou-se 0 desenvolvimento do modelo propriamente dito.

O modelo desenvolvido é o de uma rede neuronal tipo Mapas Auto-Organizáveis - SOM que interaja com o exterior recebendo dados que serão processados disponibilizando uma resposta.

A rede neuronal por sua parte é formada de neurônios que tem um comportamento específico que deve ser programado. A rede tipo SOM associa a saída dos neurônios e mesmo o seu comportamento a uma geometria de apresentação dos resultados. Essa geometria pode ser uni, bi, ou multidimensional. No caso deste desenvolvimento a saída da rede é para ser feita em uma tela de computador e, portanto, por facilidade, adotou-se a configuração bid imensional.

Considerando esses aspectos, a classe base para início do desenvolvimento da aplicação foi uma classe que tinha o comportamento da geometria associada ao neurônio, a classe CShape.

A classe seguinte, CNeuron, herda da classe CShape seu comportamento (métodos e atributos) e agrega novas funcionalidades próprias.

A classe CNeuron é a base da classe CNetwork para a qual passa todas as suas características.

A FIG. 26 apresenta a relação descrita entre as classes. 


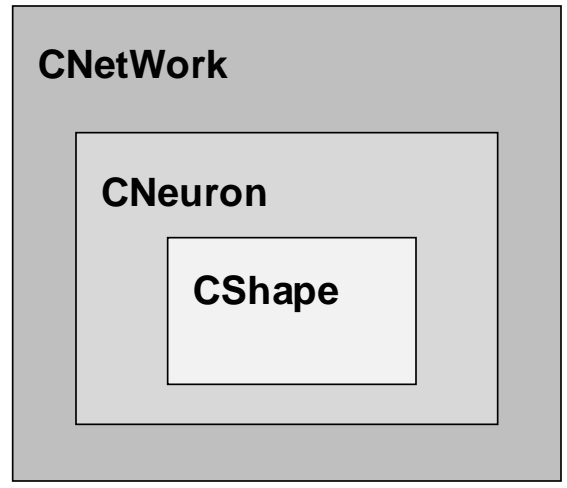

FIGURA 26 Relação entre as Classes Cshape, CNeuron e CNetwork Fonte: elaborado pelo autor.

A ligação da classe CNetwork com o exterior é feita através da classe CNetworklnput, que cuida da obtenção dos dados do exterior, de seu tratamento e do seu envio na forma apropriada para a rede CNetwork. Com esse arranjo a interface necessária com o mundo exterior é feita pela classe CNetworklnput, que pode ser alterada, conforme a interface com o exterior assim o exija. Assim as alterações requeridas pela interface com o exterior não requerem qualquer adaptação na classe CNetwork. A FIG. 27 apresenta essa relação entre essas classes e o exterior. $O$ exterior é a fonte dos dados podendo ser arquivos ou dados medidos em uma instalação e disponibilizados através de uma interface com o SICT.

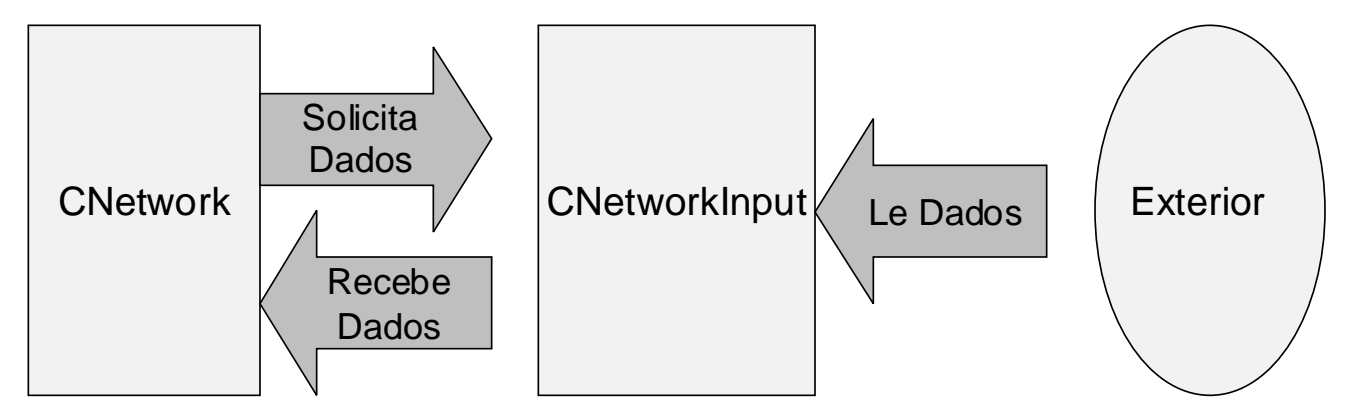

FIGURA 27 Relação entre as classes CNetwork, CNetworklnput e o Exterior Fonte: elaborado pelo autor.

Além dessas classes principais foram ainda criadas duas outras classes para que o usuário possa dar entrada em informações sobre a criação da rede, CDlgNet e sobre o processo de aprendizado CDlgLearn. Pode-se observar 
na FIG. 28 uma organização de todas essas classes na interface de desenvolvimento do programa.

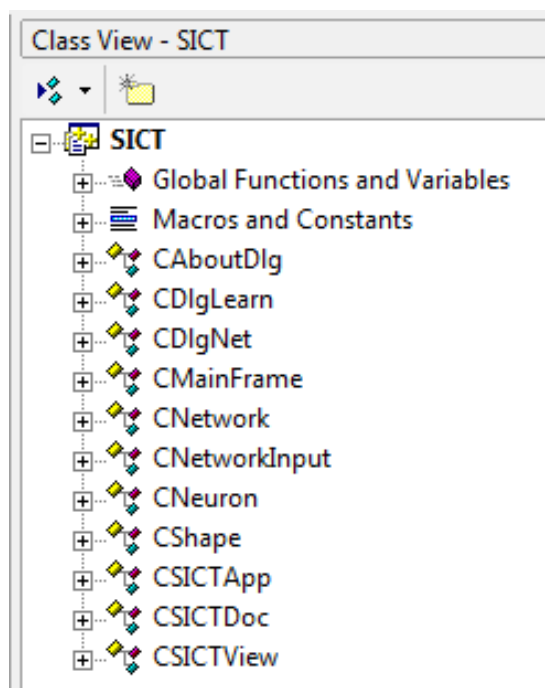

FIGURA 28 Classes utilizadas para o desenvolvimento do SICT Fonte: tela de classes do SICT.

\subsubsection{A classe CDIgNet}

A classe CDlgNet é responsável por solicitar do usuário os parâmetros para criação da rede. Para tanto ela tem métodos e atributos, mostrados na FIG. 29, guardando assim os valores fornecidos pelo usuário através de uma janela própria da classe, que está mostrada na FIG. 30. 


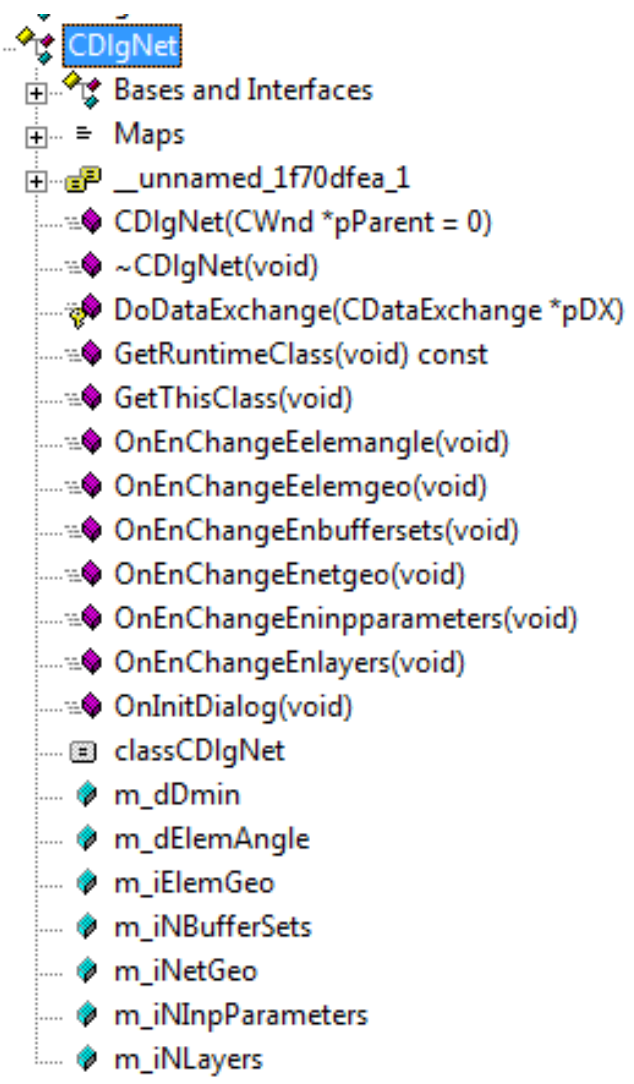

FIGURA 29 Métodos e atributos da classe CDlgNet Fonte: tela de classes do SICT.

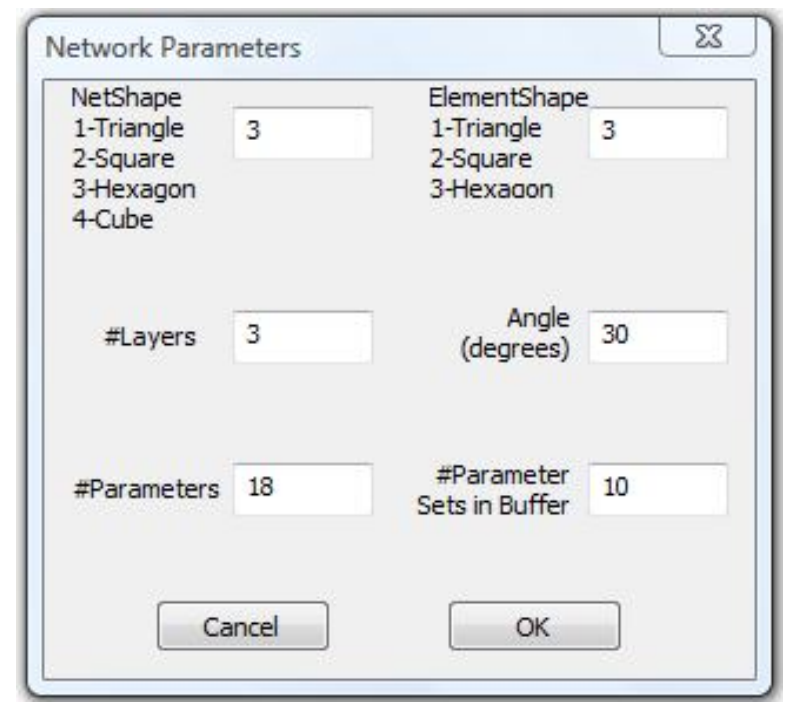

FIGURA 30 Parâmetros pedidos ao usuário para criação da rede Fonte: tela do SICT.

Os parâmetros solicitados na tela são: 
- NetShape (m_iNetGeo): especifica a forma geométrica da rede,

- ElementShape (m_iElemGeo): especifica a forma geométrica do neurônio na rede. O ElementShape em conjunto com o NetShape define as diferentes configurações geométricas que o SICT possibilita usar. Essas configurações estão listadas no QUADRO 6 e apresentadas graficamente na FIG. 31

- \#Layers (m_iNLayers): determina quantas zonas de neurônios a rede vai ter, considerando o neurônio central, que usualmente tem ordem 0 , como a zona 1. Uma zona é formada por um conjunto de neurônios vizinhos formando uma camada envolvendo a zona contígua mais interna. Na FIG. 31 todas as redes apresentadas têm três zonas, sendo que na rede cúbica, cada uma das faces tem três zonas. Apenas nas redes Quadrada/Triangular o elemento central tem ordem diferente de 0 .

- Angles (m_dElemAngle): especifica o ângulo do vértice inicial do polígono com a horizontal. Esse valor define o posicionamento da rede na tela, mas não altera a posição relativa entre os neurônios no interior da rede. A FIG. 32 apresenta duas redes Quadrada/Quadrada com 4 zonas e ângulos de $45^{\circ}$ e $90^{\circ}$ respectivamente.

- $\quad$ \#Parameters ( $\left.m \_i N I n p P a r a m e t e r s\right):$ determina o número de parâmetros que vão fazer parte do buffer, por exemplo, um buffer composto por dez temperaturas em pontos diferentes de uma instalação, terá o valor de 10 .

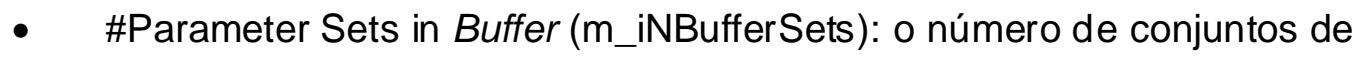
parâmetros, m_iNInpParameters, que vai formar um buffer completo. Continuando o exemplo citado anteriormente, as temperaturas nos dez pontos diferentes podem fornecer dados agregados em conjuntos de 15 medidas temporais no buffer. Assim esse buffer conteria 15 valores de medidas para cada uma das dez temperaturas em um total de 150 parâmetros. Esses dois valores, \#Parameters e \#Parameter Sets in Buffer, definem então o número de ligações 
sinápticas que cada neurônio deve possuir, no caso do exemplo 150 pesos ou ligações sinápticas.

- m_dDmin: Este atributo não é fornecido pelo usuário, mas fica guardado junto com os demais atributos dessa classe. Ele é a distância em termos relativos (0-1), que independe das dimensões e resolução externas da tela, entre dois neurônios na rede.

QUADRO 6 - Formas de rede e suas formas de neurônios possíveis

\begin{tabular}{c|c}
\hline Forma da Rede & Forma do Neurônio \\
\hline Hexagonal & $\begin{array}{l}\text { Hexagonal } \\
\text { Triangular } \\
\text { Quadrada }\end{array}$ \\
\cline { 2 - 2 } & Quadrada \\
\hline Triangular & Triangular \\
\hline Cúbica & Quadrada \\
\hline
\end{tabular}

Fonte: elaborado pelo autor.

A rede cúbica, cujos neurônios de forma quadrada estão localizados nas faces de um cubo, é apresentada na tela do SICT na forma plana, com as faces rebatidas em torno da face que contem o elemento central de ordem 0 . Essa representação é a mostrada na parte inferior da FIG. 31. Essa rede não foi utilizada e explorada com profundidade tendo sido incluída na fase final do estudo para demonstrar a capacidade do SICT em utilizar diferentes configurações e sinalizar futuros desenvolvimentos nessa área de redes espaciais tridimensionais.

A forma da rede e a forma dos neurônios determinam diferentes distribuições de distâncias entre os neurônios. Como essas distâncias são usadas no processo de treinamento, a geometria escolhida tem uma influência na configuração final da rede.

Os dados que definem o buffer foram separados em "\#Parameter" e "\#Parameter Sets in Buffer", pois posteriormente, quando da leitura dos dados externos, os "\#Parameter Sets in Buffer" de um dado parâmetro serão normalizados pelo mesmo processo. Assim, usando o exemplo anterior, todas as 15 medidas da temperatura no local 1 serão normalizados usando os mesmos 
valores de conversão, enquanto as 15 medidas da temperatura no local 2 serão normalizados usando outros valores.

a)

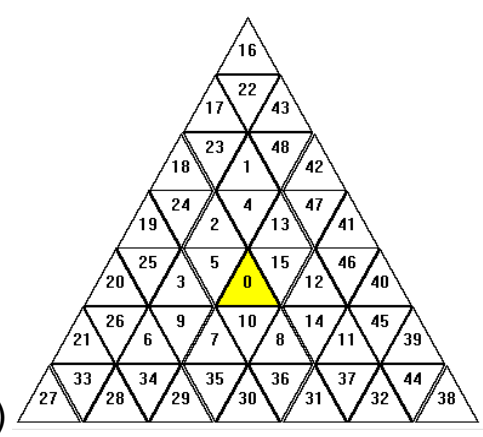

b)

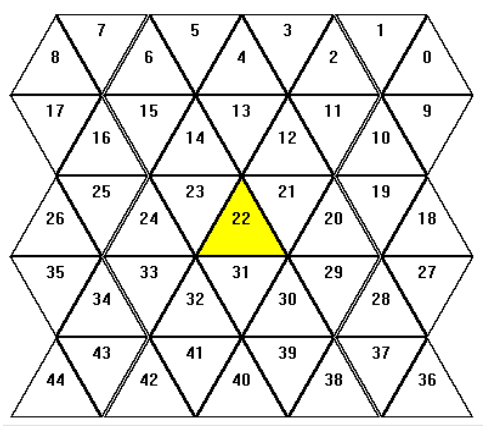

c)

\begin{tabular}{|c|c|c|c|c|}
\hline 13 & 12 & 11 & 10 & 9 \\
\hline 14 & 3 & 2 & 1 & 24 \\
\hline 15 & 4 & 0 & 8 & 23 \\
\hline 16 & 5 & 6 & 7 & 22 \\
\hline 17 & 18 & 19 & 20 & 21 \\
\hline
\end{tabular}

d)

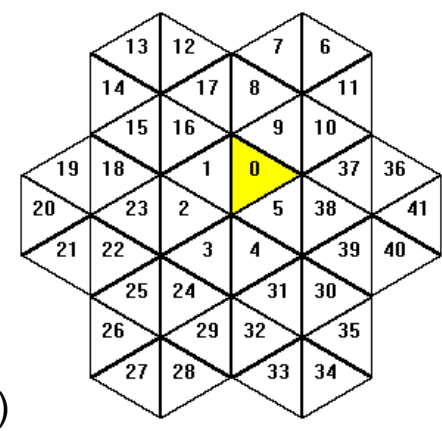

e)

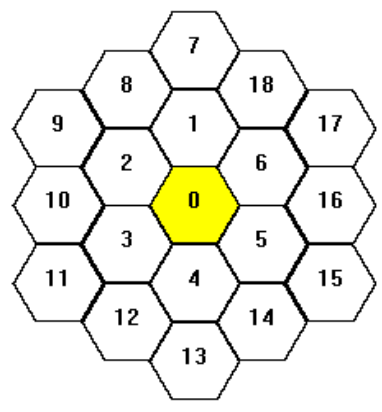

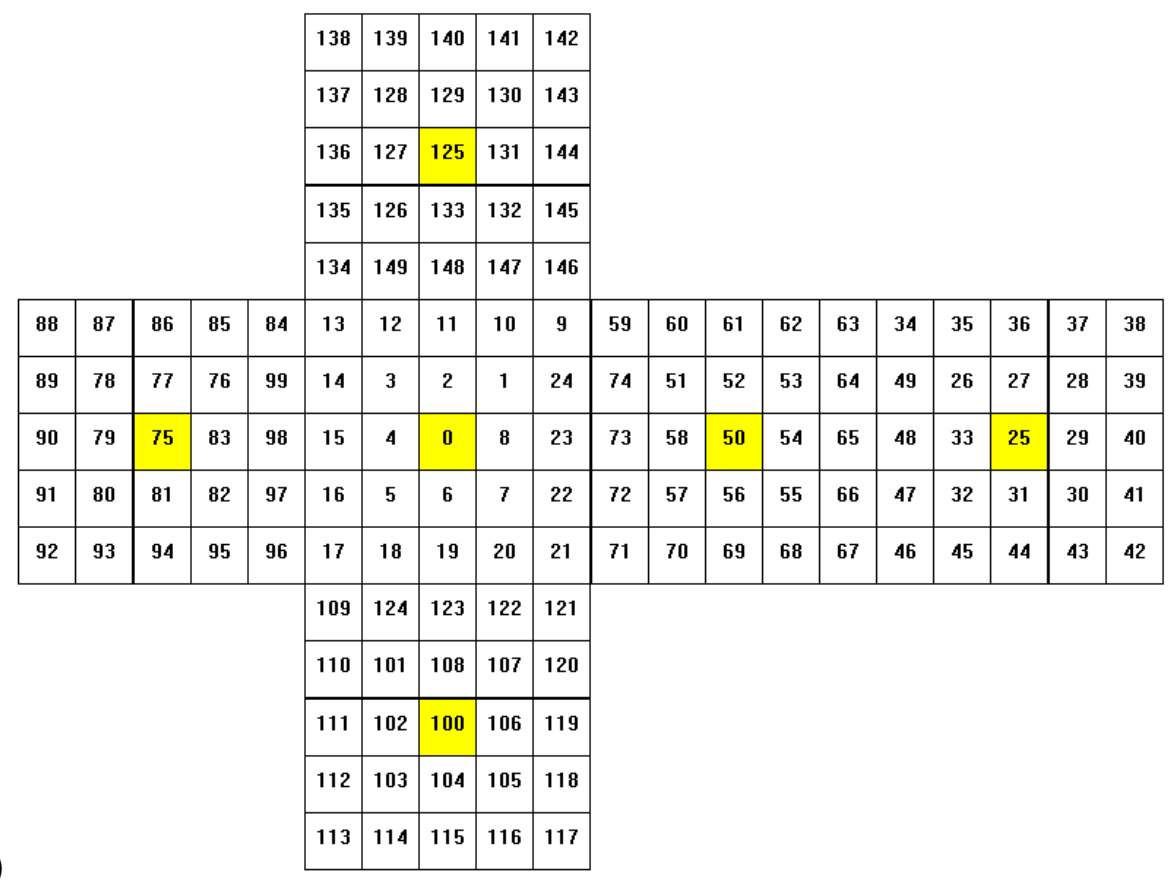

FIGURA 31 Redes a) Triangular/Triangular, b) Quadrada/Triangular,

c) Quadrada/Quadrada, d) Hexagonal/Triangular , e) Hexagonal/Hexagonal e f) Cúbica/Quadrada

Fonte: tela do SICT. 


\begin{tabular}{|c|c|c|c|c|c|c|}
\hline 31 & 30 & 29 & 28 & 27 & 26 & 25 \\
\hline 32 & 13 & 12 & 11 & 10 & $\mathbf{9}$ & 48 \\
\hline 33 & 14 & 3 & 2 & 1 & 24 & 47 \\
\hline 34 & 15 & 4 & ol & $45^{-2}$ & 23 & 46 \\
\hline 35 & 16 & 5 & 6 & 7 & 22 & 45 \\
\hline 36 & 17 & 18 & 19 & 20 & 21 & 44 \\
\hline 37 & 38 & 39 & 40 & 41 & 42 & 43 \\
\hline
\end{tabular}

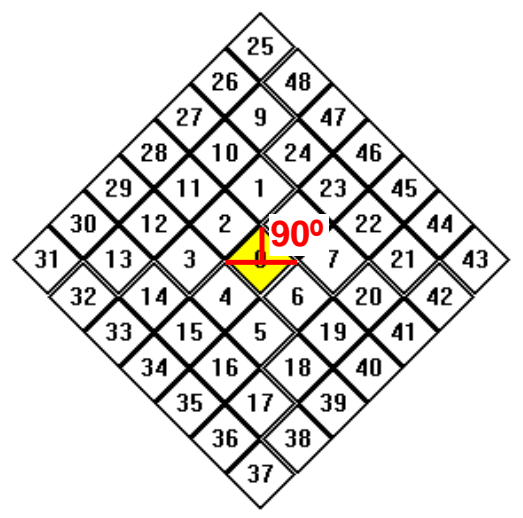

FIGURA 32 Redes Quadrada/Quadrada com ângulos de $45^{\circ}$ e $90^{\circ}$ com a horizontal

Fonte: elaborado pelo autor a partir de tela do SICT.

\subsubsection{A classe CDIgLearn}

A classe CDlgLearn é responsável por solicitar do usuário os parâmetros para o treinamento da rede. Para tanto, ela tem métodos e atributos, mostrados na FIG. 33, guardando assim os valores fornecidos pelo usuário através de uma janela própria da classe, que está mostrada na FIG. 34. Nessa classe está implementado o procedimento de aprendizagem em duas fases, de ordenamento e de convergência, descrito no item 2.2.4.1 Aprendizagem da Rede SOM. 


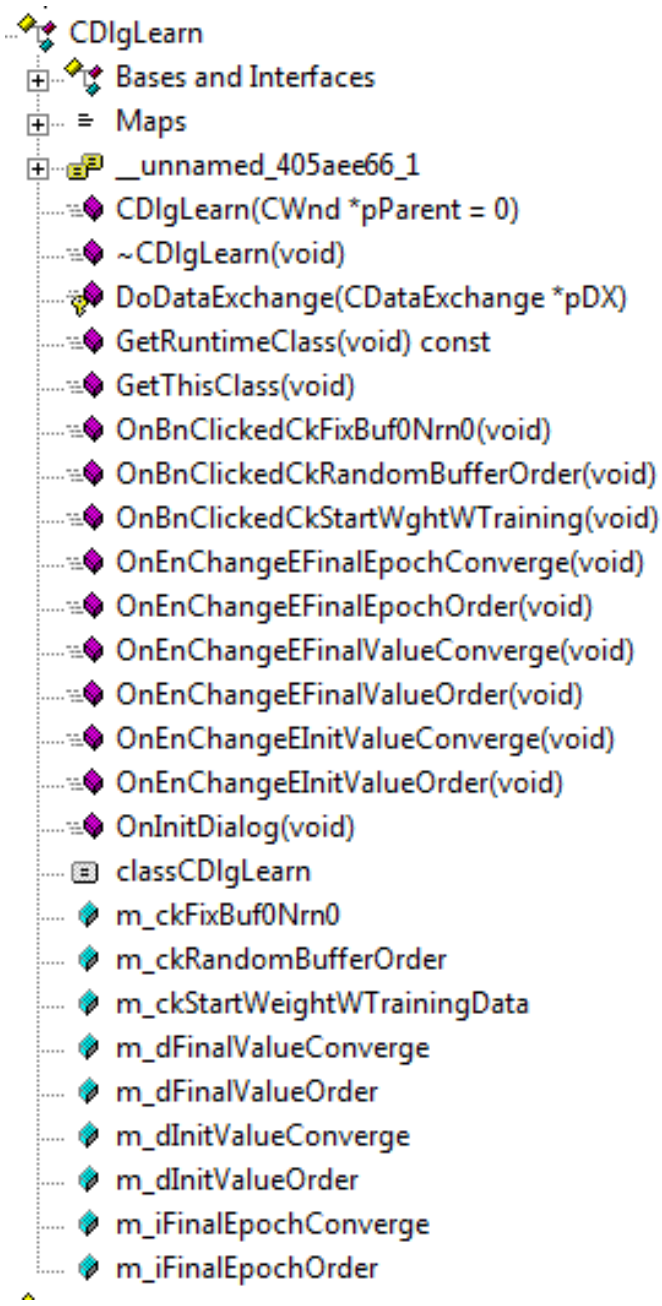

FIGURA 33 Métodos e atributos da classe CDIsLearn

Fonte: tela de classes do SICT. 


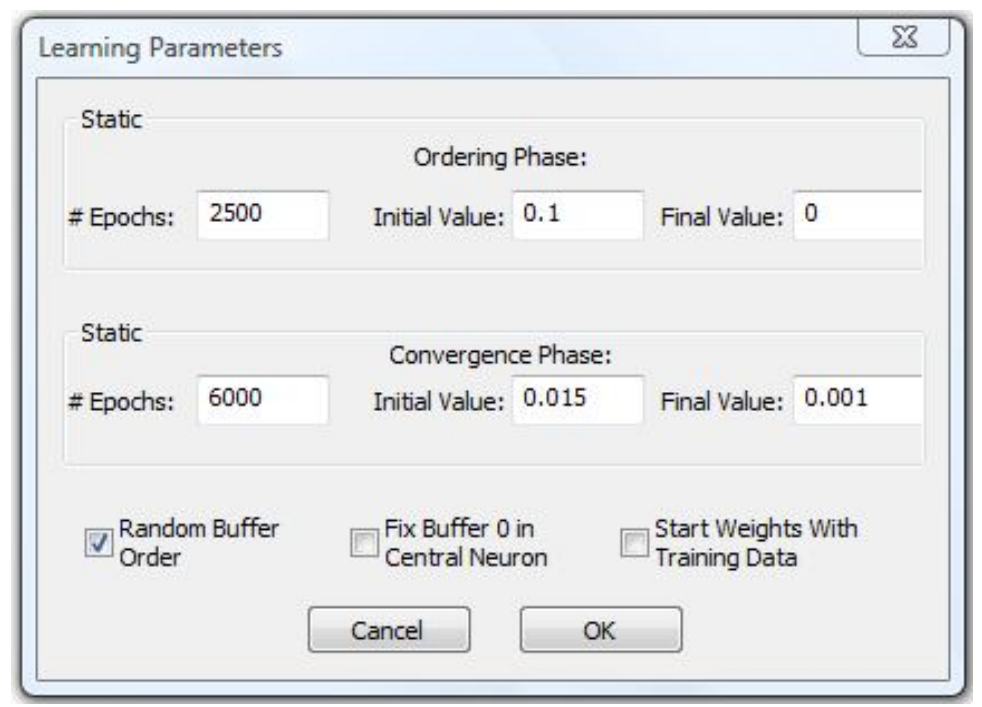

FIGURA 34 Parâmetros pedidos ao usuário para o treinamento da rede Fonte: tela do SICT.

Os valores solicitados na tela para a fase de ordenamento são:

- $\quad$ EEpochs ( $m$ iFinalEpochOrder): esse atributo guarda quantas épocas serão usadas para a fase de ordenamento.

- Initial Value (m_dlnitValueOrder): esse atributo guarda qual é o valor inicial do fator de aprendizagem, ETA, da equação (4) e é comentado no item 2.2.4.1, para a fase de ordenamento.

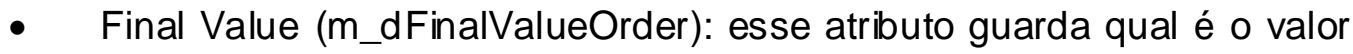
final do fator de aprendizagem, ETA, da equação (4) e é comentado no item 2.2.4.1, para a fase de ordenamento.

Os valores solicitados na tela para a fase de convergência são:

- \#Epochs (m_iFinalEpochConverge): esse atributo guarda quantas épocas serão usadas para a fase de convergência.

- Initial Value (m_dlnitValueConverge): esse atributo guarda qual é o valor inicial do fator de aprendizagem, ETA, da equação (4) e é comentado no item 2.2.4.1, para a fase de convergência. 
- $\quad$ Final Value (m_dFinalValueConverge): esse atributo guarda qual é o valor final do fator de aprendizagem, ETA, da equação (4) e é comentado no item 2.2.4.1, para a fase de convergência.

Além desses valores três seleções podem ser feitas:

- Random Buffer Order (m_ckRandomBufferOrder): se selecionada, os buffers serão apresentados em uma sequência aleatória para a rede durante as duas fases do treinamento. Caso não seja selecionada, os buffers serão sempre apresentados na mesma ordem em que foram fornecidos ao CNetworklput.

- Fixed Buffer 0 in Central Neuron (m_ckFixBuf0Nrn0): Caso selecionada, o "Buffer 0", primeiro buffer apresentado para CNetworkInput, será sempre alocado no neurônio no centro da rede, usualmente o neurônio de ordem 0. Assim os pesos do "neurônio central" serão sempre aqueles fornecidos pelo "Buffer 0".

- $\quad$ Start Weights with Training Data (m_ckStartWeightWTrainingData): Essa opção, quando selecionada, faz com que os pesos iniciais dos neurônios, isto é, o peso dos neurônios na época 0 , sejam definidos aleatoriamente. Caso esta opção não seja selecionada, os pesos iniciais dos neurônios na época 0 serão os pesos definidos pelos buffers de treinamento. Se houver mais neurônios que buffers, depois de terminada a cópia dos buffers o processo se reinicia até todos os neurônios terem seus pesos definidos. Caso contrário, se houver menos neurônios que buffer, os neurônios terão seus pesos copiados dos primeiros buffers até todos terem seus pesos definidos. 


\subsubsection{A Classe CShape}

A classe CShape representa a forma de um neurônio como visto pela rede e como este é apresentado na tela. Os atributos dessa classe guardam as principais informações sobre a representação do neurônio:

- $\quad$ m_crFillColors e m_crLineColor: guardam respectivamente as cores de preenchimento e da borda da representação dos neurônios,

- m_dRadius: guarda o raio da circunferência que circunscreve o polígono regular que representa o neurônio,

- m_dVertex0Angle: guarda o ângulo do vértice inicial do polígono com a horizontal,

- m_iNAng: guarda o número de ângulos, podendo ser 3, um triângulo, 4, um quadrado, ou 6, um hexágono,

- m_iOrder: guarda o número de ordem para identificá-lo na rede,

- m_iPlan: guarda o plano do cubo em que a forma se encontra, nas redes planas o plano é feito igual a 0 .

- $\quad$ m_ptShapeCentre: guarda a posição da forma na tela. Essa posição é especificada por um par $(x, y)$ especificando respectivamente a posição horizontal e vertical da forma na tela. Esse valor é usado para determinar a distância geométrica de um neurônio a outro durante a fase de aprendizado da rede $\mathrm{e}$

- m_rectTxt e m_Rgn: guardam respectivamente a região para apresentação do texto dentro do polígono e a região da tela que corresponde ao neurônio, para ser preenchida.

Todos esses atributos são internos a essa classe e não podem ser modificados externamente. Para alterá-los é necessária a utilização dos métodos associados a essa classe. Os principais métodos e suas funcionalidades são: 
- CShape e CShape: para a criação e destruição de objetos dessa classe,

- ChangePositionSize: modifica a posição e o tamanho da forma,

- GetColor, GetPlan, GetPos, GetRadius e Get_iOrder: retornam respectivamente a cor atual de preenchimento da forma, o plano em que a forma está localizada, a posição $(x, y)$ da forma na rede apresentada na tela do computador, o raio da forma e o número de ordem do neurônio,

- SetColor e Set-iOrder: trocam respectivamente a cor de preenchimento e o valor do número de ordem do neurônio para os valores fornecidos. O valor da posição é definido durante a criação do neurônio pelo método CShape e não é mais alterado,

- SetAll: modifica todos os atributos da forma para os valores passados como parâmetros,

- PaintShape, PaintShapeOrder e UpdateShapeView: são métodos usados para apresentar o neurônio na tela quando requerido.

- Serialize: armazena e recupera os dados dos objetos dessa classe em um arquivo externo. É usado basicamente durante os processos de salvamento e abertura de uma rede.

Todos esses métodos são de acesso público podendo ser usados dentro de outras classes. Pode-se observar na FIG. 35 a classe CShape na interface de desenvolvimento do programa. 


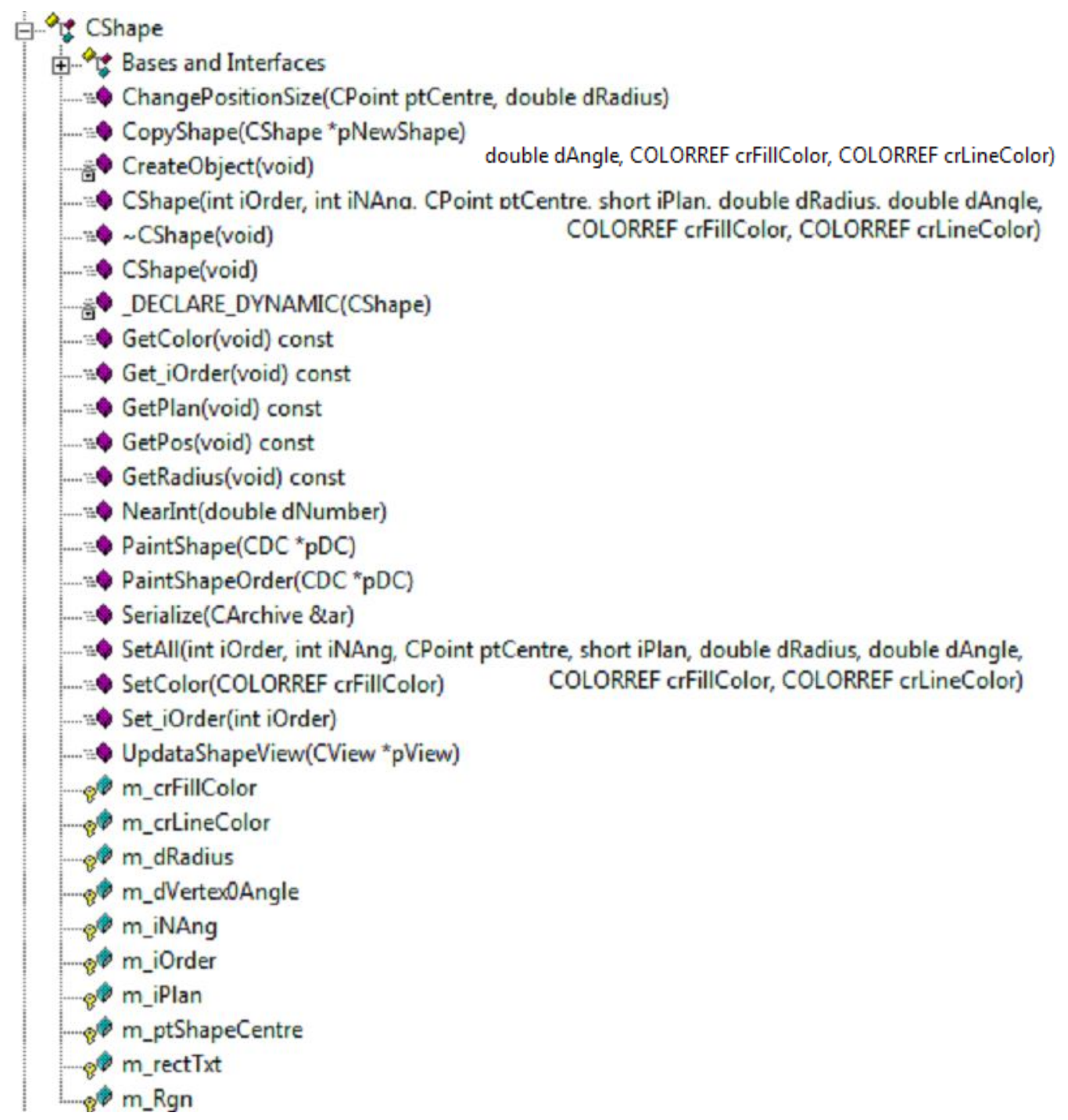

FIGURA 35 Métodos e atributos da classe CShape

Fonte: tela de classes do SICT.

\subsubsection{A Classe CNeuron}

A classe CNeuron é a classe que define os neurônios que vão formar a rede. Ela é uma classe derivada da classe CShape, herdando dela seus métodos e atributos. O modelo de neurônio utilizado é o apresentado na FIG. 31 e os atributos dessa classe são o número de ligações, ou pesos, que esse neurônio tem e o valor desses pesos. A classe CNeuron armazena, então, os valores dos pesos associados às ligações do neurônio assim como sua 
posição e sua forma. Ela contém métodos para criar um objeto CNeuron, obter os pesos a ele associados, modificar esses pesos e calcular a distância desse vetor peso a um vetor especificado.

Os 2 atributos dessa classe são então:

- m_nWeights: guarda o número de ligações do neurônio com o exterior e

- $\quad$ m_pdWeights: é uma estrutura que armazena os pesos das ligações.

Esses atributos são privados e só podem ser alterados e lidos por métodos da própria classe. Os métodos dessa classe e suas funcionalidades são:

- CNeuron e CNeuron: são métodos para a criação e destruição de objetos dessa classe.

- GetWeightsDistance: retorna a distância do vetor peso do neurônio para um vetor fornecido, conforme formulação dada pela equação (3).

- GetWeights: retorna um vetor com os pesos das ligações do neurônio.

- SetWeights: copia o vetor de pesos fornecido para o vetor de pesos do neurônio.

- Serialize: armazena e recupera os dados dos objetos dessa classe em um arquivo externo. É usado basicamente durante os processos de salvamento e abertura de uma rede.

Esses métodos são todos públicos e podem ser acessados pelas demais classes do programa. 


\subsubsection{A Classe CNetwork}

Esta classe é o módulo principal do programa. Ela é a classe que define a rede SOM e como ela se comporta. A classe CNetwork é responsável pela: Criação, Treinamento e Operação de Monitoramento da rede.

Essa classe permite criar objetos CNetwork com seis diferentes configurações geométricas que estão listadas no QUADRO 6 e cujos exemplos dessas configurações são apresentadas na FIG. 31.

Os atributos dessa rede são:

- m_bExist: guarda informação se uma rede já foi criada ou aberta e está, portanto, disponível para ser usada,

- m_Networklnput: guarda um objeto da classe CNetworklnput, que permite à rede solicitar dados para treinamento ou processamento normal e recebê-los na forma apropriada, isto é, na forma de buffers,

- m_nNeurons: guarda o número de neurônios que compõe a rede,

- m_nWghts: guarda o número de ligações que cada neurônio da rede possui,

- m_oaNeurons: guarda os objetos da classe neurônio que foram criados pela rede,

- $\quad$ m_pfNrnGeoDistTbl: guarda a distância de cada um dos neurônios que compõe a rede aos demais,

- m_piNghbrs0: guarda, para cada neurônio da rede, uma referência aos neurônios vizinhos imediatos, isto é, os mais próximos, de um neurônio. Por ex., na rede Hexagonal/Hexagonal da FIG.31, os neurônios 1, 2, 3, 4, 5 e 6 são os vizinhos imediatos do neurônio 0 , estavam a uma distância de 0,25 deste. 
- m_piNghbrs1: guarda, para cada neurônio da rede, uma referência aos neurônios seus vizinhos de grau 1, isto é, os segundos mais próximos, de um neurônio. Por ex., na rede Hexagonal/Hexagonal da FIG. 31 , os neurônios 8, 10, 12, 14, 16 e 18 são os vizinhos de grau 1 do neurônio 0 e estavam a uma distância de 0,43 deste.

- m_piNghbrs2: guarda, para cada neurônio da rede, uma referência aos neurônios vizinhos de grau 2, isto é, os terceiros mais próximos de um neurônio. Por ex., na rede Hexagonal/Hexagonal da FIG. 31, os neurônios 7, 9, 11, 13, 15 e 17 são os vizinhos de grau 2 do neurônio 0 e estavam a uma distância de 0,50 deste.

- m_pnNghbrs0: guarda quantos neurônios existem na vizinhança imediata de um neurônio,

- m_pnNghbrs1: guarda quantos neurônios existem na vizinhança de grau 1 de um neurônio,

- m_pnNghbrs2: guarda quantos neurônios existem na vizinhança de grau 2 de um neurônio,

- m_pNrnLearningColor: guarda as cores dos neurônios no fim do treinamento.

Conforme pode ser observado na FIG. 36 esses atributos são todos privados e, portanto só podem ser alterados por métodos da própria classe.

Uma lista dos métodos associados pode ser observada na FIG. 37 juntamente com os seus parâmetros de entrada. 


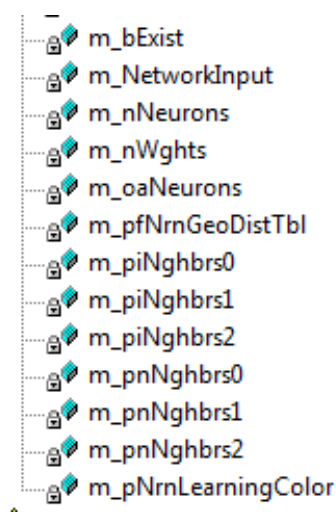

\section{FIGURA 36 Atributos da classe CNetwork Fonte: tela de classes do SICT.}

AddNeuron(const int \&iOrder, const int \&iNAng, const CPoint \&ptShapeCentre, const double \&dRadius, const CalcNrnGeoDist(voic double \&dAngle, const COLORREF \&crFillColor, const COLORREF \&crLineColor)

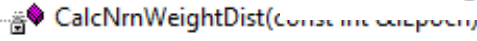

CNetwork(void)

CNetwork(void)

CreateObject(void)

_DECLARE_DYNAMIC(CNetwork)

DefNet11(int nLayers, double $\mathrm{dH}$, double dVertex0Angle, CPoint ptCentralElemCentre)

DefNet21 (int nLayers, double $\mathrm{dH}$, double dVertexOAngle, CPoint ptClientWndCentre)

DefNet22(int nLayers, double $\mathrm{dH}$, double dVertexOAngle, CPoint ptClientWndCentre)

DefNet31(int nLayers, double $\mathrm{dH}$, double dVertexOAngle, CPoint ptClientWndCentre)

DefNet33(int nLayers, double $\mathrm{dH}$, double dVertexOAngle, CPoint ptClientWndCentre)

DefNetH11(int nLayers, double dVerter0Angle, int iWidth, int iHeight, CPoint ptClientWndCentre, CPoint * pptC,

DefNetH21(int nLayers, double dVertexOAngle, int iWidth, int iHeight)

pptCentralElemCentre)

DefNetH22(int nLayers, double dVertex0Angle, int iWidth, int iHeight)

DefNetH3x(int nLayers, double dVertexOAngle, int iWidth, int iHeight)

DefNet(void)

DeleteNet(void)

DrawNet(CDC*)

Eta(const short \&iPhase, const int \&iEpoch)

ExistNet(void)

GetBufOrder(short *const piBuf, bool *const pbAux, const int \&nBuffersInTrainFile)

* GetDistance(const int \&iNeuron1, const int \&iNeuron2)

GetRandomWeights(double *const)

GetWinner(const double *const pBuffer, double \&dMin)

GetWinnerLearn(const short \&iPhase, const double *const pBuffer, double \&dMin, const short \&iLastWinner)

Learn(CDocument ${ }^{*} \mathrm{pDoc}$ )

MaxLearnDist(const short \&iPhase, const int \&iEpoch)

Neighborhood(const short \&iPhase, const double \&dDist, const double \&dMaxDist)

FoundOffWinNrnWghts(short ** paiNeuronBufferWinner, const short *pnWinnerBuffers)

RunNetwork(void)

Serialize(CArchive \&ar)

$\because$ SetDrawArea(CView * ${ }^{*}$ View)

SetNetColorWhite(void)

SetParamAsWght(const int \&nBuffersInTrainFile)

ShowNet(void)

UpdateWeights(const short \&iPhase, const int \&iWinner. const double *const oBuffer. const int \&iEnoch. const const double \&dEta, const double \&dMaxLearnDist)

\section{FIGURA 37 Métodos da classe CNetwork}

Fonte: tela de classes do SICT. 
Os métodos ligados diretamente com a criação da rede são:

- CNetwork e CNetwork: são métodos para a criação e destruição de objetos dessa classe. Como a rede em si é um objeto podem-se desenvolver, com relativa facilidade, sistemas que utilizem mais de uma rede simultaneamente.

- AddNeuron: método que cria um novo neurônio colocando-o na rede com os atributos apropriados.

- CalcNrnGeoDist: este método cria uma tabela de distância geométrica entre cada um dos neurônios para os demais. Como a distância geométrica é usada no processo de aprendizado, a tabela criada fica guardada no atributo $m \_p f N r n G e o D i s t T b l$.

- DefNet: é o método responsável pela alocação da rede na tela. Ele solicita os parâmetros de criação fornecidos pelo usuário ao módulo CDIgNet, descrito anteriormente. Em função desses parâmetros ele solicita a dimensão geométrica básica dos neurônios na rede em função da avaliação das dimensões de tela disponíveis, solicita a criação da rede, adicionando os neurônios apropriados na posição correta e finalmente solicita a criação da tabela de distâncias geométricas, $m \_p f N r n G e o D i s t T b l$.

- DefNetH11, DefNetH21, DefNetH22, DefNetH3x: são os métodos responsáveis por determinar a dimensão geométrica básica dos neurônios da rede em função da forma requerida para esses neurônios, das dimensões de tela disponíveis para a rede. Ele define também a posição do centro geométrico do neurônio central, número de ordem 0 , da rede no centro da área da tela disponível para a rede.

- DefNet11, DefNet21, DefNet22, DefNet31 e DefNet33: são os métodos que criam a rede propriamente dito. Eles adicionam os neurônios que formam a rede, com os seu atributos corretos, em função da geometria requerida para a rede, da geometria dos neurônios da rede e da 
dimensão básica calculada pelos métodos DefNetH??, descritos imediatamente antes destes.

- DeleteNet: esse método exclui a informação sobre uma rede existente, liberando a memória utilizada por esta, retornando o sistema ao seu ponto inicial.

- DrawNet: método responsável pelo gerenciamento da exibição da rede na tela. Ele é solicitado pelo módulo CSICTView para atualizar a tela sempre que requerido pelo sistema ou pelo programa. O sistema usualmente solicita a atualização quando uma janela de outro aplicativo sai da frente da tela do SICT tornando-o visível. O programa SICT solicita atualização da tela quando alguma informação na mesma é alterada, por exemplo, no caso de atualizar a cor do neurônio ativo.

- ExistNet: este método informa se existe uma rede disponível ou não.

- ShowNet: método que solicita ao sistema que a tela do SICT seja atualizada.

- Serialize: armazena e recupera os dados dos objetos dessa classe em um arquivo externo. É usado basicamente durante os processos de salvamento e abertura de uma rede.

- SetDrawArea: método que interage com o sistema para definir a área disponível para a tela do SICT e retorna como resultado uma referência (pointer) para essa área.

- SetNetColorWhite: método que faz com que as cores dos neurônios da rede fiquem brancas, eliminando as cores existentes até então.

- GetDistance: retorna a distância geométrica entre dois neurônios quaisquer, identificados pelo seus números de ordem. Esse método consulta a tabela de distâncias geométricas gerada anteriormente.

Os métodos a seguir estão relacionados com o processo de treinamento ou de aprendizagem da rede. 
- Learn: o método Learn é o responsável pelo aprendizado da rede. Inicialmente ele informa ao CNetworklnput que é um processo de aprendizagem e então inicializa as variáveis. O método considera as duas fases para 0 aprendizado, fase 1 de ordenamento e fase 2 de convergência e a cada $1 / 5$ das épocas totais de cada fase ele imprime informações sobre o andamento do treinamento. Nessas duas fases ele segue os quatro fundamentos listados no último parágrafo antes do item 2.2.4.1, o que é feito seguindo os seguinte passos:

- Inicializa os vetores de peso conforme as opções definidas pelo usuário na classe CDlgLearn, e em seguida, para cada época subsequente:

- Cada um dos buffers é apresentado à rede e determinado qual o neurônio vencedor, ou seja, cujo vetor peso está à menor distância do vetor de entrada, buffer, apresentado. Nesse processo é determinada também qual a maior distância de um buffer a um neurônio vencedor.

- Os pesos dos neurônios na vizinhança do neurônio vencedor são atualizados, segundo a equação (1).

Os métodos a seguir são solicitados pelo método Learn para desempenhar a sua função de treinar a rede a partir dos buffers de treinamento fornecidos e das especificações dos usuários na CDlgLearn.

- Eta: esse método fornece o valor do fator de aprendizagem, ETA, da equação (4). Seguindo uma abordagem sugerida por Kohonen (2001) o valor de ETA para a fase de ordenamento decresce linearmente do valor inicial para o valor final. Já para a fase de convergência adotou-se um decréscimo inversamente proporcional ao tempo e que pode ser descrito pelas equações (5) e (6). Para os valores sugeridos (default) inicialmente na tela da classe CDlgLearn, a evolução de ETA com as épocas é mostrada no GRAF.33 para a fase de ordenamento e no GRAF.34 para a fase de convergência. Esses valores foram resultado de um processo de aproximação com muitas tentativas com valores 
diferentes e ressalta-se que a recomendação citada anteriormente, de que ETA tivesse valor próximo a 1 na fase de ordenamento, não se mostrou adequada para este modelo, tendo sido adotado o valor inicial de 0,1 .

$$
\begin{gathered}
\text { EpochFr }=\mathrm{i} / \mathrm{m} \_ \text {iFinalEpochConverge } \\
\operatorname{ETA}_{C}=\left(E_{1}{ }^{*} E_{F}\right) /\left(E_{F}+E_{p o c h F r}{ }^{*}\left(E_{1}-E_{F}\right)\right)
\end{gathered}
$$

Nessas equações $E_{1}$ e $E_{F}$ são os valores inicial e final da fase de convergência fornecido pelo usuário na classe CDlgLearn e "i" é a época atual.

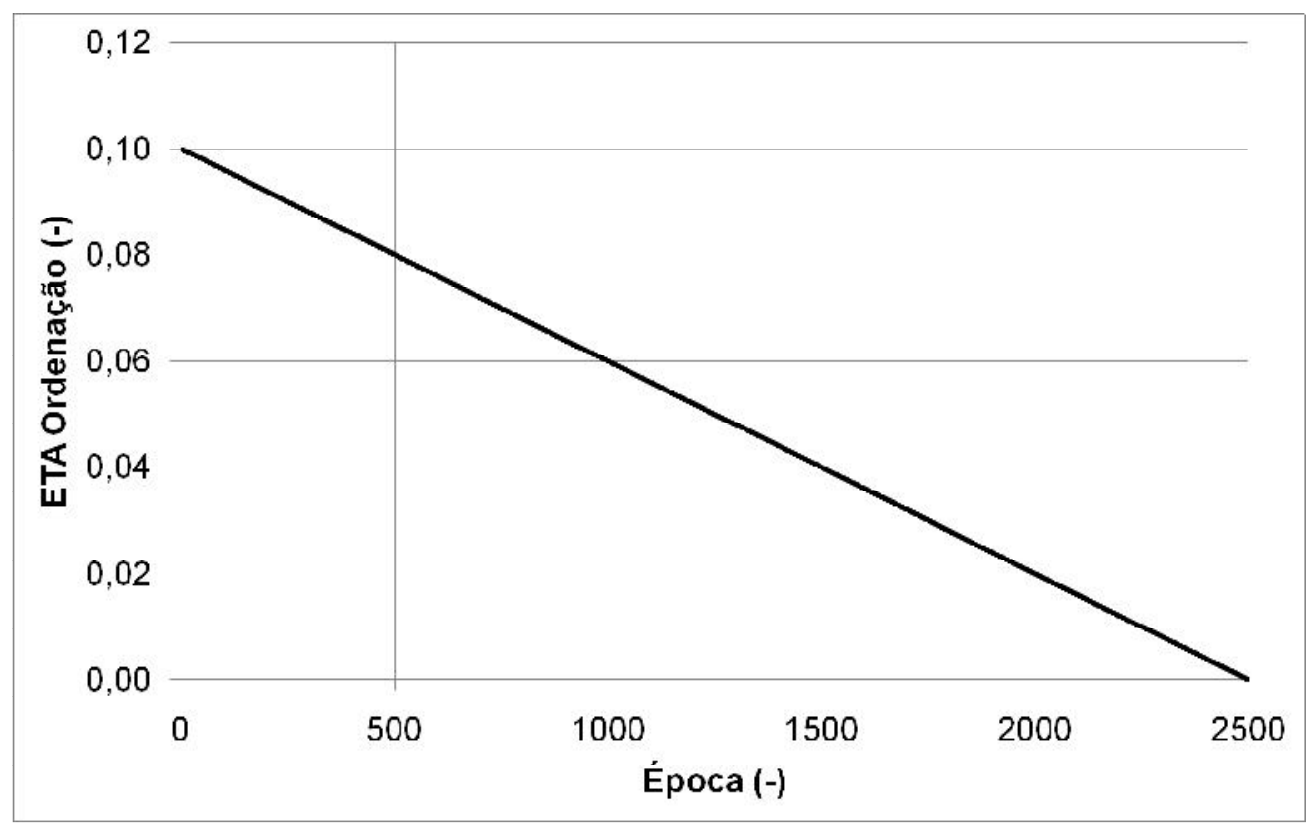

GRÁFICO 33 Evolução de ETA durante a fase de ordenamento Fonte: elaborado pelo autor. 


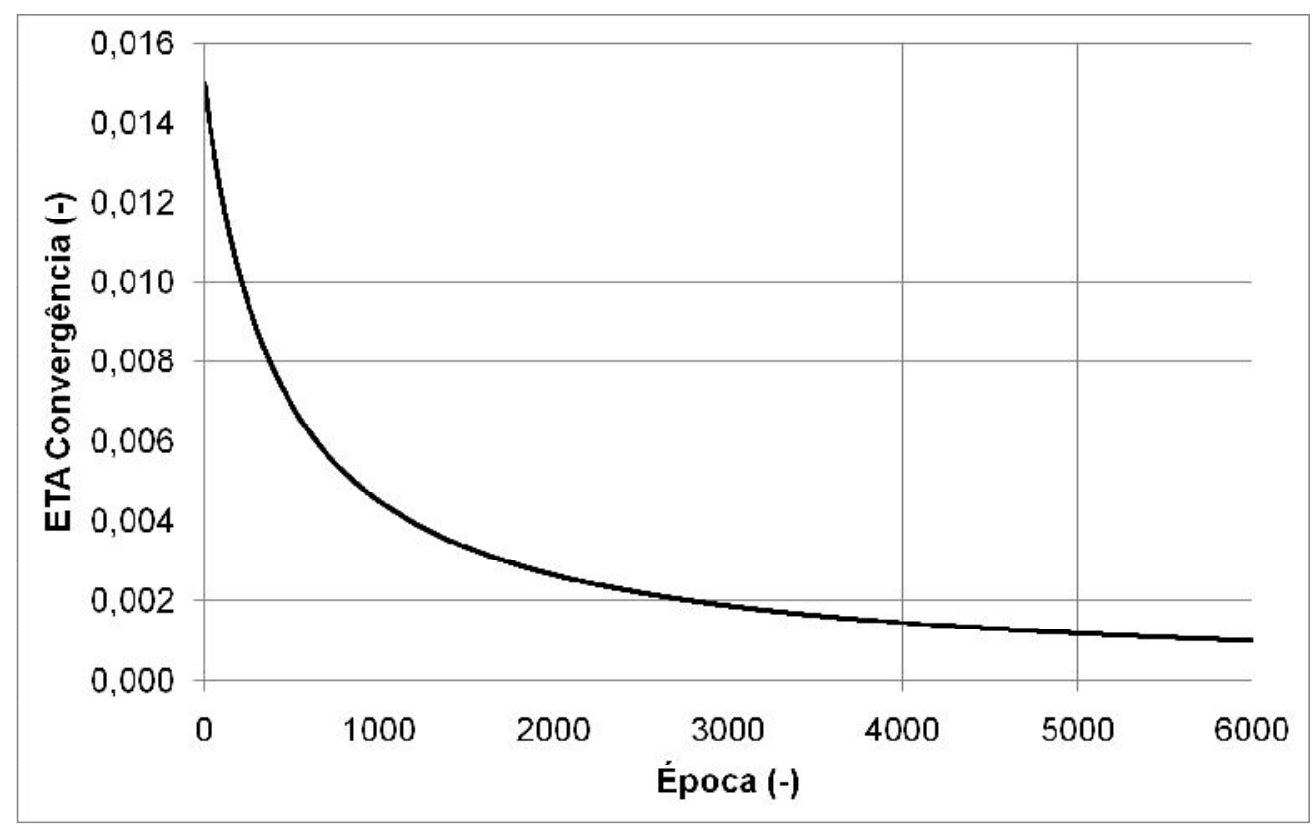

GRÁFICO 34 Evolução de ETA durante a fase de convergência Fonte: elaborado pelo autor.

- Neighborhood: esse método fornece o valor da função vizinhança, $\omega(d, i)$, da equação (4). A formulação dessa função é simples e pode ser descrita pelas equaçôes (7) e (8), para as fases de ordenamento e convergência respectivamente.

$$
\begin{aligned}
& \omega_{O}(d, i)=\operatorname{MAX}\left(0.1,1-\mathrm{d}\left(\mathrm{N}_{\mathrm{i}}, \mathrm{N}_{\mathrm{w}}\right) / \operatorname{dMax}_{\mathrm{O}}(\mathrm{i})\right) \\
& \omega_{C}(d, i)=\operatorname{MAX}\left(0.0,1-\mathrm{d}\left(\mathrm{N}_{\mathrm{i}}, \mathrm{N}_{\mathrm{w}}\right) / \operatorname{dMax}_{\mathrm{C}}(\mathrm{i})\right)
\end{aligned}
$$

Onde

MAX é a função máximo de dois valores,

$d\left(N_{1}, N_{w}\right)$ é a distância entre o neurônio i e o neurônio vencedor e dMax(i) é a máxima distância do neurônio vencedor até a qual os valores são atualizados. Qualquer neurônio localizado além dessa distância não será afetado pelo processo de atualização de pesos. 
- MaxLearnDist: esse método define a máxima distância, a partir do neurônio vencedor, em que os neurônios terão seus pesos atualizados. Ele corresponde à função dMax(i) nas equações (5) e (6).

Para a fase de convergência o valor retornado é uma constante igual a $1.1^{*} \mathrm{~m} \_d D m i n$ (menor distância entre dois neurônios, definido em CDIgNet), isto é, só serão afetados os neurônios na vizinhança imediata do neurônio vencedor.

Para a fase de ordenamento a formulação usada é similar à da equação (6), e pode ser descrita pela equação (9) como sendo:

$\operatorname{dMax}(i)_{O}=\left(\operatorname{Max}_{1}{ }^{*} \operatorname{Max}_{F}\right) /\left(\operatorname{Max}_{F}+\operatorname{EpochFr}^{*}\left(\operatorname{Max}_{1}-\operatorname{Max}_{F}\right)\right)$

Nessas equações Maxı e MaxF são os valores inicial e final da fase de ordenamento e foram definidos como:

$\operatorname{Max}_{1}=1.1$ e $\operatorname{Max}_{F}=2.5^{*} \mathrm{~m} \_\mathrm{dDmin}$. Assim, conforme sugerido por Kohonen (2001), no início da fase de ordenamento todos os neurônios da rede são atualizados e no final da fase somente os neurônios que estão até na vizinhança de grau 2, isto é, aqueles que estão a uma distância de até duas vezes a menor distância entre dois neurônios. Essa evolução pode ser observada no GRAF. 35. 


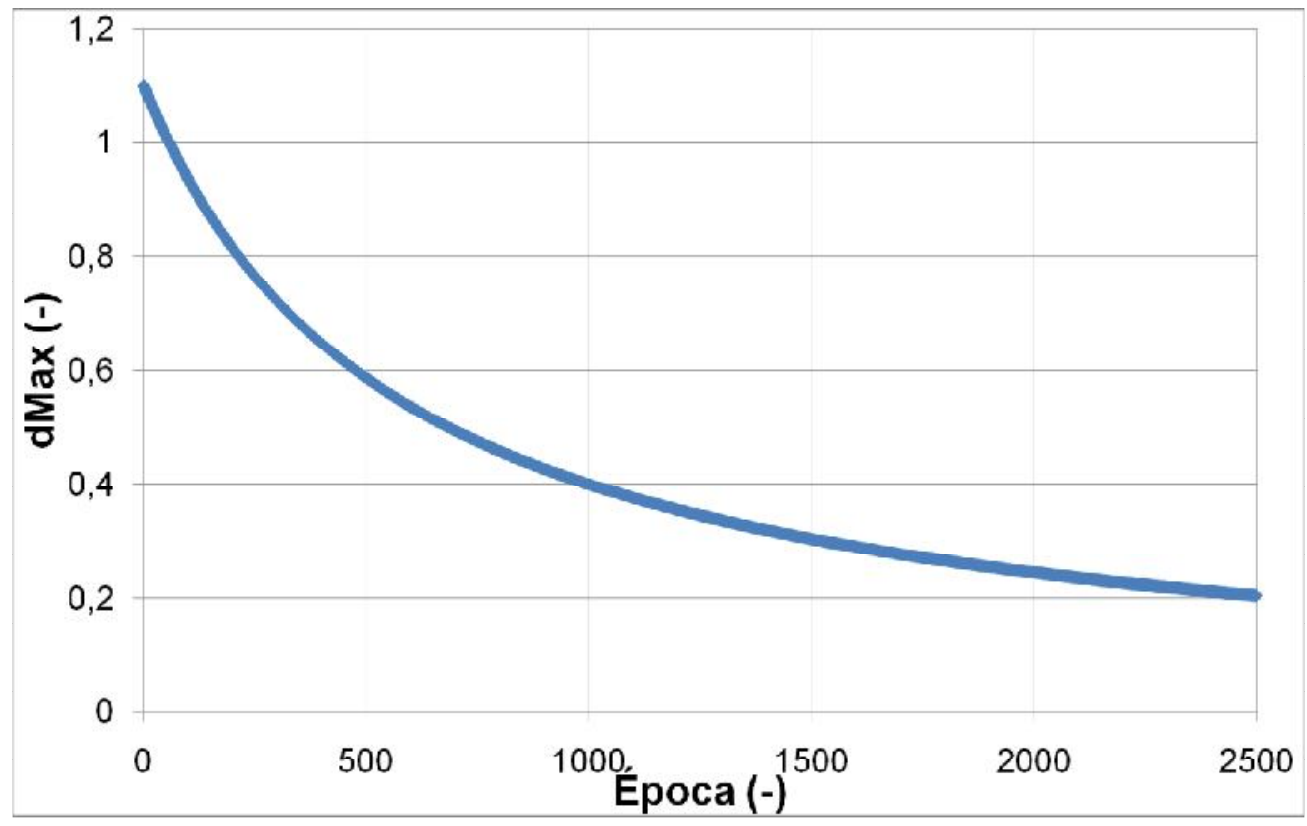

GRÁFICO 35 Distância máxima até o neurônio vencedor para atualização dos pesos durante a fase de ordenamento

Fonte: elaborado pelo autor.

- $\quad$ CalcNrnWeightDist: este método cria um arquivo com a distância entre os vetores peso de cada um dos neurônios da rede para os demais, seguindo a formulação dada pela equação (3). Os dados são gravados no início e fim das duas fases do treinamento e, para cada uma dessas fases, em um número fixo, atualmente 5 , de vezes entre esses pontos. O arquivo disponibilizado auxilia a avaliar como o processo de aprendizado evolui.

- GetBufOrder: este método disponibiliza uma lista em ordem aleatória dos buffers de treinamento.

- GetRandomWeights: esse método retorna um buffer do conjunto de buffers de treinamento em ordem aleatória, consultando a lista criada pelo método GetBufOrder.

- GetWinner: esse método retorna o neurônio vencedor para um buffer fornecido, usando a estratégia conhecida como o ganhador leva todos, winner takes all. O buffer, ou vetor de entrada, e, é comparado com o vetor peso de todos os neurônios e é calculada da distância entre eles, 
segundo a equação (3). O neurônio que apresentar a menor distância para o buffer é o vencedor.

- GetWinnerLearn: esse método foi uma otimização introduzida durante a fase final do desenvolvimento. Ele gerencia a obtenção do neurônio vencedor para um buffer, ou vetor de entrada, e, específico. Durante a fase inicial do aprendizado, a de ordenamento, o método GetWinner é usado para determinar o neurônio vencedor, já que de uma época para outra sua posição pode mudar muito dentro da rede. Já na segunda fase do aprendizado, a de convergência, onde a posição do vencedor para um mesmo buffer não muda muito, foi usado um esquema onde 0 vencedor é procurado não entre todos os neurônios, mas somente na vizinhança de grau 2 do vencedor da época anterior. Além da teoria que indica esse procedimento, foram feitos vários testes e verificado a sua propriedade. Para comparar a eficiência dos dois esquemas cita-se um caso, com 169 neurônios e buffer de 180 valores, processado usando os valores sugeridos na CDIgLearn. O tempo de processamento da primeira fase, 2500 épocas, foi de cerca de nove horas e meia $(9: 30 \mathrm{~h})$ enquanto para a segunda fase, com 6000 épocas, foram cerca de 40 minutos $(0: 40 \mathrm{~h})$, ou seja, houve uma redução de mais de vinte horas no treinamento dessa rede, o tempo total foi reduzido para menos de $1 / 3$ do anteriormente requerido.

- RoundOffWinNrnWghts: esse método faz uma otimização após as duas fases do processo de aprendizagem. Ressalta-se que não foi encontrado na literatura um método similar ao aqui proposto. Após a fase de organização do aprendizado ter terminado, é salva uma rede com essa configuração e então este método otimiza os pesos dos neurônios e salva uma nova rede. $O$ processo de aprendizagem continua então com a fase dois, de convergência, no fim da qual é salva uma nova rede e então esse método novamente otimiza os pesos dos neurônios e salva a rede. Apesar de o resultado obtido dessa otimização propiciar, em uma primeira análise, menores erros durante o monitoramento, esse procedimento não foi ainda bem testado, 
precisando mais avaliações principalmente em relação a reconhecimento de vetores que não participaram do treinamento, o que pode afetar a capacidade de generalização da rede. Durante as avaliações nesta pesquisa foi usada a rede obtida no final da fase dois de aprendizado, sem a otimização final. A otimização feita por esse método consiste em fazer com que cada valor do vetor peso do neurônio, seja a média dos valores dos buffers que ativam esse neurônio. Ou seja:

$$
\mathrm{w}_{\mathrm{n}}=\left(\sum_{b=1}^{m} \mathrm{e}_{\mathrm{n}, \mathrm{b}}\right) / \mathrm{m}
$$

Onde $w_{n}$ é a componente $n$ (dimensão $n$ ) do vetor peso e e $e_{n, b}$ é a componente $\mathrm{n}$ do vetor de entrada, buffer, $\mathrm{b}$. Essa somatória considera todos os $m$ buffers que ativam um dado neurônio.

- SetParamAsWght: esse método é o responsável por inicializar os pesos dos neurônios com os valores dos buffers, se a opção Start Weights with Training Data for selecionada pelo usuário na CDIgLearn.

- UpdateWeights: método que, uma vez conhecido o neurônio vencedor durante 0 processo de aprendizagem, dispara o processo de atualização dos vetores pesos dos neurônios na vizinhança usando os métodos anteriormente descritos.

Finalmente, o processo de monitoramento, onde a operação de uma instalação é monitorada pelo SICT, para identificar e classificar seu comportamento mostrando a avaliação em uma tela é desempenhado pelo método a seguir.

- RunNetwork: esse método é o responsável por utilizar uma rede, presumidamente treinada, para monitorar a operação de uma instalação identificando e classificando o seu comportamento. Ele dispara um processo de inicialização limpando a tela de apresentação 
do SICT, isto é, tornando todos os neurônios brancos, em seguida ele informa ao CNetworklnput que é um procedimento de monitoramento e não de treinamento. Esse método cria dois arquivos de saída o

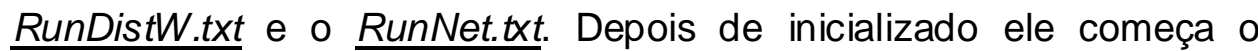
processo de monitoramento propriamente dito repetindo sequencialmente, até que terminem os dados fornecidos, os passos a seguir:

- solicita um vetor de entrada, buffer, ao CNetworklnput,

- determina o neurônio vencedor e a distância de seu vetor peso ao vetor de entrada,

- atualiza a tela para mostrar o neurônio vencedor,

- grava as informações nos arquivos de saída.

Ressalta-se aqui que este procedimento é executado muito rapidamente. Para se ter ideia da ordem de grandeza do tempo de processamento um caso de monitoramento com 18 parâmetros em uma rede com 169 neurônios processou 36000 conjuntos de parâmetros (instantes de medição) em menos de 1 minuto, o que indica uma taxa de processamento superior a 1000 pontos por segundo. Essa frequência de $1000 \mathrm{~Hz}$ está muito além de qualquer utilização que se possa pensar hoje para o SICT além de estar também acima da frequência com que os sistemas de aquisição de dados usuais na indústria operam.

\subsubsection{A Classe CNetworkInput}

Esta classe é a responsável pelo relacionamento do SICT com o exterior, ela é que obtém os dados externos, trata esses dados normalizando-os e organizando-os na forma de buffers e disponibiliza os buffers com os valores normalizados para a rede quando solicitado. Pode-se observar na FIG. 38 os 
métodos e atributos dessa classe, conforme a sua apresentação no ambiente de desenvolvimento.

Os dados de entrada para treinamento são fornecidos para o SICT em um formato diferente daqueles para monitoramento.

Para o treinamento é fornecido um arquivo com uma sequência de buffers. Cada buffer é formado por uma linha de cabeçalho seguido por dados numéricos. A linha de cabeçalho contém um identificador alfanumérico do grupo a que o buffer pertence, no exemplo da FIG.38 SSU_L_1, um identificador alfanumérico do buffer, no exemplo da FIG. 39 SSU_L_1_000_000_0U_1_-_+000, e uma tríade de números no intervalo $[0,255]$ identificando uma cor para esse buffer, no exemplo da FIG. 38240240 240. Os dados numéricos que se seguem têm a estrutura especificada pelo usuário na CDlgNet com, \#Parameters especificando o número de colunas e \#Parameter Sets in Buffer especificando o número de linhas, o que no exemplo da FIG. 38 correspondem respectivamente a 4 colunas e 5 linhas.

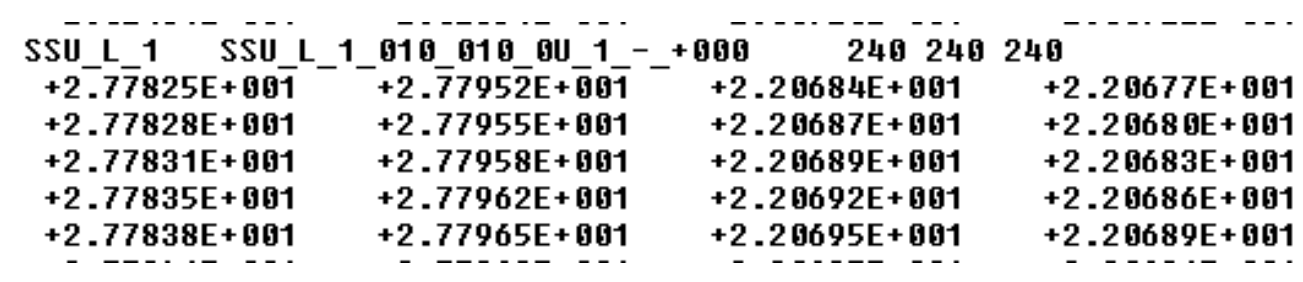

FIGURA 38 Exemplo de buffer de entrada para treinamento da rede

Fonte: arquivos de dados para o SICT

Para o monitoramento, o programa obtém do ambiente externo uma sequência de parâmetros como determinado por \#Parameters, associado a um valor de tempo. Assim, de cada vez, ele obtém uma linha com formato similar àquelas mostradas na FIG. 38, que retrata um trecho de um arquivo para monitoramento compatível com o usado como exemplo na FIG. 39. 
$+0.005000 \mathrm{e}+000+2.024300 \mathrm{e}+001+2.026200 \mathrm{e}+001+2.006950 \mathrm{e}+001+2.006960 \mathrm{e}+001$

$+6.000000 \mathrm{e}+000+2.024290 \mathrm{e}+001+2.026200 \mathrm{e}+001+2.056950 \mathrm{e}+001+2.056960 \mathrm{e}+001$

$+1.200000 \mathrm{e}+001+2.024240 \mathrm{e}+001+2.026195 \mathrm{e}+001+2.006950 \mathrm{e}+001+2.006960 \mathrm{e}+001$

FIGURA 39 Exemplo de dados de entrada para monitoramento, com os tempos de 0,6 e 12 segundos.

Fonte: arquivos de dados para o SICT

$\mathrm{Na}$ versão atual todos os objetos criados com essa classe vão ler dos mesmos arquivos de entrada, o que não representa limitação alguma para esta versão do SICT. Em estudos futuros com mais de uma rede operando simultaneamente essa classe deve ser adaptada para permitir a obtenção de dados externos de fontes diferentes em tempos diferentes.

Como pode ser observado na FIG. 40, os atributos dessa classe são todos privados e, portanto, só podem ser acessados para leitura ou alteração pelos métodos da própria classe. Alguns de seus atributos e métodos são voltados para o processo de treinamento enquanto outros para o processo de monitoramento. A seguir é apresentada uma breve descrição desses atributos, que compõe parte da funcionalidade dessa classe.

- m_iBufferSize: guarda o tamanho dos buffers, sejam eles de treinamento ou de monitoramento.

- $\quad$ m_iNParameters e m_iNBufParamSets: guardam os mesmos valores que os lidos na tela do CDlgNet, respectivamente o número de parâmetros e o número de conjuntos de parâmetros que vão formar o buffer. 


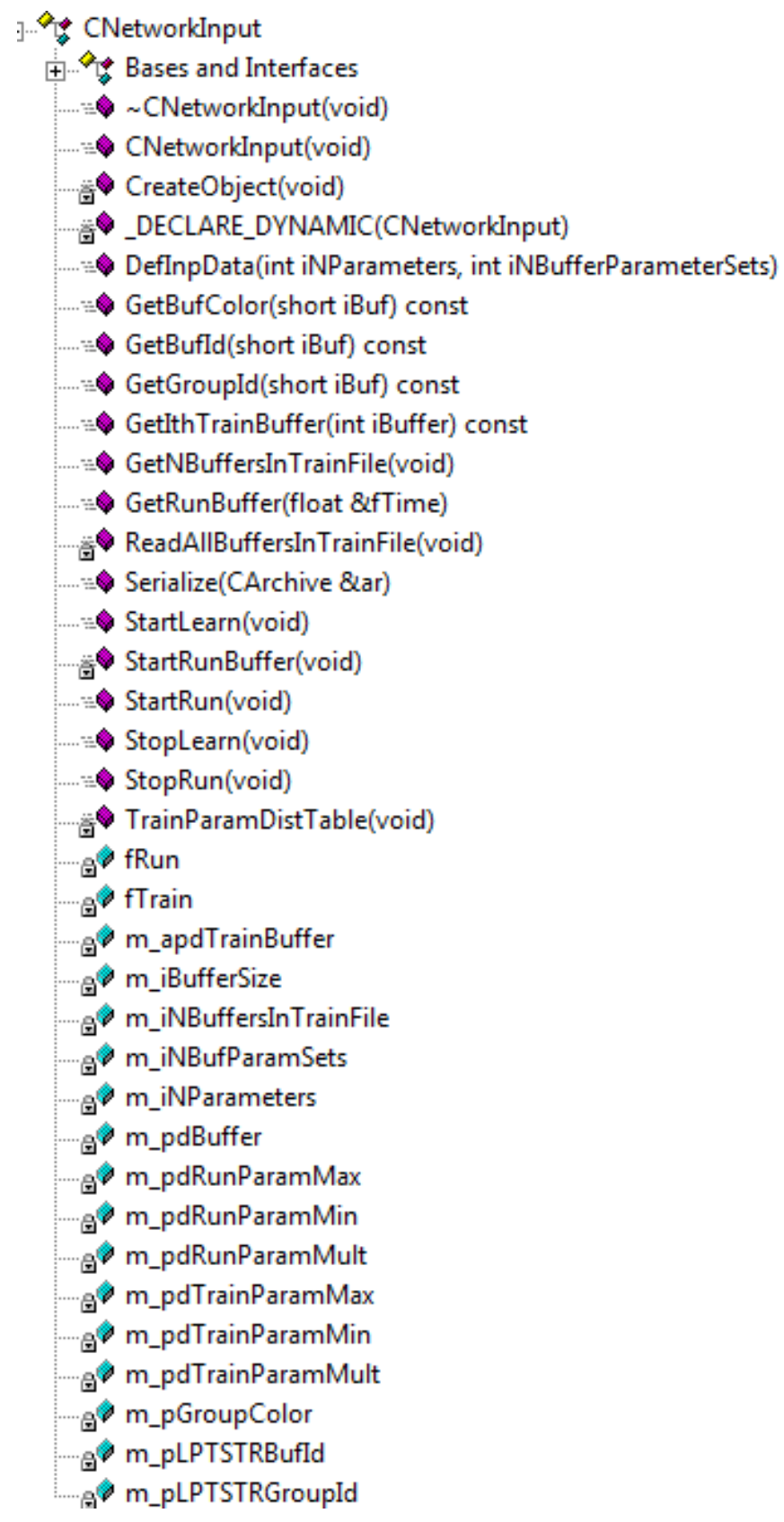

FIGURA 40 Métodos da classe CNetworkInput

Fonte: tela de classes do SICT.

Os atributos a seguir estão relacionados com o processo de treinamento.

- fTrain: guarda a referência ao arquivo que contém os dados para treinamento já na forma de buffers. 
- m_apdTrainBuffer: este atributo guarda referências a todos os buffers de treinamento disponibilizados na entrada, após o processo de normalização dos mesmos.

- $\quad$ m_iNBuffersInTrainFile: armazena o número de buffers disponibilizados para treinamento no arquivo referenciado por fTrain.

- m_pGroupColor: guarda a cor associada a um dado buffer de treinamento, como descrito na introdução da descrição desta classe.

- $\quad$ m_pLPTSTRBufld: guarda um valor alfanumérico associado a um dado buffer de treinamento, como apresentado na introdução da descrição desta classe.

- $\quad$ m_pLPTSTRGroupld: guarda um valor alfanumérico associado a um grupo de buffers de treinamento, como descrito na introdução da descrição desta classe.

- m_pdTrainParamMax: referência ao vetor, com dimensão m_iNParameters, que guarda os valores usados como máximo no processo de normalização dos dados de entrada de monitoramento.

- m_pdTrainParamMin: referência ao vetor, com dimensão m_iNParameters, que guarda os valores usados como mínimo no processo de normalização dos dados de entrada de monitoramento.

- m_pdTrainParamMult: referência ao vetor, com dimensão m_iNParameters, que guarda os fatores de multiplicação usados após a normalização dos valores de entrada de monitoramento.

Os atributos a seguir estão relacionados com o processo de monitoramento.

- fRun: esse atributo guarda a referência à fonte de dados externos durante o uso da rede no modo de monitoramento. Na versão usada até então foi usado um arquivo com dados, mas, em uma versão para acoplamento com uma instalação em tempo real, essa referência deve 
ser alterada de modo a acessar uma interface com a instalação para a leitura dos dados requeridos.

- m_pdRunParamMax: referência ao vetor, com dimensão m_iNParameters, que guarda os valores usados como máximo no processo de normalização dos dados de entrada de monitoramento.

- m_pdRunParamMin: referência ao vetor, com dimensão m_iNParameters, que guarda os valores usados como mínimo no processo de normalização dos dados de entrada de monitoramento.

- m_pdRunParamMult: referência ao vetor, com dimensão m_iNParameters, que guarda os fatores de multiplicação usados após a normalização dos valores de entrada de monitoramento.

- $\quad$ m_pdBuffer: atributo que guarda o buffer, já normalizado, montado a partir dos valores lidos da entrada.

Os métodos que atuam sobre esses atributos estão descritos a seguir.

- CNetworklnput, CNetworklnput: esses dois métodos são responsáveis pela criação e destruição de objetos dessa classe.

- Serialize: método responsável pelo salvamento e recuperação dos três atributos que guardam a estrutura dos buffers associados à rede: m_iBufferSize, m_iNParameters e m_iNBufParamSets.

Os métodos a seguir estão relacionados com o procedimento de treinamento.

- StartLearn: esse método é o primeiro a receber uma mensagem do CNetwork durante a fase de aprendizado, notificando assim que as atividades a seguir são se treinamento. Ele inicialmente lê o arquivo SICTTrainDataRng.inp e armazena os valores nos atributos m_pdTrainParamMax, m_pdTrainParamMin, m_pdTrainParamMult. Como segundo passo, esse método solicita que o método 
ReadAllBuffersInTrainFile leia todos os buffers no arquivo de treinamento com buffers, SICTTrainData.inp, e em seguida faça a normalização dos buffers armazenando-os. Finalmente solicita que o método TrainParamDistTable faça uma avaliação da distribuição desses buffers normalizados e imprima o resultado em um arquivo LearnParamDist.txt e um resumo da distribuição no arquivo LearnParamDist0.txt.

- ReadAllBuffersInTrainFile: esse método inicialmente lê todos os buffers disponibilizados pelo exterior verificando se estão em um formato correto e faz sua contagem, determinando assim o valor do atributo m_iNBuffersInTrainFile. Em seguida ele usa os valores para normalização já lidos e armazenados em m_pdTrainParamMax, m_pdTrainParamMin, m_pdTrainParamMult e transforma os buffers lidos em buffers normalizados usando a seguinte transformação para cada valor de um parâmetro do buffer:

$$
v_{N}=2^{*} f_{\text {Mult }}\left(v-\left(v_{\text {Max }}+v_{\text {Min }}\right) / 2\right) /\left(v_{\text {Max }}-v_{\text {Min }}\right)
$$

onde: $v_{N}$ é o valor normalizado que será usado pela rede, $v$ é o valor original obtido da fonte externa, e $f_{\text {Mult, }}, v_{\text {Max }}$ e $v_{\text {Min }}$ são os valores máximo, mínimo e de multiplicação fornecidos pelo usuário.

Essa transformação faz, inicialmente, com que os dados de entrada fiquem no intervalo $[-1,+1]$, se os $v_{\operatorname{Max}} \mathrm{e} \mathrm{v}_{\text {Min }}$ forem realmente os valores máximos e mínimos dos dados exteriores fornecidos. No final os valores normalizados são multiplicados pelo fator de multiplicação, o que possibilita aumentar a importância relativa entre os parâmetros fornecidos para a rede.

- TrainParamDistTable: esse método calcula a distância entre cada um dos vetores de entrada (buffers) fornecidos para treinamento e imprime essas distâncias no arquivo LearnParamDist.txt. O número de distâncias é proporcional ao quadrado do número de buffers, então usualmente nos casos práticos esse arquivo é excessivamente grande 
para ser avaliado. Foi criado então um arquivo, LearnParamDist0.txt que faz um sumário da distribuição das distâncias, mostrando a menor e a maior distância entre os buffers e a sua distribuição em dez intervalos entre o menor e o maior valor. No GRAF. 36 pode-se avaliar o tipo de resultado resumido disponibilizado, nesse exemplo havia 5572 buffers de entrada totalizando 20528028 distâncias entre buffers, sendo a menor distância entre eles de zero e a maior de 17,7. O GRAF. 36 mostra quantas distâncias entre buffers estão nas faixas marcadas na abscissa.

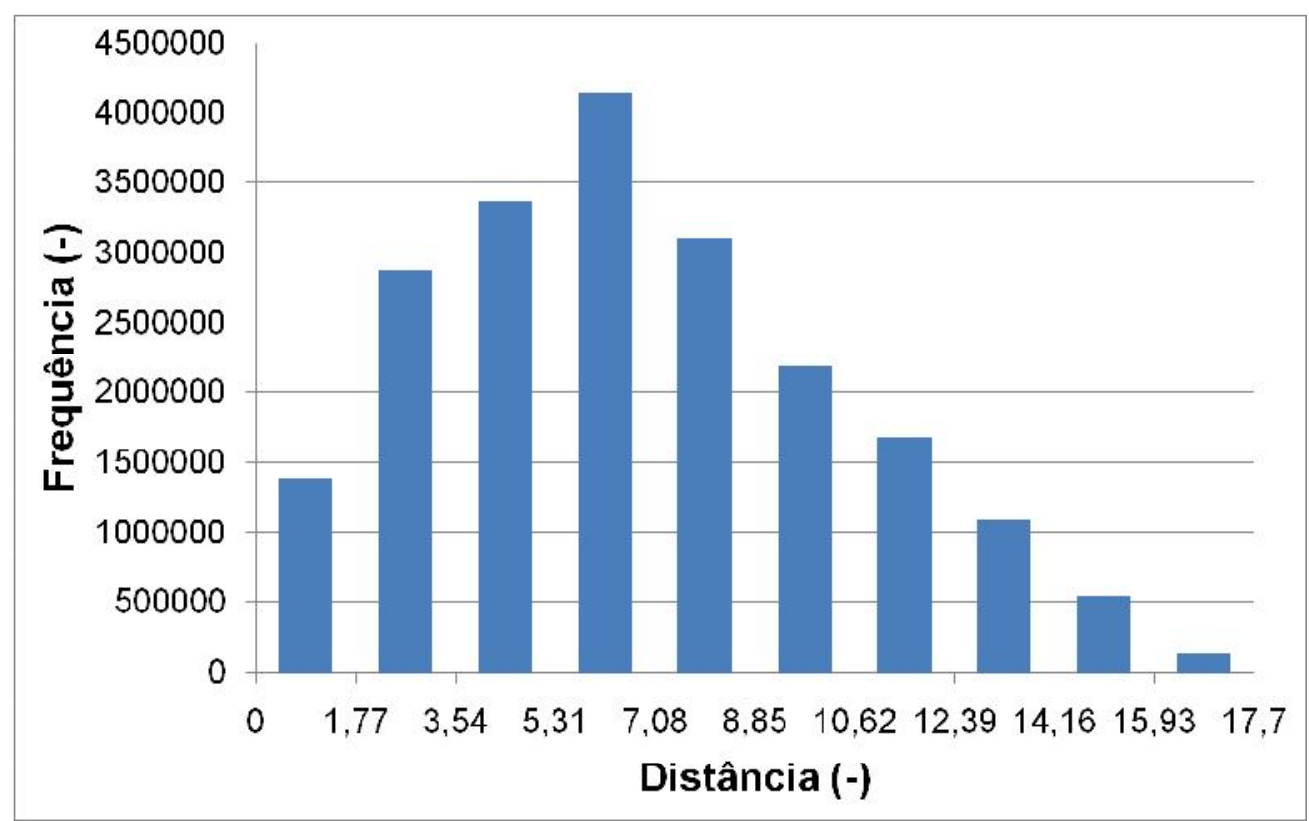

GRÁFICO 36 Distribuição da distância entre os buffers de entrada em dez faixas Fonte: elaborado pelo autor a partir de resultados do SICT

GetGroupld, GetBufld , GetBufColor: esses métodos simplesmente retornam os valores de identificação de grupo, de identificação do buffer e da cor do buffer conforme armazenado nos atributos m_pGroupColor, m_pLPTSTRBufld e m_pLPTSTRGroupld.

- GetlthTrainBuffer: esse método retorna uma referência ao buffer solicitado, que pode ser usada para manipular esse buffer. 
- GetNBuffersInTrainFile: esse método, quando solicitado, informa o número de buffers fornecido pelo exterior para treinamento.

- DeflnpData: esse método usado na inicialização do aprendizado guarda nos atributos m_iNParameters e m_iNBufParamSets, dessa classe, os valores definidos pelo usuário, calcula o tamanho do buffer, $\mathrm{m} \_$iBufferSize, e define o atributo $\mathrm{m} \_$pdBuffer, que guarda a referência a um buffer.

- StopLearn: este método fecha o arquivo de dados externos para treinamento, SICTTrainData.inp, e libera toda a memória alocada pela CNetworklnput para o treinamento da rede.

Os métodos a seguir estão relacionados com o procedimento de monitoramento.

StartRun: esse método é o primeiro a receber uma mensagem do CNetwork, durante o procedimento de monitoramento, notificando assim que as atividades a seguir são de treinamento. Ele inicialmente lê 0 arquivo SICTRunDataRng.inp e armazena os valores nos atributos m_pdRunParamMax, m_pdRunParamMin, m_pdRunParamMult. Como segundo, passo esse método abre o arquivo de dados externos de monitoramento, SICTRunData.inp, e solicita ao método StartRunBuffer que monte o primeiro buffer de monitoramento, a partir dos dados desse arquivo.

StartRunBuffer: como a estrutura do arquivo externo de monitoramento é de uma sequência de linhas com o tempo na primeira posição seguido de m_iNParameters, esse método lê o número de linhas necessárias para montar o buffer, $m$ _iNBufParamSets, e os normaliza usando o mesmo esquema que o usado no treinamento e descrito pela equação 11. O buffer assim montado tem estrutura idêntica àquele do procedimento de treinamento, uma vez que o tempo não é colocado nesse buffer.

GetRunBuffer: esse método usa o buffer anterior, já existente, elimina a linha mais antiga e cria uma nova linha de parâmetros no topo com os dados 
recém lidos do arquivo de dados exterior de monitoramento. Assim a cada solicitação de um novo buffer de monitoramento o buffer fornecido é atualizado com o último conjunto de parâmetros lidos para o tempo seguinte.

StopRun: este método fecha 0 arquivo de dados externos para monitoramento, SICTRunData.inp, e libera toda a memória alocada pela CNetworkInput para o monitoramento da rede.

\subsection{Arquivos Usados pelo Programa}

O SICT trabalha com três tipos de arquivos diferentes: os arquivos de rede, criados ou lidos, os arquivos de leitura de dados externos e os arquivos criados durante os procedimentos de treinamento ou monitoramento. Todos os arquivos de leitura devem estar em uma pasta específica, na versão atual a pasta "C:ISICT_IODATA" e todos os arquivos de saída serão também criados nessa mesma pasta.

No APÊNDICE C é apresentado um exemplo de cada arquivo lido ou criado pelo SICT, com exceção dos arquivos de rede, que são arquivos binários.

\subsubsection{Os Arquivos de Rede}

Os arquivos de rede são salvos pelo SICT, quando o usuário solicita o comando Save ou o Save As... do menu File ou quando é feito um treinamento. Esses arquivos são lidos quando se solicita o comando Open do menu File. Eles contêm toda a informação para que o SICT opere, seja no modo de treinamento, seja no modo de monitoramento. Eles guardam a estrutura da rede e todas as informações dos neurônios, incluindo forma, pesos, cores e ordem. Guardam ainda as informações para a interface do CNetwork com o CNetworklnput, possibilitando a iteração deste com os arquivos necessários para o uso da rede, seja para treinamento, seja para monitoração. $O$ salvamento e abertura desses 
arquivos são feitos pelo método serialize do CNetwork, que solicita aos métodos serialize das demais classes que auxiliem na tarefa. Na FIG. 41 pode-se observar a tela do SICT após iniciar e após abrir uma rede anteriormente treinada.

Quando é feito o treinamento, o SICT automaticamente cria quatro arquivos chamados SICTNETO 0.SICT, SICTNETO 1.SICT, SICTNET1 O.SICT e SICTNET1 1.SICT. Esses arquivos são criados, respectivamente após: o término da fase de ordenamento, a otimização posterior ao ordenamento, o término da fase de convergência e a otimização posterior à convergência.

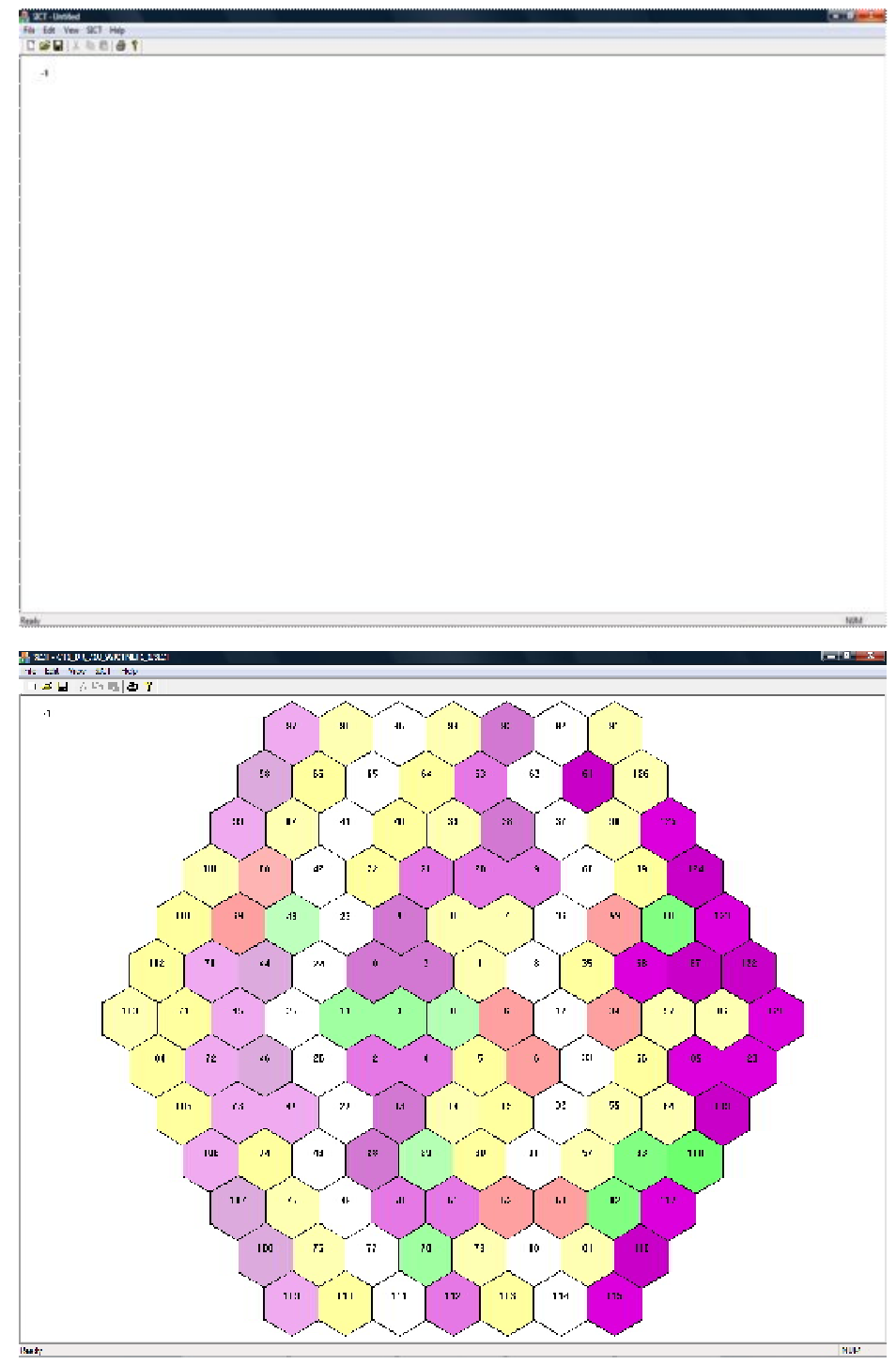

FIGURA 41 Telas do SICT após o seu in ício e após abrir uma rede treinada Fonte: telas do SICT. 


\subsubsection{Arquivos de Entrada, com Dados Externos}

No APÊNDICE C é apresentado um exemplo de cada arquivo lido ou criado pelo SICT, com exceção dos arquivos de rede, que são arquivos binários usados pelo sistema para guardar redes, presumidamente, treinadas.

Os arquivos com dados de entrada disponibilizados pelo exterior, cujo conteúdo foi descrito no item 6.2, são associados aos procedimentos de treinamento e de monitoramento. Esses arquivos são:

\section{SICTTrainData.inp \\ 2. SICTRunData.inp. \\ 3. SICTTrainDataRng.inp \\ 4. SICTRunDataRng.inp}

No APÊNDICE C pode-se observar um exemplo dos arquivos SICTTrainDataRng.inp e SICTRunDataRng.inp. No exemplo são apresentados dez parâmetros que formam o buffer e, na primeira linha, podem-se ver os valores máximos para cada parâmetro, na segunda os valores mínimos e na terceira os fatores de multiplicação. Esses são os valores que serão usados, segundo a equação 11 para normalizar os buffers de entrada obtidos do exterior.

Dos arquivos SICTTrainData.inp e SICTRunData.inp é apresentado apenas um trecho característico de cada um, já que são muito extensos para impressão. Observa-se que o SICTTrainData.inp já disponibiliza os buffers estruturados precedidos por informações para identificá-lo posteriormente. São mostrados 3 buffers, cada um com dez parâmetros e dez conjuntos de parâmetros, ou seja dez linhas e dez colunas. Já o arquivo SICTRunData.inp tem uma estrutura igual à que seria obtida de uma interface com a instalação monitorada, ou seja o tempo de medição seguido pelos parâmetros medidos e é processado, conforme descrito em 6.2, para formar os buffers de monitoramento. No exemplo apresentado pode-se ver, como no caso SICTTrainData.inp, 10 parâmetros, porém, aqui precedidos pelo tempo. 


\subsubsection{Arquivos de Saída do Treinamento}

Vários arquivos com o nome iniciados com Learn... têm informações gravadas sempre que decorrer $1 / 5$ das épocas totais de uma fase. Assim para uma fase de ordenamento de 2500, são gravadas informações para as épocas 0 , $500,1000,1500,2000,2499$. Após o fim de cada fase é gravado mais um arquivo após o processo de otimização. Essas épocas serão, por facilidade, referidas a seguir como época-Learn.

LearnBufWghts.txt. neste arquivo são gravados: a época-Learn, as identificações do Buffer, ordem e alfanumérica, o neurônio vencedor e a distância buffer - neurônio. Este arquivo permite avaliar em detalhes como está evoluindo o treinamento.

LearnChangeWin.txt: neste arquivo são armazenadas as informações para todas as épocas da fase de convergência aqueles buffers que ativaram neurônios diferentes dos ativados na época anterior. São guardadas a identificação do buffer, o neurônio que foi ativado anteriormente, o neurônio ativado na época atual e a distância buffer - neurônio da última ativação.

LearnDMax.txt neste arquivo estão guardados, para todas as épocas de cada uma das duas fases de treinamento, a maior distância buffer-neurônio, o fator de aprendizagem e o intervalo do fator de vizinhança. Os valores guardados neste arquivo são:

- dMax: maior distância entre um buffer de treinamento e um neurônio,

- $\quad$ ETA, o valor do fator de aprendizagem, e

- MinNghb e MaxNghb: que são respectivamente o menor e o maior fator de vizinhança usado na respectiva época. Esse fator de vizinhança é aquele descrito pela equação (1). 
Nos GRAF. 37 e GRAF. 38 é possível observar a evolução de dMax com as épocas para cada uma das duas fases de treinamento e nos GRAF. 39 e GRAF. 40 a evolução dos valores mínimos e máximos do fator de vizinhança em cada época.

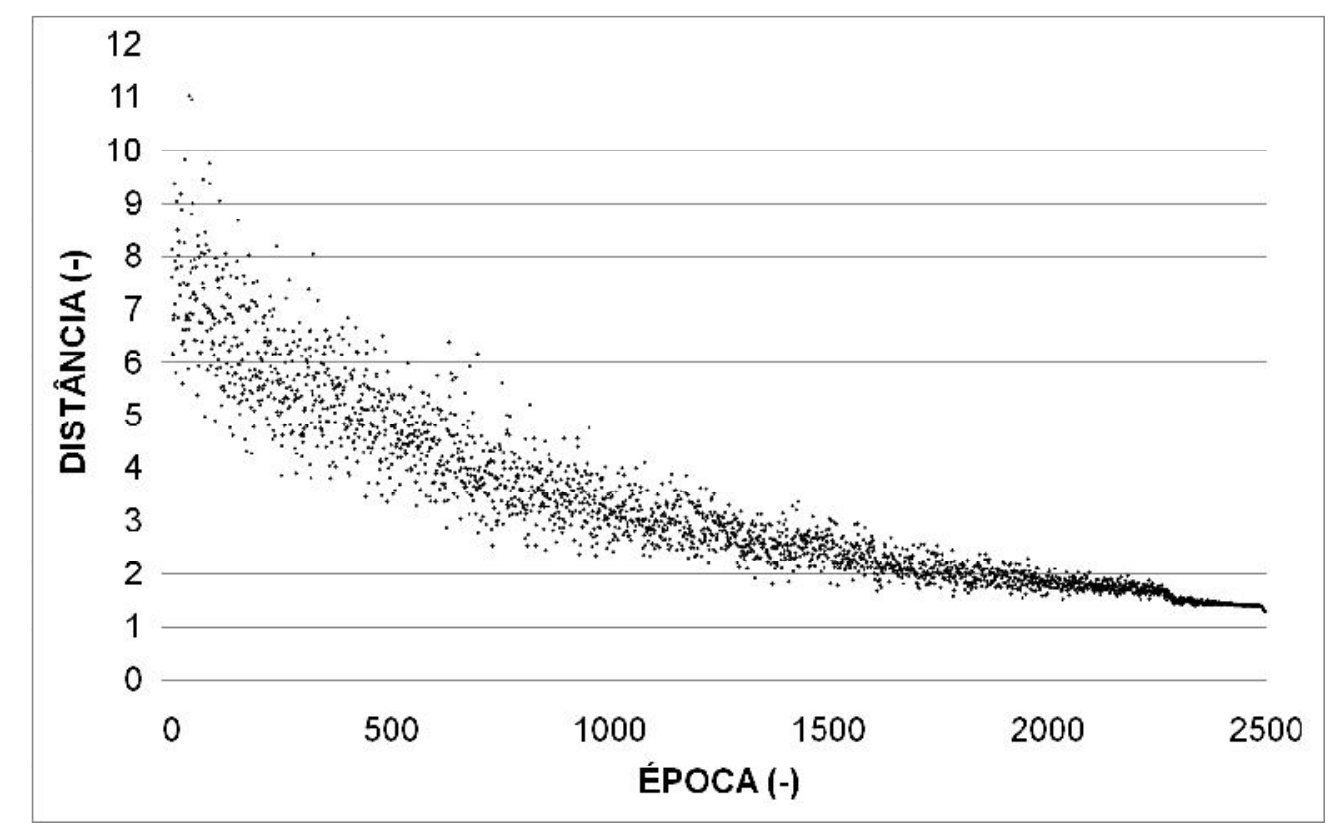

GRÁFICO 37 Evolução da distância máxima entre buffer e neurônio vencedor na fase de ordenamento

Fonte: elaborado pelo autor a partir de resultados do SICT 


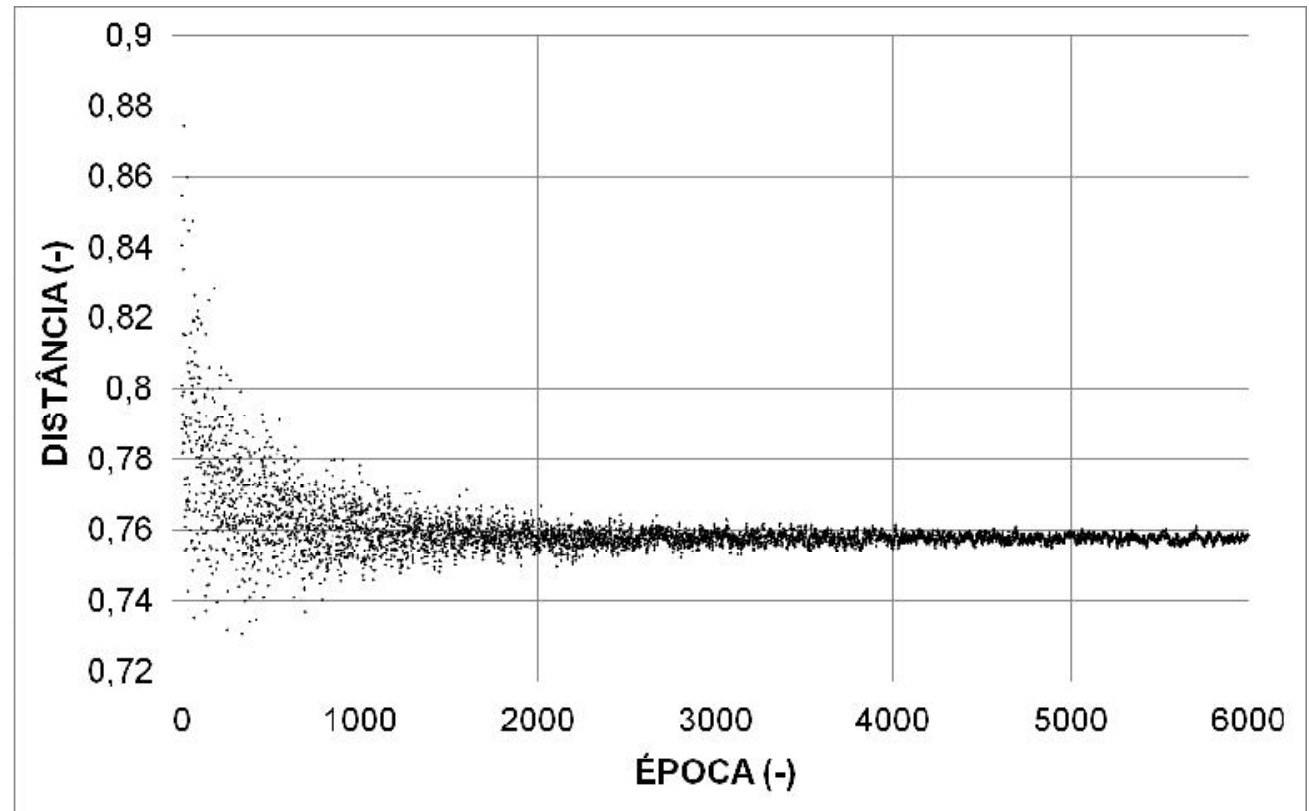

GRÁFICO 38 Evolução da distância máxima entre buffer e neurônio vencedor na fase de convergência

Fonte: elaborado pelo autor a partir de resultados do SICT

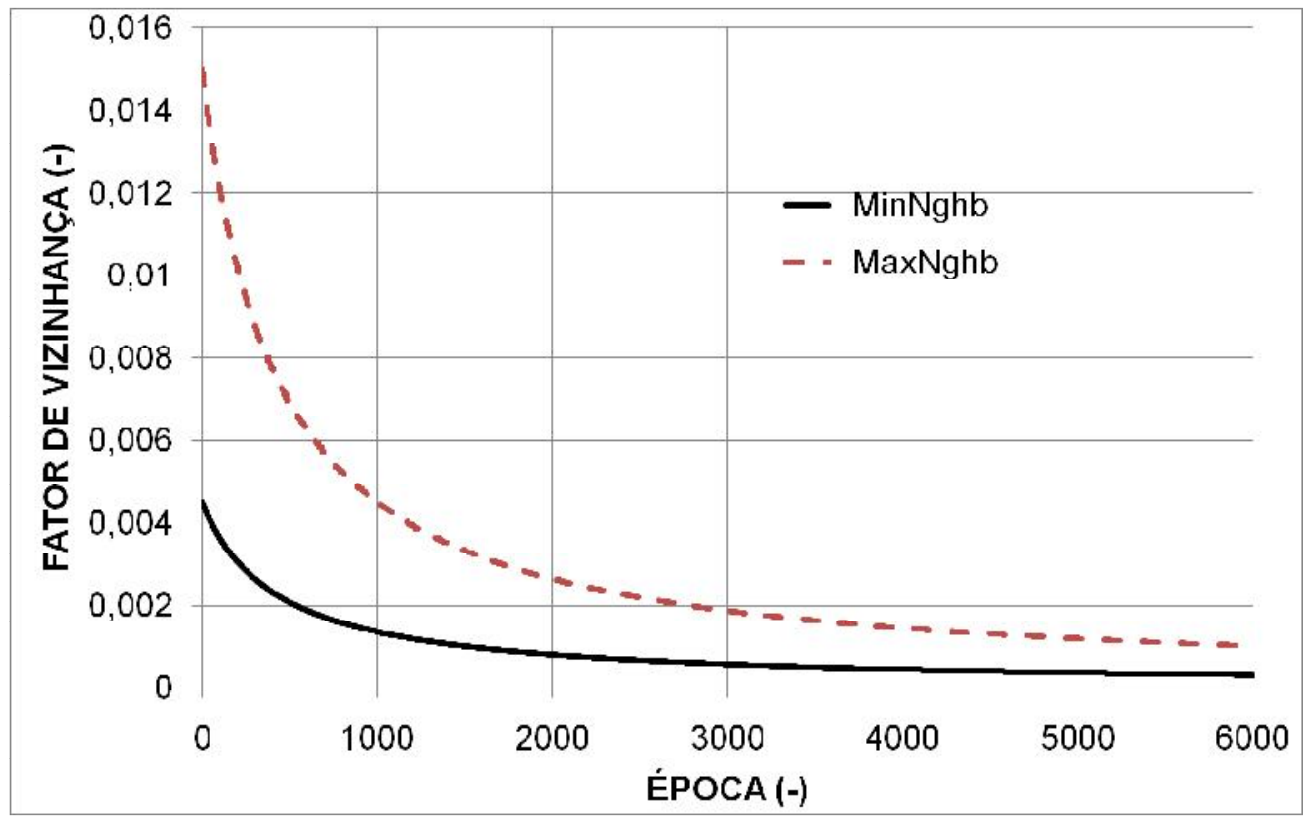

GRÁFICO 39 Evolução dos mínimos e máximos fatores de vizinhança na fase de ordenamento

Fonte: elaborado pelo autor a partir de resultados do SICT 


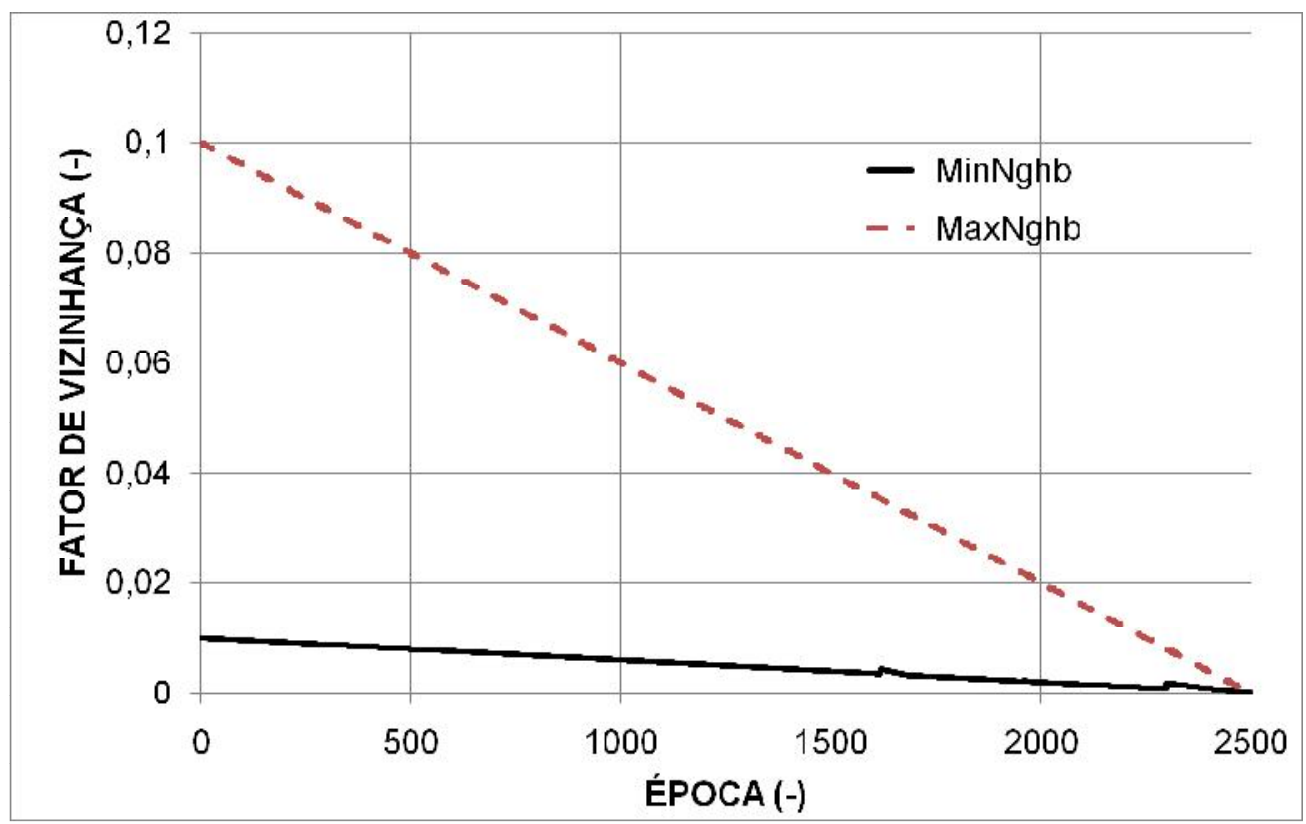

GRÁFICO 40 Evolução dos mínimos e máximos fatores de vizinhança na fase de convergência

Fonte: elaborado pelo autor a partir de resultados do SICT

LearnNetParam.txt: Este arquivo guarda as informações definidas pelo usuário na tela de CDlgLearn, permitindo uma verificação posterior, caso tenha havido algum erro na entrada dos dados.

LearnNormTrainBuf.txt: Este arquivo guarda os buffers de treinamento após o processo de normalização descrito em 6.2. Os buffers mostrados no exemplo do APÊNDICE $\mathrm{C}$ são equivalentes àqueles buffers obtidos do exterior $\mathrm{e}$ mostrados como exemplo imediatamente antes deles no arquivo SICTTrainData.inp.

LearnNrnWghts.txt: este arquivo guarda para cada época-Learn os pesos de cada um dos neurônios da rede. Pode ser útil para analisar algum problema específico.

LearnParamDist0.txt e LearnParamDist0.txt: Estes arquivos foram descritos no item 6.2, e o tipo de informação neles armazenado foi ilustrado no GRAF. 36. 
LearnWinBufsInNrn.txt. este arquivo guarda para cada época-Learn e para cada neurônio aqueles buffers que os ativaram. As colunas apresentadas no exemplo são: época-Learn, o neurônio ativado, o número de buffers que ativou aquele neurônio, a identificação desses buffers, ordem e alfanumérica, e a distância do buffer ao neurônio. Este arquivo é bastante útil para identificar quais buffers foram associados a um dado neurônio, mostrando assim qual sua característica básica. No exemplo, na época-Learn 0 , o neurônio 5 foi ativado por 4 buffers, no caso, característicos de uma queda de potência que começa a se estabilizar. De particular importância ressalta-se a época-Learn 5999 que corresponderá à configuração de rede, SICTNET1 $\quad$ 0.SICT, usada nas avaliações posteriores, se tiver sido especificado o valor sugerido de 6000 para a fase de convergência.

NrnGeomDist.txt: este arquivo é gerado logo após a criação da rede e guarda a distribuição das distâncias geométrica normalizadas, [0, 1], entre os neurônios.

No GRAF. 41 são apresentadas as distribuições das distâncias para as redes Triangular/Triangular, Quadrada/Quadrada, Hexagonal/Hexagonal e Cúbica/Quadrada, mostradas na FIG.31 e descritas no QUADRO 6. Pode-se observar que as distribuições Triangular e Quadrada são muito próximas entre si, e que a Cúbica tem a distribuição mais próxima de uma distribuição homogênea. Ressalta-se que na rede cúbica os efeitos de fronteira são menores e que todos os neurônios são completamente circundados por vizinhos. Apesar de as distribuições de distância entre os neurônios serem um pouco diferentes não foi possível determinar que uma rede tivesse um desempenho melhor que outra, nos testes realizados com o SICT para o CT1, portanto, na maior parte das avaliações apresentadas aqui as redes usadas foram Hexagonal/Hexagonal. Essa diferença de distribuição entre as diferentes redes pode ter alguma influência para usos com alguns conjuntos de dados muito particulares, mas não em geral como aqui registrado. 


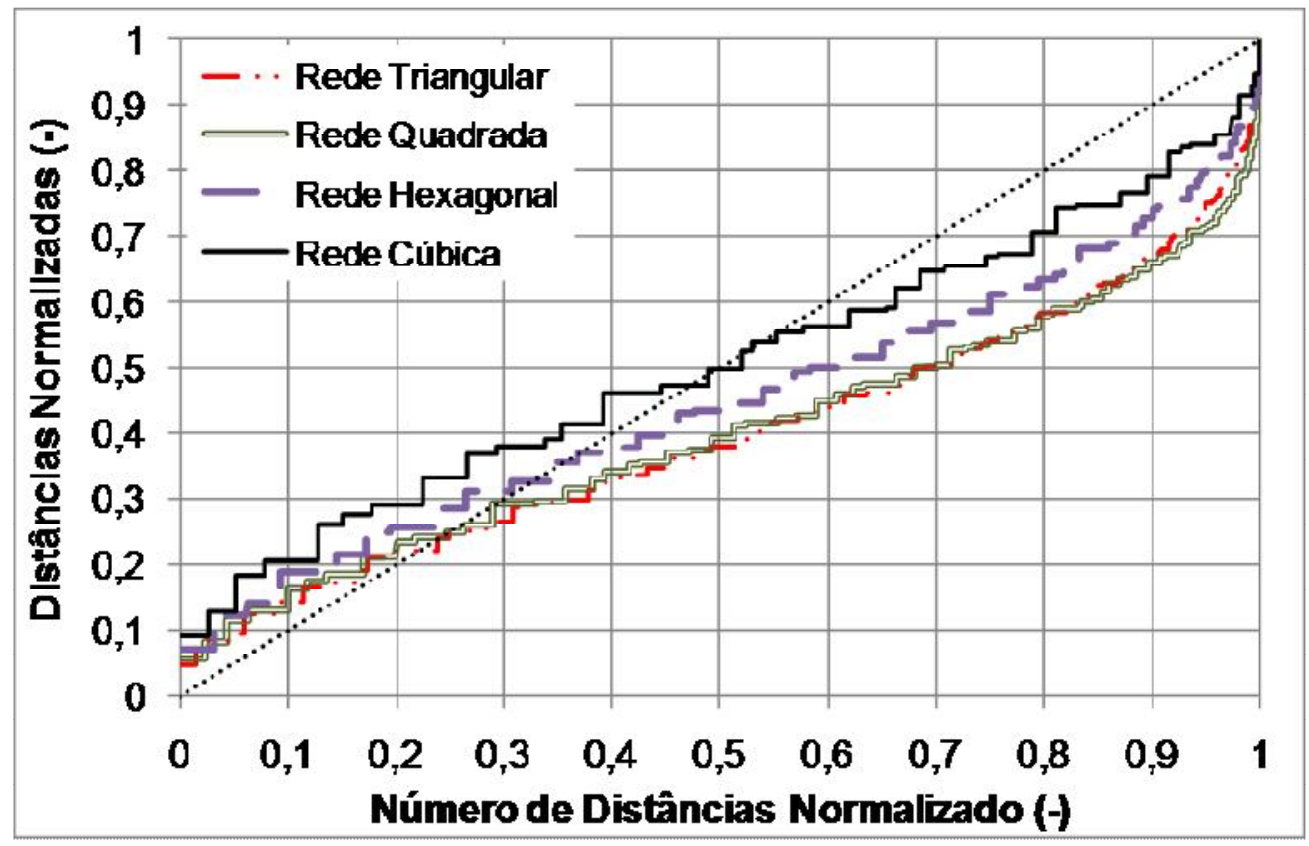

GRÁFICO 41 Distribuições das distâncias geométricas entre os neurônios nas redes Triangular/Triangular, Quadrada/Quadrada, Hexagonal/Hexagonal e Cúbica/Quadrada

Fonte: elaborado pelo autor a partir de resultados do SICT.

NrnGeomDist0: este arquivo guarda as informações definidas pelo usuário na tela de CDIgNet, permitindo uma verificação posterior caso tenha havido algum erro na entrada dos dados. Ele disponibiliza ainda:

- um sumário sobre a geometria da rede incluindo a menor e a maior distância e a menor distância normalizada,

- a distribuição das distâncias dos neurônios em dez intervalos normalizados e

- $\quad$ informações sobre todos os vizinhos imediatos e de grau 1 e 2 de cada neurônio. No exemplo, a coluna Nghn representa o nível de vizinhança, 0, 1 ou 2, as colunas Nrn0 e Nrn1 representam os dois neurônios avaliados e \#Nrn é a ordem, para um dado grau de vizinhança, em que o Nrn1 foi encontrado na vizinhança do Nrn0. Assim, no trecho mostrado no exemplo, o neurônio 0 tem seis vizinhos imediatos, os 
neurônios 1 a 6, três vizinhos de grau 1, os 8, 10 e 12 e quatro vizinhos de grau 2, os 7, 9, 11 e 13 .

NrnWghtDist????.txt: estes arquivos, onde "????" é a época-Learn, guardam a distância entre os pesos de cada neurônio da rede aos demais, guarda ainda a distância geométrica normalizada entre esses neurônios e a relação entre as distâncias dos pesos e a geométrica. O GRAF. 42 permite ver a distribuição de distância entre os pesos de neurônio vizinhos imediatos e de neurônios vizinhos de graus 1 e 2 . Essa informação é importante para se analisar posteriormente as distâncias durante o procedimento de monitoração.

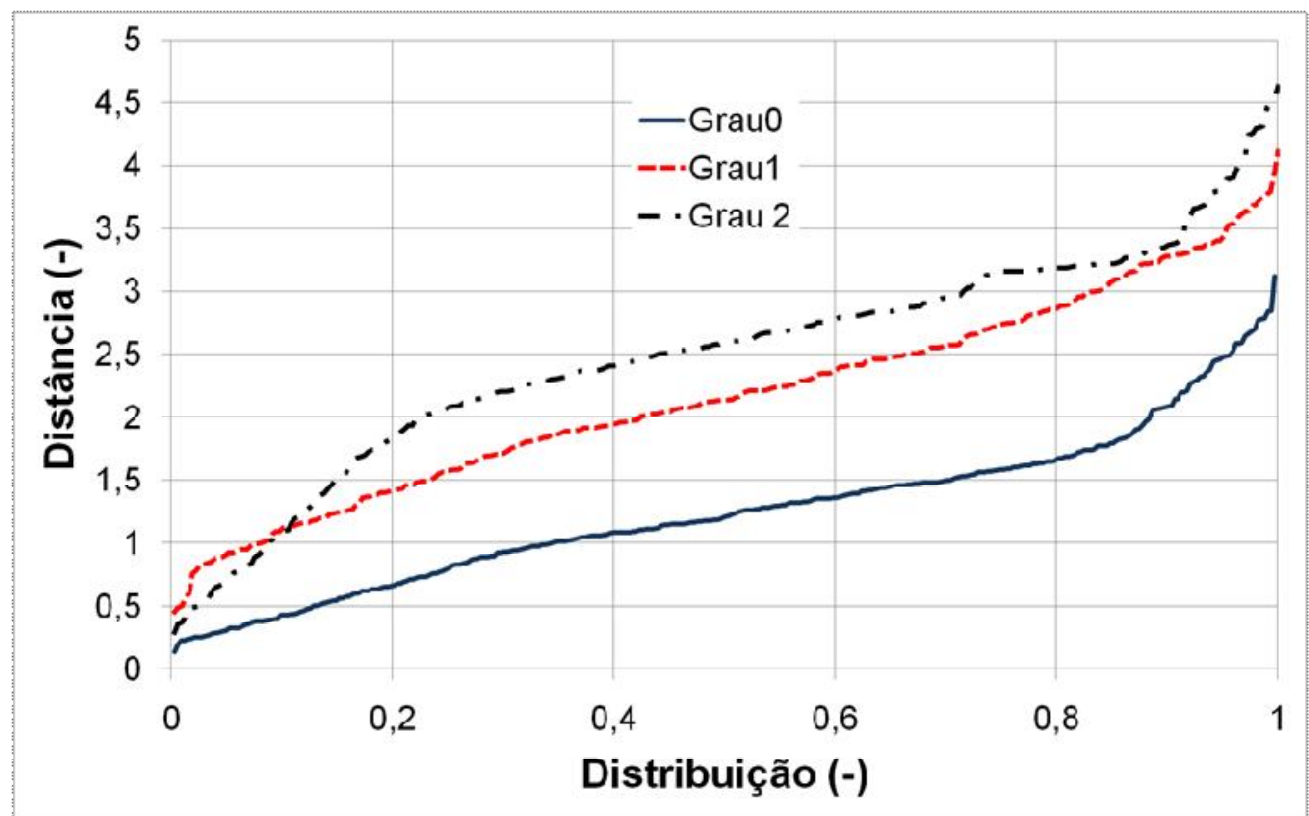

GRÁFICO 42 Distribuição das distâncias entre os pesos dos neurônios vizinhos Fonte: elaborado pelo autor a partir de resultados do SICT.

\subsubsection{Arquivos de Saída do Monitoramento}

Durante o procedimento de monitoramento além de apresentar na tela os neurônios ativados são gravados dois arquivos de saída o RunNet.txt e o RunDistW.txt. 
RunNet.txt: neste arquivo são guardados o tempo e o neurônio vencedor, no instante em que há uma mudança do neurônio vencedor, ou seja, quando o SICT identifica um estado de operação da instalação diferente do anterior.

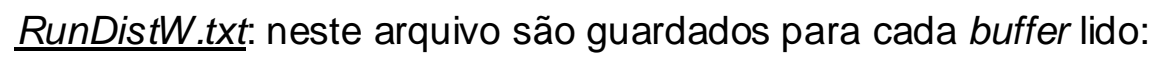

- o tempo associado ao buffer,

- o neurônio vencedor e

- a distância do vetor peso do neurônio vencedor ao buffer de monitoramento. O GRAF. 43 mostra a evolução da distância buffer de monitoramento - peso do neurônio vencedor com o tempo, para uma simulação, com o RELAP5, de mudanças de potência em degraus ascendentes no CT1. Nessa simulação os degraus aconteciam a cada 3000 s. Essa distância calculada durante o monitoramento é que permite avaliar se o neurônio ativado identificou corretamente o transiente, se o valor da distância for muitas vezes maior que a maior distância do fim do treinamento então o buffer não pode ser realmente identificado. Os trabalhos de Bartal et al. (1995) e Mol et al. (2003) ressaltam a importância de a rede ser capaz de acusar quando ela não consegue identificar corretamente o buffer que the é apresentado, sendo que nesse caso ela deve dar uma resposta do tipo Don't Know. Um mecanismo dar uma resposta Don't Know pode ser implementado no SICT através da avaliação dessa distância calculada durante o monitoramento. 


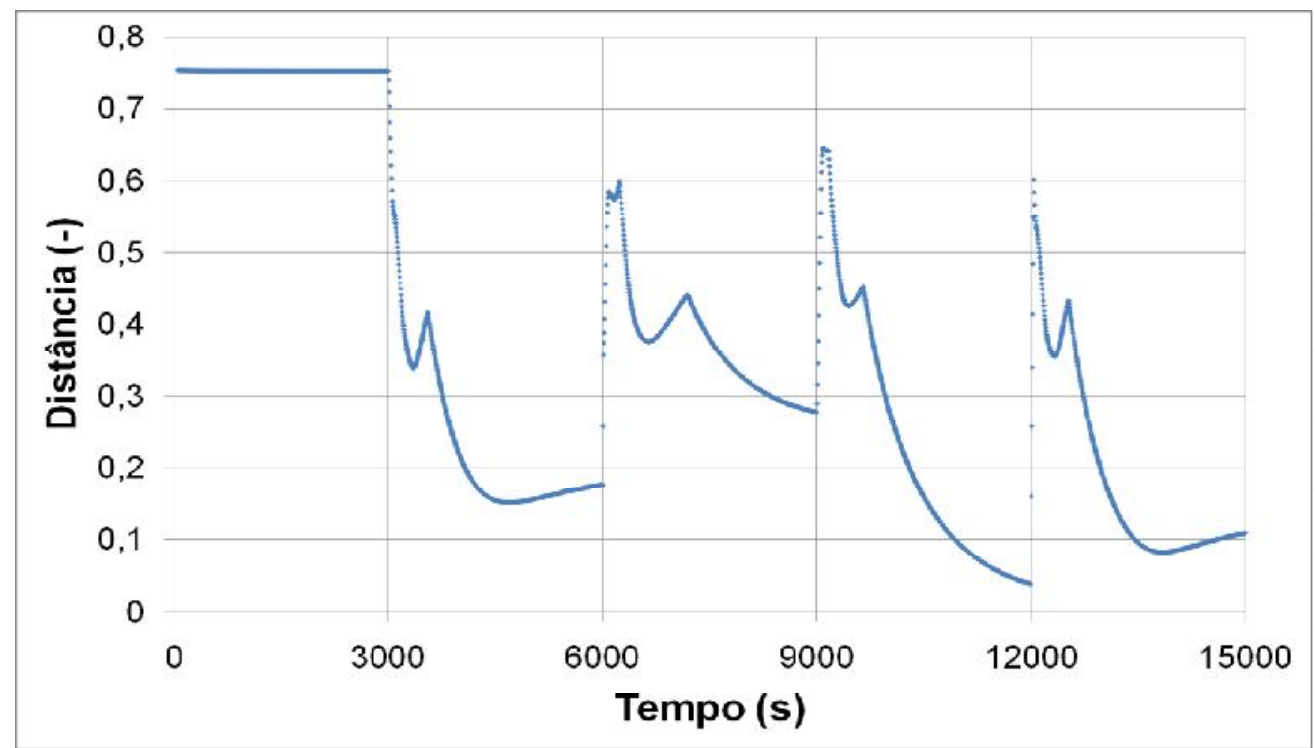

GRÁFICO 43 Distância buffer de monitoramento - neurônio com o tempo Fonte: elaborado pelo autor a partir de resultados do SICT.

\subsection{O Uso do Modelo}

Ao se iniciar o software é criada uma janela padrão do Windows com um conjunto de menus: FILE, EDIT, VIEW, SICT e HELP. Os dois primeiros e o último têm as funções padrão do Windows.

Na FIG. 42 estão mostrados os comandos disponíveis no menu File onde estão incorporadas algumas funcionalidades do SICT. Os comandos usuais desse menu permitem aqui:

- criar uma nova rede, New,

- abrir uma rede salva anteriormente, OPEN,

- $\quad$ salvar a rede com seu nome atual, Save,

- e salvar a rede atual com outro nome ou outro local, Save As... . 


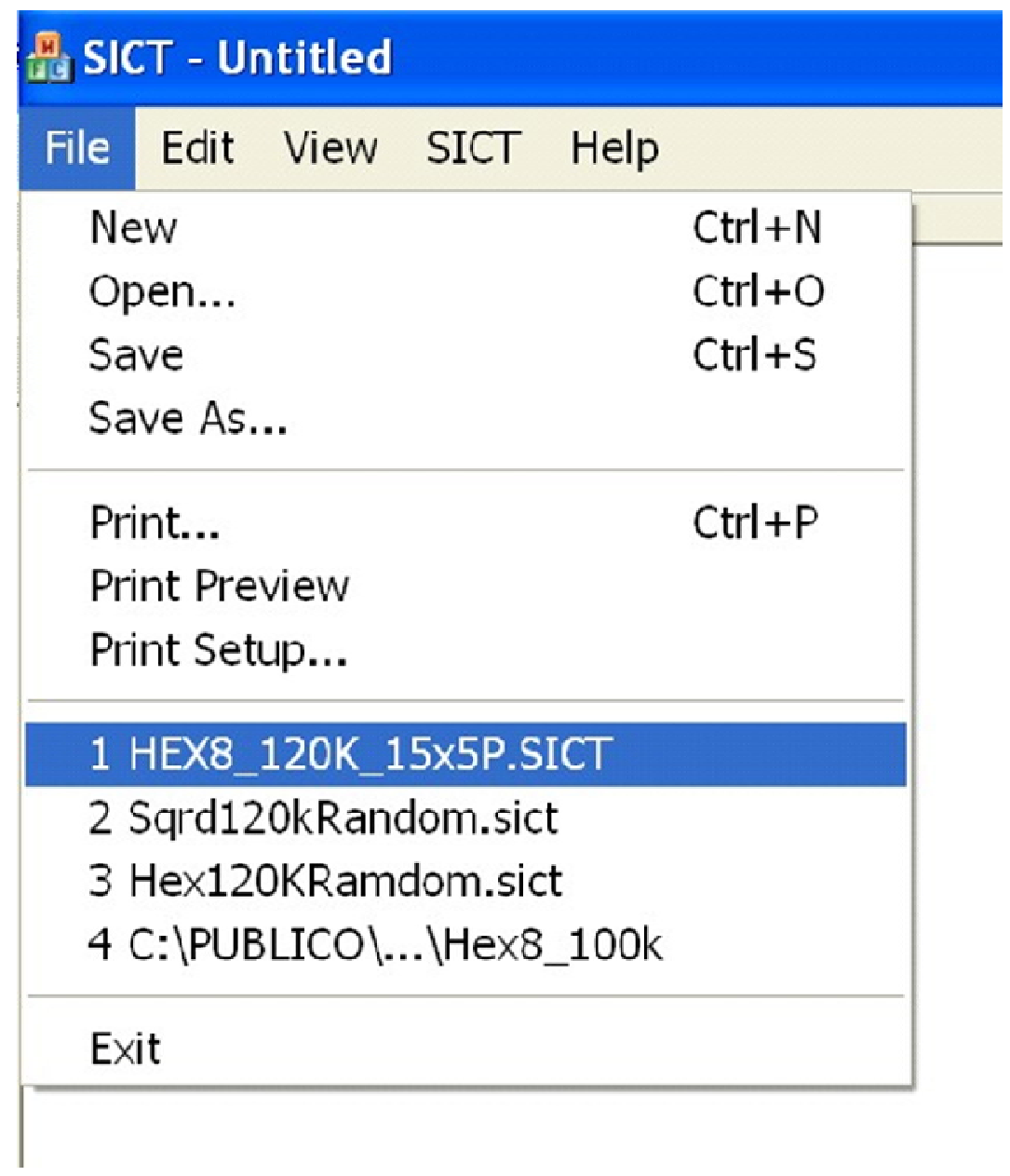

FIGURA 42 Comandos do menu FILE

Fonte: tela do SICT.

Uma rede salva contém informações sobre sua geometria, seus parâmetros de entrada, seus pesos e sua interface com o exterior. Os arquivos que armazenam as redes têm por padrão (default) a terminação.SICT.

O segundo menu de interesse é o SICT, mostrado na FIG. 43, que possibilita:

- $\quad$ criar uma nova rede, CreateNet,

- $\quad$ treinar a rede atual, Learn, e

- $\quad$ iniciar o procedimento de monitoração, Run, 


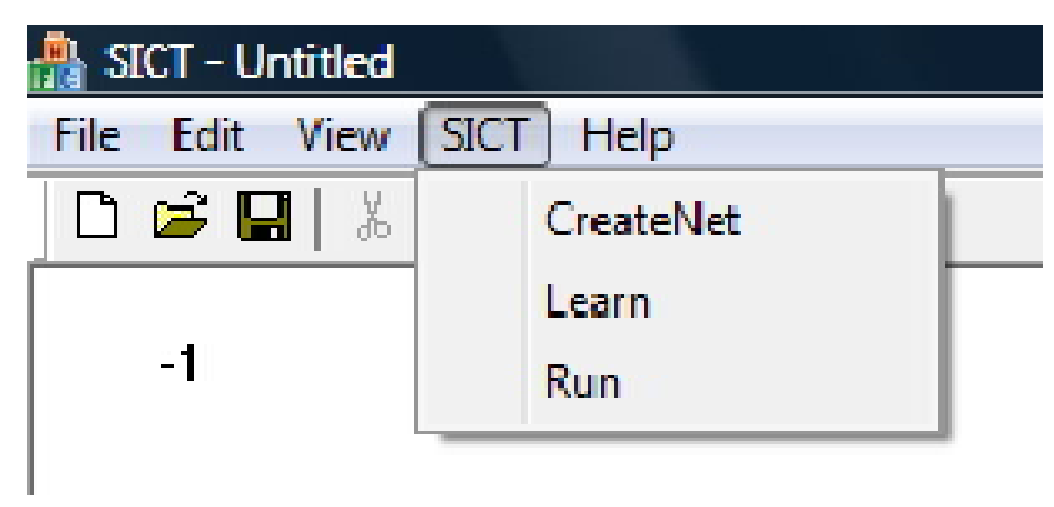

FIGURA 43 Comandos do menu SICT

Fonte: tela do SICT.

Caso se tente treinar uma rede não existente, por não ter sido criada ou aberta anteriormente, o SICT abrirá automaticamente a CDlgNet para gerar uma nova rede e somente após essa criação será iniciado o CDlgLearn para dar partida ao processo de treinamento.

De maneira similar, se o usuário tentar iniciar o procedimento de monitoramento, ativando o comando Run do menu SICT, e não existir uma rede aberta, será iniciado o processo de abrir uma rede existente, como se tivesse sido atuado o comando Open do menu File. Após a rede ter sido aberta é iniciado o procedimento de monitoramento.

Durante o procedimento de treinamento a tela do SICT só é atualizada a cada época-Learn, já que o processo de atualização atrasa muito o processamento. No canto superior esquerdo da tela do SICT é mostrada a última época-Learn que foi processada e atualizou a tela do SICT. Se o número for positivo significa que está sendo processada a fase de organização, assim na FIG. 44 a última atualização da tela foi na época 10. Caso o número seja negativo, como no exemplo da FIG. 45, indica que está sendo processada a fase de convergência do treinamento. 


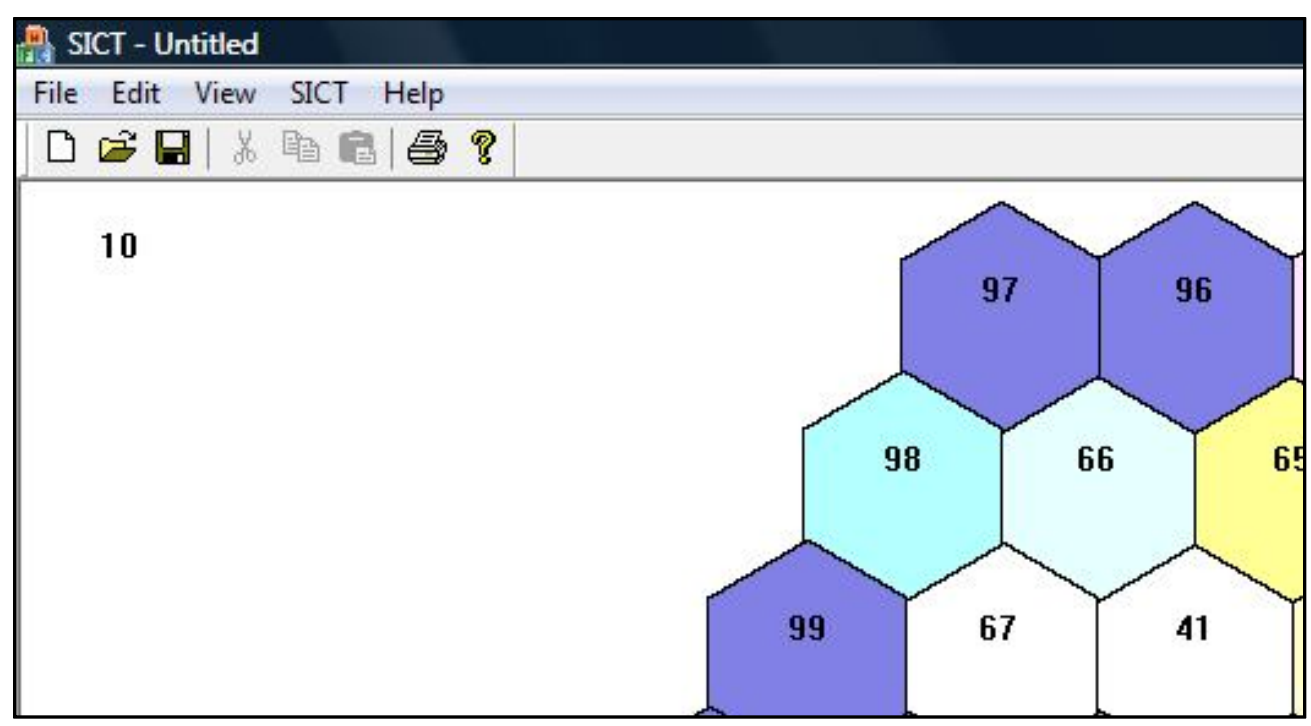

FIGURA 44 Detalhe da Tela do SICT após atualização na época 10 da fase de organização do treinamento

Fonte: tela do SICT.

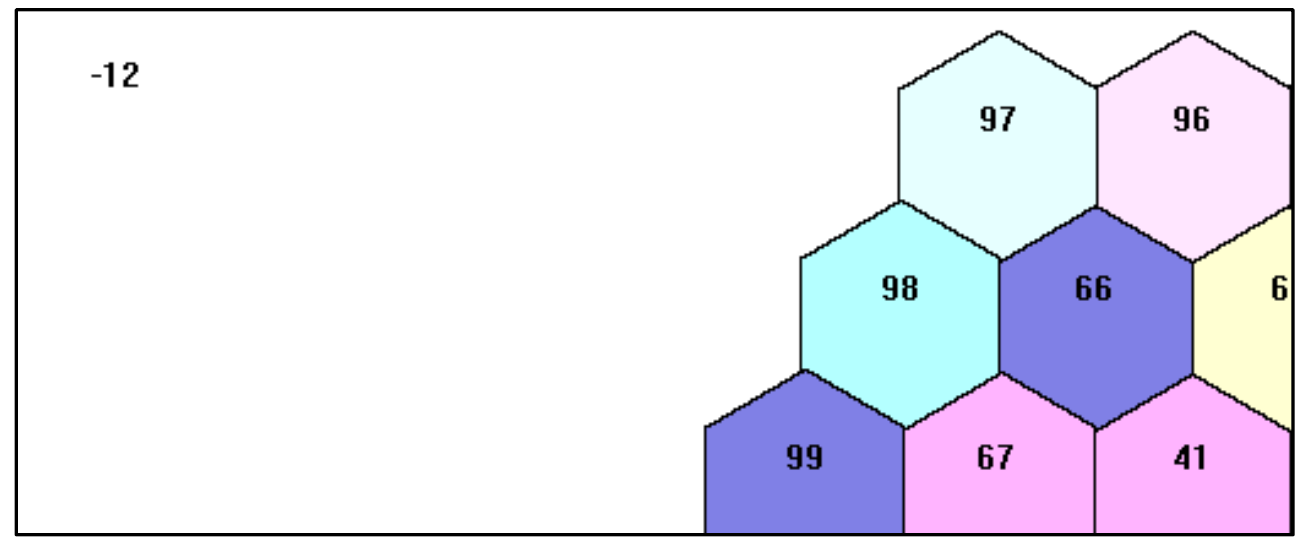

FIGURA 45 Detalhe da Tela do SICT após atualização na época 12 da fase de convergência do treinamento

Fonte: tela do SICT.

A atualização da tela do SICT durante o monitoramento ocorre cada vez que um novo conjunto de parâmetros é lido e processado. Durante o monitoramento, o número no canto superior esquerdo da tela apresenta o tempo associado ao buffer que foi lido e processado. Assim, considerando a FIG. 44 como uma tela de monitoramento o número 10 ali apresentado significa que o neurônio ativado corresponde aos parâmetros lidos no instante 10 segundos. 
Do exposto acima, conclui-se que o aplicativo desenvolvido neste trabalho, com base nos Mapas Auto-Organizáveis criado por Kohonen (2001), é funcional e disponibiliza um amplo conjunto de informações para análise do treinamento da rede neural. Após o treinamento de uma rede neuronal, ele também fornece informações detalhadas e simplificadas, em tempo real, sobre a identificação e classificação de transientes operacionais em sistemas termohidráulicos complexos como, por exemplo, o IRIS. 


\section{APLICAÇÕES DO SICT}

As aplicações do SICT foram feitas para as duas instalações tratadas neste trabalho, o Circuito Termo-hidráulico $\mathrm{N}^{\circ} 1$ e o reator IRIS. De acordo com a proposta original foram usados poucos parâmetros termo-hidráulicos para 0 treinamento da rede neuronal e para o monitoramento com o SICT. Esses parâmetros termo-hidráulicos formavam buffers para uso no treinamento da rede e durante o monitoramento.

Uma variação usada neste trabalho foi acrescentar as "derivadas" de parte das variáveis ao buffer. Essas "derivadas" foram calculadas usando-se um intervalo de tempo de $20 \mathrm{~s}$, apesar da disponibilidade de medições de 0,5 s, como descrito no capítulo 4 . Esse intervalo de $20 \mathrm{~s}$ foi determinado a partir dos dados experimentais, pois as variações das medidas durante o processo inviabilizavam o uso de intervalos muito menores e intervalos muito grandes introduziriam um atraso no reconhecimento dos padrões além de sua discriminação ficar muito prejudicada. O GRAF. 44 mostra a potência na seção de testes e o GRAF. 45 apresenta a sua "derivada", usando um intervalo de $20 \mathrm{~s}$.

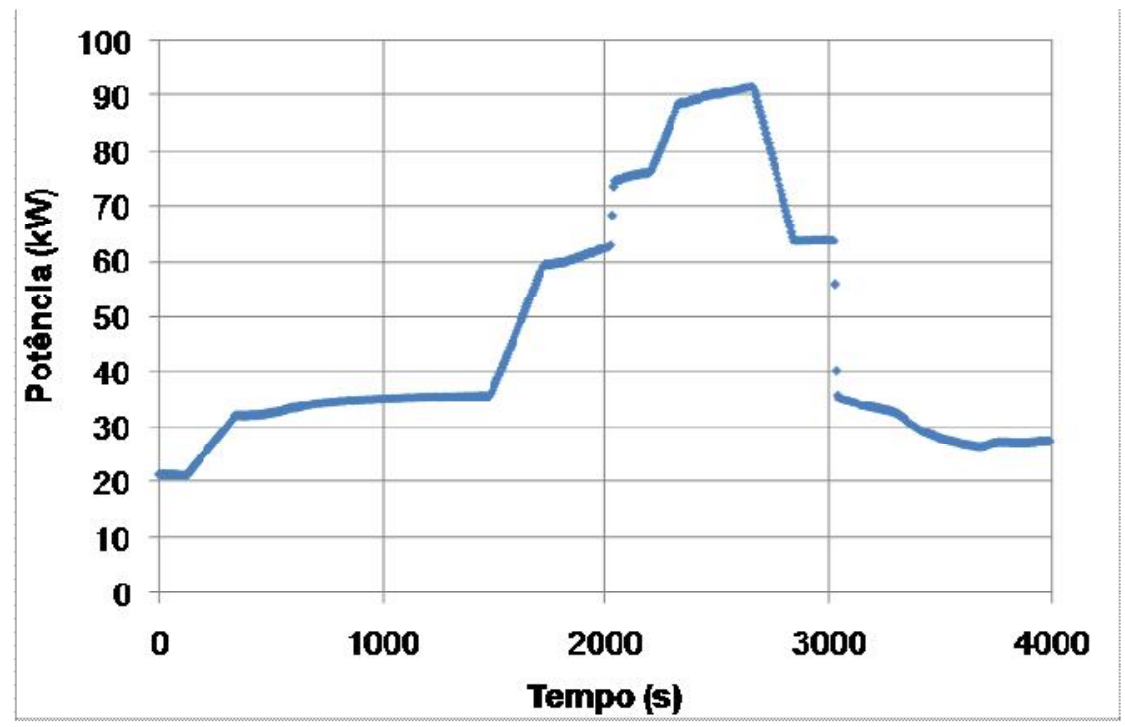

GRÁFICO 44 Potência na seção de testes - Exp06

Fonte: resultados experimentais da pesquisa 


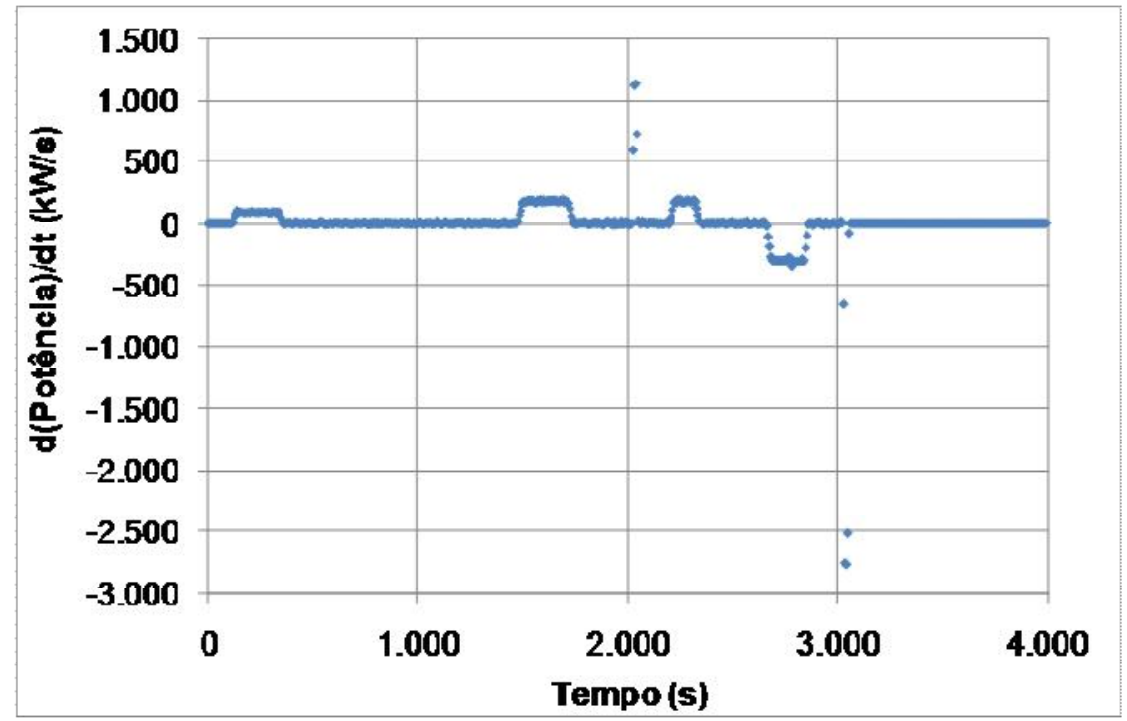

GRÁFICO 45 Derivada da potência na seção de testes - Exp06

Fonte: resultados experimentais da pesquisa

\subsection{Aplicação do SICT para o CT1}

O SICT foi usado com o CT1 para demonstrar a sua funcionalidade e para comprovar que o uso de resultados de simulações de uma instalação para o treinamento de um Sistema de Identificação e Classificação de Transientes é viável. Assim inicialmente foi feito o treinamento da rede neural do SICT com os resultados das simulações, em seguida as simulações foram usadas para avaliar a rede treinada e finalmente foi feita uma avaliação com os resultados experimentais.

\subsubsection{Treinamento do SICT para o CT1}

O treinamento do SICT é feito a partir do uso de conjuntos de buffers de treinamento, composto por parâmetros termo-hidráulicos obtidos das simulações com o RELAP5 e eventualmente de suas derivadas. 


\subsubsection{Parâmetros Termo-hidráulicos do CT1 para treinamento do SICT}

A primeira etapa executada para o treinamento foi a definição dos parâmetros termo-hidráulicos representativos do estado operacional da instalação para serem usadas no treinamento do SICT e, posteriormente, durante o processo de monitoramento da instalação.

Dez parâmetros do CT1 foram selecionados para serem usados para treinamento do SICT e posterior reconhecimento dos estados operacionais seja das simulações seja dos dados experimentais. Esses parâmetros estão mostrados no QUADRO 7.

QUADRO 7 - Parâmetros termo-hidráulicos do CT1 para treinamento do SICT

\begin{tabular}{|c|c|c|}
\hline \multirow{2}{*}{ Grandeza } & \multicolumn{2}{|l|}{ Parâmetro } \\
\hline & Identificação & Descrição \\
\hline \multirow{6}{*}{ Temperatura: } & T1 & Temperatura na saida da seção de testes \\
\hline & T4 & Temperatura na entrada do primário do trocador de calor \\
\hline & T5 & Temperatura na saída o primário do trocador de calor \\
\hline & T6 & Temperatura na saida da antiga bomba \\
\hline & T8 & Temperatura na saída da bo mba do primánio \\
\hline & T9 & Temperatura na saída do secundário do trocador de calor \\
\hline \multirow{2}{*}{$\begin{array}{l}\text { Vazão } \\
\text { Massica }\end{array}$} & PRIM_FLW & Vazão do primário \\
\hline & SEC_FLW & Vazão do secundário \\
\hline Potência & Pot & Potência na Seção de Testes \\
\hline Pressão & $P$ & Pressão no Pressurizador \\
\hline
\end{tabular}

Fonte: elaborado pelo autor

Oito derivadas desses parâmetros, mostradas no QUADRO 8, foram usadas em conjunto com os parâmetros para compor os buffers. 
QUADRO 8 - Derivadas dos parâmetros termo-hidráulicos do CT1 para treinamento do SICT

\begin{tabular}{c|c}
\hline \multicolumn{1}{c|}{ Grandeza } & Identificação \\
\hline \multirow{4}{*}{ Derivada da Temperatura } & $\mathrm{d}(\mathrm{T} 1) / \mathrm{dt}$ \\
\cline { 2 - 2 } & $\mathrm{d}(\mathrm{T} 4) / \mathrm{dt}$ \\
\cline { 2 - 2 } & $\mathrm{d}(\mathrm{T} 5) / \mathrm{dt}$ \\
\cline { 2 - 2 } & $\mathrm{d}(\mathrm{T} 6) / \mathrm{dt}$ \\
\cline { 2 - 2 } & $\mathrm{d}(\mathrm{T} 8) / \mathrm{dt}$ \\
\hline Derivada da Potência & $\mathrm{d}(\mathrm{T} 9) / \mathrm{dt}$ \\
\hline Derivada da Pressão & $\mathrm{d}(\mathrm{Pot}) / \mathrm{dt}$ \\
\hline
\end{tabular}

Fonte: elaborado pelo autor

\subsubsection{Os Buffers para treinamento para o CT1}

Para o treinamento do SICT foram preparados e usados 5 conjuntos de buffers a partir dos resultados das simulações:

- ALLOLD - degraus, rampas de 240 s e condições anormais.

- $\quad$ ALLM - degraus, rampas de $240 \mathrm{~s}$ e condições anormais, mas sem os pontos de transição muito fortes.

- $\quad \mathrm{DR}$ - buffer só com degraus e todas as rampas.

- $\quad \mathrm{AC}-$ buffer só com os casos que não são de degraus e rampas e sem os pontos de transição muito fortes.

- $\quad \mathrm{ALL}-\mathrm{AC}+\mathrm{DR}$

No APÊNDICE $F$ são mostrados os tempos de amostragem usados para formarem os conjuntos de Buffers ALLOLD, e para os demais ALLM, DR, AC e ALL que usam os mesmos tempos de amostragem. Cada buffer foi formado por 10 parâmetros termo-hidráulicos ou 18 valores, parâmetros termo-hidráulicos e derivadas que foram amostrados a cada $6 \mathrm{~s}$ a partir de um instante inicial. Os 
buffers são constituídos de 10 pontos de amostragem cobrindo então um período

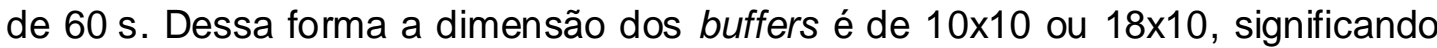
10 ou 18 parâmetros amostrados 10 vezes de 6 em 6 segundos.

\section{Conjunto de Buffers ALLOLD}

Buffers para treinar a rede em estados estacionários, degraus ascendentes e descendentes e rampas de $240 \mathrm{~s}$ ascendentes e descentes e condições acidentais ou anormais. Essa rede não usou os dados das simulações de rampas de $30 \mathrm{~s}$ e $120 \mathrm{~s}$ assim como também não usou as simulações de desligamento da bomba do secundário para potências de 40 e $80 \mathrm{~kW}$ (DESLBS40, DESLBS40_2 E DESLBS40_3, DESLBS80, DESLBS80_2 E DESLBS80_3). Os eventos dessas simulações que não foram usadas devem ser reconhecidos pelo SICT usando a plasticidade, ou capacidade de interpolação característica da rede SOM.

O QUADRO 9 mostra as simulações do CT1 com o RELAP5 que foram usadas para o treinamento da rede ALLOLD. Cada simulação indicada no QUADRO 9 foi replicada, isto é, os valores calculados para a pressão de $0,1 \mathrm{MPa}$ foram replicadas para as duas outras pressões: 0,3 e 0,5 MPa, excetuando-se as simulações de pressurização que já cobrem toda a faixa de pressão utilizada. Assim foram usados $(3 \times 2$ degraus+ $3 \times 2$ rampas $+3 \times 14$ acidentes + 4 pressurização) 58 arquivos de simulação como base de dados para 0 treinamento das redes, gerando um total de 7537 Buffers.

As condições acidentais simuladas incluem condições extremas como despressurização, degraus maiores que $15 \mathrm{~kW}$ e condições acidentais onde a temperatura atingiu picos de até $140^{\circ} \mathrm{C}$, apesar da pressão de $0,1 \mathrm{MPa}$. 
QUADRO 9 - Simulações do CT1 com o RELAP5 usadas para formar o conjunto de buffers ALLOLD.

\begin{tabular}{l|l|l|l|l}
\hline $\begin{array}{l}\text { Estados } \\
\text { Estacionários }\end{array}$ & Degraus & Rampas & Acidentes & $\begin{array}{l}\text { Pressurzaccão e } \\
\text { Despressurização }\end{array}$ \\
\hline DD7 & DD7 & R240D & $\begin{array}{l}\text { DESLBS20 } \\
\text { DESLBS60 } \\
\text { DESLBS100 }\end{array}$ & PRESSURIZA0k $^{1}$ \\
\hline DU7 & DU7 & R240U & $\begin{array}{l}\text { DESLBS20_2 } \\
\text { DESLBS60_2 } \\
\text { DESLBS100_2 }\end{array}$ & PRESSURIZA30k $^{1}$ \\
\hline & & $\begin{array}{l}\text { DESLBS20_3 } \\
\text { DESLBS60_3 } \\
\text { DESLBS100_3 }\end{array}$ & PRESSURIZA70k1 \\
\hline & & $\begin{array}{l}\text { ISOLABS } \\
\text { ISOLABS25 } \\
\text { ISOLABS75 }\end{array}$ & PRESSURIZA110k ${ }^{1}$ \\
\hline & & & $\begin{array}{l}\text { ISOLATC } \\
\text { ISOLATC25 }\end{array}$ & \\
\hline & & & &
\end{tabular}

Fonte: elaborado pelo autor

${ }^{1}$ As simulações de pressurização não são replicadas para as demais pressões, uma vez que elas cobrem toda a faixa de pressão considerada no estudo.

Os GRAF. 46, 47 e 48 mostram os conjuntos de buffers ALLOLD formados respectivamente pela potência e sua derivada, a pressão e sua derivada e a temperatura de saída da seção de testes e sua derivada.

O resultado do processo de normalização dos dados de entrada, que ocorre tanto na fase de treinamento como na fase de execução do SICT, está apresentado no GRAF. 49. É evidente, na comparação com o GRAF. 48, sem normalização, que os dados não têm sua forma alterada, mas somente sua faixa é mudada para $-1 \mathrm{a}+1$, independente da grandeza da qual se originou. 

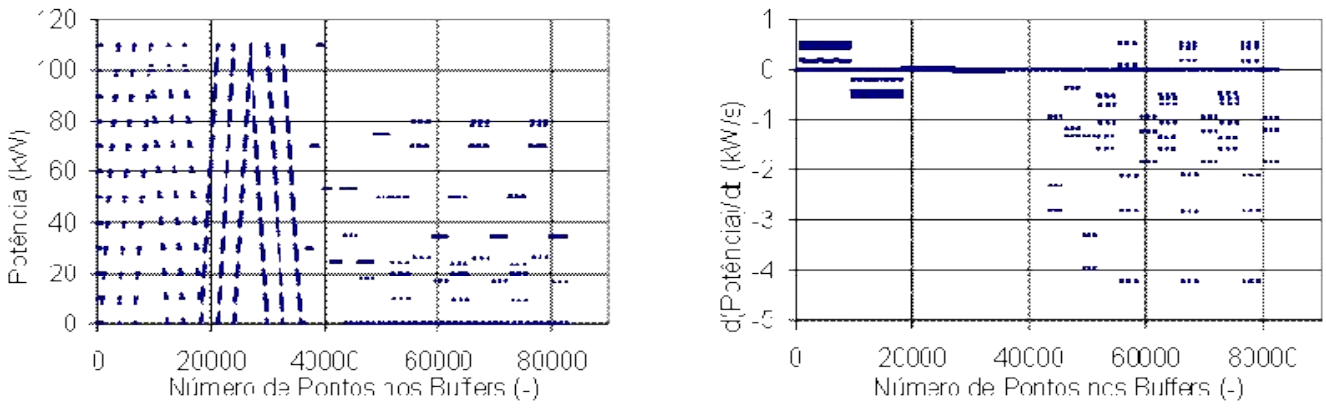

GRÁFICO 46 Potência e sua derivada no conjunto de buffers ALLOLD Fonte: elaborado pelo autor.
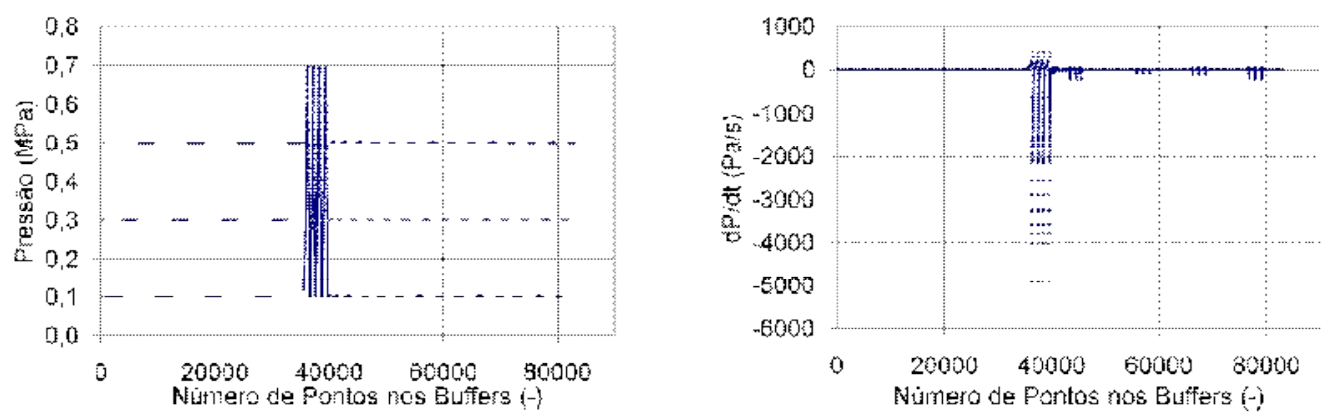

\section{GRÁFICO 47 Pressão e sua derivada no conjunto de buffers ALLOLD}

Fonte: elaborado pelo autor.
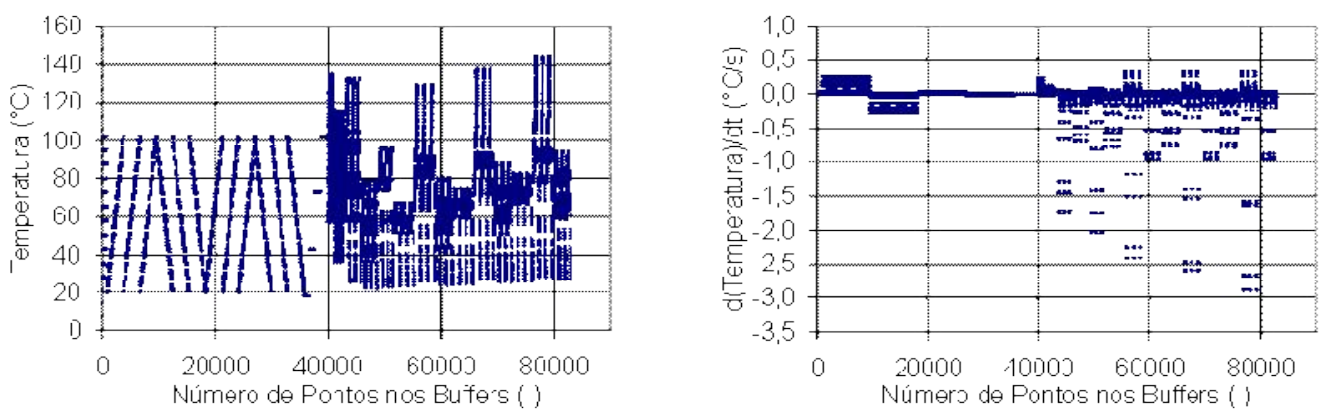

GRÁFICO 48 Temperatura de saída da Seção de Testes e sua derivada no conjunto de buffers ALLOLD

Fonte: elaborado pelo autor. 

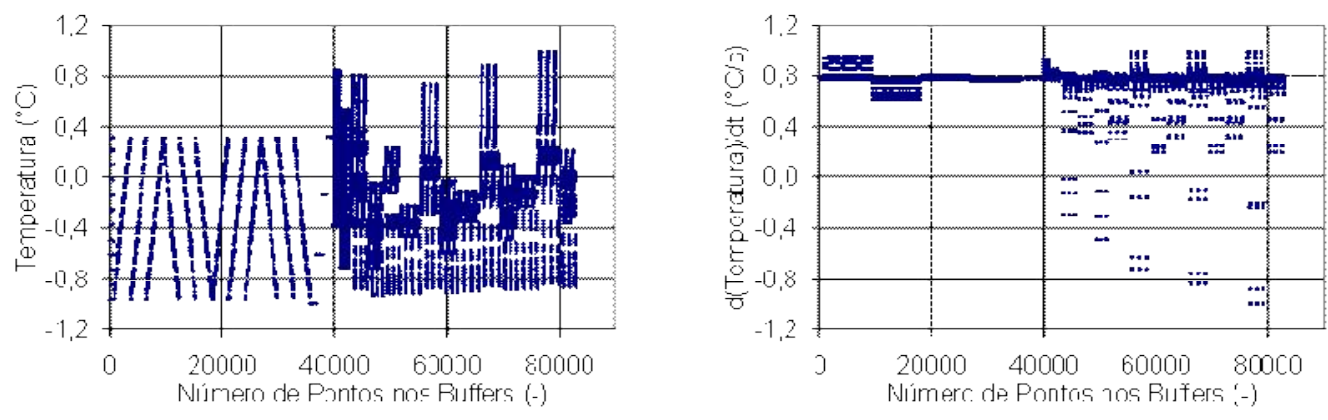

GRÁFICO 49 Temperatura de saída da Seção de testes e sua derivada normalizadas no conjunto de buffers ALLOLD

Fonte: elaborado pelo autor.

O GRAF. 50 apresenta os conjuntos de buffers ALLOLD formados pela temperatura de saída do primário do trocador de calor e sua derivada e o GRAF. 51 as mesmas informações para o secundário.
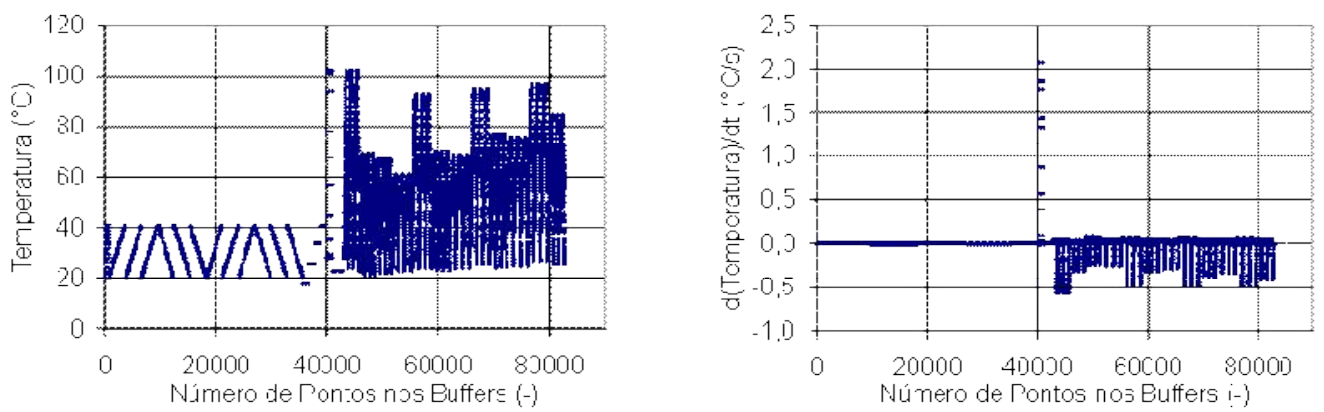

GRÁFICO 50 Temperatura de saída do primário do Trocador de Calor e sua derivada no conjunto de buffers ALLOLD

Fonte: elaborado pelo autor.
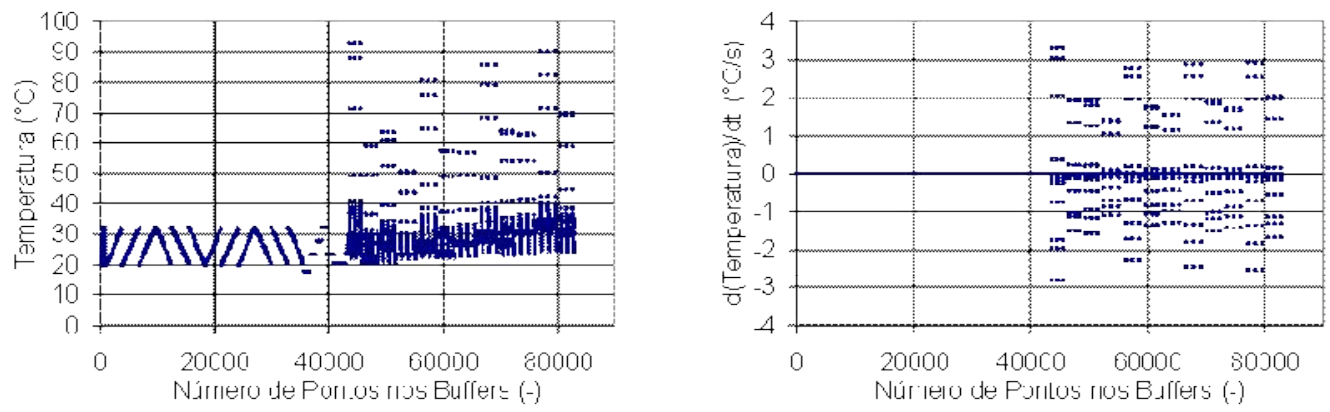

GRÁFICO 51 Temperatura de saída do secundário do Trocador de Calor e sua derivada no conjunto de buffers ALLOLD

Fonte: elaborado pelo autor. 
Os conjuntos de buffers ALLOLD formados pelas Vazões no primário e no secundário são apresentados no GRAF. 52.
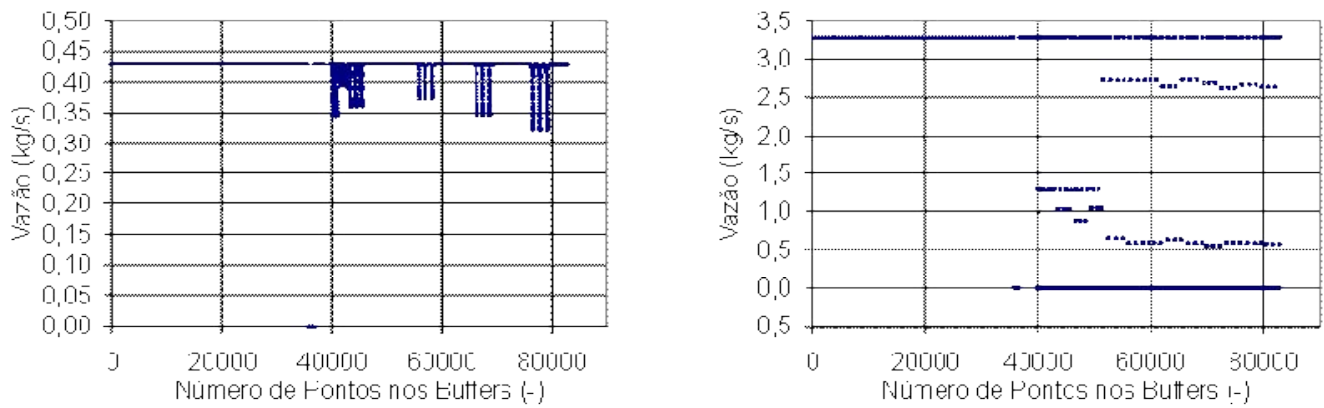

GRÁFICO 52 Vazões do Primário e do Secundário, respectivamente, no conjunto de buffers ALLOLD

Fonte: elaborado pelo autor.

\section{Conjunto de Buffers ALLM}

Como as condições anormais impunham uma sobrecarga na faixa de variação dos parâmetros, impedindo que a rede discriminasse situações de interesse, foi preparado um novo treinamento excluindo-se os buffers que diminuíam a discriminação dos parâmetros.

Os arquivos de resultados de simulação do CT1 com o RELAP5 utilizados foram os mesmos que para a rede ALLOLD, mostrados no QUADRO 9, sendo gerados 6498 Buffers.

Comparando-se os GRAF. 53 a 58, apresentados a seguir, com aqueles obtidos para a rede ALLOLD pode-se observar o resultado da eliminação dos transientes mais fortes. Por exemplo, a faixa da derivada da pressão mudou de $[-5000,500] \mathrm{Pa} / \mathrm{s}$, mostrado no GRAF. 47, para $[-50$, 200] Pa/s, mostrado no GRAF. 54, portanto uma diminuição na faixa de pressão de 5500Pa/s para $250 \mathrm{~Pa} / \mathrm{s}$, ou seja, uma diminuição de uma ordem da grandeza. 

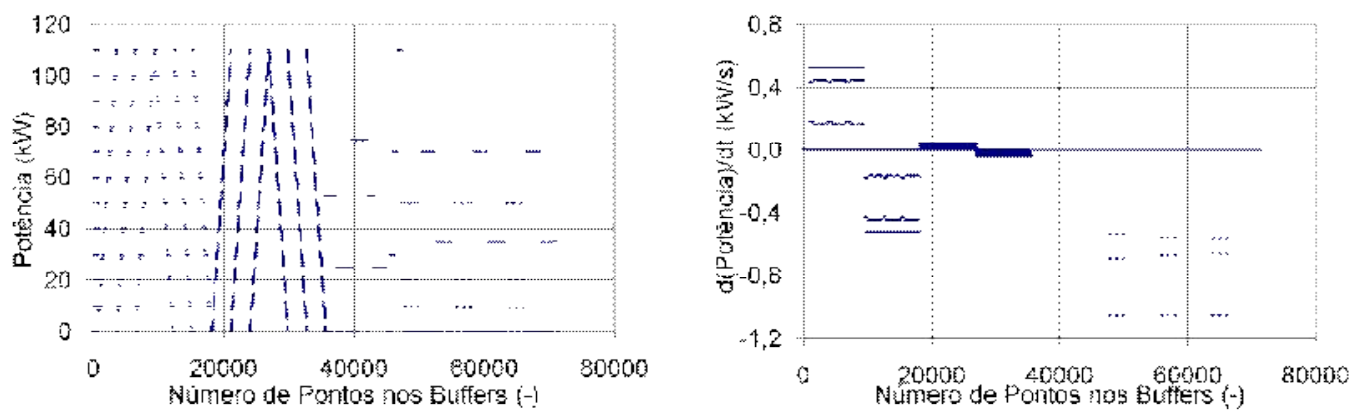

GRÁFICO 53 Potência e sua derivada no conjunto de buffers ALLM Fonte: elaborado pelo autor.
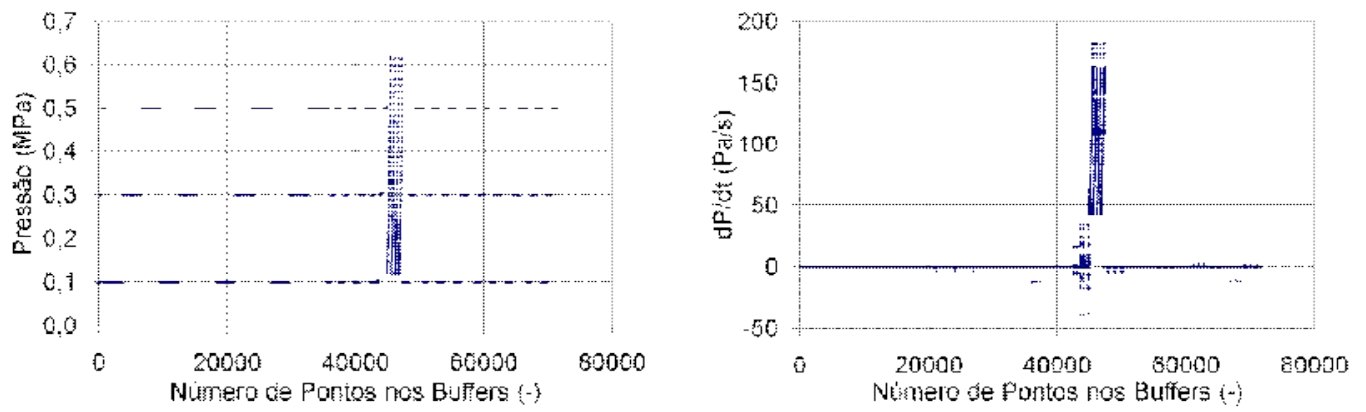

GRÁFICO 54 Pressão e sua derivada no conjunto de buffers ALLM Fonte: elaborado pelo autor.
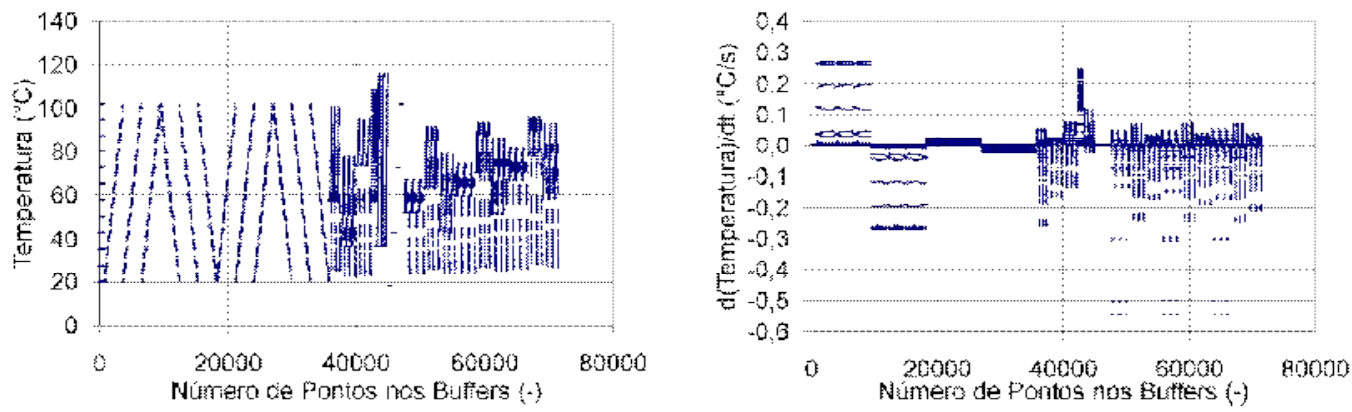

GRÁFICO 55 Temperatura de saída da Seção de Testes e sua derivada no conjunto de buffers ALLM

Fonte: elaborado pelo autor. 

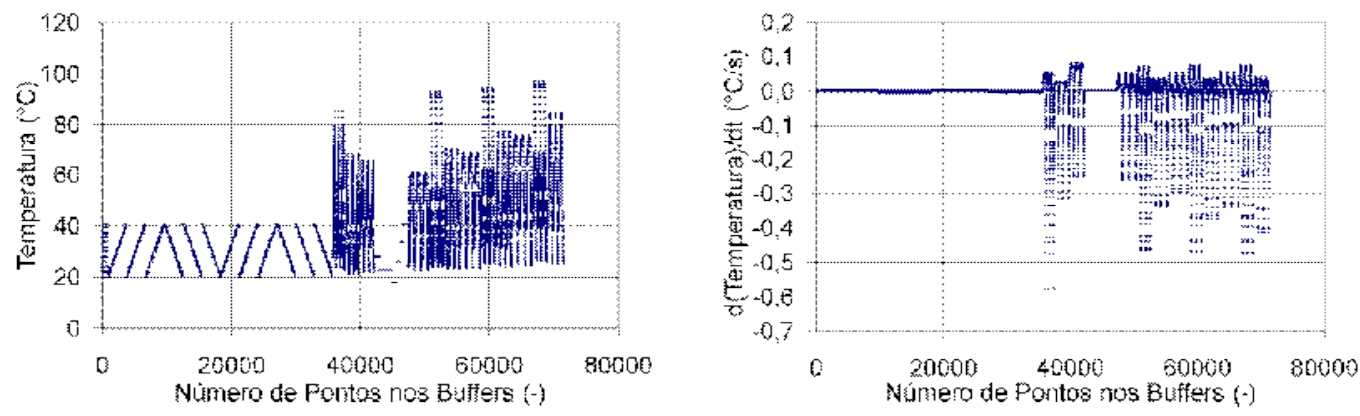

GRÁFICO 56 Temperatura de saída do primário do Trocador de Calor e sua derivada no conjunto de buffers ALLM

Fonte: elaborado pelo autor.
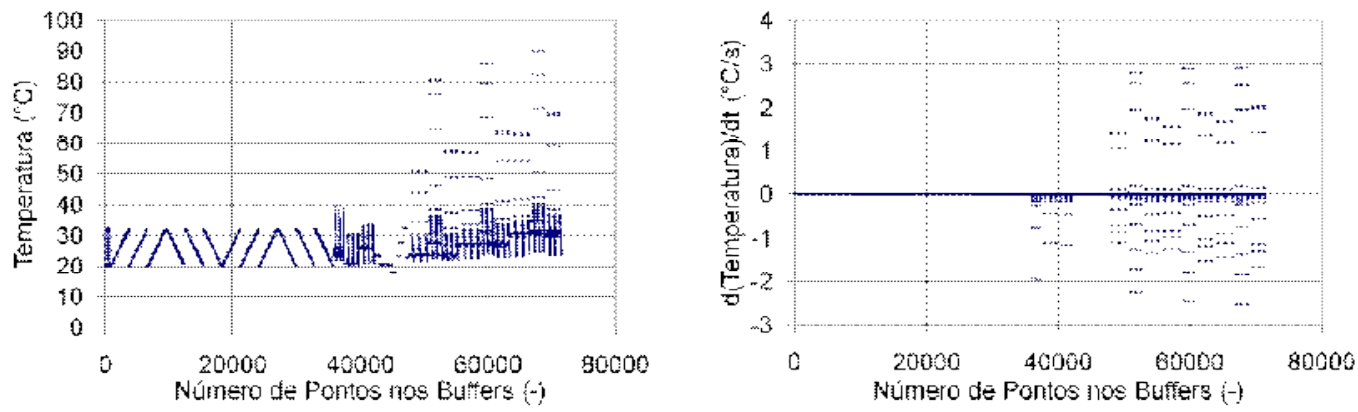

GRÁFICO 57 Temperatura de saída do secundário do Trocador de Calor e sua derivada no conjunto de buffers ALLM

Fonte: elaborado pelo autor.
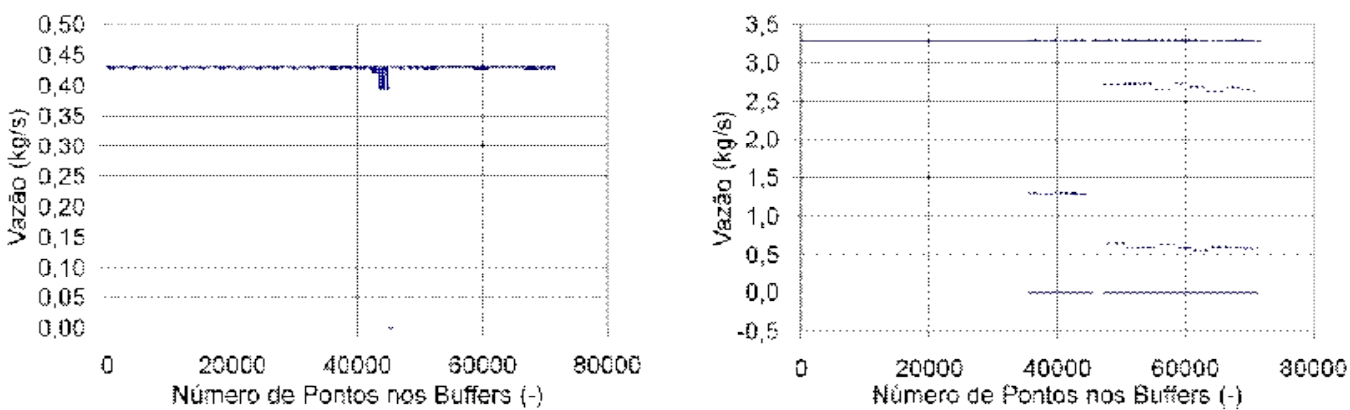

GRÁFICO 58 Vazões do Primário e do Secundário, respectivamente, no conjunto de buffers ALLM

Fonte: elaborado pelo autor.

A TAB. 2 mostra a relação entre as faixas dos parâmetros nos conjuntos de buffers ALLOLD e ALLM. Além da derivada de pressão, já avaliada anteriormente, pode-se observar que os parâmetros dT1/dt, dT4/dt, dT5/dt e $\mathrm{D}$ (Potência)/dt apresentam alterações significativas, onde a faixa dos parâmetros em ALLM é sempre menor que em ALLOLD. 
TABELA 2 - Relação entre as faixas dos parâmetros nos conjuntos de buffers ALLOLD e ALLM

\begin{tabular}{c|c}
\hline Parâmetro & $\begin{array}{c}\text { Faixa ALLOLD / } \\
\text { Faixa ALLM }\end{array}$ \\
\hline $\mathrm{T} 1$ & 1.3 \\
\hline $\mathrm{dT} 1 / \mathrm{dt}$ & 4.0 \\
\hline $\mathrm{T} 4$ & 1.0 \\
\hline $\mathrm{dT} 4 / \mathrm{dt}$ & 1.4 \\
\hline $\mathrm{T} 5$ & 1.1 \\
\hline $\mathrm{dT} 5 / \mathrm{dt}$ & 4.0 \\
\hline $\mathrm{T} 6$ & 1.0 \\
\hline $\mathrm{dT} 6 / \mathrm{dt}$ & 1.0 \\
\hline $\mathrm{T} 8$ & 1.0 \\
\hline
\end{tabular}

\begin{tabular}{c|c}
\hline Parâmetro & $\begin{array}{c}\text { Faixa ALLOLD / } \\
\text { Faixa ALLM }\end{array}$ \\
\hline $\mathrm{dT} 8 / \mathrm{dt}$ & 1.0 \\
\hline $\mathrm{T} 9$ & 1.0 \\
\hline $\mathrm{dT9} / \mathrm{dt}$ & 1.1 \\
\hline Pressão & 1.2 \\
\hline $\mathrm{D}$ (Pressão)/dt & 24.3 \\
\hline Vazão Primánio & 1.0 \\
\hline Vazão Secundário & 1.0 \\
\hline Potência & 1.0 \\
\hline $\mathrm{D}$ (Potência)/dt & 3.0 \\
\hline
\end{tabular}

Fonte: elaborado pelo autor.

\section{Conjunto de Buffers AC}

O conjunto de buffers AC foi formado com as simulações de estados estacionários e todas as simulações de acidentes, porém sem incluir as condições de transientes mais intensos, da mesma forma que foi feito para o conjunto de buffers ALLM.

O QUADRO 10 mostra as simulações do CT1 com o RELAP5 que foram usadas para o treinamento da rede AC. Da mesma forma que para os conjuntos de buffer ALLOLD e ALLM, cada simulação indicada no QUADRO 10 foi replicada para as pressões de 0,3 e 0,5 MPa, excetuando-se as simulações de pressurização que já cobrem toda a faixa de pressão utilizada. Assim foram usados (3×2 estados estacionários $+3 \times 20$ acidentes +4 pressurização) 70 arquivos de simulação como base de dados para o treinamento das redes, gerando um total de 4794 Buffers. 
QUADRO 10 - Simulações do CT1 com o RELAP5 usadas para formar o conjunto de buffers AC.

\begin{tabular}{|c|c|c|}
\hline $\begin{array}{c}\text { Estados } \\
\text { Estacionários }\end{array}$ & Acidentes & $\begin{array}{l}\text { Pressurização e } \\
\text { Despressurziação }\end{array}$ \\
\hline DD7 & \begin{tabular}{|l} 
DESLBS20 \\
DESLBS40 \\
DESLBS60 \\
DESLBS80 \\
DESLBS100
\end{tabular} & PRESSURIZAOK' \\
\hline \multirow[t]{4}{*}{ DU7 } & $\begin{array}{l}\text { DESLBS20_2 } \\
\text { DESLBS40_2 } \\
\text { DESLBS60_2 } \\
\text { DESLBS80_2 } \\
\text { DESLBS100_2 }\end{array}$ & PRESSURIZA30k ${ }^{1}$ \\
\hline & $\begin{array}{l}\text { DESLBS20_3 } \\
\text { DESLBS40_3 } \\
\text { DESLBS60_3 } \\
\text { DESLBS80_3 } \\
\text { DESLBS100_3 }\end{array}$ & PRESSURIZA70k ${ }^{1}$ \\
\hline & \begin{tabular}{|l} 
ISOLABS \\
ISOLABS25 \\
ISOLABS75
\end{tabular} & PRESSURIZA110k ${ }^{1}$ \\
\hline & $\begin{array}{l}\text { ISOLATC } \\
\text { ISOLATC25 }\end{array}$ & \\
\hline
\end{tabular}

Fonte: elaborado pelo autor

${ }^{1}$ As simulações de pressurização e despressurização não são replicadas para as demais pressões, uma vez que elas atravessam toda a faixa de pressão coberta.

Os GRAF. 59 a 64 mostram os buffers dos diversos parâmetros usados no treinamento da rede com o conjunto de buffers AC, permitindo uma visualização das diferenças com os conjuntos de buffers anteriormente apresentados. 

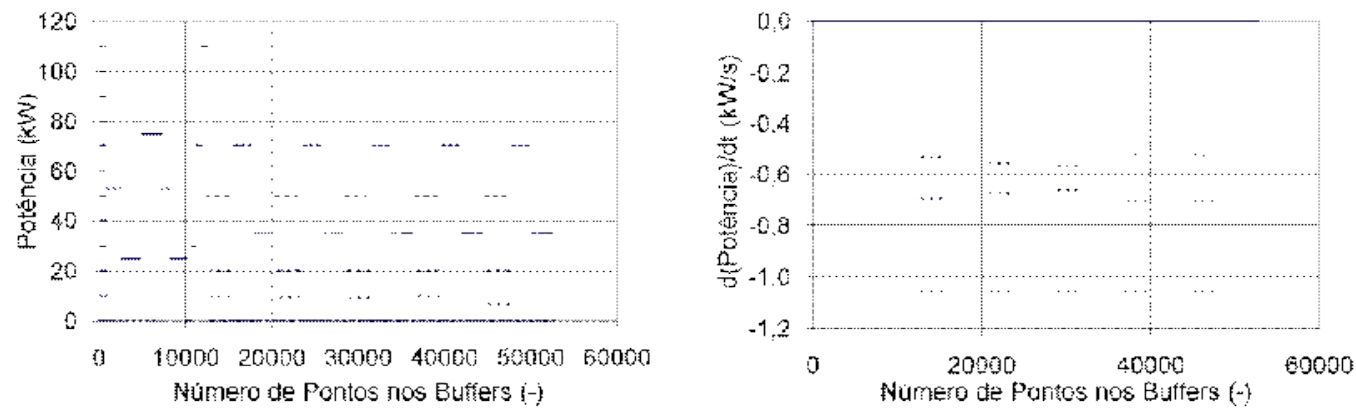

GRÁFICO 59 Potência e sua derivada no conjunto de buffers AC

Fonte: elaborado pelo autor.
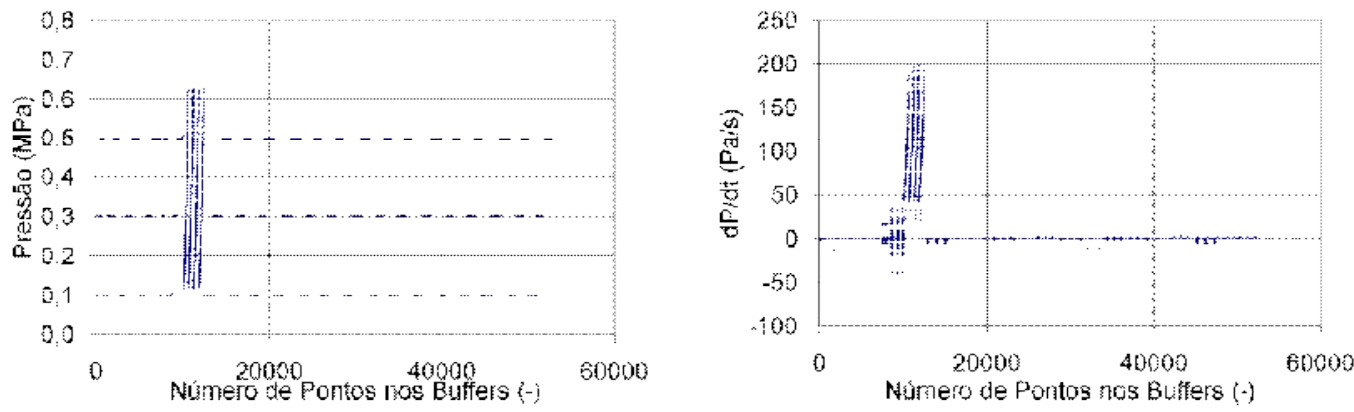

GRÁFICO 60 Pressão e sua derivada no conjunto de buffers AC

Fonte: elaborado pelo autor.
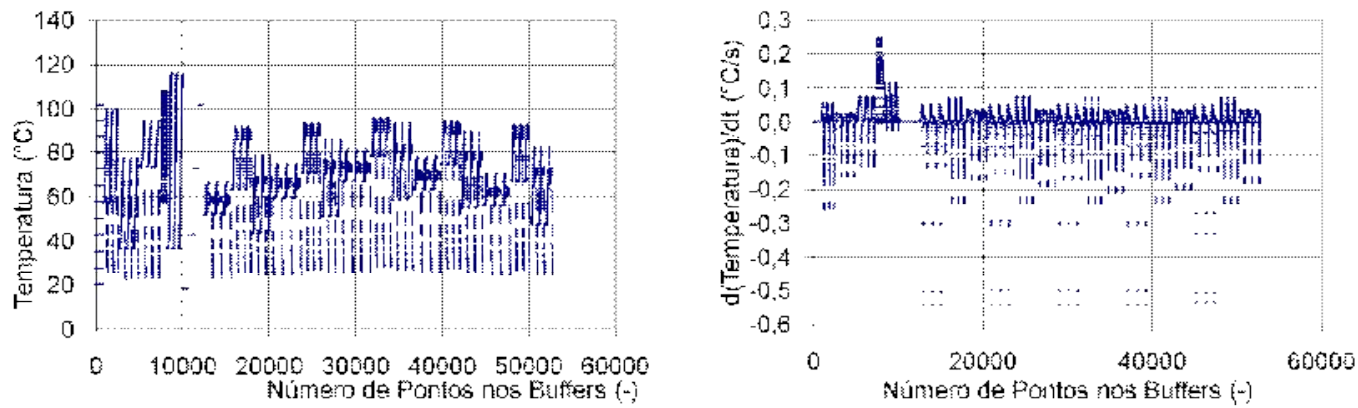

GRÁFICO 61 Temperatura de saída da Seção de Testes e sua derivada no conjunto de buffers AC

Fonte: elaborado pelo autor. 

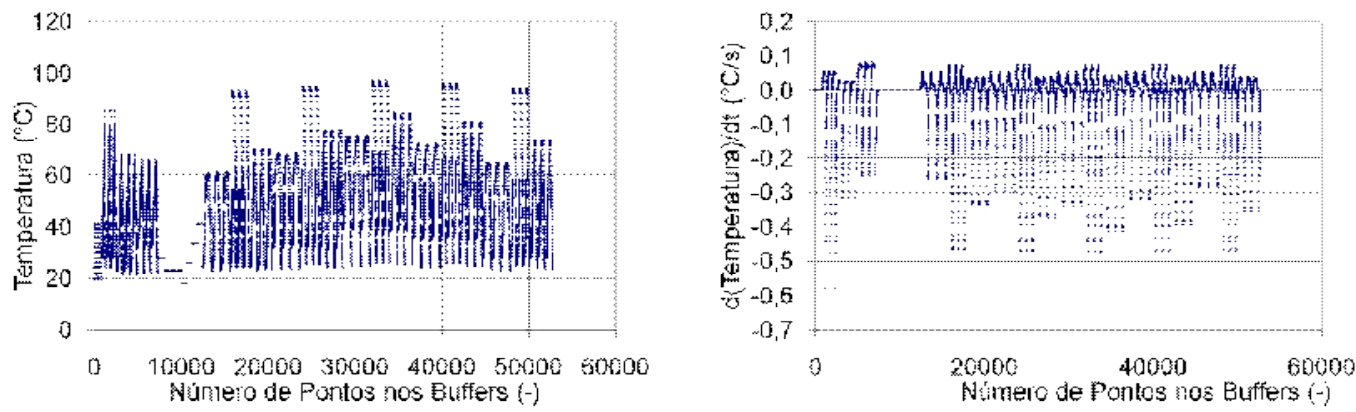

GRÁFICO 62 Temperatura de saída do primário do Trocador de Calor e sua derivada no conjunto de buffers AC

Fonte: elaborado pelo autor.
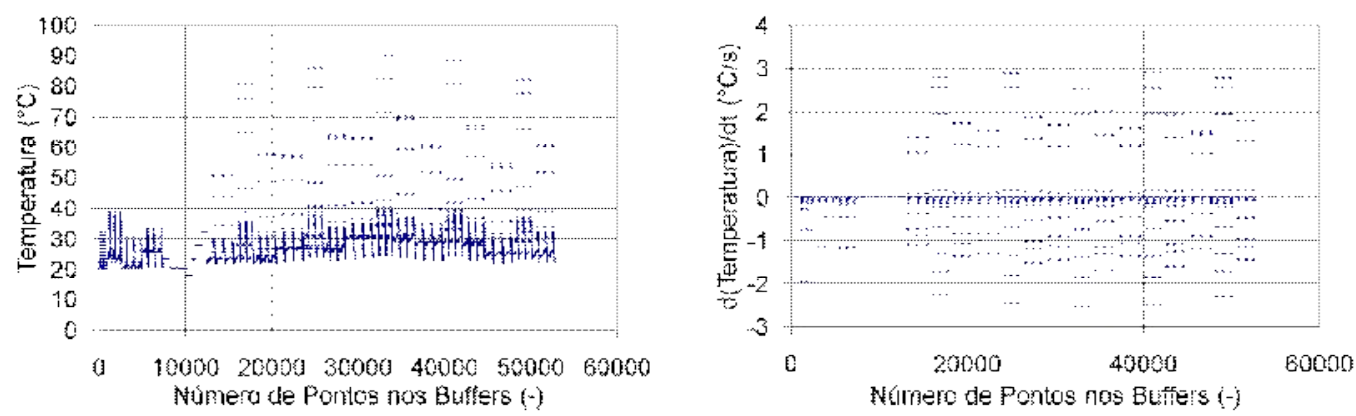

GRÁFICO 63 Temperatura de saída do secundário do Trocador de Calor e sua derivada no conjunto de buffers AC

Fonte: elaborado pelo autor.
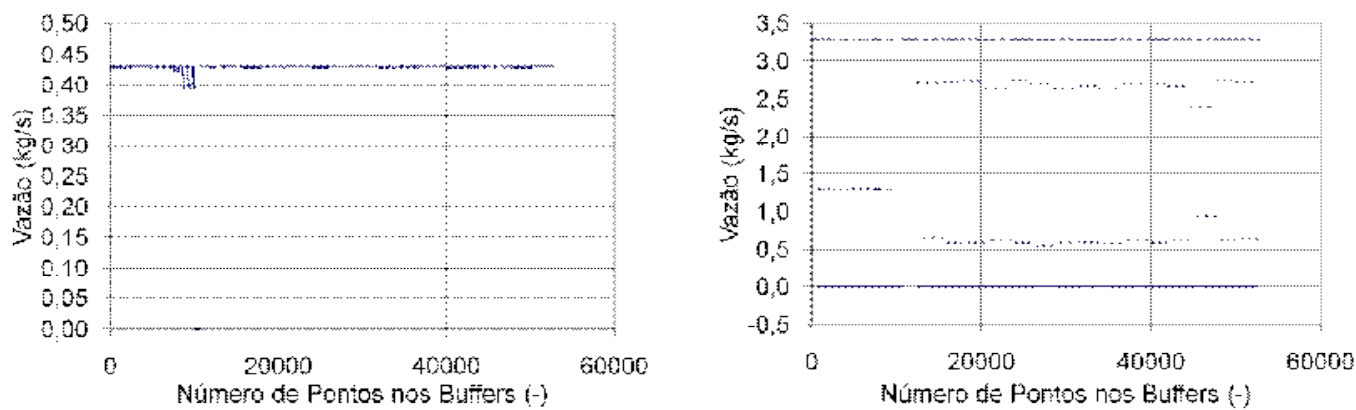

GRÁFICO 64 Vazões do Primário e do Secundário, respectivamente, no conjunto de buffers AC

Fonte: elaborado pelo autor. 


\section{Conjunto de Buffers DR}

Esse conjunto de buffers foi formado a partir das simulações de degraus e rampas de $30 \mathrm{~s}, 120 \mathrm{~s}$ e $240 \mathrm{~s}$ segundos, incluindo as condições de estado estacionário e de transientes.

O QUADRO 11 mostra as simulações do CT1 com o RELAP5 que foram usadas para o construir o conjunto de buffers DR. Da mesma forma que para os conjuntos de buffer ALLOLD e ALLM, cada simulação indicada no QUADRO 11 foi replicada para as pressões de 0,3 e 0,5 MPa. Assim foram usados ( $3 \times 2$ estados estacionários e degraus $+3 \times 6$ rampas) 24 arquivos de simulação como base de dados para o treinamento das redes, gerando um total de 6408 Buffers.

Os GRAF. 65 a 70 mostram os buffers dos diversos parâmetros usados no treinamento da rede com o conjunto de buffers DR, permitindo uma visualização das diferenças com os conjuntos de buffers anteriormente apresentados. A comparação dos GRAF. 68 e 69 com os GRAF. 50 e 51 mostra que na realidade a temperatura praticamente não varias nas saídas do primário e secundário do trocador de calor no caso do conjunto de buffers DR.

QUADRO 11 - Simulações do CT1 com o RELAP5 usadas para formar o conjunto de buffers DR.

\begin{tabular}{l|l|l}
\hline \multicolumn{1}{c|}{$\begin{array}{c}\text { Estados } \\
\text { Estacionários }\end{array}$} & \multicolumn{1}{c|}{ Degraus } & \multicolumn{1}{c}{ Rampas } \\
\hline DD7 & DD7 & R30D \\
\hline DU7 & DU7 & R30U \\
\hline & & R120D \\
\hline & & R120U \\
\hline & & R240D \\
\hline & & R240U \\
\hline
\end{tabular}

Fonte: elaborado pelo autor. 

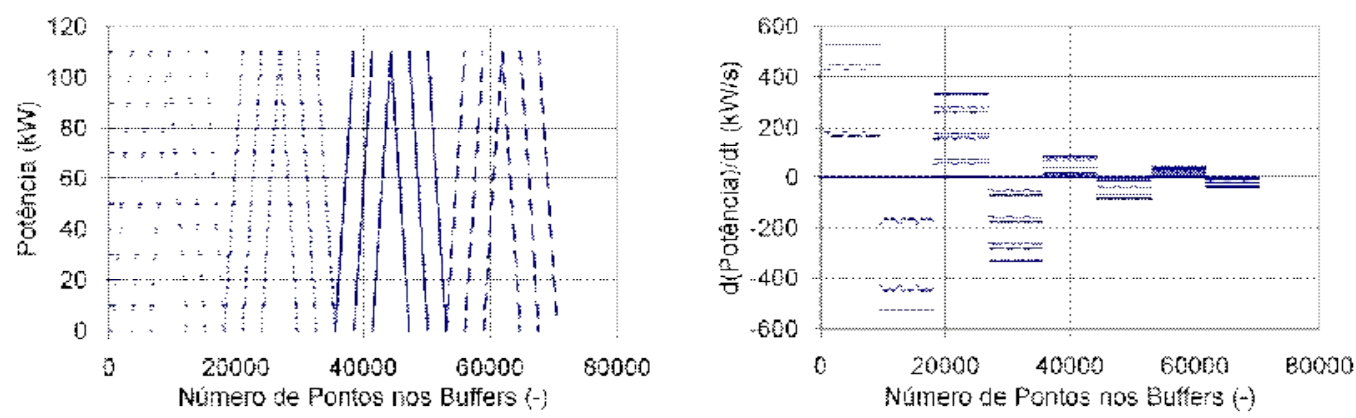

GRÁFICO 65 Potência e sua derivada no conjunto de buffers AC

Fonte: elaborado pelo autor.
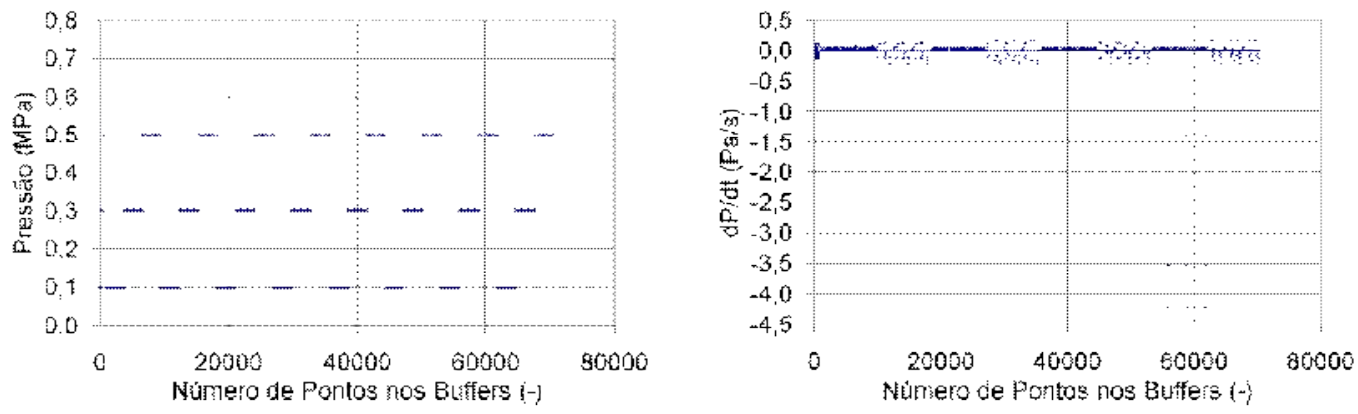

GRÁFICO 66 Pressão e sua derivada no conjunto de buffers AC

Fonte: elaborado pelo autor.
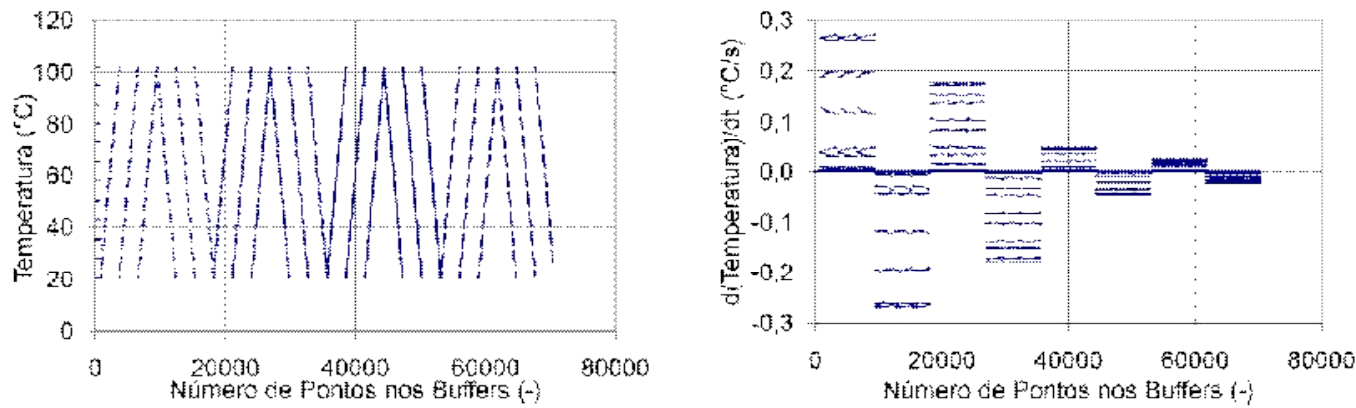

GRÁFICO 67 Temperatura de saída da Seção de Testes e sua derivada no conjunto de buffers AC

Fonte: elaborado pelo autor. 

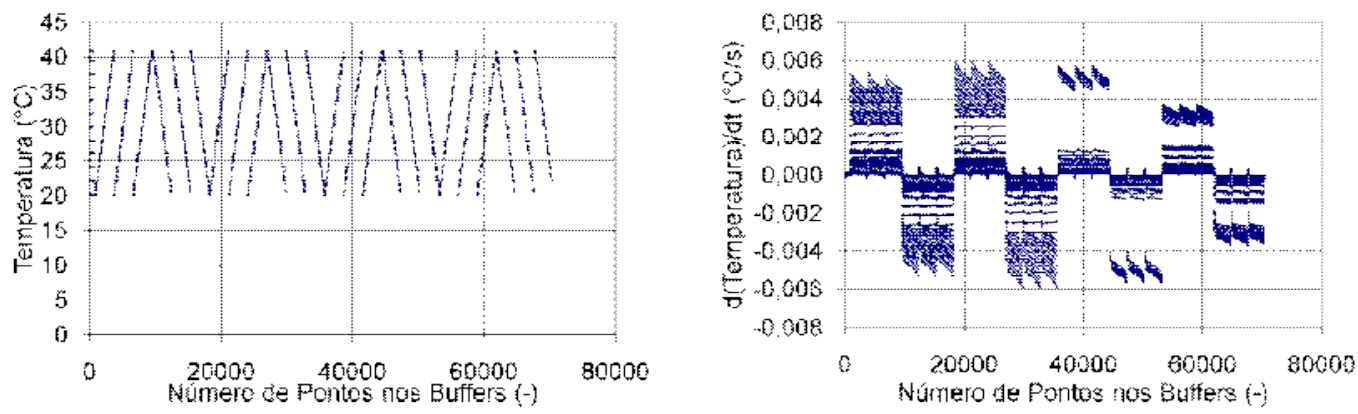

GRÁFICO 68 Temperatura de saída do primário do Trocador de Calor e sua derivada no conjunto de buffers AC

Fonte: elaborado pelo autor.
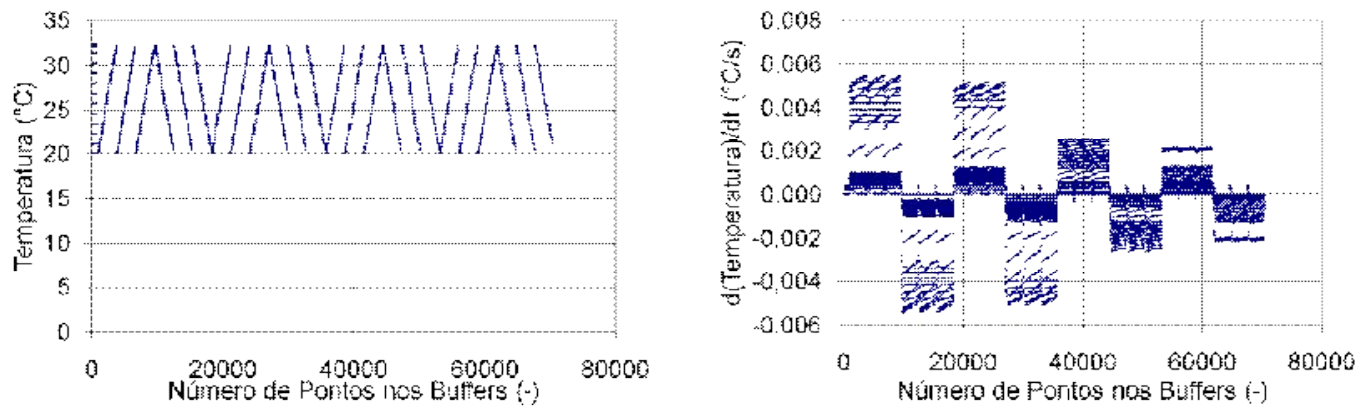

GRÁFICO 69 Temperatura de saída do secundário do Trocador de Calor e sua derivada no conjunto de buffers AC

Fonte: elaborado pelo autor.
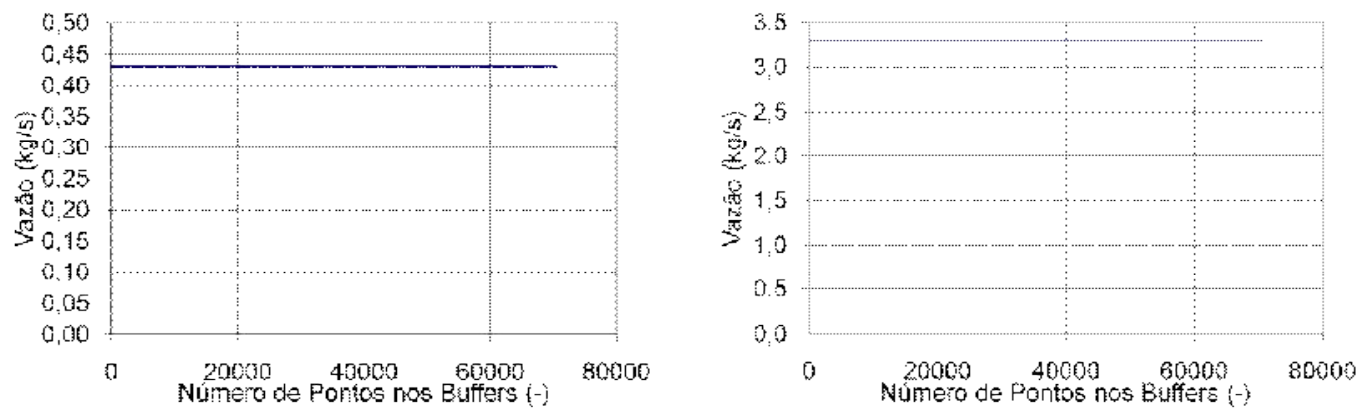

GRÁFICO 70 Vazões do Primário e do Secundário, respectivamente, no conjunto de buffers AC

Fonte: elaborado pelo autor. 


\section{Conjunto de Buffers ALL}

Os buffers ALL são formados pela junção das redes DR e AC. Assim seu treinamento consistiu de estados estacionários, degraus, rampas de 30, $120 \mathrm{e}$ 240 segundos e acidentes, excluindo os intervalos mais graves e a despressurização.

Os resultados das simulações do CT1 com o RELAP5, mostradas no QUADRO 12 foram usados para o treinamento da rede ALL. Foi usado o mesmo esquema de replicação dos resultados para as pressões de 0,3 e 0,5 MPa. Dessa forma, foram usados ( $3 \times 2$ estados estacionários e degraus $+3 \times 6$ rampas $+3 \times 20$ acidentes +4 pressurizações) 88 arquivos de simulação como base de dados para o treinamento das redes, gerando um total de 6498 buffers. 
QUADRO 12 - Simulações do CT1 com o RELAP5 usadas para formar o conjunto de buffers ALL.

\begin{tabular}{|c|c|c|c|}
\hline $\begin{array}{c}\text { Estados } \\
\text { Estacionários }\end{array}$ & Degraus & Rampas & Acidentes \\
\hline DD7 & DD7 & R30D & $\begin{array}{l}\text { DESLBS20 } \\
\text { DESLBS40 } \\
\text { DESLBS60 } \\
\text { DESLBS80 } \\
\text { DESLBS100 }\end{array}$ \\
\hline \multirow[t]{5}{*}{ DU7 } & DU7 & R30U & $\begin{array}{l}\text { DESLBS20_2 } \\
\text { DESLBS40_2 } \\
\text { DESLBS60_2 } \\
\text { DESLBS80_2 } \\
\text { DESLBS100_2 }\end{array}$ \\
\hline & & R120D & $\begin{array}{l}\text { DESLBS20_3 } \\
\text { DESLBS40_3 } \\
\text { DESLBS60_3 } \\
\text { DESLBS803 } \\
\text { DESLBS100_3 }\end{array}$ \\
\hline & & R120U & $\begin{array}{l}\text { ISOLABS } \\
\text { ISOLABS25 } \\
\text { ISOLABS75 }\end{array}$ \\
\hline & & R240D & $\begin{array}{l}\text { ISOLATC } \\
\text { ISOLATC25 }\end{array}$ \\
\hline & & R240U & $\begin{array}{l}\text { PRESSURZAOK }^{1} \\
\text { PRESSURZA30k } \\
\text { PRESSURZA70k }^{1} \\
\text { PRESSURZA110k }\end{array}$ \\
\hline
\end{tabular}

Fonte: elaborado pelo autor.

${ }^{1}$ As simulações de pressurização não são replicadas para as demais pressões, uma vez que elas atravessam toda a faixa de pressão coberta.

O QUADRO 13 apresenta um sumário dos conjuntos de buffers utilizados para treinamento do SICT para o CT1 e a TAB. 3 mostra as faixas dos parâmetros nos diversos conjuntos de buffers. 
QUADRO 13 - Conjuntos de buffers para treinamento do SICT para o CT1

\begin{tabular}{|c|c|c|c|c|c|}
\hline $\begin{array}{l}\text { ID do } \\
\text { Conjunto } \\
\text { de Buffers }\end{array}$ & $\begin{array}{l}\text { Dimen- } \\
\text { são dos } \\
\text { Buffers }\end{array}$ & $\begin{array}{l}\text { Tamanho } \\
\text { do } \\
\text { Arquivo } \\
\text { (Kb) }\end{array}$ & $\begin{array}{l}\text { Núme- } \\
\text { ro de } \\
\text { Arquivos }\end{array}$ & $\begin{array}{c}\text { Núme- } \\
\text { ro de } \\
\text { Buffers }\end{array}$ & Obs \\
\hline \multirow[t]{2}{*}{ ALLOLD } & $18 \times 10$ & 23.086 & \multirow[t]{2}{*}{58} & \multirow[t]{2}{*}{7537} & $\begin{array}{l}\text { Degraus, Rampas de } 240 \mathrm{~s} \text { e } \\
\text { Acidentes exceto: DesIBS40, } \\
\text { DesIBS80, DesIBS40_2, }\end{array}$ \\
\hline & $10 \times 10$ & 13.076 & & & $\begin{array}{l}\text { DesIBS80_2, DesIBS40_3 e } \\
\text { DesIBS80_3 }\end{array}$ \\
\hline ALLM & $\begin{array}{l}18 \times 10 \\
10 \times 10\end{array}$ & $\begin{array}{l}19.904 \\
11.274\end{array}$ & 58 & 6498 & $\begin{array}{l}\text { Como a ALLOLD, porém } \\
\text { excluindo transientes muito } \\
\text { fortes }\end{array}$ \\
\hline \multirow[t]{2}{*}{$A C$} & $18 \times 10$ & 14.682 & \multirow[t]{2}{*}{70} & \multirow[t]{2}{*}{4794} & Condições Acidentais como em \\
\hline & $10 \times 10$ & 8.315 & & & \\
\hline \multirow{2}{*}{ DR } & $18 \times 10$ & 19.637 & \multirow{2}{*}{24} & \multirow{2}{*}{6408} & \multirow{2}{*}{$\begin{array}{l}\text { Degraus e Rampas de } 30,120 \\
\text { e } 240 \mathrm{~s}\end{array}$} \\
\hline & $10 \times 10$ & 11.127 & & & \\
\hline \multirow{2}{*}{ ALL } & $18 \times 10$ & 34.099 & \multirow{2}{*}{88} & 1113 & \multirow{2}{*}{ União de AC e DR } \\
\hline & $10 \times 10$ & 19.317 & & 0 & \\
\hline
\end{tabular}

Fonte: elaborado pelo autor.

TABELA 3 - Faixa dos parâmetros nos conjuntos de buffers do CT1

\begin{tabular}{l|l|r|r|rr|r|r|r|r|r}
\hline $\begin{array}{l}\text { Conj. de } \\
\text { Buffers }\end{array}$ & & T1 & dT1/dt & T4 & dT4/dt & T5 & dT5/dt & T6 & dT6/dt & T8 \\
\hline \multirow{2}{*}{ ALLOLD } & Max & 145 & 0.35 & 102 & 0.32 & 102 & 2.070 & 102 & 1.710 & 102 \\
\cline { 2 - 11 } & Min & 18 & -2.87 & 18 & -1.76 & 18 & -0.580 & 18 & -0.600 & 18 \\
\multirow{4}{*}{ ALLe } & Max & 116 & 0.27 & 102 & 0.26 & 97 & 0.080 & 102 & 1.700 & 102 \\
\cline { 2 - 12 } & Min & 18 & -0.54 & 18 & -1.27 & 18 & -0.600 & 18 & -0.600 & 18 \\
\hline \multirow{2}{*}{ AC } & Max & 116 & 0.27 & 102 & 0.26 & 97 & 0.080 & 102 & 1.700 & 102 \\
\cline { 2 - 11 } & Min & 18 & -0.54 & 18 & -1.27 & 18 & -0.600 & 18 & -0.600 & 18 \\
\hline \multirow{2}{*}{ DR } & Max & 102 & 0.27 & 102 & 0.25 & 41 & 0.006 & 41 & 0.007 & 41 \\
\cline { 2 - 11 } & Min & 20 & -0.27 & 20 & -0.25 & 20 & -0.006 & 20 & -0.006 & 20 \\
\hline
\end{tabular}

Fonte: elaborado pelo autor. 
TABELA 3 - Faixa dos parâmetros nos conjuntos de buffers do CT1 - Continuação

\begin{tabular}{l|l|r|r|r|rr|r|r|r|r}
\hline & & $\mathbf{d T 8} / \mathbf{d t}$ & $\mathbf{T 9}$ & $\mathbf{d T 9} / \mathbf{d t}$ & $\mathbf{P}$ & $\mathbf{d P} / \mathbf{d t}$ & Vaz.Pr. & Vaz.Sec. & Pot. & dPot/dt \\
\hline \multirow{2}{*}{ ALLOLD } & Max & 0.250 & 102 & 3.31 & 7.0 & 0.0000 & 0.43 & 3.29 & 110000 & 550 \\
\cline { 2 - 11 } & Min & -0.260 & 18 & -2.82 & 1.0 & -0.0500 & 0.00 & 0.00 & 0 & -2000 \\
\hline \multirow{2}{*}{ ALLe } & Max & 0.250 & 90 & 3.00 & 6.2 & 0.0020 & 0.43 & 3.30 & 110000 & 526 \\
\cline { 2 - 11 } & Min & -0.250 & 18 & -2.50 & 1.0 & -0.0005 & 0.00 & 0.00 & 0 & -1053 \\
\hline \multirow{2}{*}{ AC } & Max & 0.250 & 90 & 3.00 & 6.2 & 0.0020 & 0.43 & 3.30 & 110000 & 0 \\
\cline { 2 - 11 } & Min & -0.250 & 18 & -2.50 & 1.0 & -0.0005 & 0.00 & 0.00 & 0 & -1053 \\
\hline \multirow{2}{*}{ DR } & Max & 0.004 & 33 & 0.01 & 5.0 & 1.0000 & 0.43 & 3.30 & 110000 & 526 \\
& Min & -0.004 & 20 & -0.01 & 1.0 & -1.0000 & 0.00 & 0.00 & 0 & -526 \\
\hline
\end{tabular}

Fonte: elaborado pelo autor.

\subsubsection{Uso do SICT com as simulações do CT1 com o RELAP5}

Cada um dos conjuntos de buffers para treinamento da rede, anteriormente identificados como DR, AC, ALL, ALLM e ALLOLD, foi usado em 10 redes diferentes, todas usando geometria hexagonal tanto para a rede quanto para os neurônios. A TAB. 4 mostra as principais características dessas redes. 
TABELA 4 - Redes Hexagonais treinadas para o CT1

\begin{tabular}{c|c|c|c|c}
\hline Identificação & $\begin{array}{c}\text { Número de } \\
\text { Zonas }\end{array}$ & $\begin{array}{c}\text { Número de } \\
\text { Neurônios }\end{array}$ & $\begin{array}{c}\text { Parâmetros } \\
\text { de entrada }\end{array}$ & $\begin{array}{c}\text { Peso das } \\
\text { Derivadas }\end{array}$ \\
\hline 5D2V & 5 & 61 & $18^{*}$ & 2 \\
\hline 5D3V & 5 & 61 & $18^{\star}$ & 3 \\
\hline 710 & 7 & 127 & 10 & - \\
\hline $7 \mathrm{D} 1 \mathrm{~V}$ & 7 & 127 & $18^{\star}$ & 1 \\
\hline 7D2V & 7 & 127 & $18^{*}$ & 2 \\
\hline 7D3V & 7 & 127 & $18^{\star}$ & 3 \\
\hline 810 & 8 & 169 & 10 & - \\
\hline 8D1V & 8 & 169 & $18^{*}$ & 1 \\
\hline 8D2V & 8 & 169 & $18^{*}$ & 2 \\
\hline 8D3V & 8 & 169 & $18^{*}$ & 3 \\
\hline
\end{tabular}

Fonte: elaborado pelo autor.

* Os 18 parâmetros se referem a 10 parâmetros medidos, usados nas demais redes, acrescidos de 8 derivadas desses parâmetros.

Além das redes mostradas na TAB. 4, foram também treinadas, usando o conjunto de buffers ALL, quatro redes com cerca de 160 neurônios, uma rede triangular, uma quadrada, uma hexagonal e uma cúbica. As principais características dessas redes estão mostradas na TAB. 5 .

TABELA 5 - Redes com diferentes geometrias treinadas para o CT1

\begin{tabular}{l|c|c|c|c}
\hline Identificação & $\begin{array}{c}\text { Número de } \\
\text { Zonas }\end{array}$ & $\begin{array}{c}\text { Número de } \\
\text { Neurônios }\end{array}$ & $\begin{array}{c}\text { Parâmetros } \\
\text { de entrada }\end{array}$ & $\begin{array}{c}\text { Peso das } \\
\text { Derivadas }\end{array}$ \\
\hline Tri & 5 & 169 & 18 & 2 \\
\hline Qua & 7 & 169 & 18 & 2 \\
\hline Hex (8D2V) & 8 & 169 & 18 & 2 \\
Cub & 3 & 150 & 18 & 2 \\
\hline
\end{tabular}

Fonte: elaborado pelo autor. 
As avaliações do desempenho do SICT com algumas dessas redes e alguns conjuntos de buffers são apresentados a seguir.

\subsubsection{Rede 5D2V com conjunto de buffers DR ( CT1 - 5D2V - DR )}

A avaliação feita da rede treinada para o CT1 com 5 zonas de neurônios e derivadas com peso 2 usando o conjunto de buffers DR (5D2V - DR), foi sua resposta aos transientes de degrau, conforme calculados com o RELAP5 e obtida usando o modo de monitoração onde os parâmetros são disponibilizados a cada 6 s e os buffers são formados no módulo Networklnput do SICT.

O GRAF.71 mostra a distância entre os buffers do conjunto de treinamento DR e os pesos dos neurônios a eles associados no final do treinamento. Os valores máximos da distância observados são em torno de 8 e correspondem ao buffers associados aos primeiros $300 \mathrm{~s}$ dos transientes. Os buffers cujas distâncias aos pesos dos neurônios ativados por eles são menores que 2 correspondem aos buffers representando condições próximas aos estados estacionários.

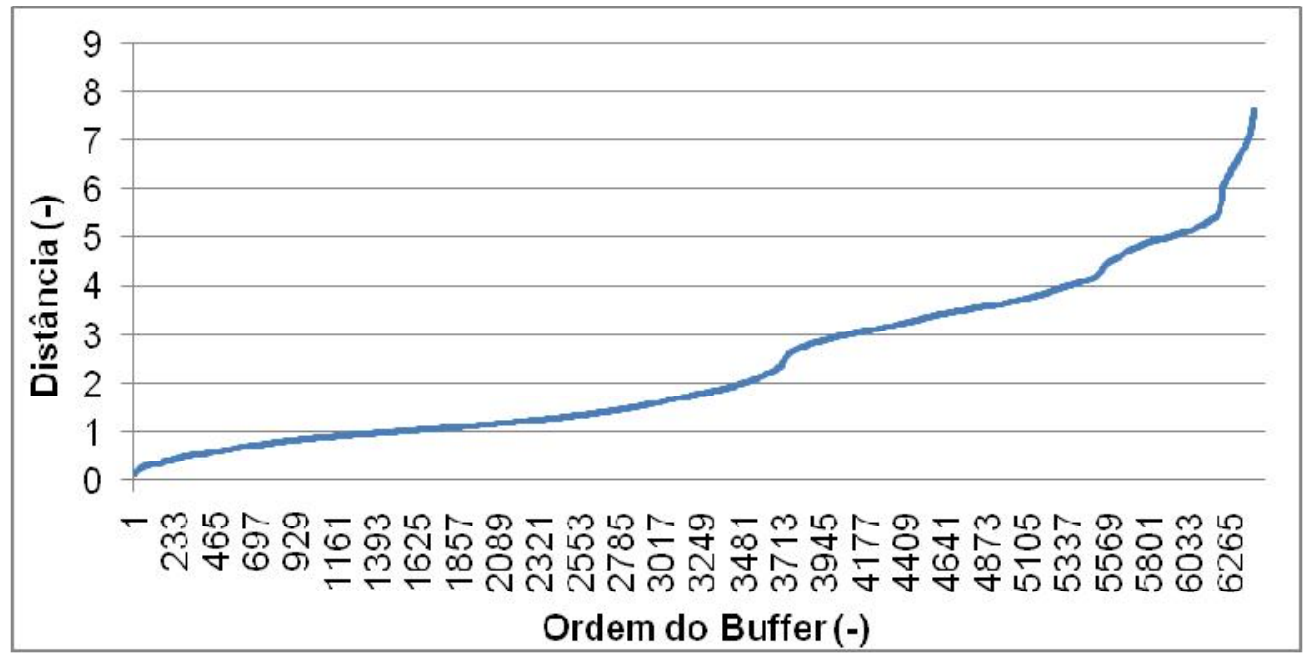

GRÁFICO 71 Distância entre os buffers de treinamento e os pesos dos neurônios para a rede CT1 - 5D2V - DR

Fonte: resultados do SICT 


\section{Teste 1: Avaliação Visual}

A FIG. 46 mostra os neurônios ativados, em cores não branca, durante os transientes de potência decrescente, a esquerda na FIG.46, e ascendente, a direita na mesma figura. Pode-se observar, comparando as duas figuras, que vários neurônios foram ativados em somente um dos casos e outros foram ativados nos dois casos. Esse comportamento está correto, já que neurônios diferentes devem diferenciar os degraus ascendentes daqueles descendentes e os neurônios iguais representariam os estados estacionários antes e depois dos degraus. APROVADA,
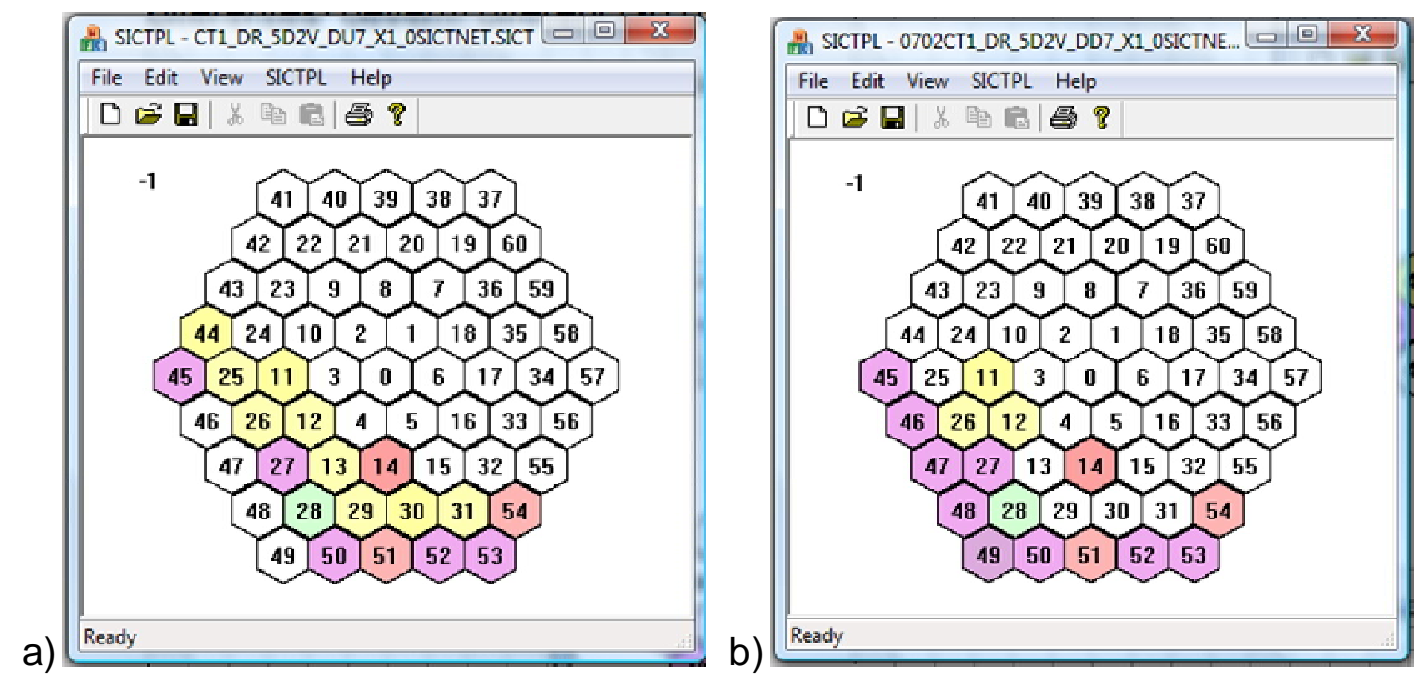

FIGURA 46 Neurônios da rede CT1 - 5D2V - DR ativados em simulações de transientes de potência a)crescente e b)decrescente

Fonte: resultados da pesquisa

\section{Teste 2: Neurônios ativados para identificar o transiente são diferentes dos ativados para identificar os estados estacionários}

A TAB. 6 mostra a sequência dos neurônios ativados durante o início dos degraus descendentes a 1 bar de pressão, em itálico sublinhado, e durante os estados estacionários. A TAB. 7 mostra os neurônios associados, a partir da TAB. 6, aos degraus decrescentes e aos estados estacionários. As TAB. 8 e 9 mostram, de maneira similar à TAB. 6 e 7 respectivamente, os neurônios associados aos degraus ascendentes a 1 bar de pressão e aos estados 
estacionários. A partir da comparação das colunas das TAB. 7 pode-se observar que o neurônio 53 foi associado tanto a um degrau quanto a um estado estacionário. Além disso, fazendo-se uma comparação cruzada entre as TAB. 7 e 9 observa-se que o neurônio 52 foi associado a degrau descendente na TAB. 7 e a estado estacionário na TAB. 9, assim a rede não satisfez os requisitos deste teste. REPROVADA

TABELA 6 - Sequência dos neurônios ativados durante o início dos degraus descendentes e durante os estados estacionários na rede CT1 - 5D2V - DR

\begin{tabular}{c|c}
\hline Tempo & $\begin{array}{c}\text { Evento / } \\
\text { Neurônio } \\
\text { Ativado }\end{array}$ \\
\hline $\mathbf{3 0 0 0}$ & DD_110_100 \\
\hline$\underline{3120}$ & $\underline{52}$ \\
\hline 4488 & 53 \\
\hline $\mathbf{6 0 0 0}$ & DD_100_90 \\
\hline$\underline{6090}$ & $\underline{52}$ \\
\hline $\mathbf{9 0 0 0}$ & DD_90_80 \\
$\underline{9024}$ & $\underline{53}$ \\
\hline 9078 & 52 \\
\hline 9582 & 51 \\
\hline $\mathbf{1 2 0 0 0}$ & DD_80_70 \\
\hline$\underline{12018}$ & $\underline{50}$ \\
\hline 12054 & 49 \\
\hline
\end{tabular}

\begin{tabular}{c|c}
\hline Tempo & $\begin{array}{c}\text { Evento / } \\
\text { Neurônio } \\
\text { Ativado }\end{array}$ \\
\hline 12510 & 50 \\
\hline $\mathbf{1 5 0 0 0}$ & DD_70_60 \\
\hline$\underline{15042}$ & $\underline{49}$ \\
\hline 15768 & $\mathbf{2 8}$ \\
\hline $\mathbf{1 8 0 0 0}$ & DD_60_50 \\
\hline 18024 & $\underline{49}$ \\
\hline 18186 & 48 \\
\hline 19530 & 27 \\
\hline $\mathbf{2 1 0 0 0}$ & DD_50_40 \\
\hline 21012 & $\underline{48}$ \\
\hline 21780 & $\mathbf{2 7}$ \\
\hline $\mathbf{2 4 0 0 0}$ & DD_40_30 \\
\hline
\end{tabular}

\begin{tabular}{c|c}
\hline Tempo & $\begin{array}{c}\text { Evento/ } \\
\text { Neurônio } \\
\text { Ativado }\end{array}$ \\
\hline 24018 & 47 \\
\hline 25236 & 26 \\
\hline 27000 & DD_30_20 \\
\hline$\underline{27018}$ & $\underline{47}$ \\
\hline 27372 & 46 \\
\hline 30000 & DD_20_10 \\
$\underline{30174}$ & $\underline{45}$ \\
\hline 33000 & DD_10_0 \\
\hline$\underline{33018}$ & $\underline{46}$ \\
\hline 33084 & 45 \\
\hline & \\
\hline & \\
\hline
\end{tabular}

Fonte: resultados da pesquisa

TABELA 7 - Neurônios ativados durante o início dos degraus descendentes (DD) e durante os estados estacionários na rede CT1 - 5D2V - DR

\begin{tabular}{c|c}
\hline $\begin{array}{c}\text { Início de degrau } \\
\text { descendente }\end{array}$ & $\begin{array}{c}\text { Estado } \\
\text { estacionário }\end{array}$ \\
\hline 45 & 26 \\
\hline 46 & 27 \\
\hline 47 & 28 \\
\hline 48 & 45 \\
\hline 49 & 46 \\
\hline 50 & 50 \\
\hline 52 & 51 \\
53 & 53 \\
\hline
\end{tabular}

Fonte: resultados da pesquisa 
TABELA 8 - Sequência dos neurônios ativados durante o início dos degraus ascendentes e durante os estados estacionários na rede CT1 - 5D2V - DR

\begin{tabular}{c|c}
\hline Tempo & $\begin{array}{c}\text { Evento / } \\
\text { Neurônio } \\
\text { Ativado }\end{array}$ \\
\hline $\mathbf{3 0 0 0}$ & DU_0_10 \\
\hline$\underline{3018}$ & $\underline{44}$ \\
\hline 3108 & 25 \\
\hline 3156 & 11 \\
\hline 3342 & 25 \\
\hline 4290 & 45 \\
\hline 6000 & DU_10_20 \\
\hline 6018 & 44 \\
\hline 6084 & 25 \\
\hline 6132 & 11 \\
\hline 6474 & 25 \\
\hline 9000 & DU_20_30 \\
\hline$\underline{9024}$ & $\underline{44}$ \\
\hline 9078 & 25 \\
\hline 9108 & 11 \\
\hline
\end{tabular}

\begin{tabular}{|c|c|}
\hline Tempo & $\begin{array}{l}\text { Evento / } \\
\text { Neurônio } \\
\text { Ativado }\end{array}$ \\
\hline 9660 & 26 \\
\hline 12000 & DU_30_40 \\
\hline 12024 & $\underline{12}$ \\
\hline 12114 & 11 \\
\hline 12510 & 12 \\
\hline 12870 & 26 \\
\hline 12912 & 27 \\
\hline 15000 & DU_40_50 \\
\hline$\underline{15018}$ & $\underline{12}$ \\
\hline 15150 & 11 \\
\hline 15324 & 12 \\
\hline 15642 & 27 \\
\hline 18000 & DU_50_60 \\
\hline$\underline{18012}$ & 13 \\
\hline 18732 & 28 \\
\hline
\end{tabular}

\begin{tabular}{c|c}
\hline Tempo & $\begin{array}{c}\text { Evento / } \\
\text { Neurônio } \\
\text { Ativado }\end{array}$ \\
\hline $\mathbf{2 1 0 0 0}$ & DU_60_70 \\
\hline$\underline{21018}$ & $\underline{13}$ \\
\hline 21042 & 14 \\
\hline 21078 & 29 \\
\hline 22542 & 50 \\
\hline 24000 & DU_70_80 \\
\hline$\underline{24006}$ & $\underline{29}$ \\
\hline 24030 & 14 \\
\hline 24078 & 29 \\
\hline 24774 & 51 \\
\hline 27000 & DU_80_90 \\
\hline$\underline{27018}$ & $\underline{30}$ \\
\hline 27126 & 29 \\
\hline 27162 & 54 \\
\hline 27504 & 51 \\
\hline
\end{tabular}

\begin{tabular}{c|c}
\hline Tempo & $\begin{array}{c}\text { Evento/ } \\
\text { Neurônio } \\
\text { Ativado }\end{array}$ \\
\hline 28236 & 52 \\
\hline 30000 & DU_90_100 \\
\hline$\underline{30018}$ & $\underline{30}$ \\
\hline 30090 & 31 \\
\hline 30126 & 54 \\
\hline 30738 & 31 \\
\hline 31332 & 53 \\
\hline 33000 & DU_100_110 \\
\hline$\underline{33006}$ & $\underline{31}$ \\
\hline 33036 & 30 \\
\hline 33072 & 31 \\
\hline 33114 & 54 \\
\hline 33822 & 53 \\
\hline & \\
\hline & \\
\hline
\end{tabular}

Fonte: resultados da pesquisa

TABELA 9 - Neurônios ativados durante o início dos degraus ascendentes e durante os estados estacionários na rede CT1 - 5D2V - DR

\begin{tabular}{c|c}
\hline $\begin{array}{c}\text { Início de degrau } \\
12\end{array}$ & $\begin{array}{c}\text { Estado } \\
25\end{array}$ \\
\hline 13 & 26 \\
\hline 29 & 27 \\
\hline 30 & 28 \\
\hline 31 & 45 \\
\hline 44 & 50 \\
\hline & 51 \\
\hline & 52 \\
& 53 \\
\hline
\end{tabular}

Fonte: resultad os da pesquisa 
Teste 3: Neurônios ativados para identificar degrau ascendente diferentes daqueles usados para identificar os degraus descendentes

Da comparação da coluna "Início de degrau" nas TAB. 7 e 9 pode-se comprovar que os neurônios associados a transientes diferentes são diferentes. Nenhum neurônio associado a degrau ascendente foi associado a degrau descendente. Assim a rede satisfez os requisitos desse teste. APROVADA

\section{Teste 4: Reconhecer todos os transientes e estados estacionários}

Na TAB. 6 pode-se observar que a rede não reconheceu os degraus estados estacionários após os degraus descendentes em $6000 \mathrm{~s}$ e em $30000 \mathrm{~s}$. Assim a rede também não satisfez os requisitos deste teste. REPROVADA

Teste 5: Os estados estacionários semelhantes após os casos ascendentes e descendentes são identificados pelos mesmos neurônios.

Durante o monitoramento com os degraus ascendentes todos os demais neurônios foram associados corretamente, com exceção do neurônio 52, que foi assossiado erradamente ao estado estacionário, conforme mostrado na TAB. 6. Essa rede não satisfaz, portanto os requisitos deste teste. REPROVADA,

Teste 6: As distâncias entre os buffers e os pesos do neurônio vencedor são compatíveis com os de treinamento.

O GRAF. 72 mostra que, durante o processo de monitoramento a partir dos dados de simulação dos degraus descendentes, as distâncias, para todos os buffers associados aos transientes e estados estacionários em que a rede foi treinada, são compatíveis com as distâncias obtidas durante o treinamento, GRAF. 71. Pode-se observar, nos GRAF. 72.b e 72.c, que durante os transientes o valor da distância chega até cerca de 8,5 enquanto durante os estados estacionários ela fica em torno de 1. A distância para eventos não treinados é até uma ordem de grandeza maior que esses valores, como pode ser observado nos primeiros $3000 \mathrm{~s}$ do GRAF. 72.a, cujo evento é um degrau de potência de 0 a 
$100 \%$ para o qual a rede não foi treinada. Esses resultados, homogêneos entre cada classe, mostram a adequação da rede a esse critério.

a)
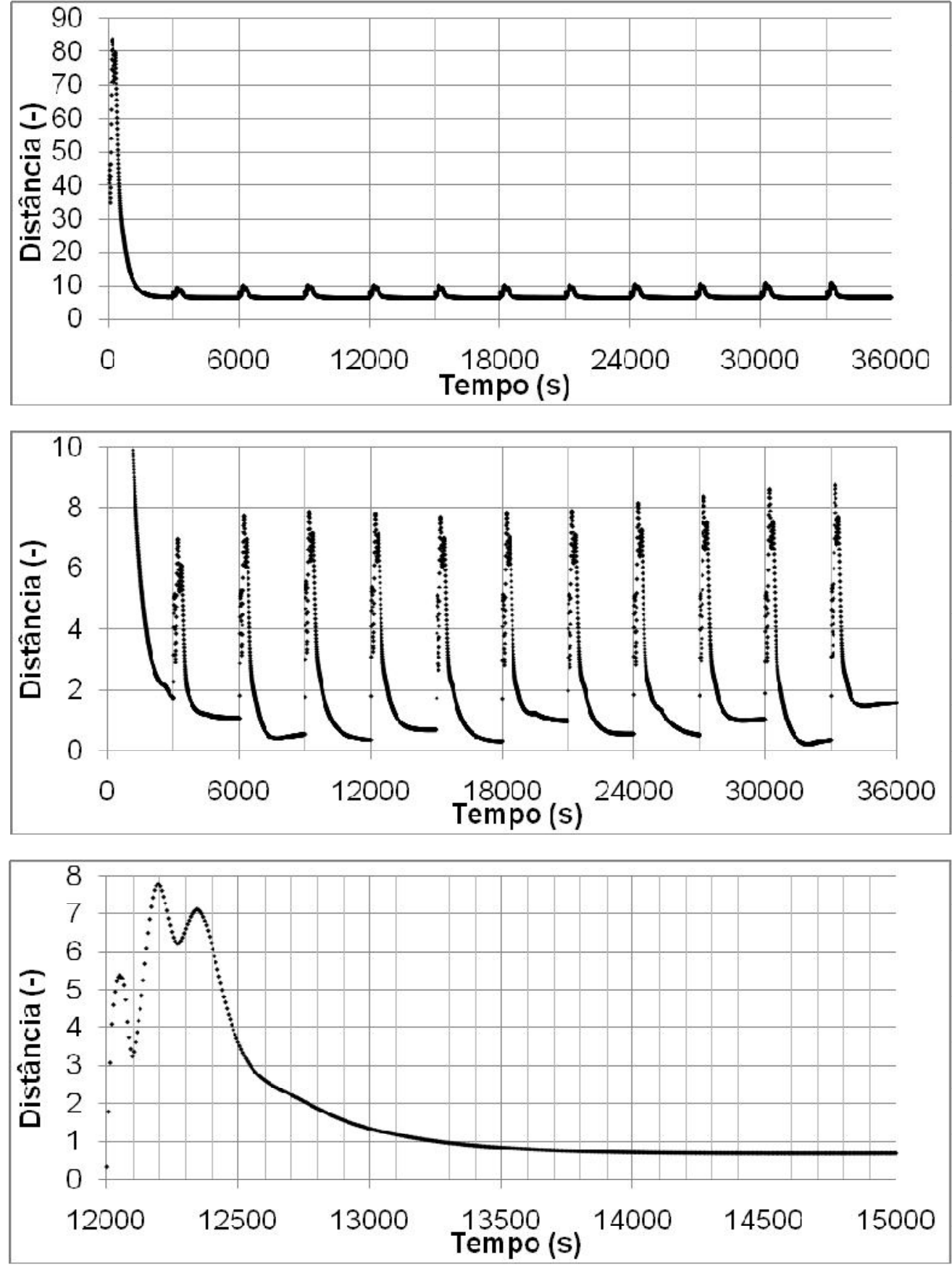

GRÁFICO 72 Distância entre os buffers e os pesos dos neurônios vencedores para degraus descendentes da rede CT1 - 5D2V - DR para o CT1

Fonte: resultados da pesquisa 
Para o monitoramento dos degraus ascendentes os valores e comportamento obtidos para essas distâncias são similares aos dos degraus descendentes, com exceção dos 3000 s iniciais que não representava um degrau de $100 \%$ da potência, mas sim um estado estacionário de potência nula. Considerando os valores e comportamentos observados a rede satisfaz os requisitos deste teste. APROVADA.

\section{CONCLUSÕES}

QUADRO 14 - Sumário das avaliações da rede 5D2V- DR para o CT1

\begin{tabular}{l|l|l}
\hline \multicolumn{1}{c|}{ Teste } & \multicolumn{1}{c}{ Resultado } \\
\hline 1 & Visual & APROVADA \\
\hline 2 & $\begin{array}{l}\text { Identificação de Transientes diferente de estados } \\
\text { estacionários }\end{array}$ & REPROV ADA \\
\hline 3 & $\begin{array}{l}\text { Identificação distinta de deg raus ascendentes e } \\
\text { descendentes }\end{array}$ & APROVADA \\
\hline 4 & Identificar todos transientes e estados estacionários & REPROV ADA \\
\hline 5 & Estados estacionários iguais nas duas avaliações & REPROV ADA \\
\hline 6 & $\begin{array}{l}\text { Distância entre os buffers e os pesos dos neurônios } \\
\text { vencedores }\end{array}$ & APROVADA \\
\hline
\end{tabular}

Fonte: elaborado pelo autor

Conforme resumido no QUADRO 14, esta rede que foi treinada especificamente para reconhecer, além dos estados estacionários, transientes de potência tipo degrau e rampa não reconhece satisfatoriamente esses transientes. Como a distância dos buffers aos pesos dos neurônios está dentro da faixa esperada e ela foi treinada com um conjunto de buffers simplificado com somente degraus, rampas e estados estacionários, conclui-se que a rede 5D2V não tem capacidade de discriminar os transientes do CT1. 


\subsubsection{Rede 5D3V com conjunto de buffers DR ( CT1 - 5D3V - DR )}

Essa rede é como a anterior 5D2V-DR, porém os pesos das derivadas foram feitos iguais a 3 e o GRAF. 73 mostra a distância entre os buffers de treinamento e os pesos dos neurônios associados a eles no fim do treinamento. Os valores máximos da distância observados é de cerca de 11, que correspondem ao buffers associados aos primeiros $400 \mathrm{~s}$ dos transientes e as distâncias abaixo de 3 correspondem aos buffers do fim do estado estacionário.

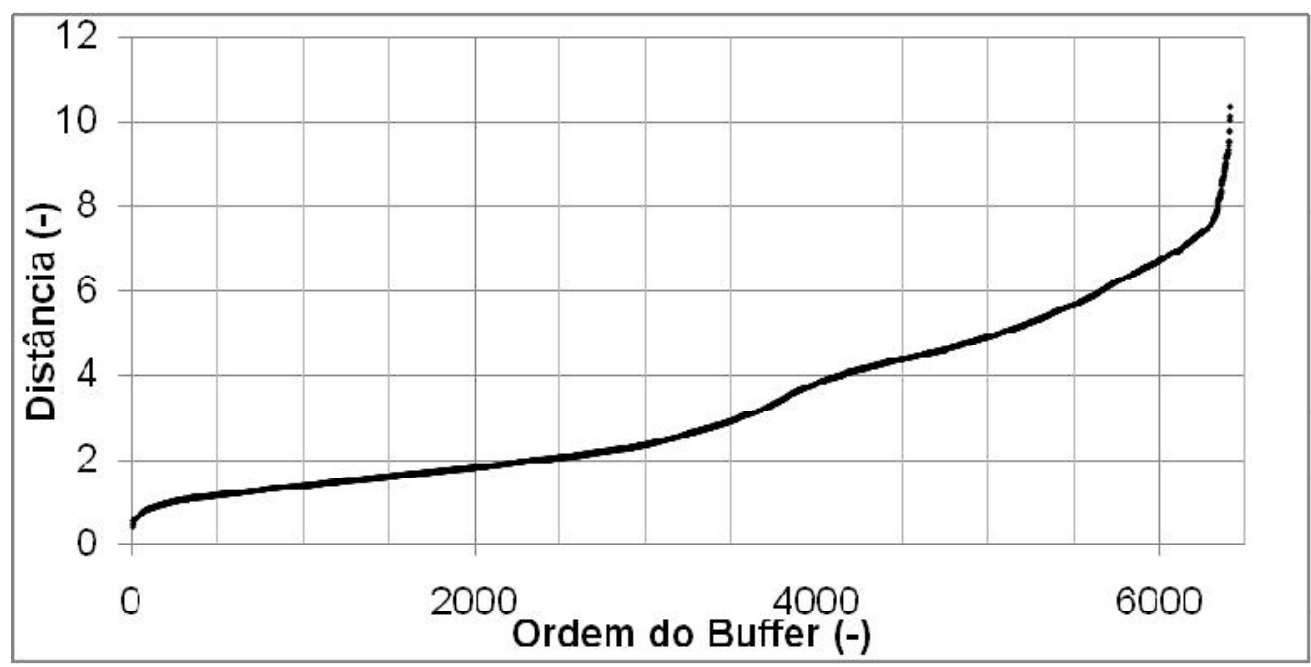

GRÁFICO 73 Distância entre os buffers de treinamento e os pesos dos neurônios para a rede CT1 - 5D3V - DR

Fonte: resultados do SICT

\section{Teste 1: Avaliação Visual}

A FIG. 47 mostra os neurônios ativados, em cores não branca, durante os transientes de potência decrescente, a esquerda na FIG.47, e ascendente, a direita na mesma figura. Pode-se observar, comparando as duas figuras, que vários neurônios foram ativados em somente um dos casos e outros foram ativados nos dois casos. Esse comportamento está correto, já que neurônios diferentes devem diferenciar os degraus ascendentes daqueles descendentes e os neurônios iguais representariam os estados estacionários antes e depois dos degraus. APROVADA, 
a)

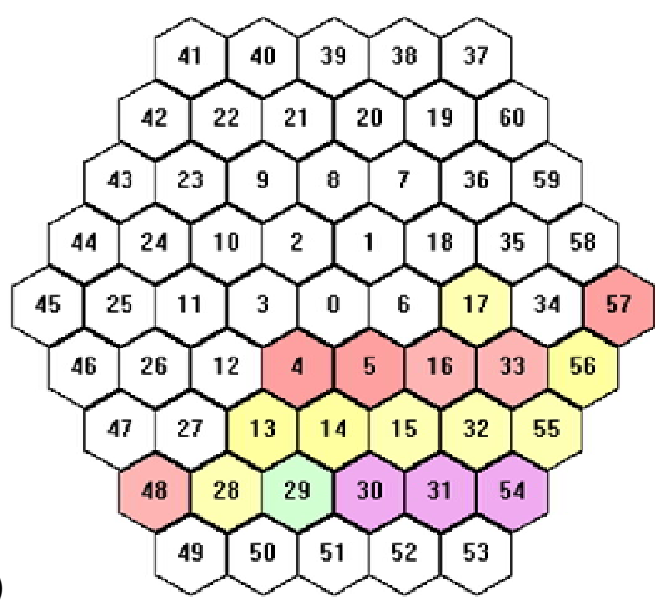

b)

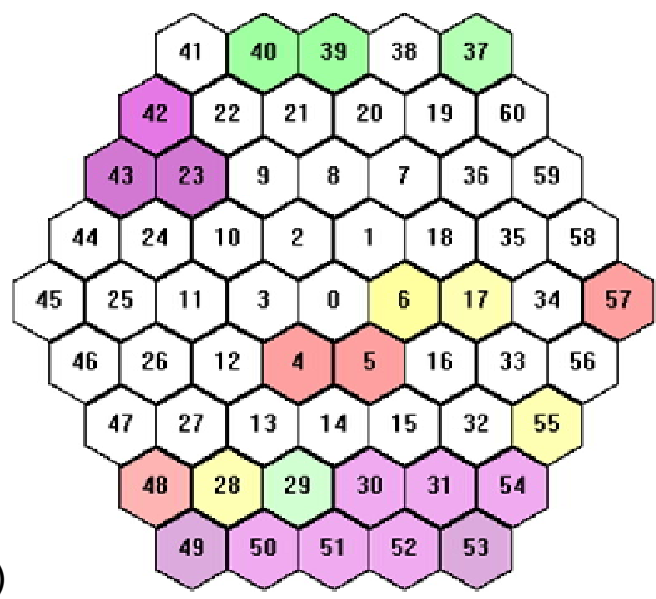

FIGURA 47 Neurônios da rede 5D3V - DR ativados em transientes de potência a) crescente e b) decrescente

Fonte: resultados da pesquisa

Teste 2: Neurônios ativados para identificar o transiente são diferentes dos ativados para identificar os estados estacionários

As TAB. 10 e 11 mostram a evolução dos neurônios associados aos degraus decrescentes e ascendentes, respectivamente, e aos estados estacionários, a 1 bar de pressão. As TAB. 12 e 13 mostram, respectivamente, os neurônios associados aos degraus ascendentes e descendentes e aos estados estacionários. A partir da comparação das colunas das TAB. 12 e 13, independentemente ou em conjunto, pode-se observar que nenhum neurônio foi associado a um degrau e a um estado estacionário simultaneamente. Portanto a rede satisfaz os requisistos deste teste. APROVADA

\section{Teste 3: Neurônios ativados para identificar degrau ascendente diferentes daqueles usados para identificar os degraus descendentes}

Da comparação da coluna "Início de degrau" nas TAB. 12 e 13 pode-se comprovar que os neurônios associados a transientes diferentes são diferentes. Nenhum neurônio associado a degrau ascendente foi associado a degrau descendente. Assim a rede satisfez os requisitos desse teste. APROVADA 
TABELA 10 - Sequência dos neurônios ativados durante o início dos degraus descendentes e durante os estados estacionários na rede 5D3V - DR

\begin{tabular}{c|c}
\hline Tempo & $\begin{array}{c}\text { Evento/ } \\
\text { Neurônio } \\
\text { Ativado }\end{array}$ \\
\hline 3000 & DD_110_100 \\
\hline$\underline{3006}$ & $\underline{49}$ \\
\hline 3066 & 50 \\
\hline 3144 & 43 \\
\hline 3156 & 42 \\
\hline 3264 & 43 \\
\hline 3462 & 50 \\
\hline 3486 & 28 \\
\hline 6000 & DD_100_90 \\
\hline$\underline{6012}$ & $\underline{49}$ \\
\hline 6060 & 50 \\
\hline 6132 & 43 \\
\hline 6138 & 42 \\
\hline 6318 & 43 \\
\hline 6540 & 50 \\
\hline 6960 & 28 \\
\hline 9000 & DD_90_80 \\
\hline 9012 & $\underline{49}$ \\
\hline 9054 & 50 \\
\hline 9132 & 42 \\
\hline 9366 & 43 \\
\hline
\end{tabular}

\begin{tabular}{c|c}
\hline Tempo & $\begin{array}{c}\text { Evento / } \\
\text { Neurônio } \\
\text { Ativado }\end{array}$ \\
\hline 9552 & 29 \\
\hline 12000 & DD_80_70 \\
\hline$\underline{12018}$ & $\underline{49}$ \\
\hline 12048 & 40 \\
\hline 12066 & 50 \\
\hline 12072 & 51 \\
\hline 12126 & 42 \\
\hline 12432 & 43 \\
\hline 12510 & 23 \\
\hline 12528 & 29 \\
\hline 15000 & DD_70_60 \\
\hline 15012 & $\underline{51}$ \\
\hline 15042 & 40 \\
\hline 15066 & 51 \\
\hline 15126 & 42 \\
\hline 15486 & 23 \\
\hline 15504 & 30 \\
\hline 18000 & DD_60_50 \\
\hline 18018 & $\underline{51}$ \\
\hline 18024 & 52 \\
\hline 18042 & 40 \\
\hline
\end{tabular}

\begin{tabular}{c|c}
\hline Tempo & $\begin{array}{c}\text { Evento / } \\
\text { Neurônio } \\
\text { Ativado }\end{array}$ \\
\hline 18072 & 51 \\
\hline 18126 & 42 \\
\hline 18468 & 30 \\
\hline 21000 & DD_50_40 \\
\hline 21012 & $\underline{52}$ \\
\hline 21042 & 39 \\
\hline 21048 & 40 \\
\hline 21066 & 52 \\
\hline 21132 & 42 \\
\hline 21432 & 31 \\
\hline 24000 & DD_40_30 \\
\hline 24012 & $\underline{52}$ \\
\hline 24036 & 39 \\
\hline 24054 & 40 \\
\hline 24066 & 53 \\
\hline 24078 & 52 \\
\hline 24138 & 42 \\
\hline 24366 & 37 \\
\hline 24408 & 31 \\
\hline 27000 & DD_30_20 \\
\hline 27018 & 53 \\
\hline 29059 \\
\hline
\end{tabular}

\begin{tabular}{c|c}
\hline Tempo & $\begin{array}{c}\text { Evento / } \\
\text { Neurônio } \\
\text { Ativado }\end{array}$ \\
\hline 27042 & 39 \\
\hline 27054 & 53 \\
\hline 27132 & 37 \\
\hline 27156 & 42 \\
\hline 27282 & 37 \\
\hline 27444 & 54 \\
\hline 30000 & DD_20_10 \\
\hline$\underline{30018}$ & $\underline{53}$ \\
\hline 30042 & $\underline{39}$ \\
\hline 30054 & 53 \\
\hline 30096 & 54 \\
\hline 30126 & 37 \\
\hline 30186 & 42 \\
\hline 30222 & 37 \\
\hline 30456 & 54 \\
\hline 33000 & DD_10_0 \\
\hline$\underline{33024}$ & $\underline{53}$ \\
\hline 33090 & 54 \\
\hline 33126 & 37 \\
\hline 33474 & 54 \\
\hline 34320 & 55 \\
\hline
\end{tabular}

Fonte: resultados da pesquisa 
TABELA 11 - Sequência dos neurônios ativados durante o início dos degraus ascendentes e durante os estados estacionários na rede 5D3V - DR

\begin{tabular}{c|c}
\hline Tempo & $\begin{array}{c}\text { Evento / } \\
\text { Neurônio } \\
\text { Ativado }\end{array}$ \\
\hline 3000 & DU_0_10 \\
\hline$\underline{3036}$ & $\underline{57}$ \\
\hline 3054 & 56 \\
\hline 3084 & 55 \\
\hline 3102 & 33 \\
\hline 3156 & 17 \\
\hline 3336 & 33 \\
\hline 3702 & 55 \\
\hline 6000 & DU_10_20 \\
\hline$\underline{6030}$ & $\underline{57}$ \\
\hline 6054 & 56 \\
\hline 6084 & 33 \\
\hline 6150 & 17 \\
\hline 6378 & 33 \\
6888 & 32 \\
\hline 8046 & 54 \\
\hline 9000 & DU_20_30 \\
\hline 9006 & $\underline{32}$ \\
\hline 9030 & 57 \\
\hline 9054 & 56 \\
9084 & 33 \\
\hline 9138 & 17 \\
\hline 9420 & 33 \\
\hline \hline 30 \\
\hline 30
\end{tabular}

\begin{tabular}{c|c}
\hline Tempo & $\begin{array}{c}\text { Evento/ } \\
\text { Neurônio } \\
\text { Ativado }\end{array}$ \\
\hline 9816 & 32 \\
\hline 11166 & 31 \\
\hline 12000 & DU_30_40 \\
\hline 12006 & $\underline{32}$ \\
\hline 12036 & 57 \\
\hline 12054 & 56 \\
\hline 12066 & 5 \\
\hline 12078 & 16 \\
\hline 12132 & 17 \\
\hline 12474 & 16 \\
\hline 12852 & 15 \\
\hline 12996 & 31 \\
\hline 15000 & DU_40_50 \\
\hline 15012 & $\underline{15}$ \\
\hline 15036 & 57 \\
\hline 15054 & 5 \\
15084 & 16 \\
\hline 15138 & 17 \\
\hline 15462 & 16 \\
\hline 15756 & 15 \\
\hline 16338 & 30 \\
\hline 18000 & DU_50_60 \\
\hline 18006 & $\underline{15}$ \\
\hline 150
\end{tabular}

\begin{tabular}{|c|c|}
\hline Tempo & $\begin{array}{c}\text { Evento/ } \\
\text { Neurônio } \\
\text { Ativado }\end{array}$ \\
\hline 18042 & 14 \\
\hline 18048 & 4 \\
\hline 18054 & 5 \\
\hline 18084 & 16 \\
\hline 18138 & 17 \\
\hline 18456 & 16 \\
\hline 18642 & 30 \\
\hline 21000 & DU_60_70 \\
\hline 21018 & $\underline{14}$ \\
\hline 21042 & 4 \\
\hline 21060 & 5 \\
\hline 21090 & 16 \\
\hline 21138 & 17 \\
\hline 21444 & 16 \\
\hline 21474 & 14 \\
\hline 21606 & 29 \\
\hline 24000 & DU_70_80 \\
\hline$\underline{24018}$ & $\underline{14}$ \\
\hline 24042 & 4 \\
\hline 24066 & 5 \\
\hline 24090 & 14 \\
\hline 24114 & 48 \\
\hline 24138 & 17 \\
\hline
\end{tabular}

\begin{tabular}{c|c}
\hline Tempo & $\begin{array}{c}\text { Evento/ } \\
\text { Neurônio } \\
\text { Ativado }\end{array}$ \\
\hline 24336 & 48 \\
\hline 24630 & 29 \\
\hline 27000 & DU_80_90 \\
\hline$\underline{27018}$ & $\underline{13}$ \\
\hline 27042 & 4 \\
\hline 27066 & 5 \\
\hline 27084 & 48 \\
\hline 27162 & 17 \\
\hline 27252 & 48 \\
\hline 27822 & 28 \\
\hline 30000 & DU_90_100 \\
\hline$\underline{30012}$ & $\underline{13}$ \\
\hline 30048 & 4 \\
\hline 30072 & 5 \\
30078 & 48 \\
\hline 30912 & 28 \\
\hline 33000 & DU_100_110 \\
\hline 33018 & $\underline{13}$ \\
\hline 33048 & 4 \\
\hline 33072 & 48 \\
33924 & 28 \\
\hline 36000 & Fim \\
\hline 30 \\
\hline 30
\end{tabular}

Fonte: resultados da pesquisa 
TABELA 12 - Neurônios ativados durante o início dos degraus descendentes (DD) e durante os estados estacionários na rede 5D3V - DR

\begin{tabular}{c|c}
\hline $\begin{array}{c}\text { Início de degrau } \\
\text { descendente }\end{array}$ & $\begin{array}{c}\text { Estado } \\
\text { estacionário }\end{array}$ \\
\hline 39 & 28 \\
\hline 40 & 29 \\
\hline 49 & 30 \\
\hline 50 & 31 \\
\hline 51 & 54 \\
52 & 55 \\
\hline 53 & \\
\hline
\end{tabular}

Fonte: resultados da pesquisa

TABELA 13 - Neurônios ativados durante o início dos degraus ascendentes e durante os estados estacionários na rede 5D3V - DR

\begin{tabular}{c|c}
\hline $\begin{array}{c}\text { Início de degrau } \\
\text { ascendente } \\
4\end{array}$ & $\begin{array}{c}\text { Estado } \\
\text { estacionário } \\
28\end{array}$ \\
\hline 5 & 29 \\
13 & 30 \\
\hline 14 & 31 \\
\hline 15 & 54 \\
\hline 32 & 55 \\
56 & \\
\hline 57 & \\
\hline
\end{tabular}

Fonte: resultados da pesquisa

\section{Teste 4: Reconhecer todos os transientes e estados estacionários}

Nas TAB. 10 e 11 pode-se observar que a rede reconheceu todos os eventos monitorados, degraus ascendentes, descendentes e estados estacionários. Assim a rede satisfaz os requisitos deste teste. APROVADA. 
Teste 5: Os estados estacionários semelhantes após os casos ascendentes e descendentes são identificados pelos mesmos neurônios.

A TAB. 14, retirada das TAB. 10 e 11 mostra que a rede reconhece adequadamente os estados estacionários, independentemente do caminho pelo qual ele foi alcançado, e discrimina os estados estacionários de alta, média e baixa potência.

TABELA 14 - Neurônios associados aos estados estacionários a diversas potências na rede 5D3V - DR

\begin{tabular}{c|c}
\hline Potência (kW) & Neurônio \\
\hline 0 & 55 \\
\hline 10 & $54 / 55$ \\
\hline 20 & 54 \\
\hline 30 & 31 \\
\hline 40 & 31 \\
\hline 50 & 30 \\
\hline
\end{tabular}

\begin{tabular}{c|c}
\hline Potência (kW) & Neurônio \\
\hline 60 & 30 \\
\hline 70 & 29 \\
\hline 80 & 29 \\
\hline 90 & 28 \\
\hline 100 & 28 \\
\hline 110 & 28 \\
\hline
\end{tabular}

Fonte: resultados da pesquisa

Teste 6: As distâncias entre os buffers e os pesos do neurônio vencedor são compatíveis com os de treinamento.

O GRAF. 74 mostra que, durante o processo de monitoramento a partir dos dados de simulação dos degraus descendentes, as distâncias, para todos os buffers associados aos transientes e estados estacionários em que a rede foi treinada, são compatíveis com as distâncias obtidas durante o treinamento, GRAF. 73. Pode-se observar, nos GRAF. 74.b e 74.c, que durante os transientes o valor da distância chega até cerca de 12, enquanto durante os estados estacionários ela fica em torno de 1. A distância para eventos não treinados é até uma ordem de grandeza maior que esses valores, como pode ser observado nos primeiros $3000 \mathrm{~s}$ do GRAF. 74.a, cujo evento é um degrau de potência de 0 a $100 \%$ para o qual a rede não foi treinada. Esses resultados, homogêneos entre cada classe, mostram a adequação da rede a esse critério. APROVADA 
a)

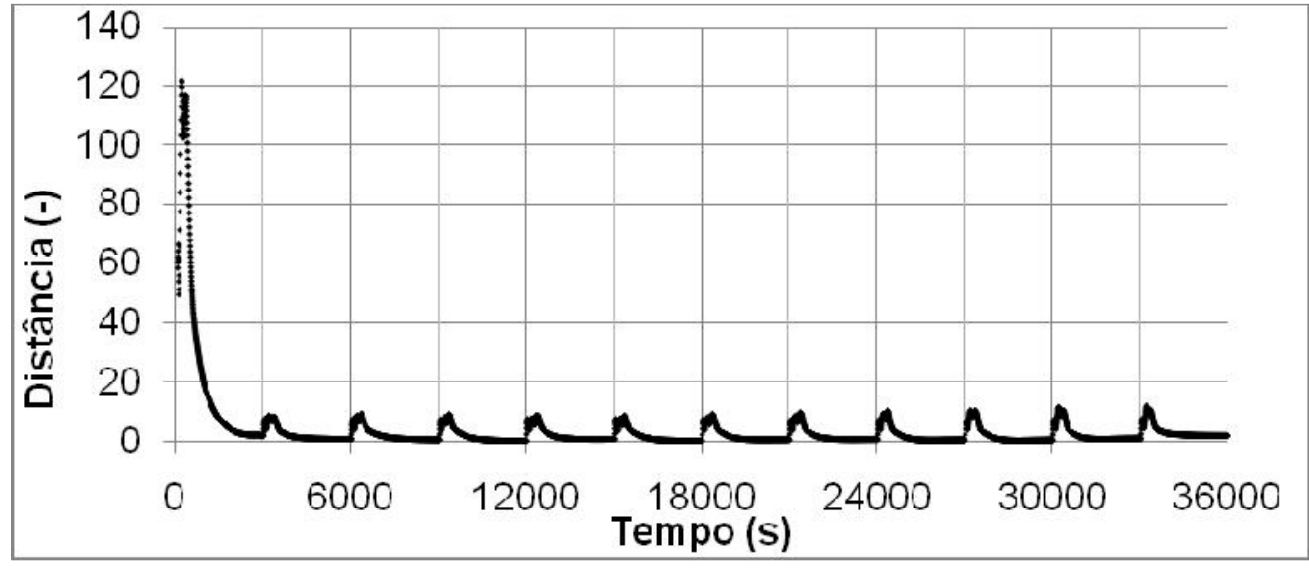

b)
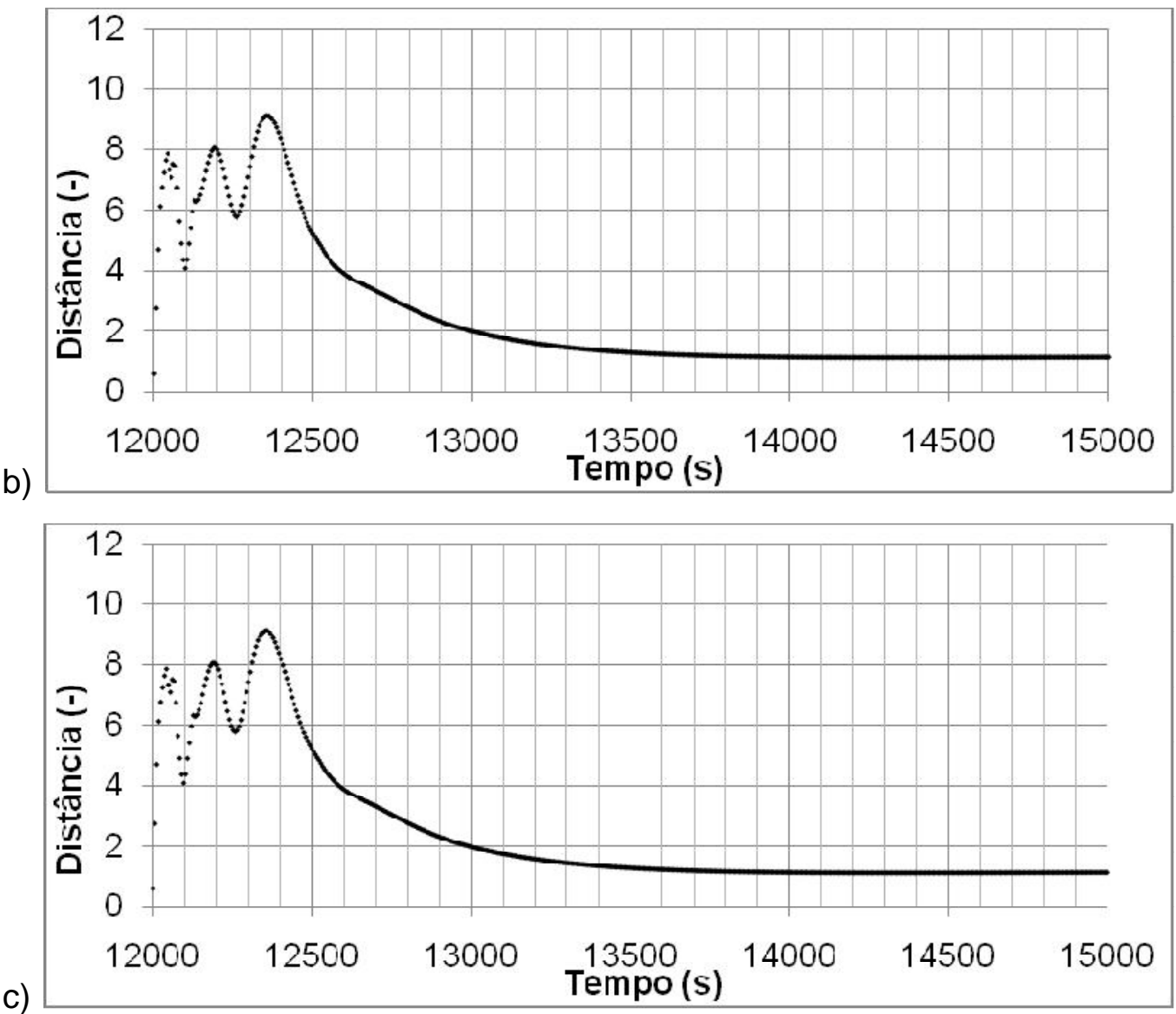

GRÁFICO 74 Distância entre os buffers e os pesos dos neurônios vencedores para degraus descendentes da rede CT1 - 5D3V - DR para o CT1

Fonte: resultados da pesquisa 


\section{CONCLUSÕES}

QUADRO 15 - Sumário das avaliações da rede CT1 - 5D2V - DR

\begin{tabular}{l|l|l}
\hline \multicolumn{2}{c|}{ Teste } & \multicolumn{1}{c}{ Resultado } \\
\hline 1 & Visual & APROVADA \\
\hline 2 & $\begin{array}{l}\text { Identificação de Transientes diferente de estados } \\
\text { estacionários }\end{array}$ & APROVADA \\
\hline 3 & $\begin{array}{l}\text { Identificação distinta de degraus ascendentes e } \\
\text { descendentes }\end{array}$ & APROVADA \\
\hline 4 & Identificar todos transientes e estados estacionários & APROVADA \\
\hline 5 & Estados estacionários iguais nas duas avaliações & APROVADA \\
\hline 6 & $\begin{array}{l}\text { Distância entre os buffers e os pesos dos neurônios } \\
\text { vencedores }\end{array}$ & APROVADA \\
\hline
\end{tabular}

Fonte: elaborado pelo autor

Conforme resumido no QUADRO 15, esta rede, treinada especificamente para reconhecer estados estacionários e transientes de potência tipo degrau e rampa, foi aprovada em todas as avaliações sendo considerada apta a monitorar esses eventos durante a operação do CT1. O uso de derivadas dos parâmetros termo-hidráulicos com pesos maiores pode ajudar a rede, mesmo com um número menor de neurônios a identificar os transientes para os quais foi treinada, apesar de que o tempo em que um transiente foi identificado inequivocamente foi menor que o tempo com a rede com derivadas com peso 2 .

\subsubsection{Rede 7 com conjunto de buffers DR (CT1 - 710 - DR)}

A avaliação feita da rede com 7 zonas de neurônios treinada usando o conjunto de buffers DR sem derivadas, isto é usando somente os 10 parâmetros termo-hidráulicos, (710-DR), foi sua resposta aos transientes de degrau, conforme calculados com o RELAP5 e obtida usando o modo de monitoração. 
O GRAF. 75 mostra as distâncias dos buffers de treinamento aos pesos dos neurônios associados a eles no fim do treinamento. Observa-se que como os buffers tem somente 10 dimensões, correspondentes aos parâmetros termo-hidráulicos, as distâncias são bem menores que para as duas redes anteriormente apresentadas, CT1 - 5D2V - DR e CT1 - 5D3V - DR.

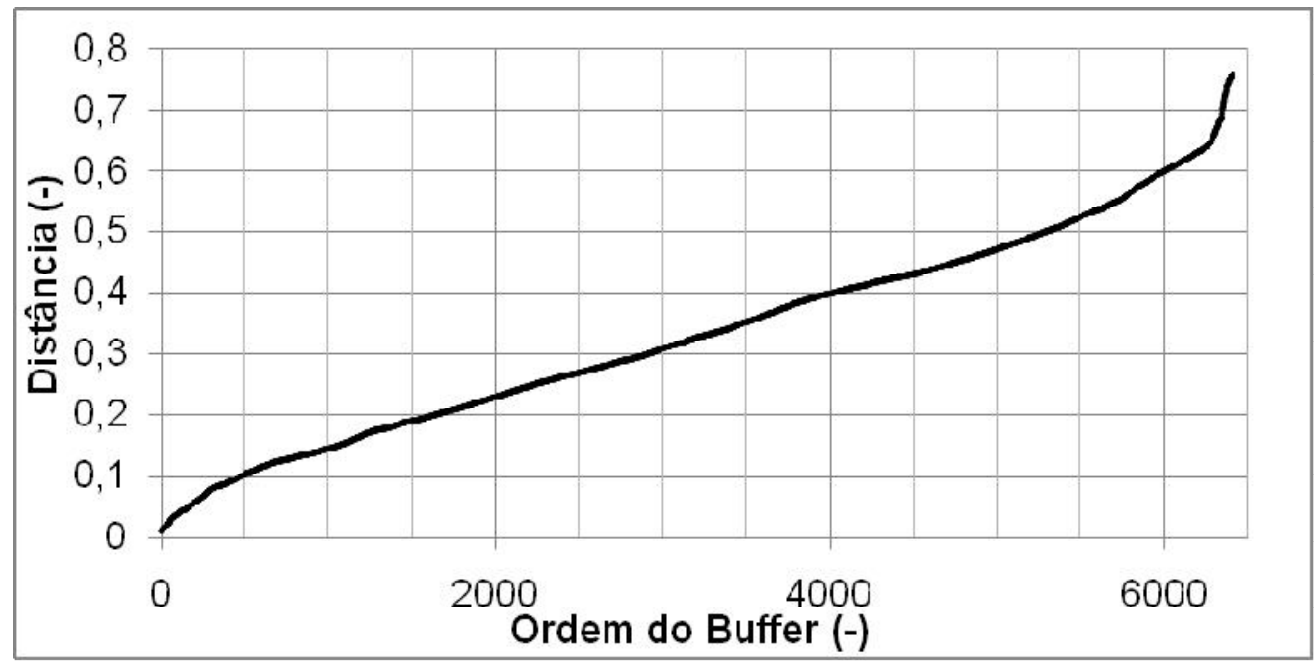

GRÁFICO 75 Distância entre os buffers de treinamento e os pesos dos neurônios para a rede CT1 - 710 - DR

Fonte: resultados do SICT

Teste 2: Neurônios ativados para identificar o transiente são diferentes dos ativados para identificar os estados estacionários

A TAB. 15 mostra os neurônios associados, aos inícios dos degraus decrescentes, aos estados estacionários após o transiente e aos estados intermediários entre eles. A TAB. 16 mostra, de maneira similar à TAB. 15, os neurônios associados aos degraus ascendentes a 1 bar de pressão, aos estados estacionários e aos estados entre esses. A partir da comparação das colunas Início do degrau e Estado estacionário nas TAB. 15 e TAB. 6, independentemente e em conjunto, pode-se observar que nenhum neurônio foi associado a um degrau e a um estado estacionário. Assim essa rede satifaz os requisitos deste teste. APROVADA. 
TABELA 15 - Neurônios ativados durante o início dos degraus descendentes (DD), durante os estados estacionários e no interlavo entre eles na rede 710 - DR

\begin{tabular}{c|c|c}
\hline $\begin{array}{c}\text { Iń́cio de degrau } \\
\text { descendente }\end{array}$ & $\begin{array}{c}\text { Estado } \\
\text { estacionário }\end{array}$ & $\begin{array}{c}\text { Estados } \\
\text { intermediários } \\
43\end{array}$ \\
45 & 66 \\
\hline 44 & 47 & 72 \\
\hline 46 & 67 & 74 \\
\hline 71 & 68 & 100 \\
\hline 73 & 69 & 101 \\
\hline 96 & 70 & \\
\hline 98 & 75 & \\
\hline 99 & 76 & \\
\hline 107 & 97 & \\
\hline 108 & 106 & \\
\hline 110 & & \\
\hline
\end{tabular}

Fonte: resultad os da pesquisa

TABELA 16 - Neurônios ativados durante o início dos degraus ascendentes (DU), durante os estados estacionários e no interlavo entre eles na rede 710 - DR

\begin{tabular}{c|c|c}
\hline $\begin{array}{c}\text { Início de degrau } \\
\text { ascendente }\end{array}$ & $\begin{array}{c}\text { Estado } \\
\text { estacionário }\end{array}$ & $\begin{array}{c}\text { Estados } \\
\text { Intermediários }\end{array}$ \\
\hline 66 & 45 & 46 \\
\hline 74 & 47 & 71 \\
\hline 97 & 67 & 72 \\
\hline 99 & 68 & 73 \\
\hline 100 & 69 & 98 \\
\hline 101 & 70 & 102 \\
\hline 102 & 75 & 107 \\
\hline 103 & 76 & \\
\hline 104 & 106 & \\
\hline 105 & 109 & \\
\hline 108 & & \\
\hline 110 & & \\
\hline
\end{tabular}

Fonte: resultados da pesquisa 
Teste 3: Neurônios ativados para identificar degrau ascendente diferentes daqueles usados para identificar os degraus descendentes

A comparação das colunas "Início de degrau" nas TAB. 15 e 16, mostra que os neurônios 108 e 110 foram ativados tanto pelos degraus ascendentes como pelos degraus descendentes. Além disso, os neurônios 66, 100 e 101 ativados durantes fases intermediárias dos degraus descendentes foram também ativados no início dos degraus ascendentes. Assim pode-se concluir que essa rede não consegue satisfazer os requisitos deste teste. REPROVADA

\section{Teste 4: Reconhecer todos os transientes e estados estacionários}

A rede reconheceu a mudança de estado no início dos transientes e os estados estacionários antes e após quase todos transientes, apesar de como visto no Teste 3 os transientes nem sempre eram classificados corretamente. Os estados estacionários de potência nula após $33000 \mathrm{~s}$ do degrau descrescente e as mudanças de estado próximo a $3000 \mathrm{~s}$ nos degraus ascendentes não foram reconhecidos. REPROVADA

Teste 5: Os estados estacionários semelhantes após os casos ascendentes e descendentes são identificados pelos mesmos neurônios.

A rede atende esse requisito. APROVADA.

Teste 6: As distâncias entre os buffers e os pesos do neurônio vencedor são compatíveis com os de treinamento.

O GRAF.76 mostra, em diferentes escalas de distância e tempo, que as distâncias para todos os buffers ligados aos transientes é de aproximadamente 0,6 enquanto para aqueles associados aos estados estacionários é em torno de 0,2 . No entanto, pode-se observar que as distâncias próximas aos $3000 \mathrm{~s}$ e após os $33000 \mathrm{~s}$ são demasiadamente grandes para situações representativas de estados estacionários. Esse resultado é consistente com o avaliado anteriormente nos Teste 3 e Teste 4. REPROVADA 

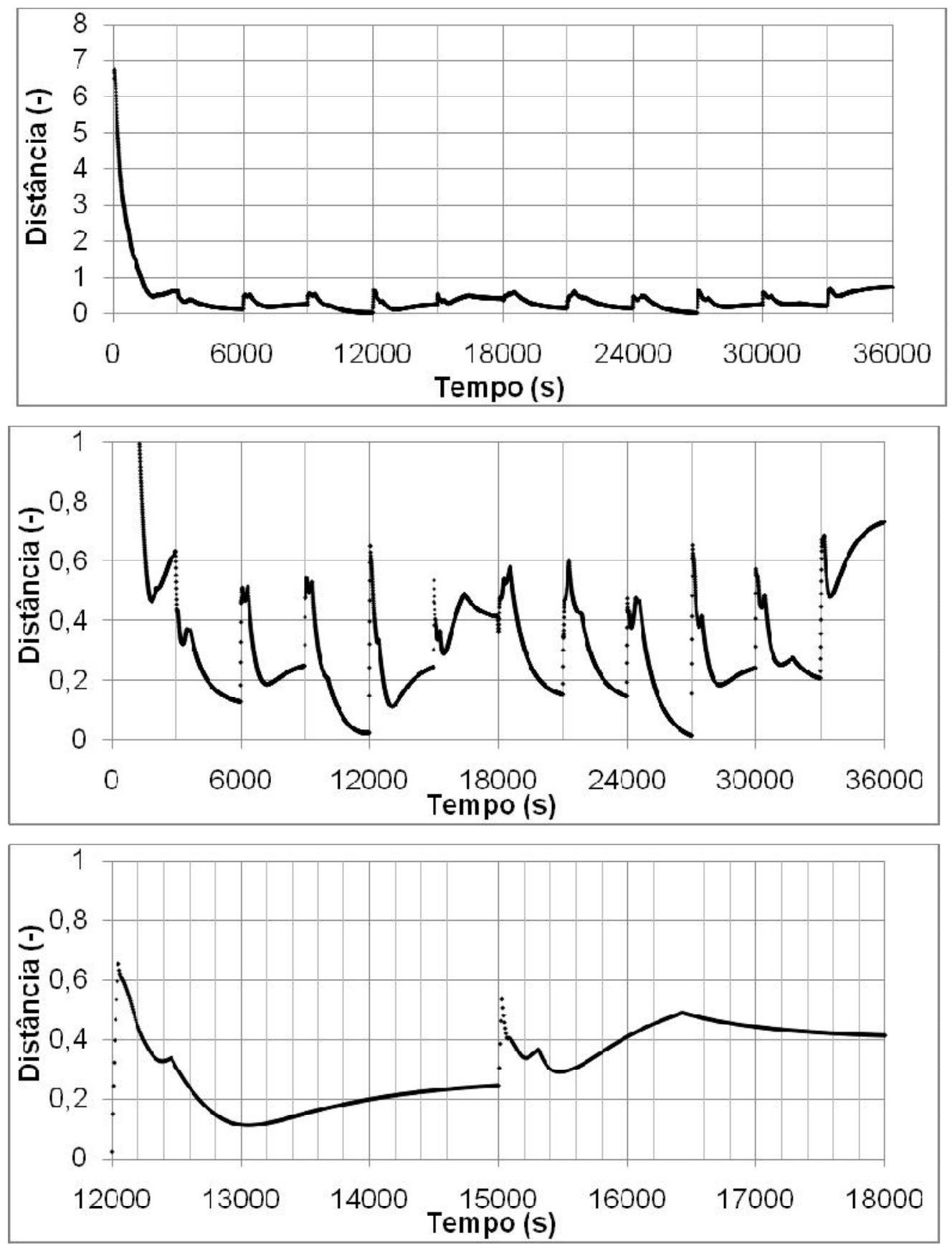

GRÁFICO 76 Distância entre os buffers e os pesos dos neurônios vencedores para degraus descendentes da rede CT1 - 710 - DR

Fonte: resultados da pesquisa 


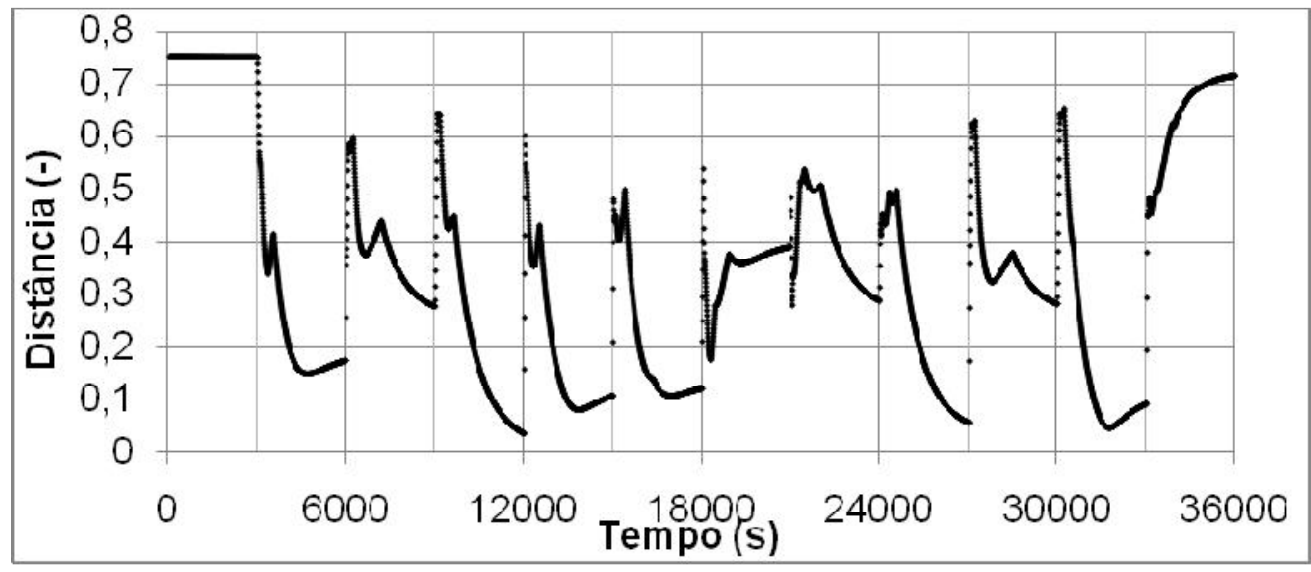

GRÁFICO 77 Distância entre os buffers e os pesos dos neurônios vencedores para degraus ascendentes da rede CT1 - 710 - DR

Fonte: resultados da pesquisa

\section{CONCLUSÕES}

QUADRO 16 - Sumário das avaliações da rede 5D2V- DR para o CT1

\begin{tabular}{l|l|l}
\hline \multicolumn{2}{c|}{ Teste } & \multicolumn{1}{c}{ Resultado } \\
\hline 1 & Visual & APROVADA \\
\hline 2 & $\begin{array}{l}\text { Identificação de Transientes diferente de estados } \\
\text { estacionários }\end{array}$ & APROVADA \\
\hline 3 & $\begin{array}{l}\text { Identificação distinta de degraus ascendentes e } \\
\text { descendentes }\end{array}$ & REPROVADA \\
\hline 4 & Identificar todos transientes e estados estacionánios & REPROVADA \\
\hline 5 & Estados estacionários iguais nas duas avaliações & APROVADA \\
\hline 6 & $\begin{array}{l}\text { Distância entre os buffers e os pesos dos neurônios } \\
\text { vencedores }\end{array}$ & REPROVADA \\
\hline
\end{tabular}

Fonte: elaborado pelo autor

Conforme resumido no QUADRO 16, esta rede que foi treinada especificamente para reconhecer, além dos estados estacionários, transientes de potência tipo degrau e rampa não consegue identificar e classificar satisfatoriamente esses transientes. 


\subsubsection{Rede 7D1V com conjunto de buffers DR (CT1 - 7D1V - DR)}

O GRAF. 78 apresenta a distribuição das distâncias entre os buffers de treinamento e os neurônios a eles associados no fim desse processo. $O$ valor máximo é menor que 4, observando-se um pronunciado aumento na parte final associada aos transientes mais fortes.

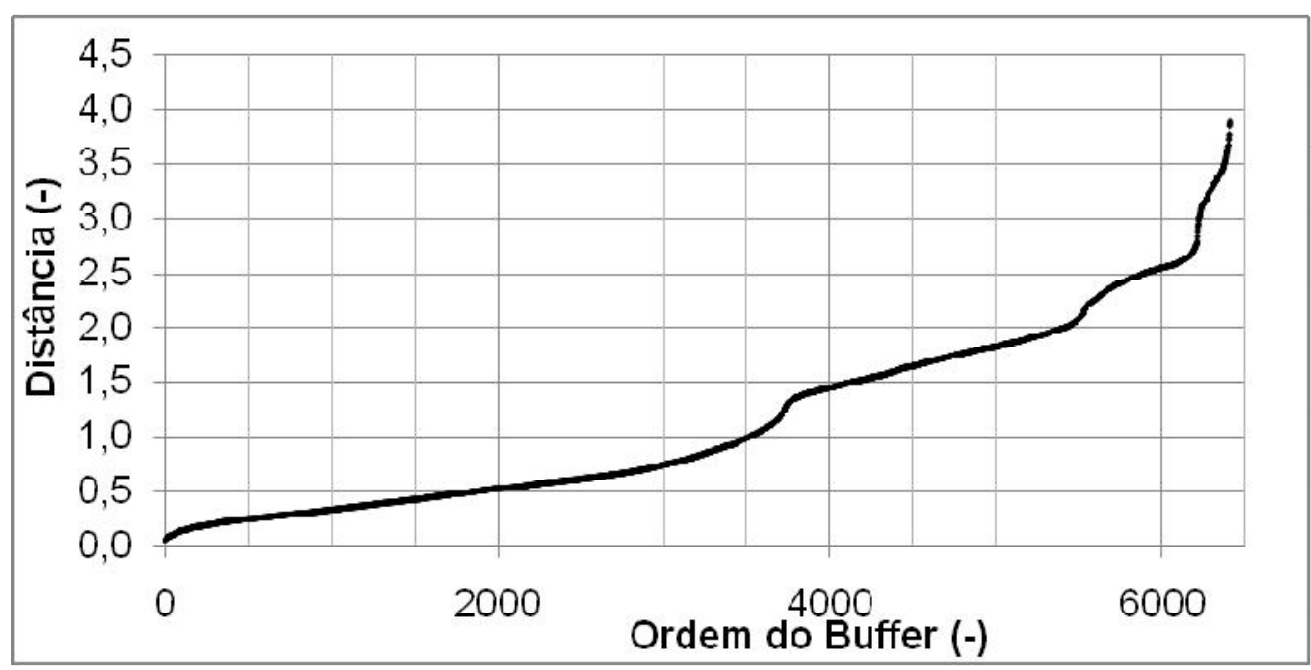

GRÁFICO 78 Distância entre os buffers de treinamento e os pesos dos neurônios para a rede CT1 - 7D1V - DR

Fonte: resultados do SICT

Teste 2: Neurônios ativados para identificar o transiente são diferentes dos ativados para identificar os estados estacionários

A TAB. 17 mostra os neurônios associados, aos inícios dos degraus decrescentes, aos estados estacionários após o transiente e aos estados intermediários entre eles. A TAB. 18 mostra, de maneira similar à TAB. 15, os neurônios associados aos degraus ascendentes a 1 bar de pressão, aos estados estacionários e aos estados entre esses. A partir da comparação das colunas Início do degrau e Estado estacionário nas TAB.17 e TAB. 18, independentemente e em conjunto, pode-se observar que nenhum neurônio foi associado a um degrau e a um estado estacionário. Assim essa rede satisfaz os requisitos deste teste. APROVADA. 
TABELA 17 - Neurônios ativados na CT1 - 7D1V - DR durante o início dos degraus descendentes, durante os estados estacionários e durante esses estados.

\begin{tabular}{c|c|c}
\hline $\begin{array}{c}\text { Início de degrau } \\
\text { descendente }\end{array}$ & $\begin{array}{c}\text { Estado } \\
\text { estacionário }\end{array}$ & $\begin{array}{c}\text { Estados } \\
\text { Intermediários }\end{array}$ \\
\hline 32 & 57 & 34 \\
\hline 33 & 61 & 35 \\
\hline 34 & 81 & 55 \\
\hline 35 & 82 & 56 \\
\hline 53 & 83 & 58 \\
\hline 54 & 84 & 59 \\
\hline 55 & 85 & 90 \\
\hline 56 & 87 & 114 \\
\hline 58 & 88 & \\
\hline 59 & 89 & \\
\hline 60 & 115 & \\
\hline 80 & & \\
\hline 92 & & \\
\hline
\end{tabular}

Fonte: resultad os da pesquisa

TABELA 18 - Neurônios ativados na CT1 - 7D1V - DR durante o início dos degraus ascendentes, durante os estados estacionários e durante esses estados.

\section{Início de degrau ascendente}

86

116

117

118

119

120

123

124

125

126

\section{Estado estacionário}

57

61

81

82

83

84

85

87

88

89

115

Fonte: resultados da pesquisa 
Teste 3: Neurônios ativados para identificar degrau ascendente diferentes daqueles usados para identificar os degraus descendentes

A comparação das colunas "Início de degrau" nas TAB. 17 e 18 mostra que os neurônios ativados tanto pelos degraus ascendentes são diferentes daqueles ativados pelos degraus descendentes. APROVADA.

\section{Teste 4: Reconhecer todos os transientes e estados estacionários}

A rede reconheceu a mudança de estado no início dos transientes e os estados estacionários antes e após quase todos transientes. APROVADA.

Teste 5: Os estados estacionários semelhantes após os casos ascendentes e descendentes são identificados pelos mesmos neurônios.

A rede atende esse requisito. APROVADA.

Teste 6: As distâncias entre os buffers e os pesos do neurônio vencedor são compatíveis com os de treinamento.

O GRAF. 79 mostra que as distâncias para todos os buffers ligados aos transientes é de aproximadamente 4 enquanto para aqueles associados aos estados estacionários é em torno de 0,5 em concordância com os resultados do treinamento apresentados no GRAF. 78. APROVADA.

Os GRAF. 80 e 81 mostram a resistência dessa rede de identificar transientes para os quais não foi treinada. O GRAF. 80 é resultado do monitoramento pelo SICT da simulação DELSBS60 e mostra que a partir de $1000 \mathrm{~s}$ até quase $4000 \mathrm{~s}$ a distância dos buffers aos neurônios é muito grande, chegando a ser duas ordens de grandeza maior que as distâncias de treinamento. O mesmo pode ser observado para a simulação ISOLABS, apresentada no GRAF. 81.

O GRAF. 82 mostra o mesmo tipo de informação para o transiente de pressurização PRESSURIZA70k. Observa-se que como esse transiente é 
bastante lento, principalmente a baixas potências, as distância não permitem rejeitar esse transiente. Os neurônios ativados durante o monitoramento estão mostrados na TAB. 19 e estão associados com estados estacionários com potência de $70 \mathrm{~kW}$ e pressão de 1, 3 e 5 bars. O neurônio 23 que está associado a um degrau e a rampa de 30 s não foi um neurônio identificado como de degrau ou de rampa durante os testes de monitoramento desses transientes a 5 bar, assim pode-se admitir esse resultado como aceitável.

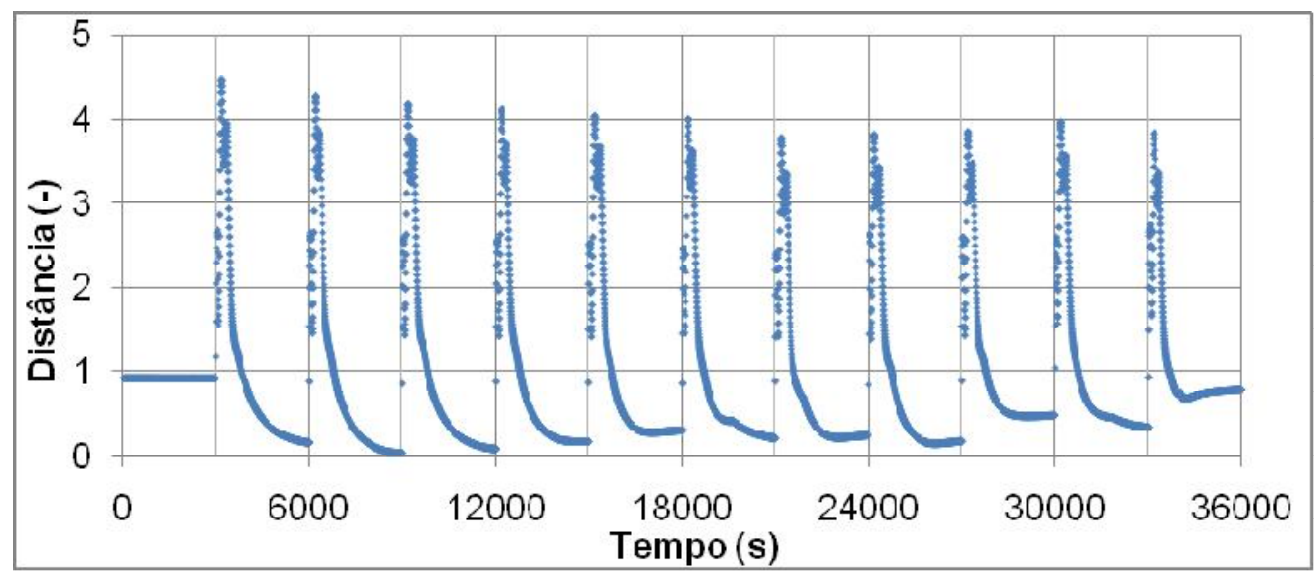

GRÁFICO 79 Distância entre os buffers e os pesos dos neurônios vencedores para degraus ascendentes da rede CT1 - 7D1V - DR

Fonte: resultados da pesquisa

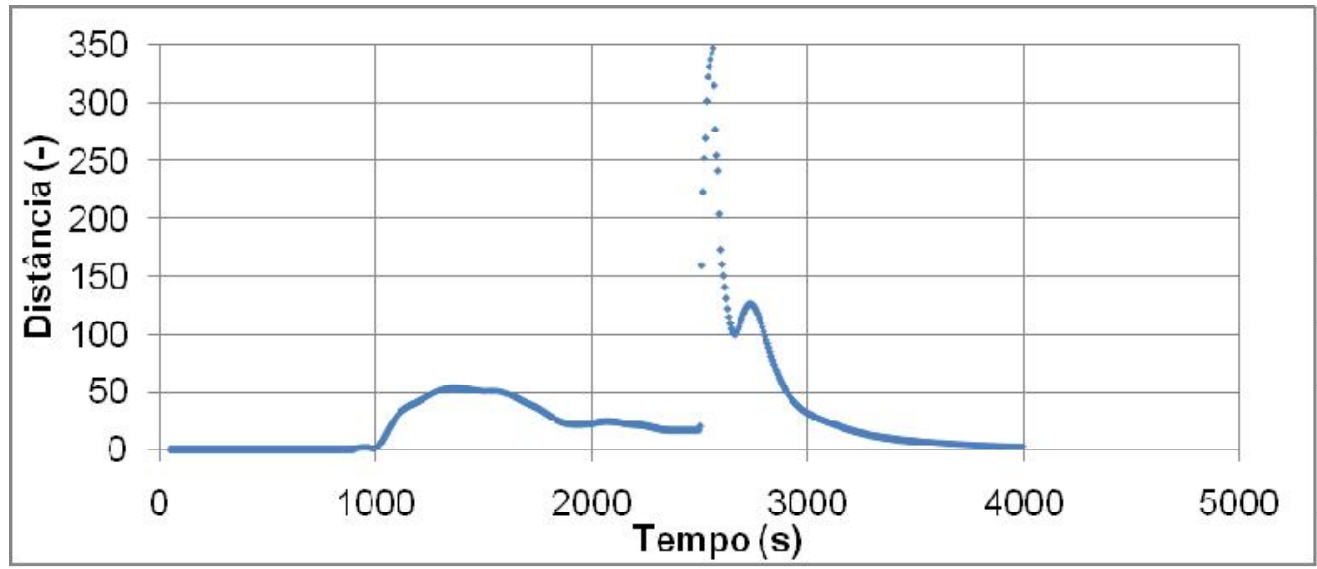

GRÁFICO 80 Distância entre os buffers e os pesos dos neurônios vencedores para a simulação DELSBS60 da rede CT1 - 7D1V - DR

Fonte: resultados da pesquisa 

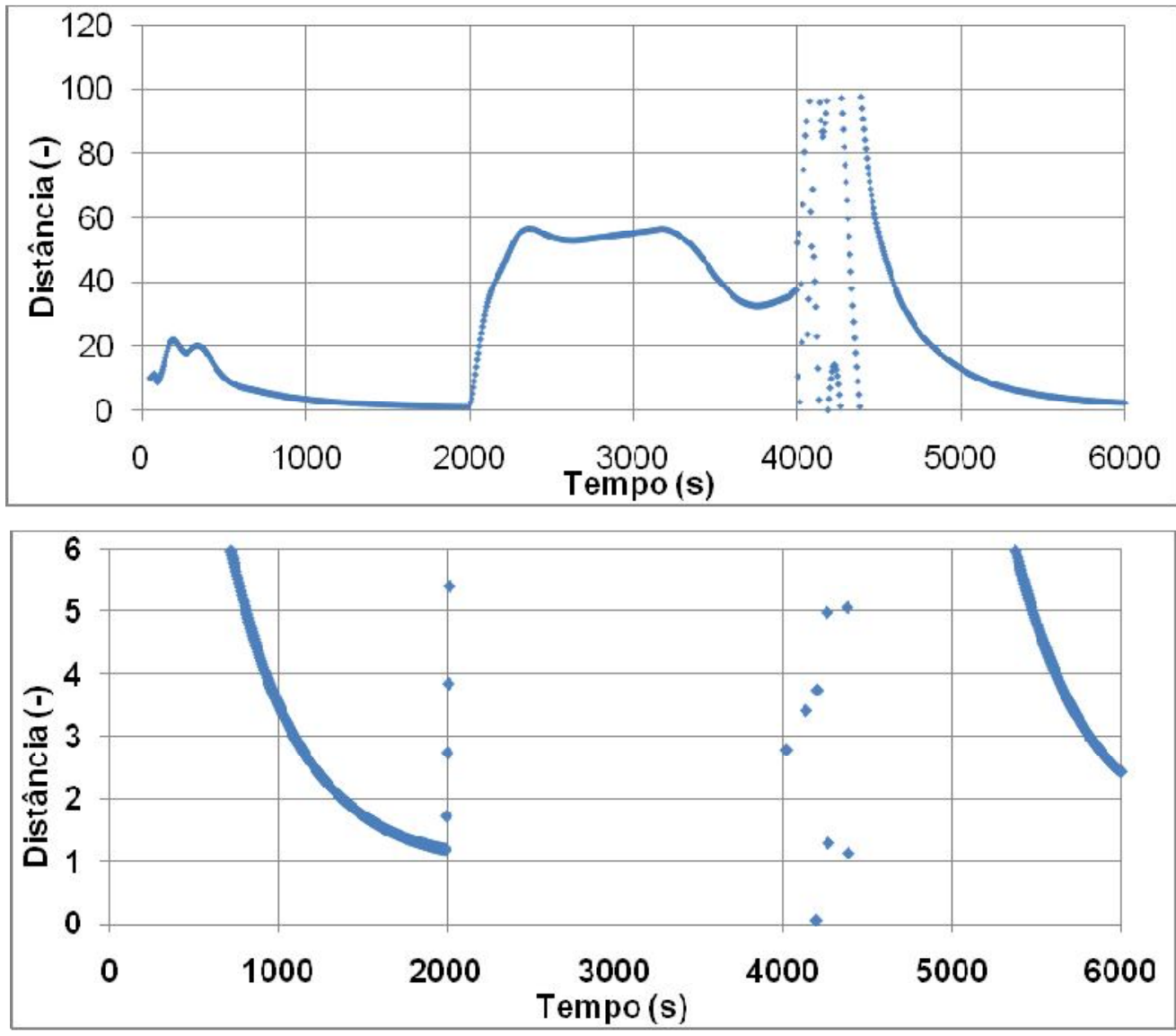

GRÁFICO 81 Distância entre os buffers e os pesos dos neurônios vencedores para a simulação ISOLABS da rede CT1 - 7D1V - DR

Fonte: resultados da pesquisa

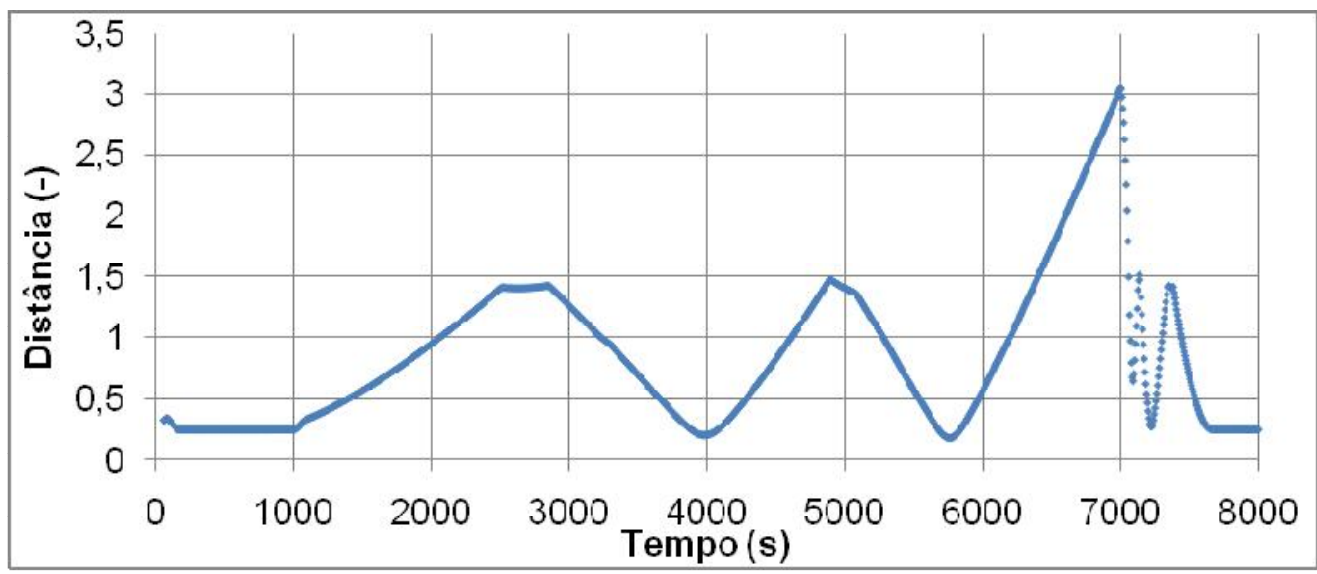

GRÁFICO 82 Distância entre os buffers e os pesos dos neurônios vencedores para a simulação PRESSURIZA70k da rede CT1 - 7D1V - DR

Fonte: resultados da pesquisa 
TABELA 19 - Neurônios ativados durante o monitoramento da simulação PRESSURIZA70k na rede CT1 - 7D1V - DR

\begin{tabular}{c|c|c|c}
\hline Neurônio & $\begin{array}{c}\text { Tempo inicial } \\
(\mathbf{s})\end{array}$ & $\begin{array}{c}\text { Tempo Final } \\
(\mathbf{s})\end{array}$ & Bufferassociado \\
\hline 87 & 0 & 2502 & SSU_H_1_070_070 \\
\hline 36 & 2503 & 2844 & - \\
\hline 8 & 2845 & 4884 & SSU_H_3_070_070 \\
\hline 23 & 4885 & 5076 & DU_H_5_070_080_99_5__+000 \\
\hline 69 & 5077 & 7122 & SSU_H_5_070_070 \\
\hline 23 & 7123 & 7134 & DU_H_5_070_080_99_5_-_000 \\
\hline 8 & 7135 & 7338 & SSU_H_3_070_070 \\
\hline 36 & 7339 & 7380 & \\
\hline 87 & 7381 & 7998 & SSU_H_1_070_070- \\
\hline
\end{tabular}

Fonte: resultados da pesquisa

\section{CONCLUSÕES}

Essa rede foi aprovada em todos os testes a que foi submetida satisfazendo assim todos os requisitos para ser considerada aprovada.

\subsubsection{Rede 810 com conjunto de buffers DR (CT1 - 810 - DR)}

O GRAF. 83 mostra as distâncias dos buffers de treinamento aos pesos dos neurônios associados a eles no fim do treinamento. Observa-se que, como os buffers tem somente 10 dimensões, correspondentes aos parâmetros termo-hidráulicos, as distâncias são bem menores que para as rede com 18 parâmetros usando derivadas. O valor máximo de distância no fim do treinamento foi aproximadamente 0,7 . 


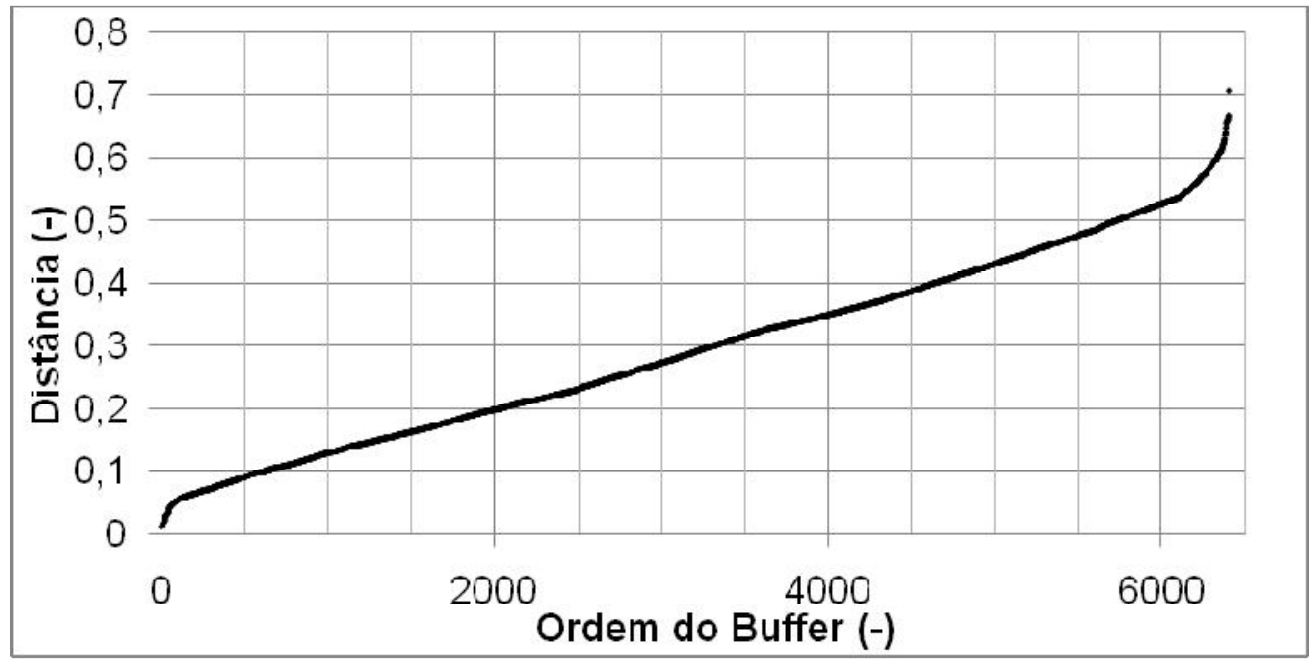

GRÁFICO 83 Distância entre os buffers de treinamento e os pesos dos neurônios para a rede CT1 - 810 - DR

Fonte: resultados do SICT

Teste 2: Neurônios ativados para identificar o transiente são diferentes dos ativados para identificar os estados estacionários

A TAB. 20 mostra os neurônios associados, aos inícios dos degraus decrescentes, aos estados estacionários após o transiente e aos estados intermediários entre eles. A TAB. 18 mostra, de maneira similar à TAB. 21, os neurônios associados aos degraus ascendentes a 1 bar de pressão, aos estados estacionários e aos estados entre esses. A partir da comparação das colunas Início do degrau e Estado estacionário nas TAB. 20 e TAB.21, independentemente e em conjunto, pode-se observar que nenhum neurônio foi associado a um degrau e a um estado estacionário. Assim essa rede satisfaz os requisitos deste teste. APROVADA.

Teste 3: Neurônios ativados para identificar degrau ascendente diferentes daqueles usados para identificar os degraus descendentes

A comparação das colunas "Início de degrau" nas TAB. 20 e 21 mostra que os neurônios ativados pelos degraus ascendentes são diferentes daqueles ativados pelos degraus descendentes, com exceção do neurônio 148, que está associado a degraus de potência a partir de $0 \mathrm{~kW}$ ou para $0 \mathrm{~kW}$, onde as 
condições ainda não são bem estabelecidas e o circuito não tem nenhum risco. Assim pode-se aceitar esse resultado como razoável. APROVADA.

TABELA 20 - Neurônios ativados na CT1 - 810 - DR durante o início dos degraus descendentes, durante os estados estacionários e entre esses estados .

\begin{tabular}{c|c|c}
\hline $\begin{array}{c}\text { Início de degrau } \\
\text { ascendente }\end{array}$ & $\begin{array}{c}\text { Estado } \\
\text { estacionário }\end{array}$ & $\begin{array}{c}\text { Estados } \\
\text { Intermediários }\end{array}$ \\
\hline 52 & 77 & 80 \\
\hline 53 & 84 & 82 \\
\hline 54 & 109 & 83 \\
\hline 55 & 113 & 111 \\
\hline 76 & 117 & 112 \\
\hline 78 & 121 & 120 \\
\hline 79 & 147 & 149 \\
\hline 81 & 151 & 153 \\
\hline 85 & 154 & 155 \\
\hline 86 & 156 & \\
\hline 122 & 160 & \\
\hline 148 & & \\
\hline
\end{tabular}

Fonte: resultados do SICT

TABELA 21 - Neurônios ativados na CT1 - 810 - DR durante o início dos degraus ascendentes, durante os estados estacionários e entre esses estados.

\begin{tabular}{c|cc}
\hline $\begin{array}{c}\text { Início de degrau } \\
\text { ascendente }\end{array}$ & $\begin{array}{c}\text { Estado } \\
\text { estacionário }\end{array}$ & $\begin{array}{c}\text { Estados } \\
\text { Intermediários }\end{array}$ \\
\hline 116 & 77 & 81 \\
\hline 148 & 84 & 110 \\
\hline 149 & 109 & 111 \\
\hline 150 & 117 & 113 \\
\hline 152 & 121 & 114 \\
\hline 153 & 151 & 115 \\
\hline 155 & 154 & 118 \\
\hline 158 & 156 & 157 \\
\hline 159 & 160 & \\
\hline 161 & 163 & \\
\hline 162 & \multicolumn{2}{l}{} \\
\hline
\end{tabular}

Fonte: resultados do SICT 


\section{Teste 4: Reconhecer todos os transientes e estados estacionários}

A rede reconheceu a mudança de estado no início dos transientes e os estados estacionários antes e após todos transientes com exceção das condições em torno do degrau de 0 a $10 \mathrm{~kW}$ onde a rede não identificou corretamente o início do degrau, mas conforme ponderado na avaliação do Teste 2 pode-se aceitar esse resultado como razoável. APROVADA.

Teste 5: Os estados estacionários semelhantes após os casos ascendentes e descendentes são identificados pelos mesmos neurônios.

A rede atende esse requisito. APROVADA.

Teste 6: As distâncias entre os buffers e os pesos do neurônio vencedor são compatíveis com os de treinamento.

Os GRAF. 84 e 85 mostram que as distâncias para todos os buffers ligados aos transientes é de até 0,6 enquanto para aqueles associados aos estados estacionários é em geral menor que de 0,2 em concordância com os resultados do treinamento apresentados no GRAF. 83. APROVADA.

Os GRAF. 86 a 88 mostram a resistência dessa rede de identificar transientes para os quais não foi treinada. O GRAF. 86 é resultado do monitoramento pelo SICT da simulação DELSBS60 e mostra que a partir de $1000 \mathrm{~s}$ até quase $4000 \mathrm{~s}$ a distância dos buffers aos neurônios é muito grande, chegando a ser duas ordens de grandeza maior que as distâncias de treinamento. O mesmo pode ser observado para a simulação ISOLABS, apresentada no GRAF. 87. 

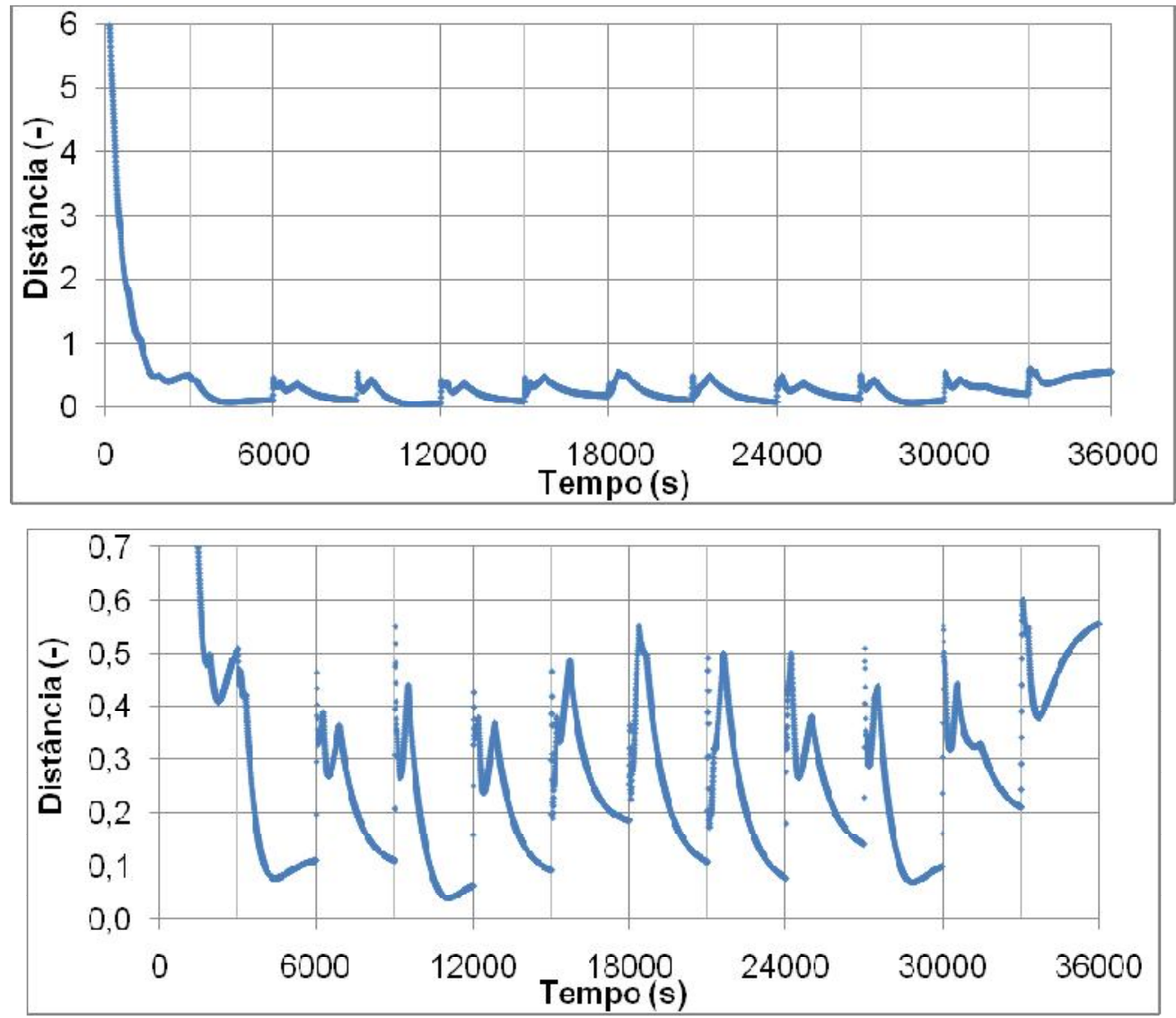

GRÁFICO 84 Distância entre os buffers e os pesos dos neurônios vencedores para degraus descendentes da rede CT1 - 810-DR

Fonte: resultados da pesquisa

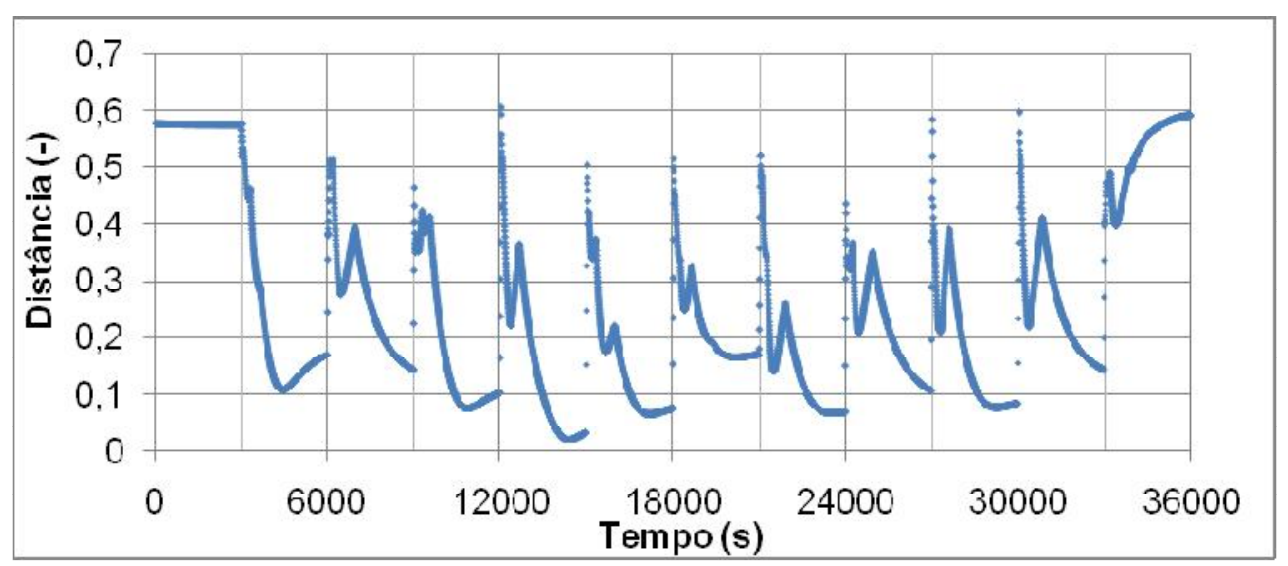

GRÁFICO 85 Distância entre os buffers e os pesos dos neurônios vencedores para degraus ascendentes da rede CT1 - $810-$ DR

Fonte: resultados da pesquisa 


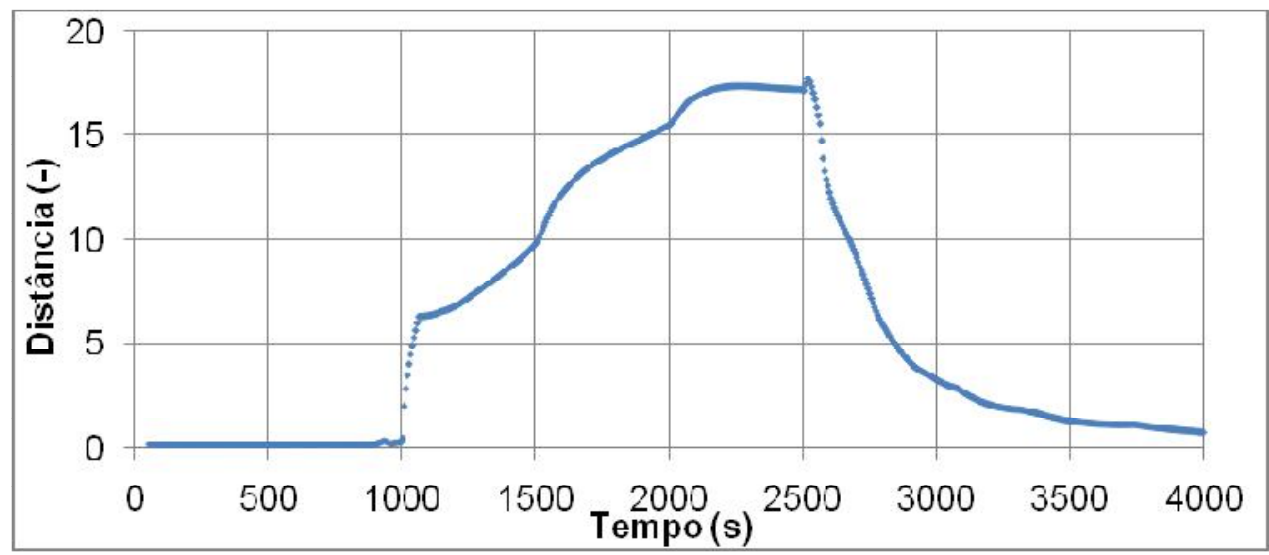

GRÁFICO 86 Distância entre os buffers e os pesos dos neurônios vencedores para a simulação DELSBS60 da rede CT1 - 810 - DR

Fonte: resultados da pesquisa

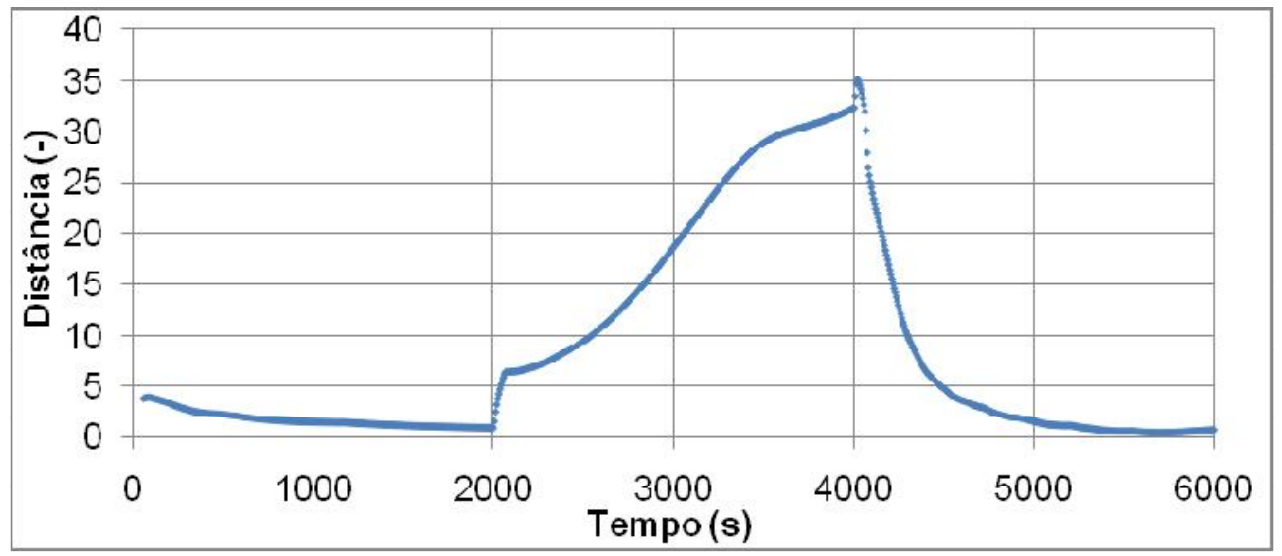

GRÁFICO 87 Distância entre os buffers e os pesos dos neurônios vencedores para a simulação ISOLABS da rede CT1 - 7D1V - DR

Fonte: resultados da pesquisa

O GRAF. 88 mostra o mesmo tipo de informação para o transiente de pressurização PRESSURIZA70k e neste caso a distância fica a maior parte do tempo abaixo de 1 não permitindo rejeitar os neurônios ativados. No entanto, os neurônios ativados durante o monitoramento estão mostrados na TAB. 20 e estão associados com estados estacionários com potência de $70 \mathrm{~kW}$ e pressão de 1,3 e 5 bars ou não estão associados a nenhum buffer em particular. Como esse é um transiente lento esse é um resultado que pode ser considerado razoável. 


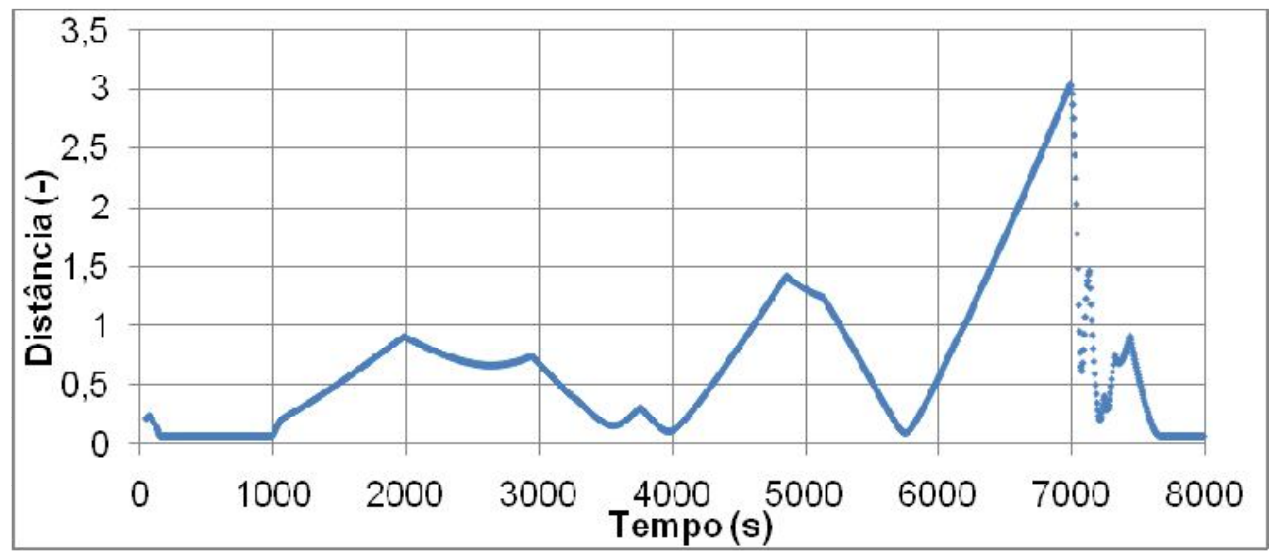

GRÁFICO 88 Distância entre os buffers e os pesos dos neurônios vencedores para a simulação PRESSURIZA70k da rede CT1 - 810 - DR

Fonte: resultados da pesquisa

TABELA 22 - Neurônios ativados durante o monitoramento da simulação PRESSURIZA70k na rede CT1 - 7D1V - DR

\begin{tabular}{|c|c|c|c|}
\hline Neurônio & $\begin{array}{c}\text { Tempo } \\
\text { inicial (s) }\end{array}$ & $\begin{array}{c}\text { Tempo } \\
\text { Final (s) }\end{array}$ & Buffer associado \\
\hline 117 & 0 & 1992 & SSU_H_1_070_070 \\
\hline 32 & 1993 & 2952 & - \\
33 & 2953 & 3774 & - \\
\hline 17 & 3775 & 4830 & SSU_H_3_070_070 \\
\hline 20 & 4831 & 5142 & - \\
\hline 95 & 5143 & 7122 & SSU_H_5_070_070 \\
\hline 20 & 7123 & 7140 & - \\
\hline 17 & 7141 & 7254 & SSU_H_3_070_070 \\
\hline 33 & 7255 & 7332 & - \\
\hline 32 & 7333 & 7452 & - \\
\hline 117 & 7453 & 8000 & SSU_H_1_070_070 \\
\hline
\end{tabular}

Fonte: resultados da pesquisa

\section{CONCLUSÕES}

Essa rede foi aprovada em todos os testes a que foi submetida com algumas ressalvas para as condições iniciais e de pressurização. 


\subsubsection{Rede 8D3V com conjunto de buffers DR (CT1 - 8D3V - DR)}

O GRAF. 89 mostra a distribuição das distâncias dos buffers de treinamento aos pesos dos neurônios associados a eles no fim do treinamento. Observa-se que, como os buffers são formados com os 10 parâmetros e suas derivadas,com peso 3. As distâncias máximas associadas aos transientes mais fortes chegam a quase 8 enquanto aquelas associadas aos estados estacionários são menores que 1 .

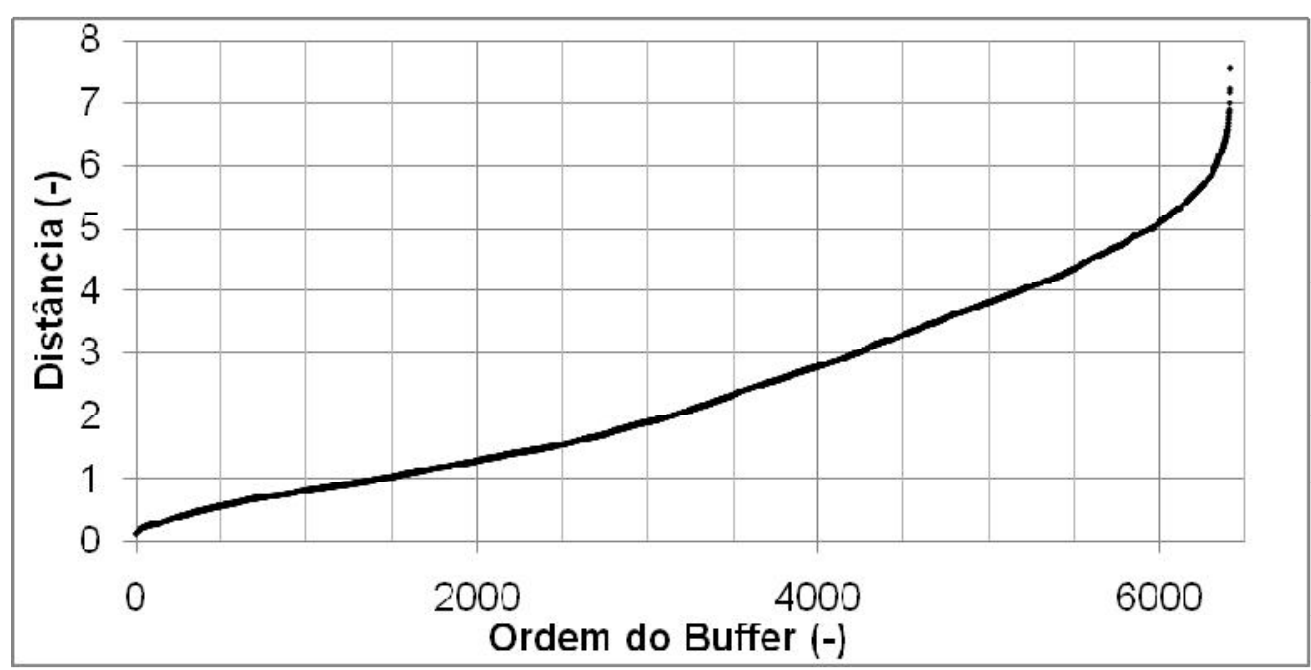

GRÁFICO 89 Distância entre os buffers de treinamento e os pesos dos neurônios para a rede CT1 - 8D3V - DR

Fonte: resultados do SICT

A TAB. 23 mostra que os neurônios ativados pelos degraus ascendentes, descendentes e estados estacionários são únicos para cada classe. Os neurônios para os degraus foram não só o inicial mas todos os que foram ativados nos primeiros $48 \mathrm{~s}$ após o início do transiente, o que representou uma média de cerca de 3 neurônios para cada intervalo. 
TABELA 23 - Neurônios ativados durante os $48 \mathrm{~s}$ iniciais dos degraus ascendentes e descendentes, e durante os estados estacionários.

\begin{tabular}{c|c|c}
\hline $\begin{array}{c}\text { Neurônios } \\
\text { ativados para } \\
\text { degraus } \\
\text { descendentes }\end{array}$ & $\begin{array}{c}\text { Neurônios } \\
\text { ativados para } \\
\text { degraus } \\
\text { ascendentes }\end{array}$ & $\begin{array}{c}\text { Neurônios } \\
\text { ativados para } \\
\text { estados } \\
\text { estacionários }\end{array}$ \\
\hline 0 & 7 & 1 \\
\hline 3 & 8 & 2 \\
\hline 4 & 9 & 10 \\
\hline 5 & 23 & 18 \\
\hline 6 & 43 & 23 \\
\hline 15 & 68 & 24 \\
16 & 88 & 35 \\
\hline 33 & 93 & 43 \\
\hline 34 & 94 & 44 \\
\hline 57 & 95 & 58 \\
\hline 70 & 122 & 69 \\
\hline 102 & 130 & 69 \\
\hline 103 & 131 & 87 \\
\hline 104 & 132 & \\
\hline 140 & 164 & \\
\hline 141 & 165 & \\
\hline 142 & & \\
\hline 143 & & \\
\hline
\end{tabular}

Fonte: resultados do SICT

Os GRAF. 90 e 91 mostram que essa rede apresenta uma distância em geral menor que 10 para os transientes e menor que 1 para os estados estacionários.

Os GRAF. 92 e 93 mostram a resistência dessa rede de identificar transientes para os quais não foi treinada. Os maiores valores da distância máxima nesses gráficos são bastante grandes, chegando a ser maior que 1000, indicando uma grande rejeição dessa rede a eventos a que não foi treinada. 


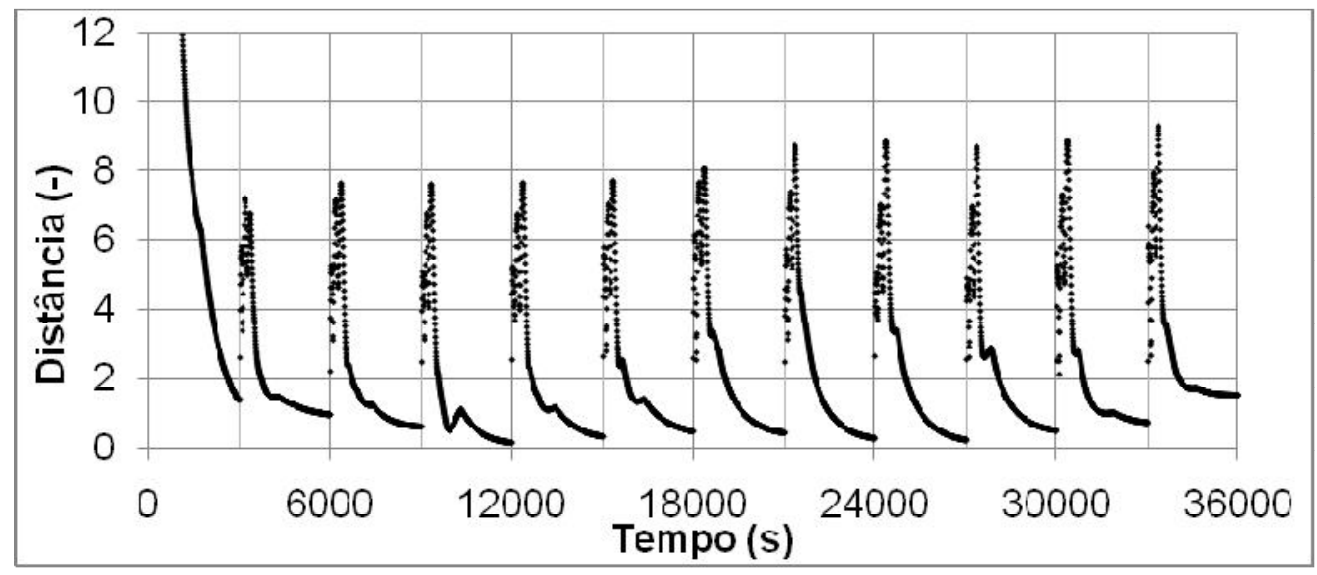

GRÁFICO 90 Distância entre os buffers e os pesos dos neurônios vencedores para degraus descendentes da rede CT1 - 8D3V - DR

Fonte: resultados da pesquisa

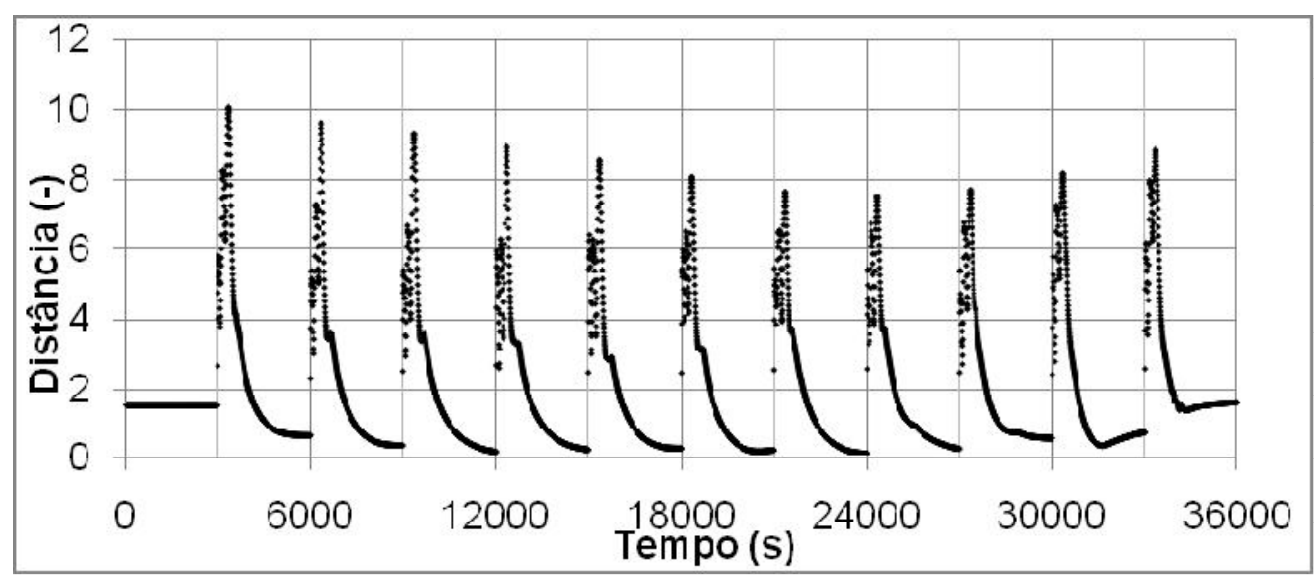

GRÁFICO 91 Distância entre os buffers e os pesos dos neurônios vencedores para degraus ascendentes da rede CT1 - 8D3V - DR

Fonte: resultados do SICT

Os GRAF. 92 e 93 mostram a resistência dessa rede de identificar transientes para os quais não foi treinada. Os maiores valores da distância máxima nesses gráficos são bastante grandes, chegando a ser maior que 3000, indicando uma grande rejeição dessa rede a eventos a que não foi treinada. 

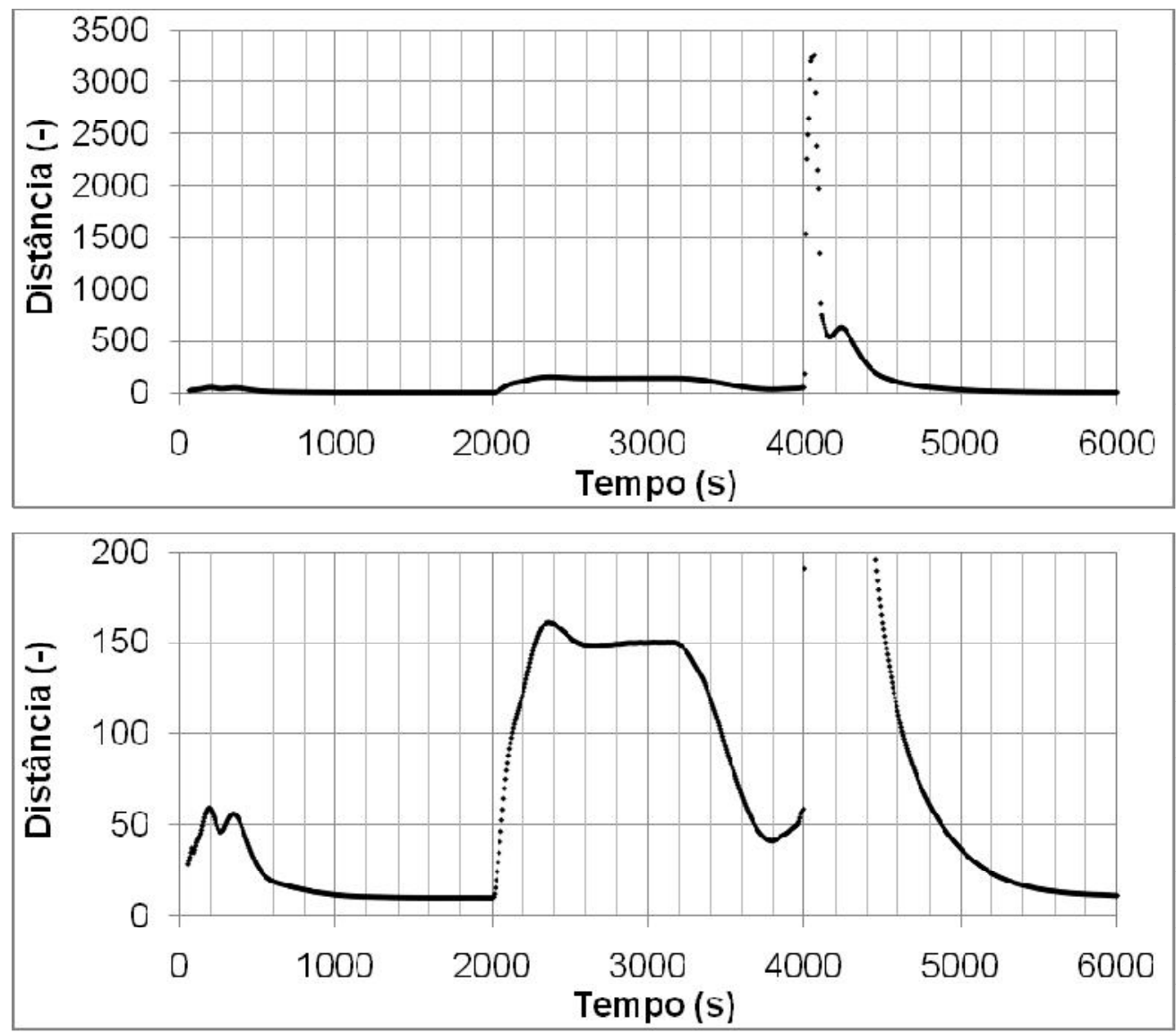

GRÁFICO 92 Distância entre os buffers e os pesos dos neurônios vencedores para a simulação ISOLABS da rede CT1 - 8D3V - DR

Fonte: resultados da pesquisa

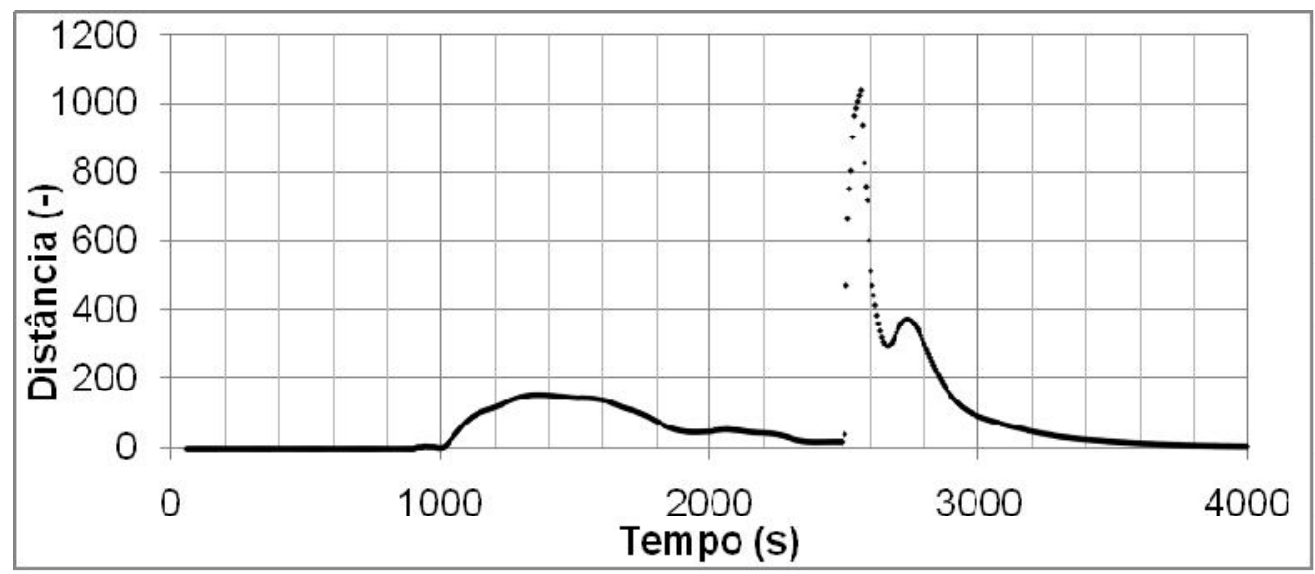

GRÁFICO 93 Distância entre os buffers e os pesos dos neurônios vencedores para a simulação DESLBS60 da rede CT1 - 8D3V - DR

Fonte: resultados da pesquisa 
O GRAF. 94 mostra que para o transiente de pressurização PRESSURIZA70k a distância fica a maior parte do tempo abaixo de 2 não permitindo rejeitar os neurônios ativados. No entanto, os neurônios ativados durante o monitoramento, mostrados na TAB. 24 , estão associados aos estados estacionários com potência de $70 \mathrm{~kW}$ e pressão de 1, 3 e 5 bars ou não estão associados a nenhum buffer em particular. Como esse é um transiente lento esse é um resultado que pode ser considerado razoável.

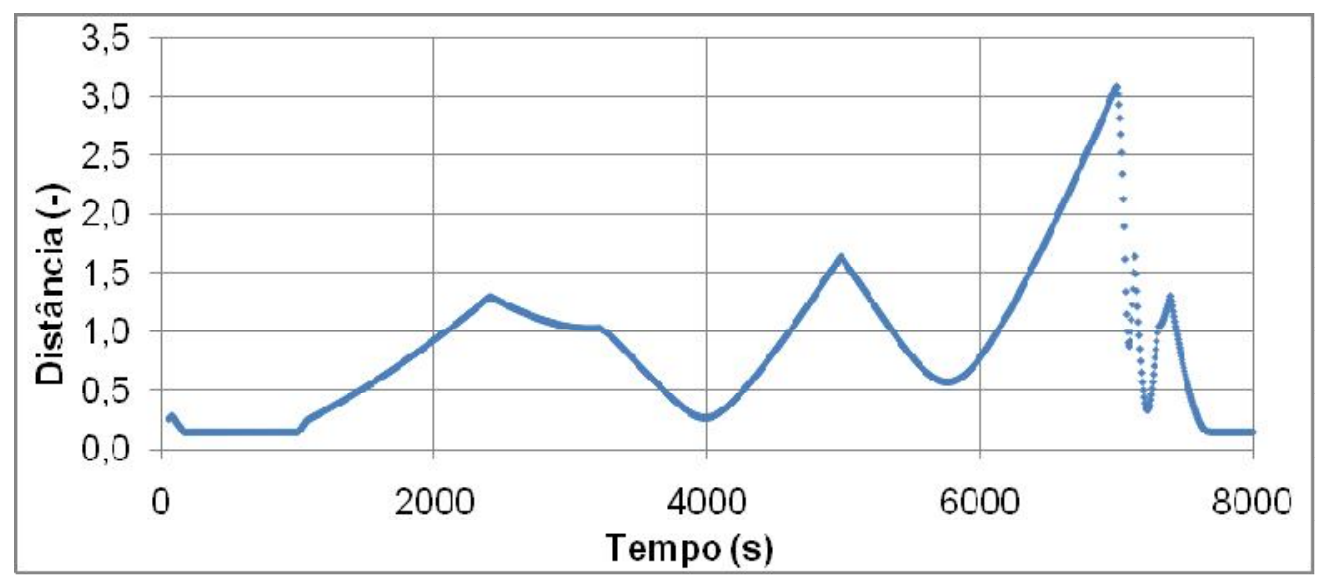

GRÁFICO 94 Distância entre os buffers e os pesos dos neurônios vencedores para a simulação da PRESSURIZA70k da rede CT1 - 8D3V - DR

Fonte: resultados do SICT

TABELA 24 - Sequencia de neurônios ativados na rede CT1 - 8D3V - DR

\begin{tabular}{c|c|c}
\hline Tempo & Neurônio & Buffer associado \\
\hline 54.00 & 10 & ss70p1 \\
\hline 2406.00 & 22 & u60\&70p1-3 \\
\hline 3216.00 & 40 & ss70p3 \\
\hline 4980.00 & 77 & ss70p5 \\
\hline 7134.00 & 40 & ss70p3 \\
\hline 7308.00 & 22 & u60\&70p1-3 \\
\hline 7398.00 & 10 & ss70p1 \\
\hline
\end{tabular}

Fonte: resultados do SICT 


\subsubsection{Conclusões sobre as Redes usando o buffer DR para o CT1}

Da avaliação das várias redes treinadas com o conjunto de buffers DR pode-se observar que as redes com menor número de zonas, 5, ou neurônios têm dificuldade de identificar e classificar os transientes e estados estacionários para os quais foram treinadas enquanto as redes com mais zonas, 8 , identificam e classificam mais facilmente os degraus, rampas e estados estacionários.

A introdução de derivadas aumenta a capacidade dessas redes de identificar os transientes. Para as derivadas com pesos grande, 3 , os transientes são identificados logo no seu início mas sua classificação é mais difícil, já que os neurônios ativados mudam muito frequentemente.

As redes de maneira geral apresentaram boa resistência a identificar erradamente transientes para os quais não foram treinadas com exceção dos transientes muito lentos como a pressurização e algumas condições próximas da potência nula.

A pressurização e despressurização em particular não foram reconhecidas por essas redes, pois foi usado um valor muito alto para a faixa de derivada de pressão durante 0 treinamento e durante o monitoramento, praticamente desabilitando esse valor. No entanto observou que os neurônios ativados por essas simulações foram neurônios em geral associados a estados estacionários a diferentes pressões o que torna o resultado aceitável. A definição de faixas de variação apropriadas para a derivada de pressão possibilitou o reconhecimento desses transientes a partir de 0,3 $\mathrm{MPa}$ em testes realizados com outras redes.

O QUADRO 17 apresenta um resumo do desempenho das diferentes redes treinadas com o conjunto de buffers DR. 
QUADRO 17 - Resumo da avaliação das redes do CT1 treinadas com o conjunto de buffers DR

\begin{tabular}{c|c|l}
\hline REDE DR & Avaliação & \multicolumn{1}{c}{ Observação } \\
\hline 5D2 & Reprovada & $\begin{array}{l}\text { Rede com baixo desempenho, deixou de } \\
\text { identificar alguns estados e identificou } \\
\text { outros de maneira errada. }\end{array}$ \\
\hline 5D3 & Aprovada & \\
\hline 7-10 & Reprovada & $\begin{array}{l}\text { Mesmo Neurônio ativado para degraus } \\
\text { ascendentes e descendentes }\end{array}$ \\
\hline 7D1 & Aprovada & \\
\hline 7D2 & Aprovada & \\
\hline 7D3 & Aprovada & \\
\hline 8-10 & Aprovada & $\begin{array}{l}\text { Mostrou dificuldades em condições } \\
\text { iniciais, que as redes com derivadas } \\
\text { aprovadas não tiveram. }\end{array}$ \\
\hline 8D1 & Aprovada & \\
\hline 8D2 & Aprovada & \\
\hline 8D3 & Aprovada & \\
\hline
\end{tabular}

Fonte: resultados do SICT

\subsubsection{Redes Triangular, Quadrada, Hexagonal e Cúbica com conjunto de buffers ALL (CT1 - D2V - ALL)}

As redes triangular, quadrada hexagonal e cúbica, descritas em 7.1.2 e na TAB. 5 foram treinadas com o conjunto de buffers ALL usando derivadas com peso 2 é feita uma avaliação dessas redes.

A FIG. 48 mostra como os buffers, identificados nas figuras por diferentes cores, se agruparam aos seus semelhantes em todas as quatro redes, indicando um treinamento correto. As cores associadas aos buffers que ativaram os neurônios após o treinamento estão mostradas na parte inferior da figura.

A TAB. 25 mostra os valores máximos, mínimos médios e o desvio padrão das distâncias buffer-neurônio após o treinamento para cada uma das quatro redes, pode-se observar que os valores são bastante próximos. 

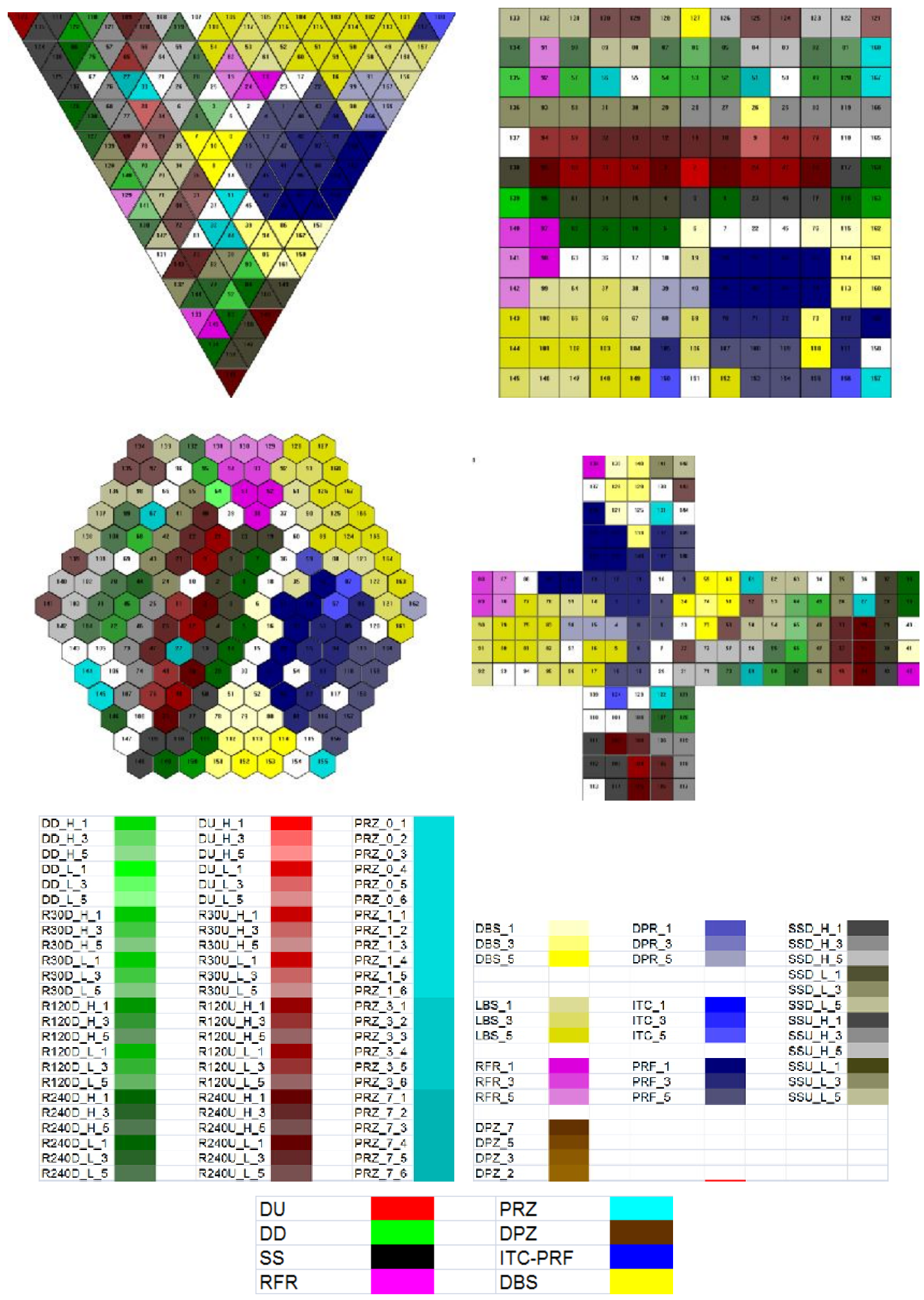

FIGURA 48 Arranjos dos buffers nas redes triangular, quadrada, hexagonal e cúbica após o treinamento e o código de cores empregado

Fonte: resultados do SICT 
TABELA 25 - Distribuições das distâncias buffer-neurônio para rede triangular, quadrada, hexagonal e cúbica

\begin{tabular}{c|cc|c|c}
\hline \multirow{2}{*}{ Rede } & \multicolumn{4}{|c}{ Distância } \\
\cline { 2 - 5 } & Máxima & Média & Mínima & $\begin{array}{c}\text { Desvio } \\
\text { Padrão }\end{array}$ \\
\hline Triangular & 5.63 & 1.27 & 0.07 & 0.97 \\
\hline Quadrada & 7.19 & 1.36 & 0.05 & 1.10 \\
\hline hexagonal & 6.96 & 1.40 & 0.04 & 1.16 \\
\hline Cúbica & 7.23 & 1.41 & 0.07 & 1.13 \\
\hline
\end{tabular}

Fonte: resultados da pesquisa

O GRAF. 95 apresenta a distribuição das distâncias buffer-neurônio nas quatro redes e pode-se comprovar que os resultados após o treinamento em todas essas redes é muito parecido, a rede que tem uma distribuição um pouco afastada das demais é a rede quadrada.

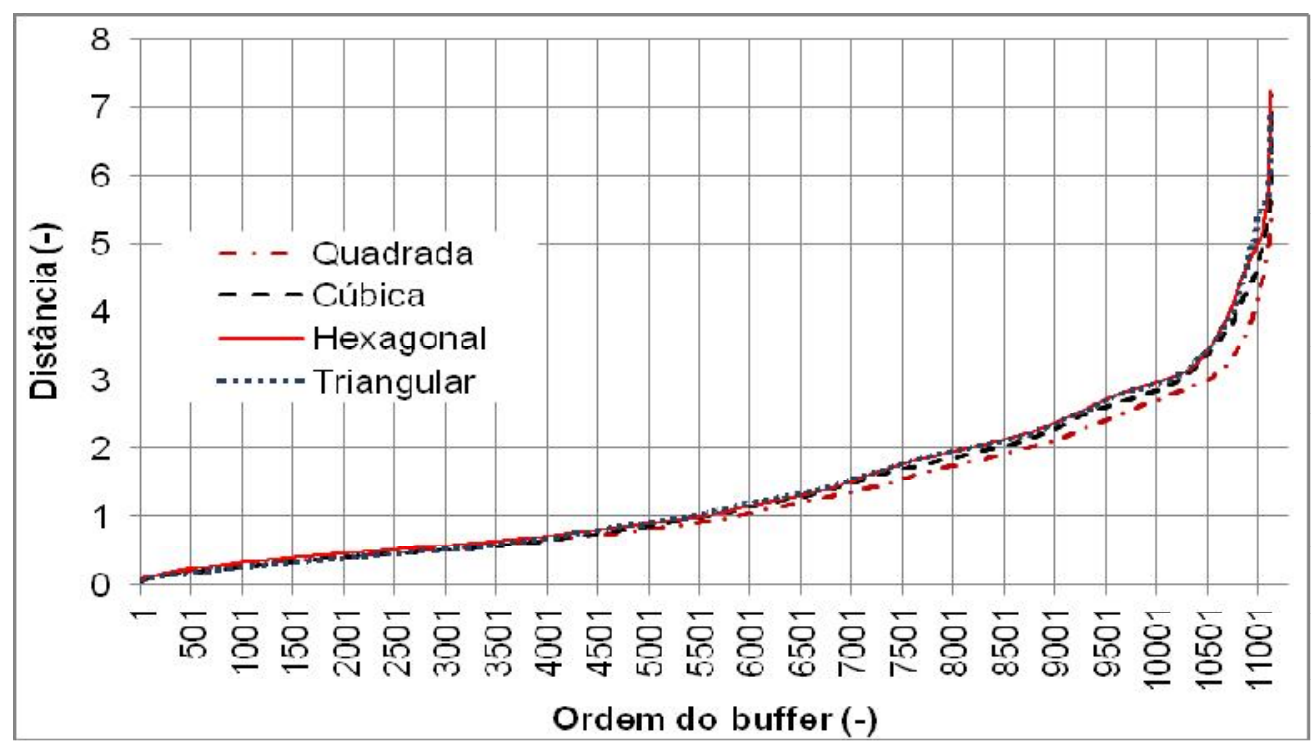

GRÁFICO 95 Distâncias dos buffers aos neurônios nas redes triangular, quadrada, hexagonal e cúbica após o treinamento com o conjunto de buffers ALL

Fonte: resultados do SICT

Os resultados do monitoramento das simulações dos transientes, degraus, rampas e estados estacionários, mostrou que essas redes conseguem atender á tarefa de identificar e classificar os estados do CT1 para os quais foi treinada e indicar aquelas condições que ela não reconhece. 


\section{Degraus descendentes}

O GRAF. 96 apresenta as distâncias durante o monitoramento da simulação de degraus descendentes para essas quatro redes. Observa-se que o resultado apresentado por elas é muito parecido, sendo as distâncias máximas durante os transientes em torno de 3 e durante os estados estacionários, em geral, menor que 0,5. Esses valores são menores que os observados para eventos semelhantes nas redes treinadas com o conjunto de buffers DR, já que as faixas de variação dos parâmetros e suas derivadas são bem maiores.

O GRAF. 97 mostra os neurônios ativados durante o monitoramento da simulação de degraus decrescentes na rede cúbica. Pode-se observar que nos instantes múltiplos de $3000 \mathrm{~s}$, instantes esses em que ocorrem os degraus de potência, a rede não identifica o transiente mudando de um estado estacionário para outro. Por exemplo, após 12000 s ela muda do neurônio 103 para o 114 que permanece ativo até após $15000 \mathrm{~s}$. O mesmo efeito de não identificação do transiente foi observado na rede triangular para rampa de 10\% de potência ascendente de $240 \mathrm{~s}$. Nesses dois casos a distância ficou nos valores esperados indicando que o número de neurônios não é suficiente para discriminar todos os transientes disponibilizados pelo conjunto de buffers ALL usando o peso das derivadas igual a 2 . 
a)

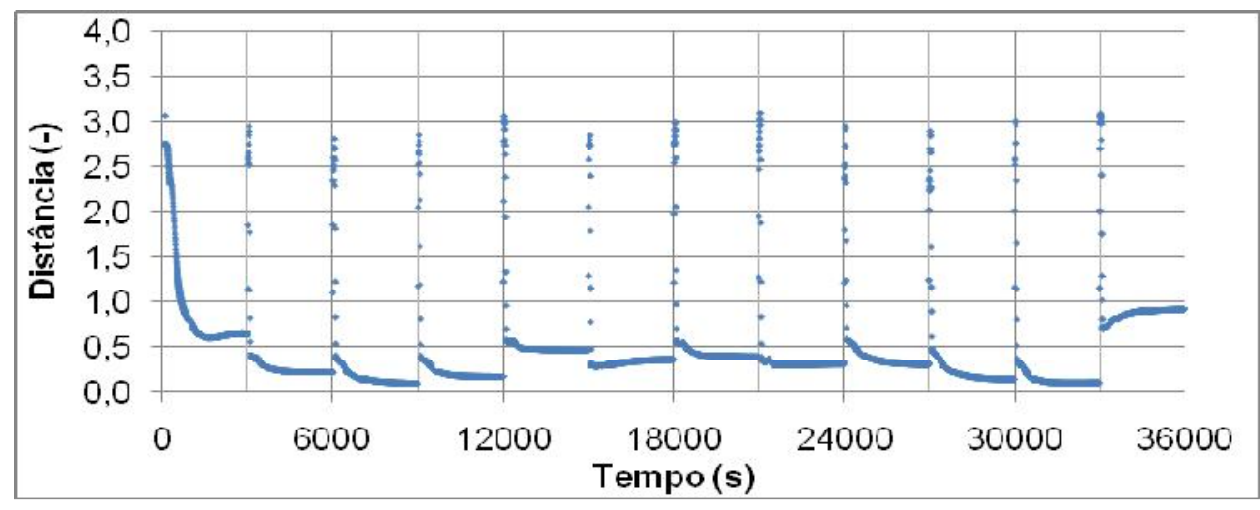

b)

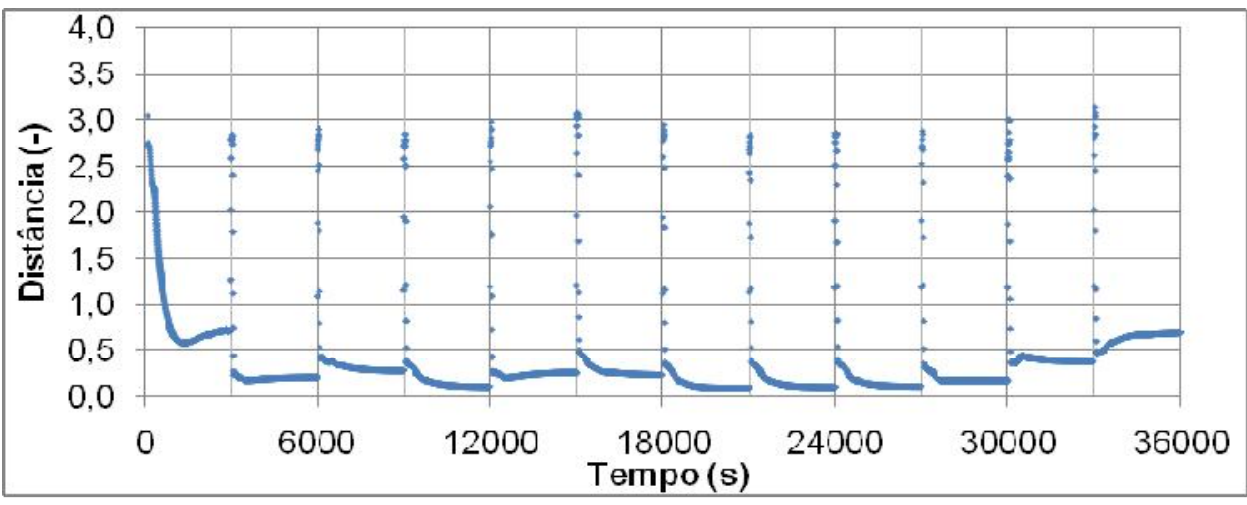

c)

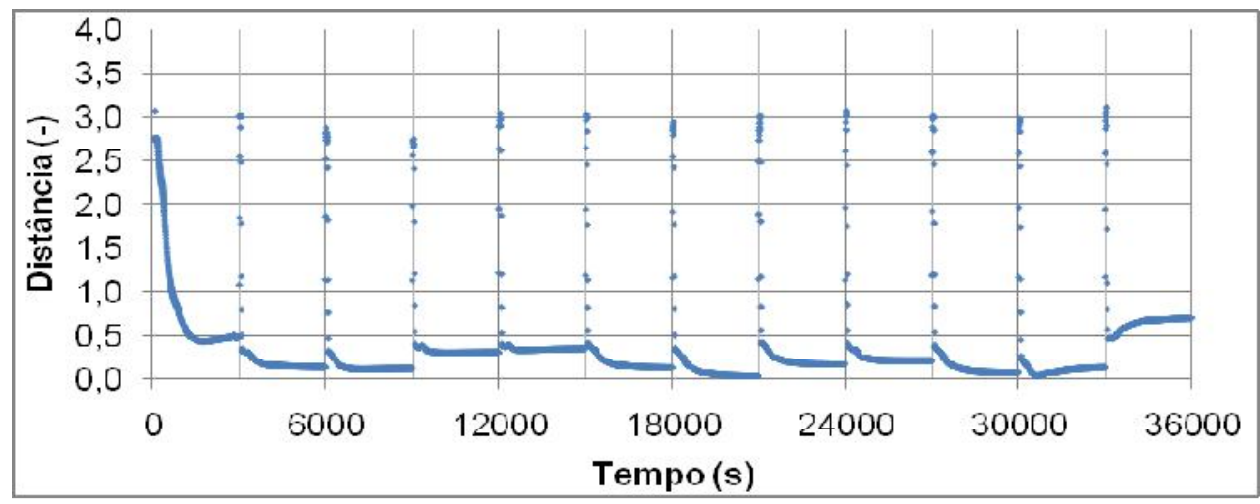

d)

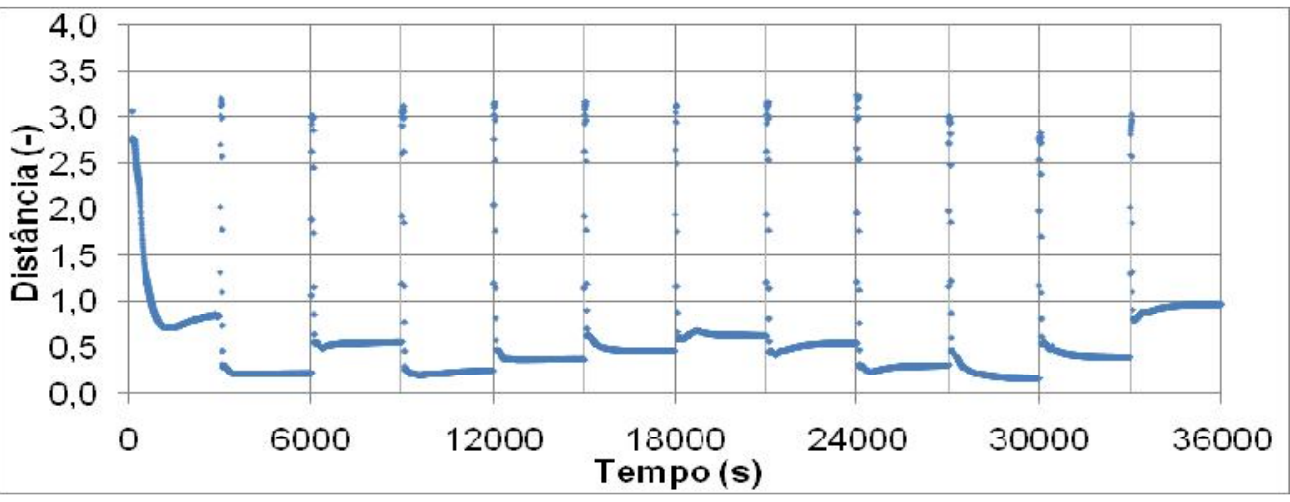

GRÁFICO 96 Distâncias durante o monitoramento da simulação de degraus descendentes para rede a) Triangular b) Quadrada c) Hexagonal d) Cúbica 


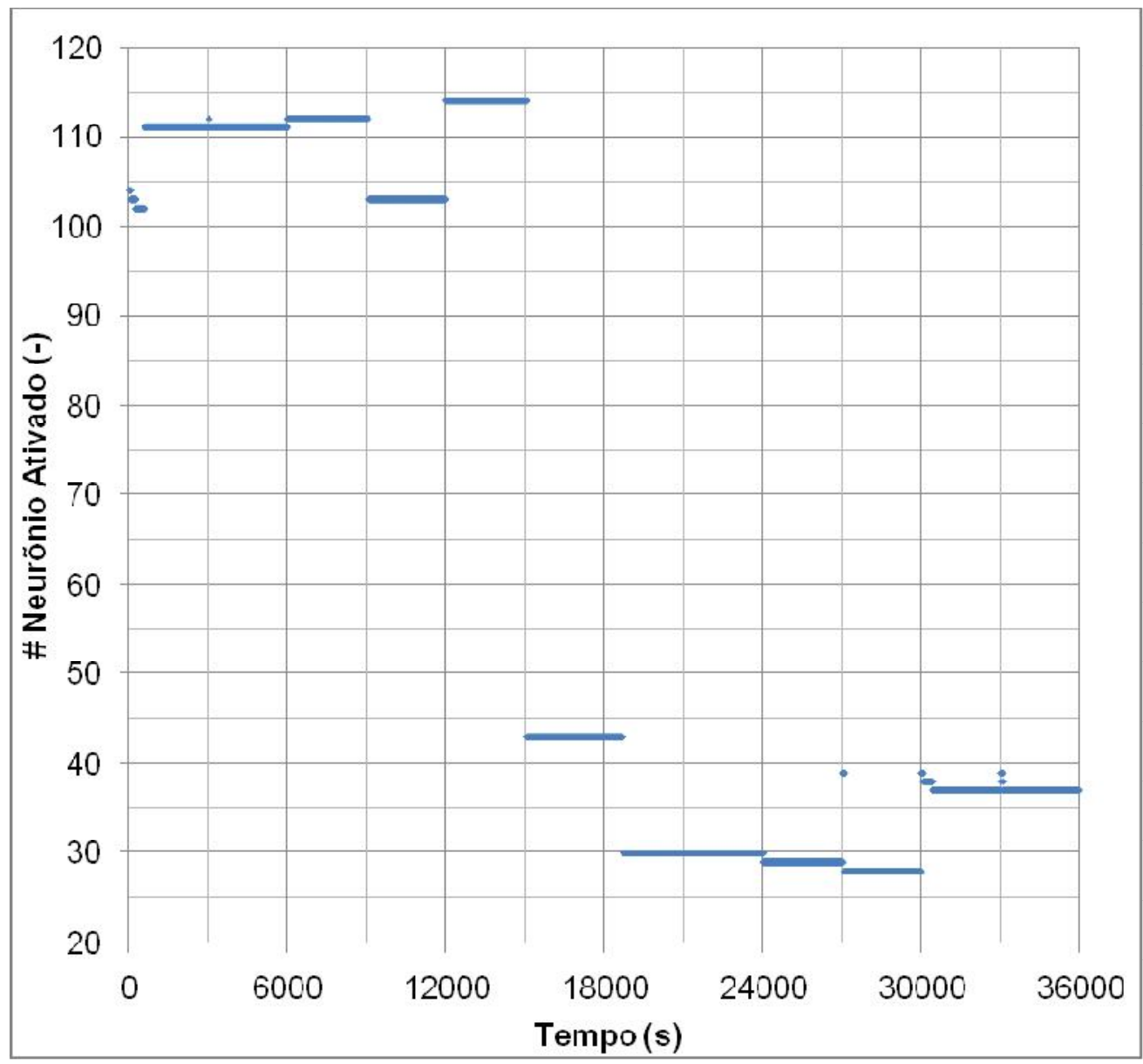

GRÁFICO 97 Neurônios ativados pela rede cúbica para a simulação dos degraus descendentes

Fonte: resultados do SICT

\section{Pressurização}

A avaliação do monitoramento das simulações de pressurização mostrou que essas redes conseguem identificar o transiente de pressurização logo após sua fase inicial, diferentemente das redes treinadas com os conjuntos de buffers DR apresentadas anteriormente. O GRAF. 98 mostra as distâncias durante o monitoramento, pode-se notar que entre $1200 \mathrm{~s}$ até $7000 \mathrm{~s}$ elas estão em uma faixa compatível com aquelas do treinamento, destacando-se que após cerca de $6400 \mathrm{~s}$ as condições estão fora da faixa de treinamento, conforme mostrado no GRAF. 205 do APÊNDICE F. Após $7000 \mathrm{~s}$ ocorre a despressurização, transiente para o qual a rede não é treinada e assim a 
distância chega a valores maiores que 160 indicando que a rede não identifica essas condições.
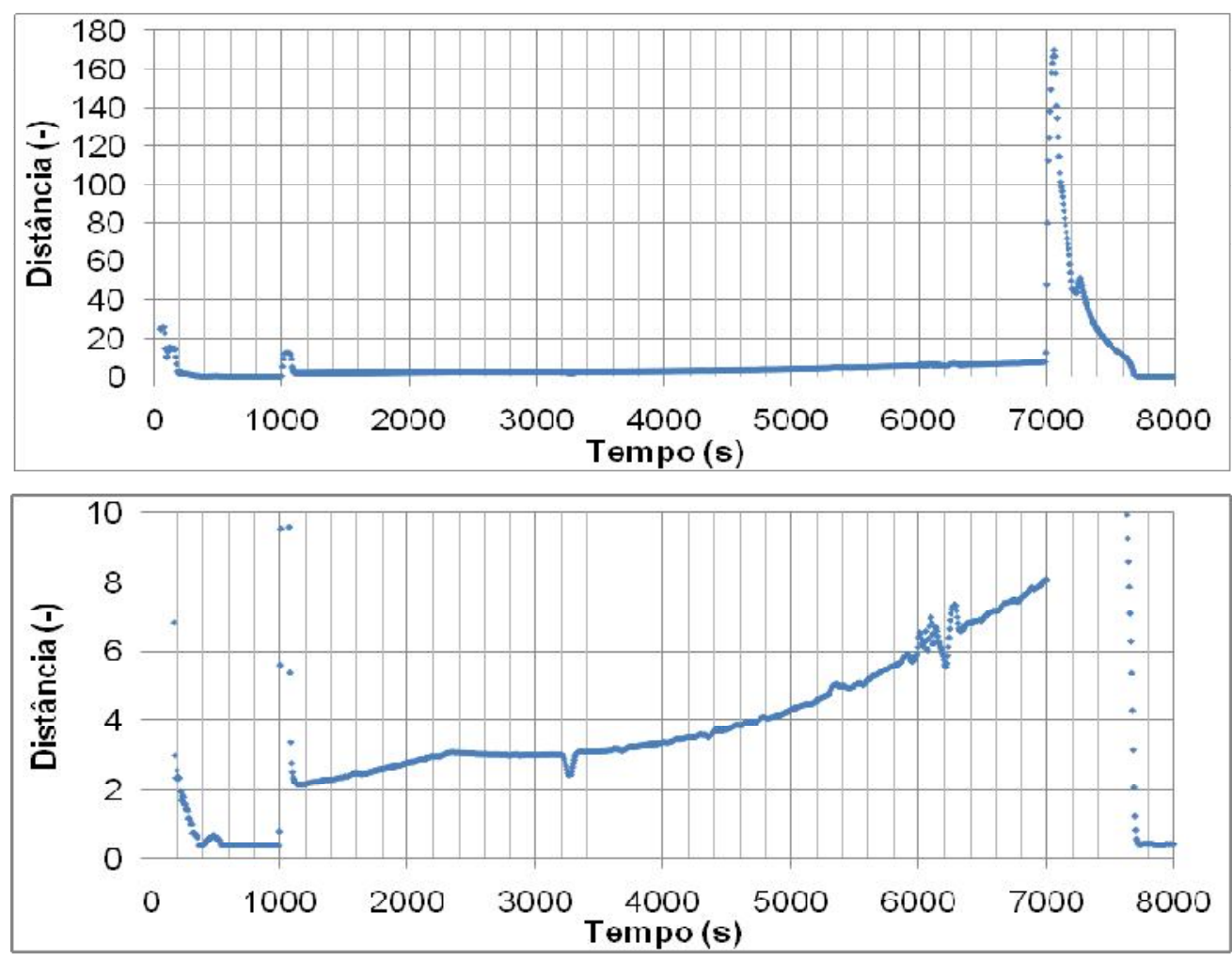

GRÁFICO 98 Distâncias buffer-neurônio para a rede cúbica durante o monitoramento da simulação PRESSURIZA70k

Fonte: resultados do SICT

O GRAF. 99 e o Quadro 18 mostram os neurônios ativados durante o monitoramento da simulação PRESSURIZA70k. Logo após 1000 s o neu rônio 115 é ativado permanecendo assim até 2350 s quando é ativado o 69 seguido pelo 62 até 7000 s. Os neurônios 69 e 122 estão associados unicamente aos buffers de pressurização identificando assim corretamente esse estado. Após $7000 \mathrm{~s}$, quando se dá a despressurização, são ativados os neurônios 57 e 118, associados a estados estacionários de 5 e 3 bars respectivamente, porém essas identificações são invalidadas pelas distâncias buffer-neurônio, GRAF. 98. 


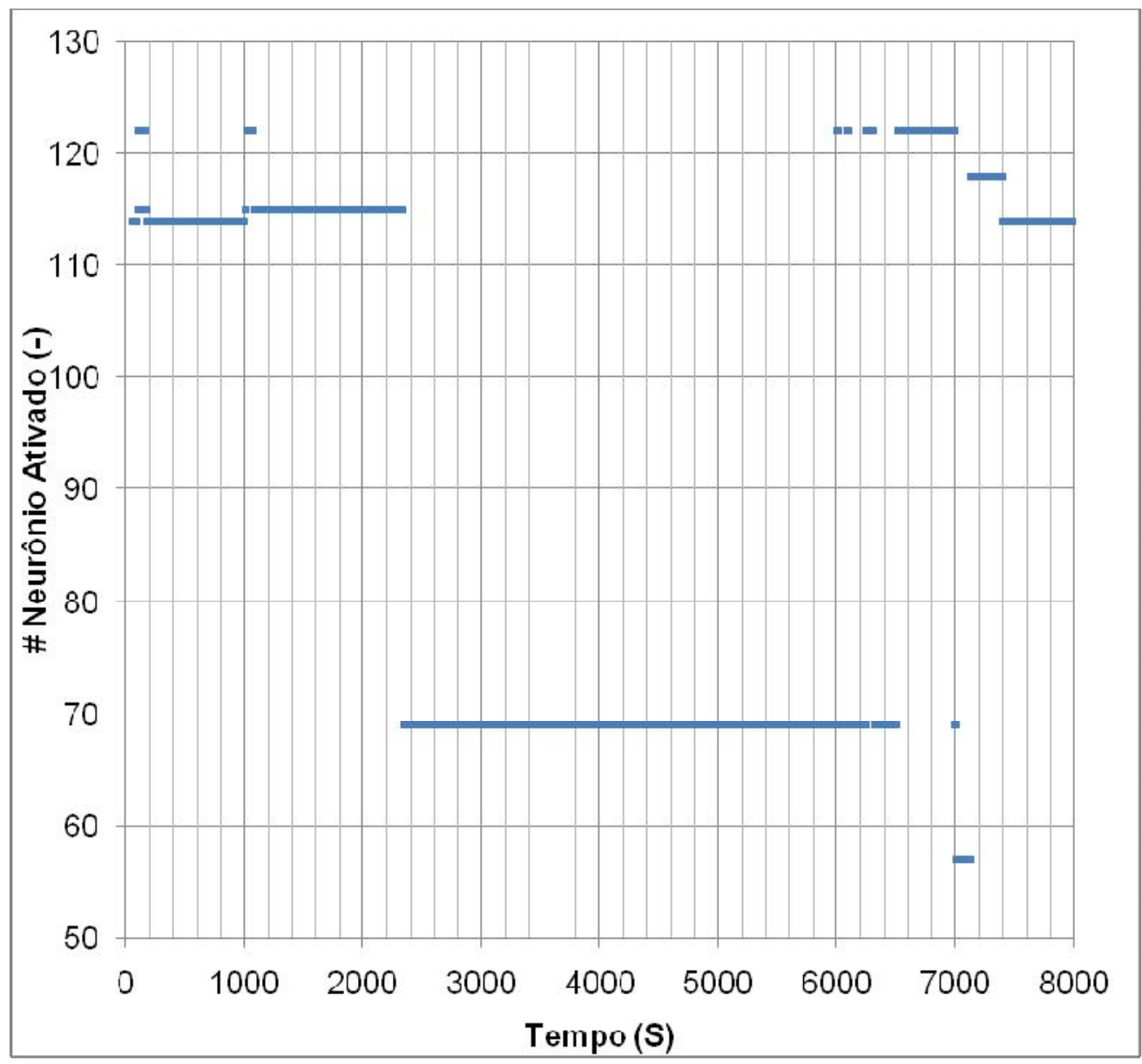

GRÁFICO 99 Neurônios ativados pela rede cúbica para a simulação PRESSURIZA70k

Fonte: resultados do SICT

QUADRO 18 - Neurônios ativados pela rede cúbica para a simulação

PRESSURIZA70k

\begin{tabular}{c|l}
\hline Neurônio & \multicolumn{1}{|c}{ Condições dos buffers associados ao neurônio } \\
\hline 57 & Estado estacionário a 5 bars \\
\hline 69 & Pressurização \\
\hline 114 & Estado estacionário a 1 bar \\
\hline 115 & Vários transien tes lentos incluindo pressurização \\
\hline 118 & Estado estacionário a 3 bars \\
\hline 122 & Pressurização \\
\hline
\end{tabular}

Fonte: resultados do SICT 


\section{Isolamento do Trocador de Calor}

O GRAF. 100 mostra as distâncias durante o monitoramento da simulação do isolamento do trocador de calor ISOLATC. Pode-se observar que, após $2000 \mathrm{~s}$ quando se inicia o isolamento, as distâncias ficam dentro do valor máximo do treinamento exceto pelo período em torno de $2700 \mathrm{~s}$, quando ocorreu uma explosão de vapor, e após 2900 s quando a transferência de calor se deteriorou.

O QUADRO 19 e o GRAF. 101 mostram os neurônios ativados durante o transiente. De 2300 s a $2700 \mathrm{~s}$ a rede identificou corretamente o transiente como um isolamento da bomba do secundário e após o evento em $2700 \mathrm{~s}$, que não pode ser identificado, ela identificou as condições como de perda de refrigeração o que está correto.
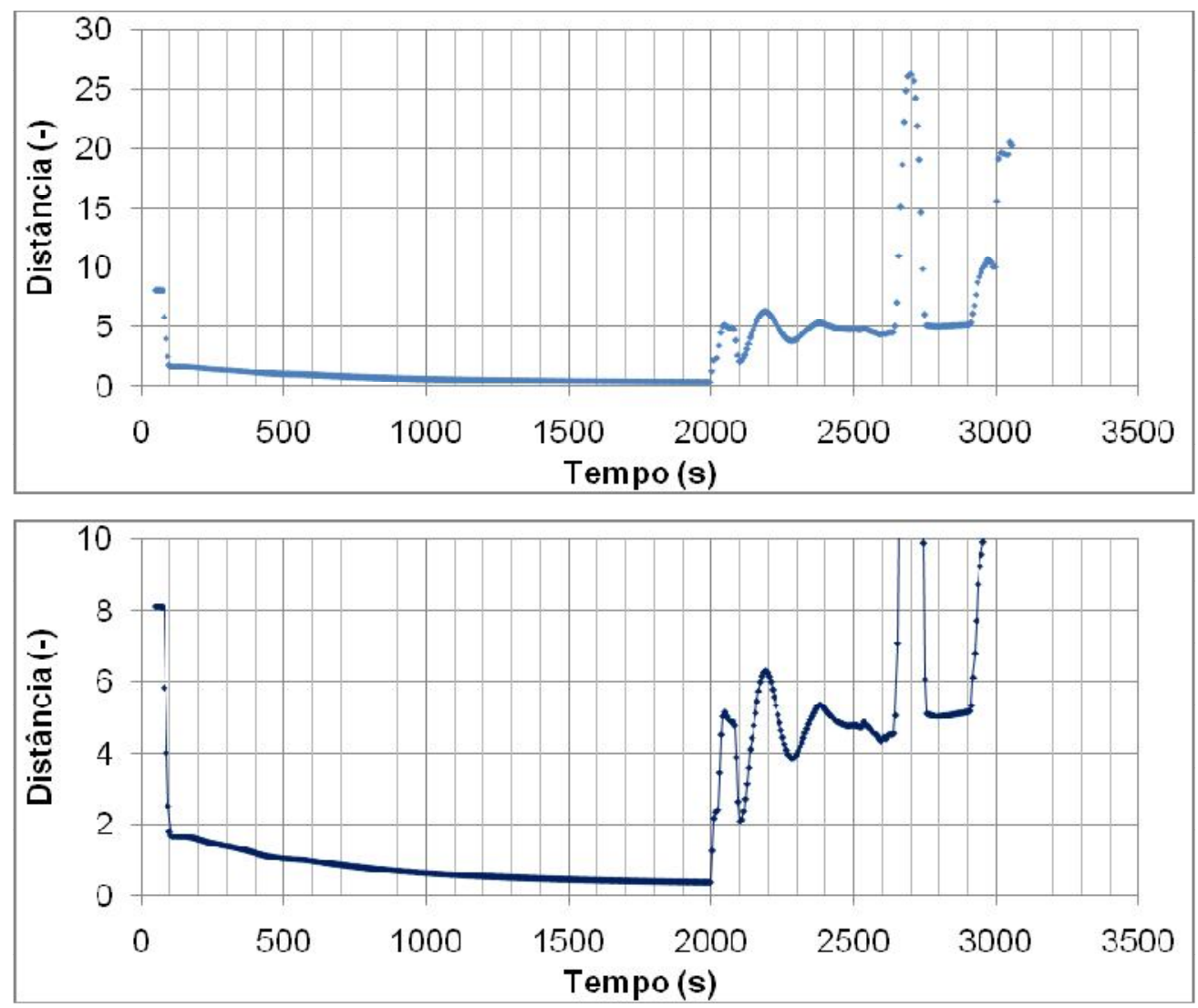

GRÁFICO 100 Distâncias buffer-neurônio para a rede cúbica durante o monitoramento da simulação ISOLATC

Fonte: resultados do SICT 
QUADRO 19 - Neurônios ativados na rede hexagonal durante monitoração da simulação ISOLATC

\begin{tabular}{cl}
\hline Neurônios & \multicolumn{1}{c}{ Buffers associados } \\
\hline 31 & Perda de refrigeração \\
33 & Perda de refrigeração \\
\hline 51 & Desligamento da bomba do secundário \\
\hline 52 & Desligamento da bomba do secundário \\
\hline 57 & Isolamento Trocador de Cabr \\
\hline 79 & Desligamento da bo mba do secundário \\
\hline 87 & Isolamento Trocador de Cabr \\
\hline 88 & Ligamento da Bomba do Secundário \\
123 & Perda de refrigeração \\
\hline
\end{tabular}

Fonte: resultados do SICT

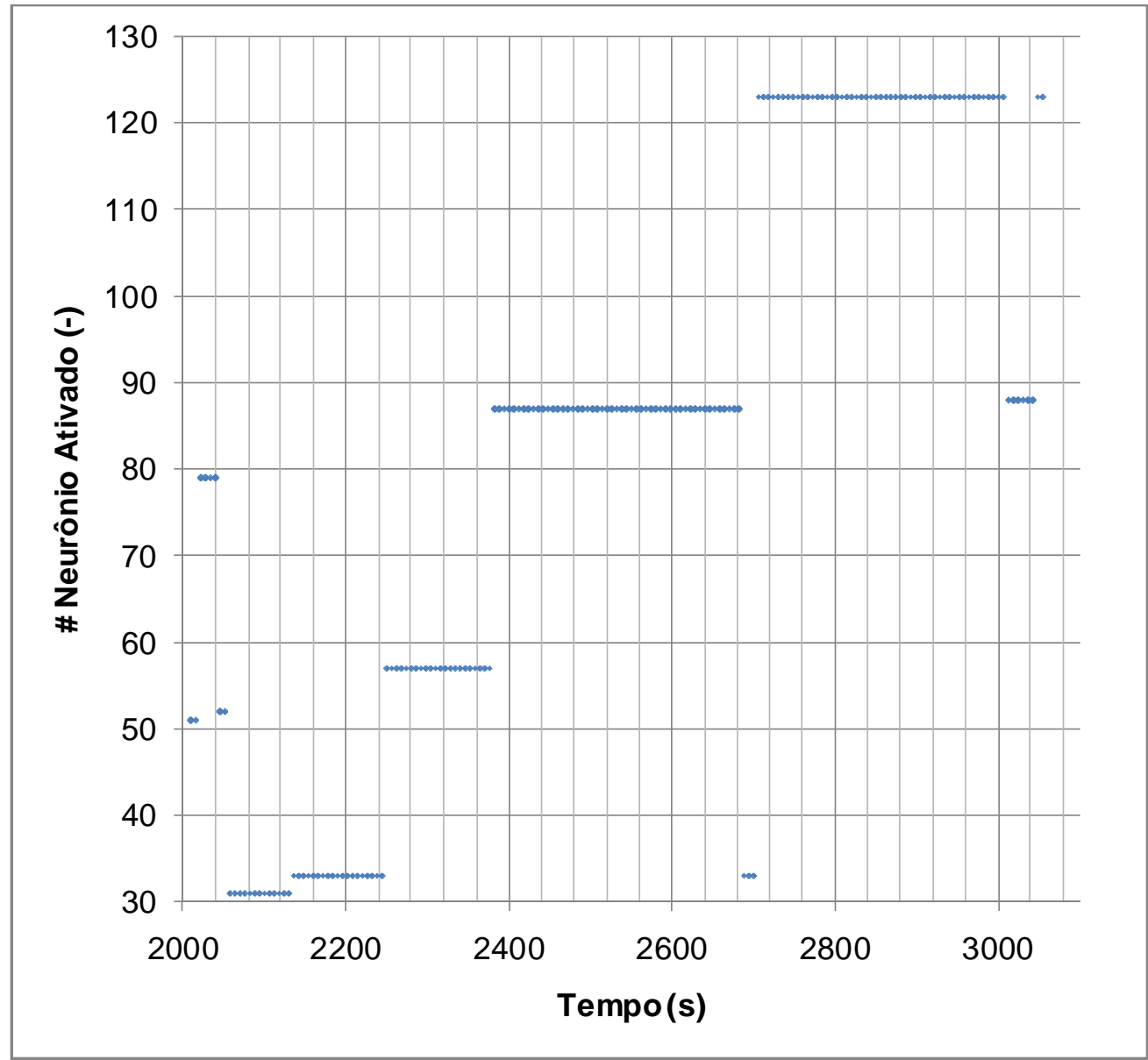

GRÁFICO 101 Neurônios ativados na rede hexagonal durante monitoração da simulação ISOLATC

Fonte: resultados do SICT 


\subsubsection{Conclusões sobre as redes Triangular, Quadrada, Hexagonal e Cúbica com conjunto de buffers ALL}

As redes triangular, quadrada, hexagonal e cúbica mostraram um desempenho muito semelhante entre $\mathrm{si}$, quando treinadas com o conjunto de buffers ALL e avaliadas usando o monitoramento das simulações do RELAP5. A configuração usada para essas redes, cerca de 160 neurônios e com o uso de derivadas com peso dois durante o treinamento possibilitou que essas redes identificassem quase todos os transientes para os quais foram treinadas e, como previsto no comportamento das redes neuronais, outros transientes similares a esses. Essas redes demonstraram a capacidade acusar, através do alto valor das distâncias buffer-neurônio, quando as condições apresentadas a ela não são similares a nada para o que ela foi treinada, evitando assim falsas identificações. A não identificação de alguns transientes se deve, entre outros possíveis fatores, ao número de neurônios usados, aproximadamente 160, que teria que ser maior para o uso com o conjunto de buffers ALL.

\subsubsection{Uso do SICT com resultados experimentais}

Quando usados os dados experimentais o comportamento obtido foi bastante similar ao que se obteve usando os resultados de simulação. Para a avaliação do desempenho das redes com os dados experimentais foram analisados comparativamente, numa primeira abordagem:

- a imagem da tela do SICT, após a monitoração de um experimento, quando existir uma simulação equivalente ou quando forem encontradas discrepâncias,

- $\quad$ as distâncias dos buffers aos neurônios durante a monitoração dos resultados dos experimentos $\mathrm{e}$ 
- os neurônios ativados durante os transientes e estados estacionários dos experimentos.

\subsubsection{Experimento 11: degraus ascendentes}

Resultados do experimento 11 podem ser vistos nos GRAF. 116 a 119 do APÊNDICE D.

\section{Rede 8D3V com conjunto de buffers DR (CT1 - 8D3V - DR) Exp11}

A FIG. 49 mostra os neurônios ativados por mudanças de potência em degraus ascendentes usando o monitoramento a partir de a) dados dos resultados do experimento 11 no CT1, à esquerda, e de b) simulações com o RELAP5, à direita. Pode-se observar a semelhança entre os neurônios ativados. Os neurônios discrepantes foram avaliados individualmente e pôde-se determinar que representam condições que não eram comuns aos dois conjuntos de dados de monitoramento, mas sim associados a transitórios de inicialização.

a)

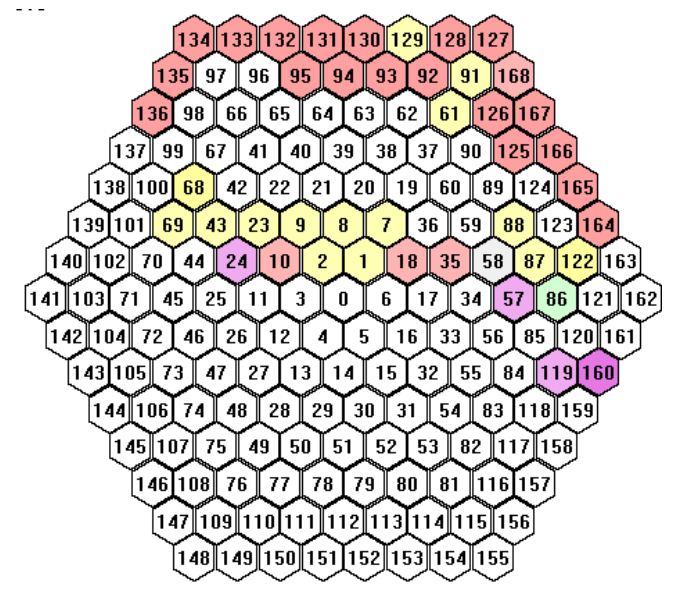

b)

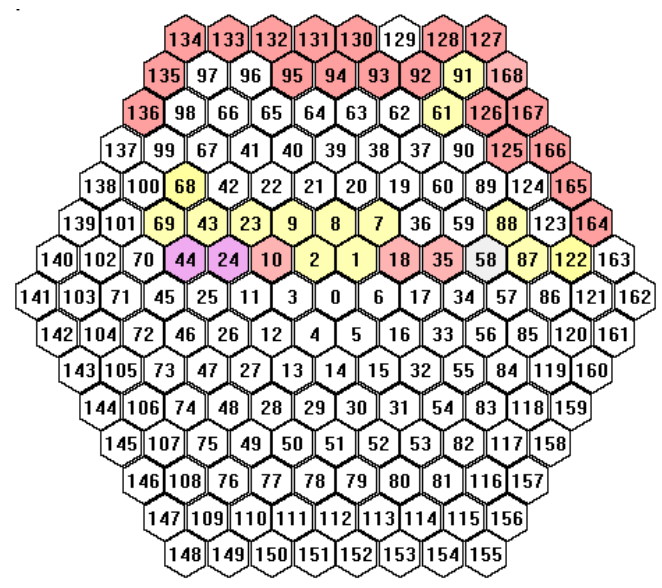

FIGURA 49 Neurônios ativados durante: a) o experimento 11 e b) a simulação de degraus ascendentes com a rede CT1 - 8D3V - DR

Fonte: resultados do SICT

O GRAF. 102 mostra a evolução da distância buffer-neurônio ao longo do experimento. Pode-se observar que as manobras iniciais até $200 \mathrm{~s}$ e as finais 
após 9000 , para os quais o SICT não foi treinado, apresentam distâncias muito maiores que os dos transientes e estados estacionários. As distâncias nas condições treinadas são geralmente menores que 20, ou seja, cerca de até três vezes maiores que os valores máximos do treinamento, GRAF. 89, e cerca de duas vezes maior que as distâncias máximas durante o monitoramento da simulação de degraus ascendentes, GRAF. 91.
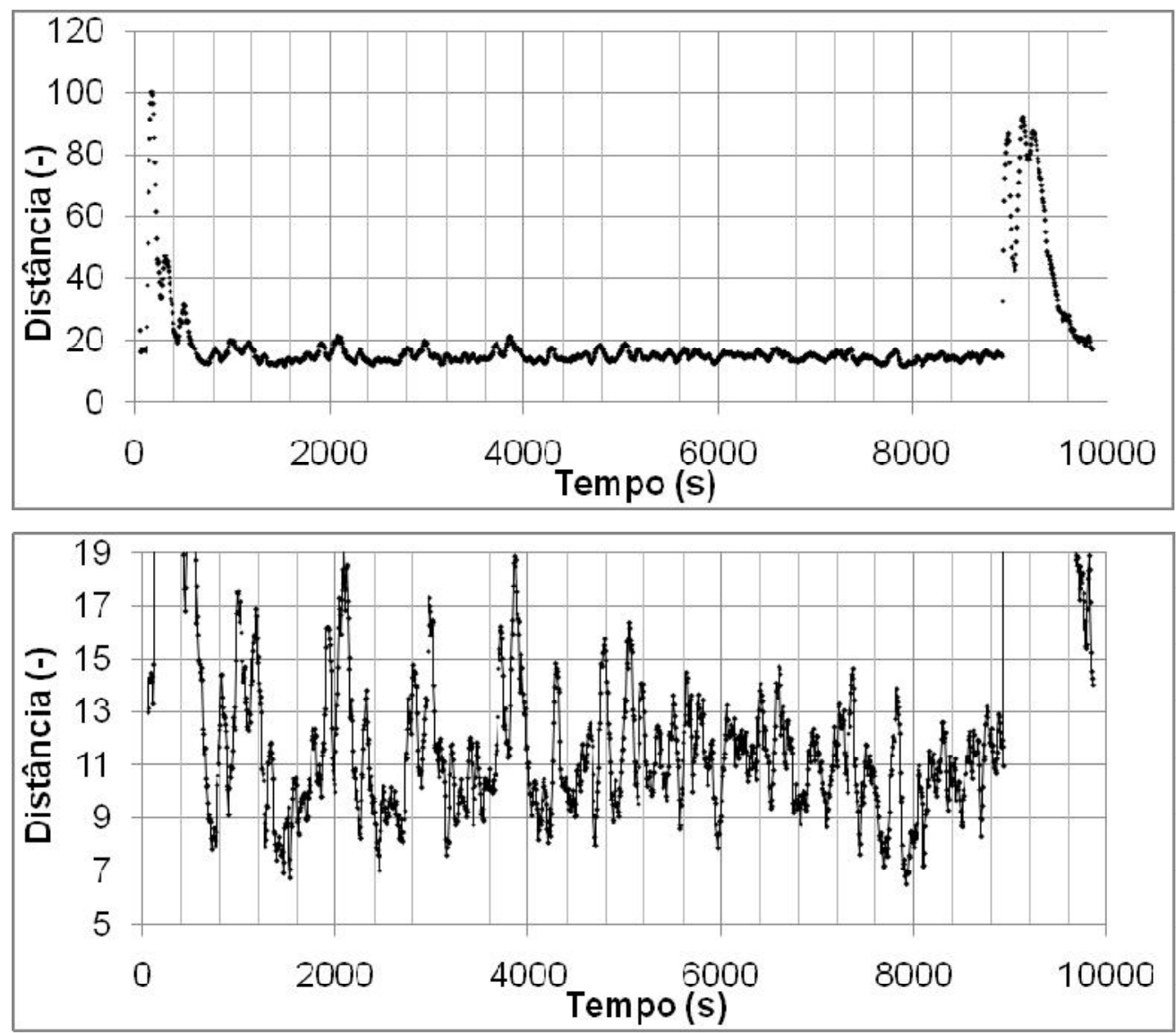

GRÁFICO 102 Distâncias entre os buffers e os neurônios durante monitoração do experimento 11 com rede CT1 - 8D3V - DR

Fonte: resultados do SICT

\section{Rede Cúbica com conjunto de buffers ALL (CT1 - CUB - ALL) Exp11}

A FIG. 50 mostra os neurônios ativados na rede cúbica por mudanças de potência em degraus ascendentes usando o monitoramento a partir de a) dados dos resultados do experimento 11 no CT1, à esquerda, e de b) simulações com o RELAP5, à direita. Pode-se observar a semelhança entre os 
neurônios ativados. Os neurônios discrepantes foram avaliados individualmente e pôde-se determinar que representam condições que não eram comuns aos dois conjuntos de dados de monitoramento, mas sim associados a transitórios de inicialização e desligamento de circuito no início e no fim do experimento. Comparando-se a FIG. 49 com a FIG. 50 observa-se um menor número de neurônios ativados na rede cúbica, devido a dois motivos:

- o conjunto de buffers ALL tem quase o dobro de buffers que a o DR, QUADRO 13, fazendo com esses fiquem mais condensados com seus semelhantes, uma vez que ambas as redes têm aproximadamente 160 neurônios e

- a rede DR usou derivadas com peso 3 no treinamento e a rede cúbica usou peso 2, o que como já mostrado, quando maior o peso da derivada mais neurônios são ativados durante os transientes.
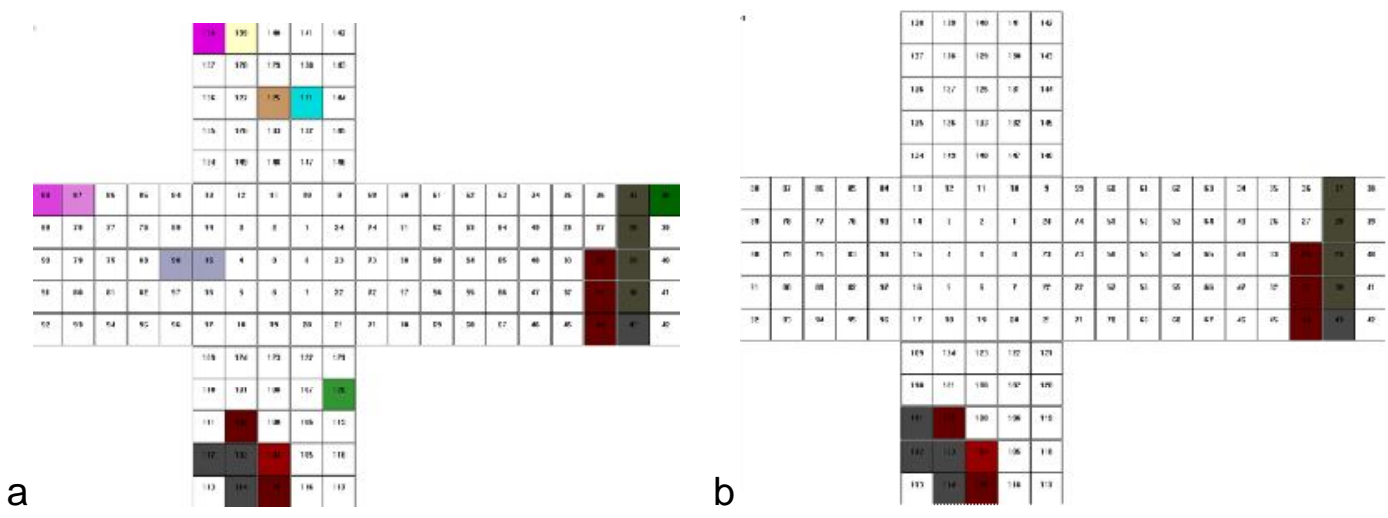

FIGURA 50 Neurônios ativados: a) durante o experimento 11 e b) durante simulações de degraus ascendentes com rede cúbica CT1 - CUB - ALL

Fonte: resultados do SICT

O GRAF. 103 mostra a evolução da distância buffer-neurônio ao longo do experimento 11. Diferentemente dos resultados do GRAF. 101 este gráfico mostra que essa rede identifica as condições iniciais até $2000 \mathrm{~s}$ e também reconhece uma situação problemática logo após $9000 \mathrm{~s}$. Outra diferença observada nesses gráficos é o valor da distância buffer-neurônio, que é bem menor na rede treinada com o conjunto de buffers ALL. Deve-se notar que as 
distâncias mostradas no GRAF. 102 são menores que o valor máximo da TAB. 25 e aproximadamente iguais às do GRAF. 96.

Da mesma forma que descrito na avaliação da simulação de degraus descendentes pela rede cúbica no 7.1.2.8 essa rede deixou de identificar os dois degraus iniciais em torno de $800 \mathrm{~s}$ e $1700 \mathrm{~s}$. Esse comportamento ainda que esperado, pois ocorreu durante o monitoramento da simulação, é indesejado.
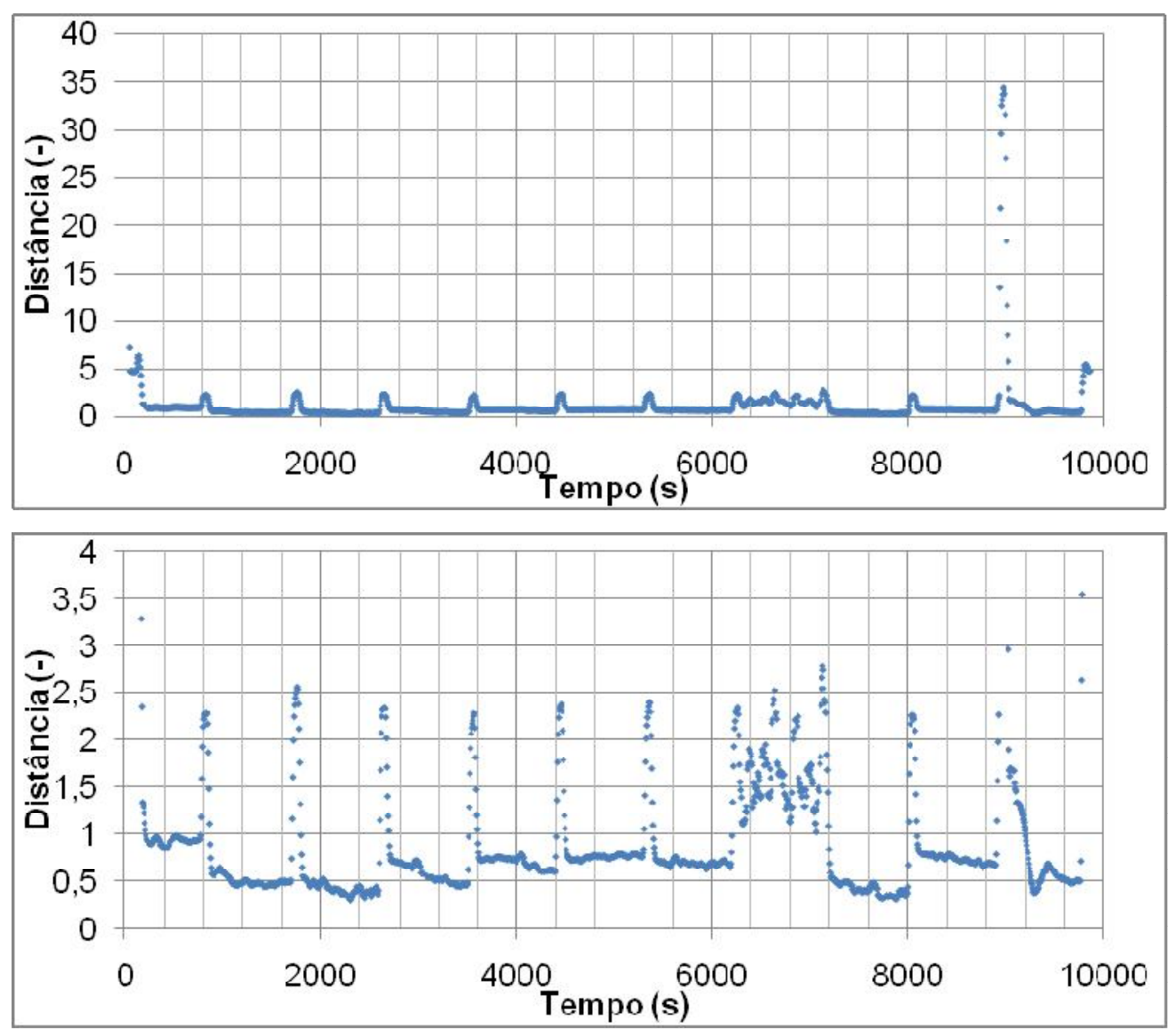

GRÁFICO 103 Distâncias entre os buffers e os neurônios durante monitoração do experimento $11 \mathrm{com}$ rede cúbica CT1 - CUB - ALL

Fonte: resultados do SICT 


\subsubsection{Experimento 12: degraus descendentes}

Resultados do experimento 12 podem ser vistos nos GRAF. 120 e 121 do APÊNDICE D.

\section{Rede 8D3V com conjunto de buffers DR (CT1 - 8D3V - DR) Exp12}

A FIG. 51 mostra, de maneira similar à FIG. 49, os neurônios ativados por mudanças de potência em degraus descendentes usando o monitoramento a partir dos dados dos resultados do experimento 12 no CT1. Pode-se novamente observar a semelhança entre os neurônios ativados. Os neurônios discrepantes foram avaliados individualmente e pôde-se determinar que representam condições que não são comuns aos dois conjuntos de dados de monitoramento, mas sim associados a transitórios de inicialização e desligamento de circuito no início e no fim do experimento.

a)

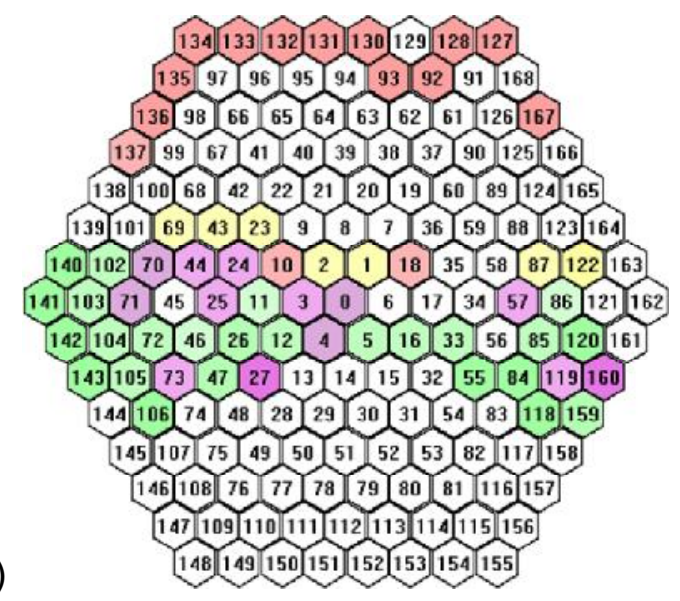

FIGURA 51 Neurônios ativados: a) durante o experimento 12 e b) durante simulações de degraus descendentes com rede CT1 - 8D3V - DR

Fonte: resultados do SICT

De maneira similar ao GRAF. 102, o GRAF. 104 também mostra as distâncias durante 0 monitoramento do experimento 12 e aquelas durante a simulação equivalente. As mesmas observações e conclusões feitas para a avaliação das redes com o experimento 11 puderam ser constatadas a partir desses resultados. $O$ transiente de desligamento e o transiente inicial de aumento 
de potência de zero para $100 \%$ foram os responsáveis pelas discrepâncias de neurônios ativados observados na FIG. 51.
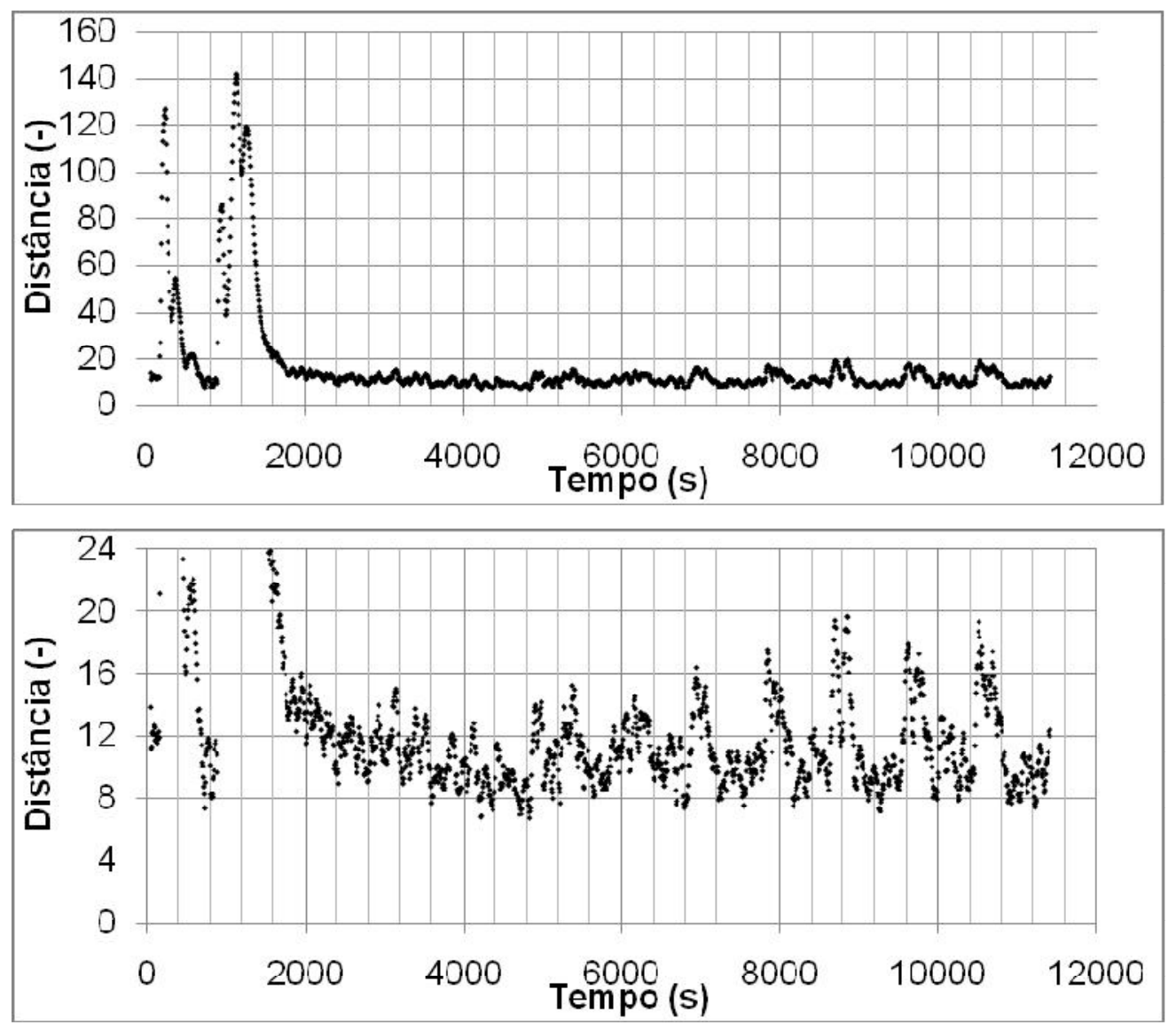

GRÁFICO 104 Distâncias entre os buffers e os neurônios durante monitoração do experimento 12 com a rede CT1 - 8D3V - DR

Fonte: resultados do SICT

\section{Rede Cúbica com conjunto de buffers ALL (CT1 - CUB - ALL) Exp12}

A FIG. 52 mostra os neurônios ativados na rede cúbica por mudanças de potência em degraus descendentes usando o monitoramento a partir de a) dados dos resultados do experimento 12 no CT1, à esquerda, e de b) simulações com o RELAP5, à direita. Pode-se observar a semelhança entre os neurônios ativados.

O GRAF. 105 mostra que as distâncias estão conforme o esperado para essa rede com esse experimento de maneira similar ao GRAF. 103. 

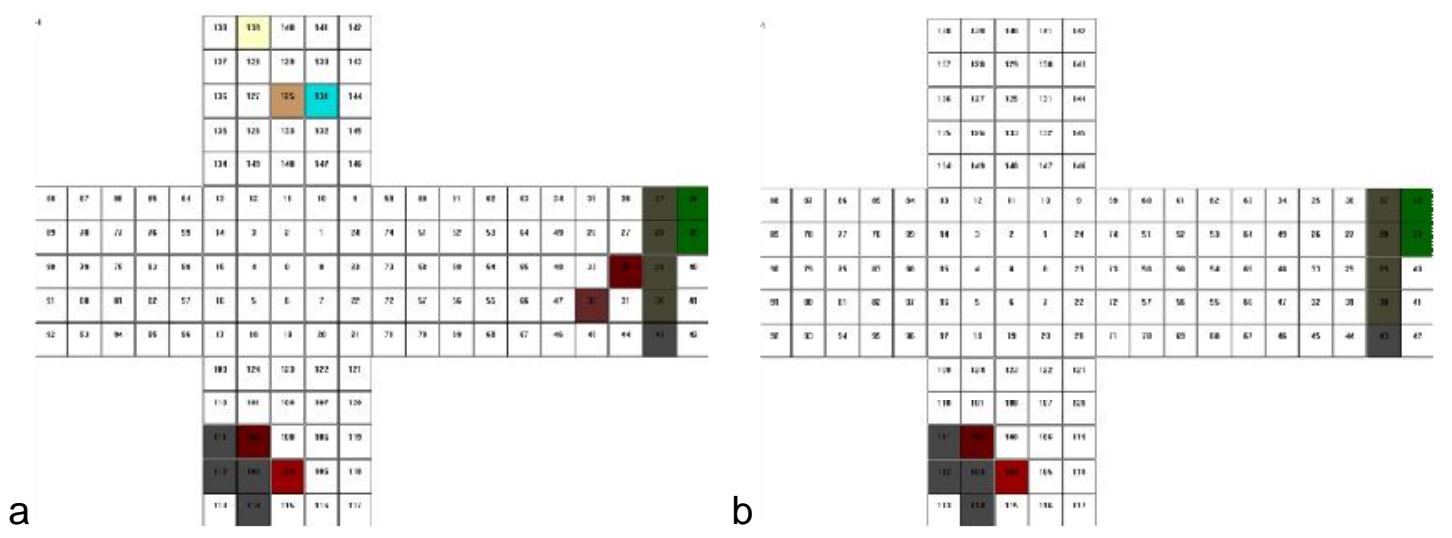

FIGURA 52 Neurônios ativados: a) durante o experimento 11 e b) durante simulações de degraus ascendentes com rede cúbica CT1 - CUB - ALL

Fonte: resultados do SICT
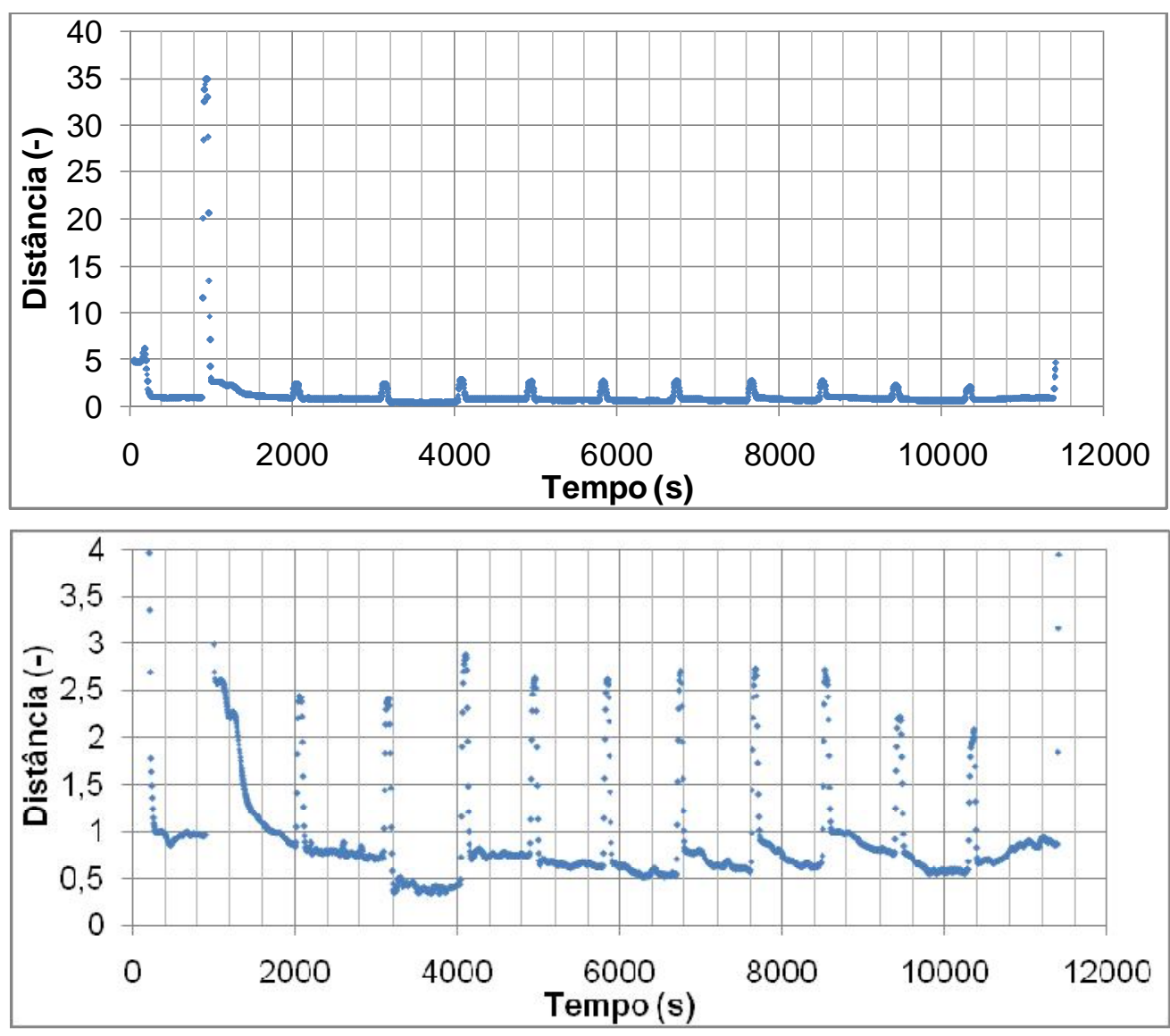

GRÁFICO 105 Distâncias entre os buffers e os neurônios durante monitoração do experimento 12 com rede cúbica CT1 - CUB - ALL

Fonte: resultados do SICT 
O GRAF. 106 mostra de maneira similar ao GRAF. 97 que a rede cúbica não identifica todos os transientes. Nesse gráfico pode-se observar que os transientes entre 4500 s e 8000 s não foram identificados como tal.

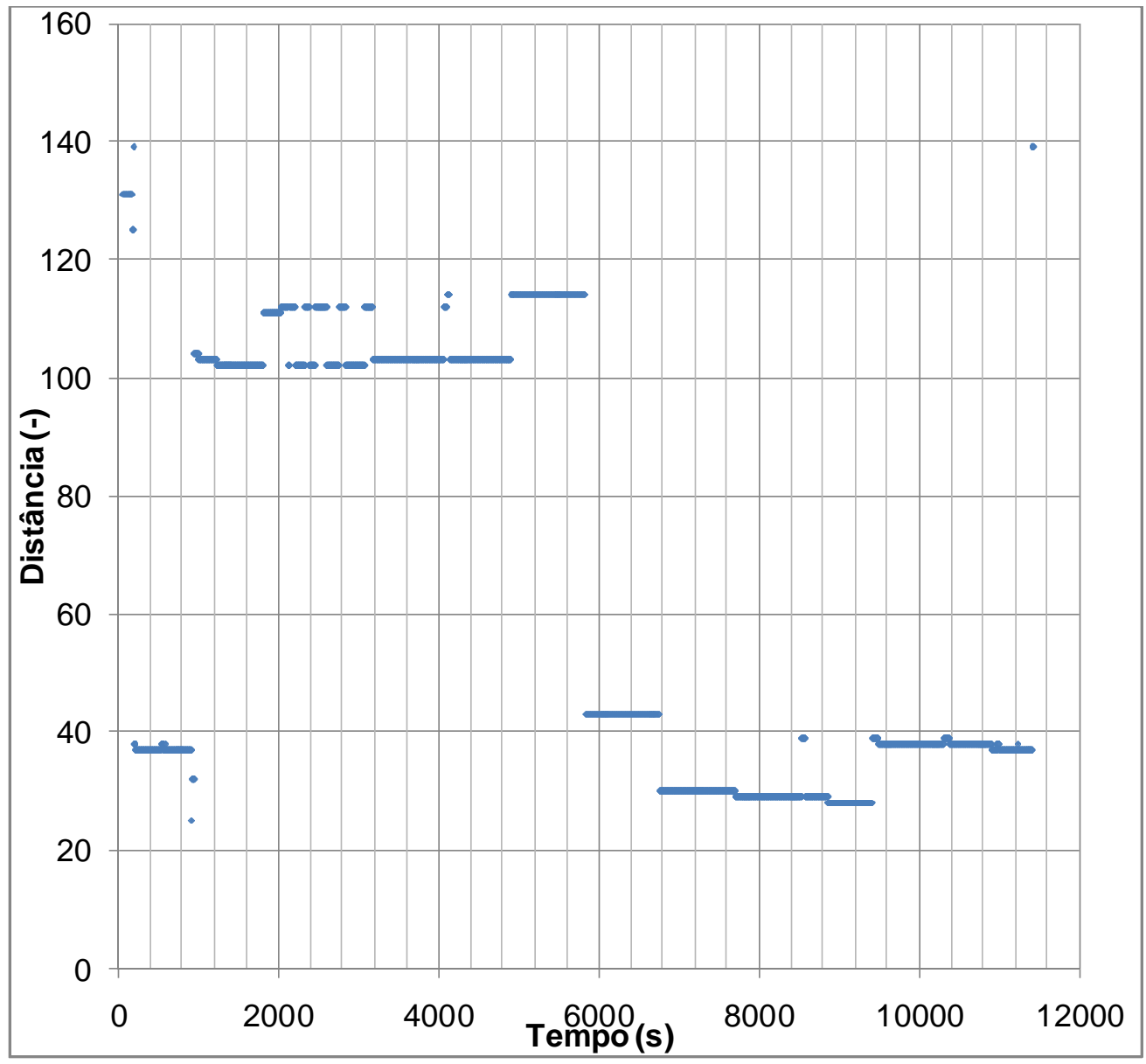

GRÁFICO 106 Neurônios ativados pela rede cúbica para a simulação dos degraus descendentes

Fonte: resultados do SICT

\subsubsection{Experimento 18: rampas de $240 \mathrm{~s}$ ascendentes}

Resultados do experimento 18 podem ser vistos nos GRAF. 134 e 135 do APÊNDICE D. Pode-se observar que esse experimento não foi até a potência de $100 \%$, tendo sido interrompido quando a potência estava em $60 \mathrm{~kW}$. 


\section{Rede 8D3V com conjunto de buffers DR (CT1 - 8D3V - DR) Exp18}

A FIG. 53 mostra os neurônios ativados por mudanças de potência, em rampas de $10 \%$ de potência ascendentes em $240 \mathrm{~s}$; à esquerda estão os resultados do experimento e à direita os resultados da simulação. $O$ monitoramento da simulação foi feita até a potência de $60 \%$, já que o experimento 18 foi terminado quando a potência estava nesse valor, conforme mostrado no GRAF.134. Os neurônios discrepantes foram avaliados individualmente e pôde-se determinar que representam condições que não são comuns aos dois conjuntos de dados de monitoramento, mas sim associados a transitórios de inicialização e desligamento de circuito no início e no fim do experimento.

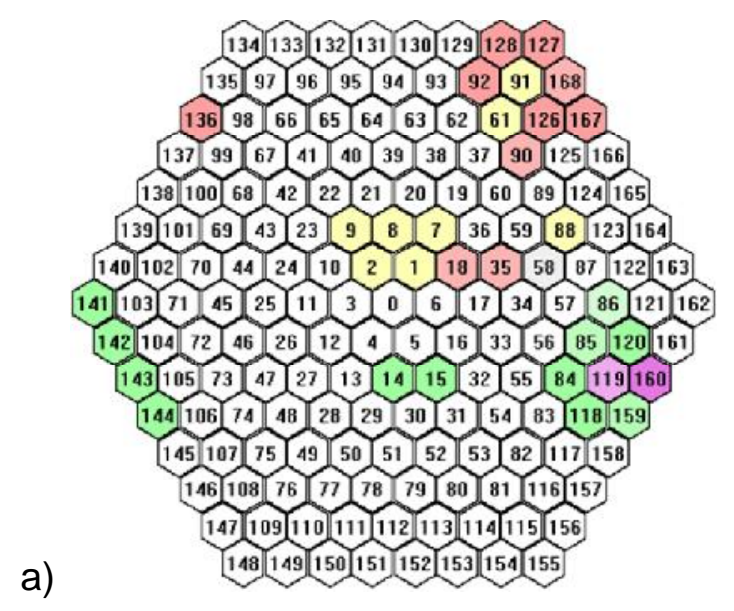

b)

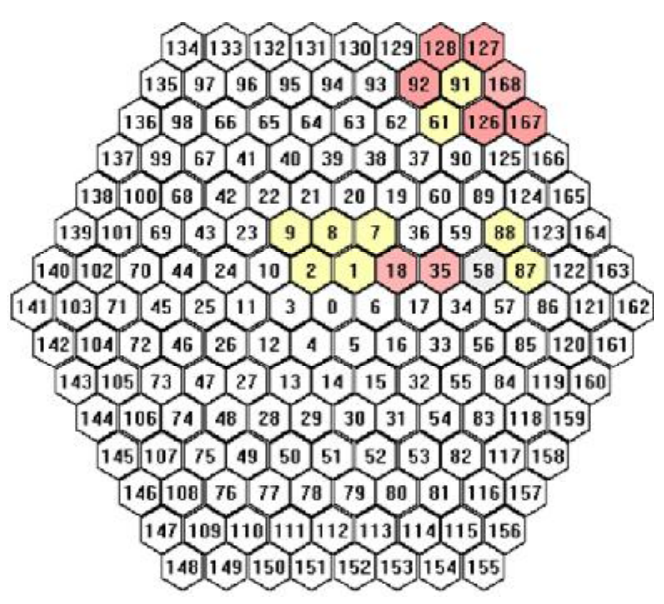

FIGURA 53 Neurônios ativados: a) durante o experimento 18 e b) durante simulações de rampas ascendentes de $240 \mathrm{~s}$ com a rede CT1 - 8D3V - DR

Fonte: resultados do SICT

O GRAF. 107 mostra a evolução da distância buffer-neurônio ao longo do experimento. Pode-se observar que as manobras iniciais até $700 \mathrm{~s}$ e as finais após $5500 \mathrm{~s}$, para os quais o SICT não foi treinado, apresentam distâncias muito maiores que os dos transientes e estados estacionários e estão associados aos neurônios discrepantes da FIG. 50. As distâncias nas condições treinadas são geralmente menores que 15, ou seja, cerca de até duas vezes maiores que os valores máximos do treinamento, GRAF. 89. 

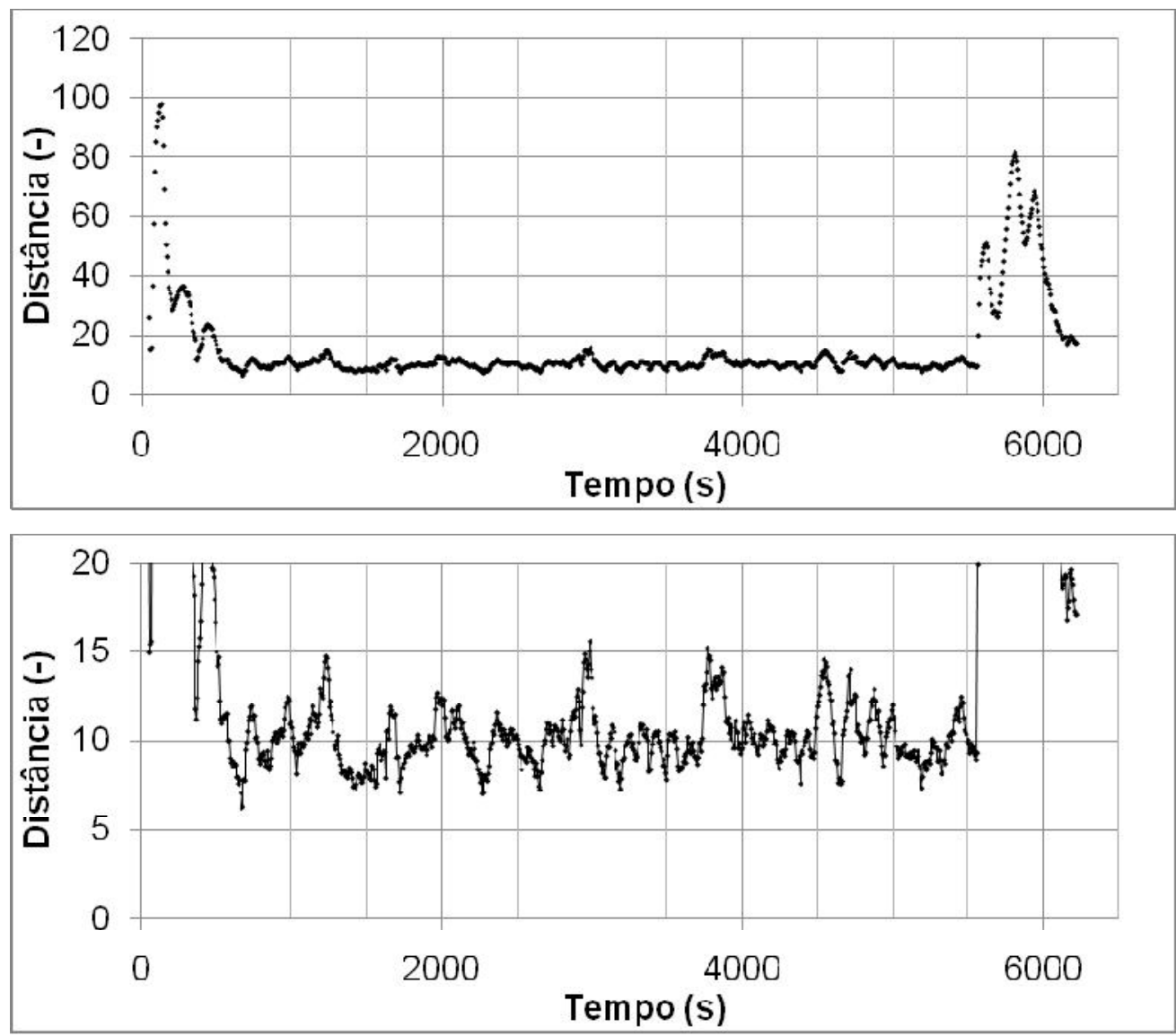

GRÁFICO 107 Distâncias entre os buffers e os neurônios durante monitoração do experimento $18 \mathrm{com}$ a rede CT1 - 8D3V - DR

Fonte: resultados do SICT

\subsubsection{Experimento 21: rampas de 240 s descendentes}

Resultados do experimento 21 podem ser vistos nos GRAF. 140 e 141 do APÊNDICE D. Esses resultados mostram que até $10000 \mathrm{~s}$ são feitas rampas descendentes de $10 \%$ de potência a 240 s e em cerca de 11000 s e 14000 s são feitas manobras para as quais o SICT não foi treinado.

\section{Rede 8D3V com conjunto de buffers DR (CT1 - 8D3V - DR) Exp21}

A FIG. 54 mostra os neurônios ativados por mudanças de potência, em rampas de $10 \%$ de potência descendentes em 240 s, durante o monitoramento a 
partir dos dados dos resultados do experimento 21 no CT1 - a) - e de resultados de simulação-b). Pode-se observar a semelhança no padrão dos neurônios ativados mostrados na tela do SICT para as duas situações. À direita da FIG. foram reapresentados os resultados do monitoramento eliminando-se os neurônios ativados por condições iniciais e finais.

a)

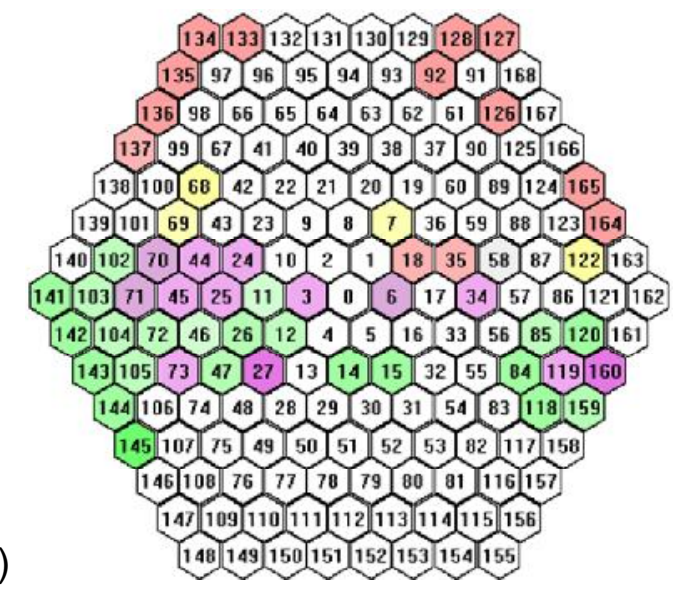

b)

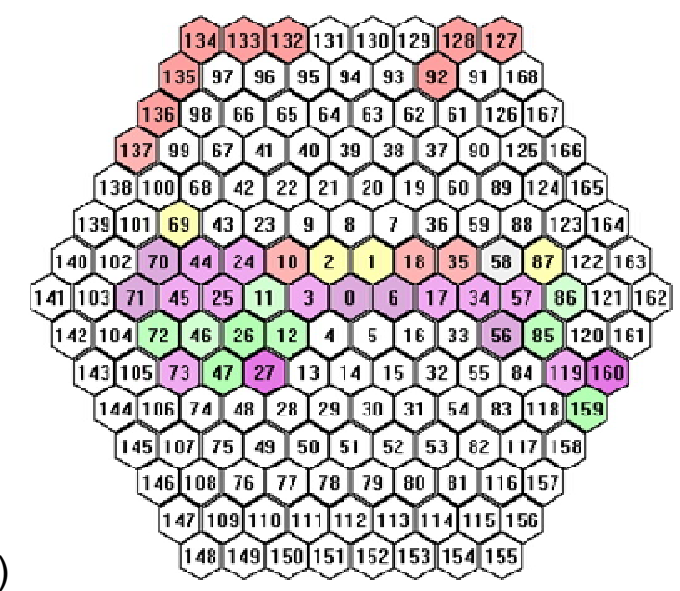

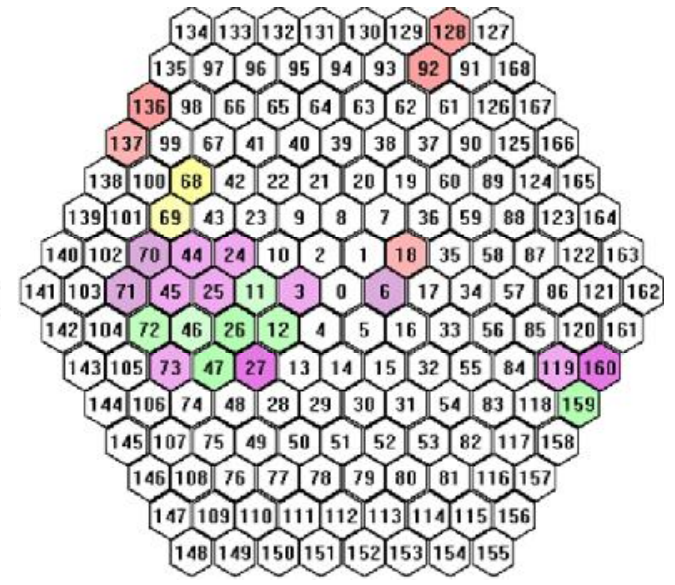

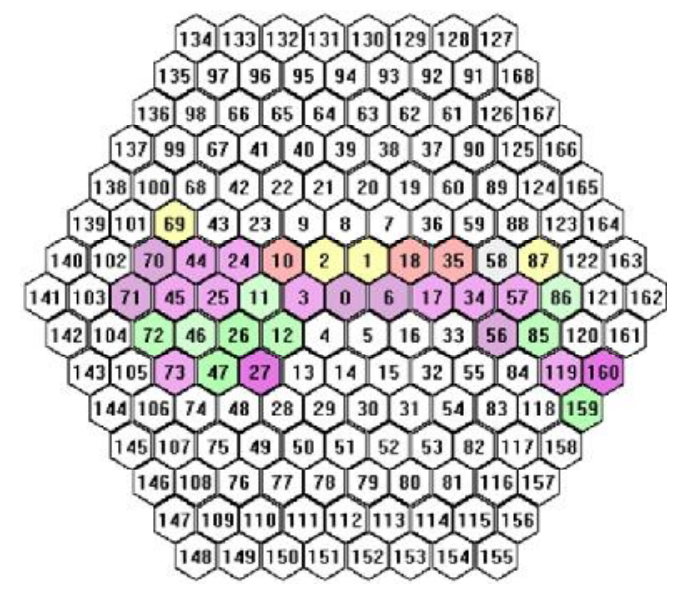

FIGURA 54 Neurônios ativados: a) durante o experimento 21 e b) durante simulações de rampas descendentes de $240 \mathrm{~s}$ com a rede CT1 - 8D3V - DR

\section{Fonte: resultados do SICT}

Os neurônios discrepantes à esquerda da FIG. 54 foram avaliados individualmente e pôde-se determinar que representam condições que não são comuns aos dois conjuntos de dados de monitoramento, mas sim associados a transitórios de inicialização e desligamento de circuito no início e no fim do experimento. 
O GRAF. 108 mostra a evolução da distância buffer-neurônio ao longo do experimento 21 até $1000 \mathrm{~s}$. Pode-se observar que as manobras iniciais até 2000 s e, para os quais o SICT não foi treinado, apresentam distâncias muito maiores que os dos transientes e estados estacionários e estão associados aos neurônios discrepantes à esquerda da FIG. 51. As distâncias nas condições treinadas são geralmente menores que 15, ou seja, cerca de até duas vezes maiores que os valores máximos do treinamento, GRAF. 89. Em torno de $2500 \mathrm{~s}$ pode-se observar um pico na evolução da distância, esse pico foi devido a oscilações durante o experimento e foram os responsáveis pelos neurônios discrepantes observados à direita da FIG. 51 .
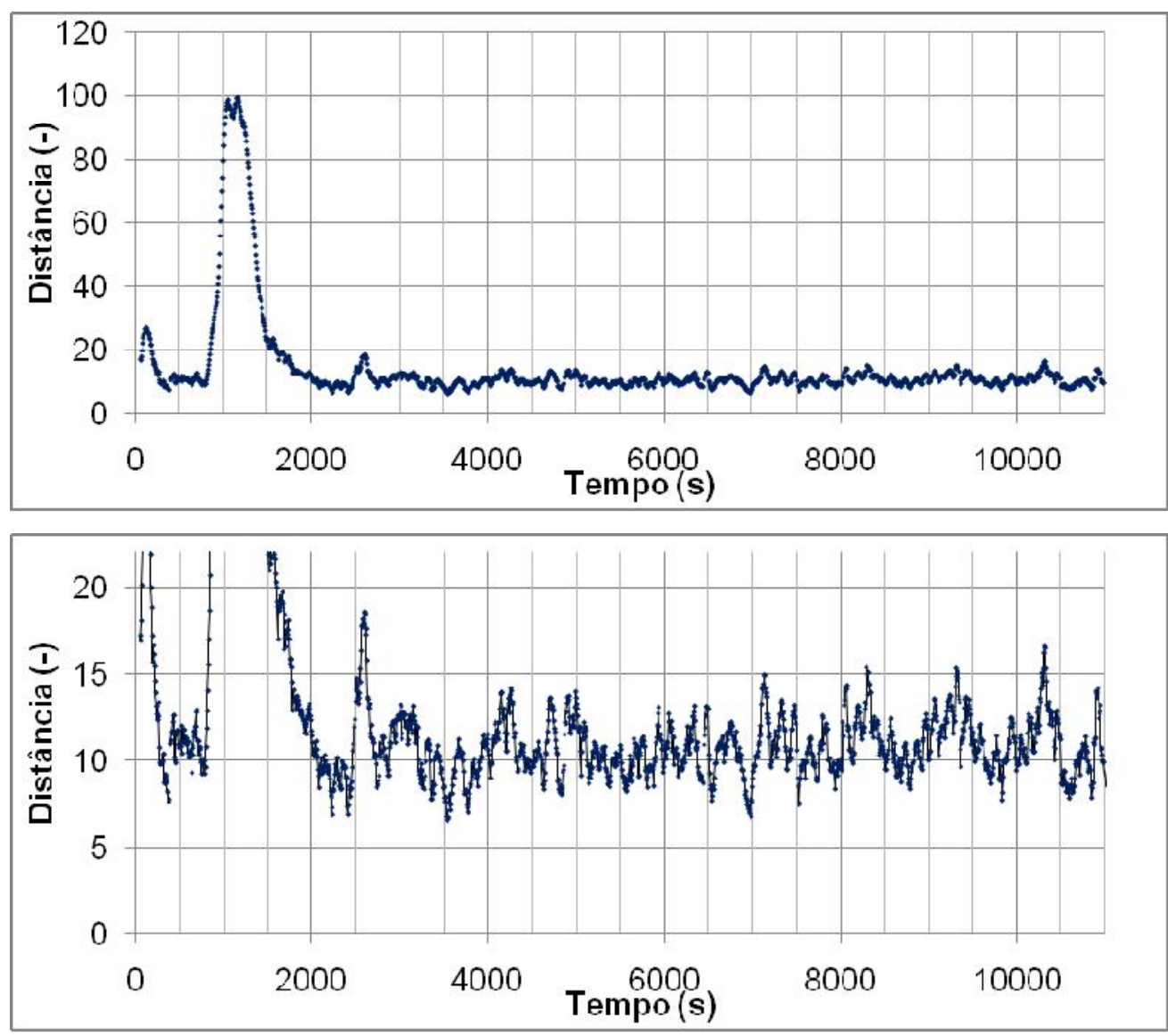

GRÁFICO 108 Distâncias entre os buffers e os neurônios durante monitoração do experimento $21 \mathrm{com}$ a rede CT1 - 8D3V - DR

Fonte: resultados do SICT 


\subsubsection{Experimento 23: desligamento Bomba do Secundário}

Resultados do experimento 23 podem ser vistos nos GRAF. 146 a 149 do APÊNDICE D. Esses resultados mostram que a cerca de $800 \mathrm{~s}$ é feito um degrau de $35 \%$ e outro de $70 \%$ após $3500 \mathrm{~s}$. A bomba do secundário é desligada em cerca de $1200 \mathrm{~s}$ é ligada novamente em $3000 \mathrm{~s}$, sendo novamente desligada em $4900 \mathrm{~s}$ e religada em $5200 \mathrm{~s}$.

\section{Rede 8D3V com conjunto de buffers DR (CT1 - 8D3V - DR) Exp23}

O SICT treinado com o conjunto de buffers DR não foi treinado para reconhecer os transientes de desligamento da bomba do secundário. O GRAF. 99 mostra que nos intervalos de $400 \mathrm{~s}$ a $800 \mathrm{~s}, 1500 \mathrm{~s}$ a $1700 \mathrm{~s}$ e entre $4000 \mathrm{~s}$ e $4900 \mathrm{~s}$, ou seja, em condições de estado estacionário a potência nula, 35\% e $100 \%$ respectivamente, as distâncias ficam abaixo de 20 indicando uma identificação válida das condições apresentadas para o SICT. Fora desses intervalos, onde as condições são de degraus muito grandes e de desligamento da bomba do secundário a distância fica bem acima desse valor de 20 , indicando que ela não identifica corretamente essas condições apresentadas a ela durante $o$ monitoramento. 

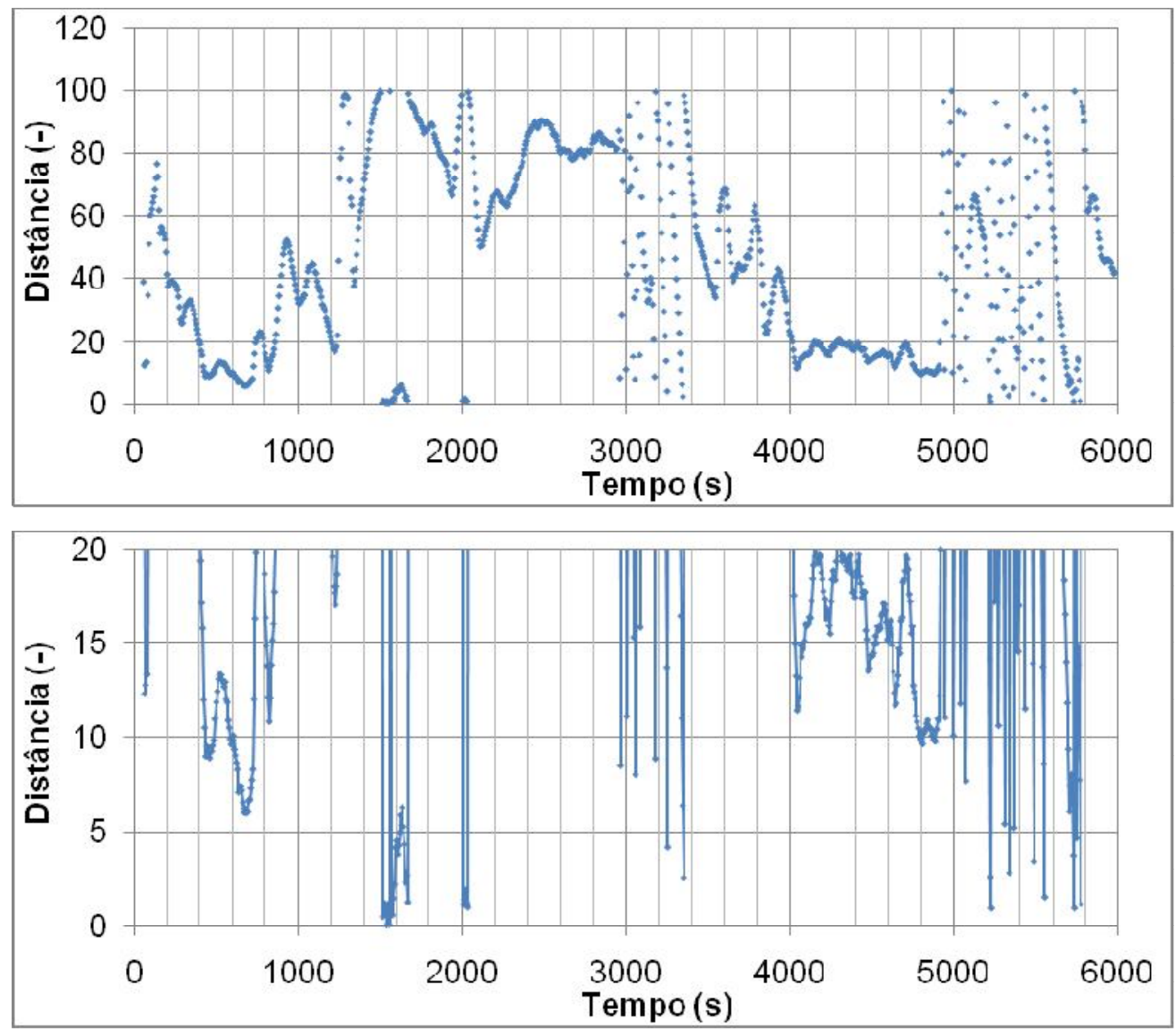

GRÁFICO 109 Distâncias entre os buffers e os neurônios durante monitoração do experimento $23 \mathrm{com}$ a rede CT1 - 8D3V - DR

Fonte: resultados do SICT

\section{Rede Cúbica com conjunto de buffers ALL (CT1 - CUB - ALL) Exp23}

A FIG. 55 mostra os neurônios ativados na rede cúbica por desligamento da bomba do secundário em diversas condições. À esquerda da figura está o resultado do monitoramento do experimento 23 e à direita 0 do monitoramento da simulação DESLBS40_2, similar à simulação mostrada nos GRAF. 185 a 187 do APÊNDICE F. Pode-se observar a semelhança entre os neurônios ativados nos dois casos apesar de as evoluções temporais e de eventos do experimento e da simulação serem diferentes. 

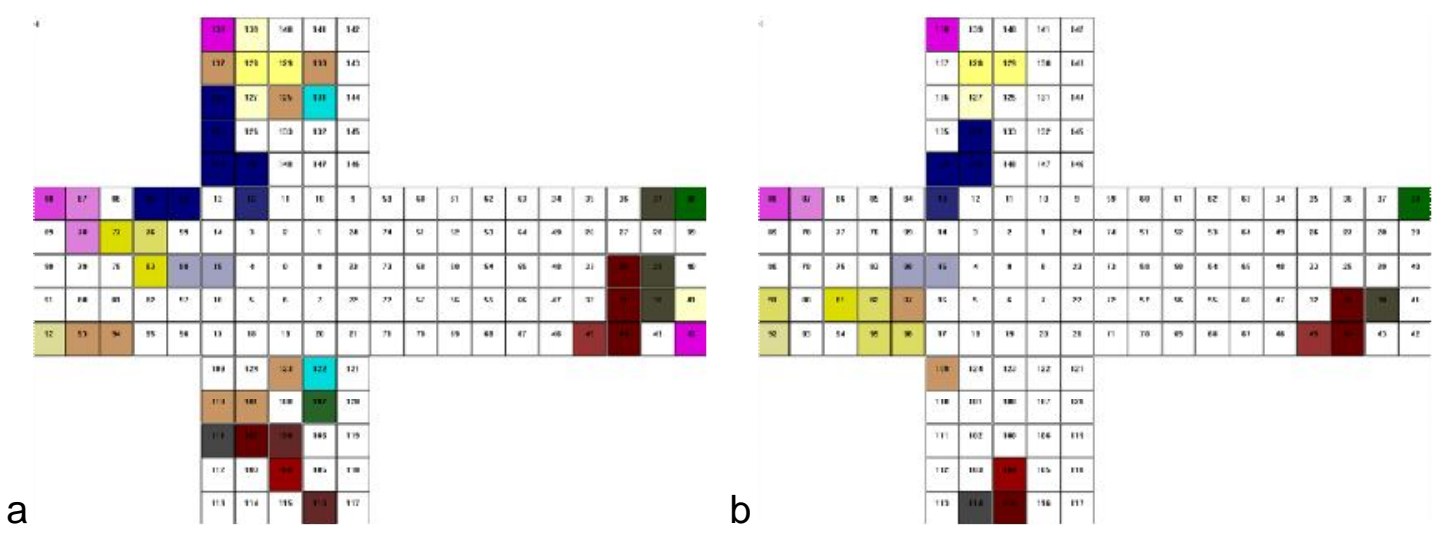

FIGURA 55 Neurônios ativados: a) durante o experimento 23 e b) durante simulação de desligamento da bomba, DESLBS40_2 com rede cúbica CT1 - CUB - ALL

Fonte: resultados do SICT

Para fim de complementar a avaliação do desempenho da rede no monitoramento de experimentos com esse tipo de transiente é mostrado no GRAF. 110 a evolução das distâncias buffer-neurônio durante a monitoração do experimento e no GRAF. 111 a evolução do monitoramento da simulação DESLBS40_2. Pode-se observar que ambos os resultados mostram valores similares, geralmente abaixo de 6 além de poder se observar semelhanças na forma da evolução durante os transientes.

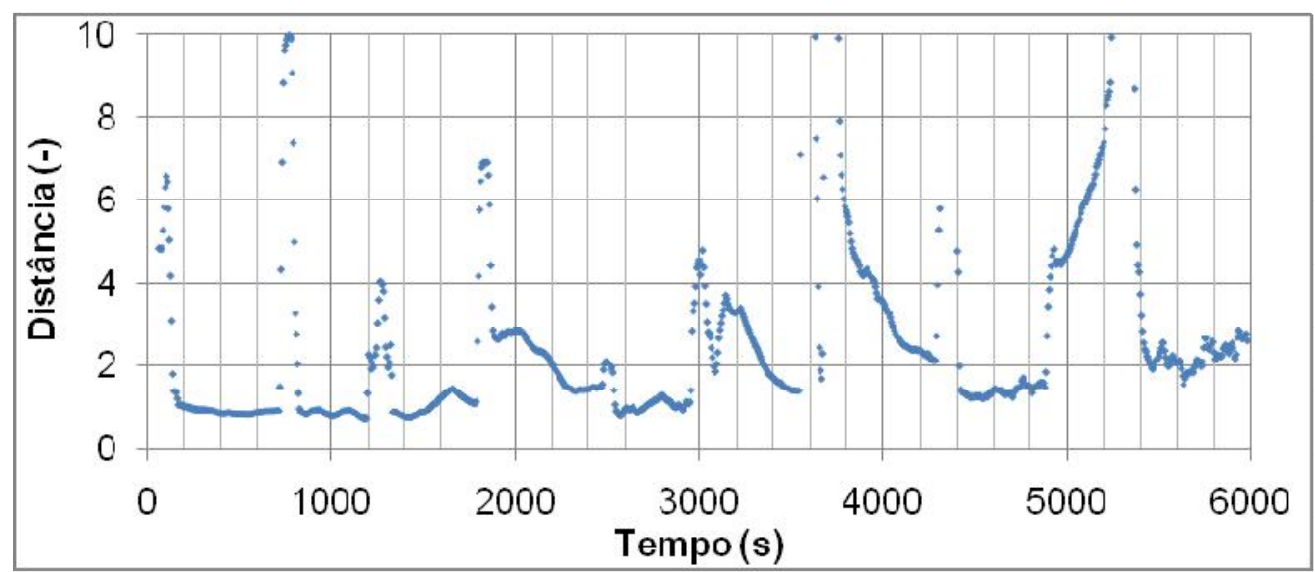

GRÁFICO 110 Distâncias entre os buffers e os neurônios durante monitoração do experimento 23 com a rede cúbica CT1 - CUB - ALL

Fonte: resultados do SICT 


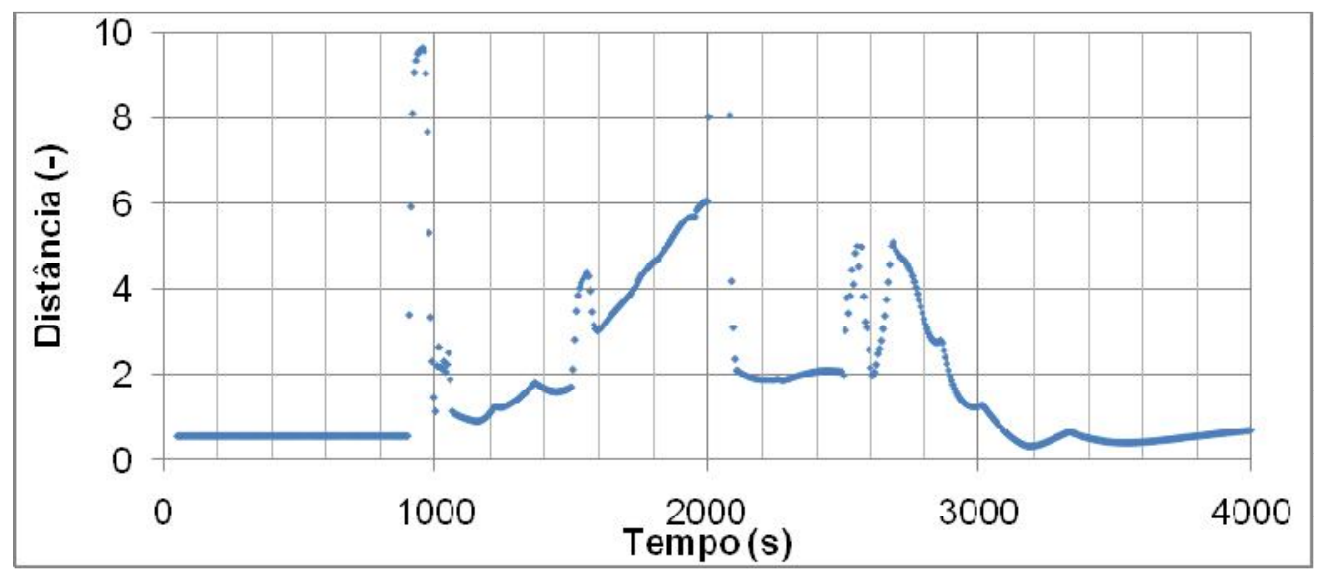

GRÁFICO 111 Distâncias entre os buffers e os neurônios durante monitoração da simulação DESLBS40_2 com a rede cúbica CT1 - CUB - ALL

Fonte: resultados do SICT

\subsection{Aplicação do SICT para o IRIS}

\subsubsection{Dados para treinamento e avaliação do SICT para o IRIS}

As variáveis selecionadas para comporem o conjunto a ser apresentado e monitorado pelo SICT são variáveis que compõe a base do sistema de controle. Essas variáveis foram também consideradas as mais relevantes, em uma avaliação, feita por dois supervisores de operação de central nuclear de potência no Brasil, sobre quais os parâmetros mais importantes para uso no SICT. Eles mencionaram ainda que, além dessas variáveis, a pressão do vácuo no condensador é uma variável importante para os operadores durante a operação, ressaltando, no entanto, que ela não é relevante para a segurança da central, mas sim para sua economicidade.

As variáveis selecionadas foram então introduzidas como dez variáveis de controle, numeradas de 10 a 19, na simulação do IRIS com o RELAP5. Essas variáveis de controle (CNTRLVAR) que contêm os valores das grandezas que serão usadas como entrada para o SICT, seja durante o treinamento seja durante 
a fase de monitoramento, são listadas a seguir juntamente com grandezas representadas por cada uma e a respectiva unidade de medida:

- CNTRLVAR-10 Potência Nuclear Normalizada (-),

- CNTRLVAR-11 Potência Normalizada da Turbina (-)

- CNTRLVAR-12 Nível do Pressurizador (m)

- CNTRLVAR - 13 Temperatura Média do Primário $\left({ }^{\circ} \mathrm{C}\right)$

- CNTRLVAR - 14 Diferença de Temperatura no Primário $\left({ }^{\circ} \mathrm{C}\right)$

- CNTRLVAR-15 Temperatura na parte baixa da Região Inferior (Lower Downcomer) $\left({ }^{\circ} \mathrm{C}\right)$

- CNTRLVAR-16 Temperatura na Sucção da Bomba do Primário $\left({ }^{\circ} \mathrm{C}\right)$

- CNTRLVAR - 17 Pressão no Pressurizador (bar),

- CNTRLVAR-18 Pressão no Coletor de Vapor (Steam header) (bar) e

- CNTRLVAR - 19 Vazão Normalizada no Primário (-).

A Potência Normalizada na Turbina

Nas simulações, a Potência Normalizada na Turbina (CNTRLVAR 11) apresentou valores variando entre 1.176300 e -0.243901 . Os valores negativos ocorreram nos casos de desligamento de turbina, por cerca de 1 segundo antes de atingir o valor zero, indicando não uma potência efetivamente negativa na turbina, mas tão somente um rápido transiente associado à maneira de se medir a potência através da vazão que chega à turbina. Em casos de queda rápida da pressão do secundário pode haver uma inversão de fluxo de vapor na região, antes da atuação dos equipamentos de proteção e controle. Considerando-se o fato desses valores negativos estarem restritos a um ou dois pontos da amostragem para o SICT não justifica investigar outro método de medida da 
potência da turbina ou mesmo limitar externamente esse valor a zero. Outra variável de controle que apresentou resultados negativos foi o nível do pressurizador que conforme a sua implementação atual permite valores entre 0,081 e $4,4118 \mathrm{~m}$. Nos resultados obtidos nas simulações a sua variação ficou entre $-0,081$ e $4,371 \mathrm{~m}$.

Para o IRIS foram usados três diferentes conjuntos de buffers para treinamento:

- $\quad \mathrm{ALL}-$ com os dados de todas as simulações.

- $\quad \mathrm{DR}-$ com dados de degraus e rampas.

- $\quad \mathrm{AC}-$ com os dados de condições anormais e acidentes.

Esses conjuntos de buffers foram formados em duas versões: pelas dez variáveis termo-hidráulicas selecionadas ou pelas dez variáveis acrescidas de suas derivadas, com exceção da derivada da vazão, totalizando assim dezenove valores para formar os buffers.

Os buffers de treinamento foram compostos de 10 amostragens dos valores a cada $6 \mathrm{~s}$, isto é, os buffers formados por 10 variáveis têm 10 valores de cada variável amostradas a cada $6 \mathrm{~s}$ totalizando 100 valores que cobrem um intervalo de tempo de $60 \mathrm{~s}$. O GRAF. 217 do APÊNDICE G mostra no seu início uma faixa com a região coberta pelo primeiro buffer do conjunto de buffers.

Os conjuntos de buffers, DR, AC e ALL, para o IRIS são formados com buffers cujo buffer inicial começa em $46 \mathrm{~s}$ seguido por outros buffers que se iniciam a cada $6 \mathrm{~s}$ até $346 \mathrm{~s}$ e posteriormente por buffers que se iniciam a cada $50 \mathrm{~s}$ até $646 \mathrm{~s}$. Ou seja, os 300 segundos iniciais do transiente fornecem um buffer a cada $6 \mathrm{~s}$ e os $300 \mathrm{~s}$ seguintes fornecem um buffer a cada 50 segundos, totalizando 57 buffers que cobrem os primeiros $600 \mathrm{~s}$ do transiente. O GRAF. 217 do APÊNDICE G mostra a área das simulações que são usadas para construir os buffers de treinamento. 


\subsubsection{Uso do SICT com as simulações do IRIS com o RELAP5}

As mesmas 10 configurações de redes usadas para o CT1 foram testadas com os conjuntos de buffers feitos a partir das simulações do IRIS. Serão apresentados resultados das redes hexagonais, com oito zonas sem derivadas e com derivadas usando o peso 3 e treinadas usando o conjunto de buffer ALL.

\subsubsection{REDE 810 para o IRIS com o conjunto de buffers ALL (IRIS-810-ALL)}

A FIG. 57 mostra o arranjo dos buffers na rede após o treinamento. Pode-se perceber através do arranjo das cores iguais, ou próximas, representando condições semelhantes que houve a ordenação esperada no fim do treinamento. O GRAF. 112 mostra ainda que a distância máxima entre os buffers de treinamento e os pesos dos neurônios é menor que quatro, mas que a grande maioria, cerca de $75 \%$, fica abaixo de 0,5. Para fins de comparação a maior distância entre dois buffers é pouco menos que 15 e a distância média entre os pesos dos neurônios vizinhos é aproximadamente 1,3. 


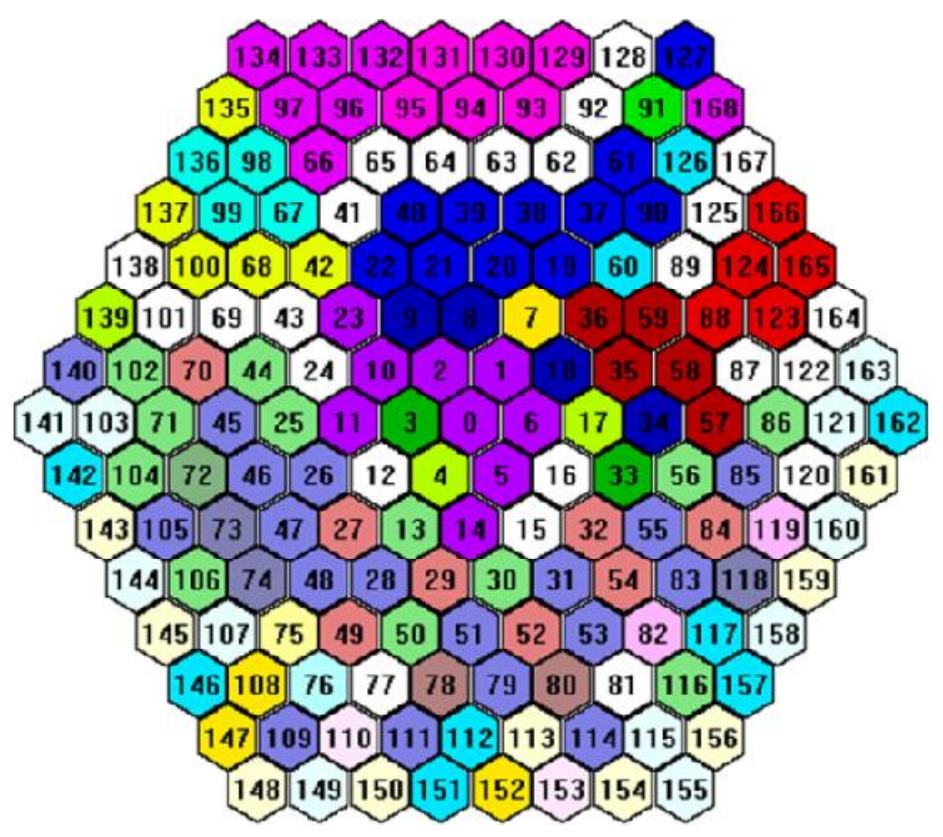

FIGURA 56 Arranjo dos buffers na rede hexagonal IRIS-810-ALL após o treinamento.

Fonte: resultados do SICT

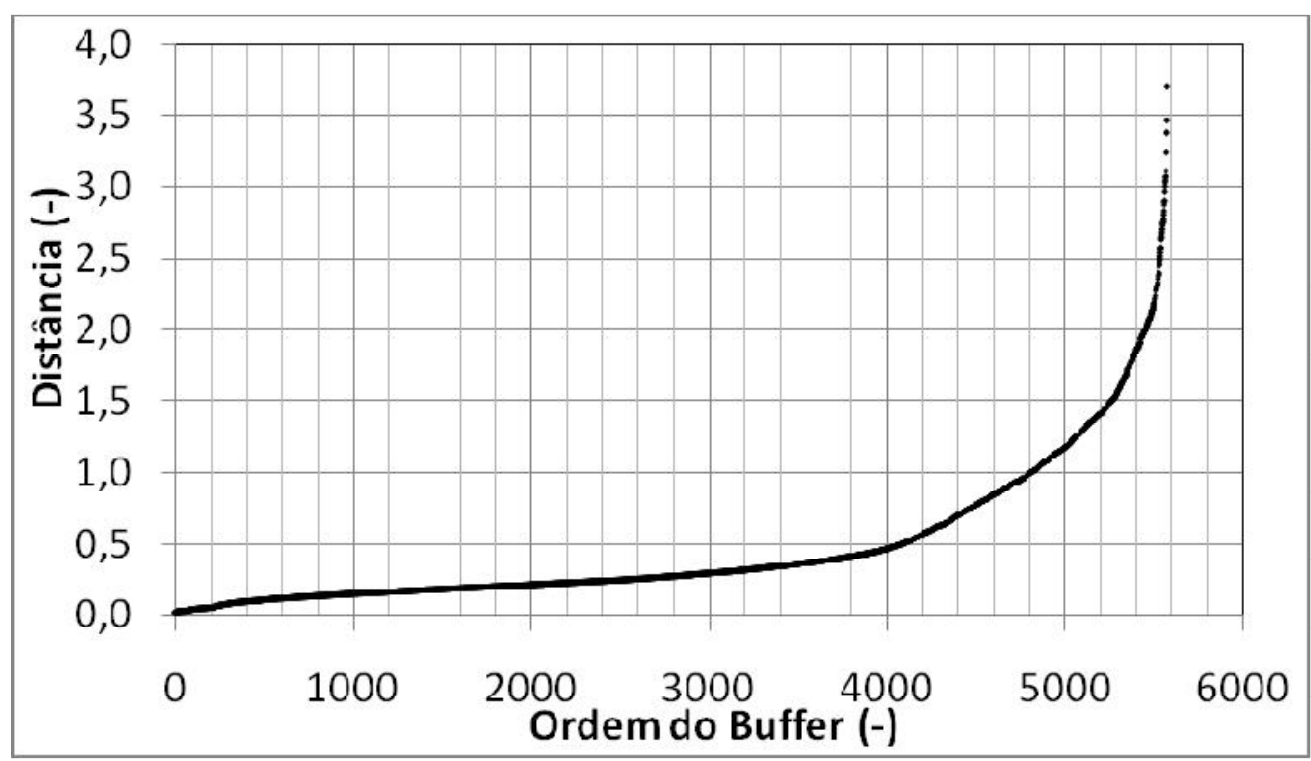

GRÁFICO 112 Distância entre os buffers e os pesos dos neurônios para a rede IRIS - 810 - ALL após o treinamento

Fonte: resultados do SICT

O QUADRO 20 mostra uma lista de transientes simulados com o RELAP5 e processados com a função de monitoramento do SICT gerando as imagens na tela que estão mostradas na FIG. 57. 
QUADRO 20 - Telas do SICT para Transientes do IRIS monitorados e apresentados na FIG. 57

\begin{tabular}{|c|c|}
\hline $\begin{array}{l}\text { Índice na } \\
\text { Figura } 57\end{array}$ & Transiente monitorado \\
\hline A & Degrau ascendente de potência de 60 para 70 \% (STP-60->70) \\
\hline $\mathrm{B}$ & Rampa ascendente 120 s de potência de 60 para $70 \%$ (RMP5-60->70) \\
\hline C & Rampa ascendente 240 s de potência de 60 para 70 \% (RMP25-60->70) \\
\hline $\mathrm{D}$ & Degrau descendente de potência de 80 para 70 \% (STP-80->70) \\
\hline $\mathrm{E}$ & Degrau descendente de potência de 70 para 60 \% (STP-70->60) \\
\hline $\mathrm{F}$ & Ruptura de tubos do gerador de vapor (2) a 60\% de potência (SGTR2-60) \\
\hline G & Ruptura de tubos do gerador de vapor (2) a 60\% de potência (SGTR-60) \\
\hline $\mathrm{H}$ & Ruptura total da linha de vapor a $60 \%$ de potência (SLDER-60) \\
\hline I & Perda total da água de alimentação a $60 \%$ de potência (TLFW-60) \\
\hline $\mathrm{J}$ & Perda parcial da água de alimentação a 60\% de potência (PLFW-60) \\
\hline $\mathrm{K}$ & $\begin{array}{l}\text { Abertura da válvula de segurança do pressunizador a } 60 \% \text { de potência } \\
\text { (PSV-60) }\end{array}$ \\
\hline$L$ & Desligamento de 2 bombas do primário a 60\% de potência (2PT-60) \\
\hline M & Desligamento da turbina a 60\% de potência (TT-60) \\
\hline $\mathrm{N}$ & Desligamento do reator a $60 \%$ de potência (RT-60) \\
\hline
\end{tabular}

Fonte: elaborado pelo autor

As três primeiras imagens da FIG. 57 representam subidas de potência de $10 \%$, e pode-se observar que os neurônios ativados são praticamente os mesmos diferindo um pouco. Já as imagens $\boldsymbol{D}$ e $\boldsymbol{E}$ mostram neurônios ativados na mesma região, porém um pouco mais a direita, pois elas representam simulações de mudanças de potência descendentes. Pode-se notar a semelhança entre: as imagens $\boldsymbol{F}$ e $\boldsymbol{G}$, que representam duas simulações diferentes de ruptura de tubos do gerador de vapor; as imagens $\boldsymbol{I}$ e $\boldsymbol{J}$ representado perdas total e parcial de água de alimentação e entre as $\mathrm{M}$ e $\mathrm{N}$ e aproximadamente a $\mathrm{L}$ que representam 3 desligamentos que o de 2 bombas, o da turbina e o do reator. Essas imagens semelhantes para transientes semelhantes e diferentes para evento bem distintos entre si demonstram a capacidade da rede de identificar e classificar os diversos transientes.

Os GRAF. 113 a, b e c mostram que as distâncias durante o monitoramento estão na faixa aceitável, particularmente nos $600 \mathrm{~s}$ iniciais. 


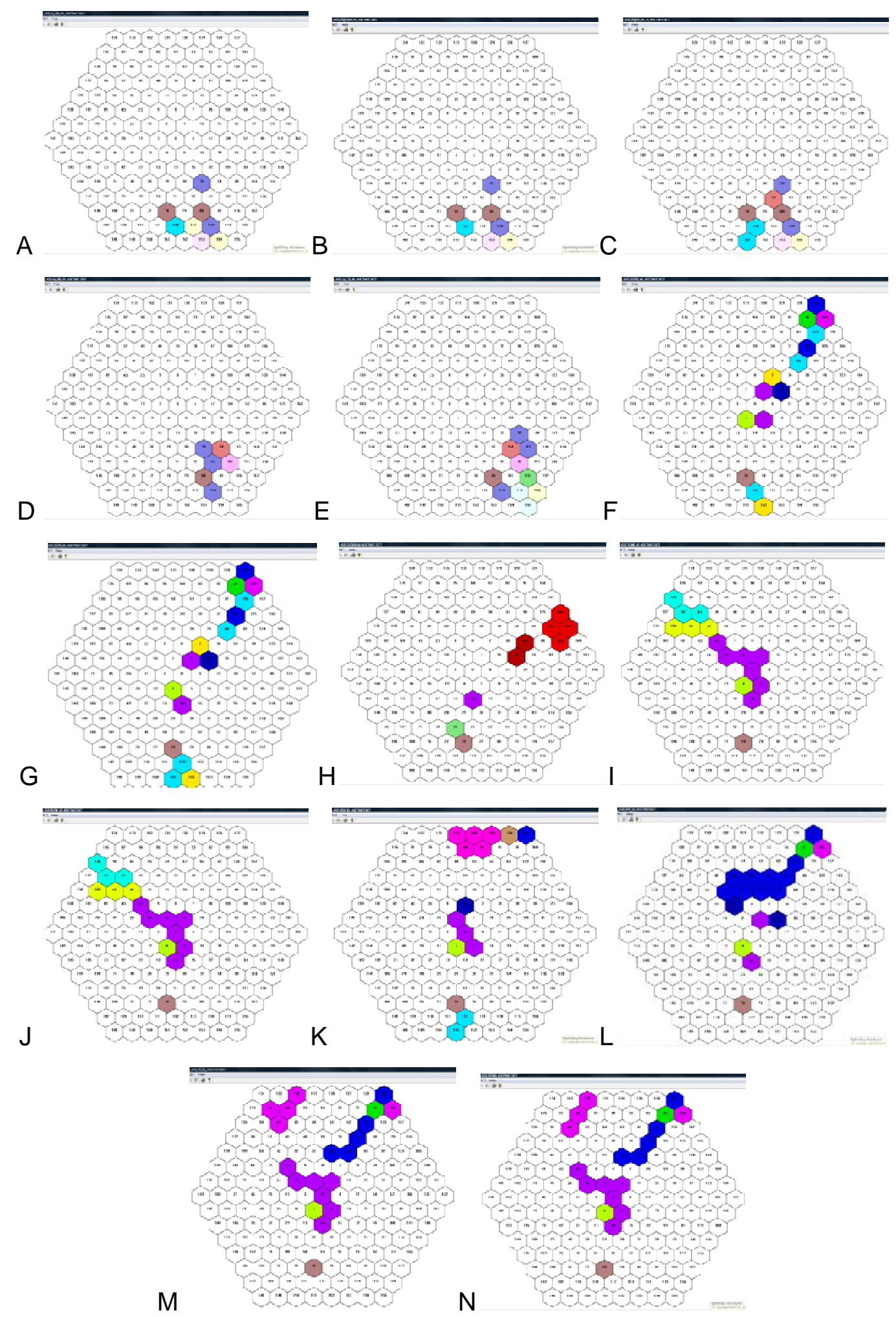

FIGURA 57 Telas do SICT para a rede IRIS-810-ALL após monitoramento dos transientes do QUADRO 20.

Fonte: resultados do SICT 

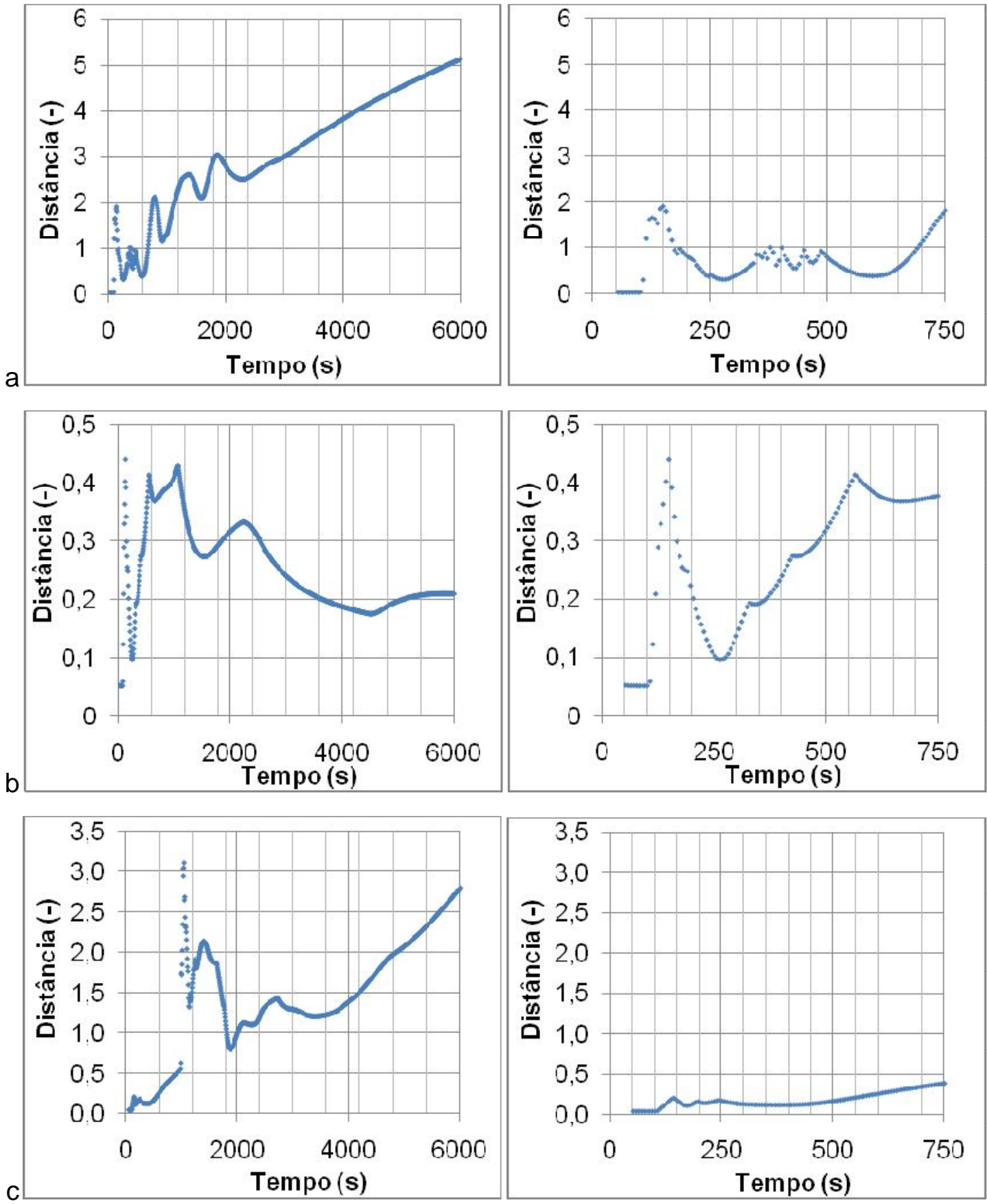

GRÁFICO 113 Distâncias buffer-neurônio na rede IRIS-810-ALL para os casos a) 2PT-60, b) STP-60->70 e c) SGTR-60

Fonte: resultados do SICT

Quando avaliada detalhadamente essa rede mostrou-se incapaz de classificar corretamente todos os transientes. Ela de maneira similar à rede CT1810-ALL deixa de classificar algumas mudanças de potência de maneira correta. 
7.2.2.2 REDE 8D3V para o IRIS com o conjunto de buffers ALL (IRIS-810ALL)

A FIG. 58 mostra o arranjo dos buffers na rede após o treinamento. Pode-se perceber através do arranjo das cores iguais, ou próximas, representando condições semelhantes que houve a ordenação bastante acentuada no fim do treinamento.

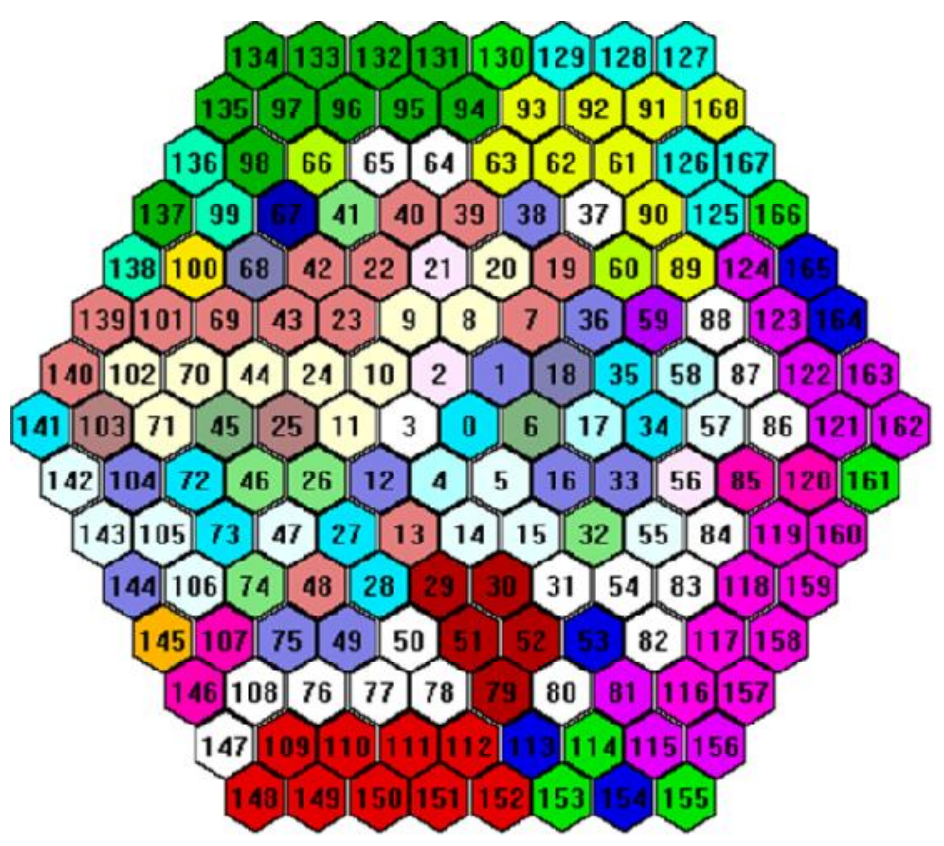

FIGURA 58 Arranjo dos buffers na rede hexagonal IRIS-8D3V-ALL após o treinamento.

Fonte: resultados do SICT

O GRAF. 112 mostra que a distância máxima entre os buffers de treinamento e os pesos dos neurônios, após a rede ter sido treinada, é menor que 12, mas que a grande maioria, cerca de $80 \%$, fica abaixo de 2. Para fins de comparação a maior distância entre dois buffers do conjunto de treinamento ALL é pouco menos que 15 e a distância média entre os pesos dos neurônios vizinhos é aproximadamente 2,4. 


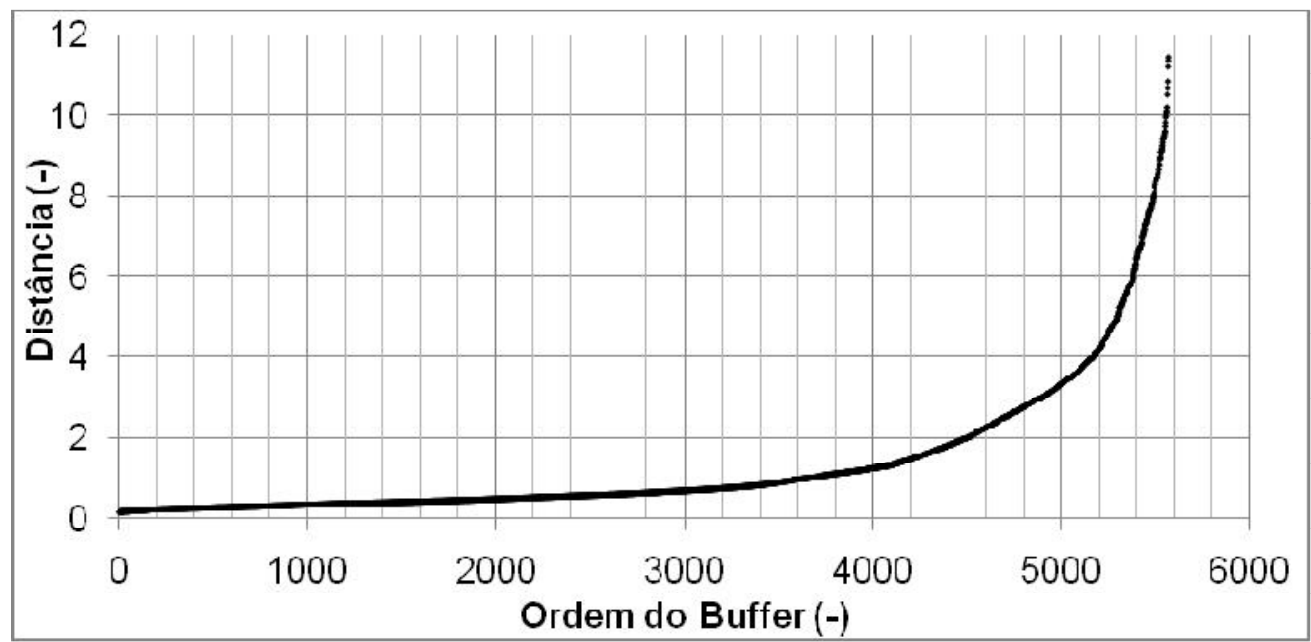

GRÁFICO 114 Distância entre os buffers e os pesos dos neurônios para a rede IRIS - 8D3V - ALL após o treinamento

Fonte: resultados do SICT

A FIG.59 apresenta telas do SICT após o monitoramento das simulações listadas no QUADRO. 20. As três primeiras imagens da FIG. 59, A, B e C, representam subidas de potência de $10 \%$, e pode-se observar que os neurônios ativados apesar de estarem na mesma região são diferentes indicando uma maior capacidade dessa rede de discriminar entre transientes semelhantes. Já as imagens $\boldsymbol{D}$ e $\boldsymbol{E}$, que representam simulações de mudanças de potência descendentes, mostram neurônios ativados na mesma região, mas ligeiramente acima e novamente com neurônios distintos entre si. Ressalta-se aqui a diferença entre as imagens $\boldsymbol{I}$ e $\boldsymbol{J}$ de perda de água de alimentação que tem evoluções diferentes e que o SICT os diferencia apesar de alocá-los na mesma região do mapa de saída. As telas $\mathbf{I}, \mathbf{L}, \mathbf{M}$ e $\mathbf{N}$ representam transientes que terminam desligando o reator e o SICT identifica essa semelhança como mostrado nessas imagens. Essas imagens mostrando neurônios ativados na mesma região para transientes semelhantes e diferentes para eventos bem distintos entre si demonstram a capacidade da rede de identificar e classificar distintamente os diversos transientes incluindo aqueles que são semelhantes.

Os GRAF. 115 a, b e c mostram que as distâncias durante o monitoramento estão na faixa aceitável, comparáveis com os valores do GRAF. 114, particularmente nos $600 \mathrm{~s}$ iniciais. 


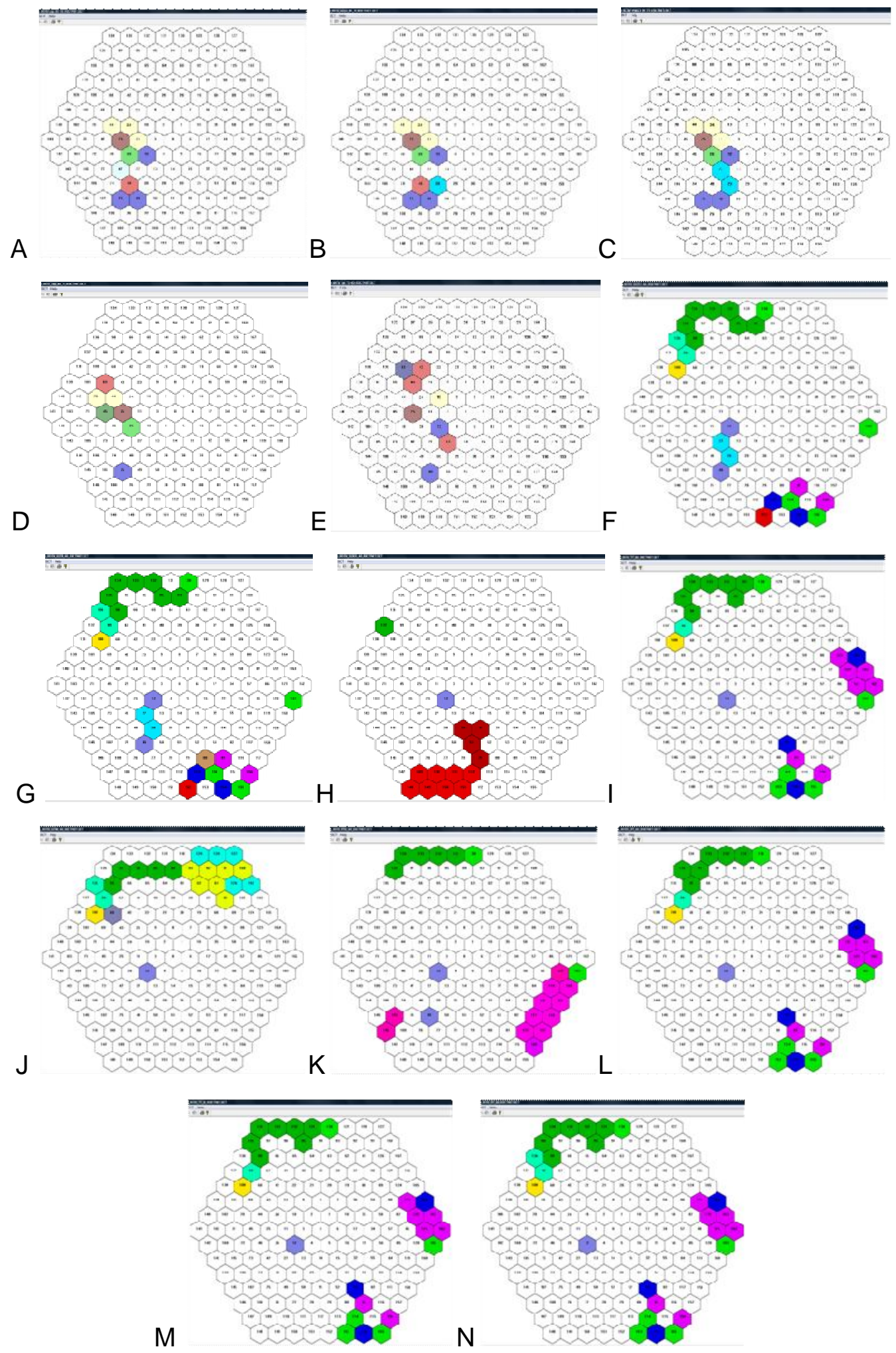

FIGURA 59 Telas do SICT para a rede IRIS-810-ALL após monitoramento dos transientes do QUADRO 20.

Fonte: resultados do SICT 

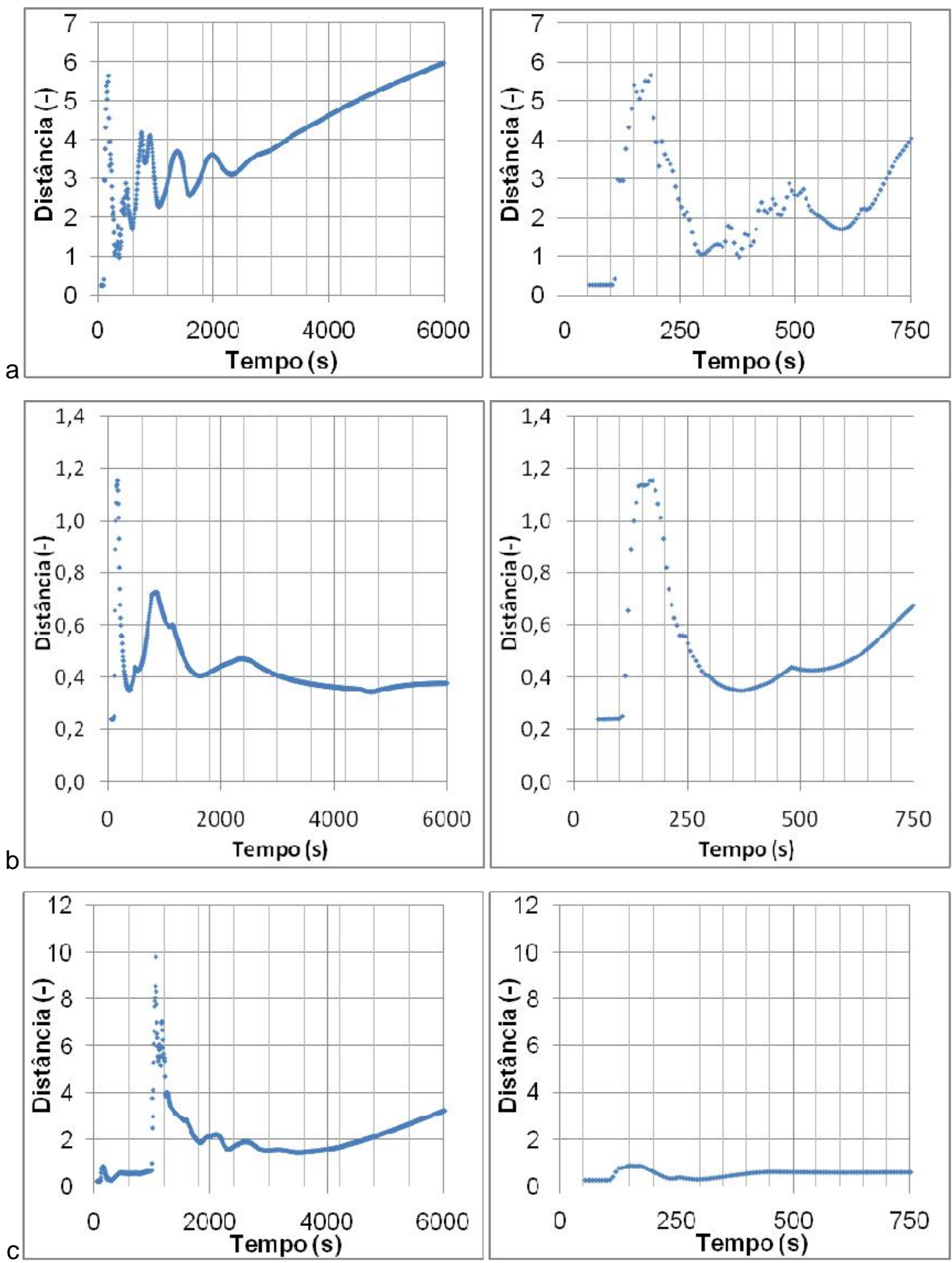

GRÁFICO 115 Distâncias buffer-neurônio na rede IRIS-8D3V-ALL para os casos a) 2PT-60, b) STP-60->70 e c) SGTR-60

Fonte: resultados do SICT 
Como mostrado nas figuras e gráficos deste item todos os transientes, acidentes e estados estacionários ativam neurônios diferentes em áreas do Mapa de saída e situações semelhantes ativam neurônios em áreas próximas. Esse fato juntamente com a inspeção dos neurônios ativados no arquivo LearnWinBufsInNrn e dos testes mostrados no item 7.1.2.1 mostram que essa rede consegue identificar os diferentes transientes das 91 simulações feitas com o RELAP5. O arquivo LearnWinBufsInNrn é o que guarda a lista dos buffers de treinamento associados a cada neurônio, e é denominado de livro de códigos (codebook) por Kohonen (2001).

\subsection{Considerações sobre o uso do SICT}

O uso extensivo do SICT nas diversas situações de treinamento e monitoração de simulações do RELAP5 e de experimentos permite fazer as seguintes colocações mais gerais:

O tempo de treinamento é bastante longo, em torno de 6 horas em um computador Quadcore Q6600 a 2,4GHz, enquanto o processo de monitoração é ordens de grandeza mais rápido que o necessário para monitoração de qualquer evento em tempo real, por exemplo, para executar, em uma rede de 271 neurônios com buffers de 10 amostragens de 18 parâmetros, o processo de monitoração de uma simulação de $36000 \mathrm{~s}$ foram necessários menos de $40 \mathrm{~s}$.

A avaliação qualitativa dos resultados disponibilizados pelo SICT é bastante simples, no entanto a avaliação ampla e profunda verificando os vários testes apresentados para cada transiente é muito trabalhosa representando uma grande dificuldade para sua perfeita execução.

A tela do SICT, que corresponde à saída do Mapa Auto-Organizado satisfaz as necessidades de desenvolvimento, porém precisará ser reformulada para servir de suporte a equipes de operação de reatores nucleares. 


\subsubsection{Considerações do uso do SICT com simulações do RELAP5}

O SICT foi usado com diversos conjuntos de buffers e configurações de redes diferentes. De maneira geral as redes com derivadas forneceram maior capacidade de identificação e classificação que as que usaram somente os parâmetros termo-hidráulicos. O uso de derivada com peso três, o maior usado nas avaliações, tem alta capacidade de identificação dos transientes, mas seus resultados são mais trabalhosos de serem interpretados, pois mais neurônios são envolvidos para cada evento monitorado.

Redes treinadas com conjuntos de buffers muito grandes e com faixas de parâmetros amplas têm maior dificuldade de discriminar eventos semelhantes, sendo que uma opção para compensar esse efeito é o aumento do número de neurônios da rede. Como o aumento de neurônios traz também dificuldades de avaliação dos resultados, uma opção que pode se mostrar interessante é o uso de duas redes treinadas para faixas de parâmetros diferentes e com menor número de neurônios. Neste trabalho foram criadas redes com conjuntos de buffers divididos que indicam a viabilidade dessa opção.

Foram observadas pequenas diferenças nos desempenho de redes com configuração triangular, quadrada, hexagonal e cúbica que devem ser mais bem exploradas em trabalhos futuros.

\subsubsection{Considerações do uso do SICT com os resultados experimentais}

O uso do SICT para monitoramento dos resultados obtidos durante os experimentos demonstrou a tese de que é viável se fazer o treinamento da rede com dados de simulação e a sua posterior utilização para avaliar os experimentos. Uma primeira indicação dessa capacidade da rede havia sido comprovada pelo uso da rede treinada usando simulações afinadas de alguns poucos experimentos para treinamento da rede e posteriormente o uso dessa rede para identificar os transientes desses experimentos. Os resultados 
apresentados no tópico 7.1.3 demonstram de forma ampla que a rede mesmo sendo treinada com simulações genéricas de transientes bem diversos tem a capacidade de identificar condições experimentais aproximadas às das simulações com as quais foi treinada.

Outra consequência importante decorrente do uso dos experimentos foi a verificação que não se poderiam utilizar as derivadas diretas dos parâmetros termo-hidráulicos como dado de treinamento do SICT. Apesar de a utilização das derivadas diretas ter funcionado corretamente durante o monitoramento das simulações, posteriormente não apresentaram resultado semelhante com o monitoramento dos experimentos devido o ruído inerente aos valores medidos. Entre outras opções a se investigar, tais como o tratamento dos sinais medidos através de filtros ou o uso de médias móveis desses valores, foi então desenvolvido o uso da derivada atrasada de $20 \mathrm{~s}$, que passou a dar resultados satisfatórios tanto para as simulações como para os experimentos.

Pode se verificar que quando o conjunto de buffers usado para treinar a rede é maior que outro, com os seus parâmetros tendo uma faixa mais ampla de variação, a diferença entre as distâncias obtidas com o monitoramento das simulações e aquelas obtidas com o monitoramento dos experimentos diminui bastante.

\subsubsection{Outras considerações}

O SICT foi treinado com simulações do CT1 e posteriormente as redes assim treinadas forneceram resultados similares durante o monitoramento das simulações e de experimentos semelhantes entre si, comprovando que, na metodologia utilizada é viável, o uso de simulações para treinar redes que vão trabalhar com dados medidos em campo.

Os resultados do treinamento do SICT para o IRIS usando resultados de simulação geraram redes que identificaram os transientes e condições anormais adequadamente, embora muitas tenham apresentado falhas de 
identificação em casos particulares isolados e, portanto devem ser descartadas como opção de uso em situações que requeira confiabilidade.

Pode-se dizer que foi obtida uma versão de rede neuronal para o SICT que monitorando poucos parâmetros termo-hidráulicos da central é capaz de identificar os seus diferentes estados operacionais. 


\section{CONSIDERAÇÕES FINAIS}

Esta tese teve como objetivo o desenvolvimento de um sistema de identificação e classificação de estados estacionários, transientes e acidentes. $O$ objetivo maior desse sistema é contribuir para estudos que levem a um sistema de suporte equipe de operação do IRIS, com o fim de tornar a operação mais segura e aumentar o fator disponibilidade do reator, devido à redução de paradas forçadas.

Para atingir o objetivo proposto foi necessária a realização do dos seguintes passos: a) Desenvolvimento do aplicativo SICT usando a linguagem $\mathrm{C}_{++}$; b) Realização de experimentos em circuito termo-hidráulico - CT1, gerando um banco de dados de resultados experimentais para uso no SICT; c) Simulações do CT1, com o RELAP5, gerando um banco de dados para treinamento e para o desenvolvimento do SICT. (Ressalta-se a validação da simulação do CT1 através do uso de resultado experimentais); d) Simulações com o RELAP5 do reator nuclear integral IRIS; e) Treinamento do SICT para o CT1 usando os dados de simulação do mesmo para treinamento, f) Validação do SICT treinado para o CT1, e de todo o procedimento de anteriormente descrito, usando tanto os dados de simulação do CT1 quanto os experimentais; g) Treinamento do SICT usando os dados de simulação do IRIS, h) Avaliação do SICT treinado para o IRIS usando dados de simulação do IRIS.

Considera-se que o objetivo do trabalho foi atingido, pois foi feito o desenvolvimento de um Sistema de Identificação e Classificação de Transientes para o IRIS baseado em uma metodologia de utilização de resultados de simulações com o código RELAP5. Metodologia essa que foi comprovada através do uso dos dados, levantados nos experimentos realizados no Circuito de Testes $\mathrm{N}^{0} 1$, em uma versão do SICT treinada para esse circuito. Uma versão final do SICT para utilização efetiva no IRIS depende ainda de muitos desenvolvimentos tais como melhor conhecimento do sistema de controle, simulações de mais acidentes, redes com maiores dimensões ou com uso de duas redes simultaneamente, avaliação pormenorizada da resposta da rede a todos os 
estados de identificação e classificação previstos entre outros, no entanto, metodologias e ferramentas para esses desenvolvimentos foram em grande parte já disponibilizadas durante este trabalho.

O aplicativo SICT desenvolvido comprovou sua funcionalidade e estabilidade. Ao longo do seu desenvolvimento e uso surgiram necessidades de várias informações sobre o funcionamento do sistema, na sua fase de treinamento e de monitoramento, dos dados fornecidos para a rede e de como o treinamento estava evoluindo, entre outros. O aplicativo SICT foi programado para disponibilizar essas informações na forma de arquivos, durante o treinamento, e na tela de apresentação durante a fase de monitoramento, fazendo dele uma ferramenta poderosa para o desenvolvimento de um Sistema de Identificação e Classificação de Transientes.

O programa SICT foi desenvolvido em $\mathrm{C}_{++}$, que possibilita uma Programação Orientada a Objeto. O programa desenvolvido partiu do modelo de um neurônio, para utilização em redes neuronais artificiais, para montar Mapas Auto Organizáveis bidimensionais, nas geometrias triangular, quadrada e hexagonal. A interface do SICT com o mundo exterior foi desenvolvido como um objeto separado, que pode ser facilmente adaptado para diferentes instalações. A criação do aplicativo em uma programação orientada a objeto disponibiliza a utilização dos diversos objetos, neurônios, redes e interfaces por outros programas sem necessidade de fazer sua reprogramação. Assim o programa está disponível para uso em outros desenvolvimentos nessa área.

A utilização do CT1 para realização de experimentos exigiu a adaptação do mesmo, que agora pode operar em uma faixa de vazão de 1/4 da vazão para o qual o circuito foi originalmente projetado, permitindo outros experimentos que não eram possíveis anteriormente. O desenvolvimento de programa de operação com travas de segurança e permitindo o uso do computador para o controle da potência do retificador também contribui par melhorar o uso do CT1 em novas campanhas de teste. 
Foram realizados vinte e sete experimentos no CT1, em escoamento, normalmente, monofásico, dos quais três foram para aferição da instrumentação e do sistema de coleta de dados, mas 24 foram experimentos de diversas situações operacionais possíveis. As medidas dos parâmetros termo-hidráulicos realizadas em forma digital foram feitas a cada meio segundo e estão armazenadas formando uma base de dados de experimentos para uso em futuros desenvolvimentos.

A metodologia exigiu o uso de simulações do RELAP5 tanto para o CT1 quanto para o IRIS. A nodalização do CT1 foi testada e ajustada usando os resultados de experimentos e reproduz com fidelidades as condições usadas nos experimentos. Essa nodalização, que inclui o efeito da potência do primário na temperatura da água de refrigeração do secundário, pode ser usada em estudos futuros de simulações do CT1.

A simulação do IRIS foi particularmente relevante por ter levantado problemas no sistema de controle proposto e em algumas conexões e implantado soluções para os mesmos. Isso viabilizou o uso do RELAP5 para realizar simulações de transientes e condições anormais e acidentais em toda a faixa de operação normal do IRIS e disponibilizou essa nodalização para outros estudos.

Usando a nodalização final testada para o IRIS, foram executadas 91 simulações abrangendo diferentes transientes como mudanças de potência, em degraus e em duas rampas diferentes, partindo de diferentes condições operacionais e também diferentes condições anormais e acidentes. Todos os testes, simulados para fornecerem resultados a cada meio segundo por $6000 \mathrm{~s}$, foram usados e estão armazenados podendo ser usados em futuros desenvolvimentos.

Foi comprovado que um Sistema de Identificação e Classificação de Transientes que monitore poucos parâmetros termo-hidráulicos do IRIS pode ser obtido usando-se o aplicativo e a metodologia desenvolvidos. A introdução das derivadas "atrasadas" das variáveis monitoradas trouxe um maior poder de discriminação de transientes para a rede mostrando a pertinência de seu uso. A 
utilização de diferentes geometrias de rede parece não afetar fortemente o desempenho do SICT, no entanto essa opção deve ser confirmada com maiores estudos, particularmente no que se refere ao uso de redes espaciais, como a rede cúbica apresentada neste trabalho.

Diversas áreas podem e devem ainda ser investigadas em estudos futuros. A utilização de técnicas de tratamento de sinais nos resultados experimentais, como por exemplo, o cálculo de média móvel, e então usar a derivada direta desses sinais tratados. A reordenação da tela do SICT para apresentar uma informação facilmente entendida pela equipe de operação deve ser implementada, possivelmente usando técnicas disponíveis para tal com as redes de Mapas Auto-Organizáveis. A avaliação da confiabilidade da resposta da rede incluindo a implementação de respostas do tipo Don't Know. A escolha de outros conjuntos de treinamentos que melhorem a identificação de transientes particulares assim como de buffers com outros tamanhos e diferentes frequências de amostragem das medidas são temas para estudos futuros. Havendo a disponibilidade de um sistema de controle atualizado para simulação do IRIS, a sistemática e os programas auxiliares criados neste projeto viabilizam a aplicação desta metodologia para treinar uma nova rede em pouco tempo, da ordem de meses. 


\section{REFERÊNCIAS}

ANSI - American National Standard Institute N18.2, "Nuclear Safety Criteria for the Design of Stationary PWR Plants," 1973. apud ORIANI, L., Accident Analysis for the International Reactor Innovative and Secure (IRIS). Rev. 0. Westinghouse, November, 2002.

ARONNE, I.D.; JACOMINO, V. M. F. The liberalization of the Brazilian electricity system and its effects on the environment. In: 1ST GRENELEM PROJECT MEETING, September 2001, Santiago do Chile. Proceedings... Santiago do Chile, 2001. CD-ROM.

ARONNE, I. D., et al. Simulação de Estados Estacionários de um PWR Integral e de Transientes para mudança de Potência entre esses Estados usando o RELAP5Mod3. In: XIV ENCONTRO DE FÍSICA DE REATORES E TERMOHIDRÁULICA, 2005, Santos, SP. Proceedings... Santos:INAC, 2005. CD-ROM.

ARONNE, I. D., et al. Simulation of IRIS transients with RELAP5. In: XV ENCONTRO DE FÍSICA DE REATORES E TERMO-HIDRÁULICA, 2007, Santos SP. Proceedings ...Santos: INAC, 2007. CD-ROM.

ARONNE, I. D., et al. Thermo-hydraulic experiments for the development of a system for identification and classification of transients (SICT). In: XV Encontro de Física de Reatores e Termo-hidráulica, 2007, Santos, SP. Proceedings... Santos: INAC, 2007. CD-ROM.

ARTEAGA, C. C. S., Experimentos Termo-hidráulicos para Apoio no Desenvolvimento do Sistema de Identificação e Classificação de Transientes (SICT). Belo Horizonte: Departamento de Engenharia Mecânica da UFMG, 2007. 116p. Relatório.

AZEVEDO, C. V. G., PALMIERI, E. T., ARONNE, I. D. Veloso, M. A., Neiva, B. C., Descrição do Reator IRIS, NI-EC3_08/06, Centro de Desenvolvimento de Energia Nuclear, 2006. 28 p. Nota Informativa. 
BAPTISTA F., B. D.; BARROSO, A. C. O. Identification of IRIS Reactor Transients with Self-Organized Maps. In: INTERNATIONAL CONFERENCE ON GLOBAL ENVIRONMENT AND ADVANCED NUCLEAR POWER PLANTSGENES4/ANP2003. Kioto, 2003. Proceedings...Kioto. 2003.

BARRETO, G. A. Redes neurais não-supervisionadas temporais para identificação e controle de sistemas dinâmicos. 2003. 213 p.. Tese (Doutorado Engenharia Elétrica) - Escola Engenharia de São Carlos, Universidade de São Paulo (USP), São Carlos, Brasil.

BARROSO, A. C. O., BAPTISTA F., B. D., ARONNE, I. D., MACEDO, L. A., SAMPAIO, P. A. B., MORAES, M., "IRIS Pressurizer Design," In: ICAPP '03. Cordoba, Spain, May 4-7, 2003. Proceedings...Córdoba, 2003.

BARTAL, Y.; LIN, J., UHRIG, R. E. Nuclear Power Plant Transient Diagnostics Using Artificial Neural Networks that Allow "Don't-Know" Classifications. Nuclear Technology v. 110, n.3, p.436-449, June 1995.

BRAGA, A. P.; LUDERMIR, T. B.; CARVALHO, A. C. P.L.F. Redes Neurais Artificiais: teoria e aplicações. Rio de Janeiro, RJ: LTC, 2000.

CAMMI, A., CASELLA, F. RICOTTI, M. E. , SCHIAVO, F. STORRICK, G. D. ObjectOriented Simulation for the Control of the IRIS Nuclear Power Plant. In: "http://www.ifac.cz/". 16th IFAC WORLD CONGRESS, Prague, July 3-8, 2005. Proceedings...Prague.2005.

CARELLI, M. D. et al. The Design and Safety Features of the IRIS Reactor. In: $11^{\text {th }}$ INTERNATIONAL CONFERENCE ON NUCLEAR ENGINEERING, ICONE11, Tokyo, JAPAN, April 20-23, 2003. Proceedings...Japan: IAEA, 2003.

CARELLI, M. D., CONWAY L.E., ORIANI L., PETROVIÆ B., et al., The Design and Safety Features of the IRIS Reactor, Nuclear Engineering and Design, v. 230. p. 151-167, May, 2004.

CHAPMAN, D., Visual C++.NET in 21 Tagen. Der optimale Weg zum Programmierprofi. Markt+Technik Verlag. Juli, 2002. 
CHEON, S. W.; CHANG, S. H. Application of Neural Networks to Connectionist Expert System for Transient Identification in Nuclear Power Plants. Nuclear Technology, v. 102, n. 2, p. 177-181, May 1993.

$\mathrm{CHO}$, S. B. Ensemble of structure-adaptive Self-Organizing Maps for high performance classification. International Journal of Information Sciences, v. $123, \quad$ n. 1-2, p. 103-114, March 2000. Disponível em: <http://candy.yonsei.ac.kr/publications/Papers/INS2000.ps>.

CIONCOLINI, A., CAMMI, L., CINOTTI, G., CASTELLI, C., LOMBARDI, L., LUZZI, M. E., RICOTTI. Thermal Hydraulic Analysis of IRIS Reactor Coiled Tube Steam Generator. NUCLEAR MATHEMATICAL AND COMPUTATIONAL SCIENCES: A CENTURY IN REVIEW, A CENTURY ANEW. Gatlinburg, Tennessee, April 2003, Proceedings...Gatlinburg: American Nuclear Society, 2003. CD-ROM.

FANTONI, P., MAZZOLA, A. Multiple-Failure Signal Validation in Nuclear Power Plants using Artificial Neural Networks. Nuclear Technology, v. 113, p. 368-374, March 1996.

GRGIC, D., BAJS, T., et al. IRIS RELAP 5 mod 3.3 Nodalization and Steady State Qualification, IRIS Consortium, September 22, 2002. Documento de Projeto.

GUO, Z.; UHRIG, R. E. (1992) Use of artificial neural networks to analyze nuclear power plant performance. Nuclear Technology, v. 99, p.36-42, July 1992.

HAYKIN, S. Neural Networks: a comprehensive foundation. 2nd ed. Upper Saddle River, N.J.: Prentice-Hall, 1999.

IAEA - INTERNATIONAL ATOMIC ENERGY AGENCY. International Project on Innovative Nuclear Reactors and Fuel Cycles (INPRO), August 2003. Disponível em: http://www.iaea.org/img/assets/3836/brochure.pdf.

IAEA - INTERNATIONAL ATOMIC ENERGY AGENCY - . Nuclear Technology Review. General Conference, Vienna, August 2000. 
IAEA - INTERNATIONAL ATOMIC ENERGY AGENCY. Status of Advanced Light Water Cooled Reactor Designs - 2004, IAEA-TECDOC-1391, Vienna, 2004.

IGAMI, M.P.Z.; ZARPELON, L.M.C. (Org). Guia para a elaboração de dissertações e teses: preparado para orientação dos alunos de Pós-graduação do IPEN. SP: IPEN, Divisão de Informação e Documentação Científicas, 2002. Disponível em:

http://www.ipen.br/conteudo/upload/200609111605540.guia_teses.pdf. Acesso em: 30 de novembro de 2008.

KLEIN, S. A.; ALVARADO, F. L. Engineering Equation Solver (EES), Professional Version_6.352, October, 2001.

KOHONEN, T. Self-Organizing Maps. 3. ed. Berlin, Springer, 2001.

KUJAWSKI, J. M. KITCH, D. M., CONWAY, L. E. The IRIS Spool - Type Reactor Coolant Pump. In: INTERNATIONAL CONFERENCE ON NUCLEAR ENGINEERING, April, 2002 Arlinghton, USA. Proceedings... Arlinghton, 2002. CD-ROM.

LIBERTY, J. Sams Teach Yourself $\mathrm{C}_{++}$in 21 Days, Third Edition, SAMS publishing. February 16, 1999.

MCQUEEN, T. A., et al. A recurrent self-organizing map for temporal sequence processing In: Applications and Science in Soft Computing, A. Lotfi \& J.Garibaldi (ed.). Advances in Soft Computing Series, Springer:p. 3-8, 2003.

MOL, A. C. de A., et al., A neural model for transiente identification in dynamic processes with "don't know" response. Pergamon: Annals of Nuclear Energy v. 30, p. 1365-1381, 2003. Disponível em: <http://www.sciencedirect.com/>. 
MOZER, M. C. Neural net architectures for temporal sequence processing. In: WEIGEND, A. S. AND GERSHENFELD, N. A. Time Series Prediction: Forecasting the Future and Understanding the Past. Reading, MA: AddisonWesley, p. 243-264, 1994. Disponível em:

$<$ http://www.cs.colorado.edu/ mozer/papers/timeseries.html>.

NEVO, A.D. IRIS Spool Pumps - RELAP MODEL. IRIS Consortium, April 21, 2002. DRAFT

NEVO, A.D., ORIANI, L., CONWAY, L., Preliminary IRIS Safety Analyses: Transientes and Accidents for the International Reactor Innovative and Secure (IRIS). Westinghouse, 2002.

NUREG CR-5535-VI, RELAP5/MOD3 Code Manual, Volumes I - V, Idaho National Engineering Laboratory, June, 1995.

OJA, M.; KASKI, S.; KOHONEN, T. Bibliography of Self-Organizing Map (SOM) Papers: 1998-2001 Addendum. Neural Computing Surveys. Helsinki University of Technology, 2002. Disponível em: <http://www.icsi.berkeley.edu/ jagota/NCS>.

OHGA, Y., et al. Evaluation Test of Event Identification Method Using Neural Network at Kashiwazaki Kariwa Nuclear Power Station Unit No.4. Journal of Nuclear Science and Technology, v. 33, n. 5, p. 439-447, 1996.

OHGA, Y.; SEKI, H. Abnormal event identification in nuclear power plants using a neural network and knowledge processing. Nuclear Technology, v. 101, p. 159167, 1993.

ORIANI, L., Accident Analysis for the International Reactor Innovative and Secure (IRIS). Rev. 0. Westinghouse, November 01, 2002.

ORIANI, L., GRGIC, D., et al. IRIS Base Input Deck and Steady State Qualification for RELAP5 MOD3.3. Rev. 2.4. Westinghouse, August 01, 2004. Documento confidencial.

PC-LabCard, Users Manual. 2nd. ed. Taiwan, Advantec, 1994. 
ROGNER, H-H.; LANGLOIS, L.M. Moving Targets: economic competitiveness of nuclear power. In: IAEA Bulletin, v. 42, n. 2, 2000.

ROVERSO, D. Soft computing tools for transient classification. Elsevier: Information Sciences v.127, p.137-156, 2000. Disponível em: $<$ http://www.elsevier.com/locate/ins>.

SANTOS, $\mathrm{H}$, et al. Symptom based diagnostic system for nuclear power plant operations using artificial neural networks. Reliability Engineering and System Safety, v. 82, p. 33-40, 2003. Disponível em: <http://www.sciencedirect.com> .

SOUZA, A. M. T, COLARES, K. Descrição Final do Circuito Térmico № 1. NT01/75, Vol. 1, NUCLEBRAS/DTD/IPR. Janeiro 1975. Nota Técnica.

UPADHYAYA, B. R.; ERYUREK, E. Application of neural networks for sensor validation and plant monitoring. Neural Technology, v. 97, p. 179-176, 1992.

US-DOE - UNITED STATES DEPARTMENT OF ENERGY The U.S. Generation IV Implementation Strategy. September 2003. Disponível em: $<$ http://www.nuclear.gov/reports/Gen-IV_Implementation_Plan_9-9-03.pdf>.

US-DOE - UNITED STATES DEPARTMENT OF ENERGY -. Overview of Generation IV Technology Roadmap. April 2002, Disponível em: <http://www.nuclear.energy.gov/nerac/neracPDFs/todreasApr02NERAC.pdf> Acesso em janeiro 2008.

UNIVERSIDADE POLITÉCNICA DE MILÃO. Projeto IRIS. Itália, Abril, 2003. Disponível em: <http://www.hulk.cesnef.polimi.it>, acesso em 2003.

YAMASAKI, T., et al. Neural networks handling sequential patterns. Information Sciences, v. 159, p. 141-154, 2004. 
APÊNDICE A

CONVERSÕES DOS SINAIS MEDIDOS 
Neste APÊNDICE, são apresentadas as equações dos parâmetros medidos e calculados, e as respectivas equações de incertezas implementadas no programa de coleta e tratamento de dados. Durante os experimentos, tais grandezas são exibidas em tempo real na tela do computador.

1- Parâmetros primários

1.1- Equação de conversão do sinal lido, em Volts, para unidades de engenharia apropriadas

$Y_{i}=A_{i} \bar{U}_{i}+B_{i}$

Onde:

$\mathrm{Y}_{0}=$ temperatura na entrada da seção de testes, $\mathrm{T} 1\left({ }^{\circ} \mathrm{C}\right)$;

$\mathrm{Y}_{1}=$ temperatura na saída da seção de testes, $\mathrm{T} 2\left({ }^{\circ} \mathrm{C}\right) ;$

$\mathrm{Y}_{2}=$ temperatura do pressurizador, $\mathrm{T} 3\left({ }^{\circ} \mathrm{C}\right)$

$\mathrm{Y}_{3}=$ temperatura na entrada do trocador de calor, $\mathrm{T} 4\left({ }^{\circ} \mathrm{C}\right)$;

$\mathrm{Y}_{4}=$ temperatura na saída do trocador de calor, $\mathrm{T} 5\left({ }^{\circ} \mathrm{C}\right)$;

$\mathrm{Y}_{5}=$ temperatura após o by-pass, $\mathrm{T} 6\left({ }^{\circ} \mathrm{C}\right)$;

$\mathrm{Y}_{6}=$ temperatura na entrada da bomba, $\mathrm{T7}\left({ }^{\circ} \mathrm{C}\right)$

$\mathrm{Y}_{7}=$ temperatura na saída da bomba, $\mathrm{T} 8\left({ }^{\circ} \mathrm{C}\right)$;

$\mathrm{Y}_{8}=$ temperatura na saída do trocador de calor - circuito secundário, $\mathrm{T9}\left({ }^{\circ} \mathrm{C}\right)$;

$Y_{9}=$ pressão do pressurizador, p1 (bar);

$\mathrm{Y}_{10}=$ pressão na saída da bomba, p2 (bar);

$Y_{11}=$ diferença de pressão na placa de orifício, DP1 (mbar):

$\mathrm{Y}_{12}=$ diferença de pressão na placa de orifí́cio - circuito secundário, DP2 (mbar);

$Y_{13}=$ tensão na seção de testes, $V_{S T}(V)$;

$\mathrm{Y}_{14}=$ temperatura na entrada do trocador de calor - circuito secundário, T10 $\left({ }^{\circ} \mathrm{C}\right)$.

$\bar{U}_{i}=\frac{\sum_{j=1}^{N} U_{i}^{j}}{N}=$ tensão média de $\mathrm{N}$ leituras no computador [V]

$s_{U_{i}}=\sqrt{\frac{\sum_{j-1}^{N}\left(U_{i}^{j}-\bar{U}_{i}\right)^{2}}{N-1}}=$ desvio padrão

$S_{\bar{U}_{i}}=\frac{S_{U_{i}}}{\sqrt{N}}=$ desvio padrão médio

Para as linhas calibradas, $A_{i}$ e $B_{i}$ são os coeficientes da reta ajustada por regressão: 


$\begin{array}{ll}A_{0}=480,4600 & B_{0}=-94,9000 \\ A_{1}=482,2800 & B_{1}=-95,6400 \\ A_{2}=727,3234 & B_{2}=-147,3340 \\ A_{3}=380,6195 & B_{3}=-70,0482 \\ A_{4}=483,0190 & B_{4}=-96,4151 \\ A_{5}=487,4857 & B_{5}=-96,9764 \\ A_{6}=485,8236 & B_{6}=-96,6792 \\ A_{7}=477,5298 & B_{7}=-95,2694 \\ A_{8}=379,8601 & B_{8}=-70,0410 \\ A_{9}=7,3736 & B_{9}=-1,4879 \\ A_{10}=7,3692 & B_{10}=-1,5003 \\ A_{11}=615,5817 & B_{11}=-123,2938 \\ A_{12}=616,0266 & B_{12}=-124,4945 \\ A_{13}=101,0000 & B_{13}=0,0000 \\ A_{14}=1000,000 & B_{14}=0,0000\end{array}$

$\frac{\delta Y_{i}}{Y_{i}}=\left(\left(\frac{A_{i} \delta \bar{U}_{i}}{Y_{i}}\right)^{2}+\left(\frac{\delta R}{R}\right)^{2}+\left(\frac{\delta T r_{i}}{Y_{i}}\right)^{2}\right)^{1 / 2}=$ incerteza das medições

$\delta \bar{U}_{i}=\left((0,00244)^{2}+(0,001)^{2}+\left(2 s_{U i}\right)^{2}\right)^{1 / 2}, \quad$ incerteza devida às placas e devida à dispersão $\frac{\delta R}{R}=0,0013=$ incerteza da resistência utilizada na placa 789

Para linhas calibradas:

$\delta T r_{i}=2 s_{i}^{c}+\delta c \quad, \quad s_{i}^{c}=$ erro padrão da curva ajustada e $\delta$ c o erro do sistema padrão

2- Parâmetros derivados

2.1- Equação da potência elétrica na seção de testes

$$
P_{S T}=\frac{V_{S T}{ }^{2}}{1,7174 * 10^{-9} * V_{S T}{ }^{3}+4,6097 * 10^{-7} * V_{S T}{ }^{2}-1,0142 * 10^{-5} * V_{S T}+6,4433 * 10^{-2}}[\mathrm{~kW}]
$$

2.2- Equação das vazões mássica e volumétrica

$$
\begin{aligned}
& q_{m}=C_{d} E \frac{\pi}{4} d^{2} \sqrt{2 \rho D P}[\mathrm{~kg} / \mathrm{s}] \\
& q_{v}=\frac{3600 q_{m}}{\rho}\left[\mathrm{m}^{3} / \mathrm{h}\right] \\
& C_{d}=0,5959+0,0312 \beta^{2,1}-0,184 \beta^{8}+0,0029 \beta^{2,5}\left[\frac{10^{6}}{\operatorname{Re}_{D}}\right]^{0,75}+0,039 \beta^{4}\left(1-B^{4}\right)^{-1}-0,015839 \beta^{3} \\
& E=\left(1-\beta^{4}\right)^{-1 / 2}
\end{aligned}
$$


$\beta=\frac{d}{D}$

$\operatorname{Re}_{D}=\frac{4 q_{m}}{\pi D \mu}$

Onde:

$\mathrm{d}=$ diâmetro do orifício da placa do circuito principal $=0,014253 \mathrm{~m}$

$\mathrm{D}=$ diâmetro da tubulação da placa do circuito principal $=0,0555 \mathrm{~m}$

$\mathrm{d}=$ diâmetro do orifício da placa do circuito de remoção de calor $=0,02935375 \mathrm{~m}$

$\mathrm{D}=$ diâmetro da tubulação da placa do circuito de remoção de calor $=0,05304 \mathrm{~m}$

$$
\begin{aligned}
& \frac{\delta q_{m}}{q_{m}}=\left[\left(\frac{\delta C_{d}}{C_{d}}\right)^{2}+\left(\frac{\delta E}{E}\right)^{2}+4\left(\frac{\beta^{4}}{C_{d} E}\right)^{2}\left(\frac{\delta D}{D}\right)^{2}+\right. \\
& \left.4\left(1+\frac{\beta^{4}}{C_{d} E}\right)^{2}\left(\frac{\delta d}{d}\right)^{2}+\frac{1}{4}\left(\frac{\delta D P}{D P}\right)^{2}+\frac{1}{4}\left(\frac{\delta \rho}{\rho}\right)^{2}\right]^{1 / 2} \\
& \frac{\delta C_{d}}{C_{d}}=\frac{\beta}{100} \\
& \frac{\delta E}{E}=\frac{\beta^{4}}{\left(1-\beta^{4}\right) \frac{\delta \beta}{\beta}} \\
& \frac{\delta \beta}{\beta}=\left(\left(\frac{\delta d}{d}\right)^{2}+\left(\frac{\delta D}{D}\right)^{2}\right)^{1 / 2}
\end{aligned}
$$

Para a placa de orifício do circuito principal:

$$
\begin{aligned}
& \frac{\delta d}{d}=0,0007 \\
& \frac{\delta D}{D}=0,004
\end{aligned}
$$

Para a placa de orifício do circuito de remoção de calor:

$$
\begin{aligned}
& \frac{\delta d}{d}=0,0007 \\
& \frac{\delta D}{D}=0,03
\end{aligned}
$$

\section{3- Densidade e viscosidade da água}

$\rho=9,518 \times 10^{-6} \mathrm{~T}^{3}-0,48589 \times 10^{-2} \mathrm{~T}^{2}-3,33214 \times 10^{-2} \mathrm{~T}^{2}+1000,8\left[\mathrm{~kg} / \mathrm{m}^{3}\right]$ $\mu=1,3335 \times 10^{-11} \mathrm{~T}^{4}-4,6749 \times 10^{-9} \mathrm{~T}^{3}+6,4297 \times 10^{-7} \mathrm{~T}^{2}-4,4918 \times 10^{-5} \mathrm{~T}+1,6832 \times 10^{-3}$ [Pa.s] 
APÊNDICE B

\section{PROCEDIMENTOS PARA OPERAÇÃO DO CT1}




\section{Passos sequenciais ao Iniciar a Operação}

1-) Ligar o computador e conferir o relógio.

2-) Rodar o programa de coleta e tratamento de dados (Quick Basic).

3-) Ligar a chave da instrumentação na parte inferior do CT1.

4-) Conferir as posições das válvulas:

Válvula da saída da bomba - aberta;

Válvula do bypass da bomba - fechada;

Válvula da saída do trocador de calor (em cima) - aberta;

Válvula do bypass do trocador de calor (atrás) - fechada;

Válvula após o pré-aquecedor antes da bomba (eletrônica) - aberta;

Válvula do bypass da seção de testes (à frente)- fechada;

Válvula da saída da seção de testes para o circuito (posição trocada) - aberta;

Válvula da saída da seção de testes para o pressurizador (posição trocada) fechada;

Válvula de entrada do trocador de calor (circuito secundário) - aberta.

5-) Conferir o nível de água do pressurizador.

6-) Abrir e fechar a válvula de alívio do pressurizador.

7-) Inspecionar a seção de testes:

Verificar se as mangueiras estão no lugar;

Verificar se não existe metal em contato com a ST;

Verificar se as cordoalhas de alimentação elétrica estão livres;

Verificar se não existe risco de algo próximo afetar a segurança da ST.

8-) Ligar o painel de controle (girar a chave).

9-) Ligar a bomba do circuito primário (em baixo da botoeira da torre).

10-) Ligar a bomba do circuito secundário (B102).

11-) Ligar a torre de refrigeração.

12-) Para ligar o suprimento de potência da ST, seguir os próximos passos.

13-) Ligar multímetro.

14-) Ligar a fonte de corrente e ajustar para $21,7 \mathrm{~V}$.

15-) Ligar o disjuntor da sala dos retificadores.

16-) Para ligar o retificador principal da sala 1:

Ligar o comando;

Apertar o reset para desligar o alarme que dispara;

Ligar o relé mestre; 
Ligar o disjuntor principal.

17-) Para ligar o retificador de $120 \mathrm{~kW}$ da sala 2:

Verificar se os ajustes de potência e o limite de corrente estão zerados;

Girar a chave de energização;

Inibir o comando local.

18-) Para ligar a unidade remota na sala de controle:

Verificar se os ajustes de potência, fino e grosso, estão zerados;

Ajustar o limite de corrente para $15 \mathrm{~A}$;

Habilitar comando externo (chave atrás do painel da unidade remota);

Habilitar o comando remoto (chave 3);

Ligar o retificador (chave 1);

Habilitar o modo de operação manual (chave 2);

Habilitar o sinal de comando externo (chave 4).

19-) Operar as mudanças de potência usando o computador.

20-) Operar as mudanças de vazões manualmente, girando as válvulas.

\section{Passos sequenciais ao Finalizar a Operação}

1-) Zerar a potência no computador (tecla Z).

2-) Para desligar o suprimento de potência da ST, seguir os próximos passos.

3-) Desligar o multímetro.

4-) Para desligar a unidade remota na sala de controle:

Inibir comando externo (chave atrás do painel da unidade remota);

Habilitar o sinal de comando normal (chave 4);

Inibir o comando remoto (chave 3 );

5-) Para desligar o retificad or de $120 \mathrm{~kW}$ da sala 2:

Girar a chave de energização;

Verificar se os ajustes de potência e o limite de corrente estão zerados.

6-) Para desligar o retificad or principal da sala 1:

Desligar o disjuntor principal;

Desligar o relé mestre;

Desligar o comando.

7-) Desligar a fonte de corrente.

8-) Desligar a torre de refrigeração. 
9-) Desligar a bomba do circuito secundário (B102).

10-) Desligar a bomba do circuito primário (em baixo da botoeira da torre).

11-) Desligar o painel de controle (girar a chave).

12-) Parar o programa de coleta e tratamento de dados (Quick Basic).

13-) Desligar o computador.

14-) Desligar a chave da instrumentação.

15-) Retornar todas as válvulas às suas posições iniciais. 
LearnBufWghts.txt

\begin{tabular}{|c|c|c|c|c|}
\hline $\begin{array}{l}\text { iEpochs } \\
0\end{array}$ & $\begin{array}{l}\text { Buffer } \\
0\end{array}$ & $\begin{array}{c}\text { BUFFER ID } \\
\text { SSU_L_1_000_000_0U_1_-_+000 }\end{array}$ & $\begin{array}{l}\text { WinNrn } \\
115\end{array}$ & $\begin{array}{l}\text { P-W_Dist } \\
5.198059\end{array}$ \\
\hline 0 & 1 & SSU_L_1_010_010_0U_1_-_+000 & 115 & 4.025858 \\
\hline 0 & 2 & SSU_L_1_020_020_0U_1_-_+000 & 115 & 3.179239 \\
\hline 0 & 3 & SSU_L_1_030_030_0U_1_-_+000 & 121 & 2.739976 \\
\hline 5999 & 6403 & R240D_L_5_010_000_02_5_-_+060 & 61 & 0.303722 \\
\hline 5999 & 6404 & R240D_L_5_010_000_02_5_-- +200 & 61 & 0.501978 \\
\hline 5999 & 6405 & R240D_L_5_010_000_02_5_-- +500 & 91 & 0.451273 \\
\hline 6000 & 0 & SSU_L_1_000_000_0U_1_-_+000 & 96 & 0.344438 \\
\hline 6000 & 1 & SSU_L_1_010_010_0U_1_- +000 & 97 & 0.224318 \\
\hline 6000 & 2 & SSU_L_1_020_020_0U_1_-_+000 & 67 & 0.194714 \\
\hline 6000 & 3 & SSU_L_1_030_030_0U_1_- +000 & 68 & 0.0289 \\
\hline
\end{tabular}

\section{LearnChangeWin.txt}

\begin{tabular}{|c|c|c|}
\hline iEpoch & Buffer & BUFFER_ID \\
\hline 0 & 0 & SSU_L_1_000_000_0U_1_-_+000 \\
\hline 0 & 1 & SSU_L $1010+0100 U^{-} 1--+000$ \\
\hline 0 & 2 & SSU_L_1_020_020_0U_1_- +000 \\
\hline 0 & 3 & SSU_L_1_030_030_0U_1_- +000 \\
\hline 0 & 4 & SSU_L_1_040_040_0U_1_-- +000 \\
\hline ' & ' & .' \\
\hline ' & ' & . \\
\hline ' & ' & ' \\
\hline 5992 & 719 & DU_L_5_040_050_99_5_-_+999 \\
\hline 5992 & 2109 & R30U_H_3_070_080_99_3_-_+500 \\
\hline 5993 & 3916 & R120U_H_5-060_070 $02 \overline{5}-\overline{-}--030$ \\
\hline 5993 & 5253 & R240U_H_3_060_070_02_3_-_+500 \\
\hline 5994 & 719 & DU_L_5_040_050_99_5_-_+999 \\
\hline 5996 & 4498 & R120D_L_3_030_020_02_3_-_+006 \\
\hline 5997 & 3916 & R120U_H_5_060_070_02_5_--030 \\
\hline 5998 & 3916 & R120U_H_5_060_070_02 $5--030$ \\
\hline
\end{tabular}

$\begin{array}{rrl}\text { LastWin } & \text { New Win } & \text { Dist } \\ -1 & 96 & 0.71576 \\ -1 & 66 & 0.22881 \\ -1 & 67 & 0.05898 \\ -1 & 68 & 0.24781 \\ -1 & 101 & 0.17778 \\ : & : & \vdots \\ \vdots & & \vdots \\ 57 & 34 & 0.22363 \\ 28 & 29 & 0.54877 \\ 85 & 120 & 0.14924 \\ 16 & 15 & 0.60263 \\ 34 & 57 & 0.22309 \\ 21 & 20 & 0.2004 \\ 120 & 85 & 0.14864 \\ 85 & 120 & 0.14876\end{array}$


$\underline{\text { LearnDMax.txt }}$

$\begin{array}{lllll}\text { iEpoch } & \text { dMax } & \text { ETA } & \text { MinNghb } & \text { MaxNghb } \\ 0 & 7.61047 & 0.1 & 0.01 & 0.1 \\ 1 & 8.13599 & 0.09996 & 0.01 & 0.09996 \\ 2 & 6.17392 & 0.09992 & 0.00999 & 0.09992 \\ 3 & 6.13742 & 0.09988 & 0.00999 & 0.09988\end{array}$

LearnNetParam.txt

$\mathrm{m} \_\mathrm{iNetGeo}=3, \mathrm{~m} \_\mathrm{i} E l e m G e 0=3, \mathrm{~m} \_\mathrm{dElemAngle}=30.0, \mathrm{~m} \_\mathrm{iNLayers}=7$.

$n$ EpochsOrder $=2500$ InitOrderValue $=0.1000$ FinalOrderValue $=0.000$

$n$ EpochsCnvrg $=6000$ InitCnvrgValue $=0.0150$ FinalCnvrgValue $=0.001$

Random $=1, \quad$ Buf0Nrn0 $=0, \quad$ StartWghtsWTrainData $=0$

LearnNormTrainBuf.txt. esta informação se encontra após o SICTRAINData.inp para facilidade de comparação com o mesmo.

\section{LearnNrnWghts.txt}

\begin{tabular}{|c|c|c|c|c|c|c|}
\hline iEpoch & Neuron & Neuron_Weights & & & & \\
\hline 0 & 0 & 0.291 & 0.286 & 0.241 & 0.240 & 0.227 \\
\hline 0 & 1 & 0.259 & 0.254 & 0.209 & 0.208 & 0.195 \\
\hline 0 & 2 & 0.238 & 0.233 & 0.189 & 0.188 & 0.176 \\
\hline 0 & 3 & 0.269 & 0.264 & 0.219 & 0.218 & 0.205 \\
\hline 0 & 4 & 0.317 & 0.312 & 0.266 & 0.265 & 0.252 \\
\hline 0 & 5 & 0.337 & 0.332 & 0.285 & 0.284 & 0.271 \\
\hline 0 & 6 & 0.309 & 0.304 & 0.258 & 0.257 & 0.244 \\
\hline . & . & - & . & . & . & . \\
\hline & : & : & : & : & . & : \\
\hline 5999 & 0 & 0.042 & 0.045 & 0.024 & 0.024 & 0.017 \\
\hline 5999 & 1 & 0.163 & 0.171 & 0.174 & 0.174 & 0.170 \\
\hline 5999 & 2 & 0.188 & 0.186 & 0.151 & 0.150 & 0.141 \\
\hline 5999 & 3 & 0.016 & 0.009 & -0.044 & -0.045 & -0.055 \\
\hline 5999 & 4 & -0.113 & -0.115 & -0.150 & -0.150 & -0.157 \\
\hline 5999 & 5 & -0.113 & -0.108 & -0.121 & -0.120 & -0.124 \\
\hline 5999 & 6 & 0.008 & 0.019 & 0.025 & 0.026 & 0.023 \\
\hline : & . & . & : & : & $:$ & . \\
\hline ' & : & : & : & : & " & : \\
\hline
\end{tabular}




\section{LearnParamDist.txt}

\begin{tabular}{|c|c|c|c|c|}
\hline FROM & TO & Distance & FROM & TO \\
\hline 0 & 1 & 1.026402 & SS_20_000 & SS_30_000 \\
\hline 0 & 2 & 2.047451 & SS_20_000 & $\mathrm{SS}_{-} 40 \_000$ \\
\hline 0 & 3 & 3.084985 & SS_20_000 & SS_50_000 \\
\hline 0 & 4 & 4.12777 & SS_20_000 & SS_60_000 \\
\hline 0 & 5 & 5.190936 & SS_20_- 000 & $\mathrm{SS}_{-}^{\top} 70_{-}^{-} 000$ \\
\hline 0 & 6 & 6.163105 & SS_20_000 & SS_80_000 \\
\hline 0 & 7 & 7.24712 & SS_20_000 & SS_90_000 \\
\hline 0 & 8 & 8.587366 & SS__20_000 & SS_105_000 \\
\hline & & & & \\
\hline & & & & \\
\hline 1752 & 2482 & 4.781547 & RM P5_60_50_156 & RM P25_100_90_090 \\
\hline 1752 & 2483 & 4.766524 & RM P5_60_50_156 & RM P25_100_90_096 \\
\hline 1752 & 2484 & 4.75112 & RM P5_60_50_156 & RM P25_100_90_102 \\
\hline 1752 & 2485 & 4.735269 & RM P5_60_50_156 & RM P25_100_90_108 \\
\hline 1752 & 2486 & 4.71856 & RM P5_60_50_156 & RM P25_100_90_114 \\
\hline 1752 & 2487 & 4.70221 & RM P5_60_50_156 & RM P25_100_90_120 \\
\hline 1752 & 2488 & 4.686664 & RM P5_60_50_156 & RM P25_100_90_126 \\
\hline 1752 & 2489 & 4.670017 & RM P5_60_50_156 & RM P25_100_90_132 \\
\hline 1752 & 2490 & 4.651979 & RM P5_60_50_156 & RM P25_100_90_138 \\
\hline 1752 & 2491 & 4.633619 & RM P5_60_50_156 & RM P25_100_90_144 \\
\hline & & & & \\
\hline & & & & \\
\hline 5567 & 5571 & 1.632009 & SLDER_100_350 & SLDER_100_550 \\
\hline 5567 & 5572 & 2.163252 & SLDER_100_350 & SLDER_100_600 \\
\hline 5568 & 5569 & 0.356886 & SLDER_100_400 & SLDER_100_450 \\
\hline 5568 & 5570 & 0.730424 & SLDER_100_400 & SLDER_100_500 \\
\hline 5568 & 5571 & 1.214016 & SLDER_100_400 & SLDER_100_550 \\
\hline 5568 & 5572 & 1.746134 & SLDER_100_400 & SLDER_100_600 \\
\hline 5569 & 5570 & 0.377406 & SLDER_100_450 & SLDER_100_500 \\
\hline 5569 & 5571 & 0.866443 & SLDER_100_450 & SLDER_100_550 \\
\hline 5569 & 5572 & 1.417474 & SLDER_100_450 & SLDER_100_600 \\
\hline 5570 & 5571 & 0.512727 & SLDER_100_500 & SLDER_100_550 \\
\hline 5570 & 5572 & 1.111776 & SLDER_100_500 & SLDER_100_600 \\
\hline 5571 & 5572 & 0.677046 & SLDER_100_550 & SLDER_100_600 \\
\hline
\end{tabular}


$\underline{\text { LearnParamDist0.txt }}$

\begin{tabular}{|c|c|c|c|c|}
\hline Intervalo & $0-$ & FROM : & O TO: & 1.76972 \\
\hline Intervalo & $1-$ & FROM : & 1.76972 TO: & 3.53944 \\
\hline Intervalo & $2-$ & FROM : & 3.53944 TO: & 5.30916 \\
\hline Intervalo & $3-$ & FROM : & 5.30916 TO: & 7.07889 \\
\hline Intervalo & $4-$ & FROM : & 7.07889 TO: & 8.84861 \\
\hline Intervalo & $5-$ & FROM : & 8.84861 TO: & 10.6183 \\
\hline Intervalo & $6-$ & FROM: & 10.6183 TO: & 12.388 \\
\hline Intervalo & $7-$ & FROM : & 12.388 TO: & 14.1578 \\
\hline Intervalo & $8-$ & FROM: & 14.1578 TO: & 15.9275 \\
\hline Intervalo & $9-$ & FROM: & 15.9275 TO: & 17.6972 \\
\hline Intervalo & $0=$ & 1390281 & & \\
\hline Intervalo & $1=$ & 2877292 & & \\
\hline Intervalo & $2=$ & 3364951 & & \\
\hline Intervalo & $3=$ & 4148784 & & \\
\hline Intervalo & $4=$ & 3106677 & & \\
\hline Intervalo & $5=$ & 2191964 & & \\
\hline Intervalo & $6=$ & 1681459 & & \\
\hline Intervalo & $7=$ & 1089201 & & \\
\hline Intervalo & $8=$ & 548256 & & \\
\hline Intervalo & $9=$ & 129161 & & \\
\hline
\end{tabular}

\section{LearnWinBufsInNrn.txt}

\begin{tabular}{|c|c|c|c|c|c|}
\hline ¡Epoch & Neuron & nBuffers & Buffers & Buffer_ID & Buf_Nrn-Dist \\
\hline 0 & c & 0 & --. & ------ & \\
\hline 0 & . & 0 & 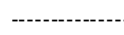 & - & \\
\hline 0 & 2 & 0 & 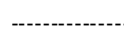 & - & \\
\hline 0 & 3 & 0 & -..--.-. & 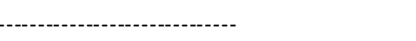 & \\
\hline 0 & 4 & 0 & - & 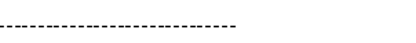 & \\
\hline 0 & 5 & 4 & 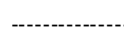 & - & \\
\hline 0 & 5 & 4 & 1313 & DD_L_3_040_030_99_3_-_+048 & 0.441139 \\
\hline 0 & 5 & 4 & 1314 & $\mathrm{DD}_{-} \mathrm{L}_{-}{ }_{3}-040+0300_{-} 99_{-} 3_{-}-{ }_{-}+054$ & 0.436972 \\
\hline 0 & 5 & 4 & 1315 & $\mathrm{DD} \mathrm{L}_{-} 3$ 3040_030_99_3_-_+060 & 0.432676 \\
\hline 0 & 5 & 4 & 6068 & R240D_L_3_040_030_02_3_-_+200 & 0.337181 \\
\hline 0 & 6 & 11 & 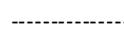 & - & \\
\hline 0 & 6 & 11 & 430 & DU_L_3_030_040_99_3_-_+750 & 0.406172 \\
\hline$\cdot$ & & · & $\cdot$ & $\cdot$ & $\cdot$ \\
\hline · & & · & $\cdot$ & $\cdot$ & · \\
\hline . & & . & . & - & . \\
\hline 5999 & c & 101 & -1.--. & (2)-- & \\
\hline 5999 & c & 101 & 29 & SSU_L_3_050_050_0U_3_-_+000 & 0.302055 \\
\hline 5999 & c & 101 & 42 & SSD_L_3_050_050_0D_3_-_+000 & 0.267067 \\
\hline 5999 & 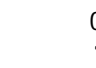 & 101 & 455 & DU_L_3_040_050_99_3_-_+999 & 0.488355 \\
\hline - & & · & $\cdot$ & · & · \\
\hline . & & . & . & . & . \\
\hline
\end{tabular}




\section{NrnGeomDist.txt}

$\begin{array}{lll}\text { FROM } & \text { TO } & \text { Distance } \\ 0 & 1 & 0.08366 \\ 0 & 2 & 0.08366 \\ 0 & 3 & 0.082867 \\ 0 & 4 & 0.08366 \\ 0 & 5 & 0.08366 \\ 0 & 6 & 0.082867 \\ 0 & 7 & 0.166796\end{array}$

$\underline{\text { NrnGeomDist0 }}$

\begin{tabular}{|c|c|c|c|c|c|c|}
\hline$m_{-}$iNetGeo $=3$ & & & & $\begin{array}{l}\mathrm{m}_{-} \text {iElemGeo }= \\
\mathrm{m}_{-} \mathrm{dElemAngle}= \\
\mathrm{m}_{-} \mathrm{iNLayers}=\end{array}$ & $\begin{array}{r}3 \\
30 \\
7\end{array}$ & \\
\hline \multirow[t]{2}{*}{ m_nNeurons=127 } & & & & $\mathrm{dM}$ axDist= & $53.3 \mathrm{iMax}=$ & $91 \mathrm{jMax}=109$ \\
\hline & & & & dM inDist= & $78 \mathrm{iMin}=$ & $61 \mathrm{jM}$ in $=126$ \\
\hline dM axDist/dM inDist & & & & 12.222273 & & \\
\hline $\mathrm{dM}$ inDist/ $\mathrm{dM}$ axDist & & & & 0.081818 & & \\
\hline Intervalo & 0 & - & FROM: & O TO: & 0.1 & \\
\hline Intervalo & 1 & - & FROM: & $0.1 \mathrm{TO}:$ & 0.2 & \\
\hline Intervalo & 2 & - & FROM: & 0.2 TO: & 0.3 & \\
\hline Intervalo & 3 & - & FROM: & 0.3 TO: & 0.4 & \\
\hline Intervalo & 4 & - & FROM: & 0.4 TO: & 0.5 & \\
\hline Intervalo & 5 & - & FROM: & 0.5 TO: & 0.6 & \\
\hline Intervalo & 6 & - & FROM : & $0.6 \mathrm{TO}:$ & 0.7 & \\
\hline Intervalo & 7 & - & FROM: & 0.7 TO: & 0.8 & \\
\hline Intervalo & 8 & - & FROM: & 0.8 TO: & 0.9 & \\
\hline Intervalo & 9 & - & FROM : & 0.9 TO: & 1 & \\
\hline Intervalo & 0 & $=$ & 342 & & & \\
\hline Intervalo & 1 & $=$ & 609 & & & \\
\hline Intervalo & 2 & $=$ & 1133 & & & \\
\hline Intervalo & 3 & $=$ & 1405 & & & \\
\hline Intervalo & 4 & $=$ & 1077 & & & \\
\hline Intervalo & 5 & $=$ & 1387 & & & \\
\hline Intervalo & 6 & $=$ & 935 & & & \\
\hline Intervalo & 7 & $=$ & 714 & & & \\
\hline Intervalo & 8 & $=$ & 332 & & & \\
\hline Intervalo & 9 & $=$ & 67 & & & \\
\hline
\end{tabular}

$\begin{array}{rcrr}\text { Nghb } & \text { Nrno } & \text { Nrn1 } & \text { \#Nrn } \\ 0 & 0 & 1 & 1 \\ 0 & 0 & 2 & 2 \\ 0 & 0 & 3 & 3 \\ 0 & 0 & 4 & 4 \\ 0 & 0 & 5 & 5 \\ 0 & 0 & 6 & 6 \\ 2 & 0 & 7 & 1 \\ 1 & 0 & 8 & 1 \\ 2 & 0 & 9 & 2 \\ 1 & 0 & 10 & 2 \\ 2 & 0 & 11 & 3 \\ 1 & 0 & 12 & 3 \\ 2 & 0 & 13 & 4\end{array}$




\section{NrnWghtDist0.txt}

$\begin{array}{rrrrrr}\text { Epoch } & \text { FROM } & \text { TO } & \text { WghtDist } & \text { GeoDist } & \text { WghtDist/GeoDist } \\ 0 & 0 & 1 & 0.269135 & 0.08366 & 3.217027 \\ 0 & 0 & 2 & 0.446749 & 0.08366 & 5.340074 \\ 0 & 0 & 3 & 0.210762 & 0.082867 & 2.543378 \\ 0 & 0 & 4 & 0.212179 & 0.08366 & 2.536221 \\ 0 & 0 & 5 & 0.385535 & 0.08366 & 4.608371 \\ 0 & 0 & 6 & 0.176143 & 0.082867 & 2.125622 \\ 0 & 0 & 7 & 0.604448 & 0.166796 & 3.623882 \\ 0 & 0 & 8 & 0.754175 & 0.144755 & 5.21002\end{array}$

\section{NrnWghtDist00.txt}

$\begin{array}{cl}3600 & \text { Intervalo } 8 \\ 3600 & \text { Intervalo } 9 \\ & \\ \text { Epoch }= & \\ 4800 & \text { m_nNeurons }=127 \\ & \\ 4800 \text { Intervalo } 0 \\ 4800 \text { Intervalo } 1 \\ 4800 \text { Intervalo } 2 \\ 4800 \text { Intervalo } 3 \\ 4800 \text { Intervalo } 4 \\ 4800 \text { Intervalo } 5 \\ 4800 \text { Intervalo } 6 \\ 4800 \text { Intervalo } 7 \\ 4800 \text { Intervalo } 8 \\ 4800 \text { Intervalo } 9\end{array}$

$=$

$=$

$\begin{array}{lrl}\mathrm{dM} \text { axDist }=16.4159 & \mathrm{iMax}=91 & \mathrm{jM} \mathrm{ax}=109 \\ \mathrm{dM} \text { inDist }=0.136398 & \mathrm{iM} \text { in }=21 & \mathrm{jM} \mathrm{in}=22 \\ = & 440 \\ = & 1034 \\ = & 1549 \\ = & 1509 \\ = & 1319 \\ = & 872 \\ = & 594 \\ = & 372 \\ = & 241 \\ = & 70\end{array}$

Epoch $=5999$ m_nNeurons $=127$

5999 Intervalo 0

5999 Intervalo 1

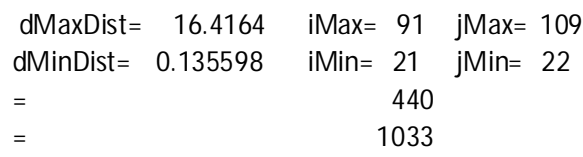

\section{NrnWghtDist4800.txt}

\begin{tabular}{rrrrrr} 
Epoch & FROM & TO & WghtDist & \multicolumn{1}{c}{ GeoDist } & WghtDist/GeoDist \\
4800 & 0 & 1 & 1.105762 & 0.08366 & 13.217383 \\
4800 & 0 & 2 & 1.171497 & 0.08366 & 14.003123 \\
4800 & 0 & 3 & 0.436788 & 0.082867 & 5.270964 \\
4800 & 0 & 4 & 1.327501 & 0.08366 & 15.867871 \\
4800 & 0 & 5 & 1.260066 & 0.08366 & 15.061814 \\
4800 & 0 & 6 & 0.304896 & 0.082867 & 3.679349 \\
4800 & 0 & 7 & 2.373051 & 0.166796 & 14.227288 \\
4800 & 0 & 8 & 2.079935 & 0.144755 & 14.36869 \\
4800 & 0 & 9 & 2.204072 & 0.166796 & 13.214202 \\
4800 & 0 & 10 & 0.947236 & 0.14429 & 6.5648 \\
4800 & 0 & 11 & 0.836984 & 0.166783 & 5.018413
\end{tabular}




\section{$\underline{\text { RunDistW.txt }}$}

Time Winner DistNeuron Buffer

54.00

$\begin{array}{lll}54.00 & 43 & 9.41761\end{array}$

$\begin{array}{lll}60.00 & 43 & 9.41685\end{array}$

$\begin{array}{lll}66.00 & 43 & 9.41563\end{array}$

$\begin{array}{lll}72.00 & 43 & 9.41423\end{array}$

$\begin{array}{lll}78.00 & 43 & 9.41286\end{array}$

$\begin{array}{lll}84.00 & 43 & 9.41267\end{array}$

$90.00 \quad 43 \quad 9.41177$

$96.00 \quad 43 \quad 9.40914$

$\begin{array}{lll}102.00 & 43 & 9.40702\end{array}$

$\begin{array}{lll}108.00 & 43 & 9.40560\end{array}$

$\begin{array}{lll}114.00 & 43 & 9.40353\end{array}$

$120.00 \quad 43 \quad 9.40149$

$\begin{array}{lll}126.00 & 43 & 9.39913\end{array}$

$\begin{array}{lll}132.00 & 43 & 9.39738\end{array}$

$\begin{array}{lll}138.00 & 43 & 9.39551\end{array}$

$\begin{array}{lll}144.00 & 43 & 9.39320\end{array}$

$\begin{array}{lll}150.00 & 43 & 9.39045\end{array}$

$\begin{array}{lll}156.00 & 43 & 9.38947\end{array}$

$\begin{array}{lll}162.00 & 43 & 9.38826\end{array}$

$\begin{array}{lll}168.00 & 43 & 9.38662\end{array}$

$\begin{array}{lll}174.00 & 43 & 9.38610\end{array}$

$\begin{array}{lll}180.00 & 43 & 9.38559\end{array}$

$\begin{array}{lll}186.00 & 43 & 9.17338\end{array}$

$\begin{array}{lll}192.00 & 43 & 8.95854\end{array}$

$\begin{array}{lll}198.00 & 43 & 8.71705\end{array}$

$204.00 \quad 43 \quad 8.46168$

$\begin{array}{lll}210.00 & 43 & 8.19789\end{array}$

$\begin{array}{lll}216.00 & 43 & 7.92463\end{array}$

$222.00 \quad 43 \quad 7.64163$

$\begin{array}{lll}228.00 & 43 & 7.34732\end{array}$

$\begin{array}{lll}234.00 & 68 & 7.03325\end{array}$

$240.00 \quad 68 \quad 6.70123$

$246.00 \quad 99 \quad 6.65142$

$252.00 \quad 99 \quad 6.59015$

$\begin{array}{lll}258.00 & 99 & 6.56879\end{array}$

$\begin{array}{lll}264.00 & 99 & 6.56079\end{array}$

270.00

$\begin{array}{ll}99 & 6.55747\end{array}$

$\begin{array}{lll}276.00 & 99 & 6.55626 \\ 282.00 & 99 & 6.55636 \\ 288.00 & 99 & 6.46800 \\ 294.00 & 99 & 6.22216 \\ 300.00 & 99 & 5.96524 \\ 306.00 & 99 & 5.69903 \\ 312.00 & 99 & 5.41963 \\ 318.00 & 99 & 5.12122 \\ 324.00 & 99 & 4.80412 \\ 330.00 & 99 & 4.46194 \\ 336.00 & 99 & 4.09191 \\ 342.00 & 99 & 3.68536 \\ 348.00 & 99 & 3.40202 \\ 354.00 & 99 & 3.39579 \\ 360.00 & 99 & 3.39022 \\ 366.00 & 99 & 3.38285 \\ 372.00 & 99 & 3.37562 \\ 378.00 & 99 & 3.37198 \\ 384.00 & 99 & 3.36826 \\ 390.00 & 99 & 3.36820 \\ 396.00 & 99 & 3.36487 \\ 402.00 & 99 & 3.35991 \\ 408.00 & 99 & 3.35302 \\ 414.00 & 99 & 3.34749 \\ 420.00 & 99 & 3.34125 \\ 426.00 & 99 & 3.33216 \\ 432.00 & 99 & 3.32339 \\ 438.00 & 99 & 3.31611 \\ 444.00 & 99 & 3.30881 \\ 450.00 & 99 & 3.29978 \\ 456.00 & 99 & 3.29290 \\ 462.00 & 99 & 3.28504 \\ 468.00 & 99 & 3.27918 \\ 474.00 & 99 & 3.27102 \\ 480.00 & 99 & 3.26486 \\ 486.00 & 99 & 3.25866\end{array}$

$\begin{array}{lll}276.00 & 99 & 6.55626\end{array}$

6.55636

$294.00 \quad 99 \quad 6.22216$

$300.00 \quad 99 \quad 5.96524$

$306.00 \quad 99 \quad 5.69903$

5.41963

$324.00 \quad 99 \quad 4.80412$

$330.00 \quad 99 \quad 4.46194$

$342.00 \quad 99-3.68536$

$348.00 \quad 99 \quad 3.40202$

3.39579

$\begin{array}{lll}366.00 & 99 & 3.38285\end{array}$

$\begin{array}{lll}372.00 & 99 & 3.37562\end{array}$

$378.00 \quad 99 \quad 3.37198$

$390.00 \quad 99 \quad 3.36820$

$\begin{array}{lll}396.00 & 99 & 3.36487\end{array}$

$408.00 \quad 99-3.35302$

$\begin{array}{lll}414.00 & 99 & 3.34749\end{array}$

$420.00 \quad 99 \quad 3.34125$

$426.00 \quad 99 \quad 3.33216$

$\begin{array}{lll}432.00 & 99 & 3.32339\end{array}$

$\begin{array}{lll}438.00 & 99 & 3.31611\end{array}$

$\begin{array}{lll}444.00 & 99 & 3.30881\end{array}$

$\begin{array}{lll}450.00 & 99 & 3.29978 \\ 456.00 & 99 & 3.29290\end{array}$

$\begin{array}{lll}462.00 & 99 & 3.28504\end{array}$

$468.00 \quad 99 \quad 3.27918$

$\begin{array}{lll}480.00 & 99 & 3.26486\end{array}$

$\begin{array}{lll}486.00 & 99 & 3.25866\end{array}$

\section{$\underline{\text { RunNet.txt }}$}

$\begin{array}{cc}\text { Time } & \text { Winner } \\ 54.00 & 43 \\ 234.00 & 68 \\ 246.00 & 99\end{array}$




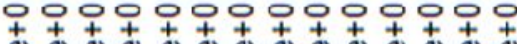
00000000000

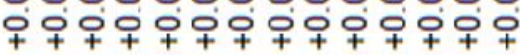

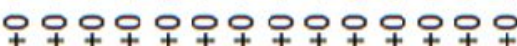

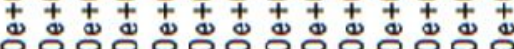

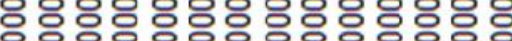

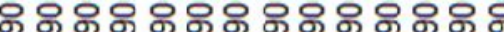
న్సన్సస్సన్సన్సన్సన్సన్స

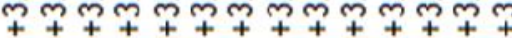

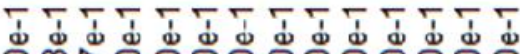

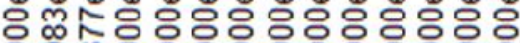

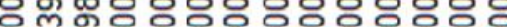

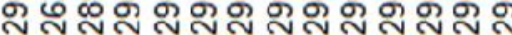

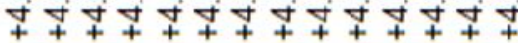
이이이이이이이

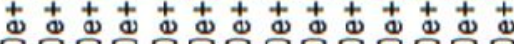

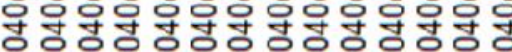
응응응응응응ㅇㅇㅇㅇㅇㅇㅇㅇ 응ㅇㅇㅇㅇㅇㅇㅇㅇㅇㅇㅇㅇㅇㅇㅇㅇㅇㅇㅇㅇㅇㅇ titt+titititit

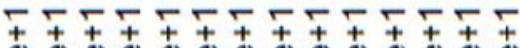

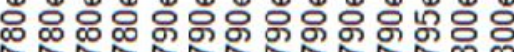
N N N N N

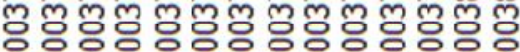

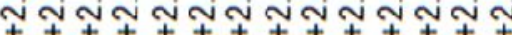
TTTTTঙTTTTT ১.

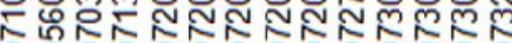

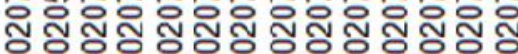

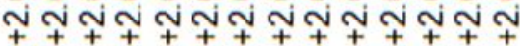

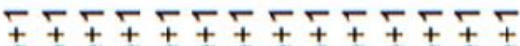

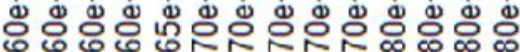

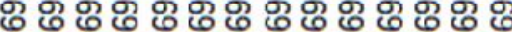
응응응ㅇㅇㅇㅇㅇㅇㅇㅇㅇㅇㅇㅇㅇㅇㅡ.

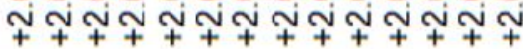

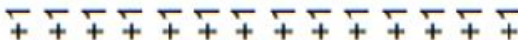
๖ั

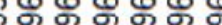

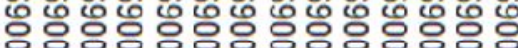

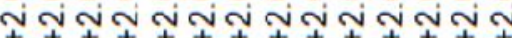
- T L T L T T L $+\begin{array}{r}+ \\ +\end{array}+\begin{gathered}+ \\ + \\ +\end{gathered}$

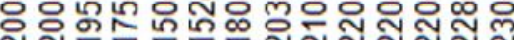
0

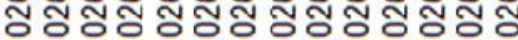

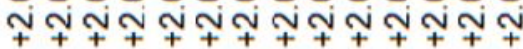

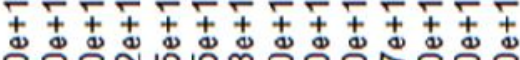
○ั ก็

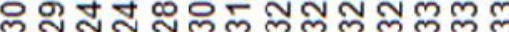

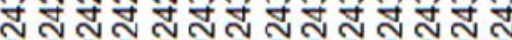
作

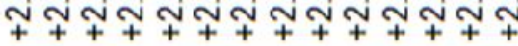

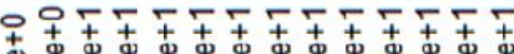
๑ั

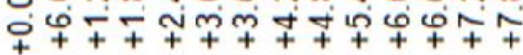


응응ㅇㅇㅇㅇㅇㅇㅇㅇㅇㅇㅇㅇ

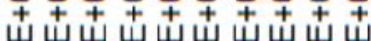
응ㅇㅇㅇㅇㅇㅇㅇㅇㅇㅇㅇㅇㅇㅇㅇ 응응응응응응응응응응

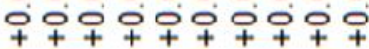
잉ㅇㅇㅇㅇㅇㅇㅇㅇㅇㅇㅇㅇㅇㅇ

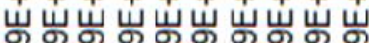

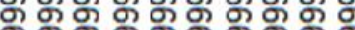

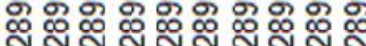
м м м м мм м

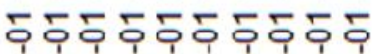
щய山ய山ய山யயس ㅇㅇㅇㅇㅇㅇㅇㅇㅇㅇㅇㅇ

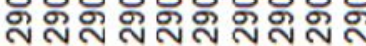
古古卉古卉卉古 응ㅇㅇㅇㅇㅇㅇㅇㅇㅇㅇㅇㅇㅇㅇㅇㅇ ய山ய山шш шயш 岁岁岁岁岁岁 응응ㅇㅇㅇㅇㅇㅇㅇㅇㅇㅇㅇㅇㅇㅇㅇㅇㅇㅇ

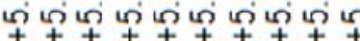

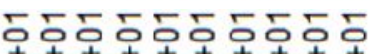

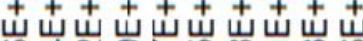
กิกสำ 응영ㅇㅇㅇ응영ㅇㅇㅇㅇㅇㅇ응

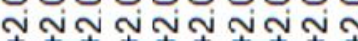

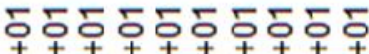

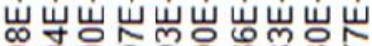

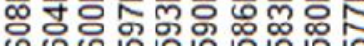

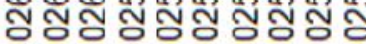

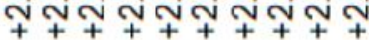

5.5 55555

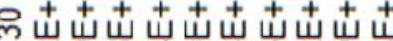

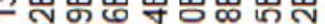

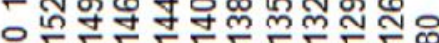

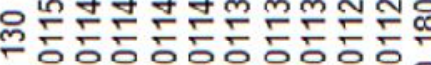

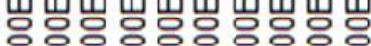

응ㅇㅇㅇㅇㅇㅇㅇㅇㅇㅇㅇㅇㅇㅇㅇ

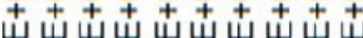

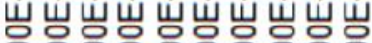
응ㅇㅇㅇㅇㅇㅇㅇㅇㅇㅇㅇㅇㅇㅇㅇㅇㅇㅇㅇㅇ 응응응응응응응응응음 우우우우웅 잉ㅇㅇㅇㅇㅇㅇㅇㅇㅇㅇㅇㅇㅇㅇ 㟧山岀岀岀山岀 응응ㅇㅇㅇㅇㅇㅇㅇㅇ응 న్సిన్సిన్సిన్సిన్సి

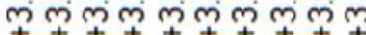

둥ㅎㅇㅎㅎㅇㅎㅇㅎㅇ

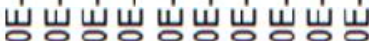
응ㅇㅇㅇㅇㅇㅇㅇㅇㅇㅇㅇㅇㅇㅇ

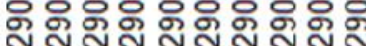
卉卉卉卉卉卉卉卉 응ㅇㅇㅇㅇㅇㅇㅇㅇㅇㅇㅇㅇ ய山ய山 шய山ش山 岁岁出岁岁岁 양ㅇㅇㅇㅇㅇㅇㅇㅇㅇㅇㅇㅇㅇㅇㅇㅇㅇㅇ $\mp+\mp \mp 5 \mp \mp \mp \mp$

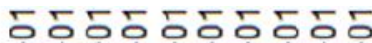
出出出出出出

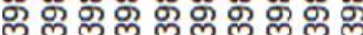

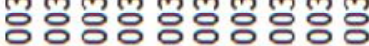

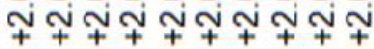

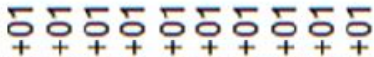

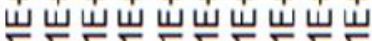
등흔흥흐응흔흥흐응응

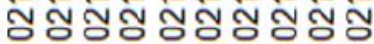
+⿱廿⿻中一冂土

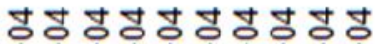

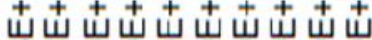

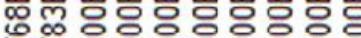
상ㅇㅇㅇㅇㅇㅇㅇㅇㅇㅇㅇ 성응응응응응응응응

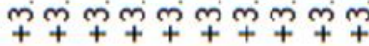
응ㅇㅇㅇㅇㅇㅇㅇㅇㅇㅇㅇ $++++++++$ 岁岁岁岁岁岁岁岁岁 ค요응용 స్స :

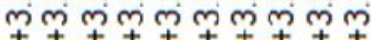

둥ㄷㅇㄷㅎㅇㄷㅇㄷㅇ

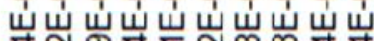

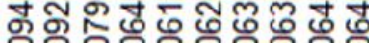

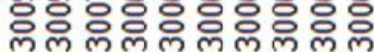
古古卉古古古古 응ㅇㅇㅇㅇㅇㅇㅇㅇㅇㅇㅇㅇㅇㅇㅇ

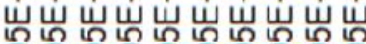

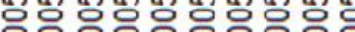
응응ㅇㅇㅇㅇㅇㅇㅇㅇㅇㅇㅇㅇㅇㅇ

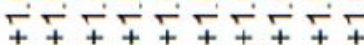
L. 우우우우우우우우우우

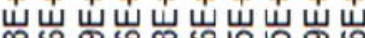
$\infty$

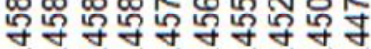

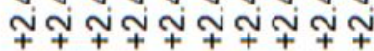
둥ㅎㅎ훟ㅎㅎㅎㅎㅎㅎㅎㅎㅜ

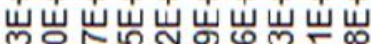

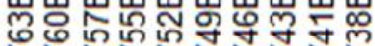
NNNNNNNNNN

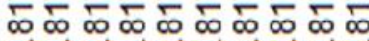

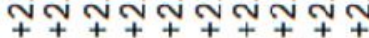

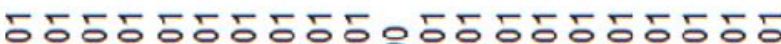
$+\begin{aligned} & + \\ & +\end{aligned}$

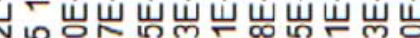

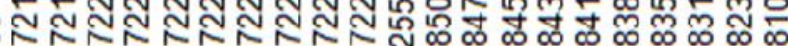

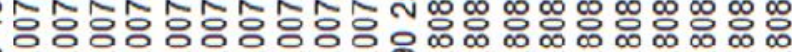

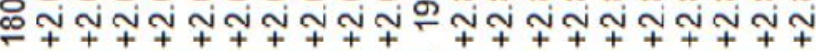

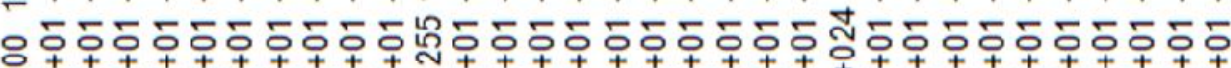
†

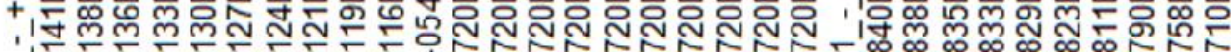

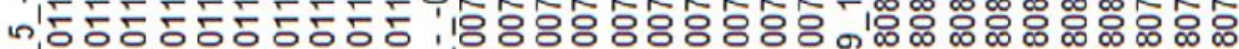

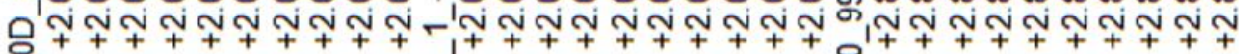

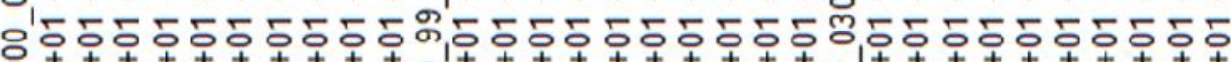

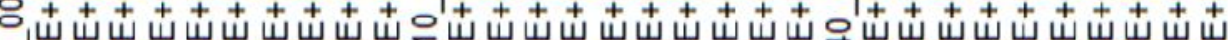

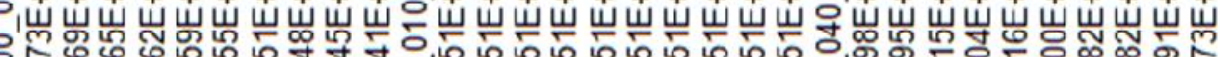

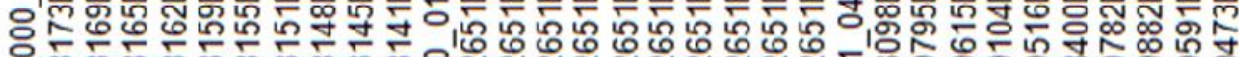

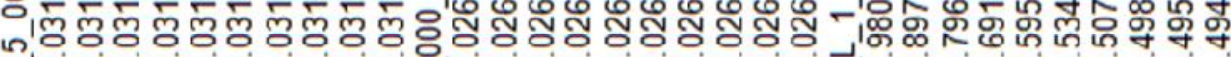

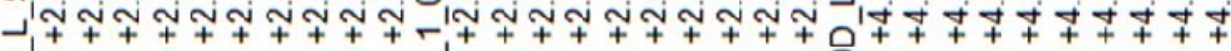

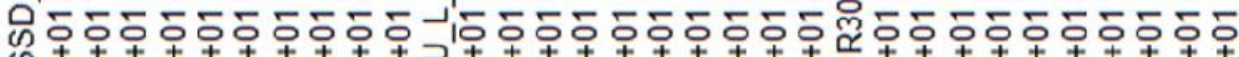

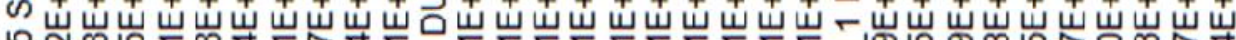
nIN

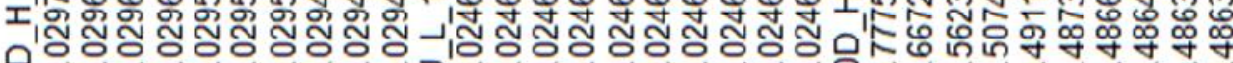
ת 


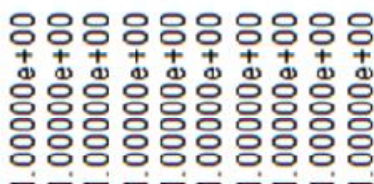

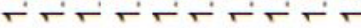

후훟ㅎㅎㅎㅎㅎㅎㅎㅎㅎㅎㅎㅎㅎㅎㅇ m̄

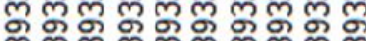

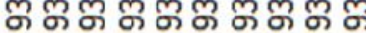

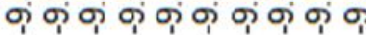

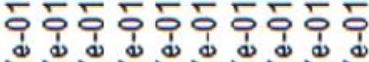

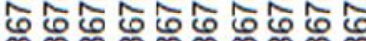
ถู่ केक कांक केक

응ㅇㅇㅇㅇㅇㅇㅇㅇㅇㅇㅇㅇㅇㅇㅇㅇ

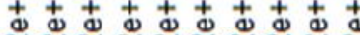

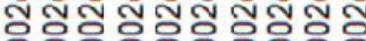
응응응응응응응응

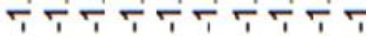

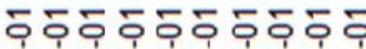

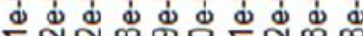

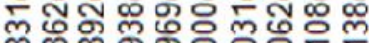
$\infty$ œ नंकानंकानंक

ธธㅎㅎㅎㅎㅎㅎㅎㅎㅎ

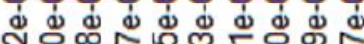

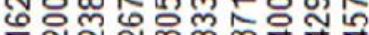

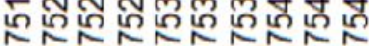
का को 이

둫ㄷㅎㅎㅎㅎㅎㄷㅎㅎㅇ
응으응응ㅇㅇ응ㅇㅇ응 $++t+t+t+4$ 응ㅇㅇㅇㅇㅇㅇㅇㅇㅇㅇㅇㅡ 응응응응ㅇㅇ은 은음은은은은은

55555555 d่d d d d d d d d లెల్లెల్లైలైల్ల के

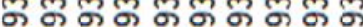
के के का के के

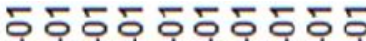
ذ่ से से से से जे से

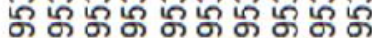
के क्र का के

둫ㄷㅎㄷㅎㅎㄷㅎㄷㅇ ฯ 1

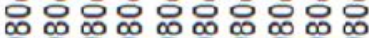

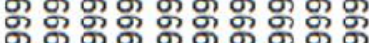

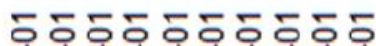

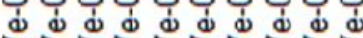
LNENENENEN $\infty 0 \infty 000000$

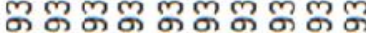
कंजनंकानंका

ธธธธธธธธธธธธธธธธธธธ

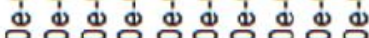
융유융ㅇㅇㅇㅇㅇㅇ ৪ুুুㅇুㅇু요

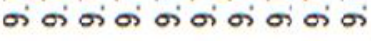

등ㅎㅎㅎㅎㅎㅎㅎㅇ ง่่ ษั้

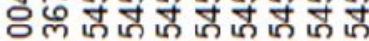

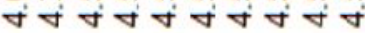

후훟ㅎㅎㅎㅎㅎㅎㅎㅎㅎㅎㅎㅎㅇ ஸे m్ల్లmల్ల m్లు ల్లm ల్లెల్లెల్ల్లైల్లిల్లె

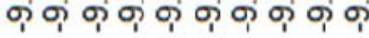

응ㅇㅇㅇㅇㅇㅇㅇㅇㅇㅇㅇㅇㅇㅇ $+ \pm+ \pm+$ 寸̛ 응ㅇㅇㅇㅇㅇㅇㅇㅇㅇㅇㅇㅇㅇㅇㅇㅇ

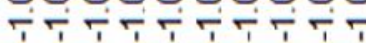

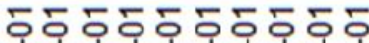
กั่

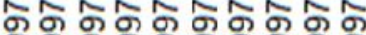

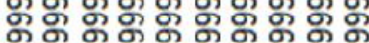
कांकांकांक का का

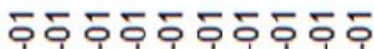

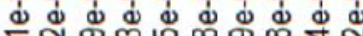

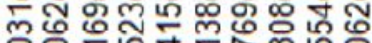

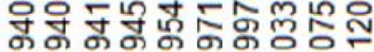

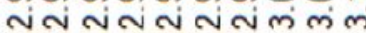

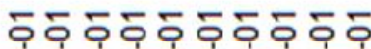
ओं่

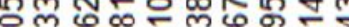

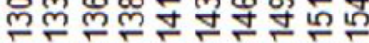
กับำกำกำ 은 dinnกnNinin

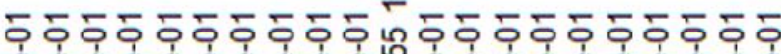
లి -

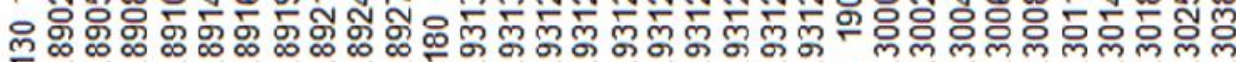
으

"i ล +

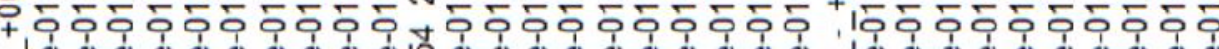
1 ஸ่

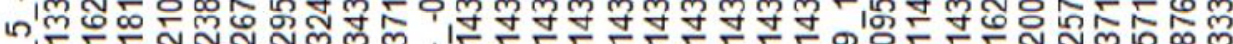

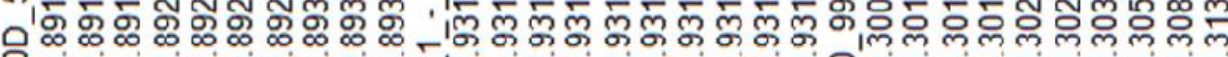
|ंबi்

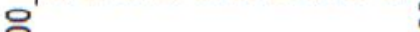
o m

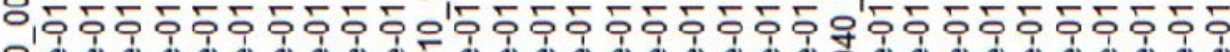
○े

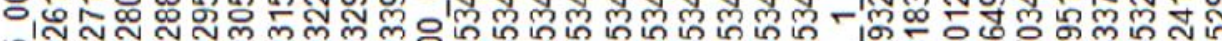

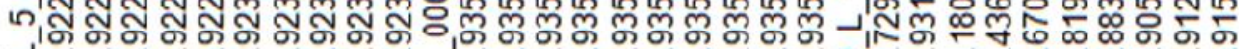

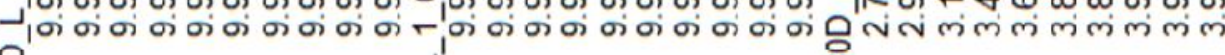
创

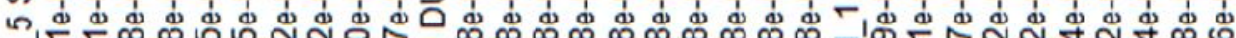

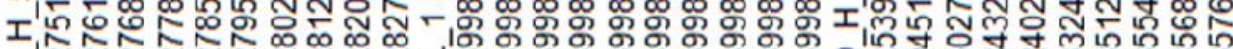

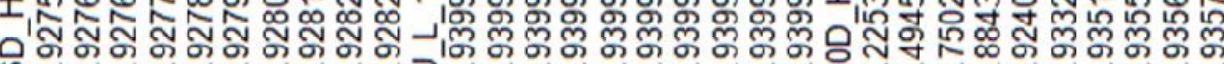

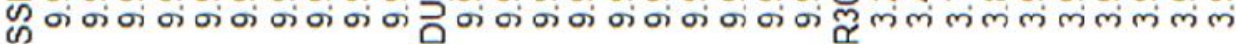


응

m 웅-

웅 응-

오은

กำ -

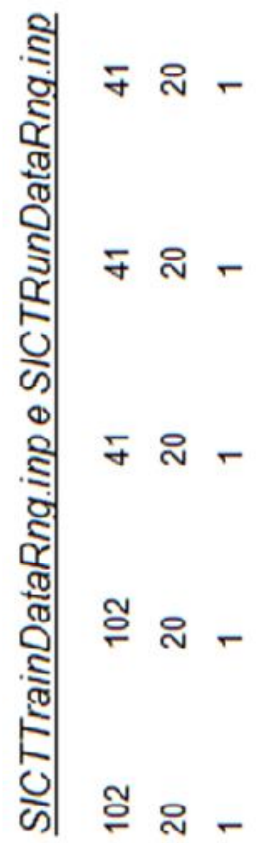




\section{EXPERIMENTO 11}

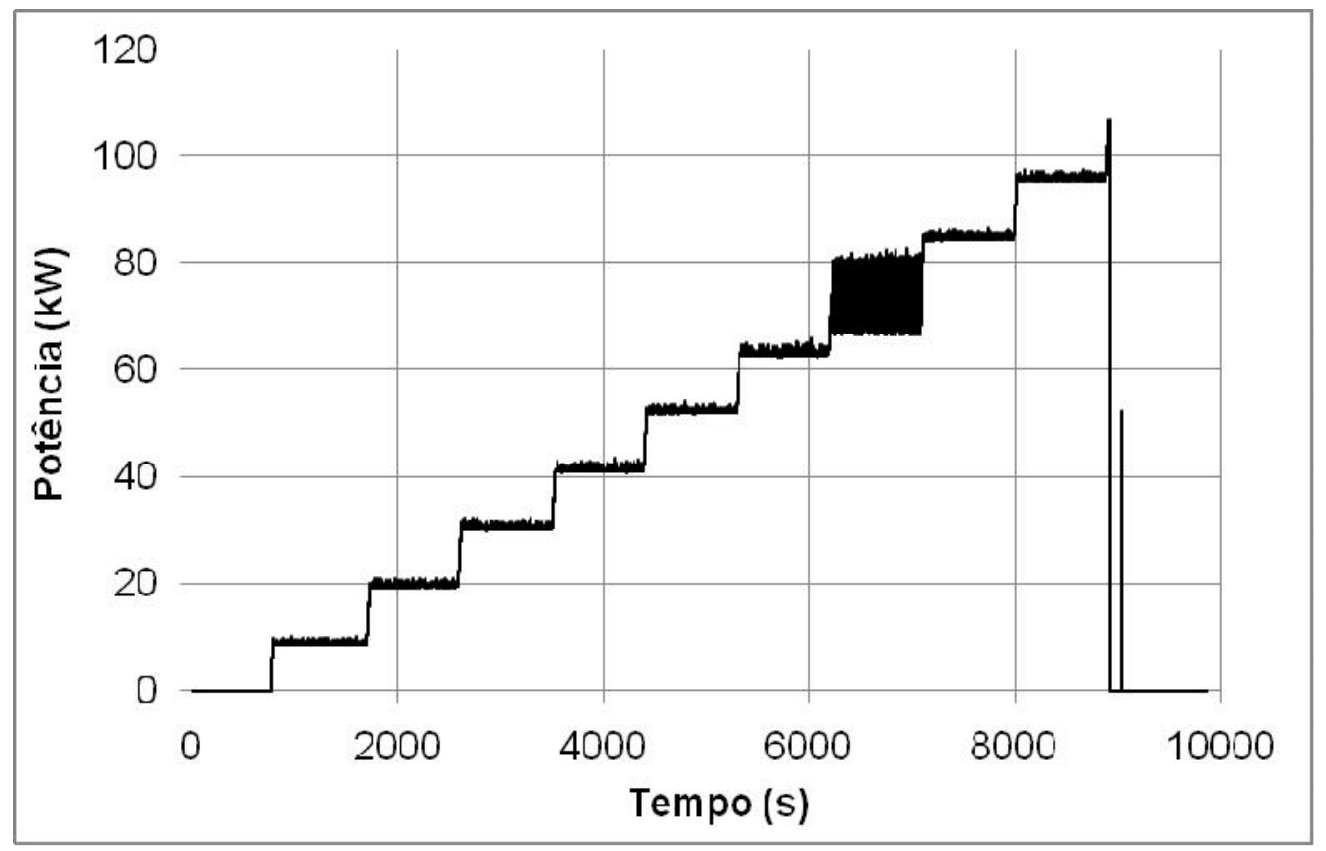

GRÁFICO 116 Potência na seção de testes - Exp11

Fonte: dados experimentais da pesquisa

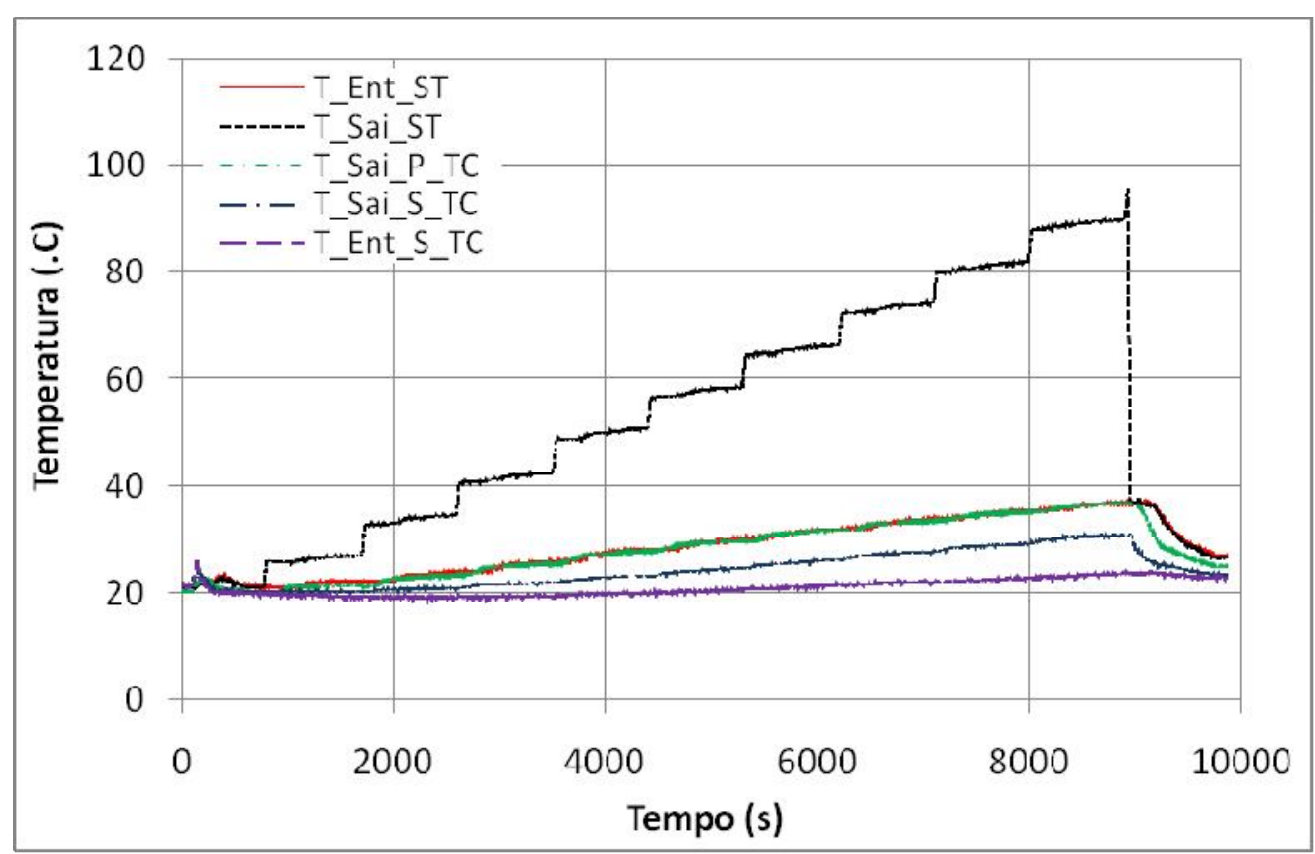

GRÁFICO 117 Temperaturas no CT1 - Exp11

Fonte: dados experimentais da pesquisa 


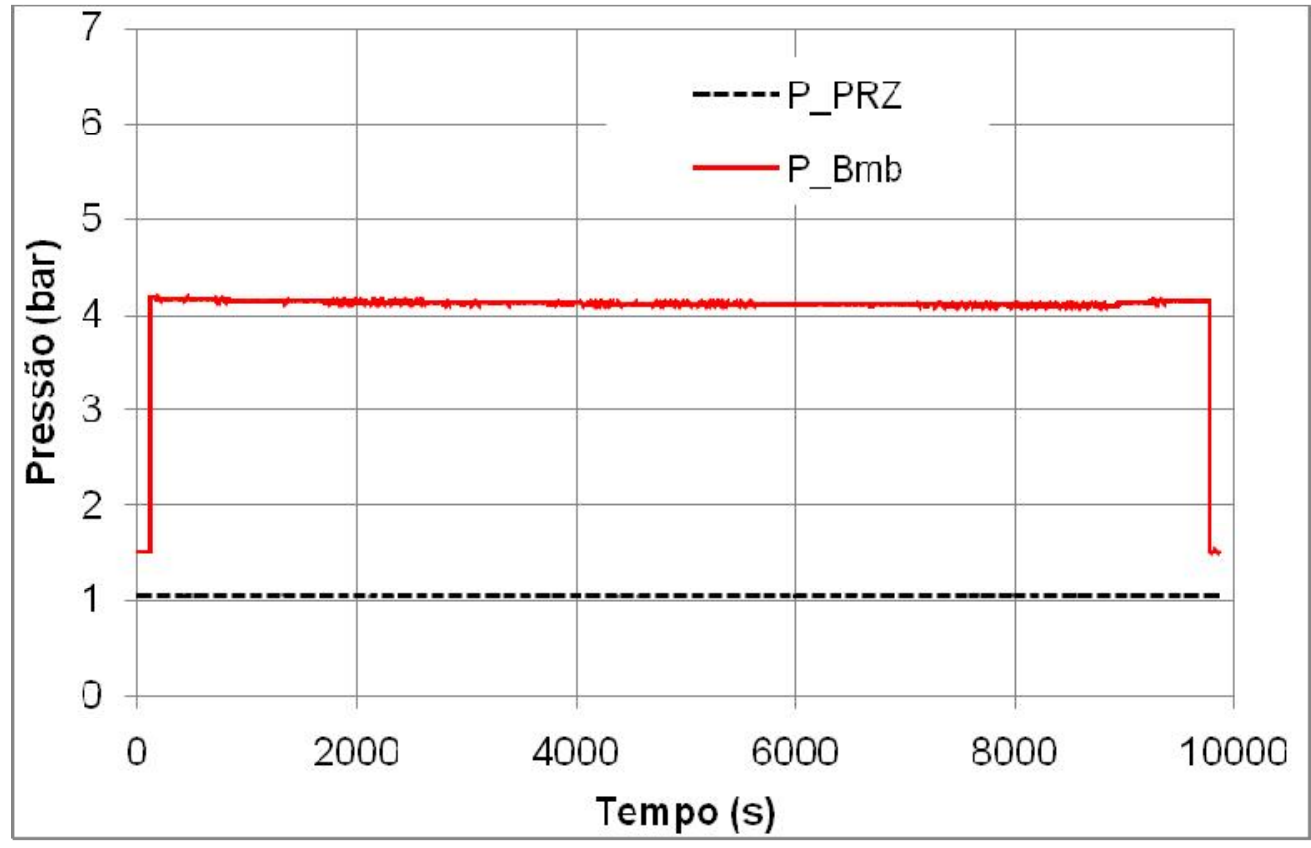

GRÁFICO 118 Pressão no pressurizador e no recalque da bomba - Exp11 Fonte: dados experimentais da pesquisa

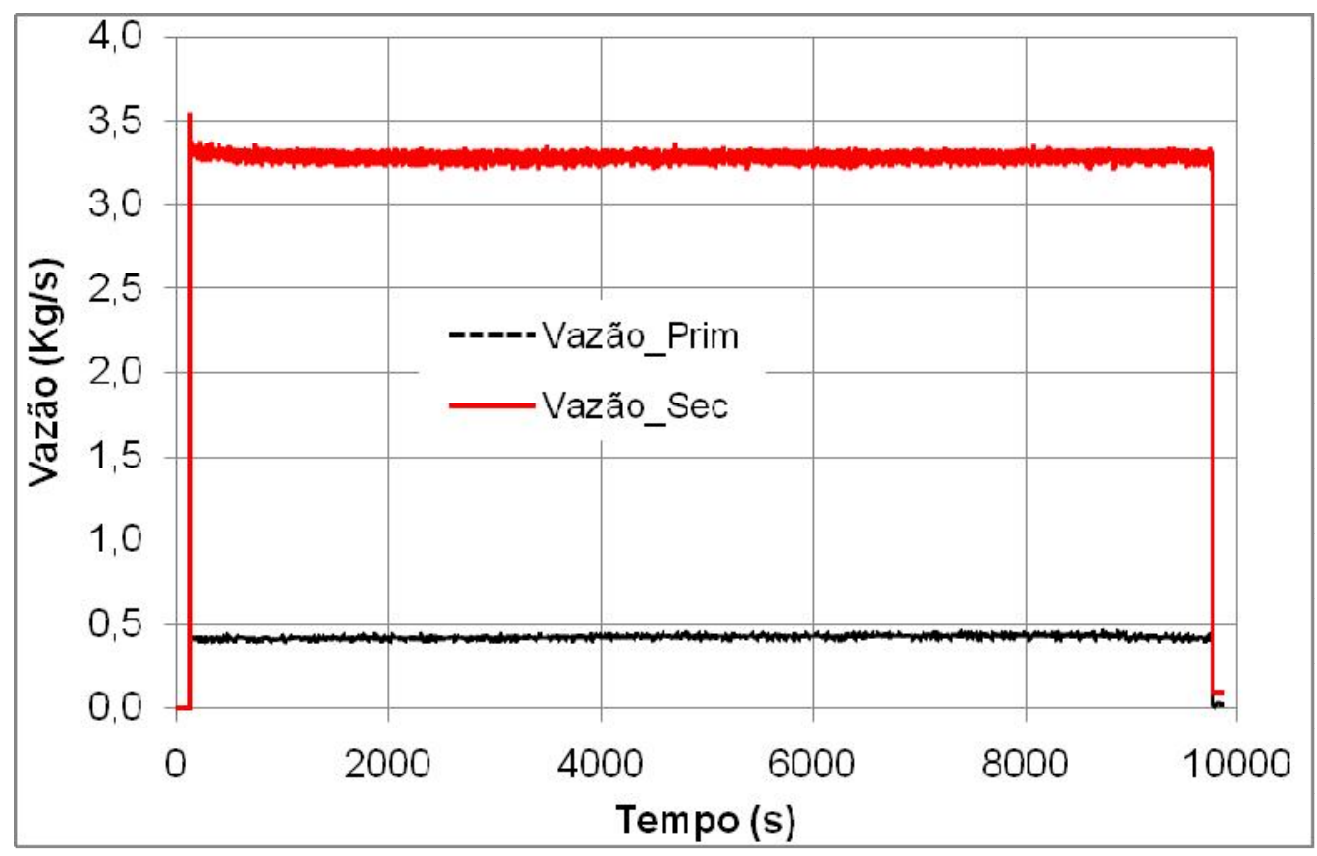

GRÁFICO 119 Vazão no primário e no secundário - Exp11

Fonte: dados experimentais da pesquisa 
EXPERIMENTO 12

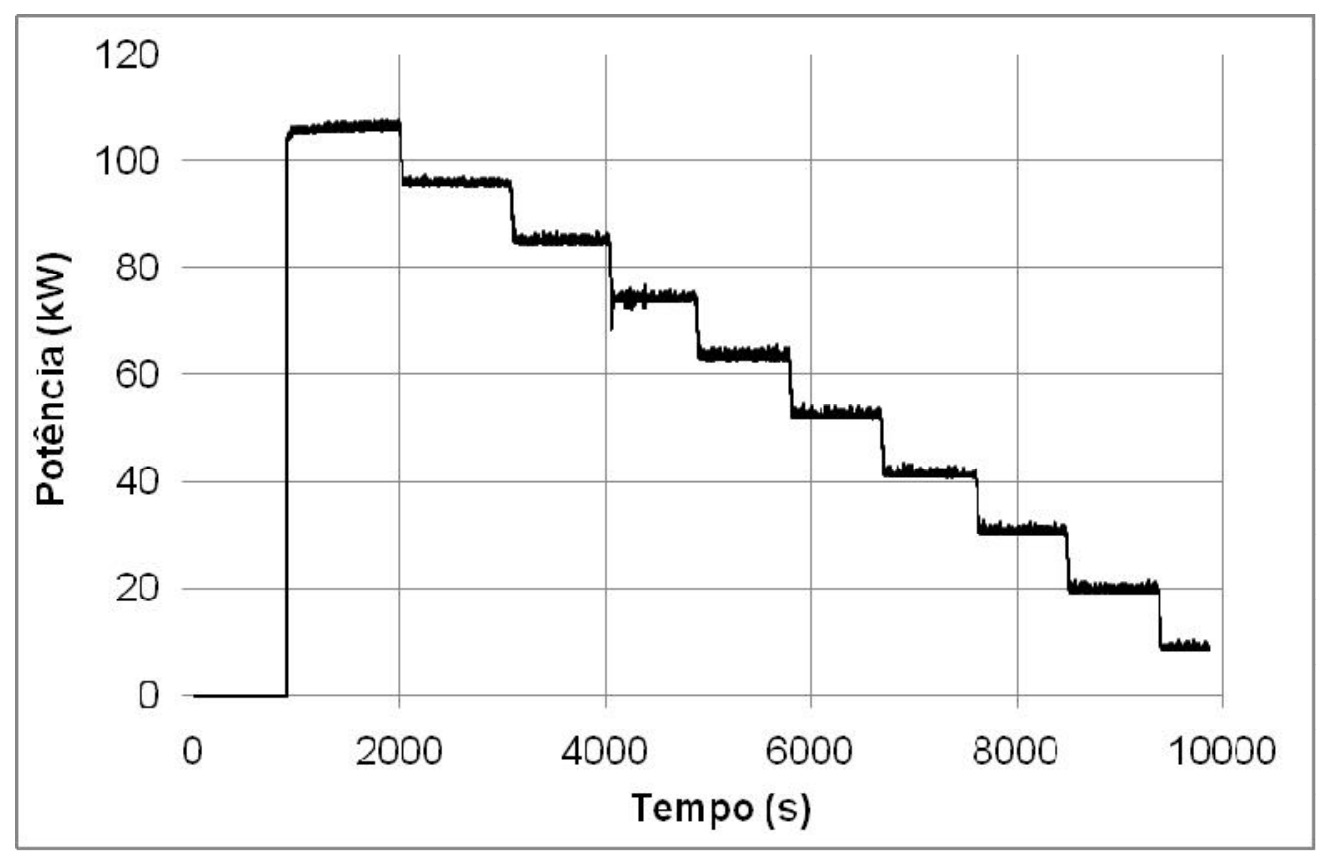

GRÁFICO 120 Potência na seção de testes - Exp12

Fonte: dados experimentais da pesquisa

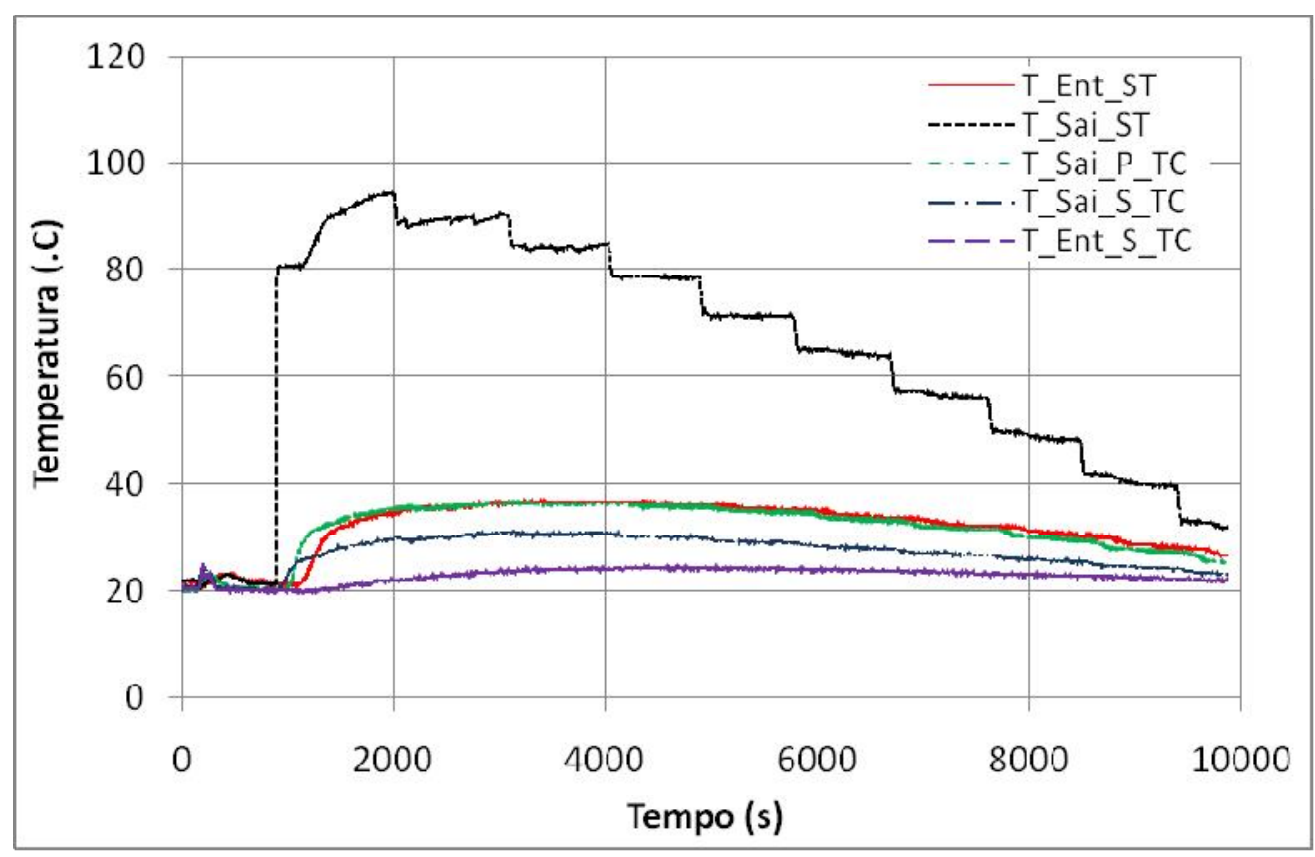

GRÁFICO 121 Temperaturas no CT1 - Exp12

Fonte: dados experimentais da pesquisa 
EXPERIMENTO 13

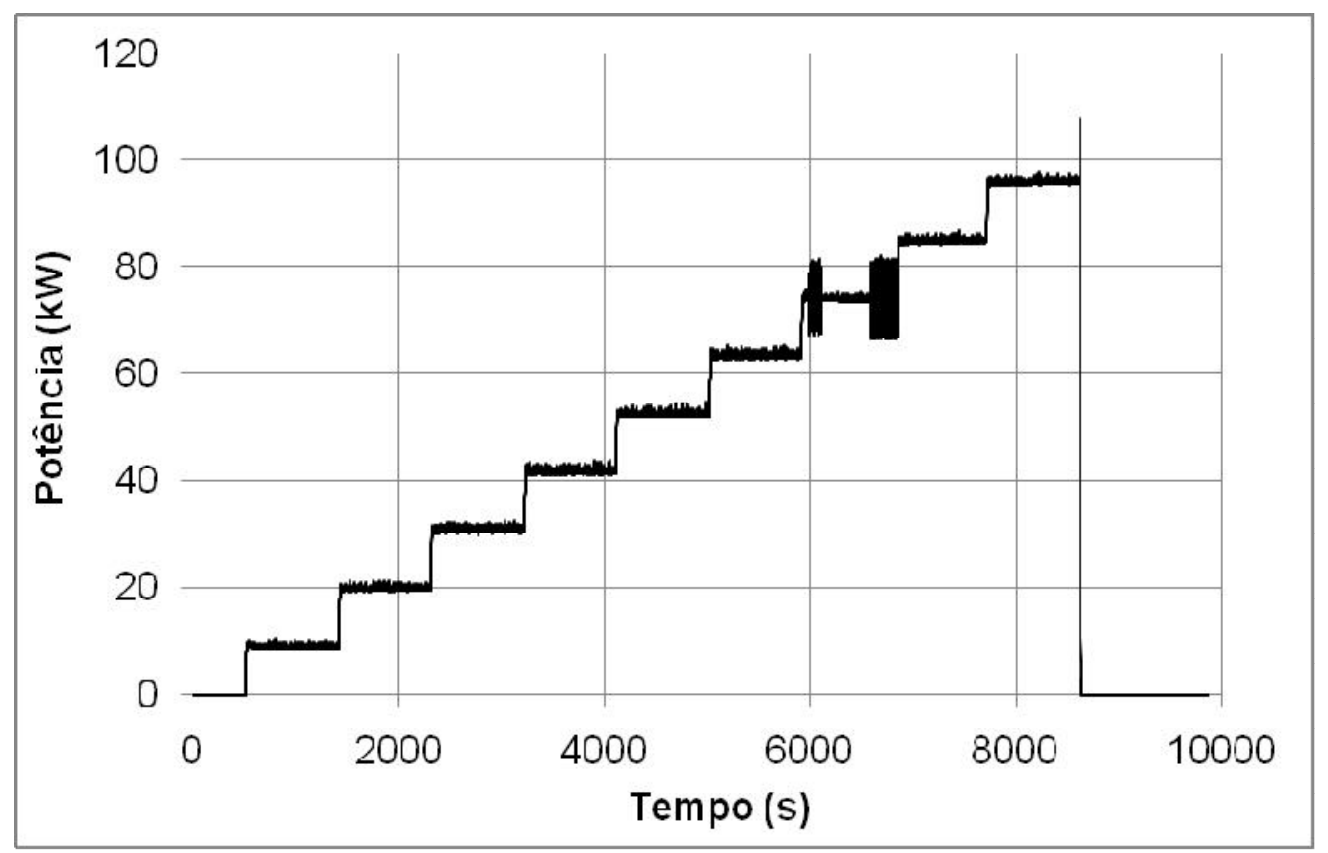

GRÁFICO 122 Potência na seção de testes - Exp 13

Fonte: dados experimentais da pesquisa

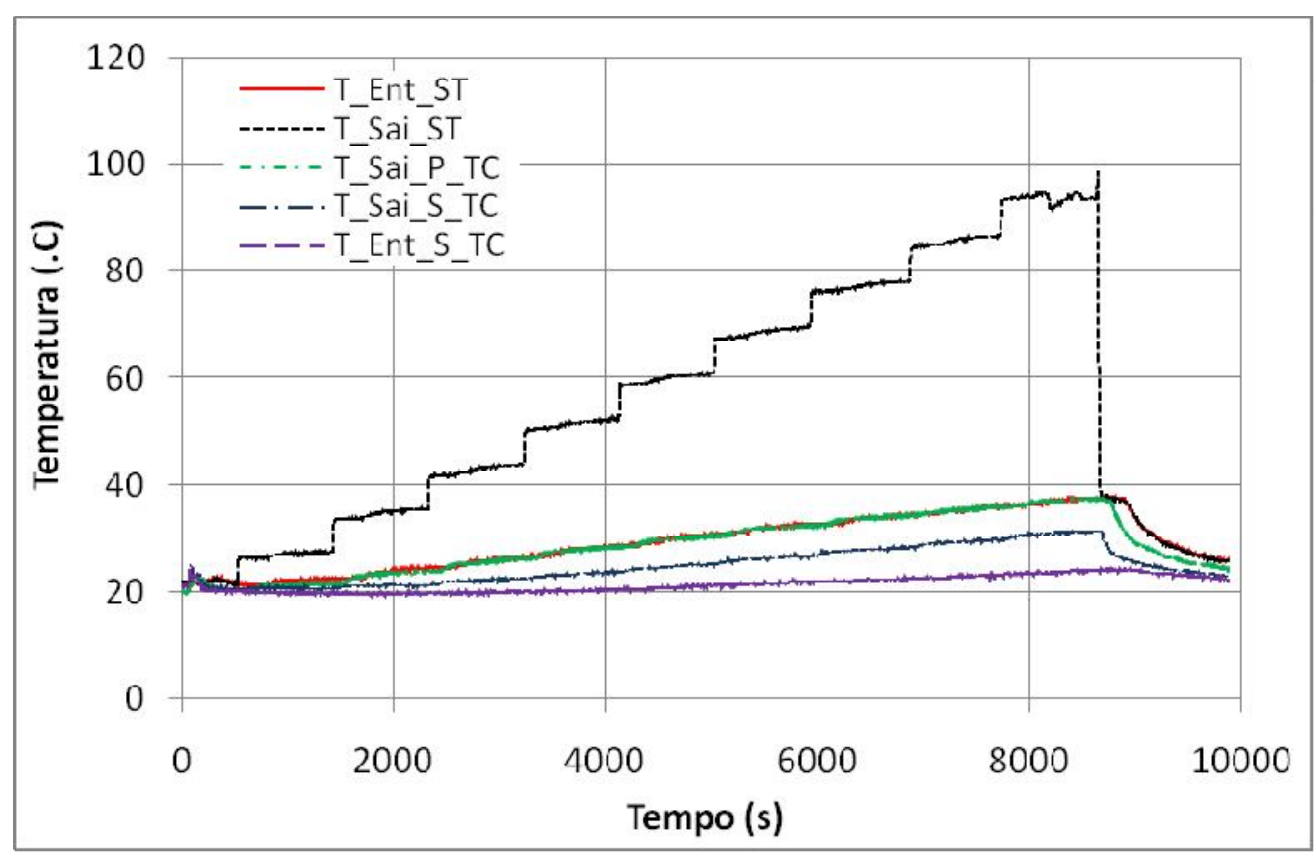

GRÁFICO 123 Temperaturas no CT1 - Exp13

Fonte: dados experimentais da pesquisa 


\section{EXPERIMENTO 14}

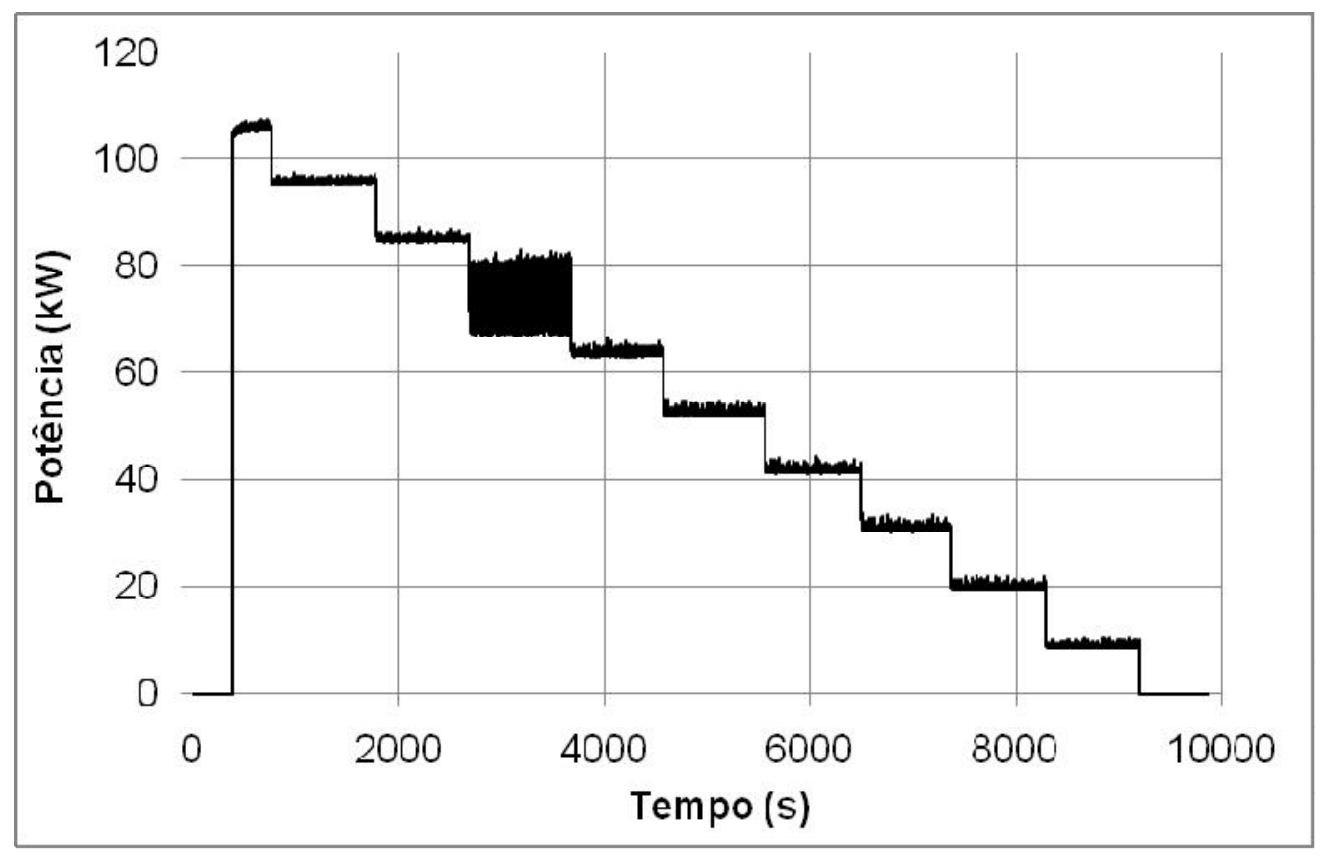

GRÁFICO 124 Potência na seção de testes - Exp14

Fonte: dados experimentais da pesquisa

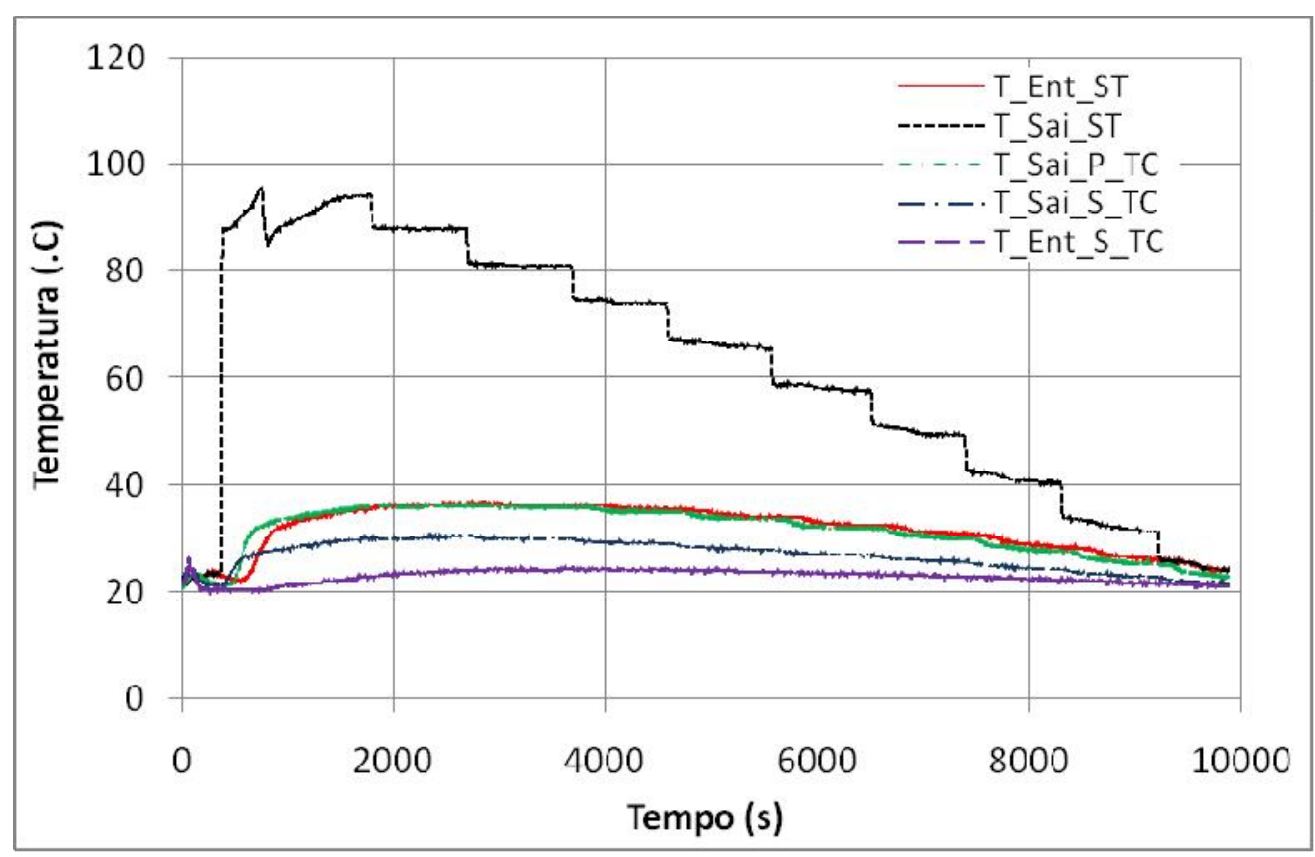

GRÁFICO 125 Temperaturas no CT1 - Exp14

Fonte: dados experimentais da pesquisa 


\section{EXPERIMENTO 15}

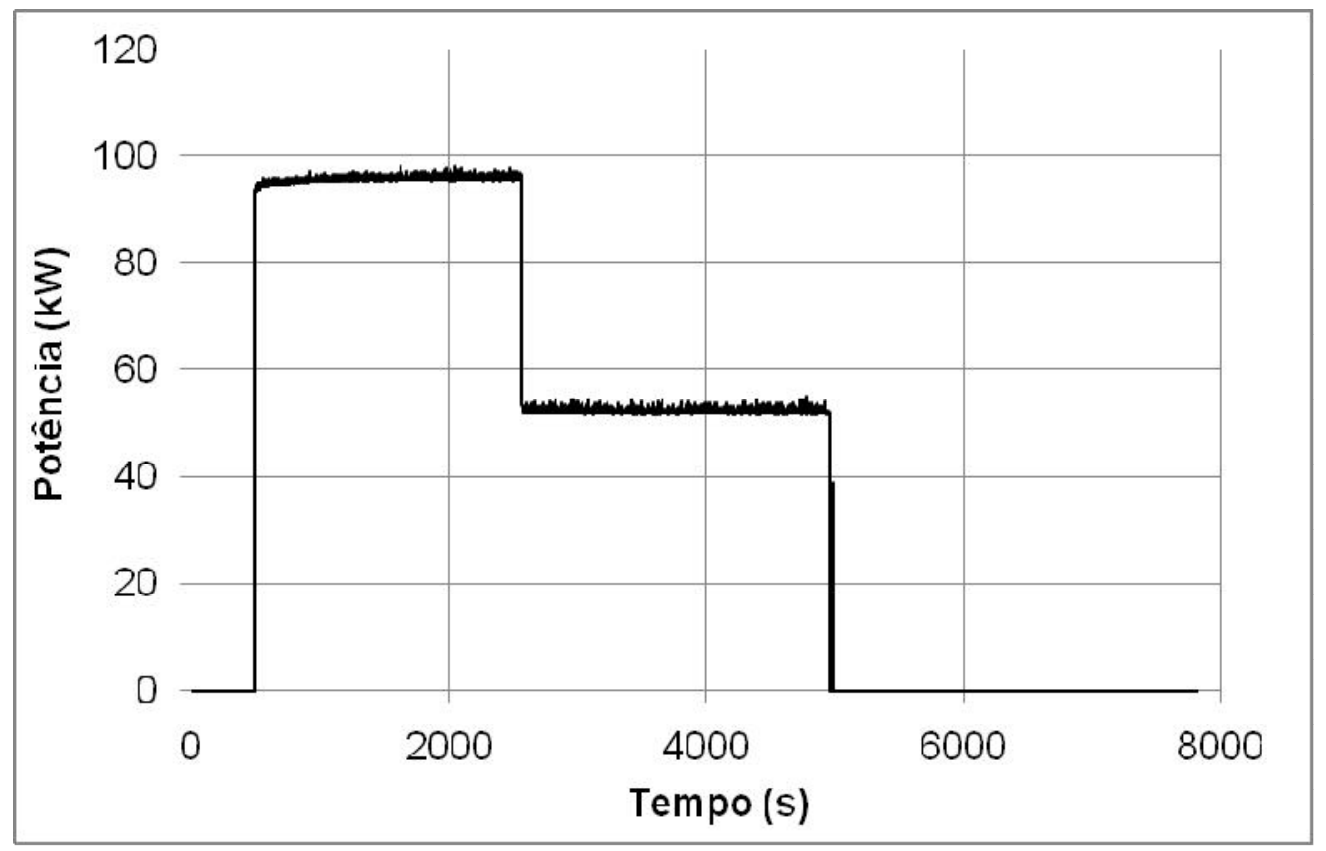

GRÁFICO 126 Potência na seção de testes - Exp 15

Fonte: dados experimentais da pesquisa

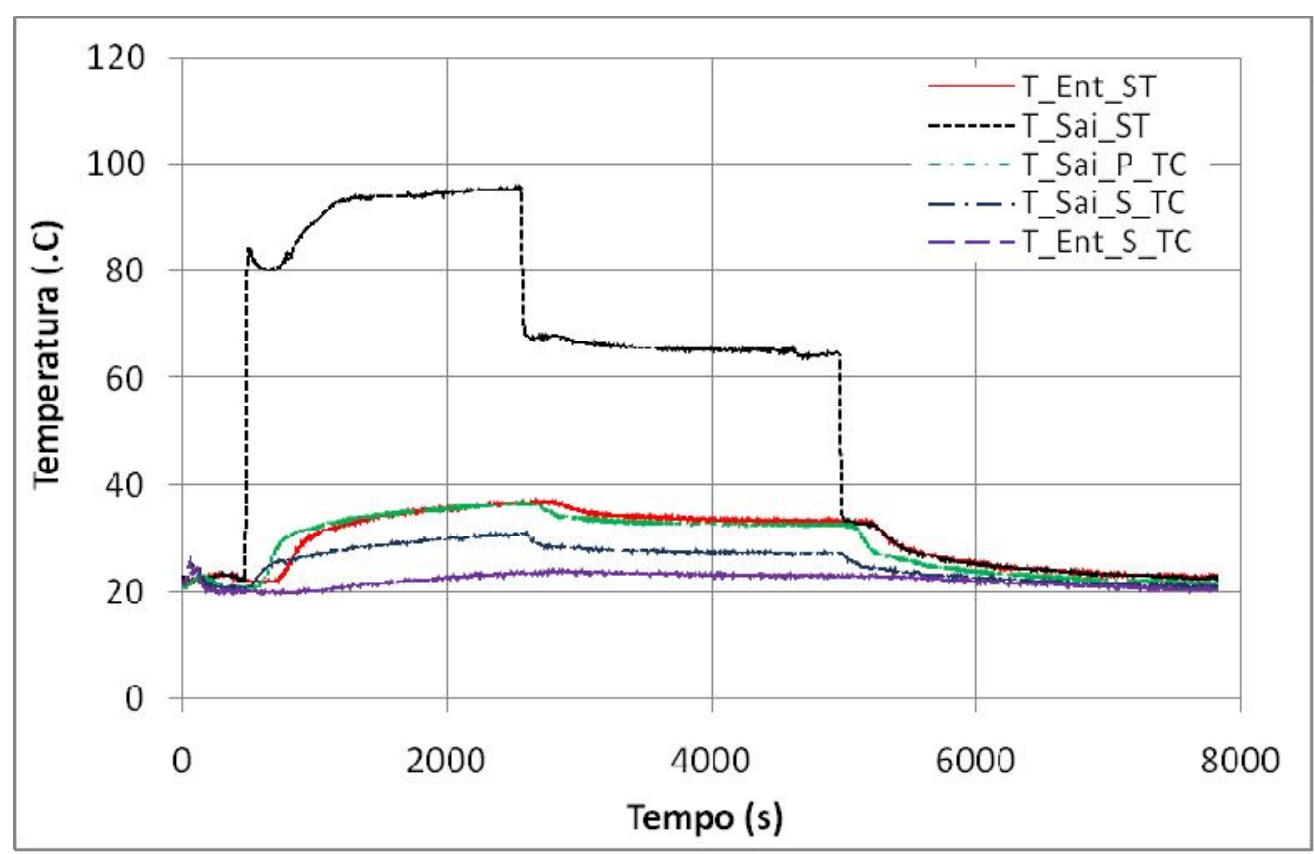

GRÁFICO 127 Temperaturas no CT1 - Exp15

Fonte: dados experimentais da pesquisa 


\section{EXPERIMENTO 16}

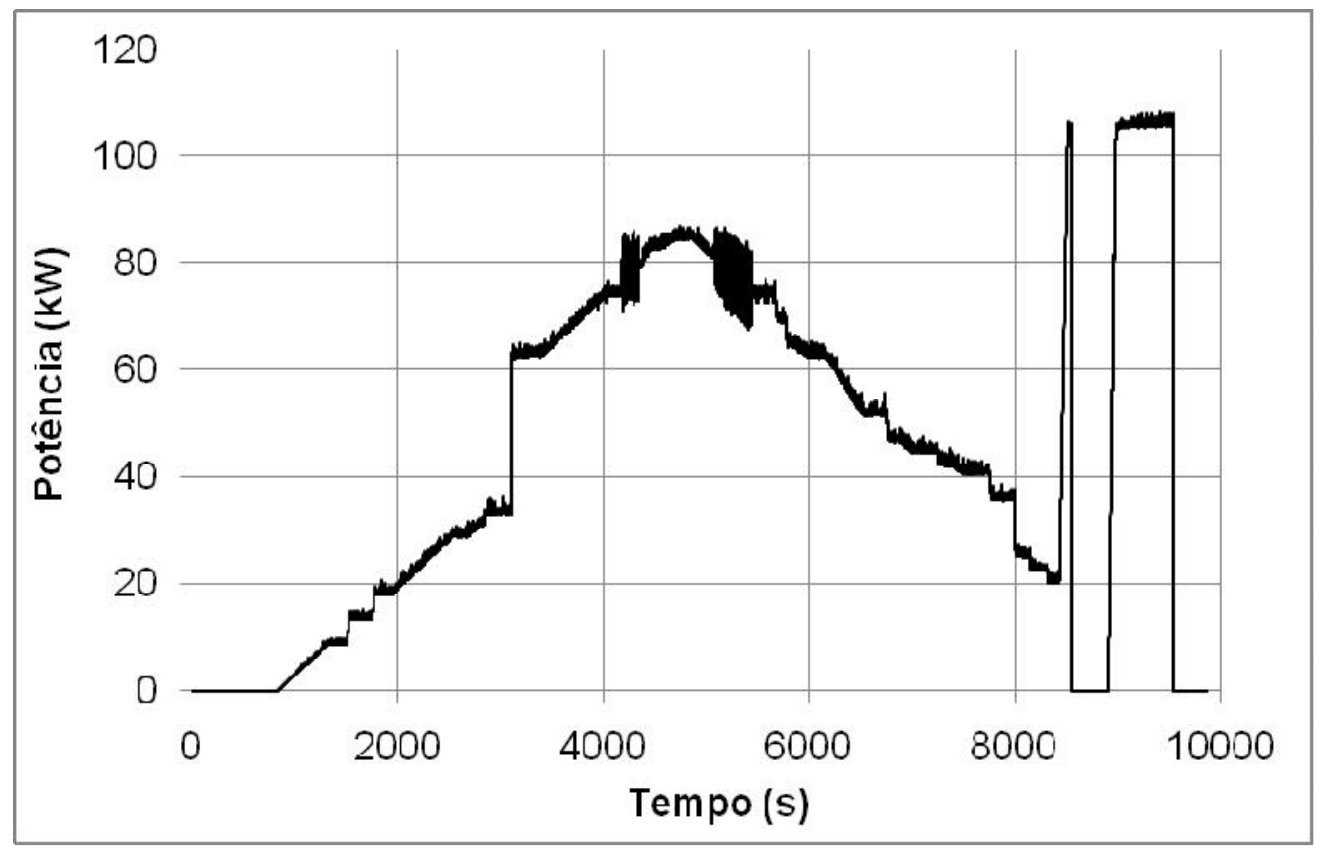

GRÁFICO 128 Potência na seção de testes - Exp 16

Fonte: dados experimentais da pesquisa

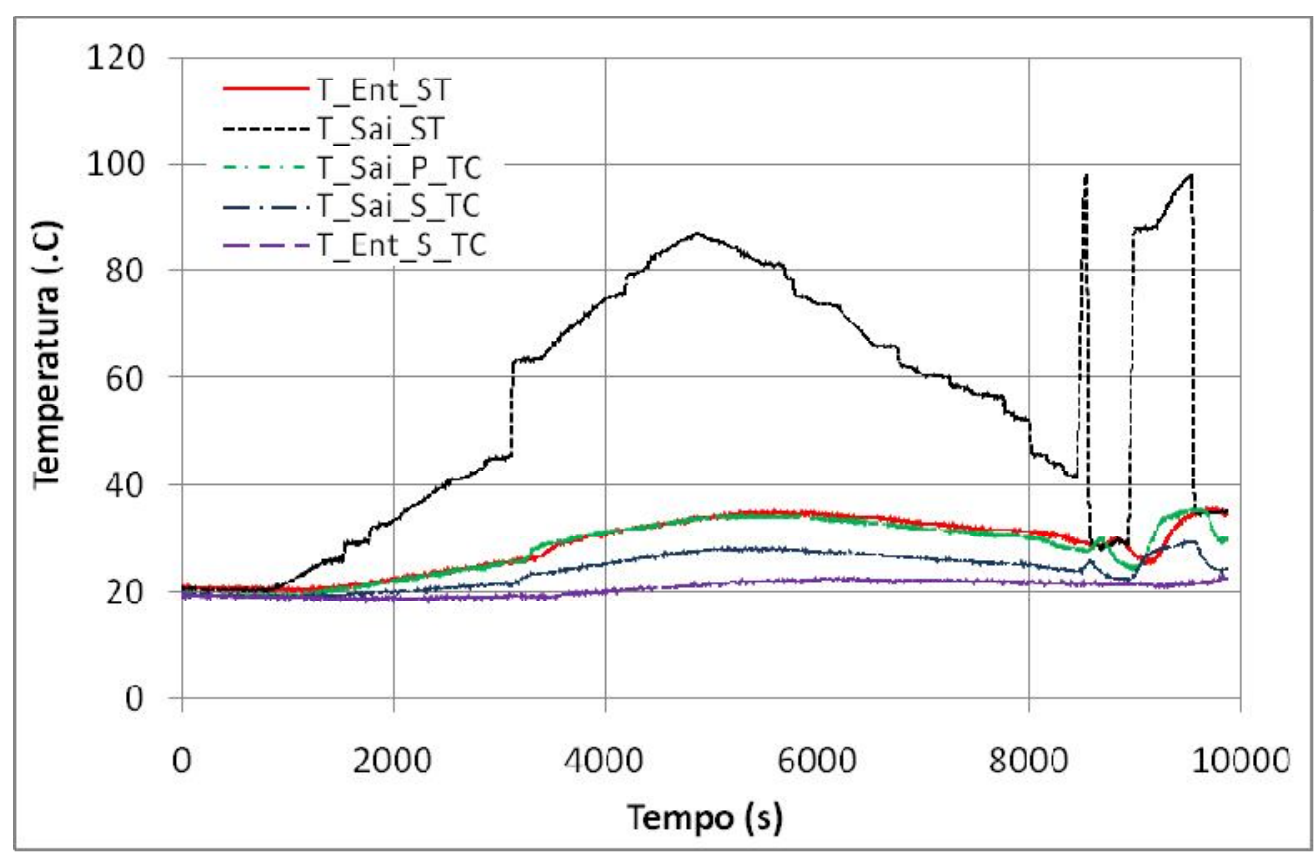

GRÁFICO 129 Temperaturas no CT1 - Exp16

Fonte: dados experimentais da pesquisa 


\section{EXPERIMENTO 17}

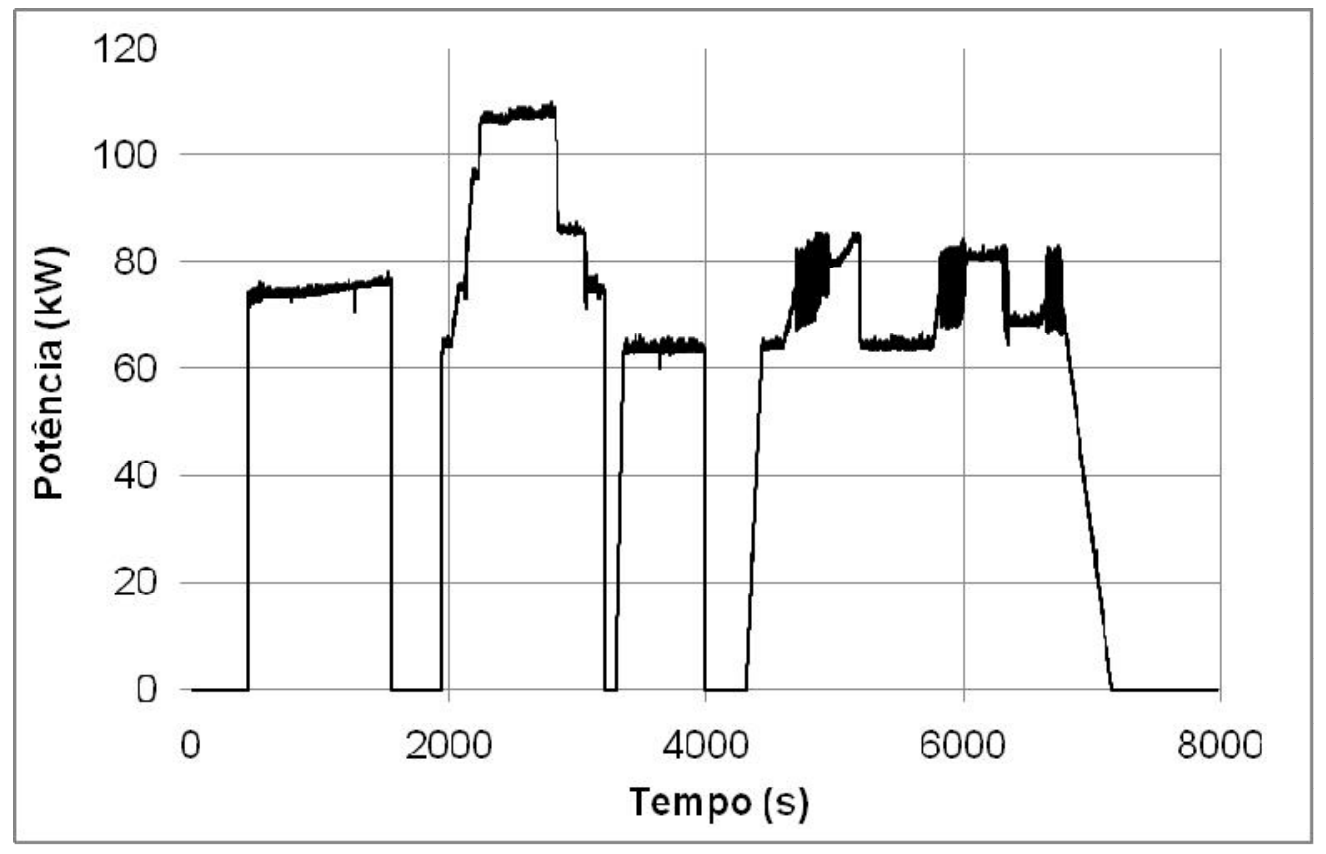

GRÁFICO 130 Potência na seção de testes - Exp17

Fonte: dados experimentais da pesquisa

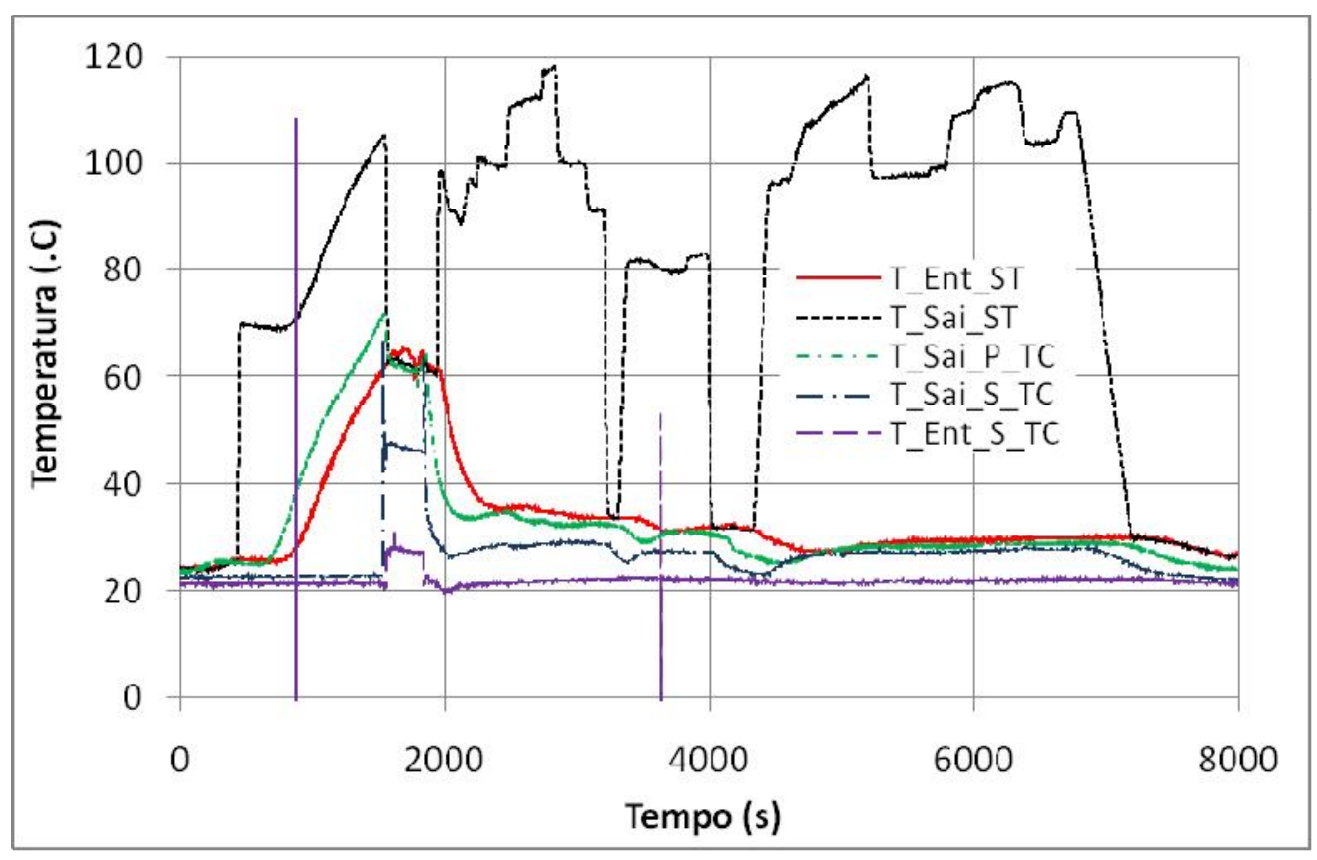

GRÁFICO 131 Temperaturas no CT1 - Exp17

Fonte: dados experimentais da pesquisa 


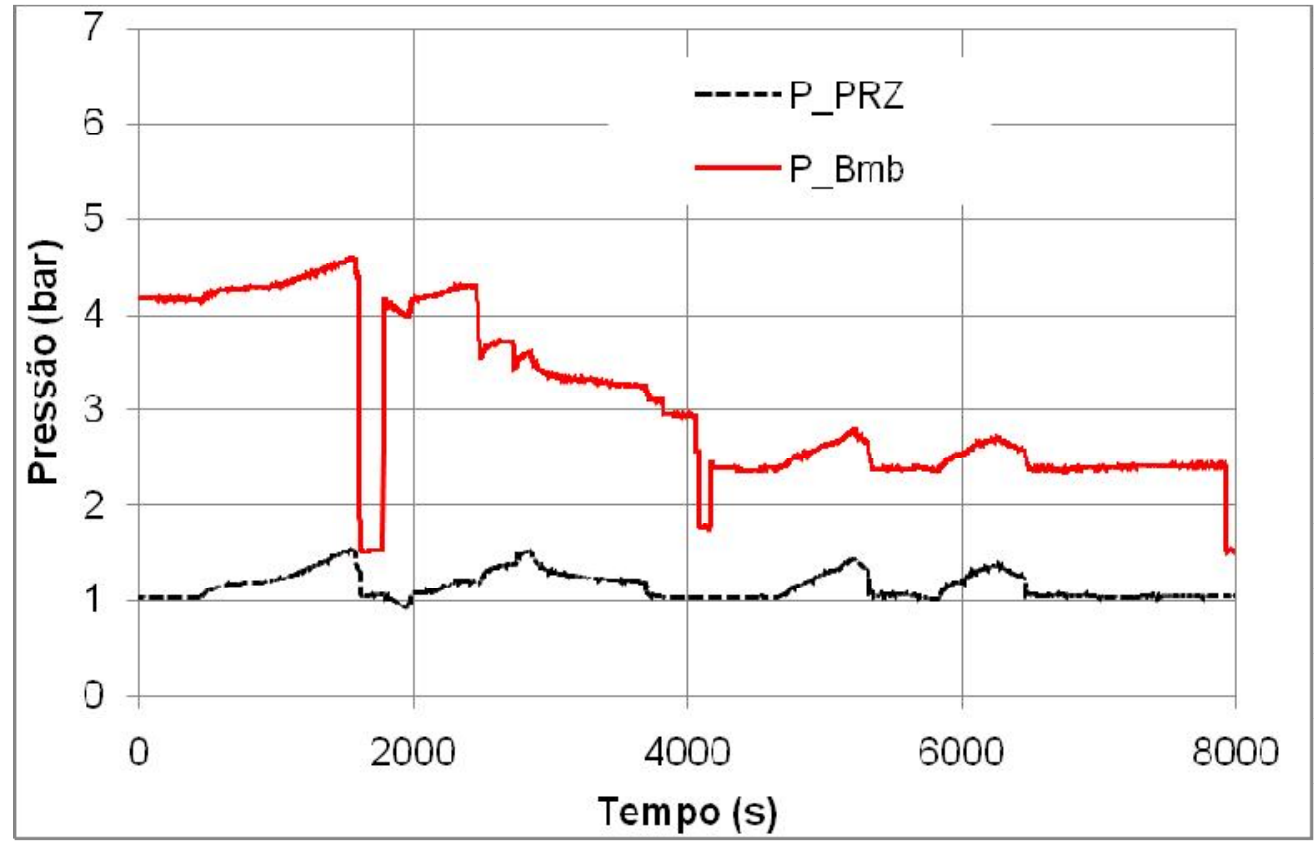

GRÁFICO 132 Pressão no pressurizador e no recalque da bomba - Exp17 Fonte: dados experimentais da pesquisa

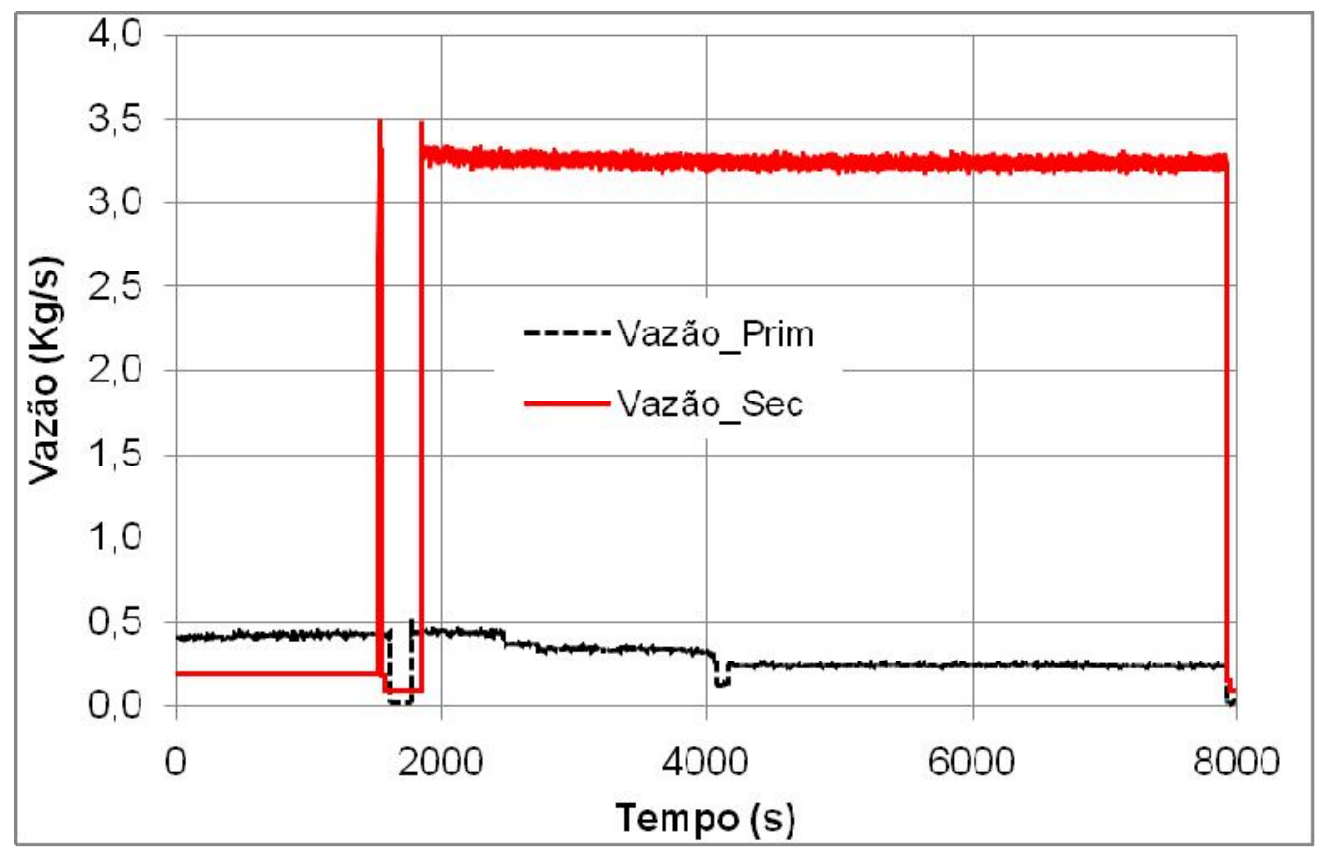

GRÁFICO 133 Vazão no primário e no secundário - Exp17

Fonte: dados experimentais da pesquisa 


\section{EXPERIMENTO 18}

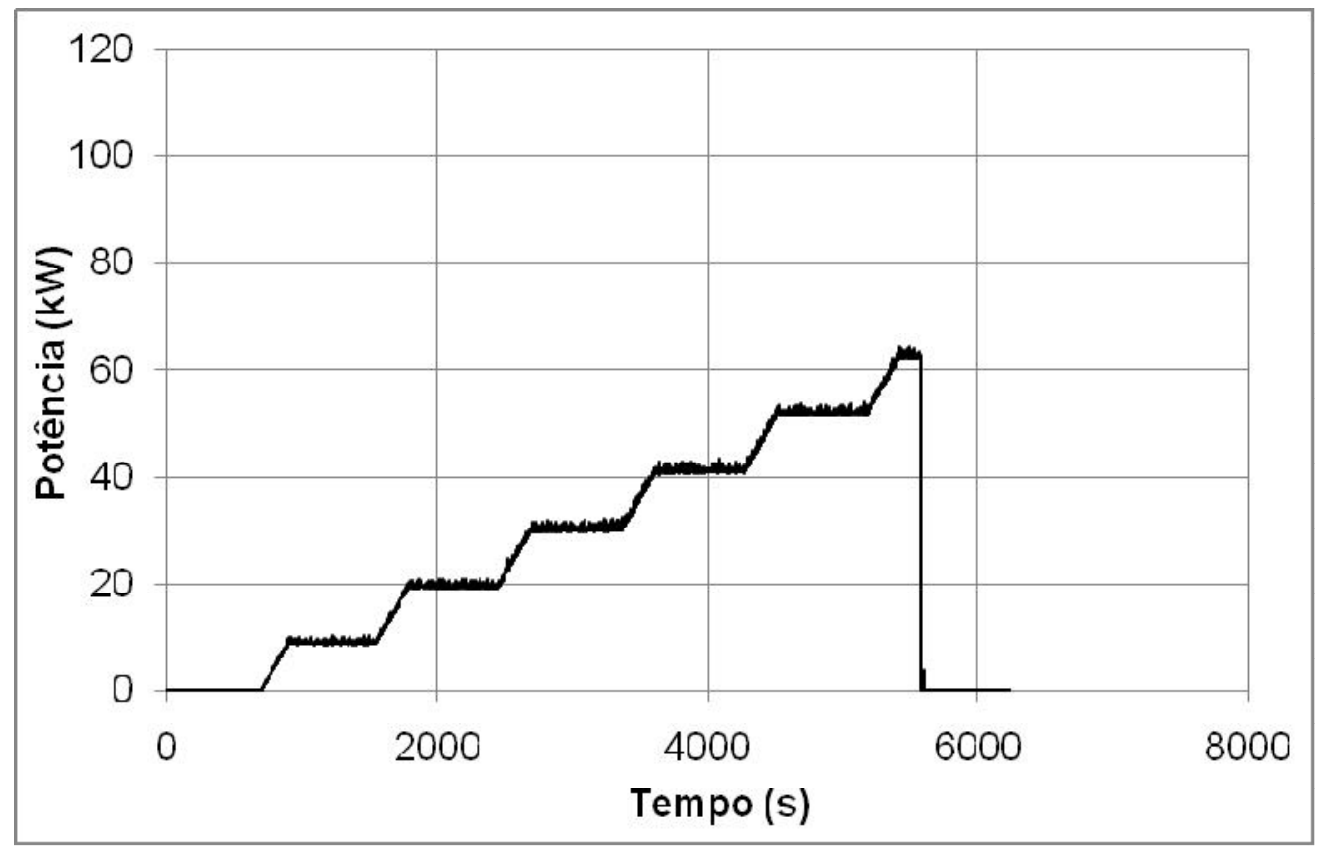

GRÁFICO 134 Potência na seção de testes - Exp 18

Fonte: dados experimentais da pesquisa

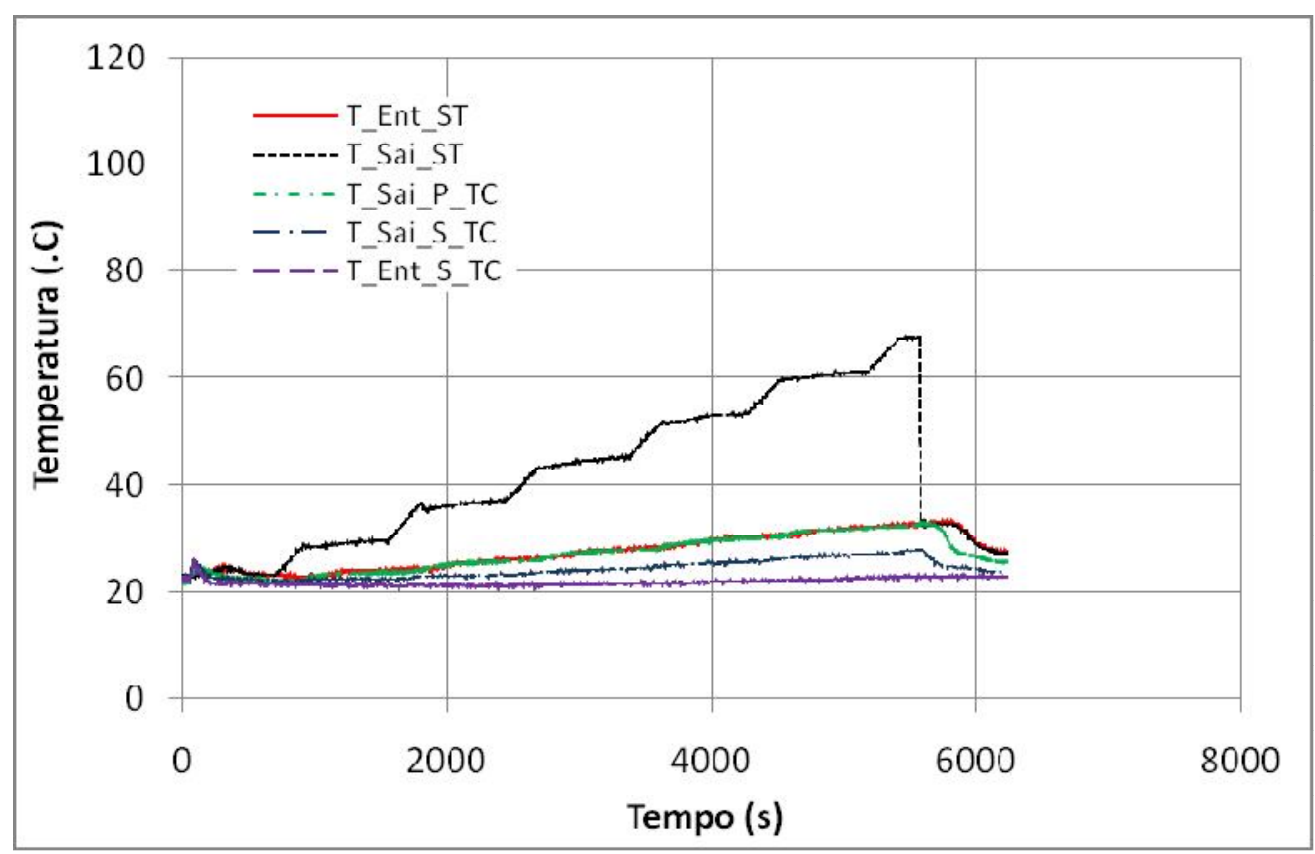

GRÁFICO 135 Temperaturas no CT1 - Exp18

Fonte: dados experimentais da pesquisa 


\section{EXPERIMENTO 19}

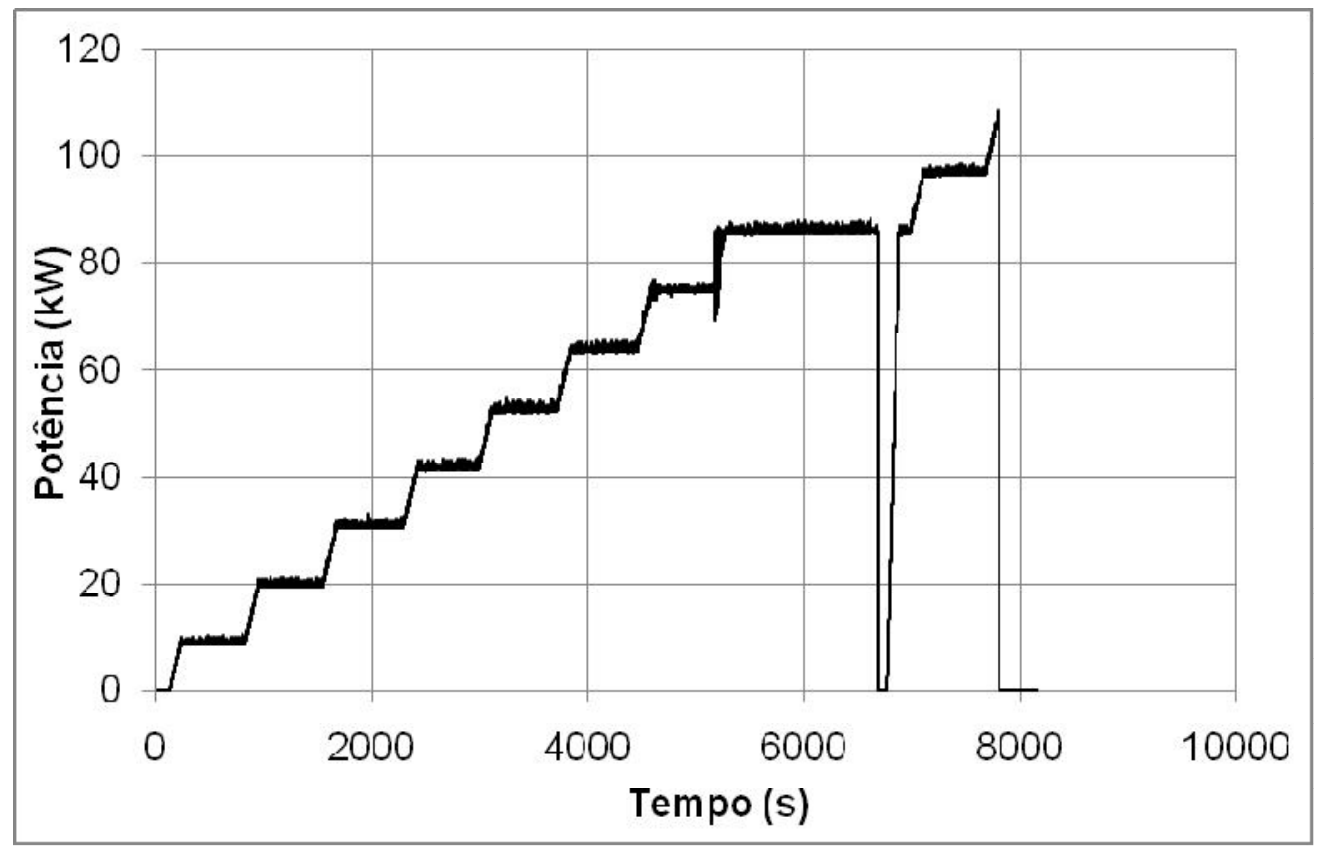

GRÁFICO 136 Potência na seção de testes - Exp 19

Fonte: dados experimentais da pesquisa

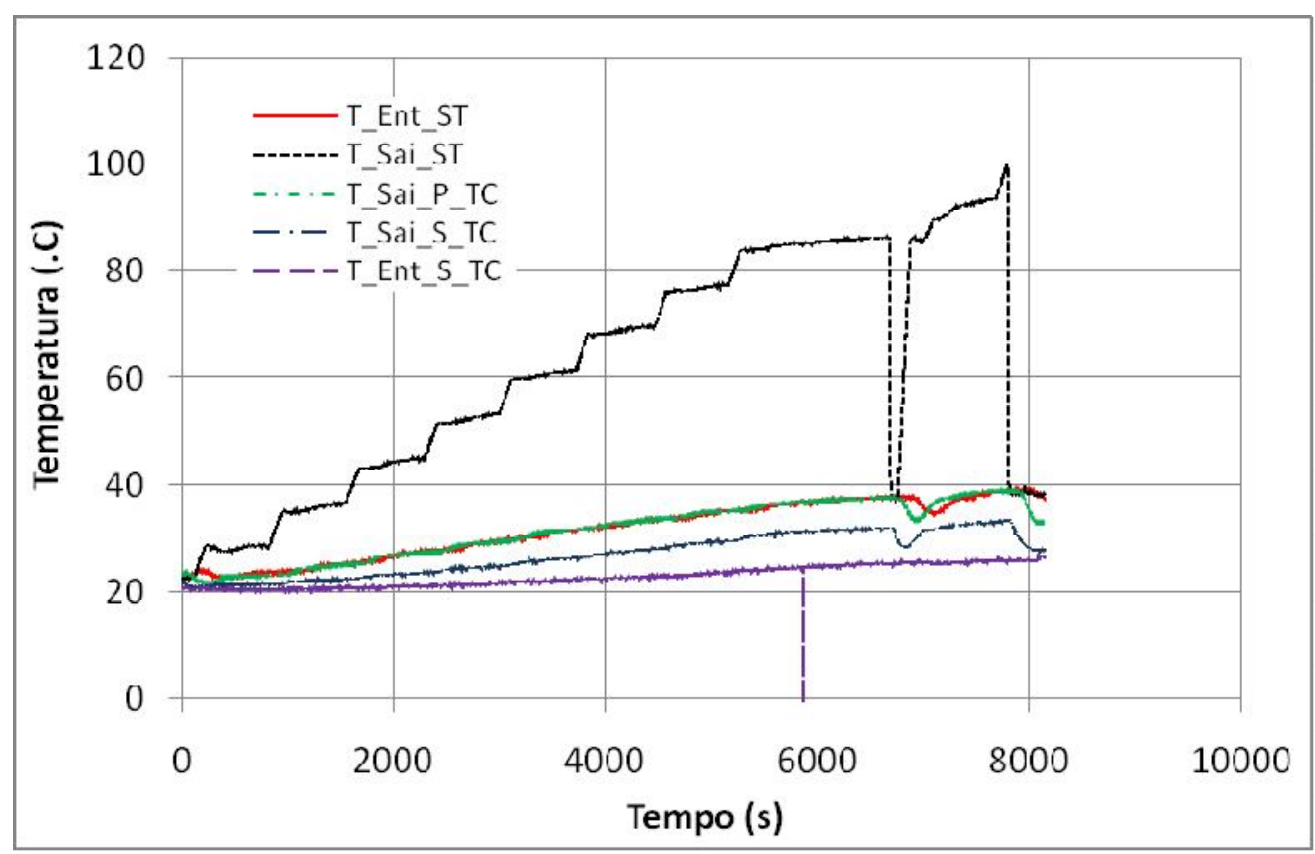

GRÁFICO 137 Temperaturas no CT1 - Exp19

Fonte: dados experimentais da pesquisa 


\section{EXPERIMENTO 20}

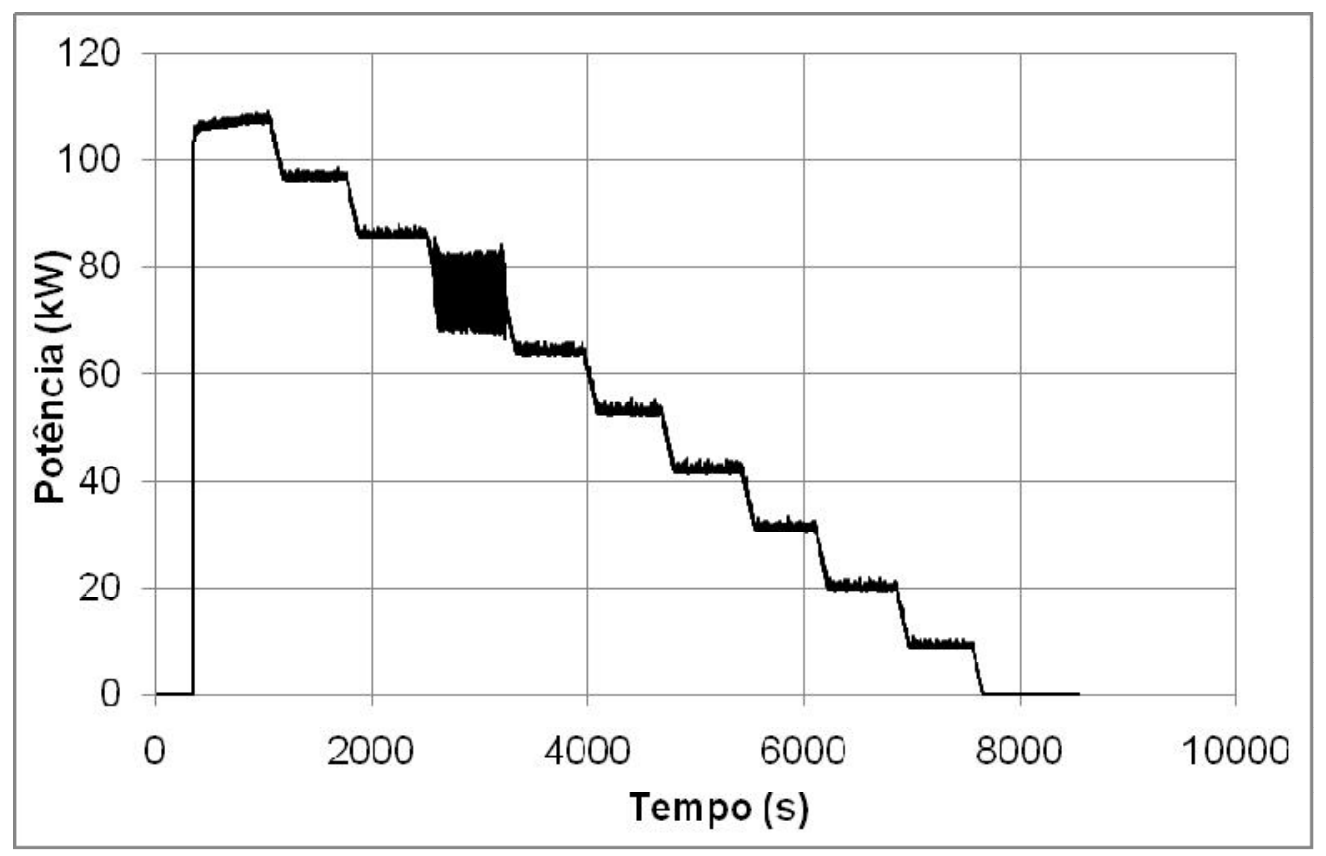

GRÁFICO 138 Potência na seção de testes - Exp20

Fonte: dados experimentais da pesquisa

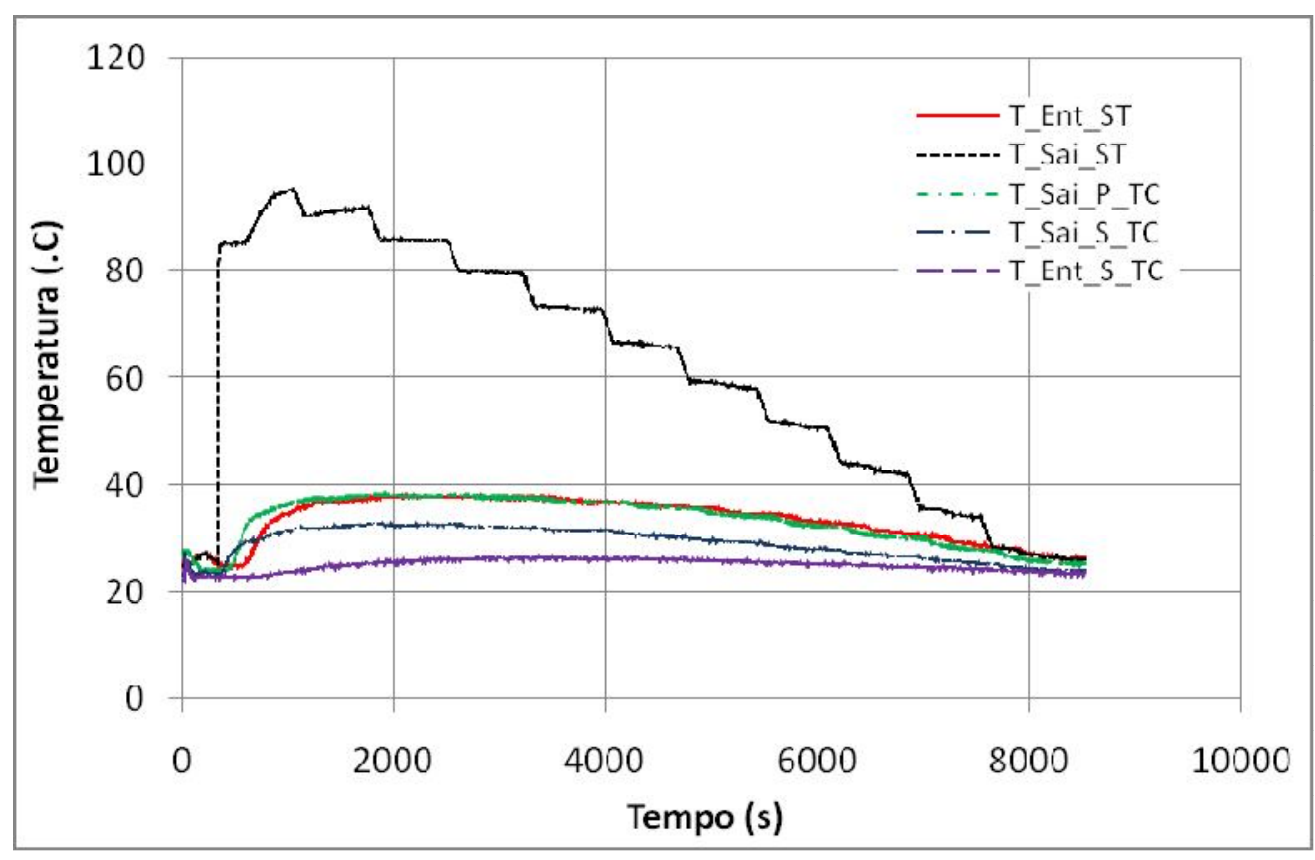

GRÁFICO 139 Temperaturas no CT1 - Exp20

Fonte: dados experimentais da pesquisa 


\section{EXPERIMENTO 21}

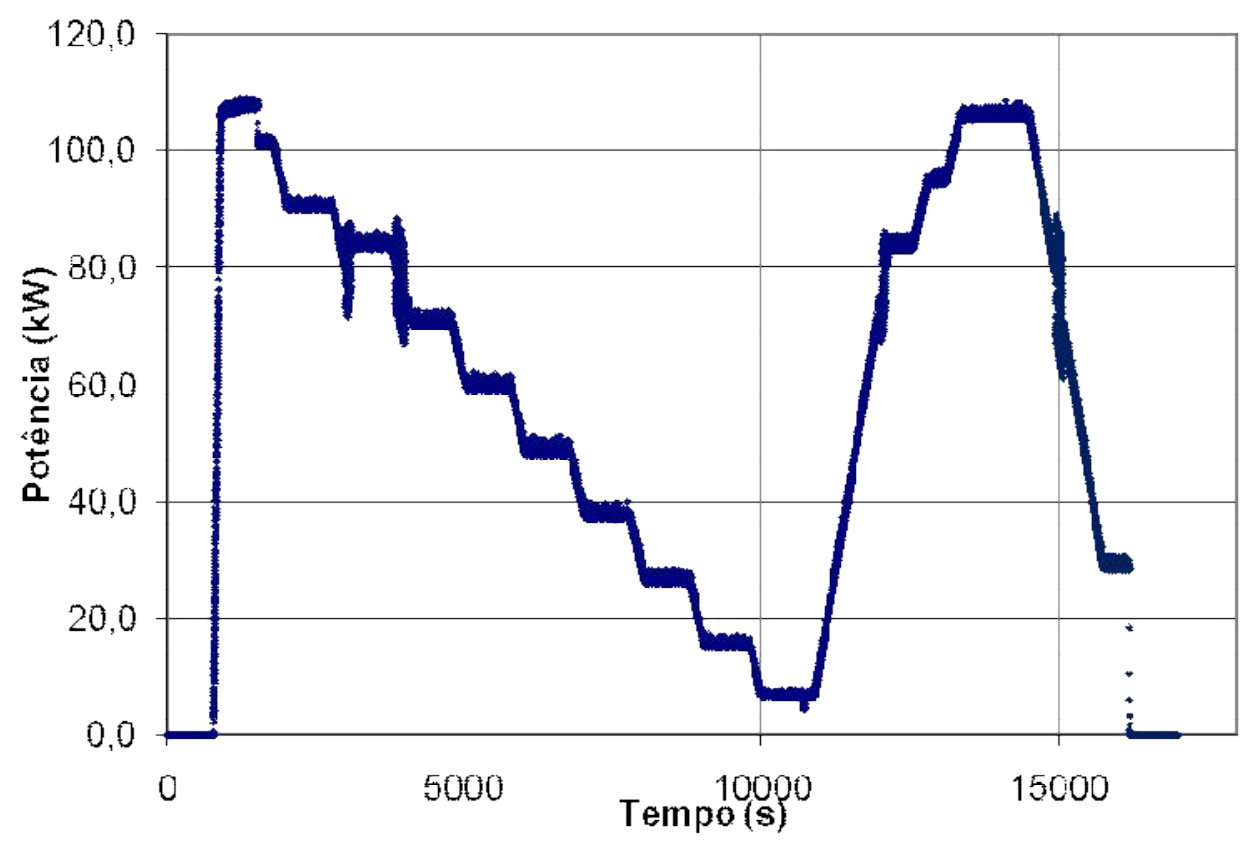

GRÁFICO 140 Potência na seção de testes - Exp21

Fonte: dados experimentais da pesquisa

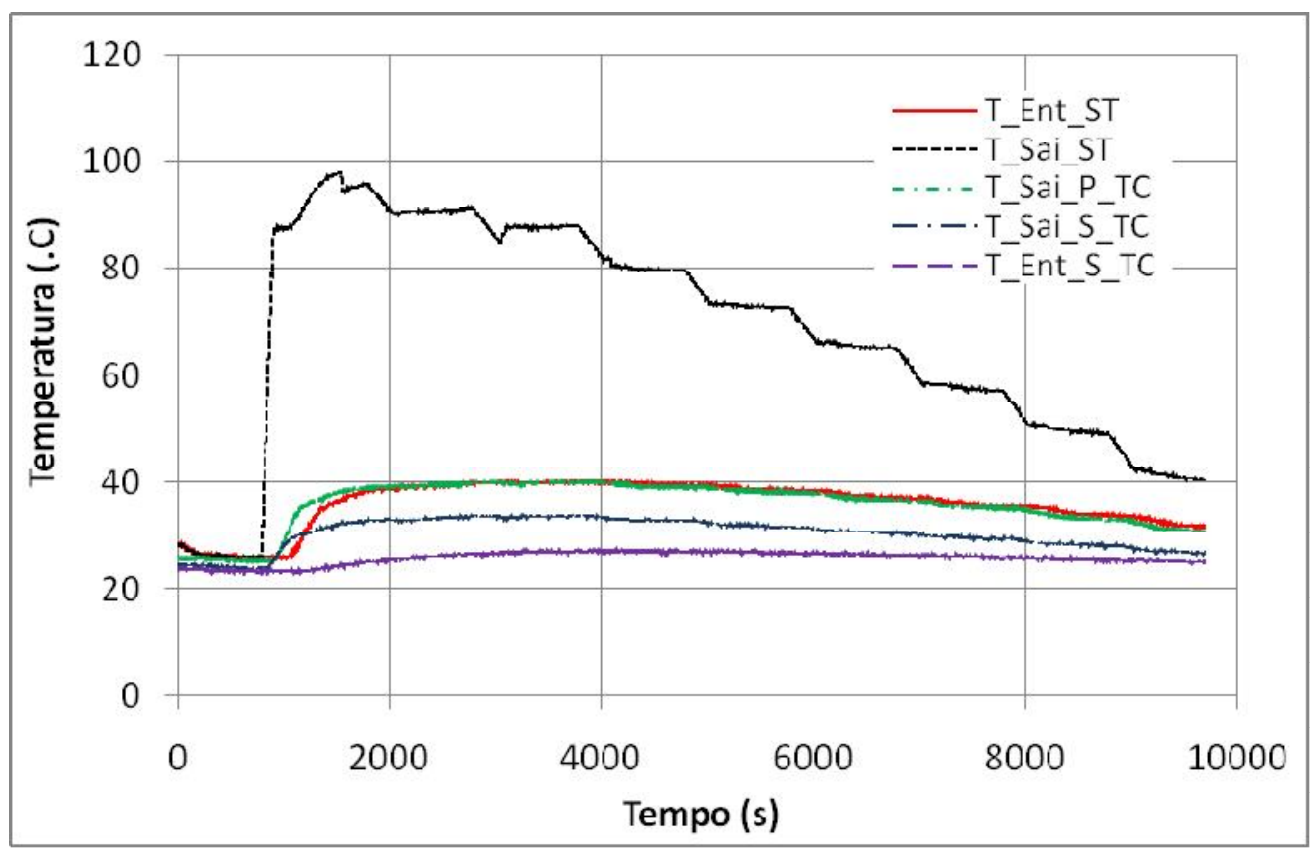

GRÁFICO 141 Temperaturas, até 10000 s, no CT1 - Exp21

Fonte: dados experimentais da pesquisa 


\section{EXPERIMENTO 22}

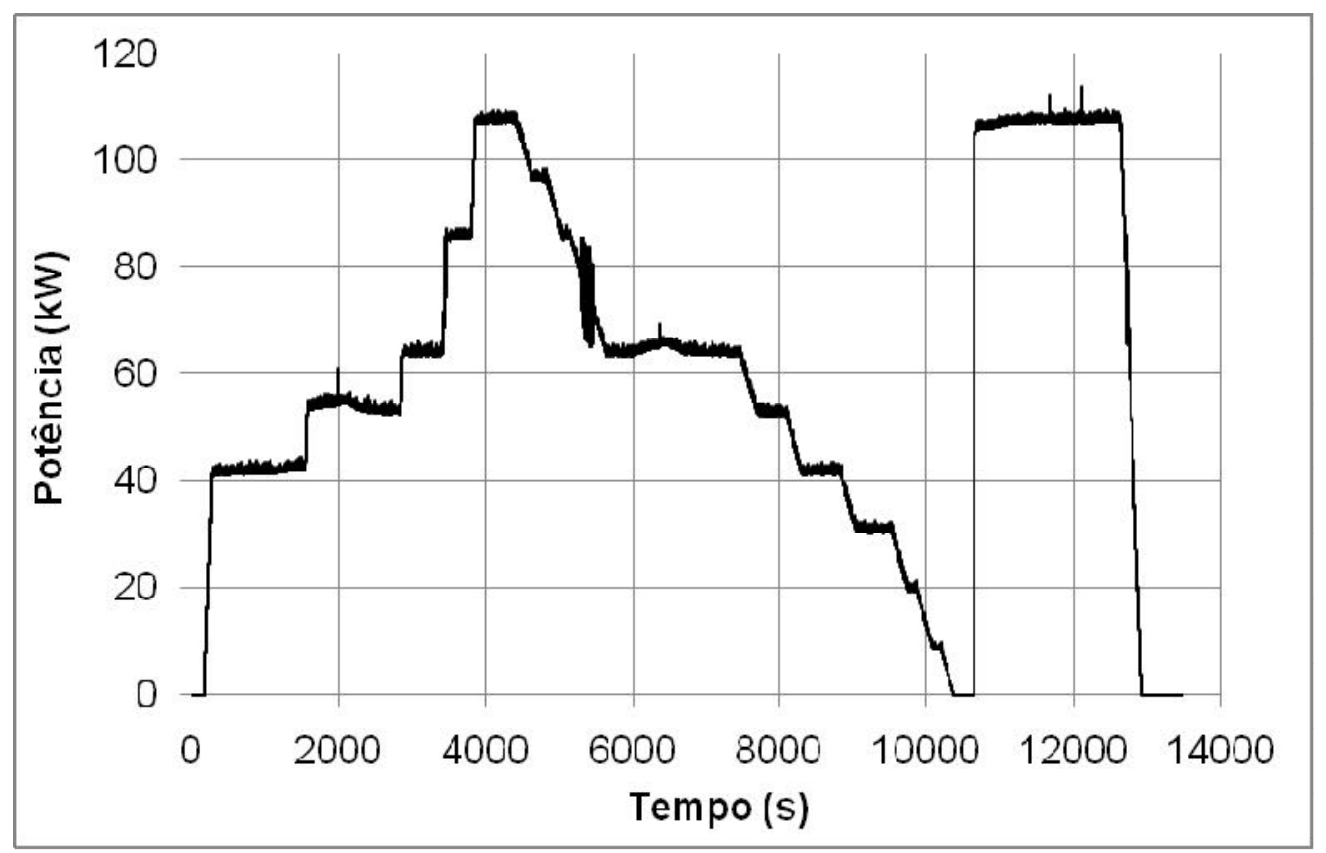

GRÁFICO 142 Potência na seção de testes - Exp22

Fonte: dados experimentais da pesquisa

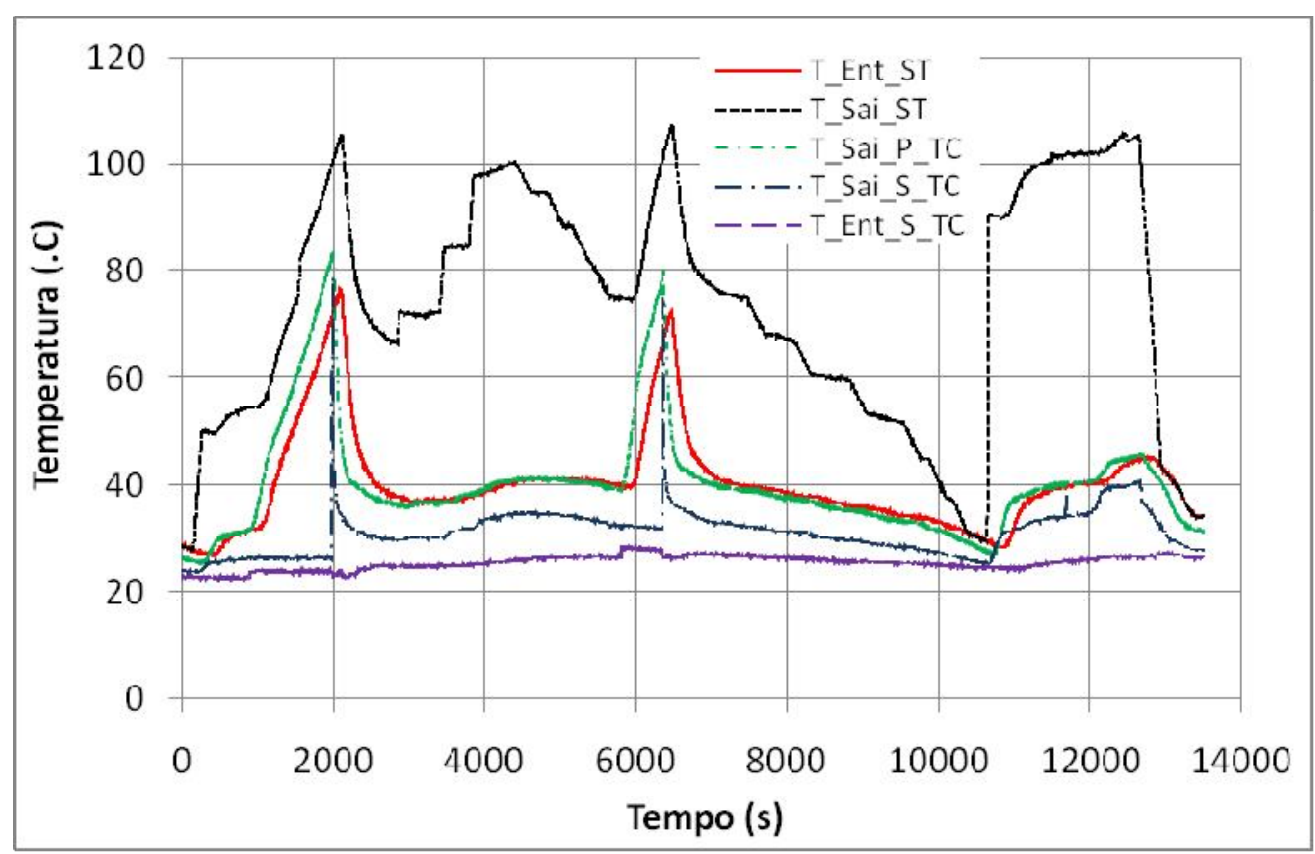

GRÁFICO 143 Temperaturas no CT1 - Exp22

Fonte: dados experimentais da pesquisa 


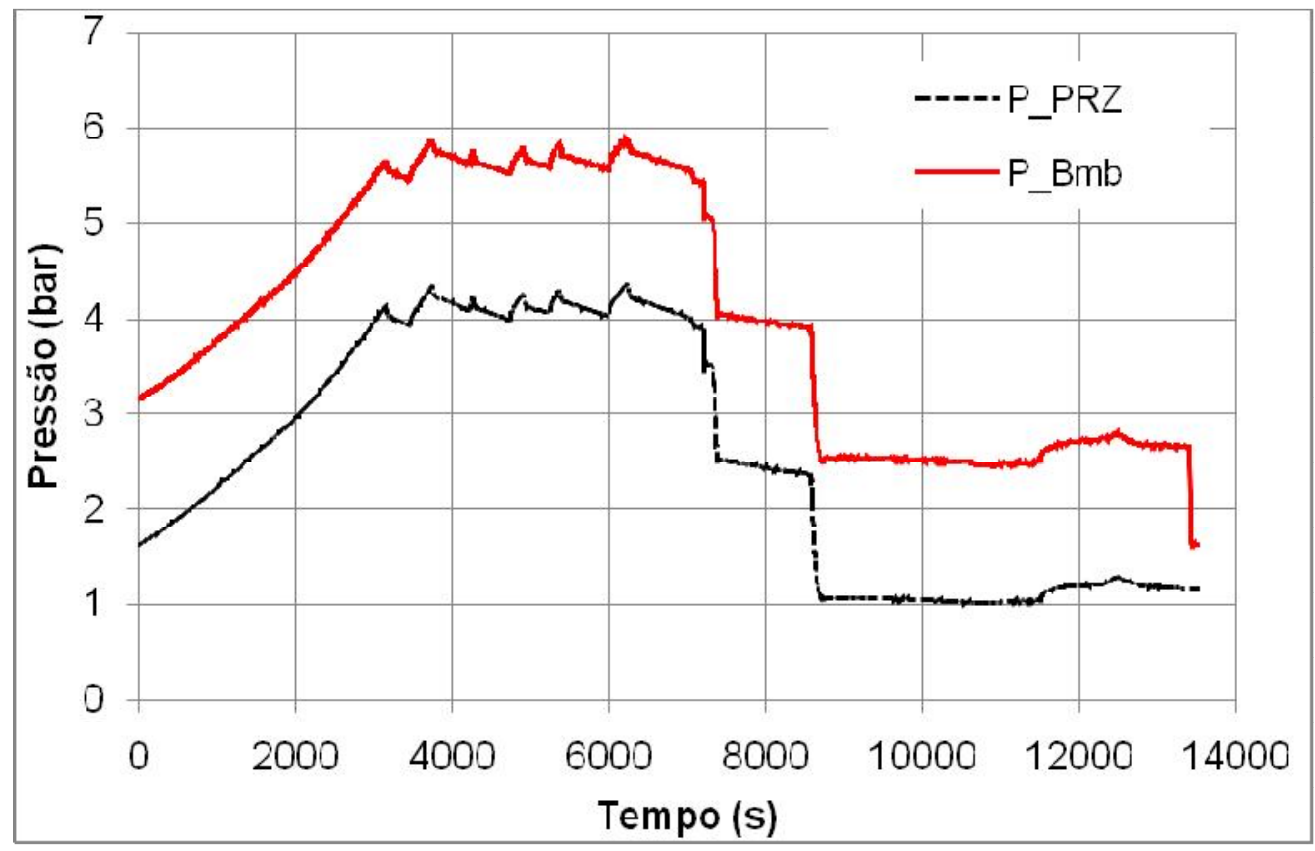

GRÁFICO 144 Pressão no pressurizador e no recalque da bomba - Exp22 Fonte: dados experimentais da pesquisa

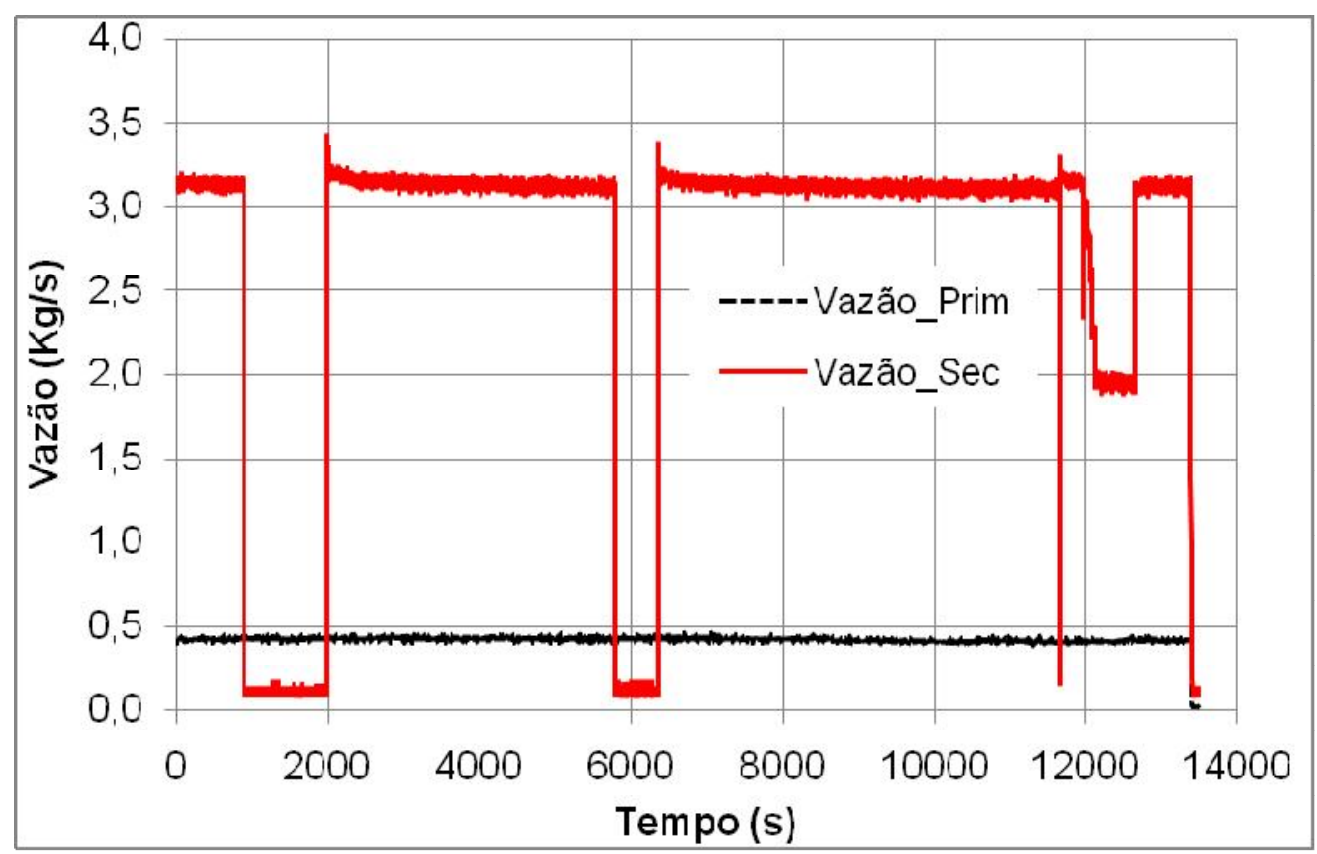

GRÁFICO 145 Vazão no primário e no secundário - Exp22

Fonte: dados experimentais da pesquisa 


\section{EXPERIMENTO 23}

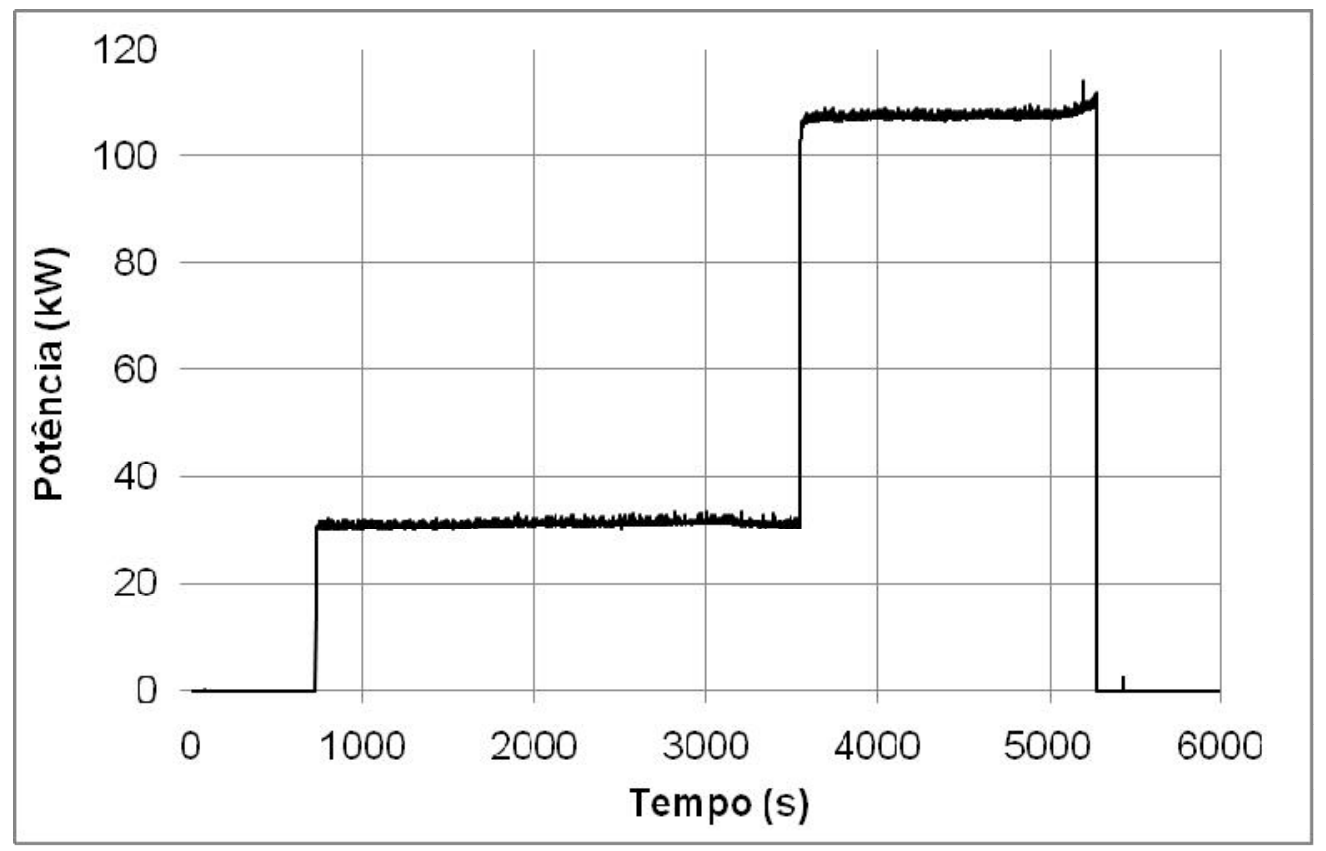

GRÁFICO 146 Potência na seção de testes - Exp23

Fonte: dados experimentais da pesquisa

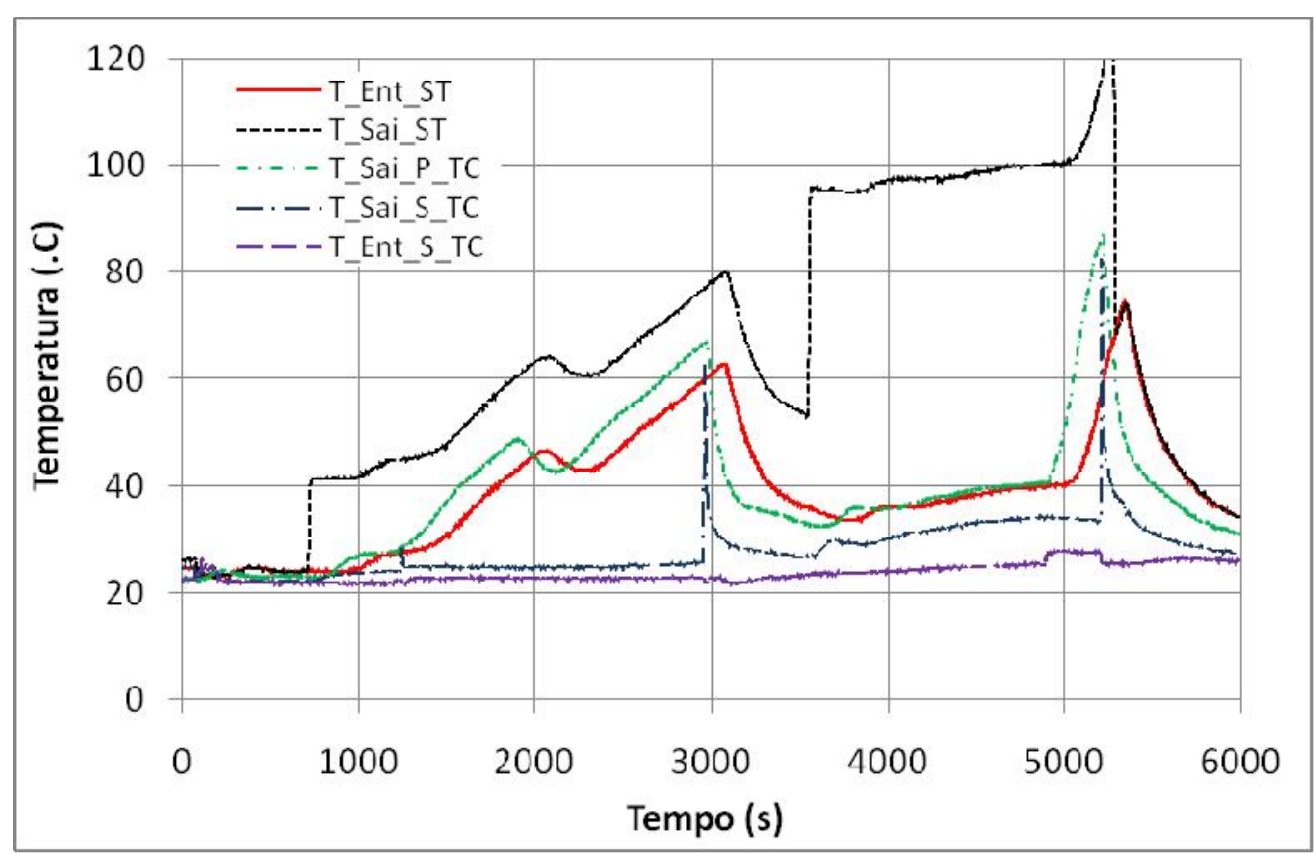

GRÁFICO 147 Temperaturas no CT1 - Exp23

Fonte: dados experimentais da pesquisa 


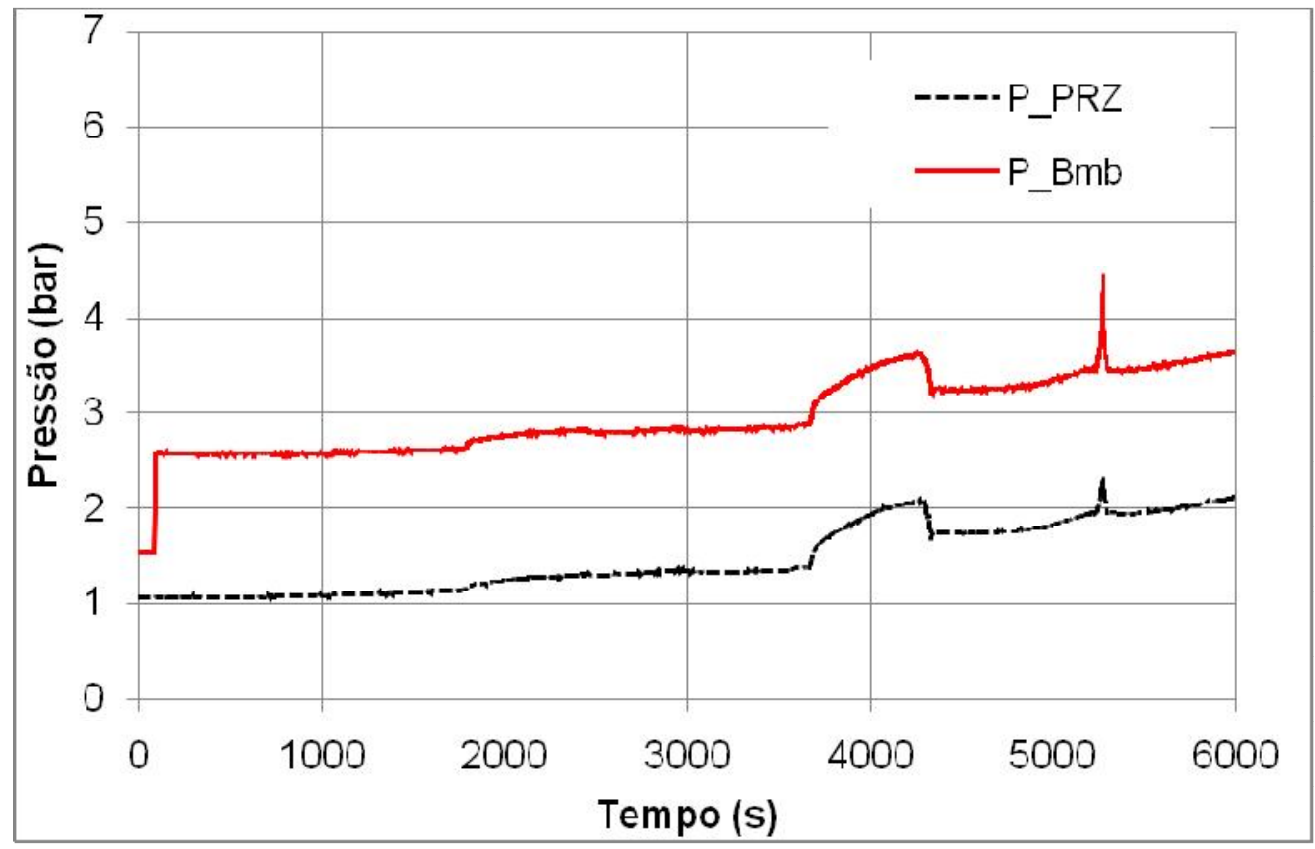

GRÁFICO 148 Pressão no pressurizador e no recalque da bomba - Exp23 Fonte: dados experimentais da pesquisa

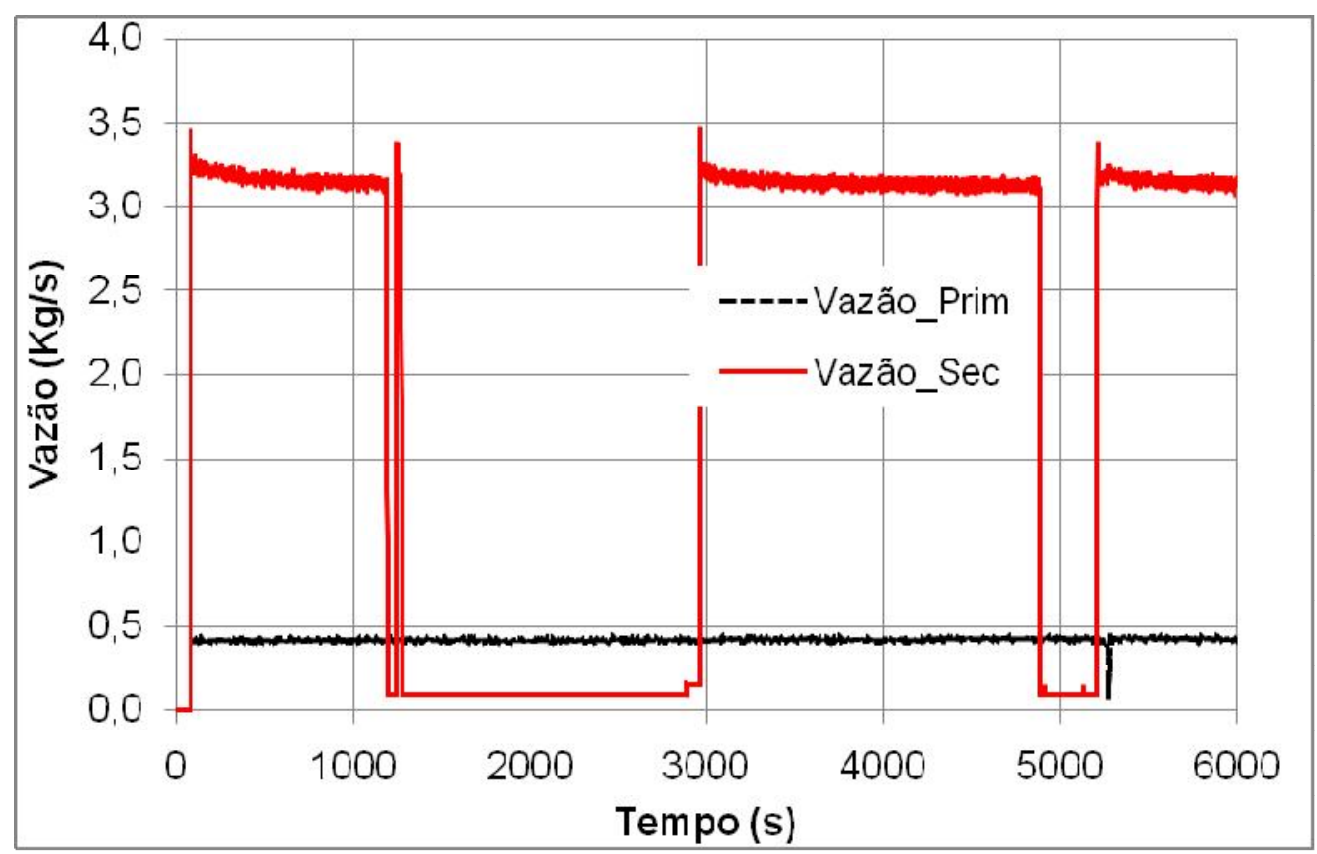

GRÁFICO 149 Vazão no primário e no secundário - Exp23

Fonte: dados experimentais da pesquisa 


\section{EXPERIMENTO 24-3}

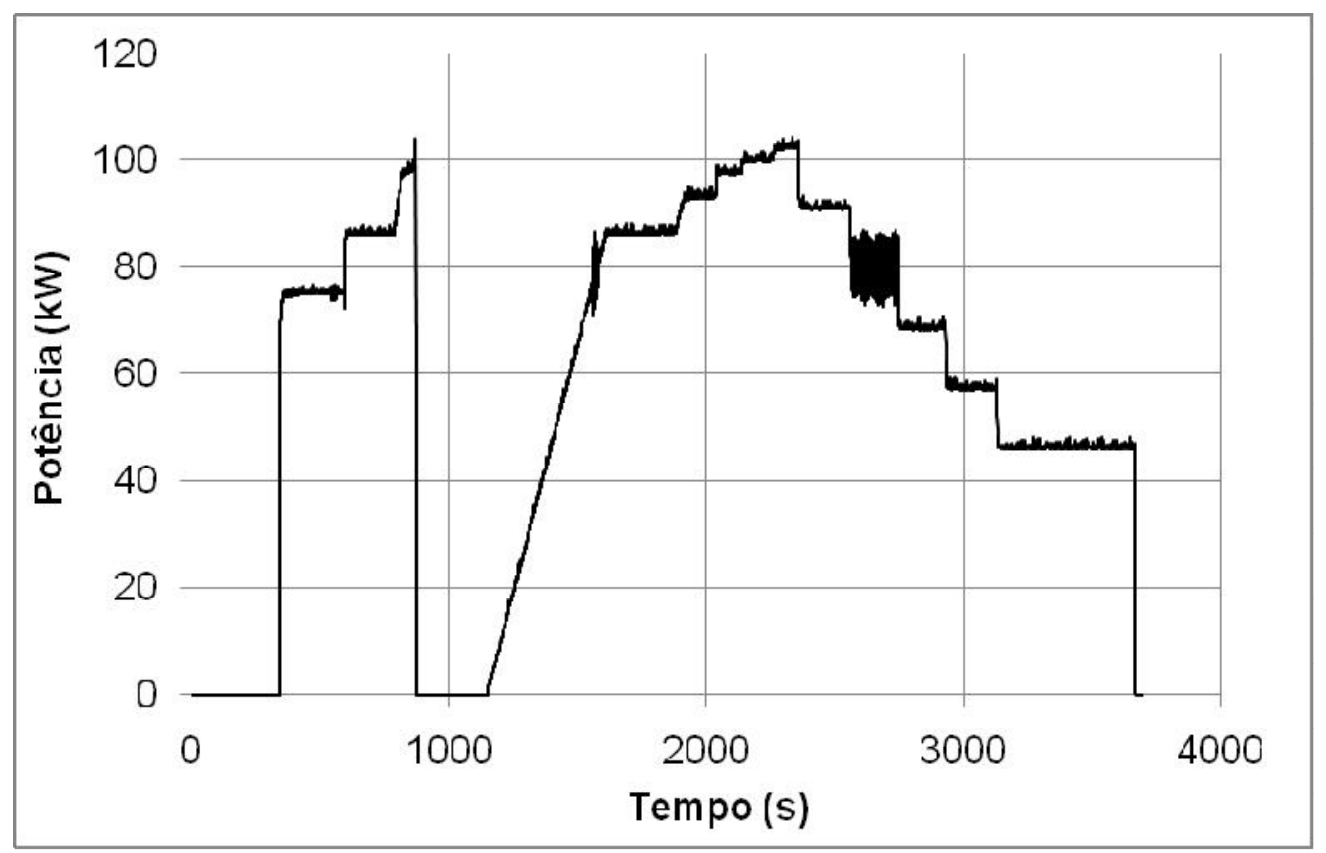

GRÁFICO 150 Potência na seção de testes - Exp24

Fonte: dados experimentais da pesquisa

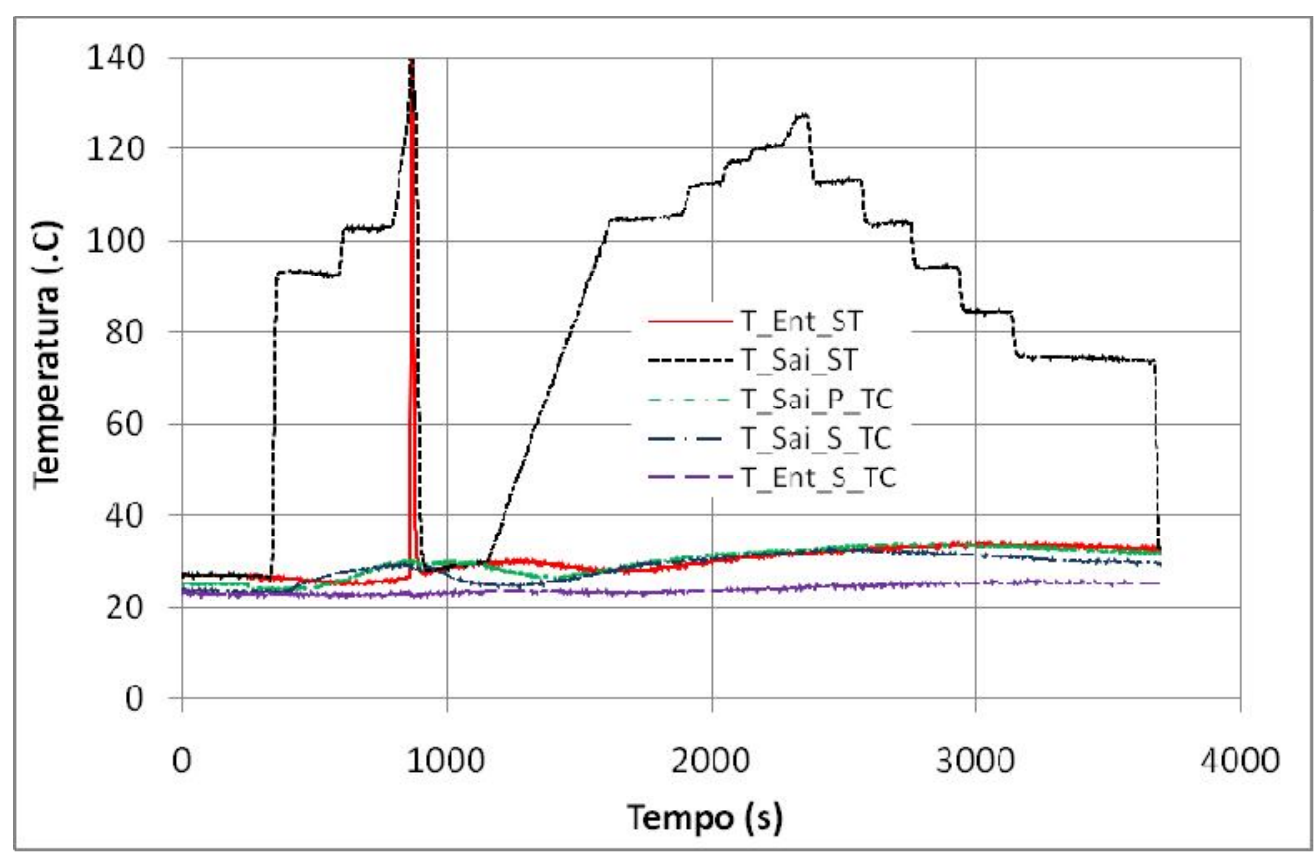

GRÁFICO 151 Temperaturas no CT1 - Exp24

Fonte: dados experimentais da pesquisa 


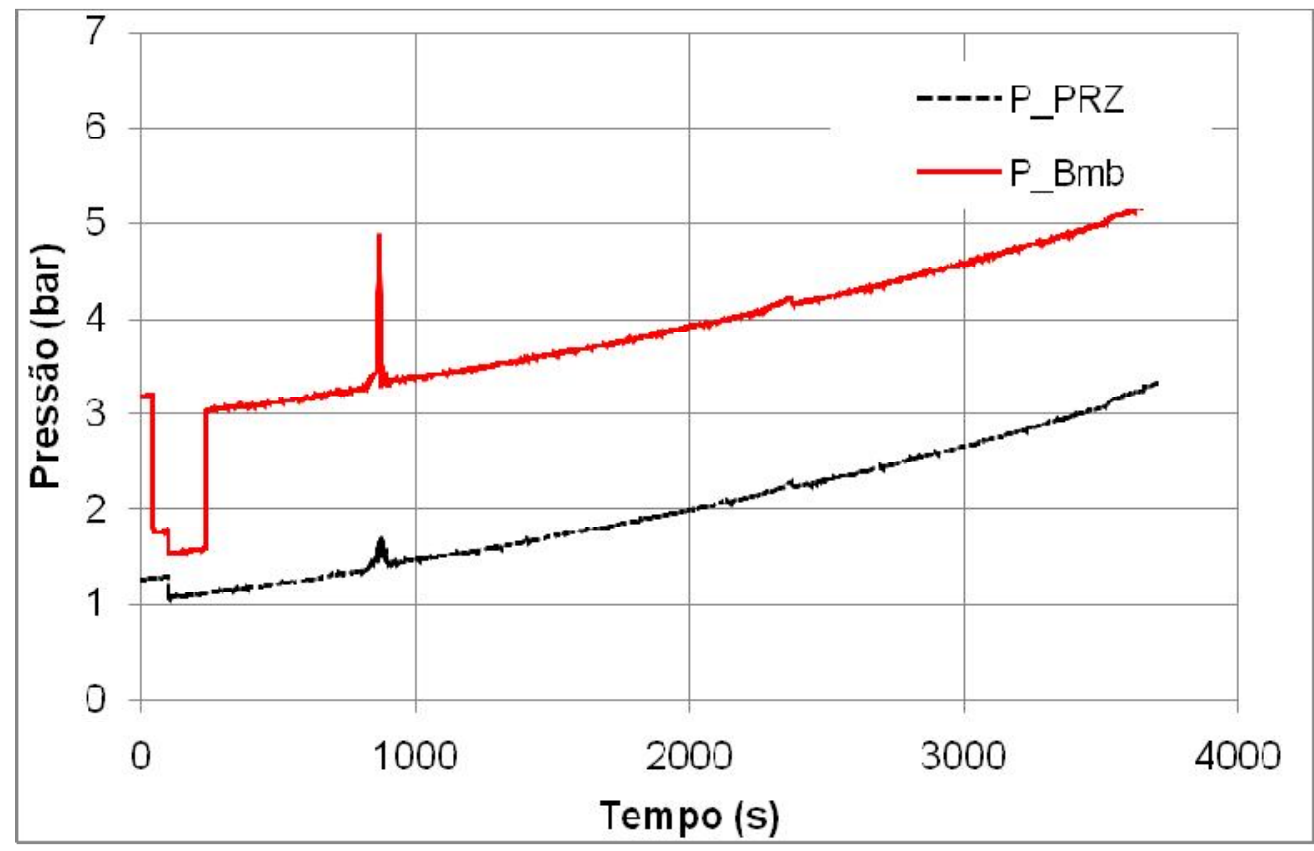

GRÁFICO 152 Pressão no pressurizador e no recalque da bomba - Exp24 Fonte: dados experimentais da pesquisa

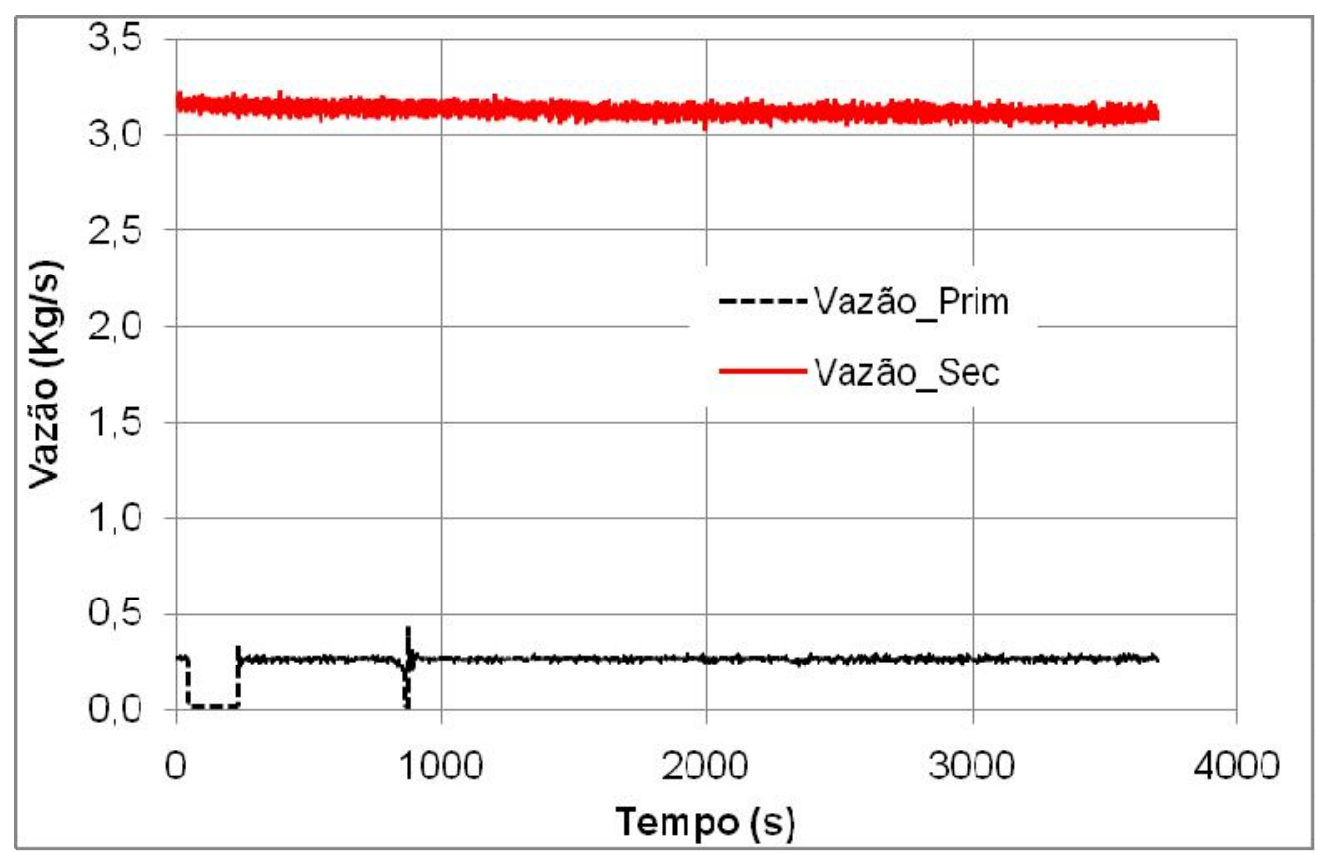

GRÁFICO 153 Vazão no primário e no secundário - Exp24

Fonte: dados experimentais da pesquisa 


\section{EXPERIMENTO 25-2}

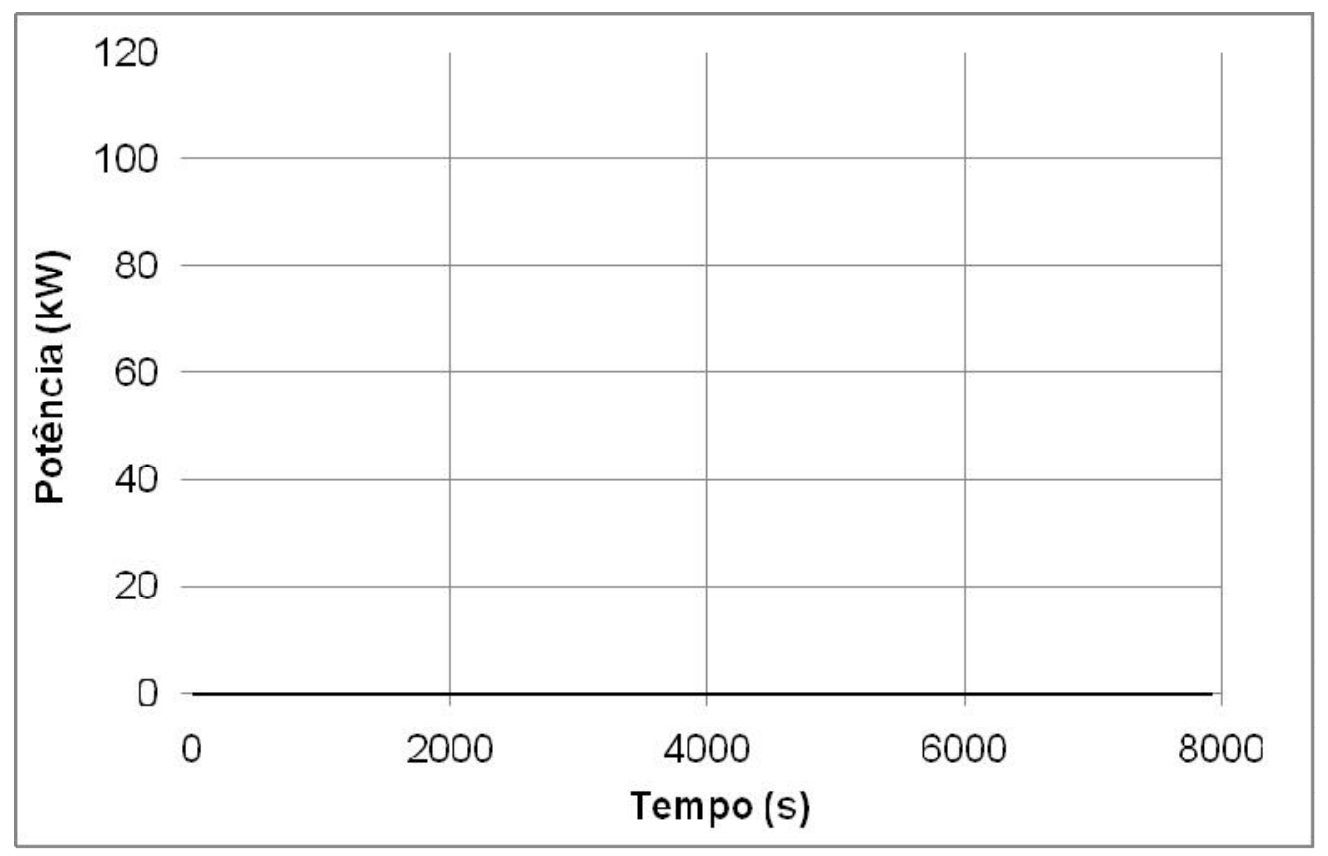

GRÁFICO 154 Potência na seção de testes - Exp25

Fonte: dados experimentais da pesquisa

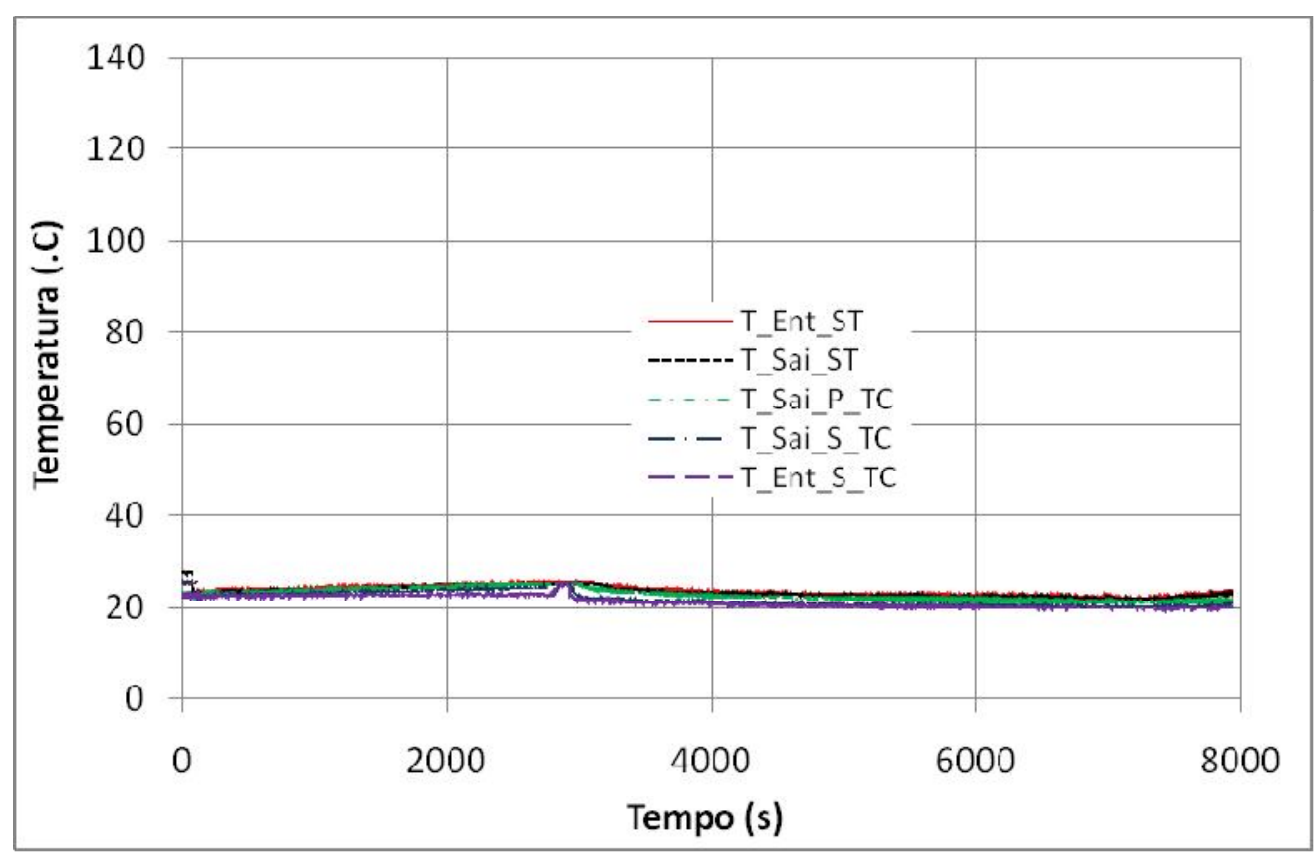

GRÁFICO 155 Temperaturas no CT1 - Exp25

Fonte: dados experimentais da pesquisa 


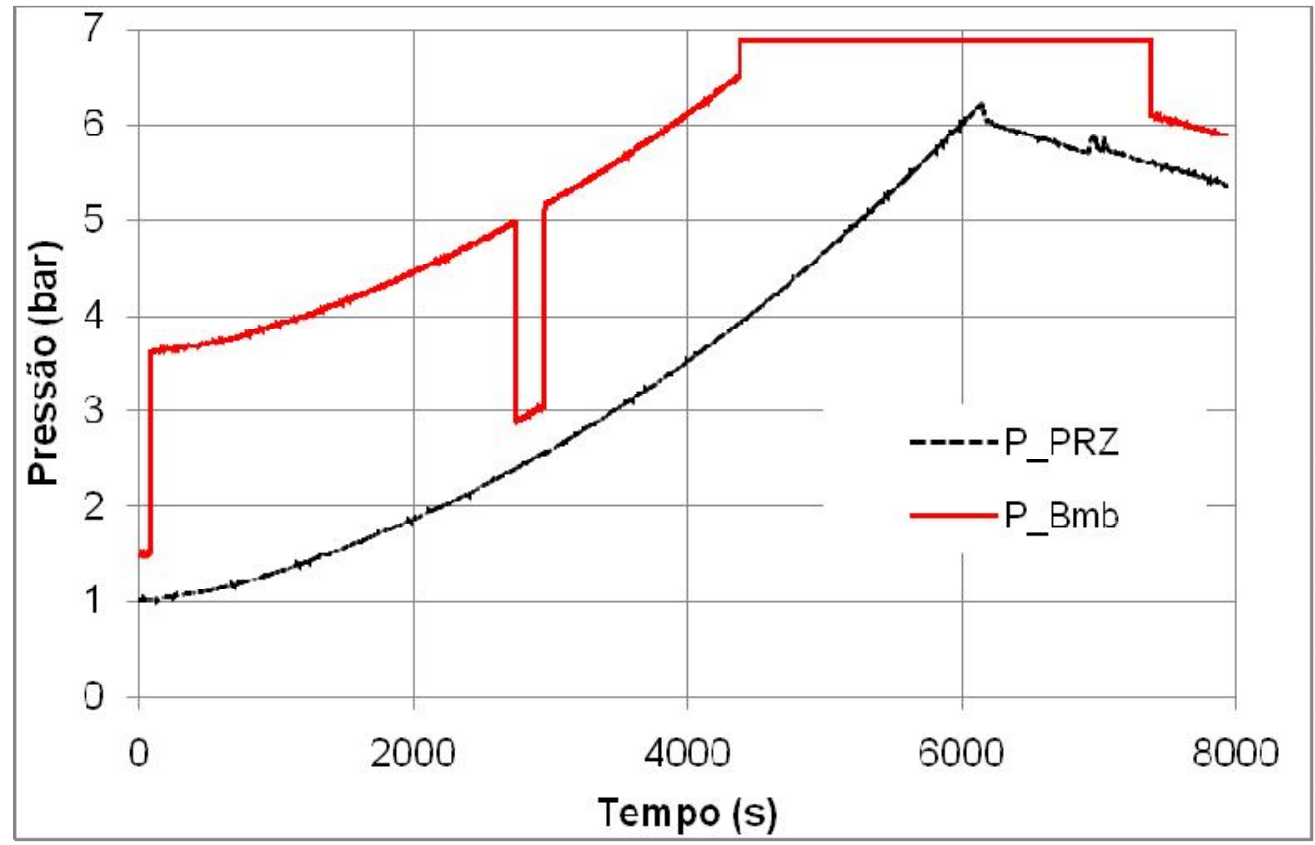

GRÁFICO 156 Pressão no pressurizador e no recalque da bomba - Exp25 Fonte: dados experimentais da pesquisa

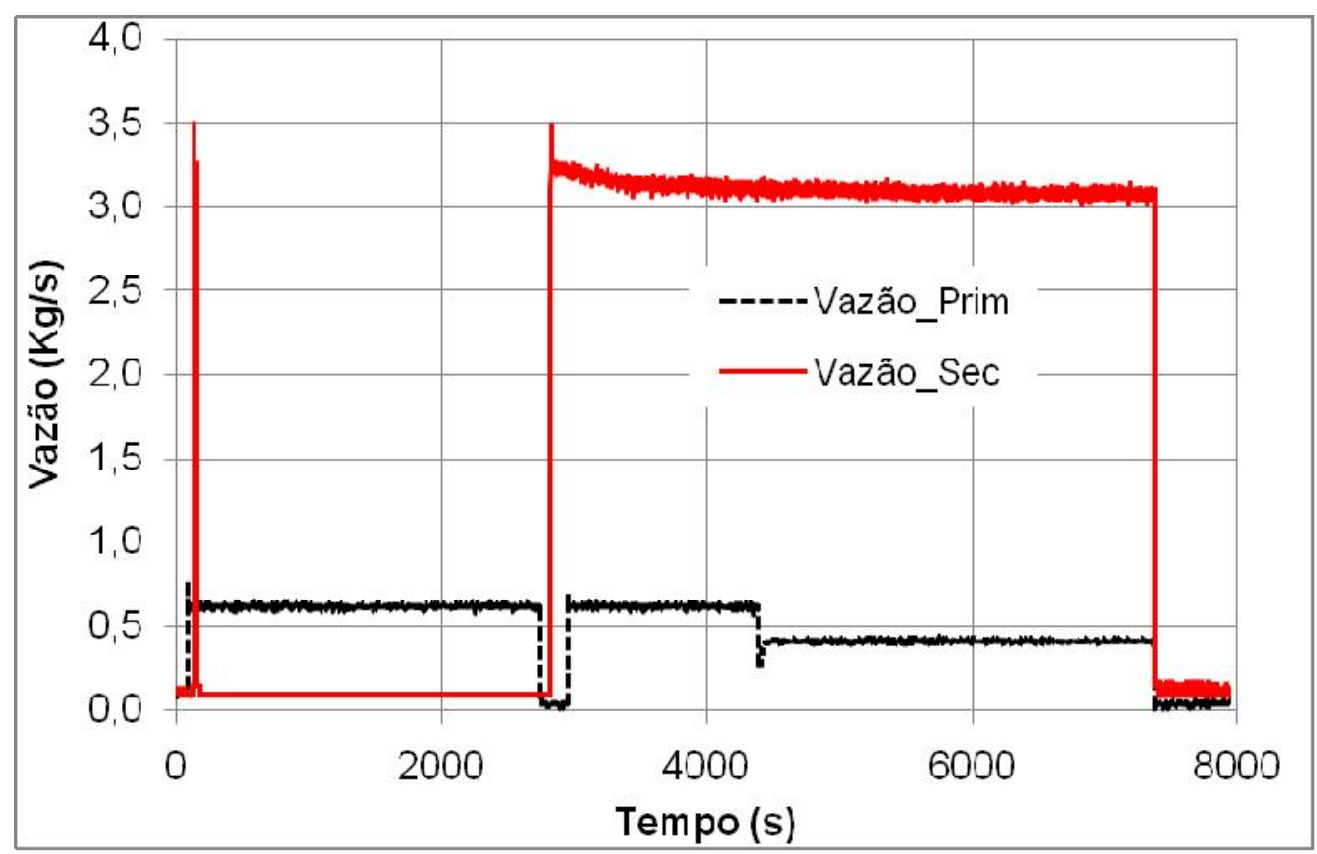

GRÁFICO 157 Vazão no primário e no secundário - Exp25

Fonte: dados experimentais da pesquisa 


\section{EXPERIMENTO 26}

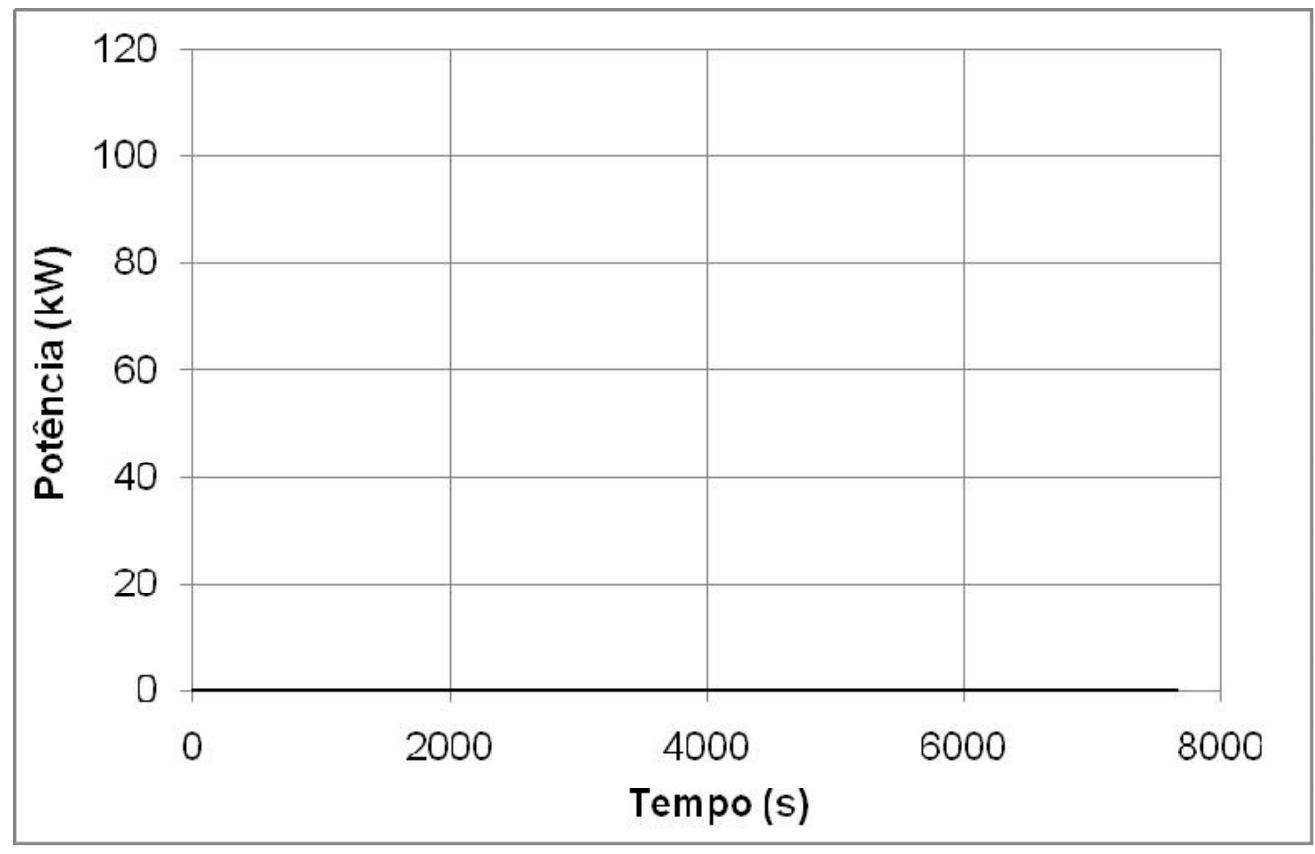

GRÁFICO 158 Potência na seção de testes - Exp26

Fonte: dados experimentais da pesquisa

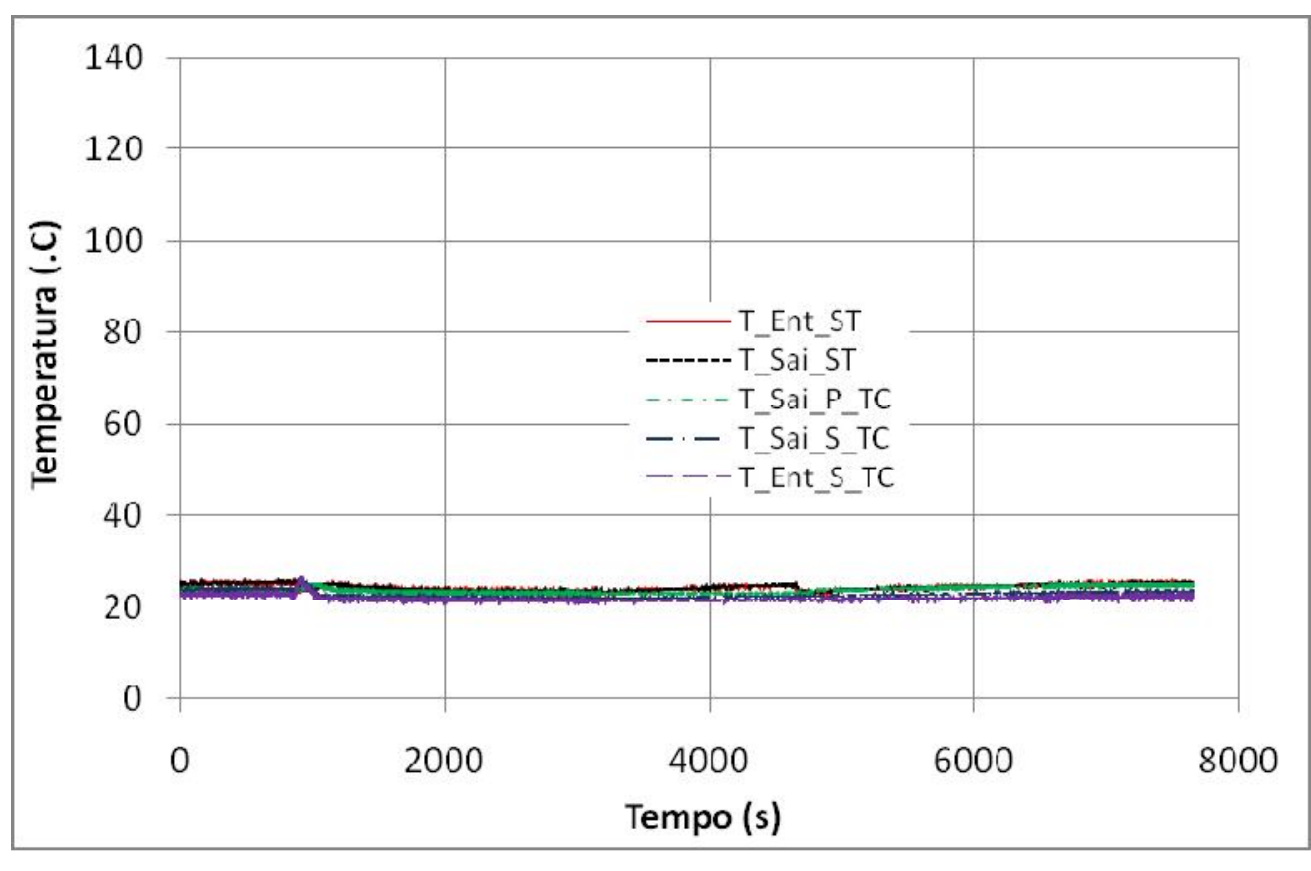

GRÁFICO 159 Temperaturas no CT1 - Exp26

Fonte: dados experimentais da pesquisa 


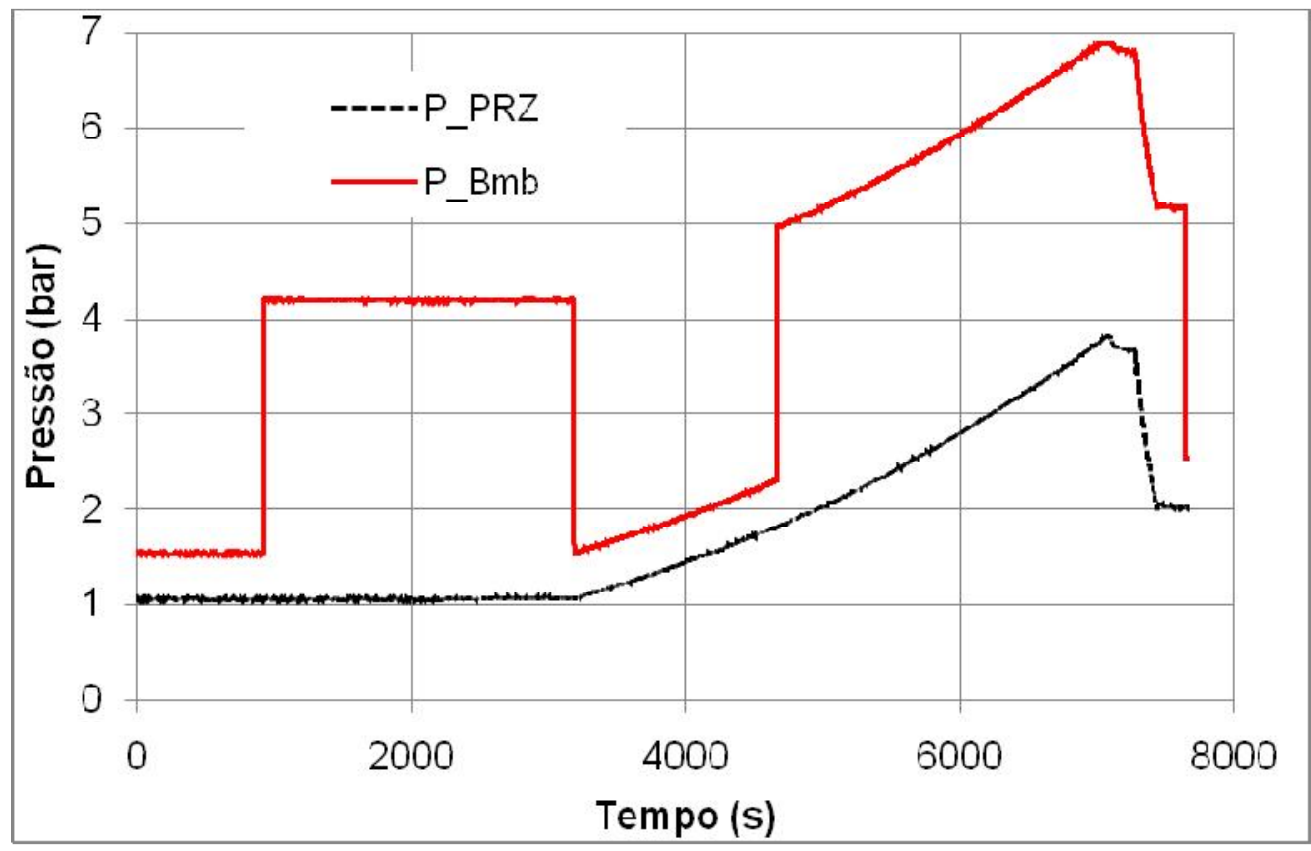

GRÁFICO 160 Pressão no pressurizador e no recalque da bomba - Exp26 Fonte: dados experimentais da pesquisa

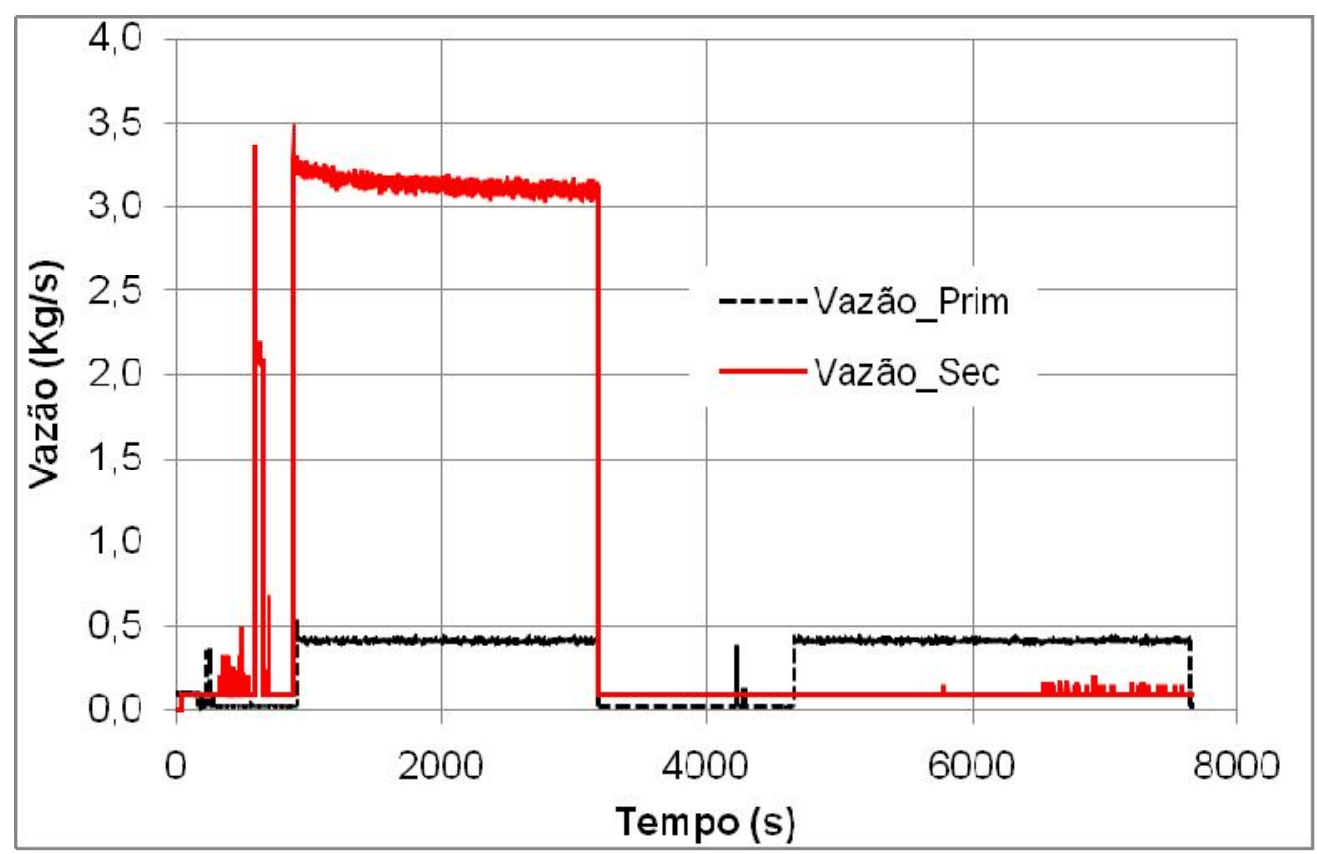

GRÁFICO 161 Vazão no primário e no secundário - Exp26

Fonte: dados experimentais da pesquisa 


\section{EXPERIMENTO 27}

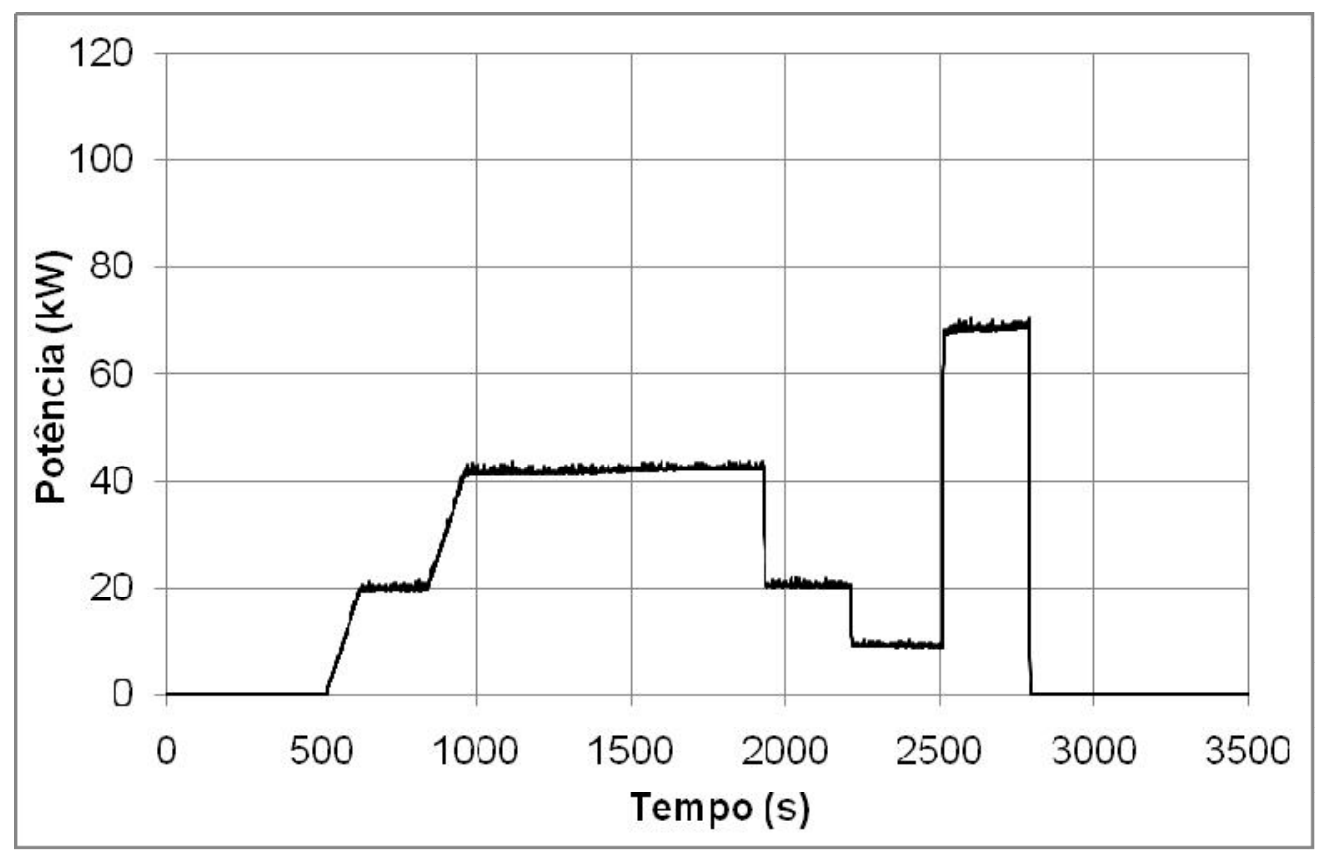

GRÁFICO 162 Potência na seção de testes - Exp27

Fonte: dados experimentais da pesquisa

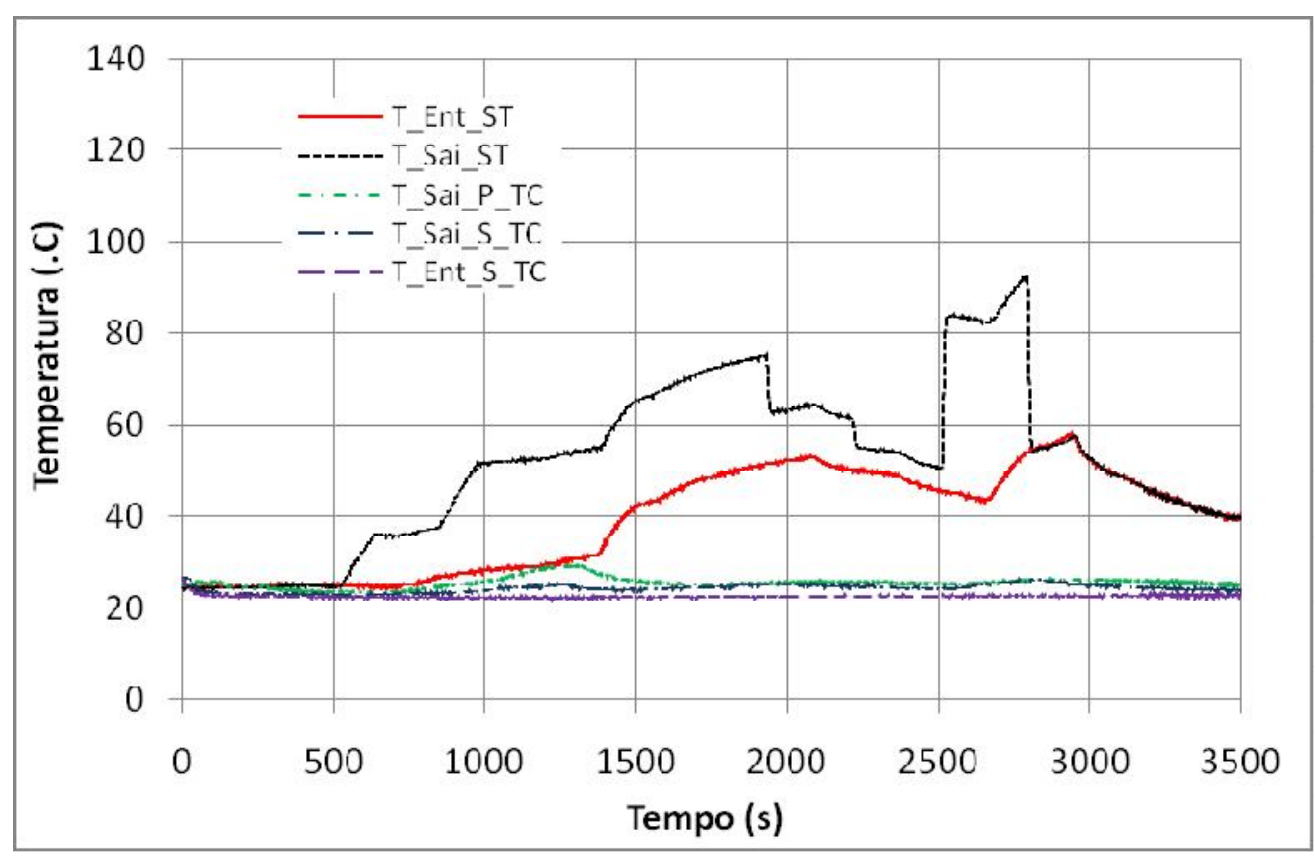

GRÁFICO 163 Temperaturas no CT1 - Exp27

Fonte: dados experimentais da pesquisa 


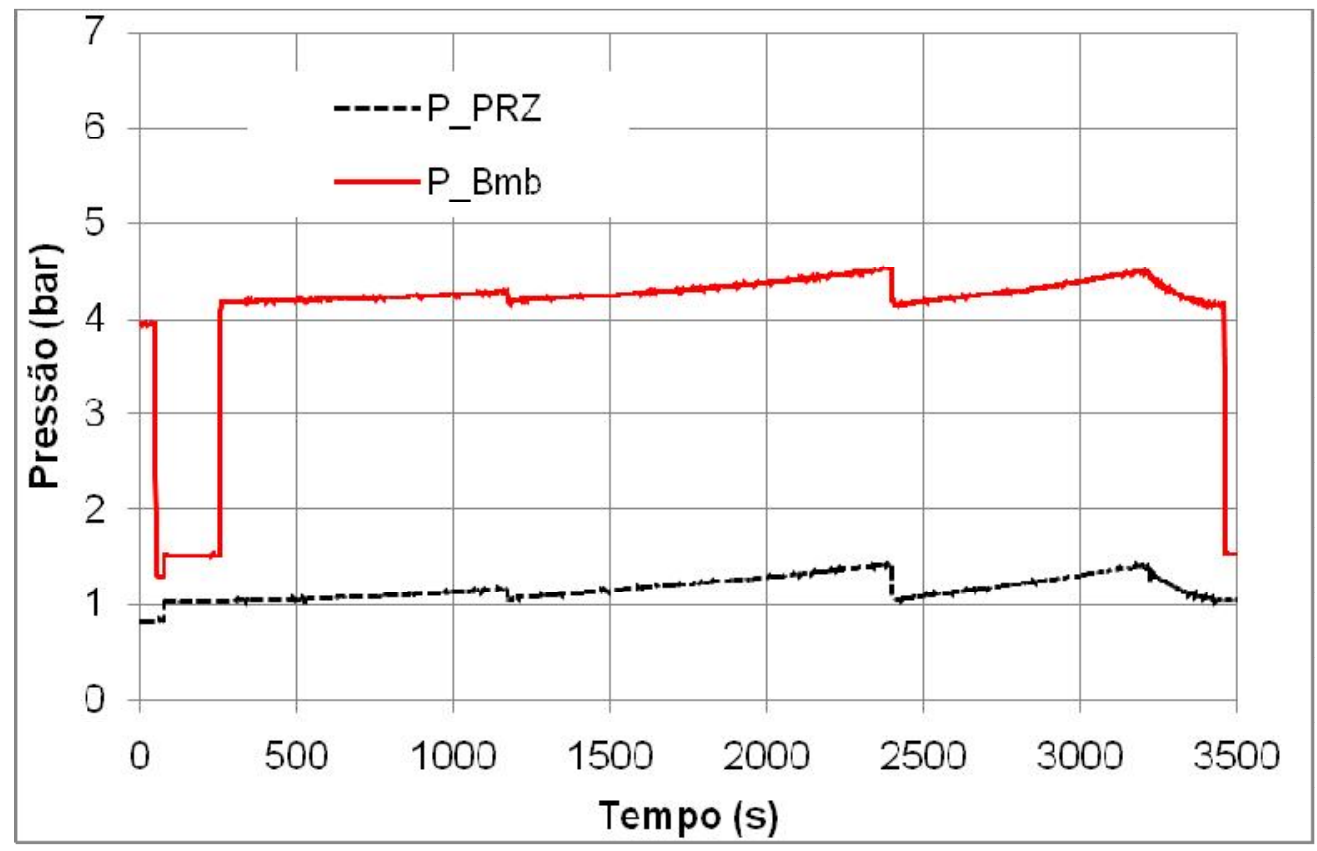

GRÁFICO 164 Pressão no pressurizador e no recalque da bomba - Exp27 Fonte: dados experimentais da pesquisa

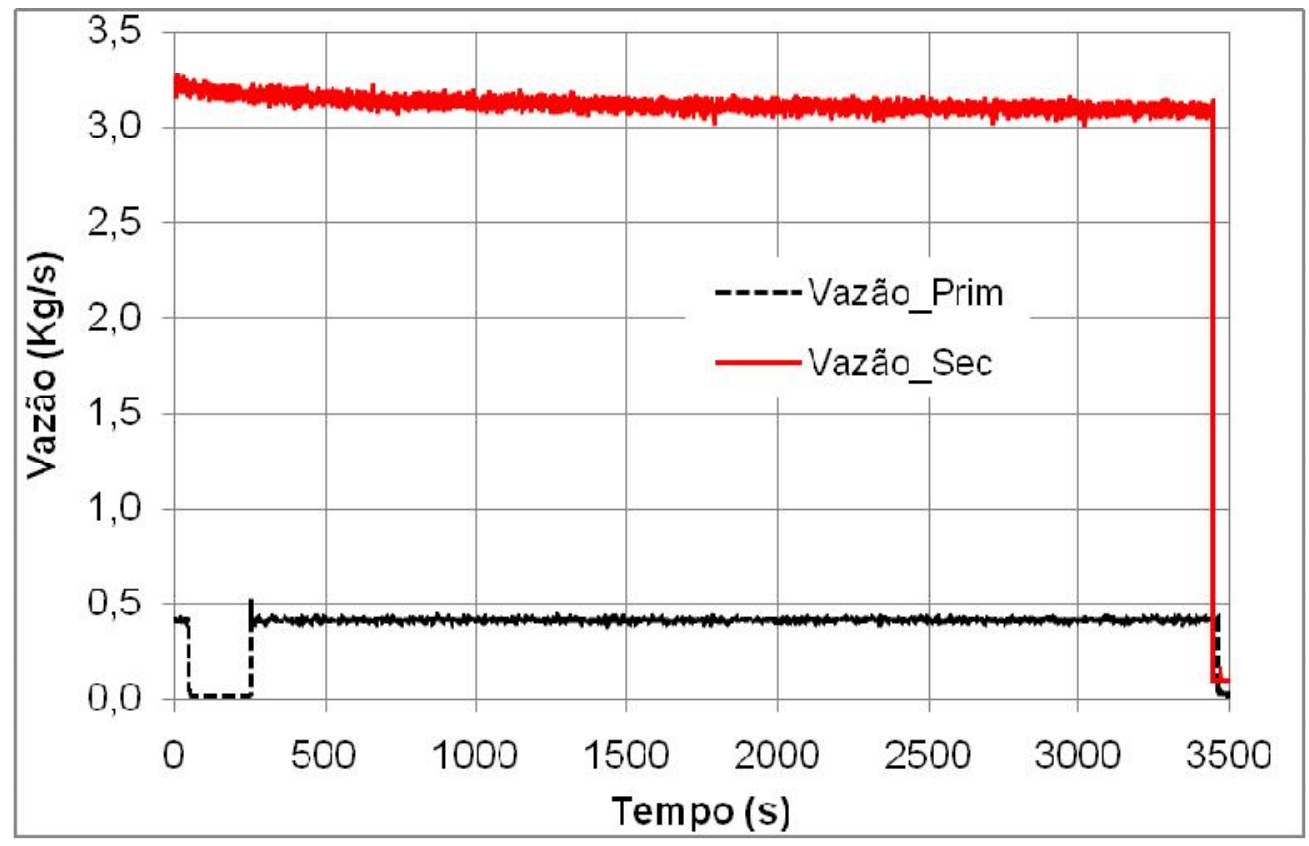

GRÁFICO 165 Vazão no primário e no secundário - Exp27 Fonte: dados experimentais da pesquisa 

E DE SUAS SIMULAÇÕES 


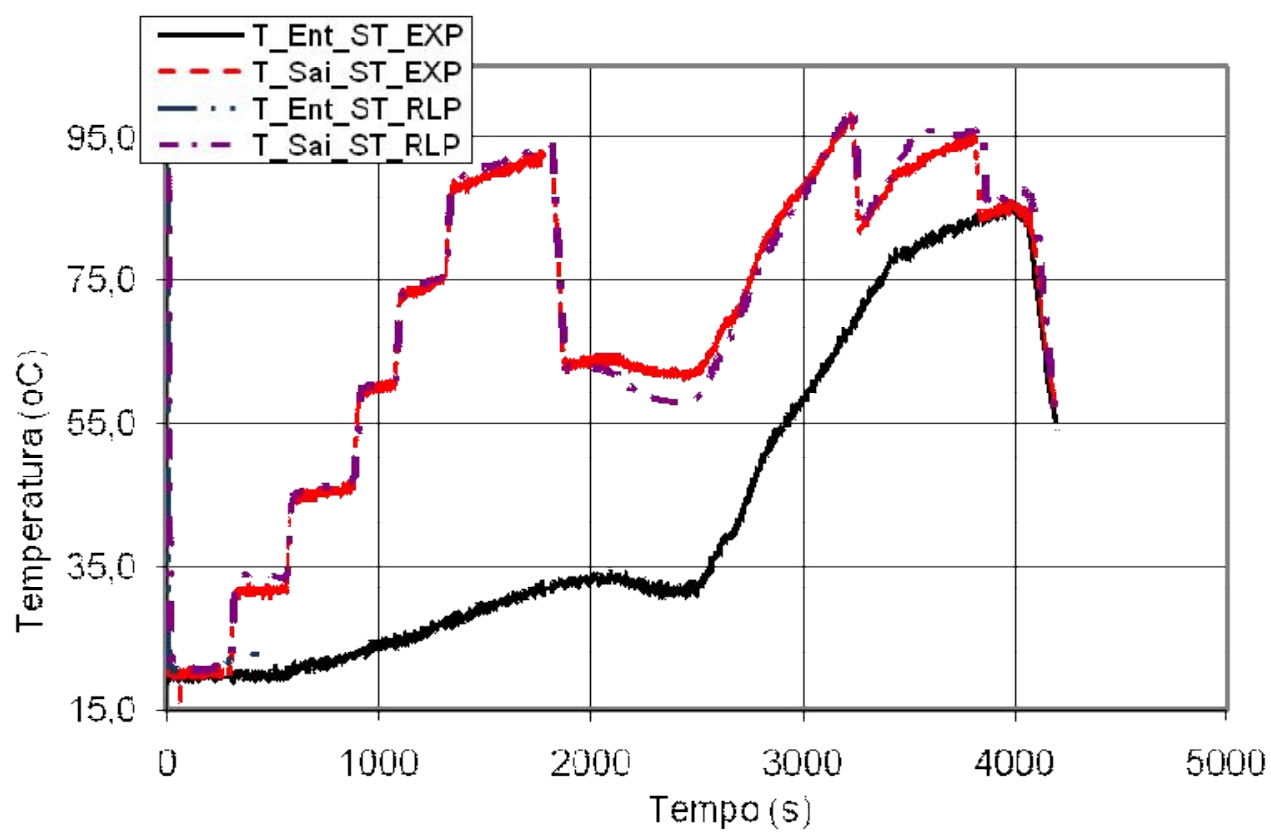

GRÁFICO 166 Temperaturas do fluido na ST, medidas e calculadas - Exp01

Fonte: dados, experimentais e de simulações, da pesquisa

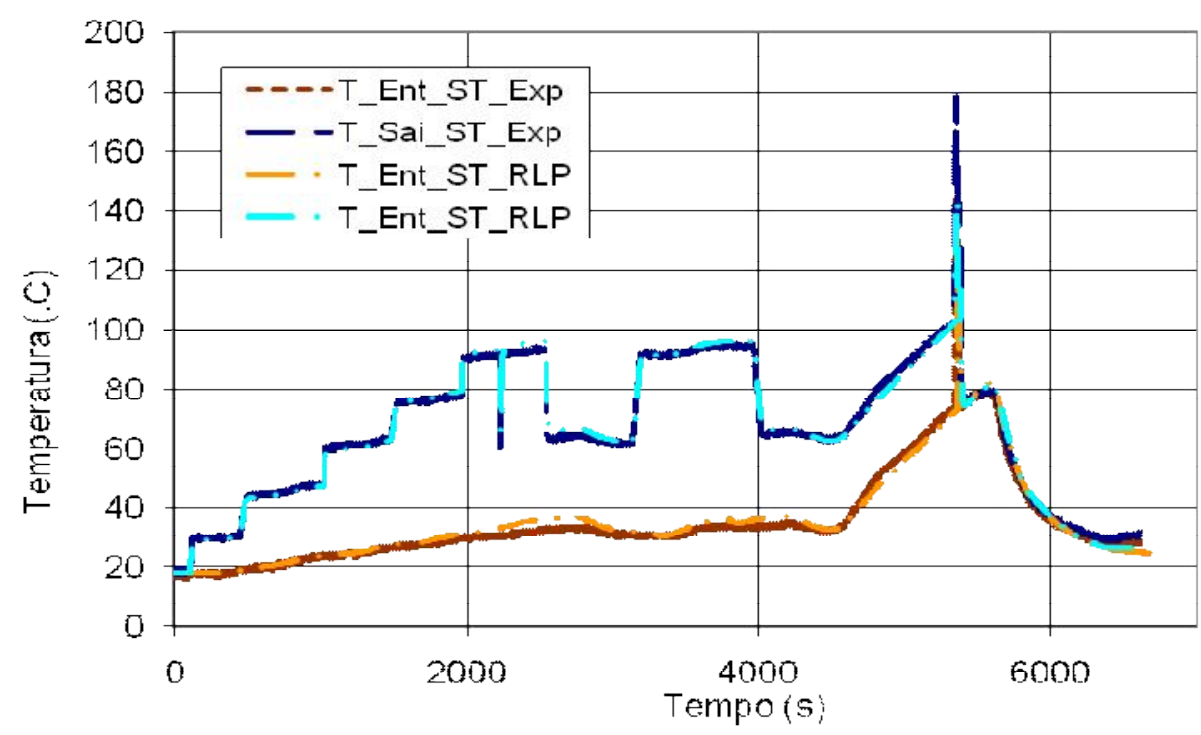

GRÁFICO 167 Temperaturas do fluido na ST, medidas e calculadas - Exp02

Fonte: dados, experimentais e de simulações, da pesquisa 


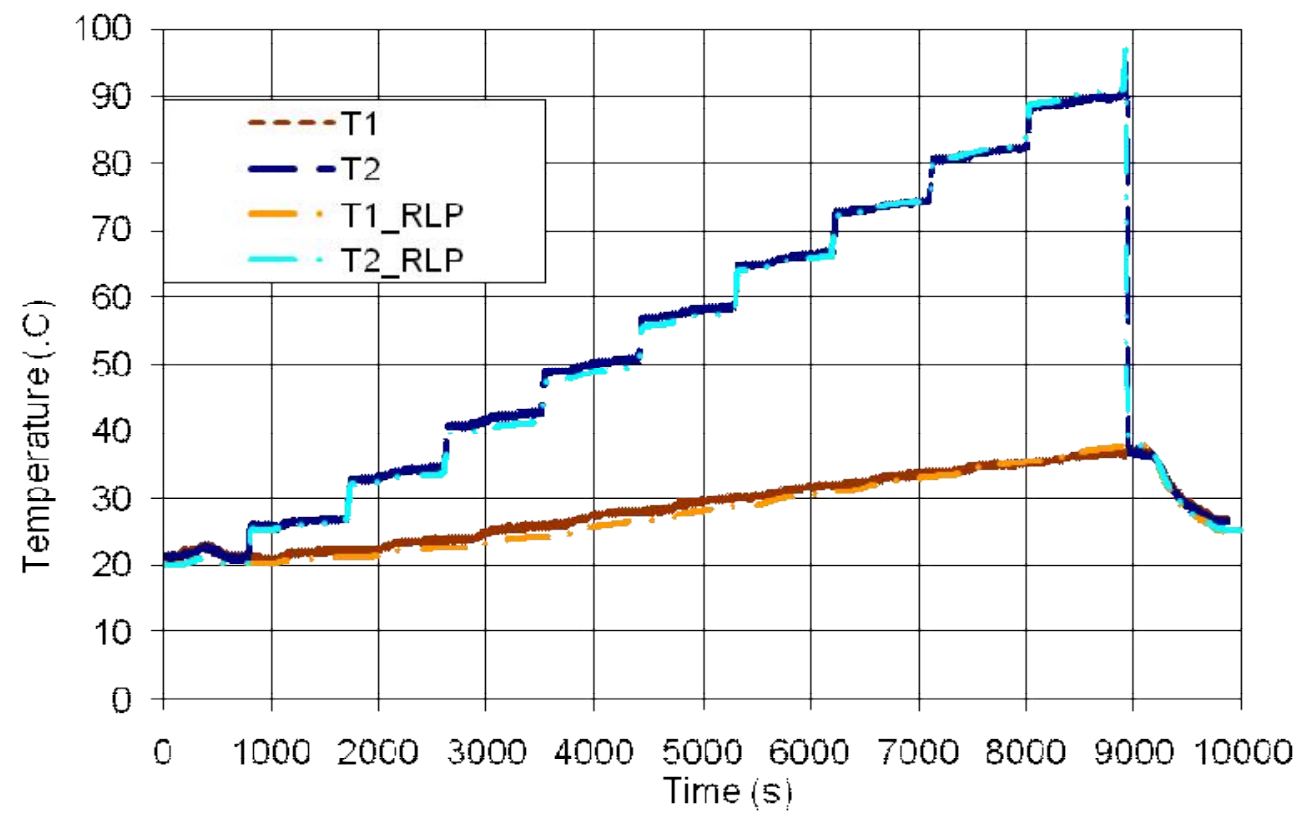

GRÁFICO 168 Temperaturas do fluido na ST, medidas e calculadas - Exp11 Fonte: dados, experimentais e de simulações, da pesquisa

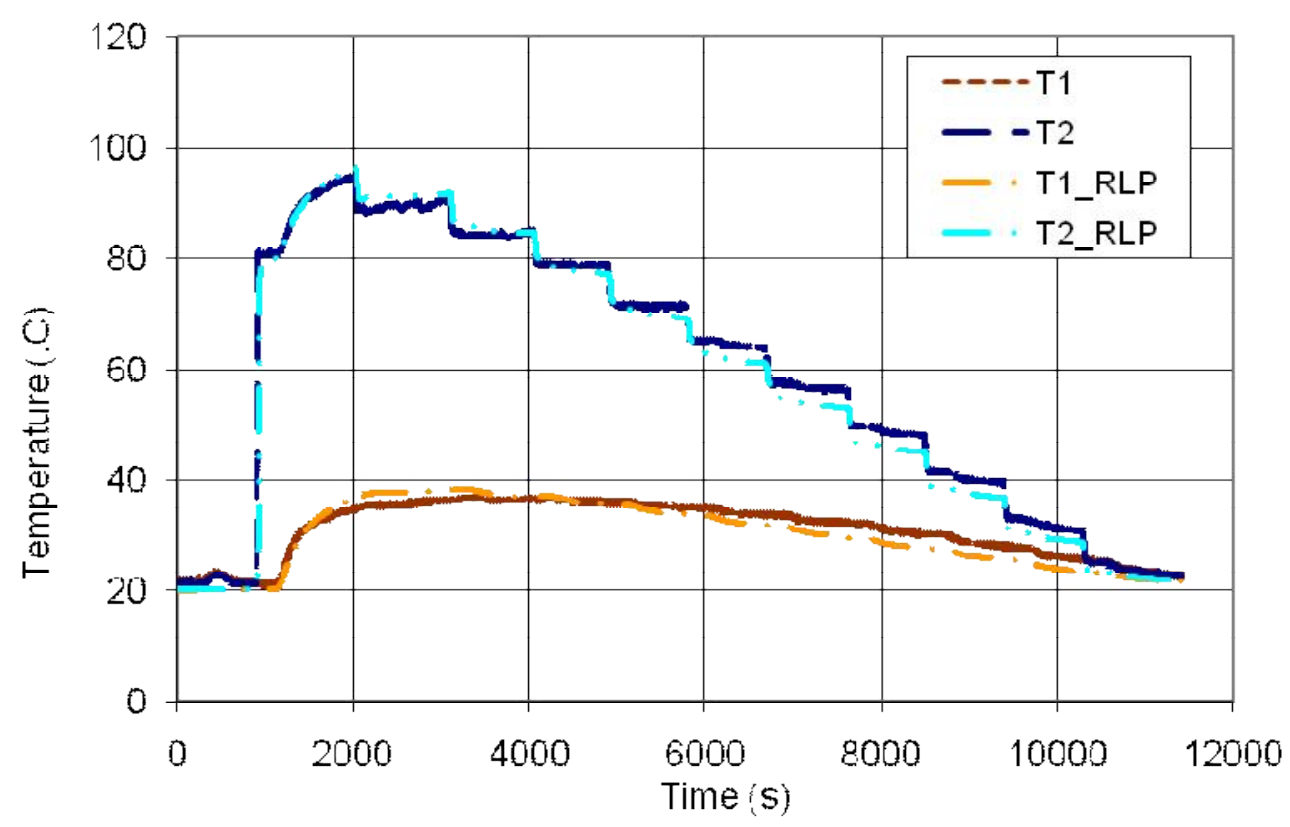

GRÁFICO 169 Temperaturas do fluido na ST, medidas e calculadas - Exp12

Fonte: dados, experimentais e de simulações, da pesquisa 


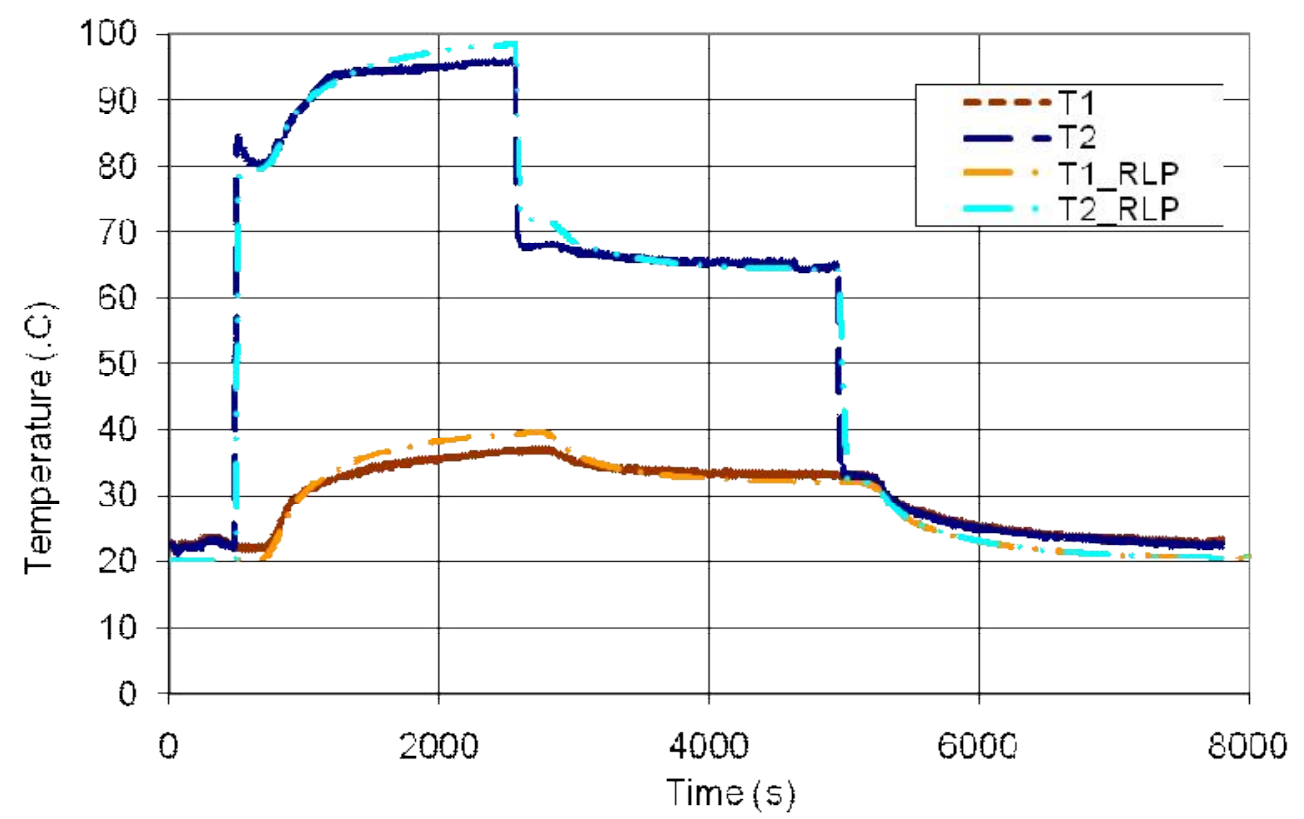

GRÁFICO 170 Temperaturas do fluido na ST, medidas e calculadas - Exp15 Fonte: dados, experimentais e de simulações, da pesquisa

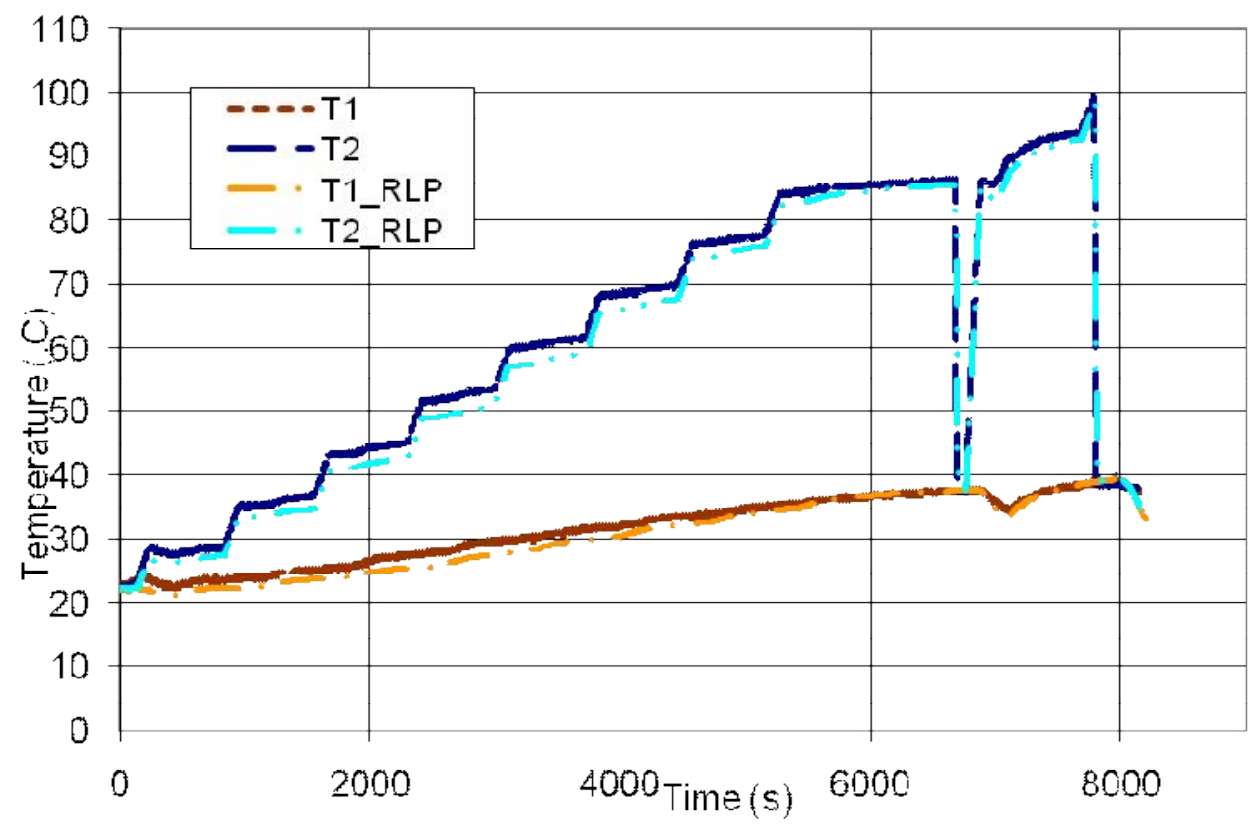

GRÁFICO 171 Temperaturas do fluido na ST, medidas e calculadas - Exp19 Fonte: dados, experimentais e de simulações, da pesquisa 


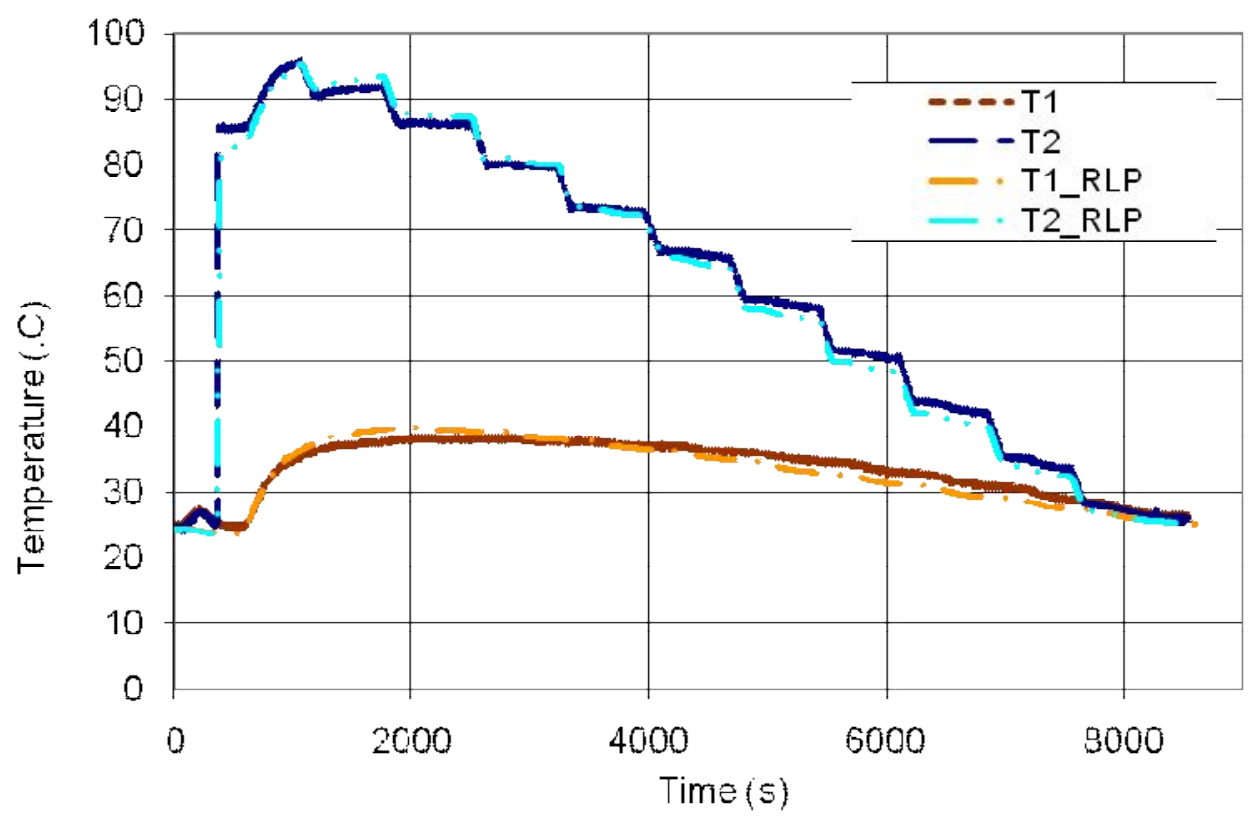

GRÁFICO 172 Temperaturas do fluido na ST, medidas e calculadas - Exp20

Fonte: dados, experimentais e de simulações, da pesquisa 
APÊNDICE F

SIMULAÇÕES DO CT1 E AMOSTRAGENS PARA FORMAÇÃO DOS CONJUNTOS DE BUFFERS DE TREINAMENTO 


\section{Degraus Decrescentes}

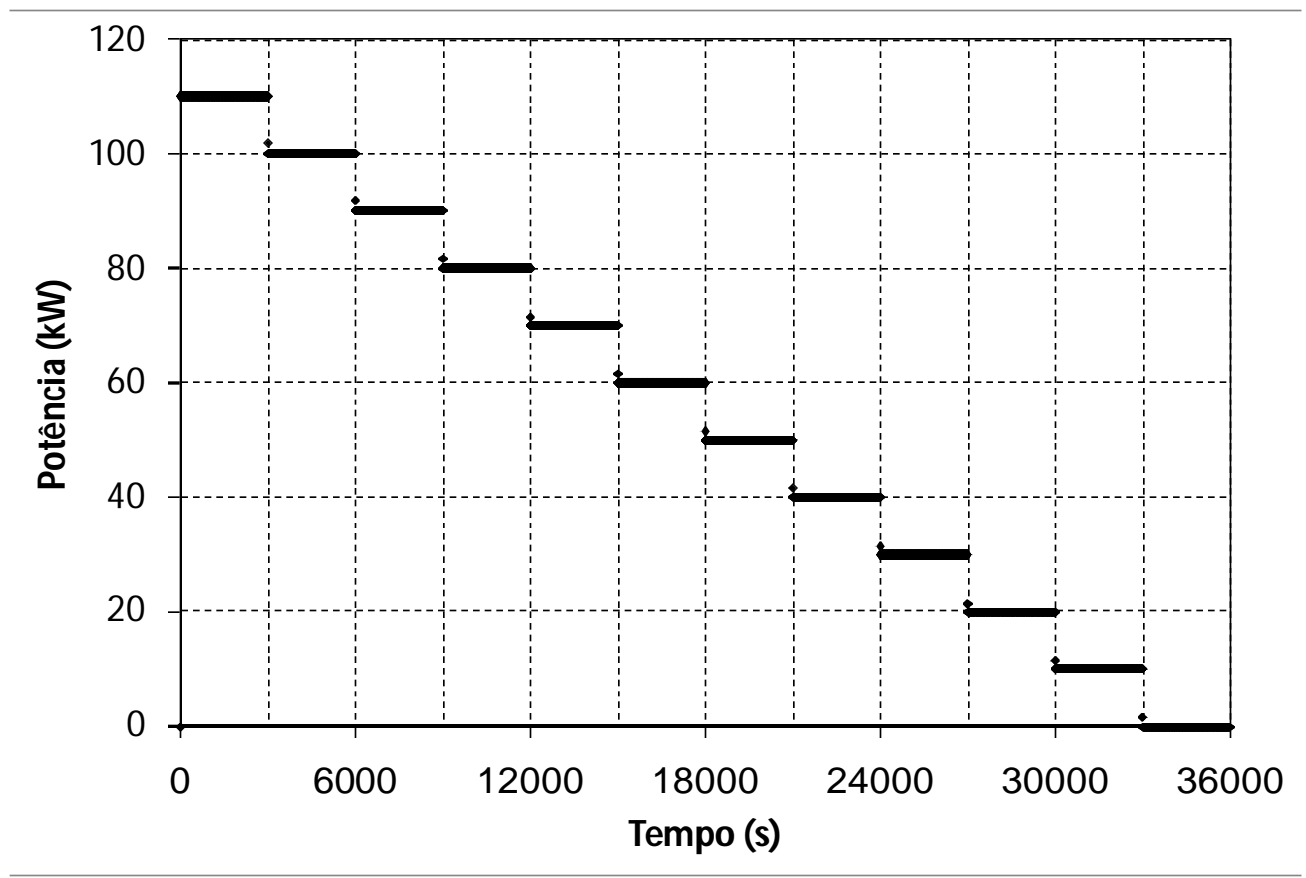

GRÁFICO 173 Potência na seção de testes para degraus decrescentes

Fonte: resultado de simulações da pesquisa

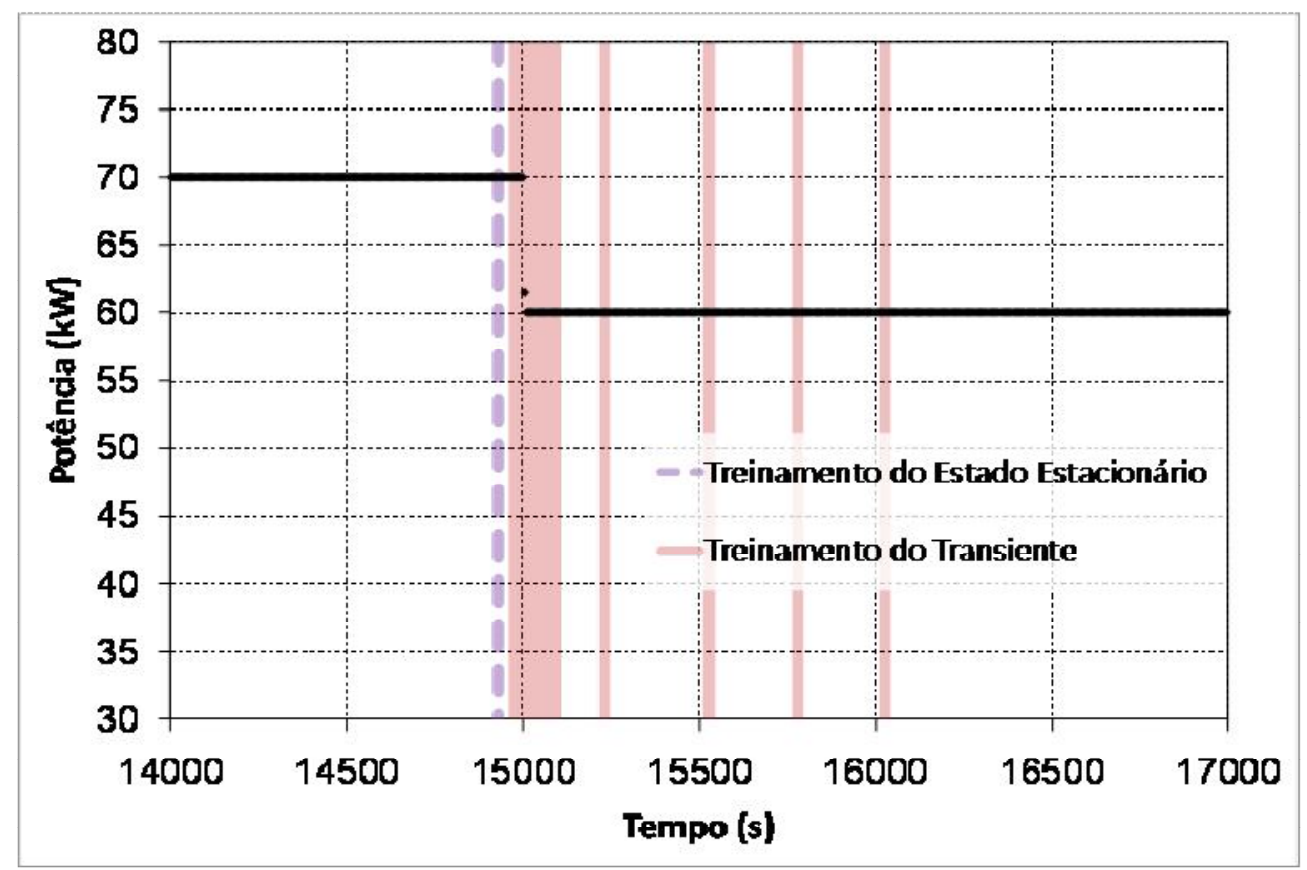

GRÁFICO 174 Amostragem da potência para todos os conjuntos de buffers de treinamento da simulação de degraus decrescentes

Fonte: resultados de simulações da pesquisa 


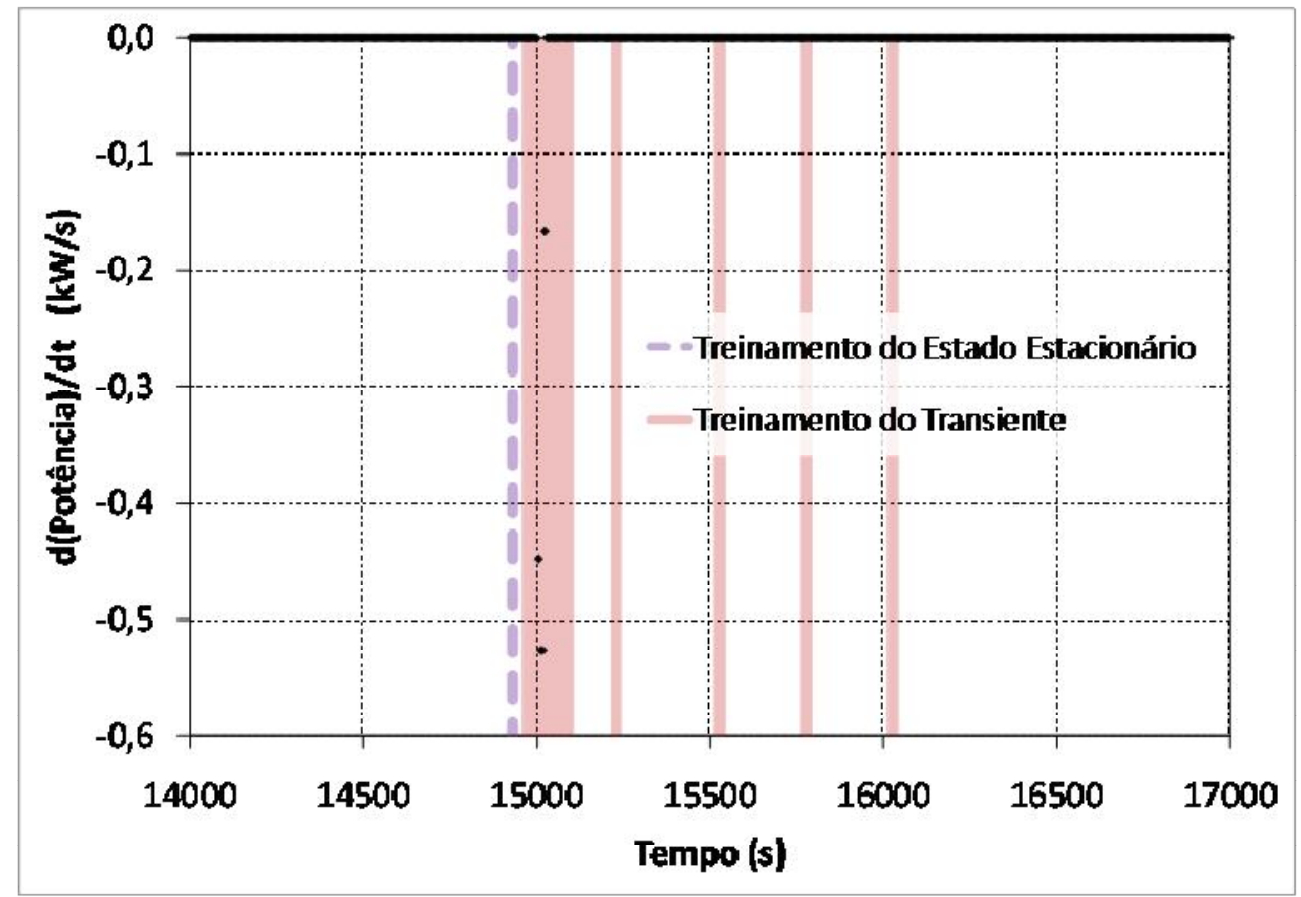

GRÁFICO 175 Amostrag em da derivada da potência para todos os conjuntos de buffers de treinamento da simulação de degraus decrescentes

Fonte: resultados de simulações da pesquisa

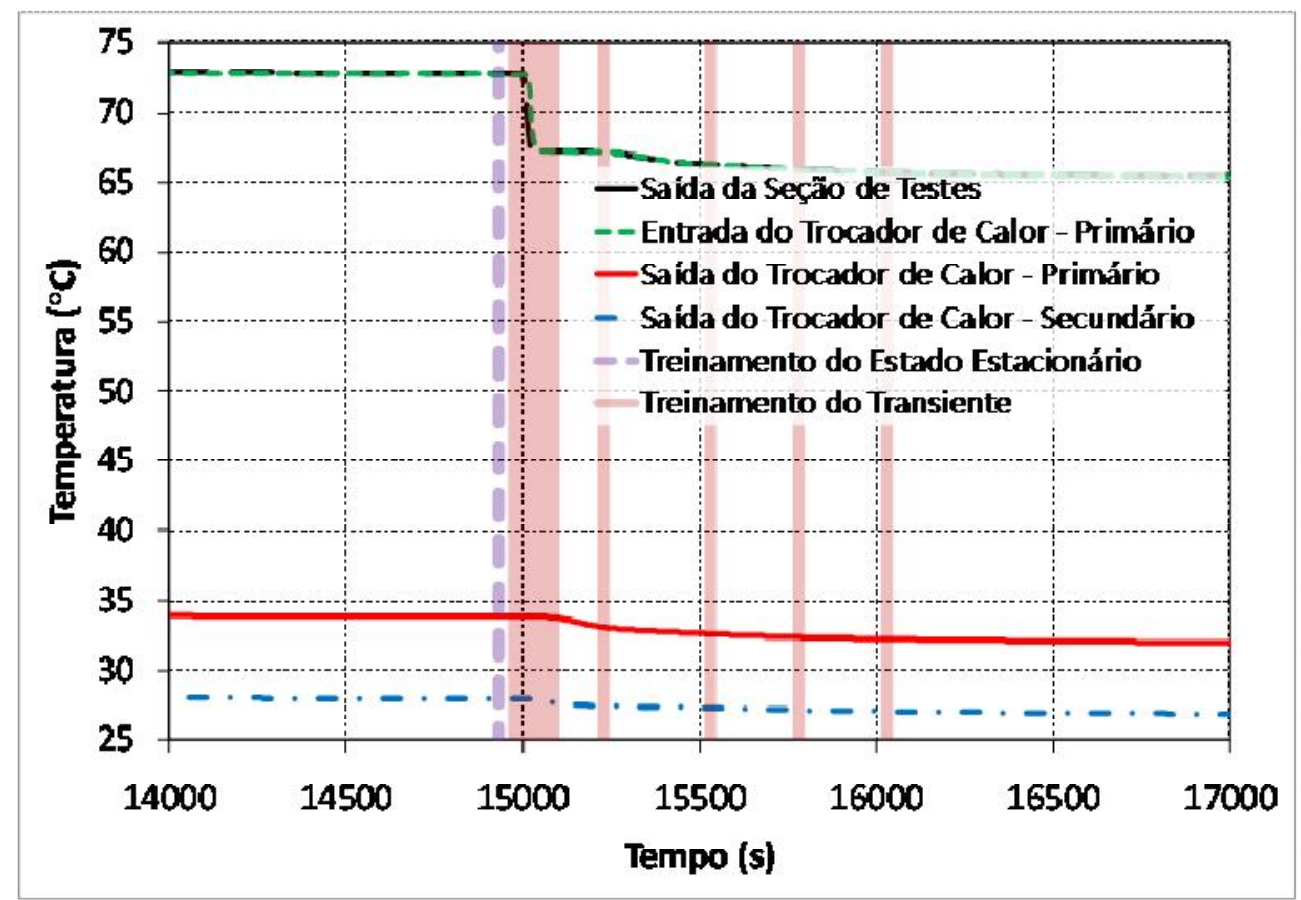

GRÁFICO 176 Amostragem de temperaturas para todos os conjuntos de buffers de treinamento da simulação de degraus decrescentes

Fonte: resultados de simulações da pesquisa 


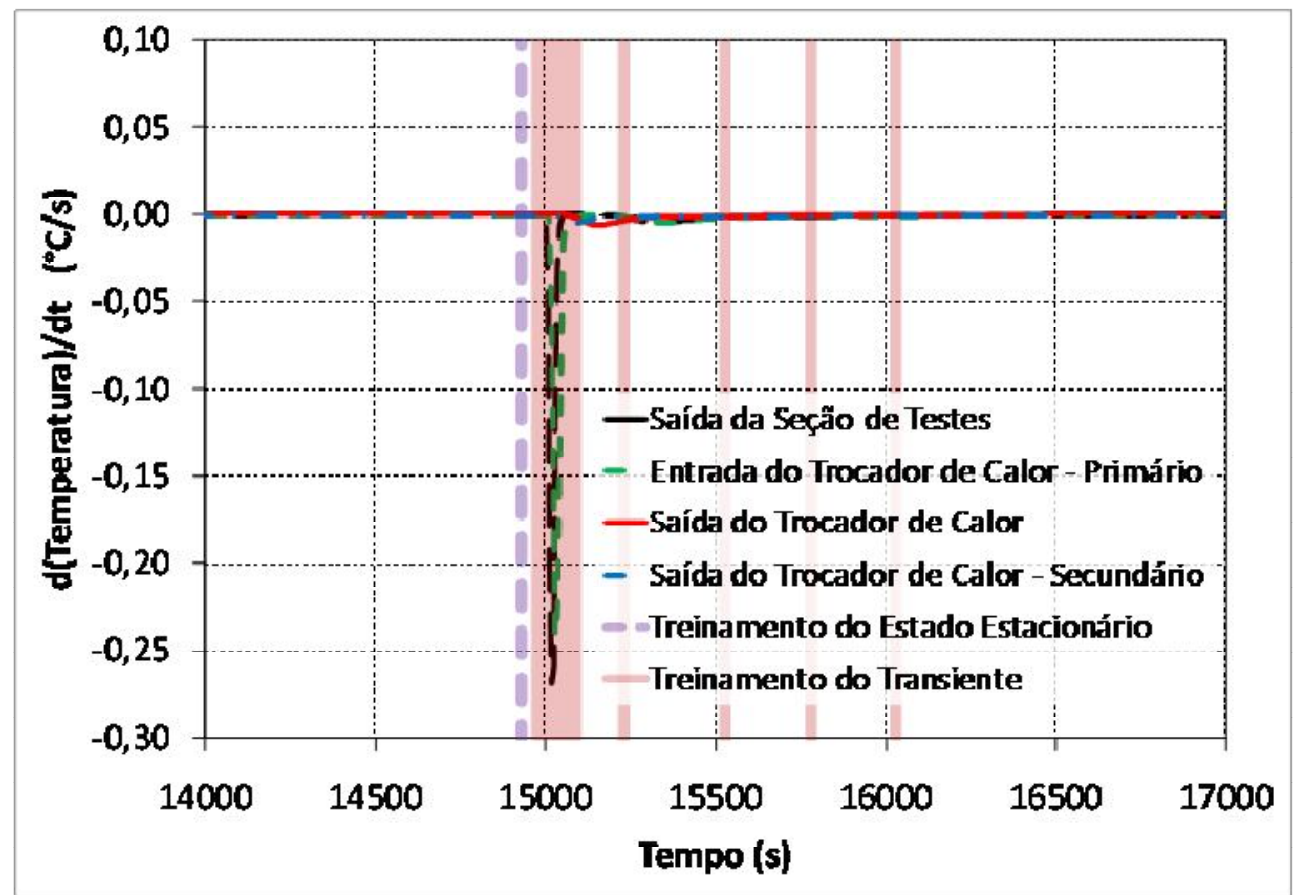

GRÁFICO 177 Amostragem de derivadas de temperaturas para todos os conjuntos de buffers de treinamento da simulação de degraus decrescentes Fonte: resultados de simulações da pesquisa 


\section{Degraus Crescentes}

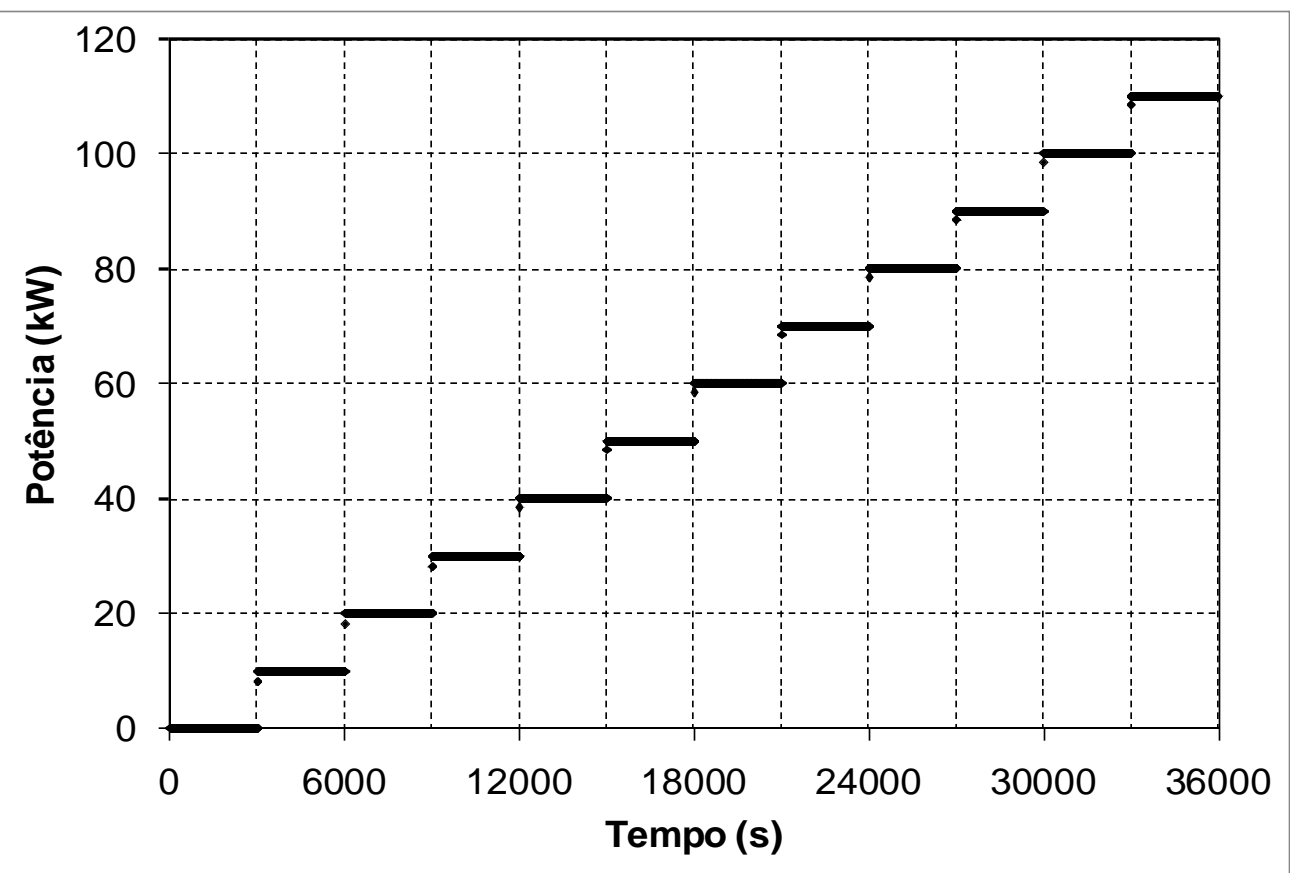

GRÁFICO 178 Potência na seção de testes para degraus crescentes

Fonte: resultado de simulações da pesquisa

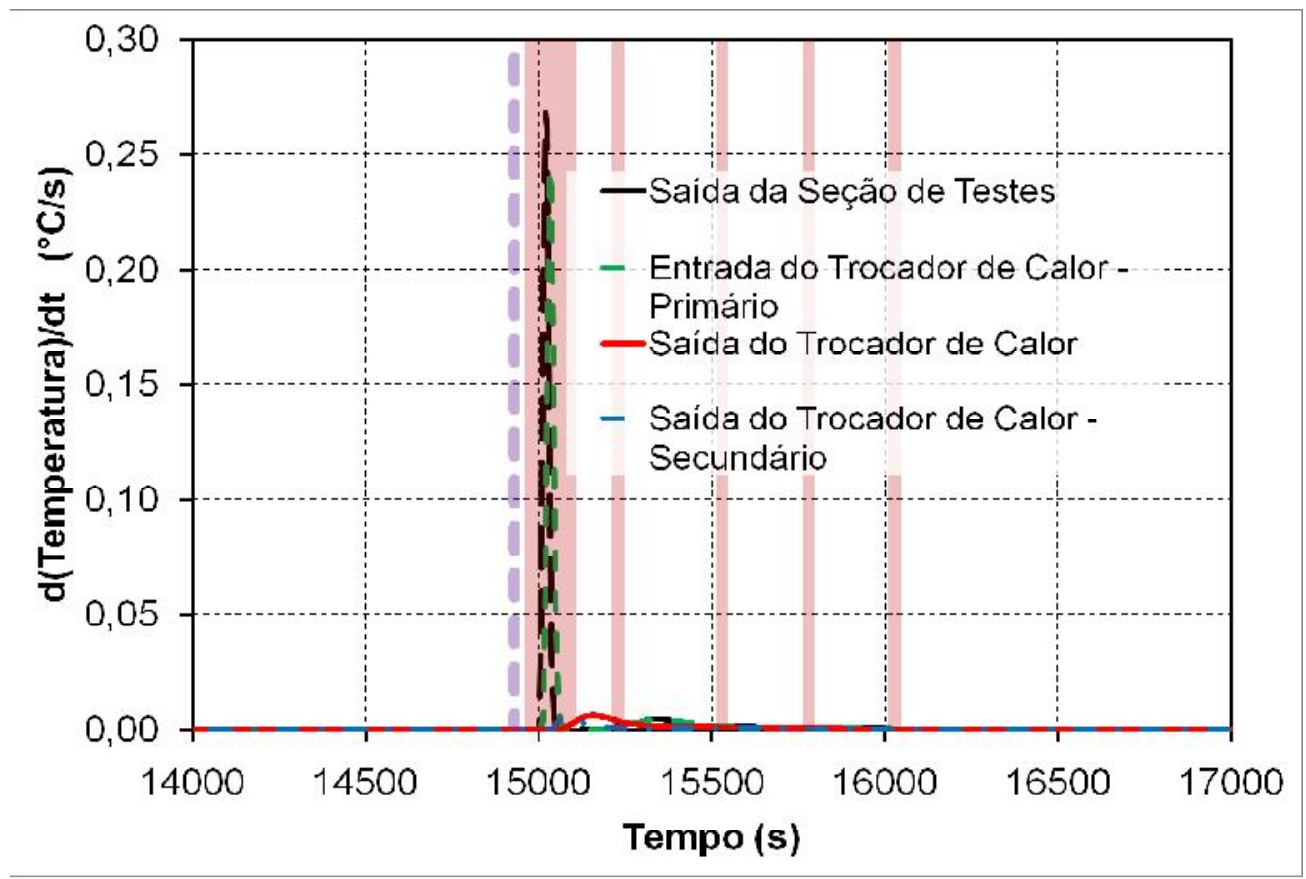

GRÁFICO 179 Amostragem de derivadas de temperaturas para todos os conjuntos de buffers de treinamento da simulação de degraus crescentes

Fonte: resultado de simulações da pesquisa 


\section{Rampas de 240 s Crescentes}

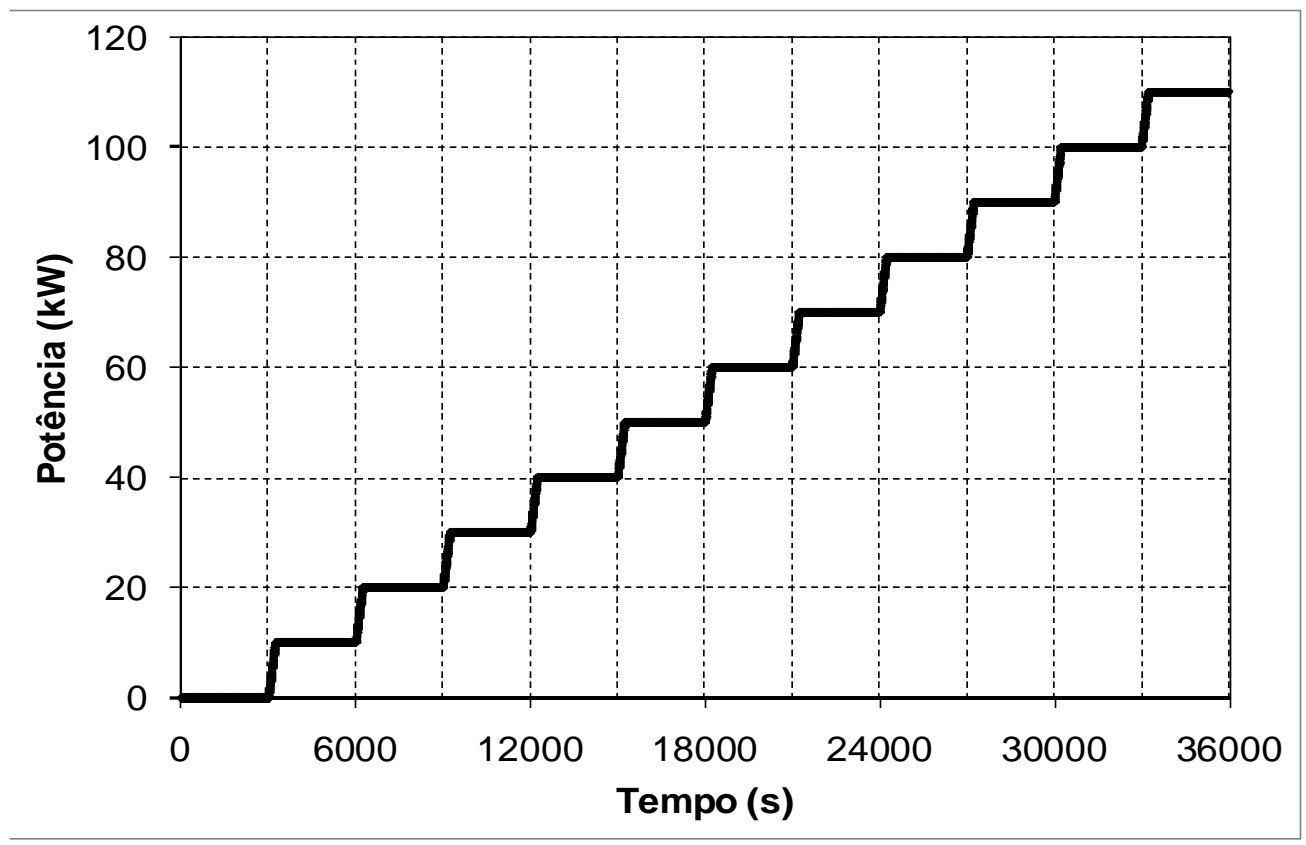

GRÁFICO 180 Potência na seção de testes para rampas de $240 \mathrm{~s}$ crescentes Fonte: resultado de simulações da pesquisa

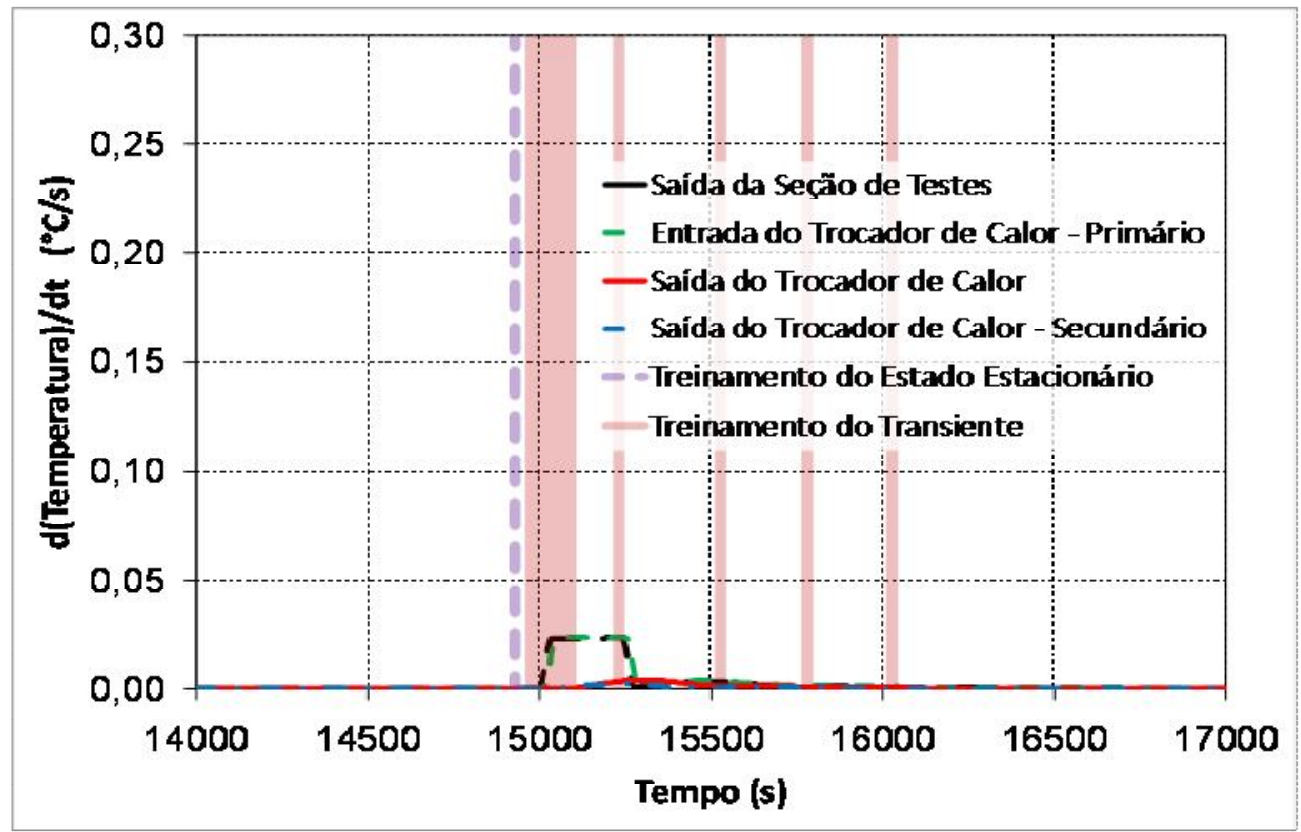

GRÁFICO 181 Amostragem de derivadas de temperaturas para todos os conjuntos de buffers de treinamento da simulação de rampas de $240 \mathrm{~s}$ crescentes

Fonte: resultado de simulações da pesquisa 


\section{Desligamento da Bomba do Secundário (DESLBS)}
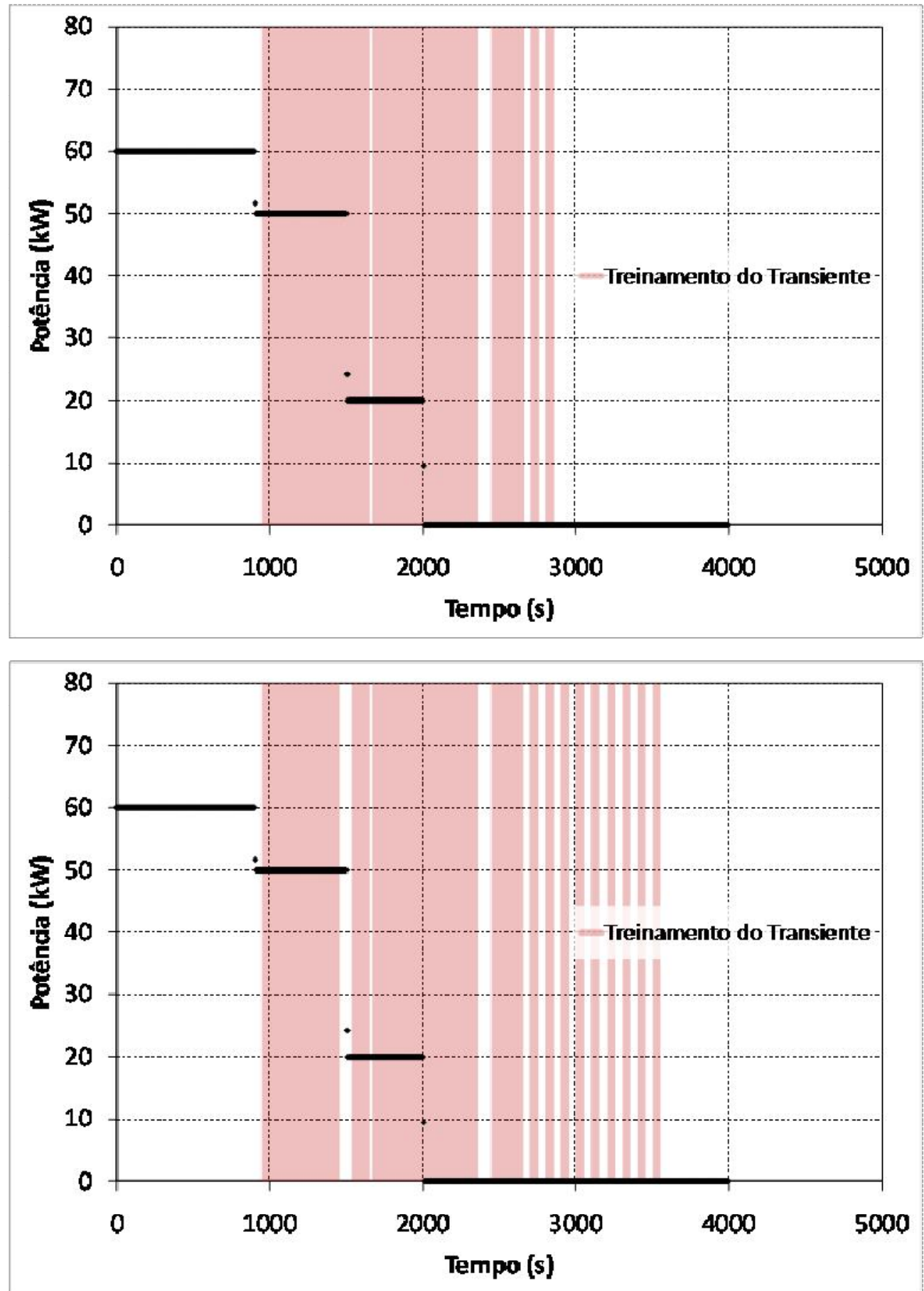

GRÁFICO 182 Amostragem da potência, para os conjuntos de buffers de treinamento, ALLOLD acima e todos os demais abaixo, da simulação do desligamento da bomba do secundário (DESLBS60)

Fonte: resultado de simulações da pesquisa 

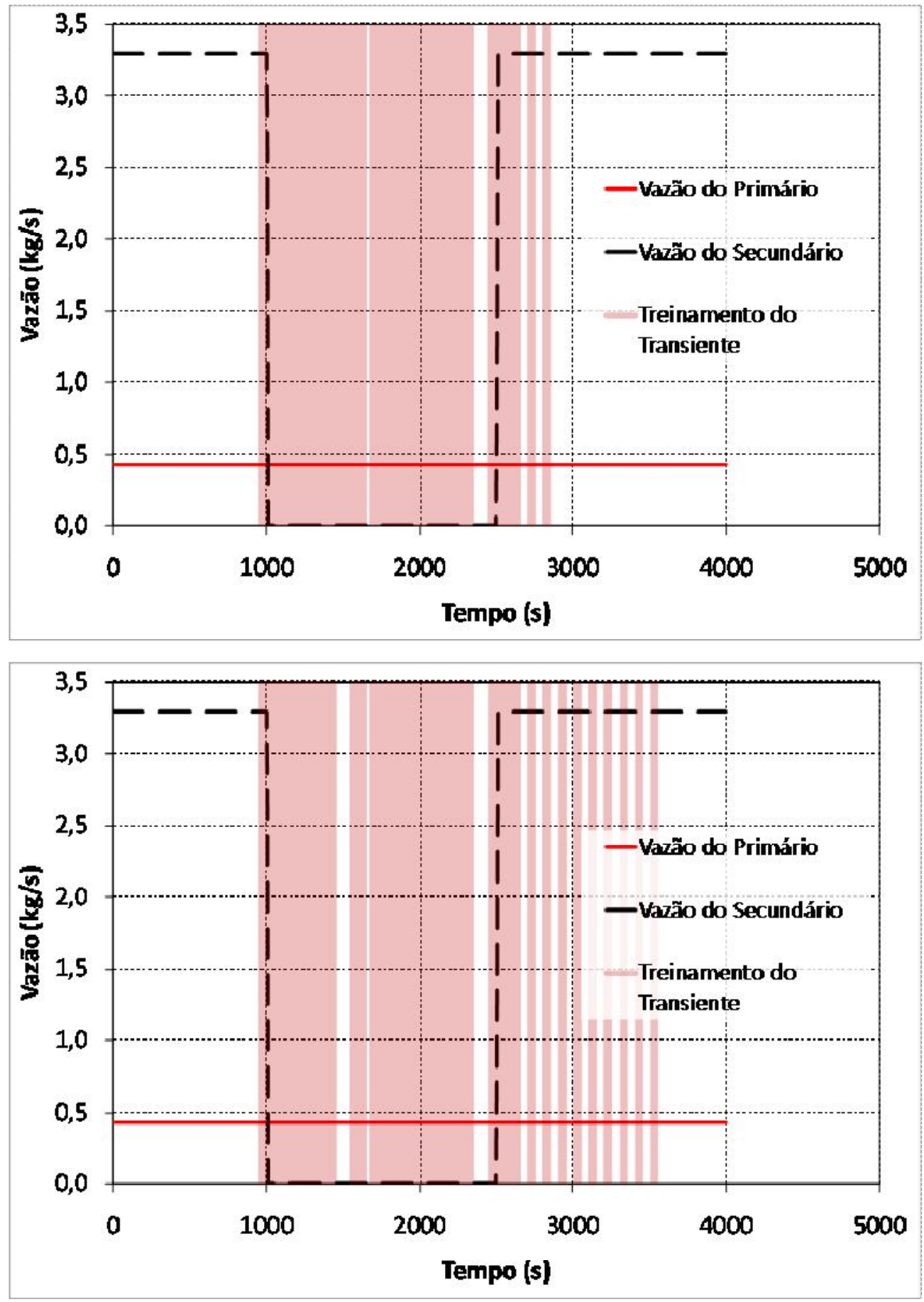

GRÁFICO 183 Amostragem da vazão, para os conjuntos de buffers de treinamento, ALLOLD acima e todos os demais abaixo, da simulação do desligamento da bomba do secundário (DESLBS, DESLBS_2 e DESLBS_3 - 60)

Fonte: resultado de simulações da pesquisa 

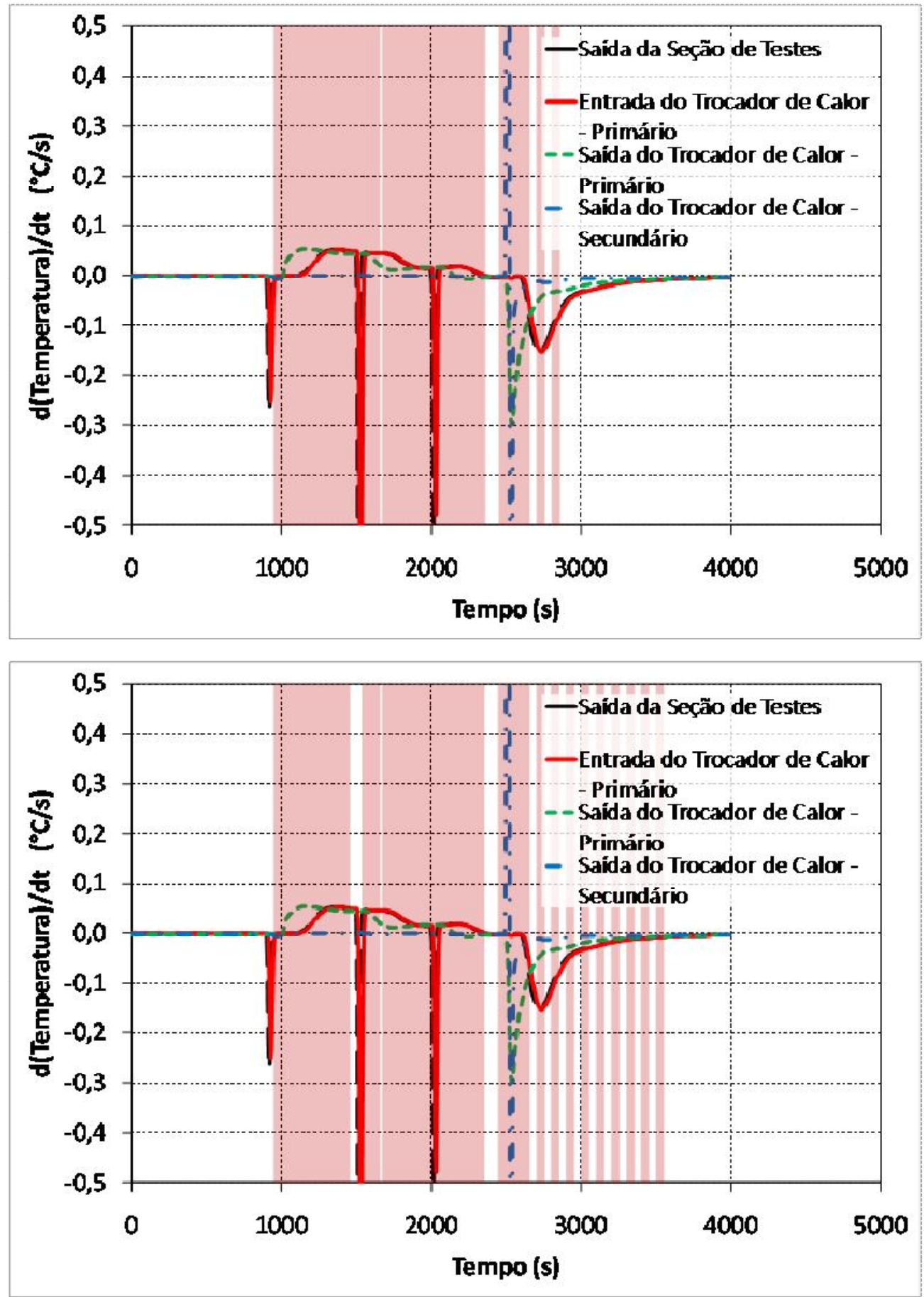

GRÁFICO 184 Amostragem de derivadas de temperaturas, para os conjuntos de buffers de treinamento, ALLOLD acima e todos os demais abaixo, da simulação de o desligamento da bomba do secundário (DESLBS60)

Fonte: resultado de simulações da pesquisa 


\section{Desligamento da Bomba do Secundário (DESLBS2)}
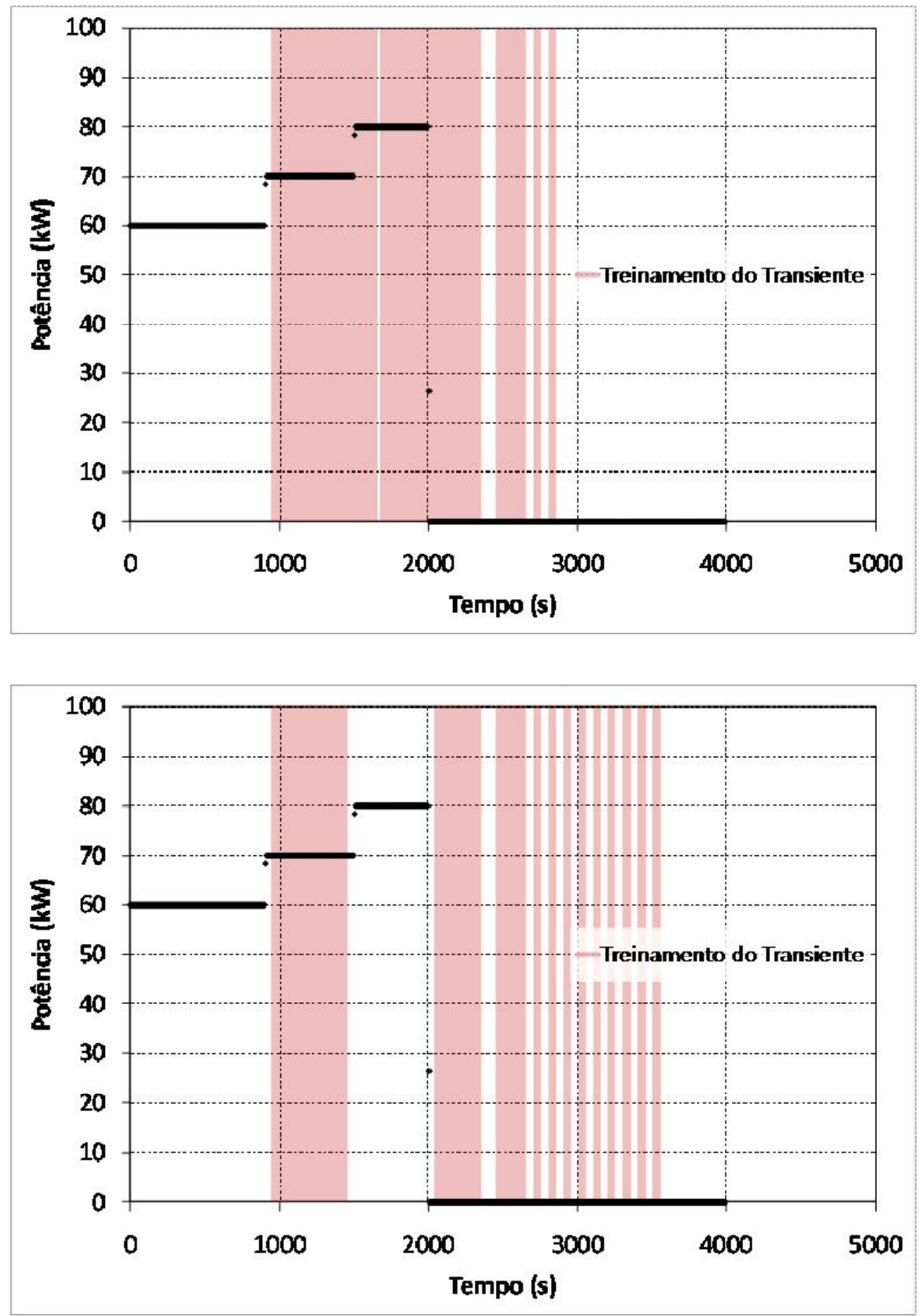

GRÁFICO 185 Amostragem da potência, para os conjuntos de buffers de treinamento, ALLOLD acima e todos os demais abaixo, da simulação do desligamento da bomba do secundário (DESLBS_2 60)

Fonte: resultado de simulações da pesquisa 

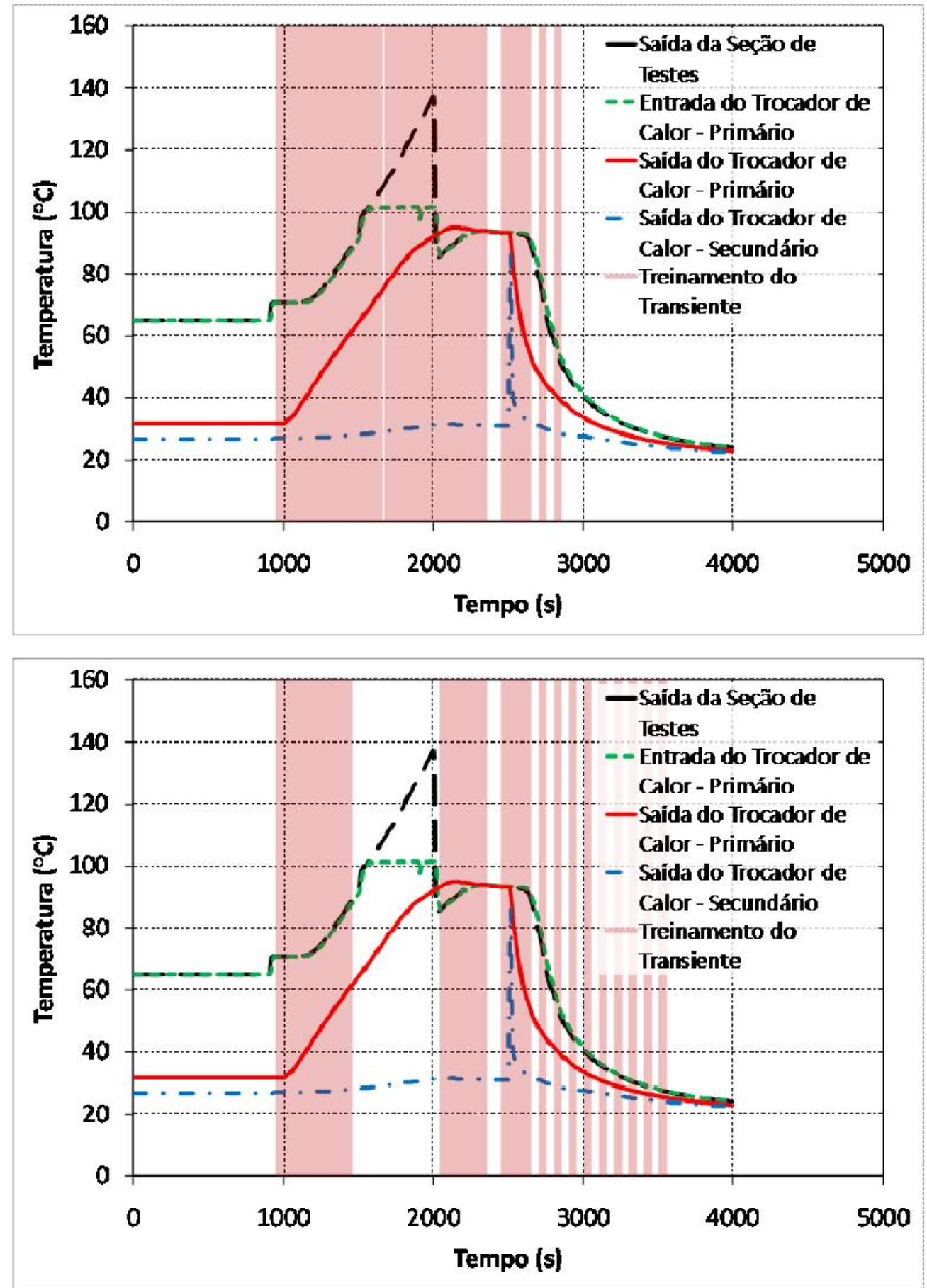

GRÁFICO 186 Amostragem de temperaturas, para os conjuntos de buffers de treinamento, ALLOLD acima e todos os demais abaixo, da simulação do desligamento da bomba do secundário (DESLBS_2 60)

Fonte: resultado de simulações da pesquisa 

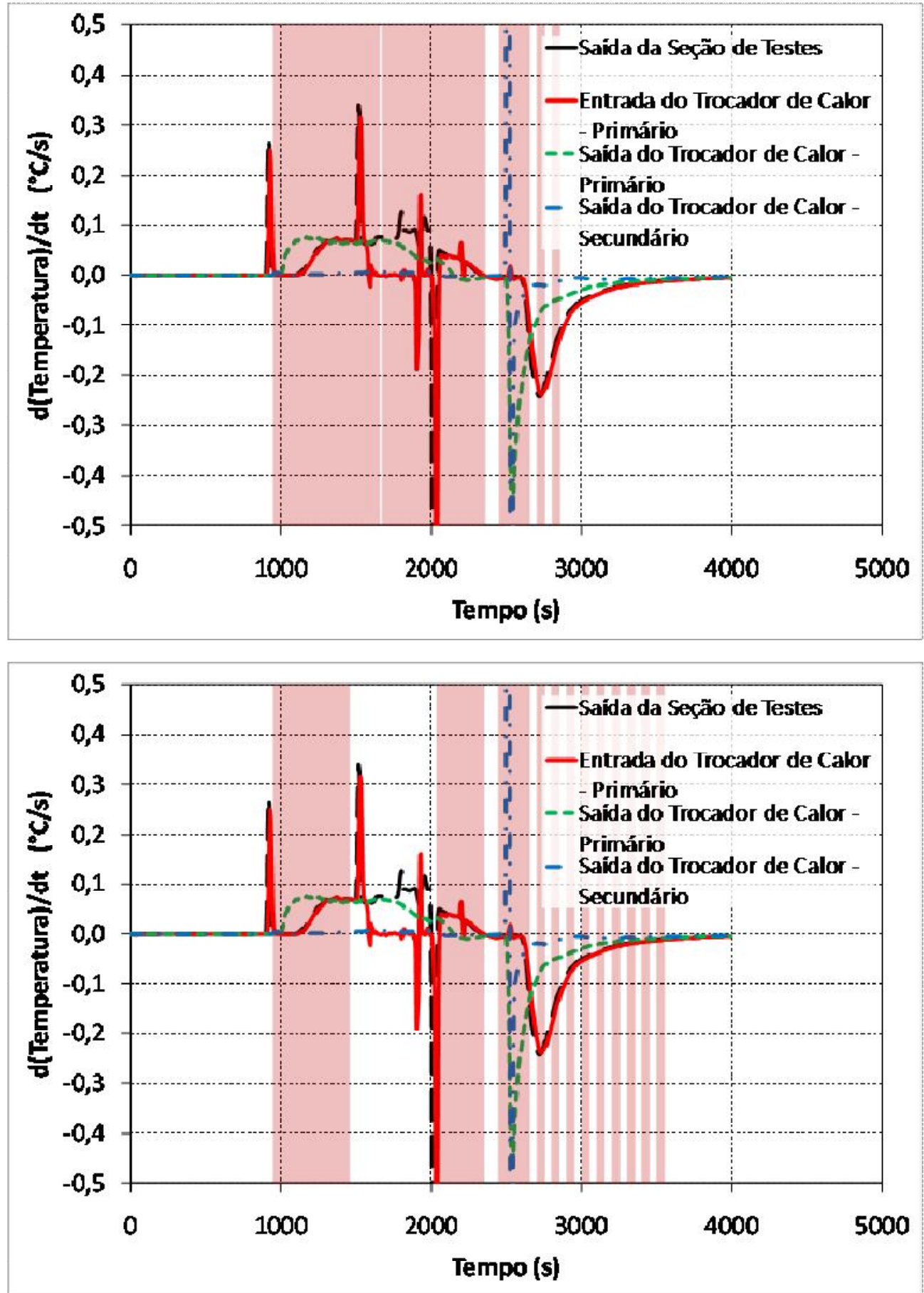

GRÁFICO 187 Amostragem de derivadas de temperaturas, para os conjuntos de buffers de treinamento, ALLOLD acima e todos os demais abaixo, da simulação do desligamento da bomba do secundário (DESLBS_260)

Fonte: resultado de simulações da pesquisa 


\section{Desligamento da Bomba do Secundário (DESLBS_3)}
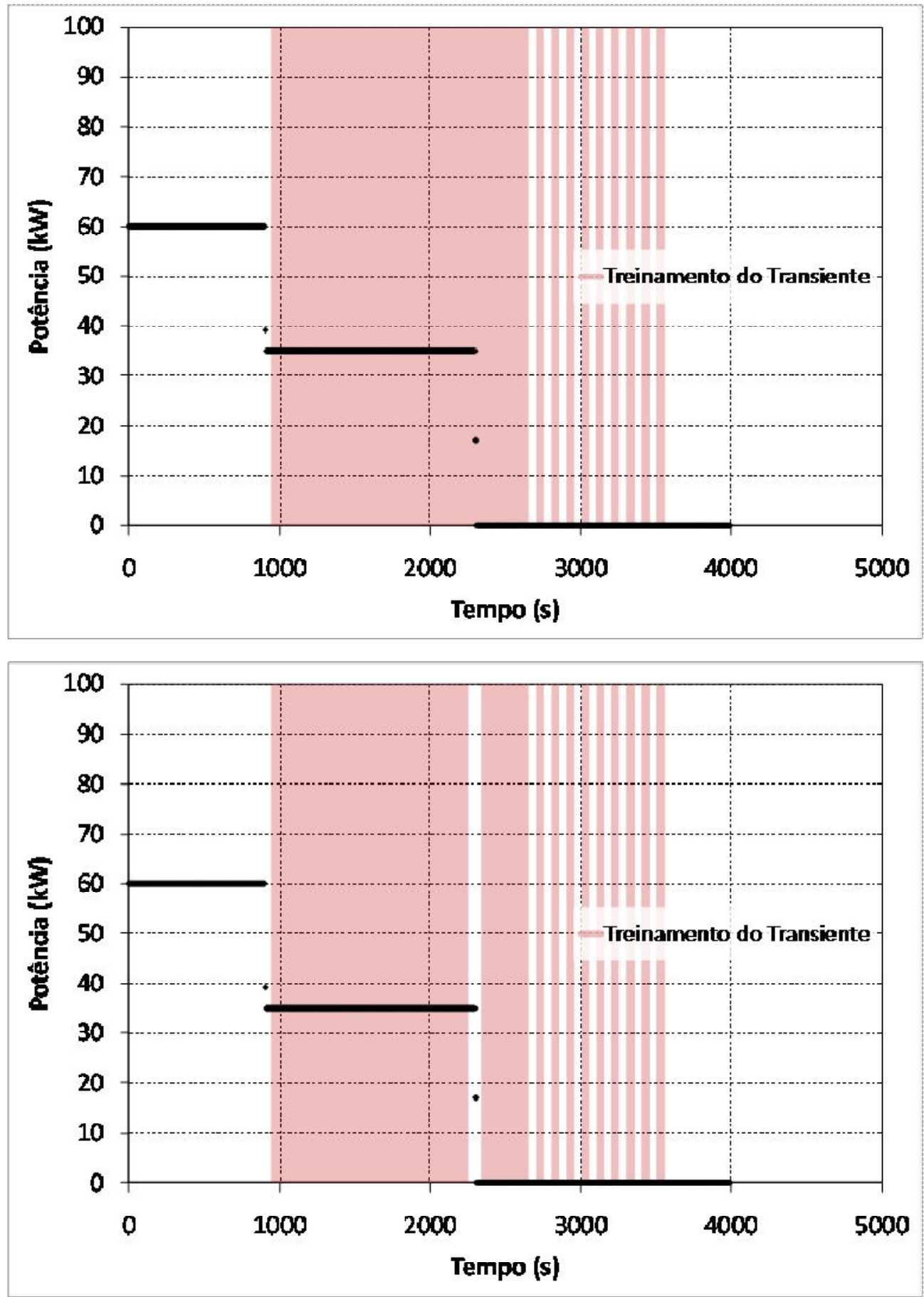

GRÁFICO 188 Amostragem da potência, para os conjuntos de buffers de treinamento, ALLOLD acima e todos os demais abaixo, da simulação do desligamento da bomba do secundário (DESLBS_3 60)

Fonte: resultado de simulações da pesquisa 


\section{Isolamento da Bomba do Secundário (ISOLABS)}
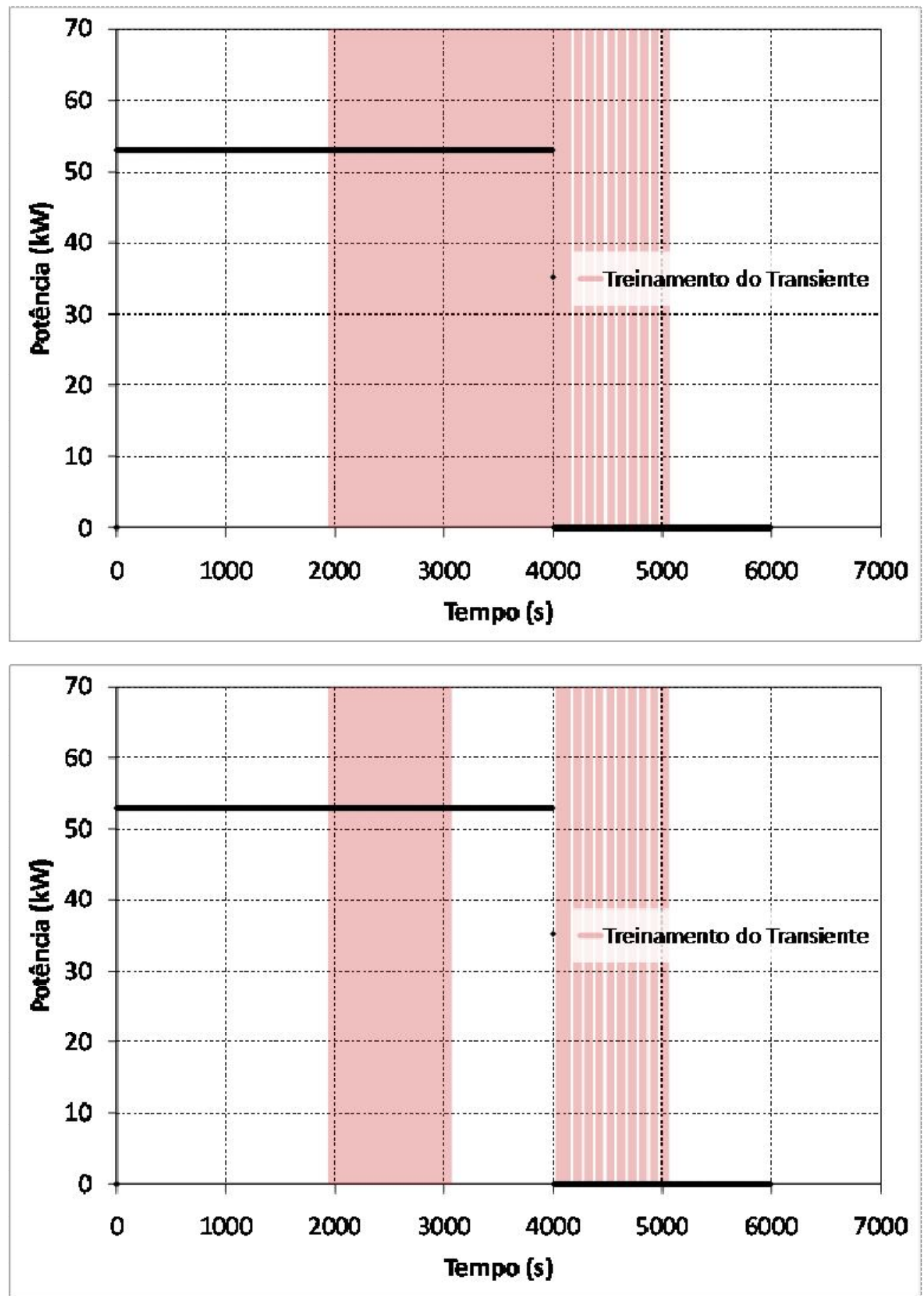

GRÁFICO 189 Amostragem da potência, para os conjuntos de buffers de treinamento, ALLOLD acima e todos os demais abaixo, da simulação do isolamento da bomba do secundário (ISOLABS)

Fonte: resultado de simulações da pesquisa 


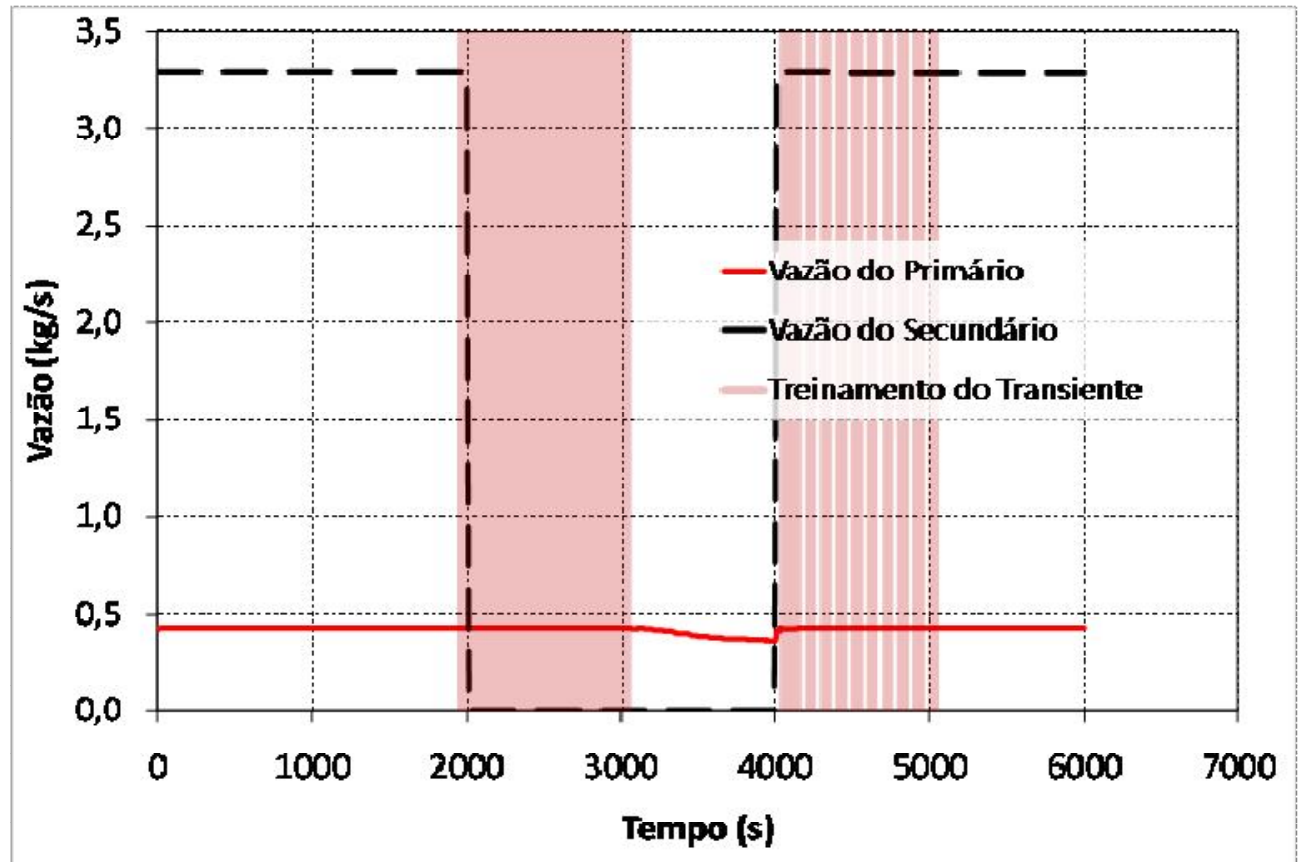

GRÁFICO 190 Amostragem da vazão, para todos os conjuntos de buffers de treinamento, exceto para o ALLOLD, da simulação do isolamento da bomba do secundário (ISOLABS)

Fonte: resultado de simulações da pesquisa

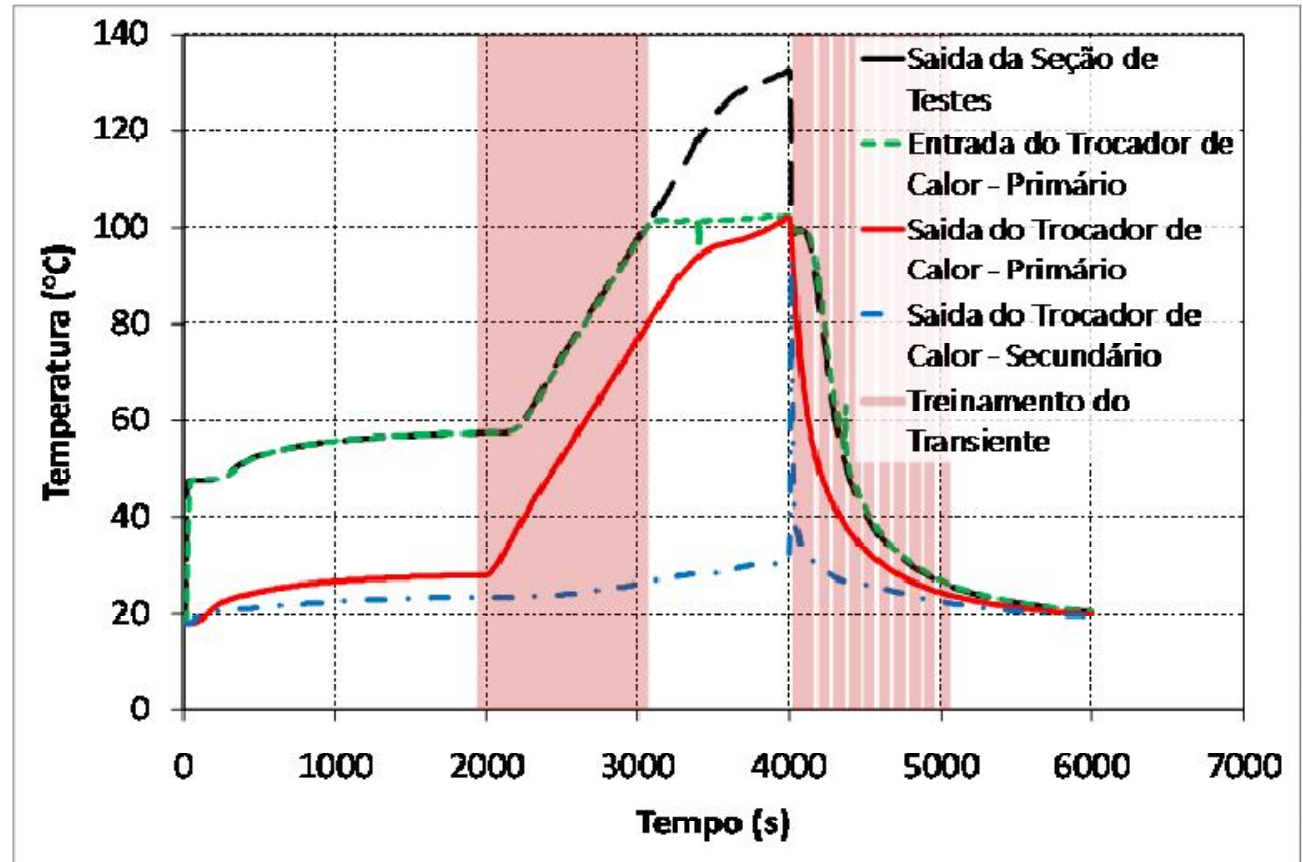

GRÁFICO 191 Amostragem de temperaturas, para todos os conjuntos de buffers de treinamento, exceto para o ALLOLD, da simulação do isolamento da bomba do secundário (ISOLABS)

Fonte: resultado de simulações da pesquisa 
Isolam ento da Bomba do Secundário (ISOLABS_25)
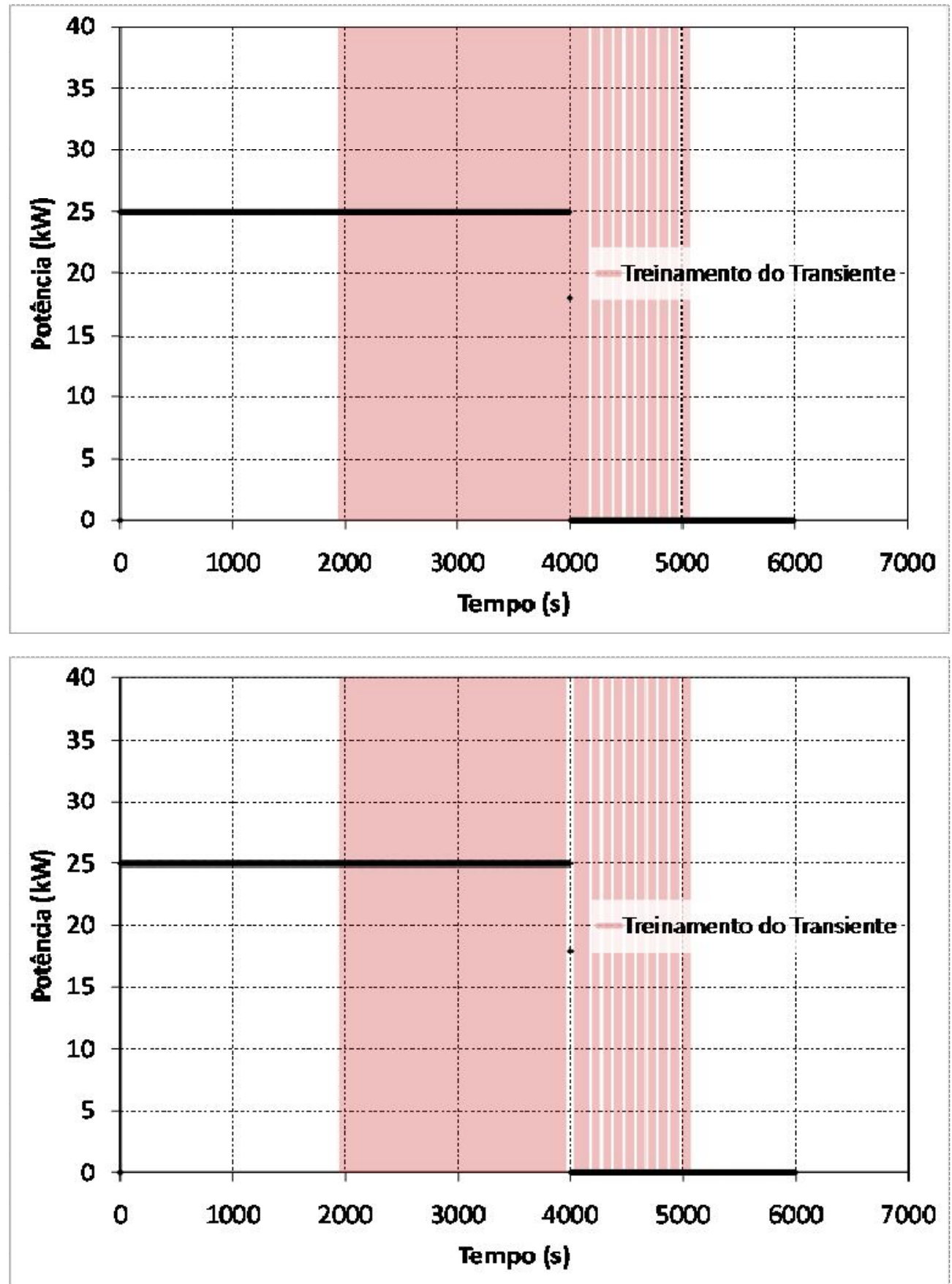

GRÁFICO 192 Amostragem da potência, para os conjuntos de buffers de treinamento, ALLOLD acima e todos os demais abaixo, da simulação do isolamento da bomba do secundário (ISOLABS_25)

Fonte: resultado de simulações da pesquisa 


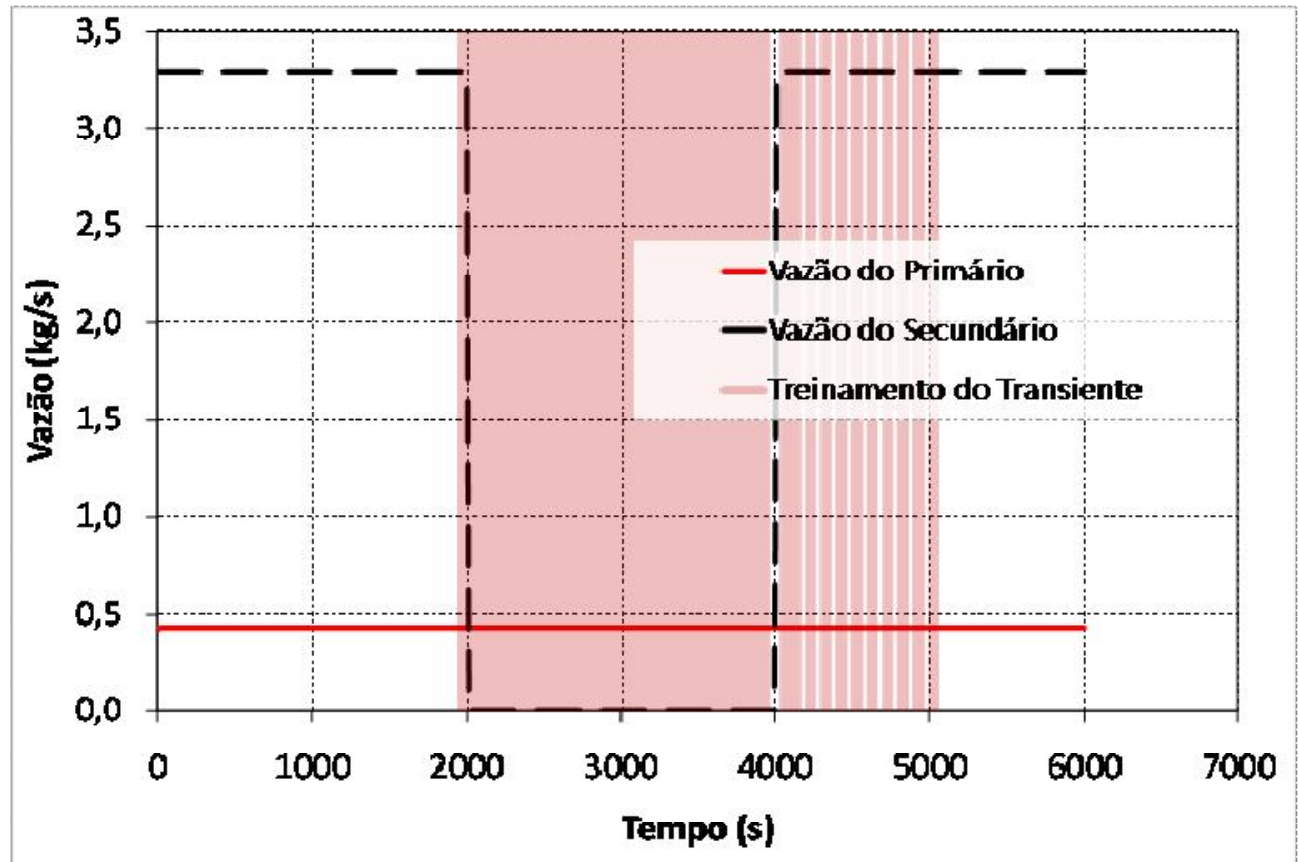

GRÁFICO 193 Amostragem da vazão, para todos os conjuntos de buffers de treinamento, exceto para o ALLOLD, da simulação do isolamento da bomba do secundário (ISOLABS_25)

Fonte: resultado de simulações da pesquisa

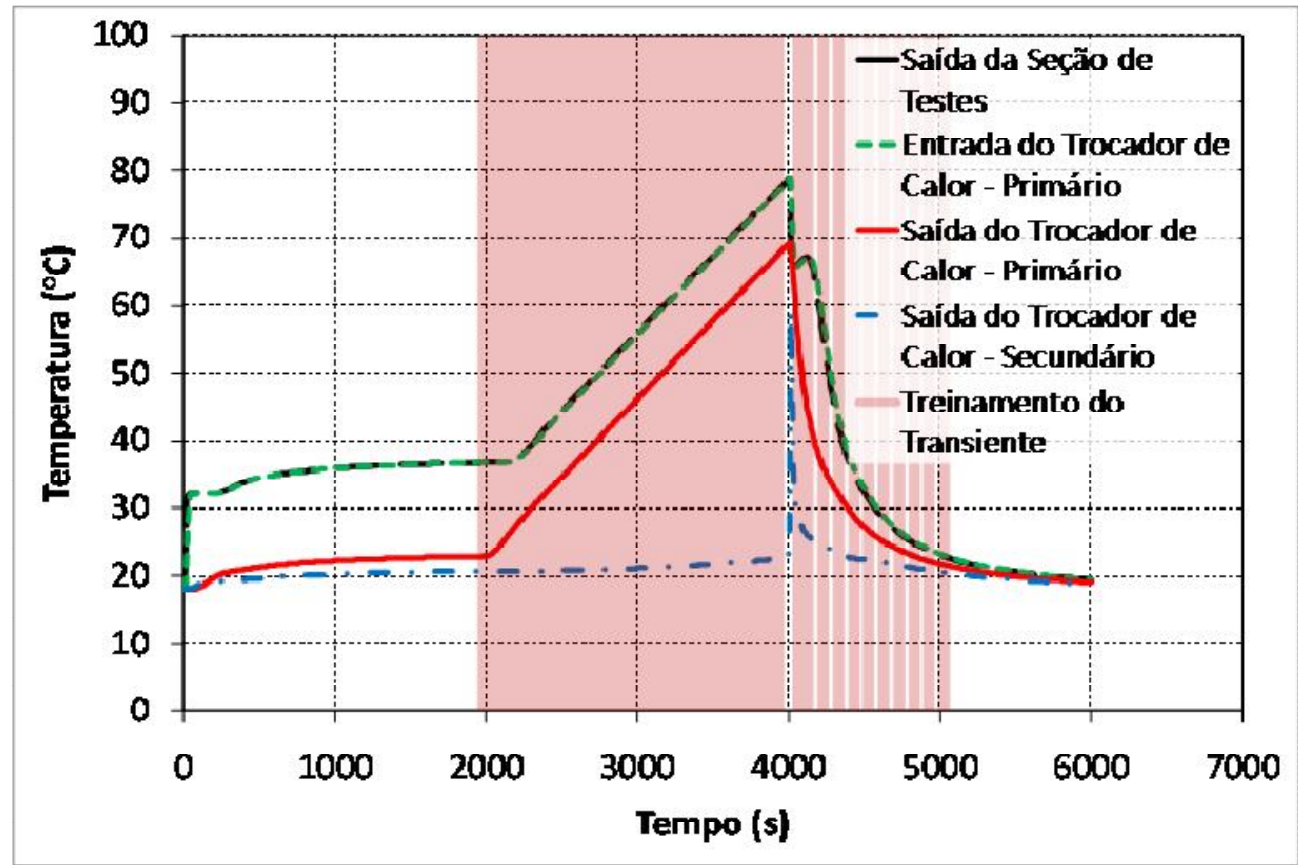

GRÁFICO 194 Amostragem de temperaturas, para todos os conjuntos de buffers de treinamento, exceto para o ALLOLD, da simulação do isolamento da bomba do secundário (ISOLABS_25)

Fonte: resultado de simulações da pesquisa 
Isolamento da Bomba do Secundário (ISOLABS_75)
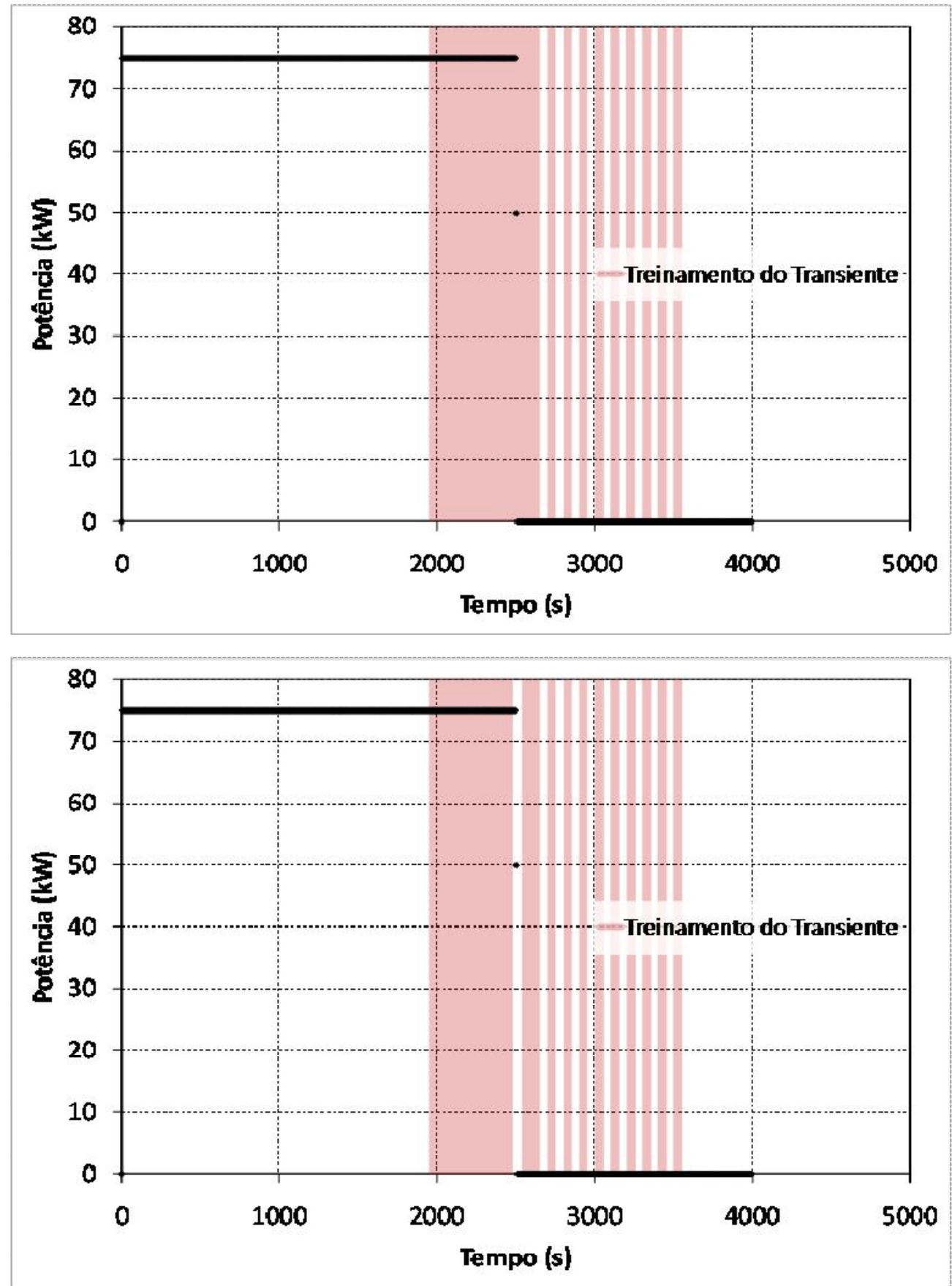

GRÁFICO 195 Amostragem da potência, para os conjuntos de buffers de treinamento, ALLOLD acima e todos os demais abaixo, da simulação do isolamento da bomba do secundário (ISOLABS_75)

Fonte: resultado de simulações da pesquisa 


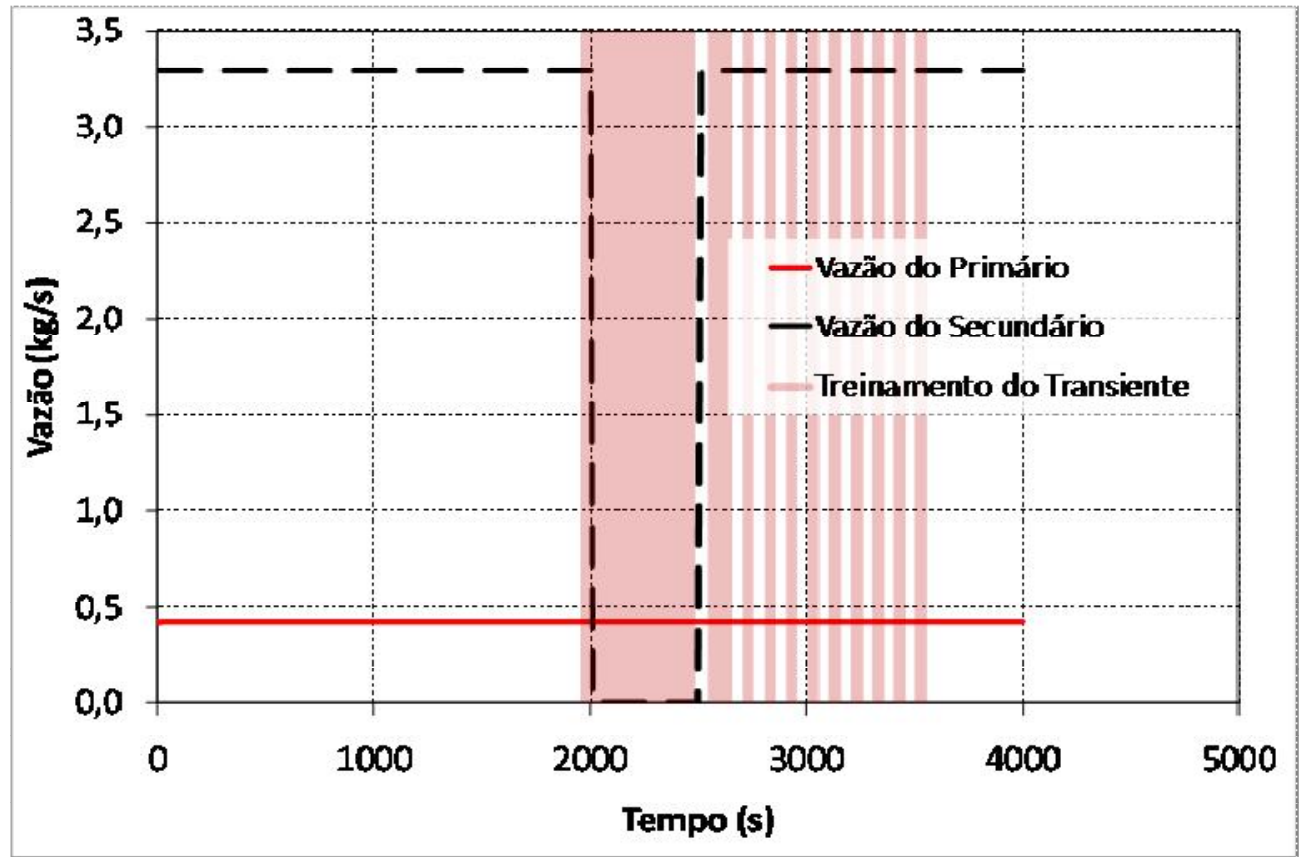

GRÁFICO 196 Amostragem da vazão, para todos os conjuntos de buffers de treinamento, exceto para o ALLOLD, da simulação do isolamento da bomba do secundário (ISOLABS_75)

Fonte: resultado de simulações da pesquisa

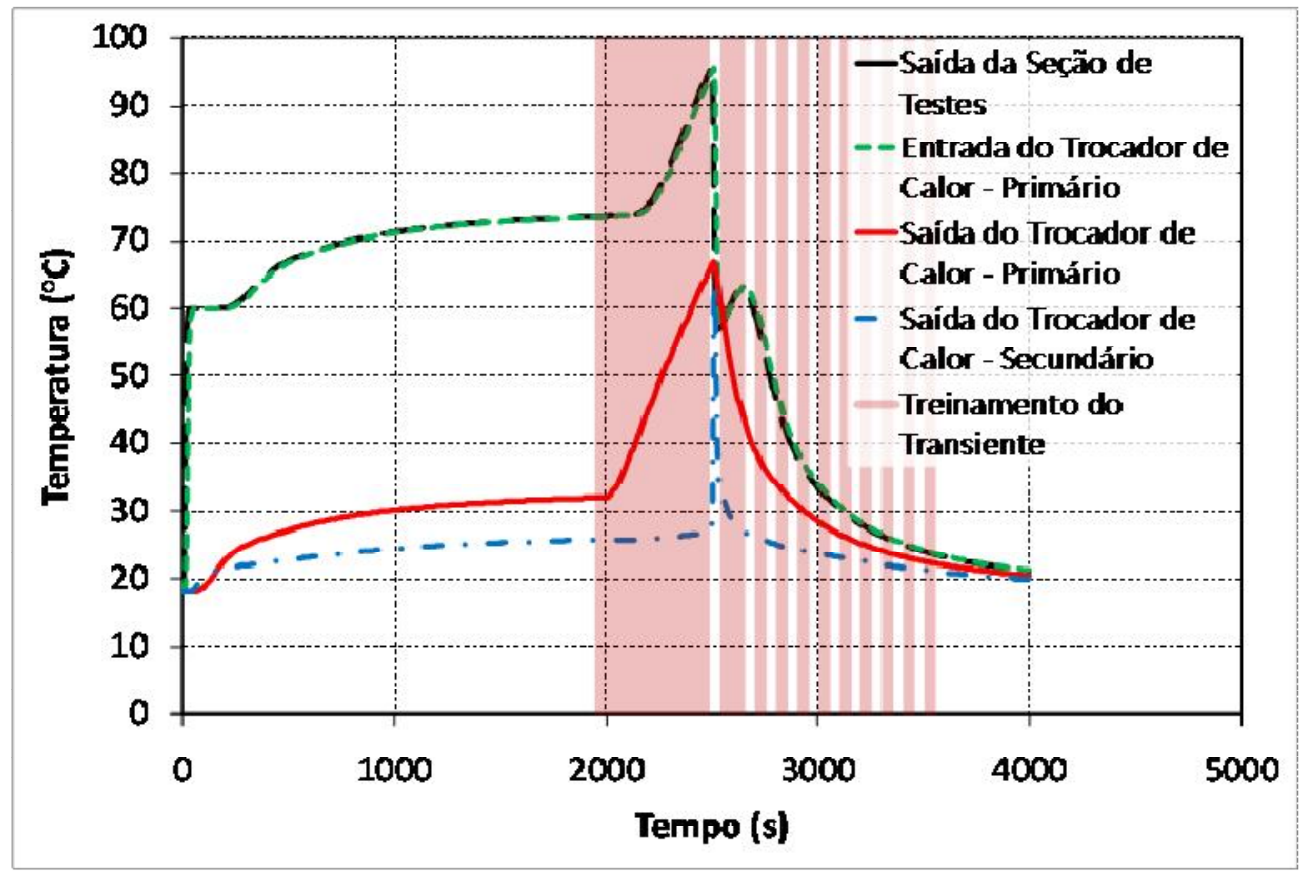

GRÁFICO 197 Amostragem de temperaturas, para todos os conjuntos de buffers de treinamento, exceto para o ALLOLD, da simulação do isolamento da bomba do secundário (ISOLABS_75)

Fonte: resultado de simulações da pesquisa 


\section{Isolam ento do Trocador de Calor (ISOLATC)}

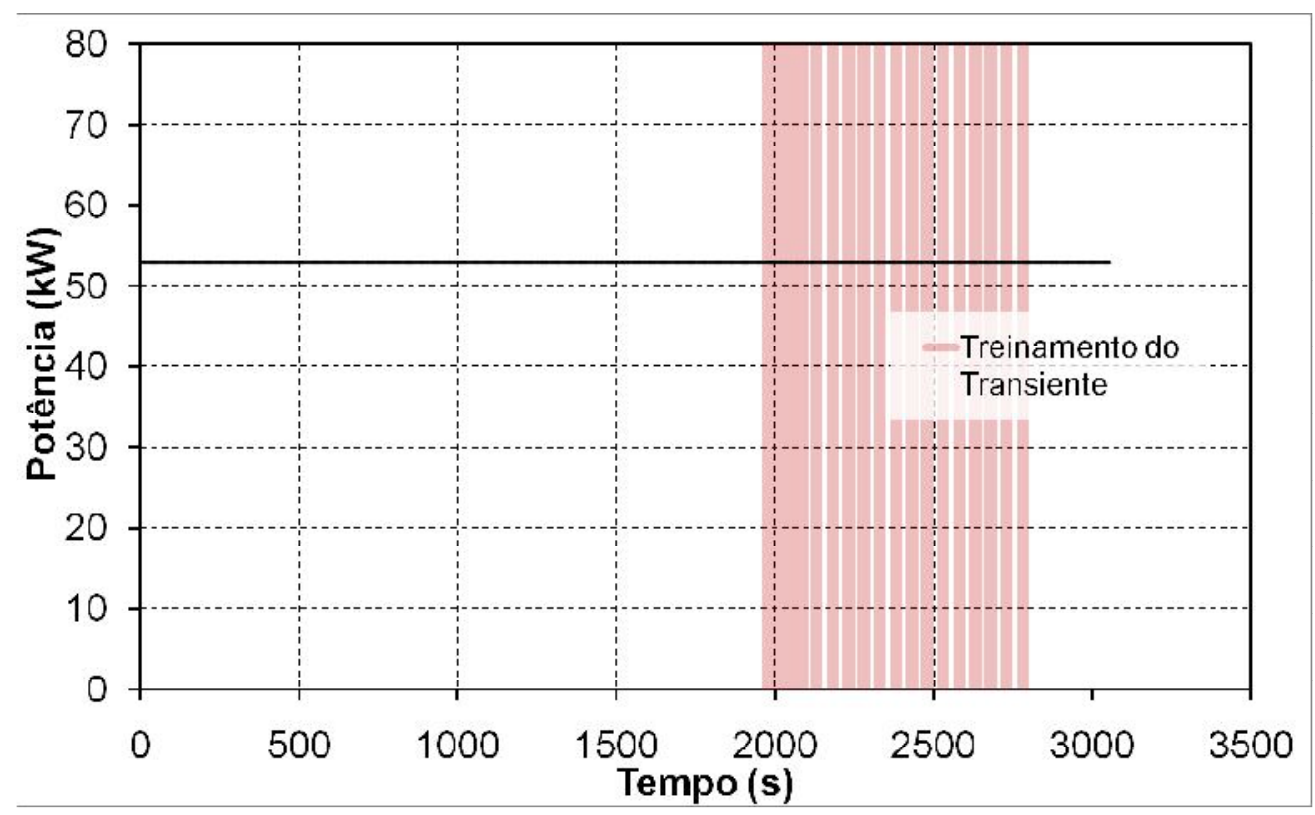

GRÁFICO 198 Amostragem da potência, para o conjunto de buffers de treinamento ALLOLD, da simulação do isolamento do trocador de calor (ISOLATC)

Fonte: resultado de simulações da pesquisa

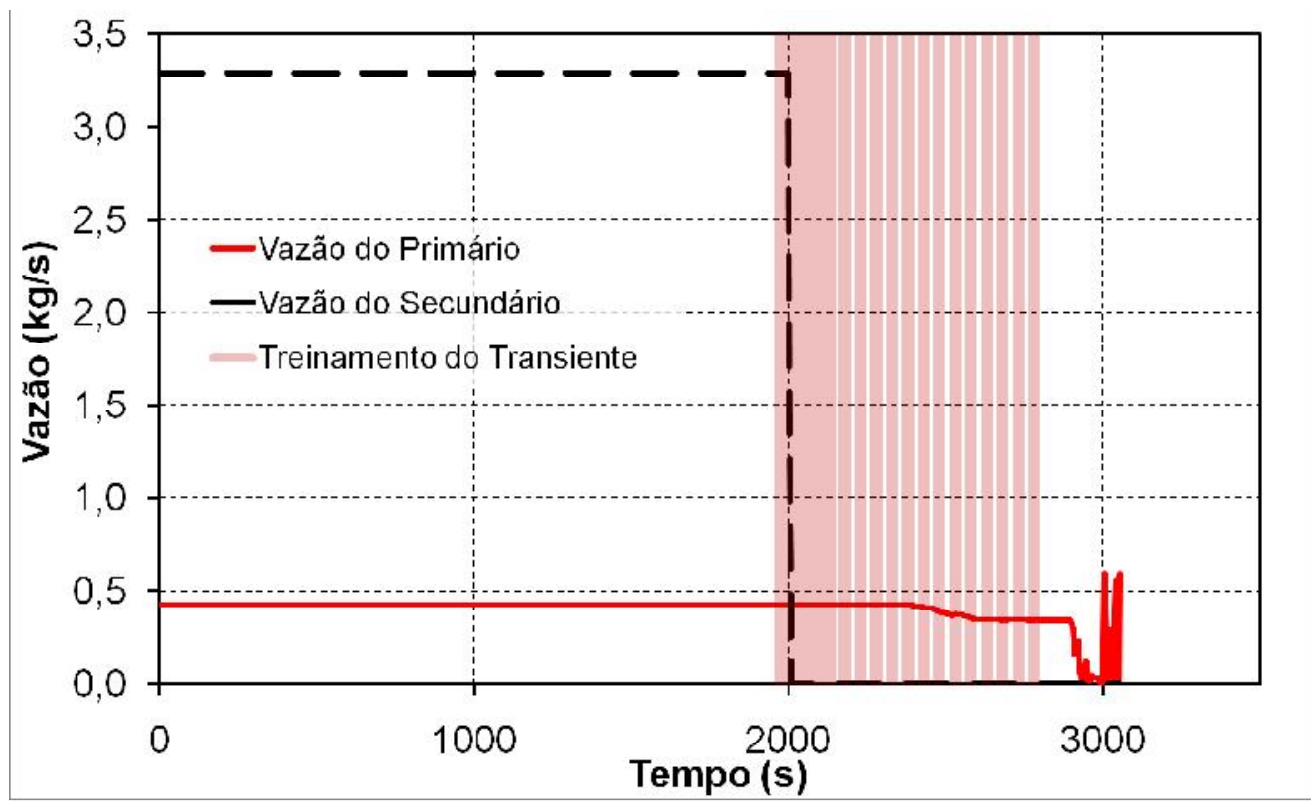

GRÁFICO 199 Amostragem da vazão, para o conjunto de buffers de treinamento ALLOLD, da simulação do isolamento do trocador de calor (ISOLATC)

Fonte: resultado de simulações da pesquisa 

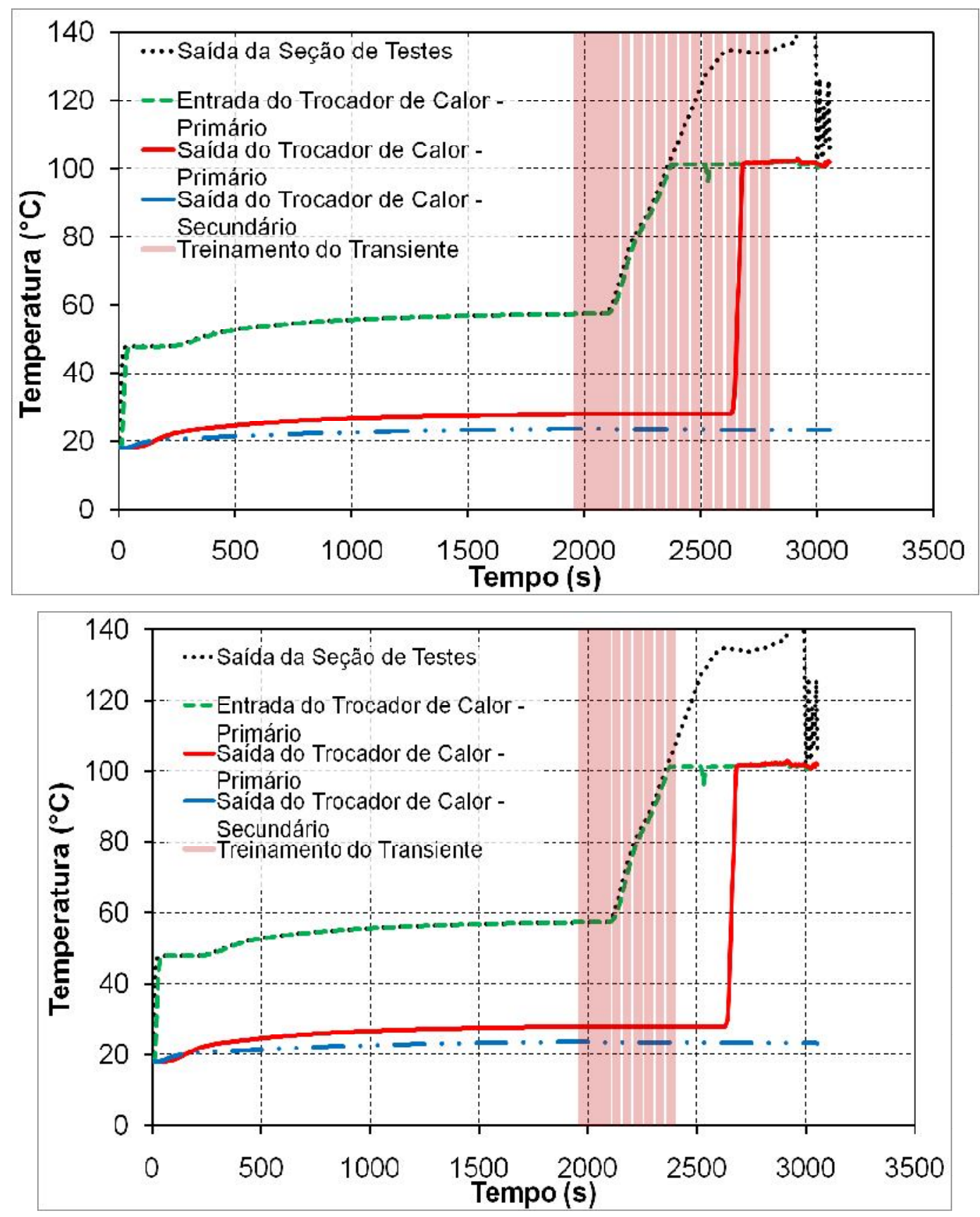

GRÁFICO 200 Amostragem das Temperaturas de entrada e saída, da ST e do Trocador de Calor, para os conjuntos de buffers de treinamento, ALLOLD acima e todos os demais abaixo, da simulação do isolamento do trocador de calor (ISOLATC)

Fonte: resultado de simulações da pesquisa 


\section{Isolamento do Trocador de Calor (ISOLATC_25)}

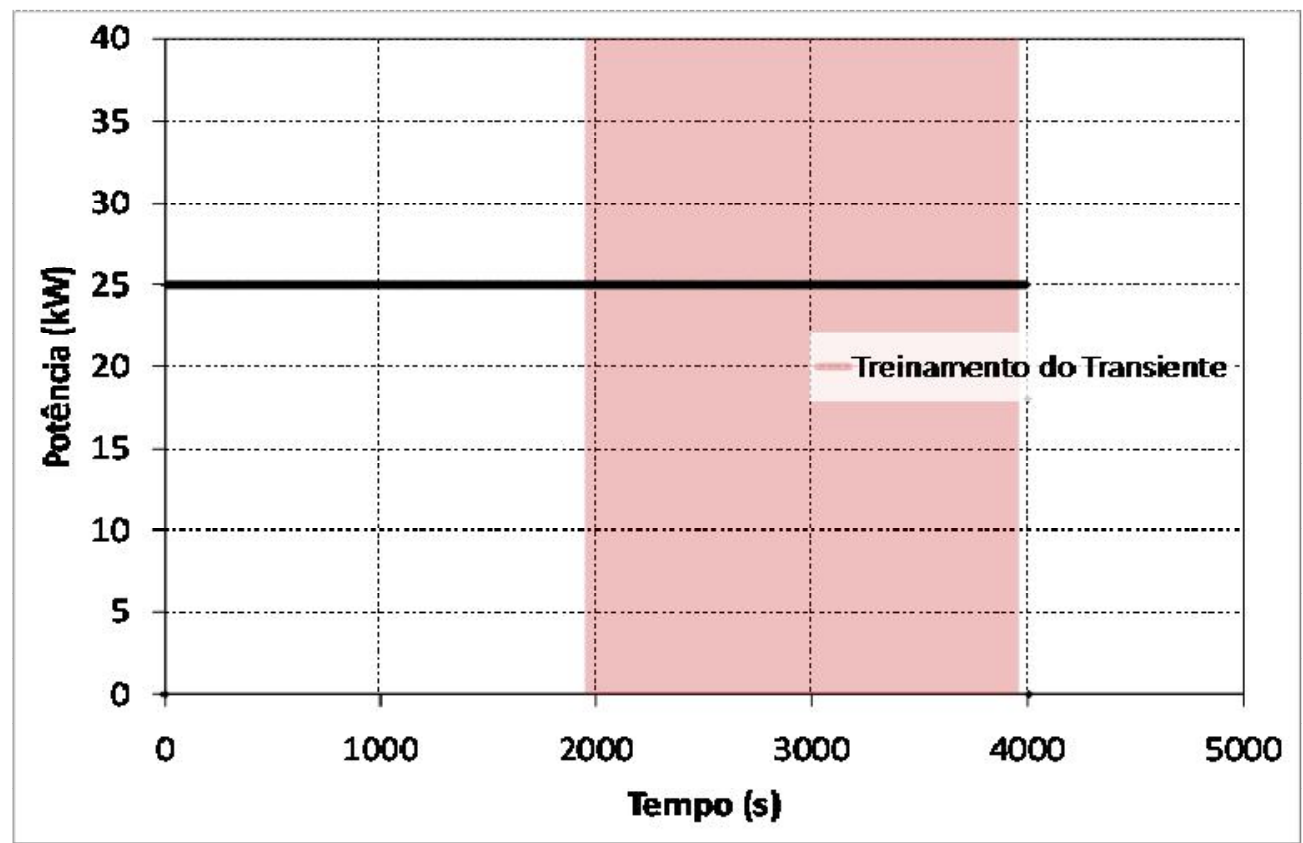

GRÁFICO 201 Amostragem da potência, para todos os conjuntos de buffers de treinamento, da simulação do isolamento do trocador de calor (ISOLATC_25)

Fonte: resultado de simulações da pesquisa

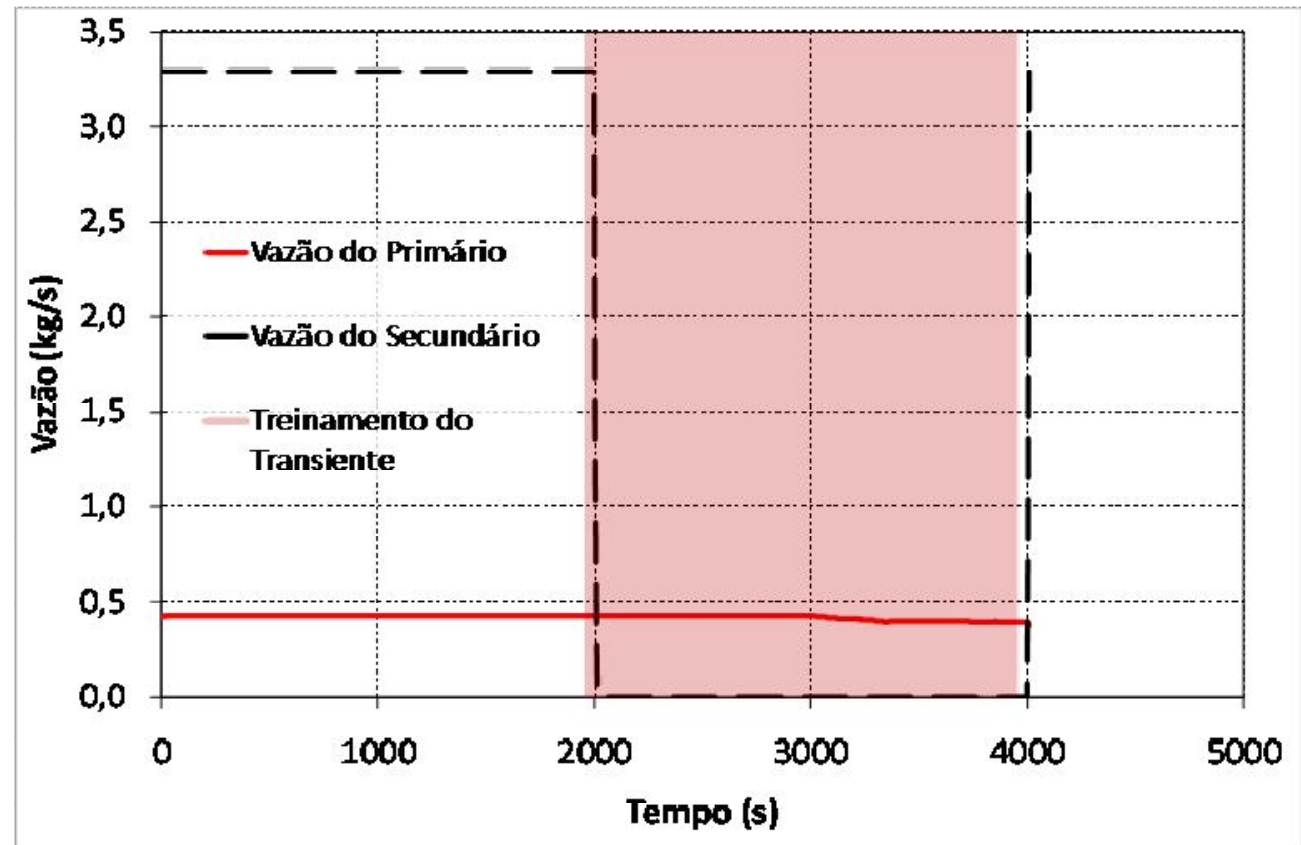

GRÁFICO 202 Amostragem das vazões, para todos os conjuntos de buffers de treinamento, da simulação do isolamento do trocador de calor (ISOLATC_25)

Fonte: resultado de simulações da pesquisa 


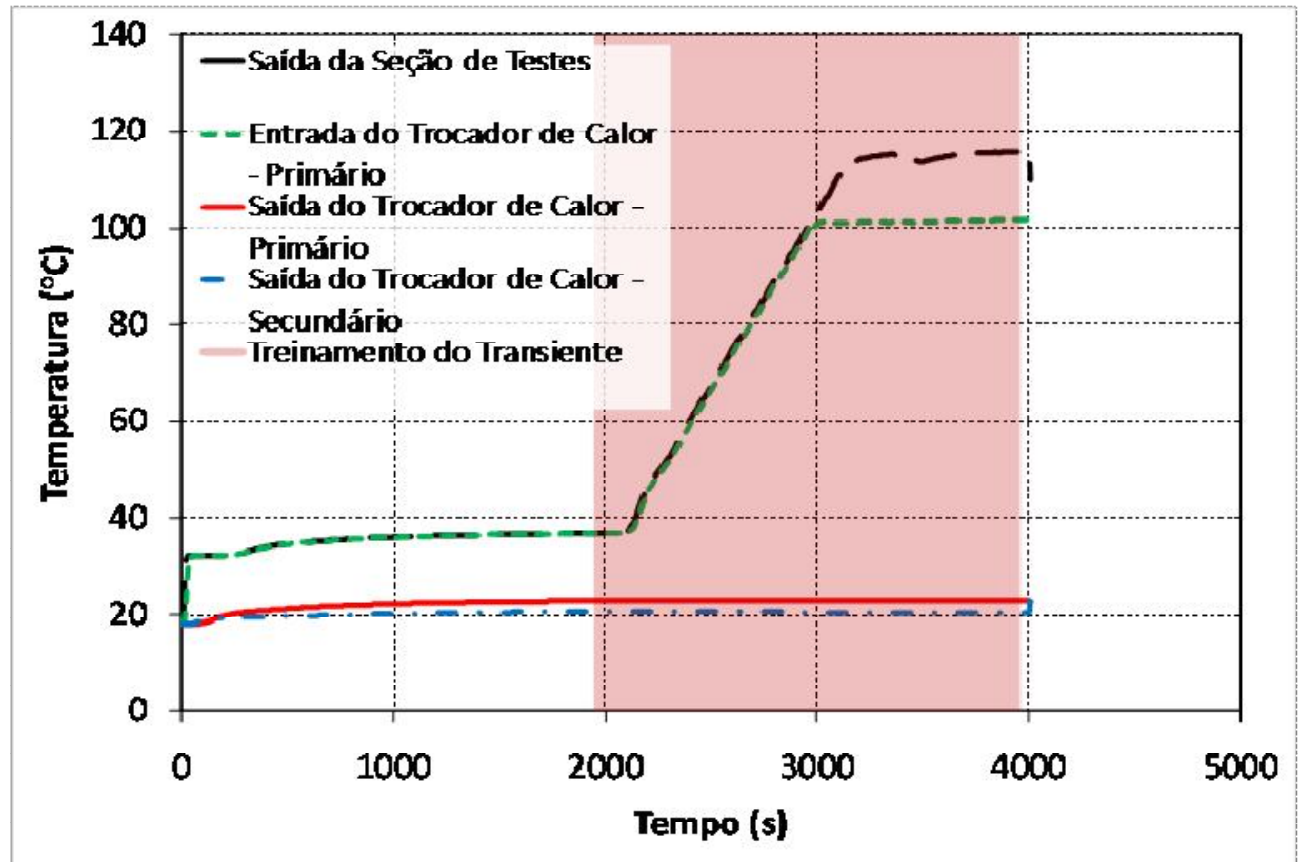

GRÁFICO 203 Amostragem de temperaturas, para todos os conjuntos de buffers de treinamento da simulação "isolamento do trocador de calor" (ISOLATC_25)

Fonte: resultado de simulações da pesquisa

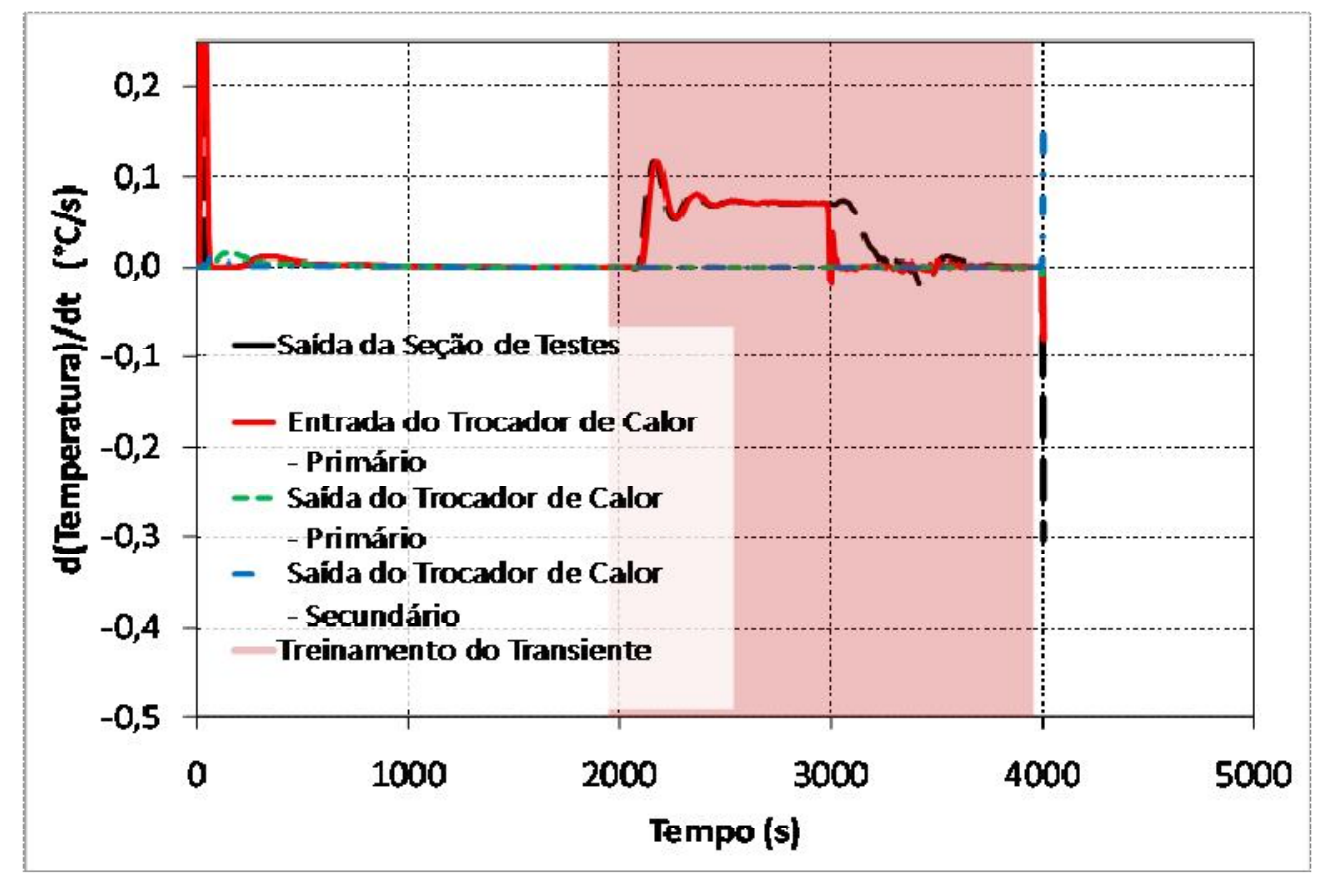

GRÁFICO 204 Amostragem de derivadas de temperaturas, para todos os conjuntos de buffers de treinamento da simulação do isolamento do trocador de calor (ISOLATC_25)

Fonte: resultado de simulações da pesquisa 


\section{Pressurização e Despressurização (PRESSURIZA70k)}
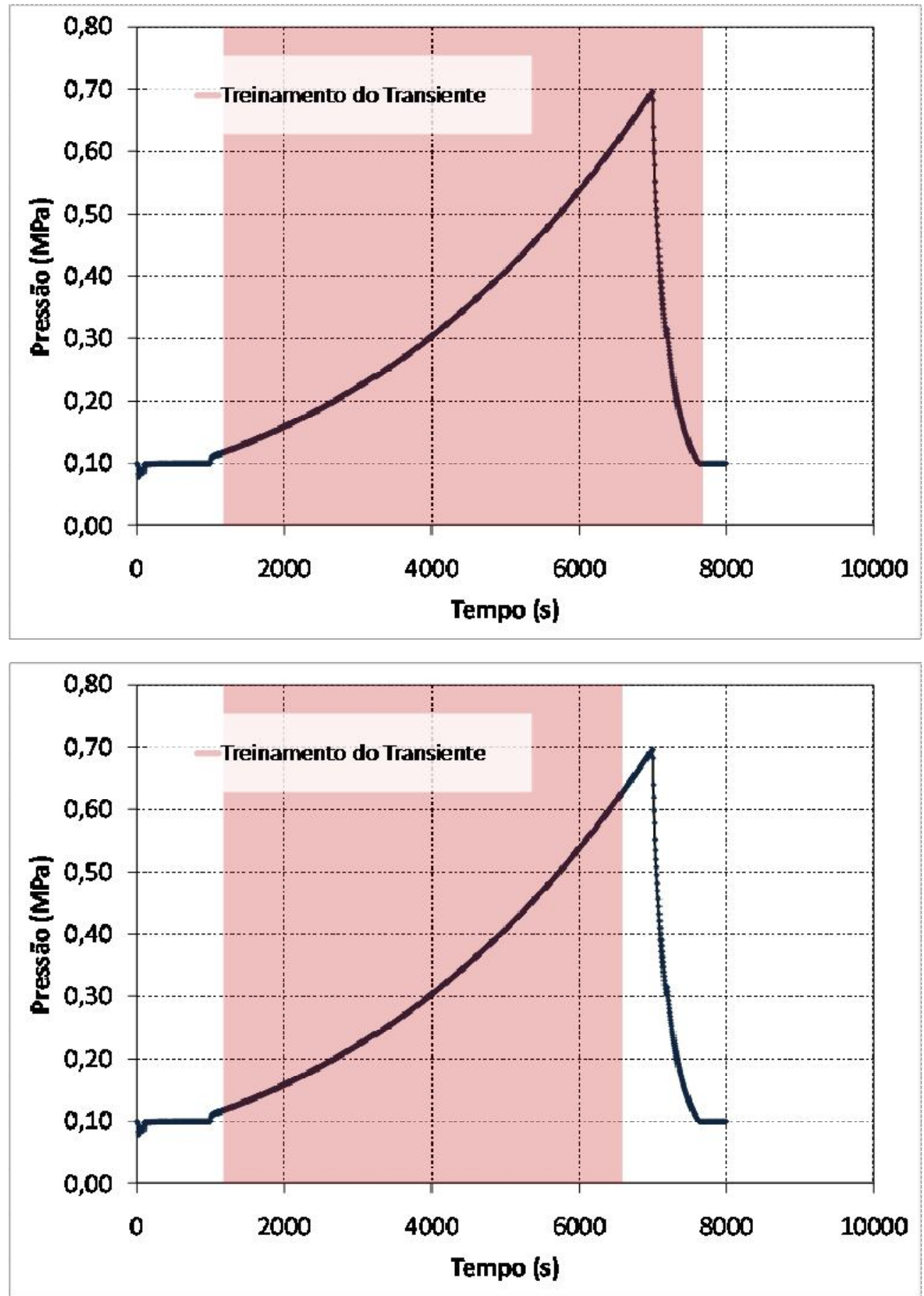

GRÁFICO 205 Amostragem da pressão, para os conjuntos de buffers de treinamento, ALLOLD acima e todos os demais abaixo, da simulação de pressurização e despressurização (PRESSURIZA70k)

Fonte: resultado de simulações da pesquisa 

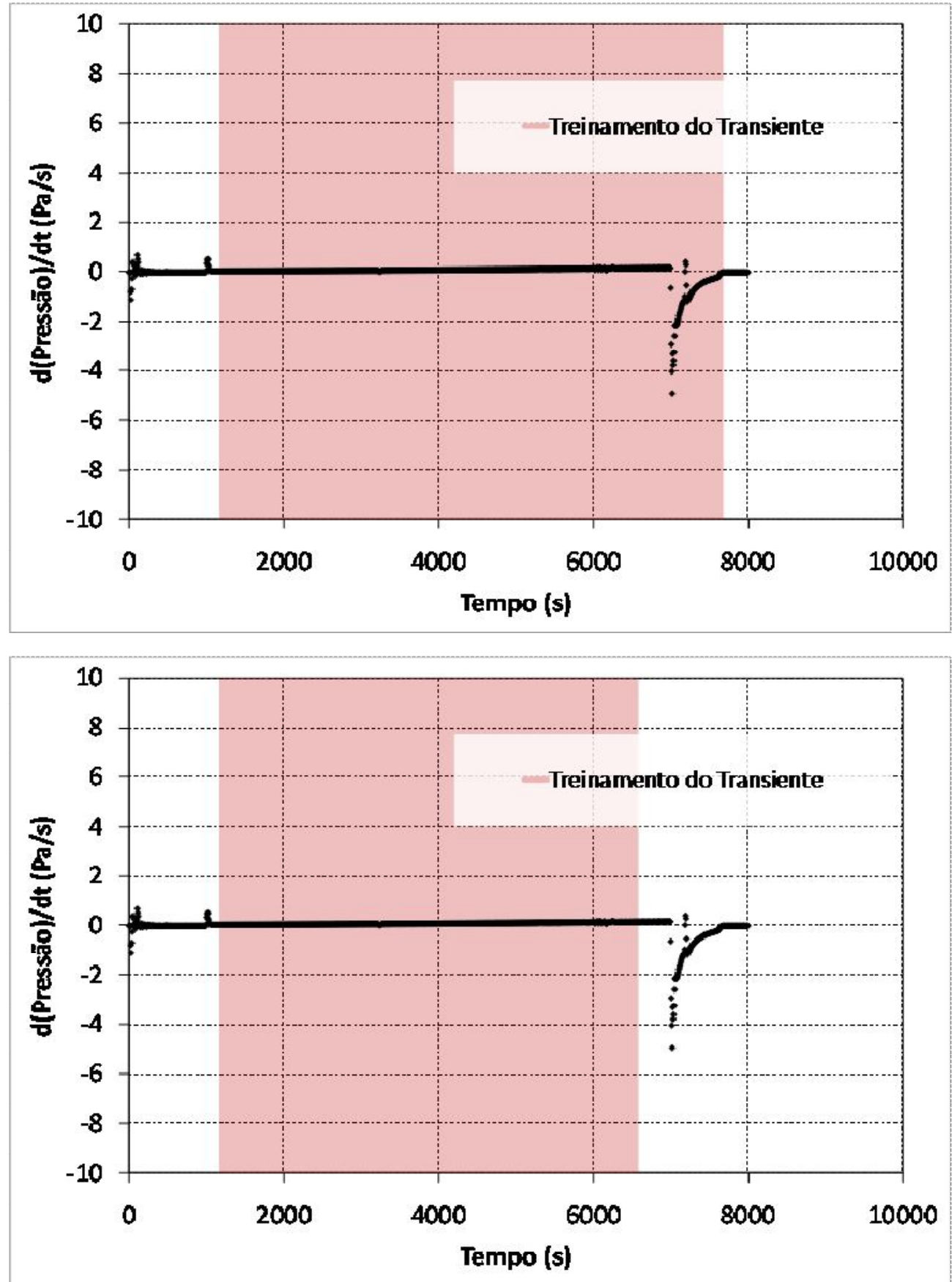

GRÁFICO 206 Amostragem da derivada da pressão, para os conjuntos de buffers de treinamento, ALLOLD acima e todos os demais abaixo, da simulação de pressurização e despressurização (PRESSURIZA70k)

Fonte: resultado de simulações da pesquisa 


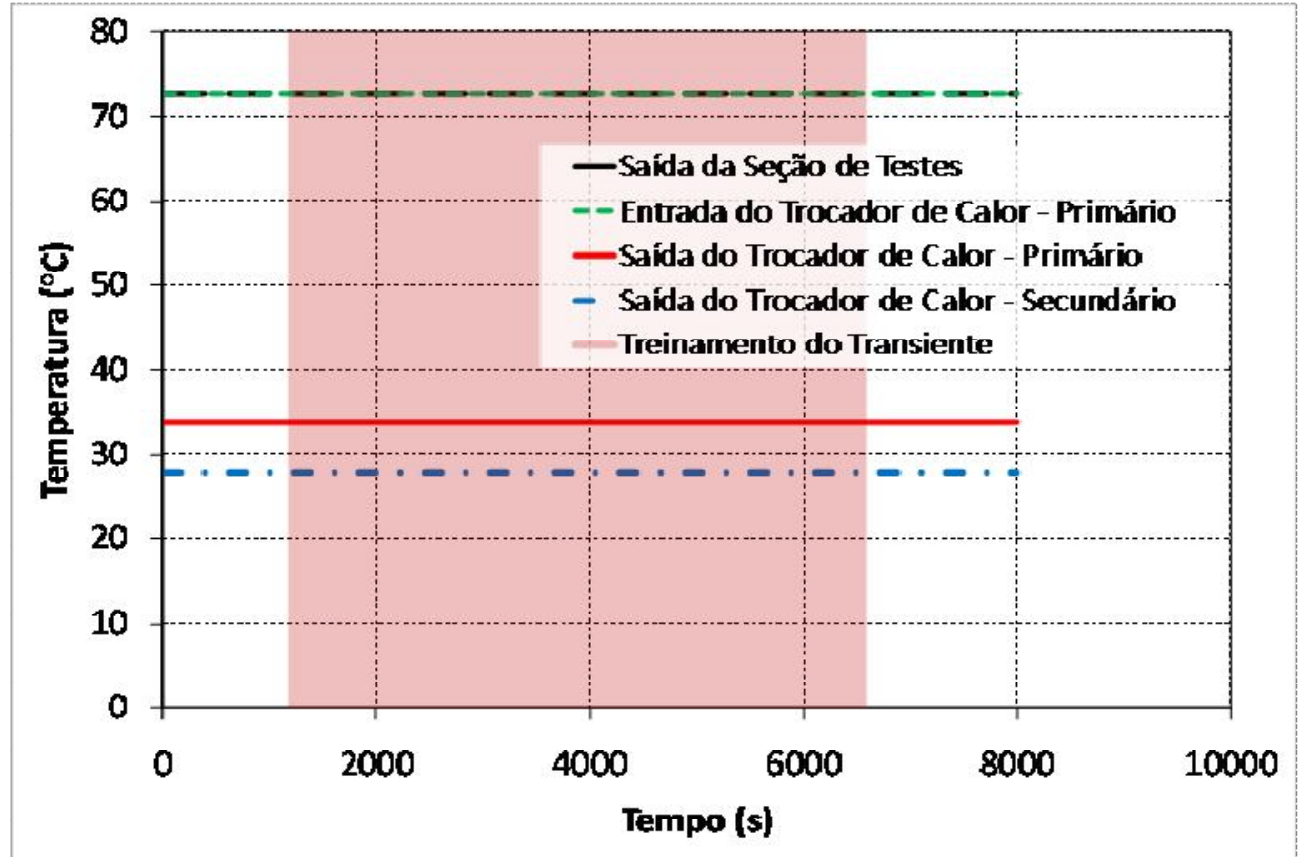

GRÁFICO 207 Amostragem da temperatura, para todos os conjuntos de buffers de treinamento, exceto o ALLOLD, da simulação de pressurização e despressurização (PRESSURIZA70k)

Fonte: resultado de simulações da pesquisa

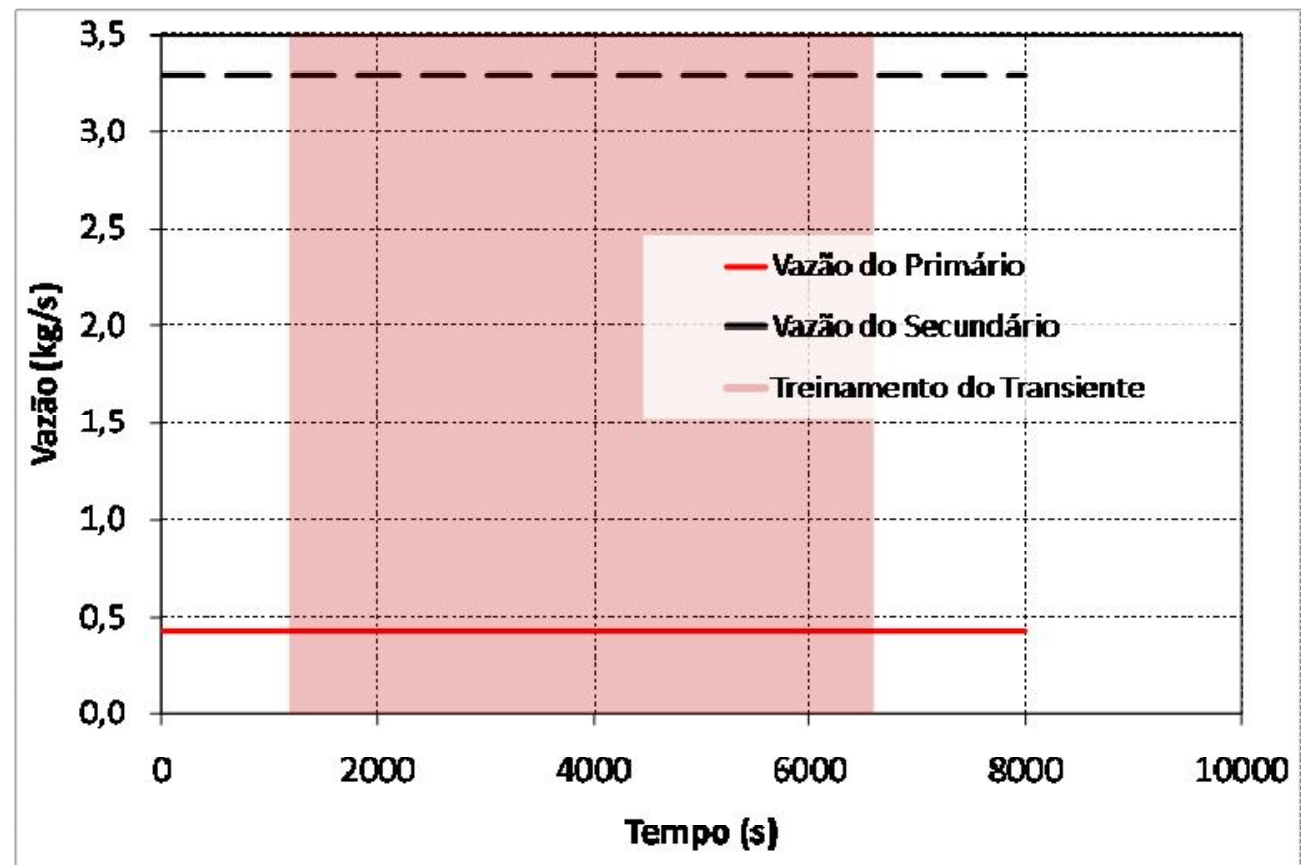

GRÁFICO 208 Amostragem das vazões, para todos os conjuntos de buffers de treinamento, exceto o ALLOLD, da simulação de pressurização e despressurização - (PRESSURIZA70k)

Fonte: resultado de simulações da pesquisa 


\section{DEGRAU de Potência de $60->70 \%$}

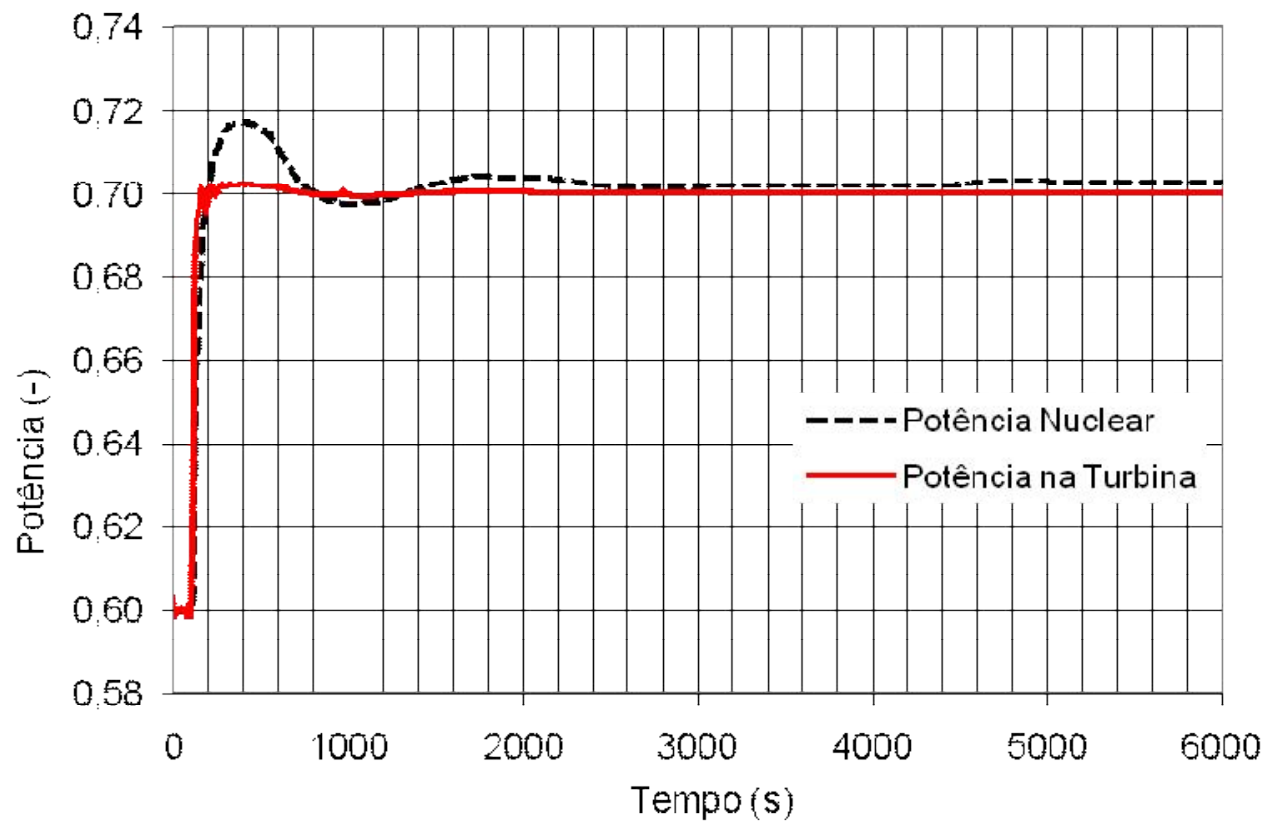

GRÁFICO 209 Potências nuclear e na turbina - degrau 60->70\% Fonte: resultado de simulações da pesquisa

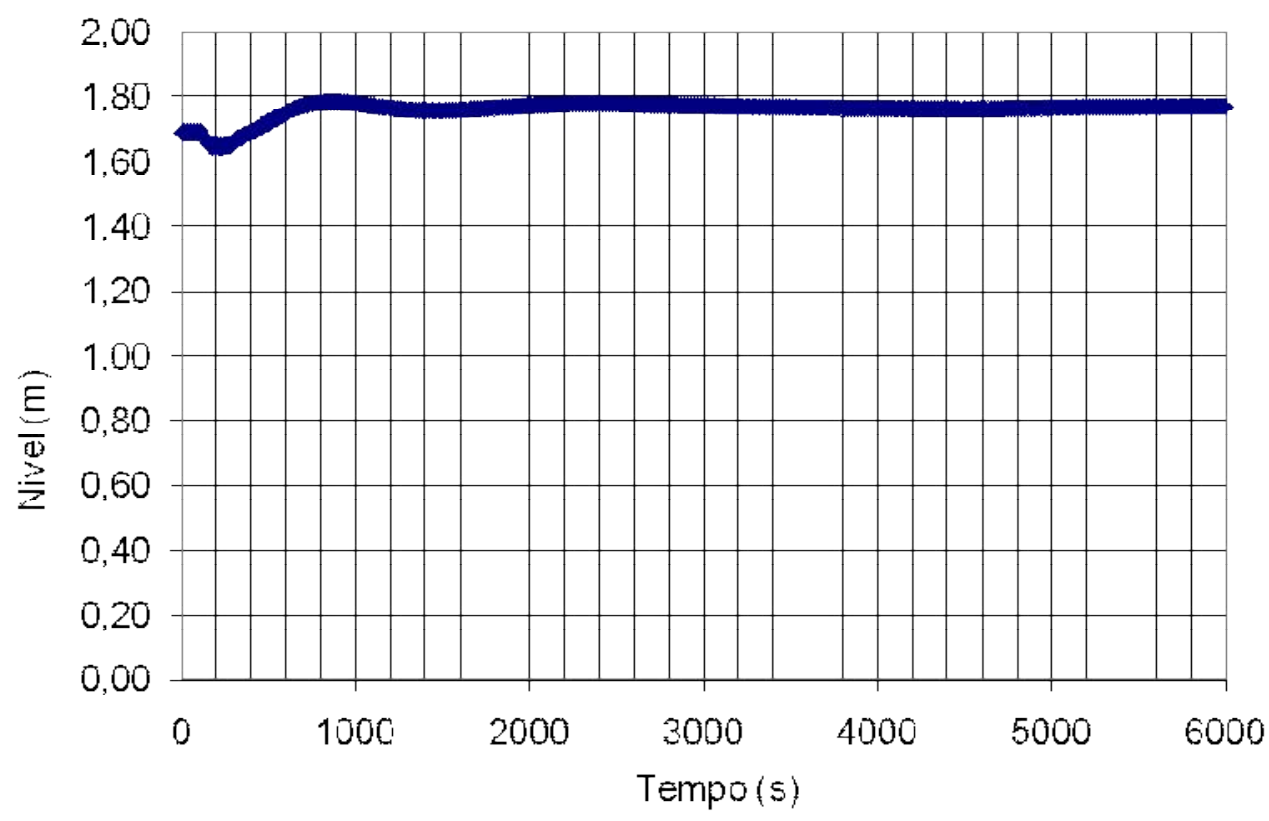

GRÁFICO 210 Nível no pressurizador - degrau 60->70\%

Fonte: resultado de simulações da pesquisa 


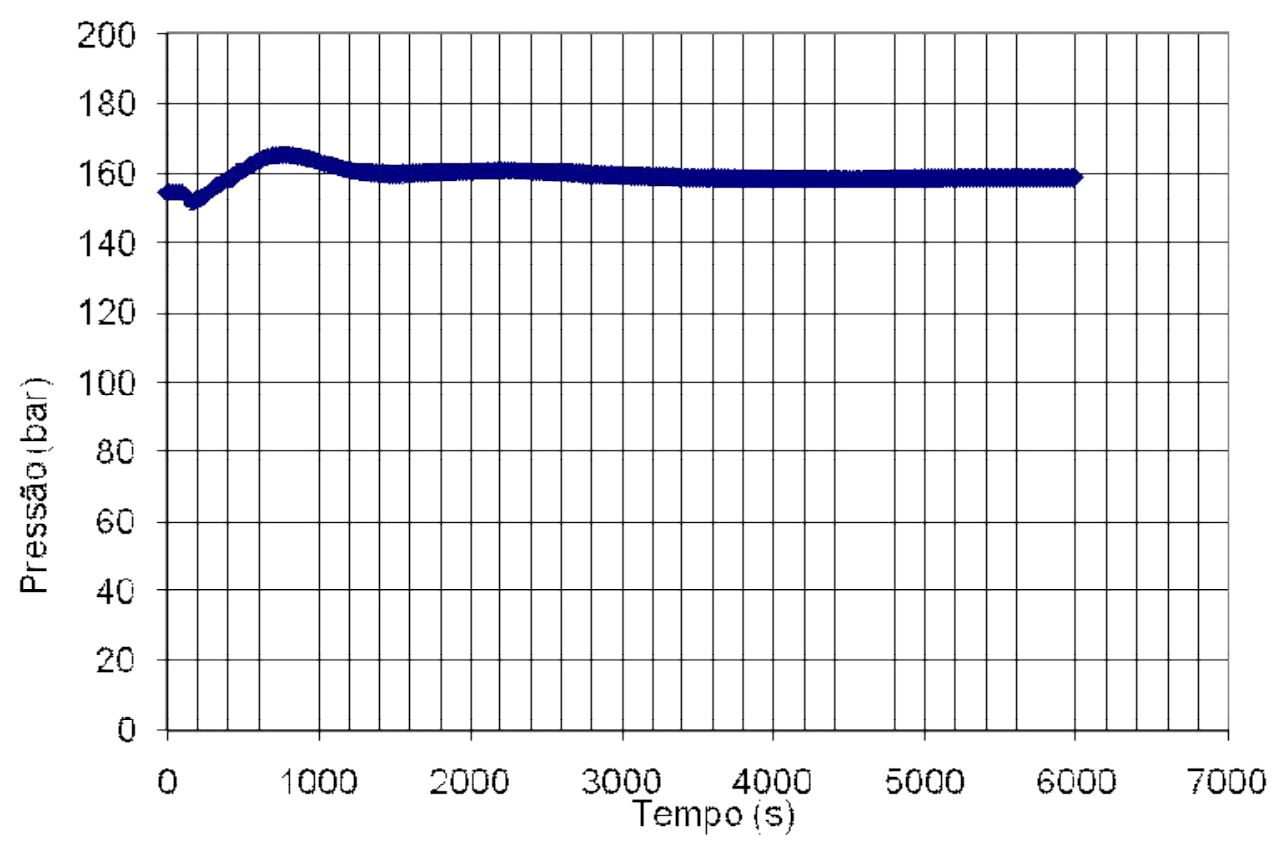

GRÁFICO 211 Pressão no pressurizador - degrau 60->70\%

Fonte: resultado de simulações da pesquisa

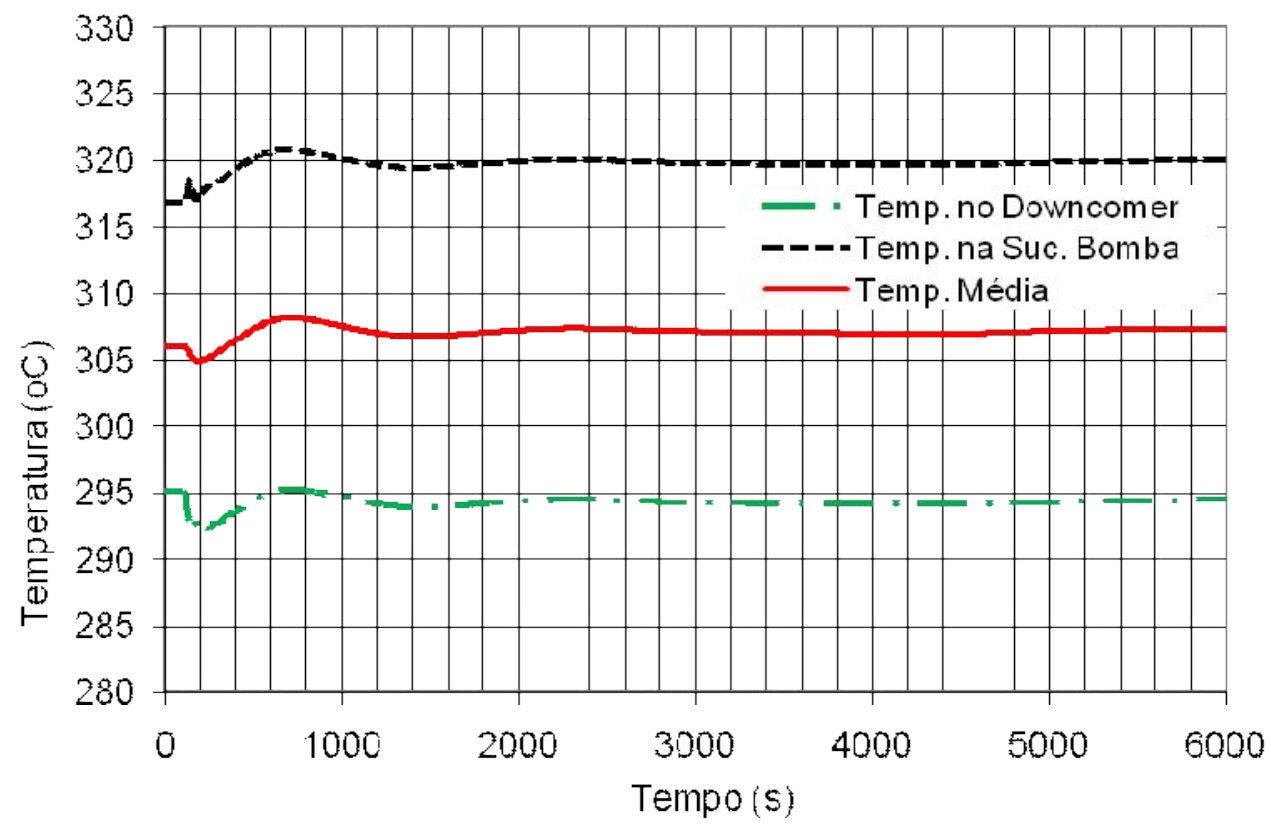

GRÁFICO 212 Temperaturas nas pernas fria e quente e media- degrau $60->70 \%$

Fonte: resultado de simulações da pesquisa 
Ruptura de Tubo do Gerador de Vapor (Steam Generator Tube Rupture SGTR2)

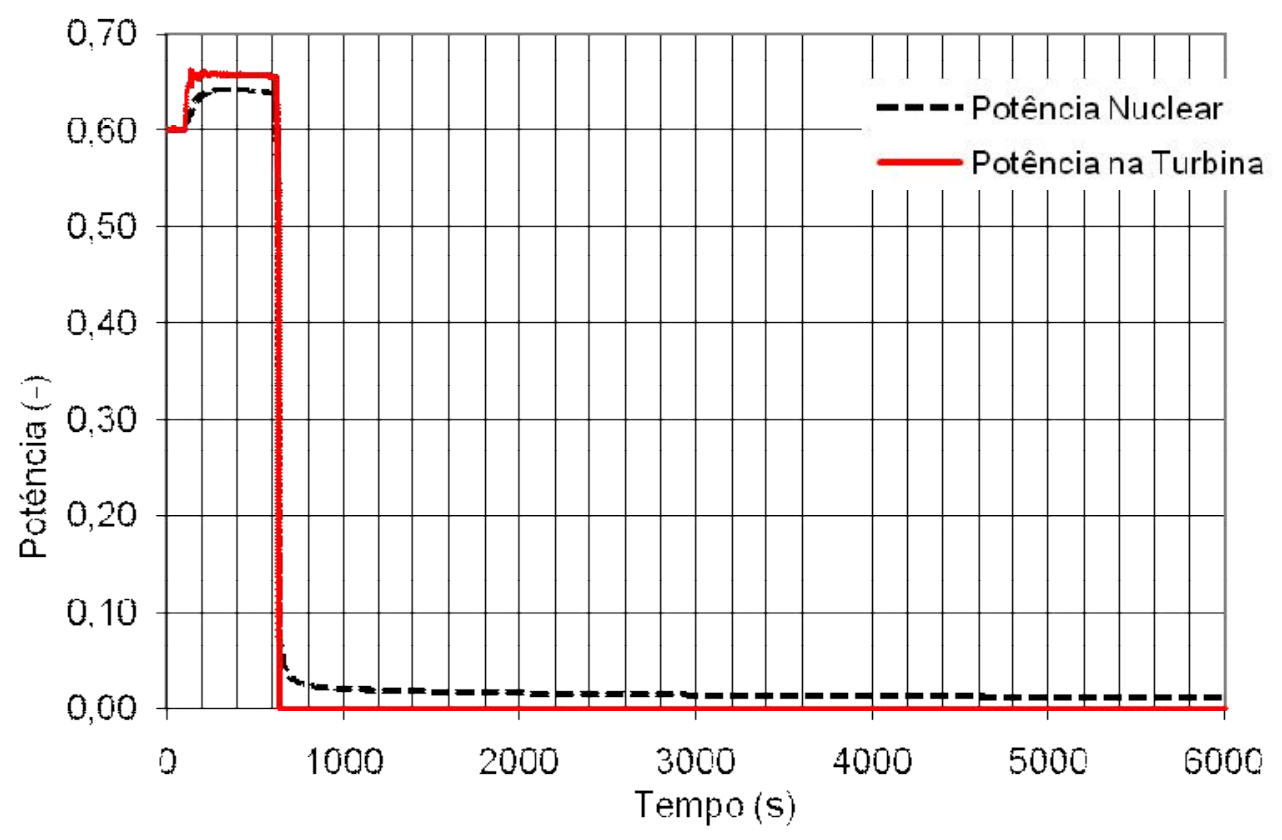

GRÁFICO 213 Potências nuclear e na turbina - SGTR2-60.

Fonte: resultado de simulações da pesquisa

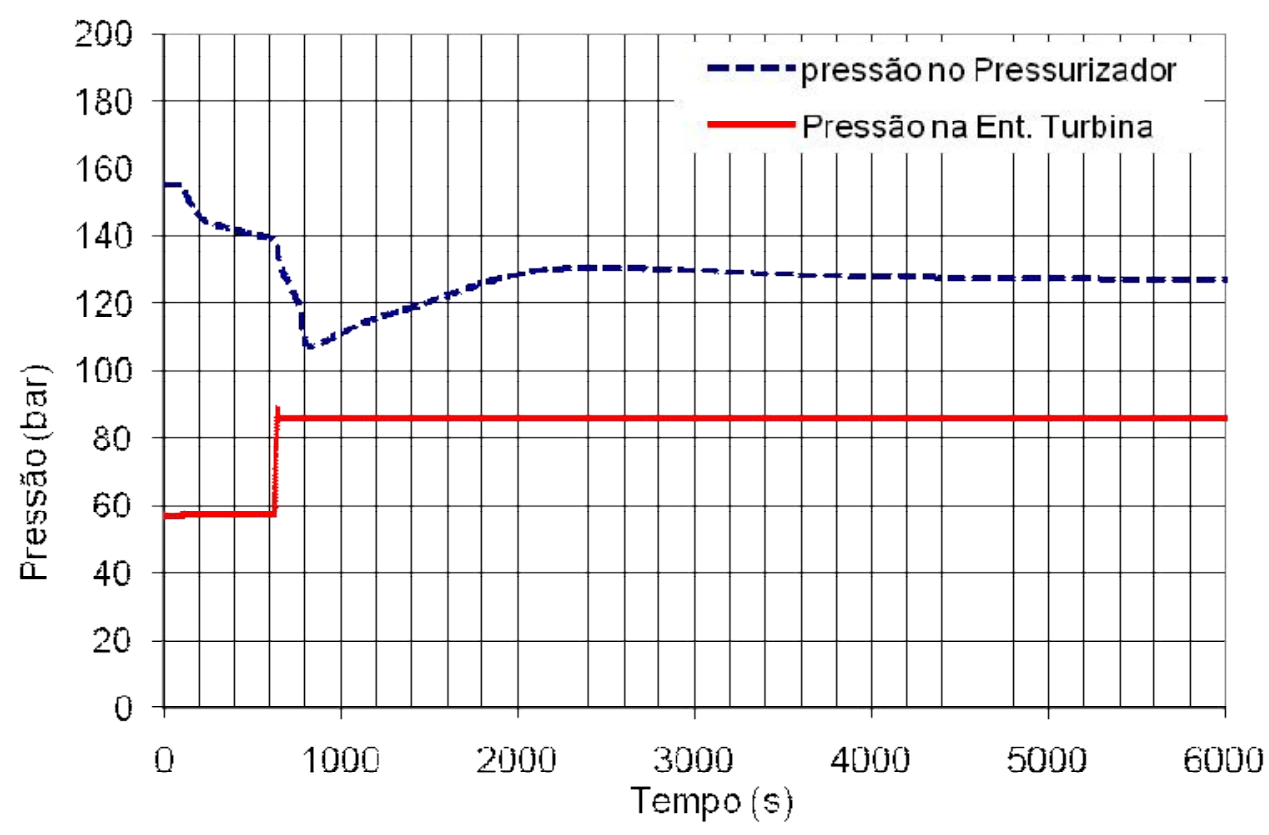

GRÁFICO 214 Pressão no pressurizador e na turbina - SGTR2-60.

Fonte: resultado de simulações da pesquisa 


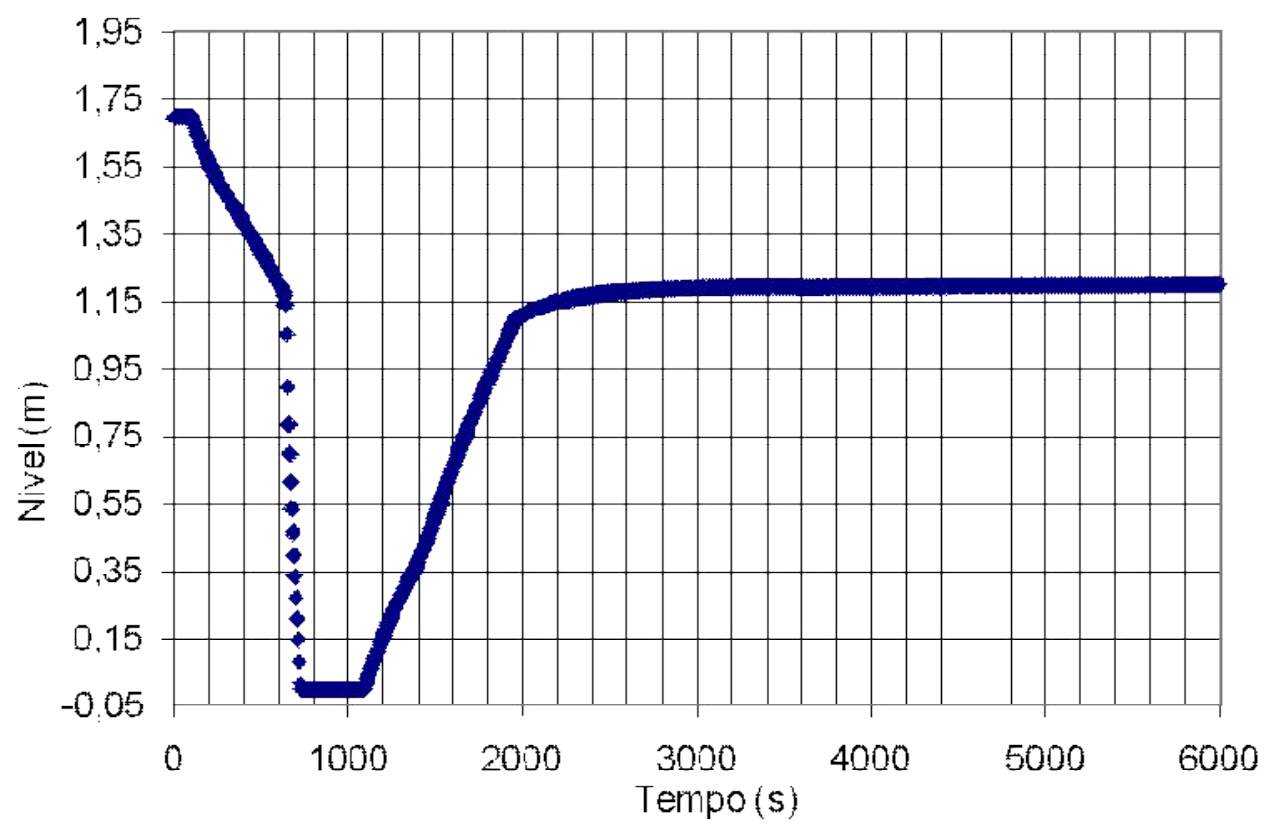

GRÁFICO 215 Nível no pressurizad or - SGTR2-60

Fonte: resultado de simulações da pesquisa

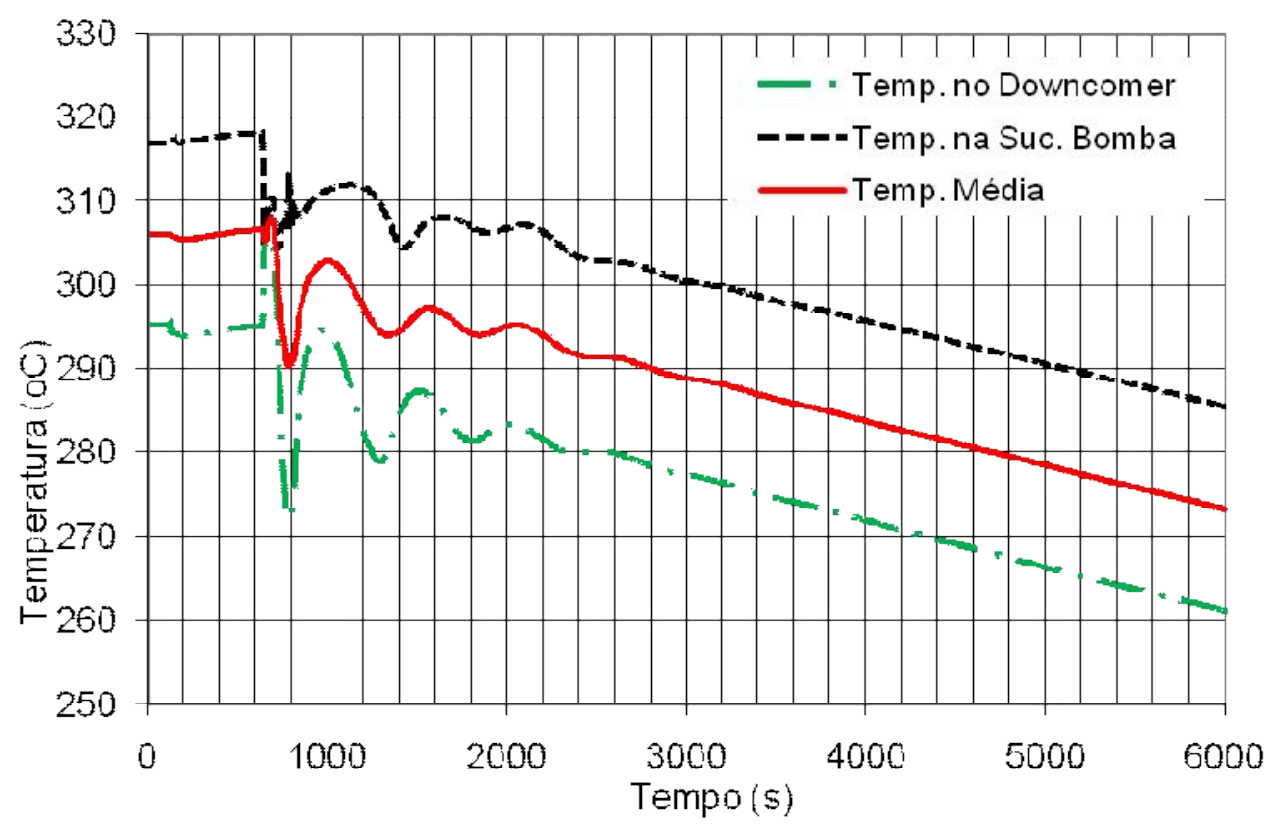

GRÁFICO 216 Temperaturas nas pernas fria e quente e media - SGTR2. Fonte: resultado de simulações da pesquisa 


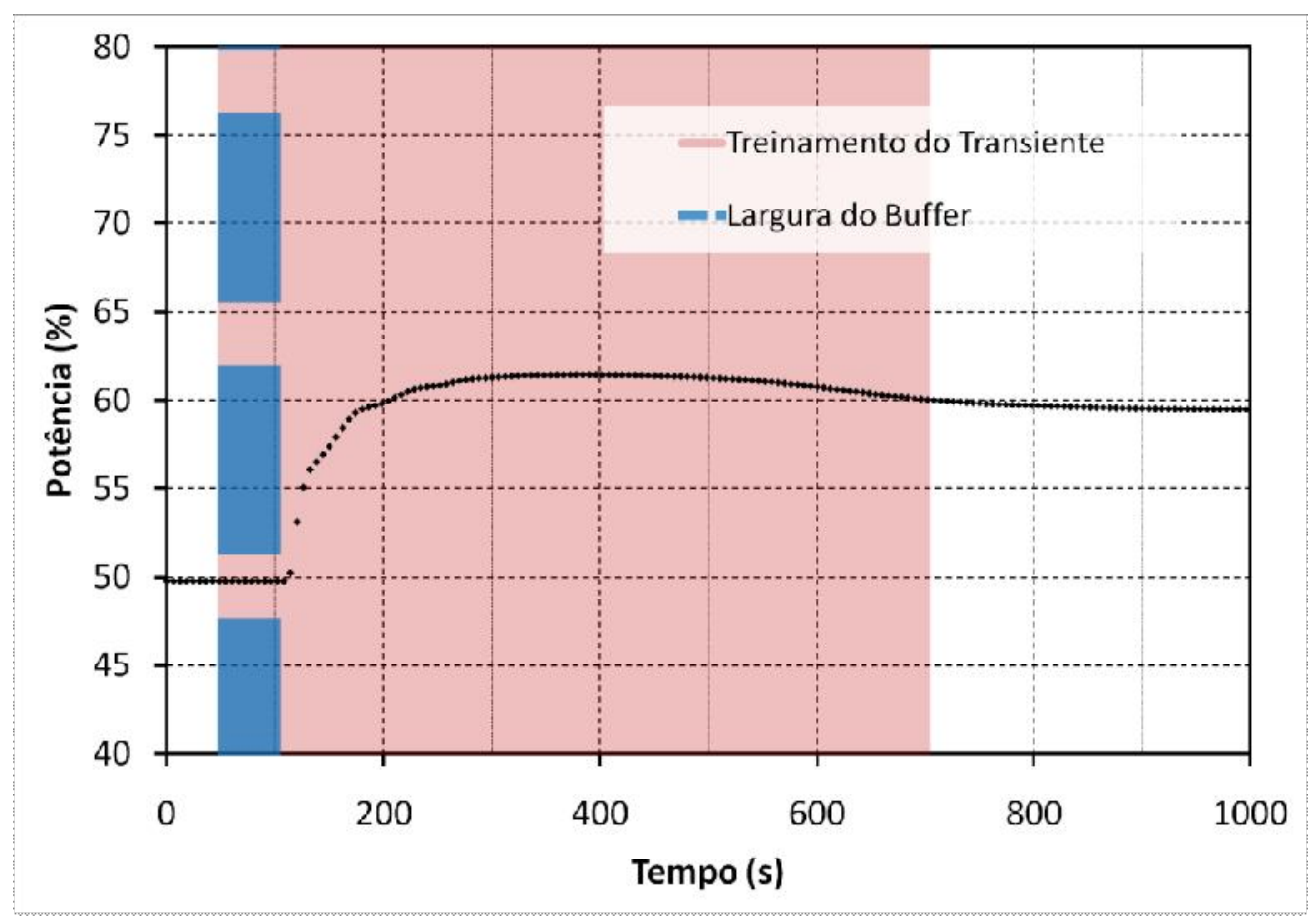

GRÁFICO 217 Potência nuclear - degrau-50->60 com indicação dos buffers usados para o treinamento das redes SOM

Fonte: resultado de simulações da pesquisa 